TARCISIO VIEIRA DE CARVALHO NETO

O princípio da impessoalidade nas decisões administrativas

Tese de Doutorado

Orientadora: Professora Titular Dra. Odete Medauar

UNIVERSIDADE DE SÃO PAULO

FACULDADE DE DIREITO

São Paulo-SP 


\section{O princípio da impessoalidade nas decisões administrativas}

Tese apresentada à Banca Examinadora do Programa de Pós-Graduação em Direito, da Faculdade de Direito da Universidade de São Paulo, como exigência parcial para obtenção do título de Doutor em Direito, na área de concentração Direito do Estado, sob a orientação da Professora Titular Dra. Odete Medauar.

\section{UNIVERSIDADE DE SÃO PAULO \\ FACULDADE DE DIREITO}

\section{São Paulo-SP}


Autorizo a reprodução e divulgação total ou parcial deste trabalho, por qualquer meio convencional ou eletrônico, para fins de estudo e pesquisa, desde que citada a fonte.

Serviço de Biblioteca e Documentação

Faculdade de Direito da Universidade de São Paulo

\begin{tabular}{|l|}
\hline \multirow{3}{*}{ Carvalho Neto, Tarcisio Vieira de } \\
O princípio da impessoalidade nas decisões \\
administrativas / Tarcisio Vieira de Carvalho Neto. \\
São Paulo: USP / Faculdade de Direito, 2014. \\
335 f. \\
Orientadora: Profa. Dra. Odete Medauar \\
Tese (Doutorado), Universidade de São Paulo, \\
USP, Programa de Pós-Graduação em Direito, Direito do \\
Estado, 2014. \\
1. Direito administrativo. 2. Decisão administrativa. \\
3. Principio da impessoalidade. 4. Conciliação \\
(Procedimento especial). 5. Interesse difuso. I. Medauar, \\
Odete. II. Título. \\
\end{tabular}




\section{Epígrafe à impessoalidade}

Graciliano Ramos foi também Prefeito de Palmeira dos Índios (AL), de 1927 a 1930. Dentre as medidas revolucionárias que adotou, em prol do interesse público, proibiu a criação de animais soltos nas ruas. E não perdoou nem o próprio pai, multado por deixar cachorros soltos, ao arrepio do Código Municipal de Posturas.

Conta-se que o senhor Sebastião Ramos, deveras aborrecido, ao queixar-se do filho quanto à multa, recebeu dele a seguinte descompostura:

- Prefeito não tem pai.

Eu posso até pagar a sua multa. Mas terei que apreender seus animais toda vez que o senhor os deixar na rua. 
Tarcisio Vieira de Carvalho Neto. O princípio da impessoalidade nas decisões administrativas. Doutorado - Faculdade de Direito, Universidade de São Paulo, São Paulo, 2014.

\section{RESUMO}

Estuda-se nesta tese o conteúdo jurídico do princípio da impessoalidade, previsto no art. 37, caput, da Constituição Federal de 1988, especificamente para fins de parametrização, controle e responsabilidade das decisões administrativas. Estruturam-se três eixos temáticos: a) noções introdutórias - ideias de aproximação necessárias ao contexto e ao conceito do princípio da impessoalidade e do alcance de sua projeção nas decisões administrativas (póspositivismo e neoconstitucionalismo; constitucionalização; julgamento por princípios; relevância dos princípios; interesse público; direito administrativo como sistema; neutralidade política e a questão da justiça); b) impessoalidade no direito administrativo - comprovação de que o princípio da impessoalidade ostenta arquétipo aberto para conferir maiores cobertura e proteção aos valores tutelados pelo texto constitucional, com ênfase à organização administrativa impessoal para assegurar um agir naturalmente impessoal (instrumentalização recíproca de princípios constitucionais; antecedentes históricos; direito estrangeiro; doutrina brasileira; impessoalidade na Constituição, nas leis e na jurisprudência; conceito de impessoalidade); c) impessoalidade nas decisões administrativas - construção de um conceito de impessoalidade específico para as decisões administrativas, concebido desde a ideia de ponderação e conciliação de todos os interesses legítimos - públicos e privados - envolvidos em cada caso concreto (conceito e distinção de decisão administrativa impessoal em relação à decisão judicial imparcial; garantias e requisitos para a adoção de decisões impessoais, com destaque para os deveres de fundamentação (motivação), processualização e participação; algumas implicações de decisões impessoais [funcionário de fato; diminuição da discricionariedade; desvio de poder; motivação na dispensa de empregados públicos; responsabilidade civil extracontratual do Estado; necessidade de reconhecimento dos direitos dos administrados; nepotismo e revisitação da reformatio in pejus]; consequências da quebra da impessoalidade nas decisões administrativas [anulação; responsabilização do Estado e responsabilização do servidor] e, finalmente, técnicas para adoção de decisões administrativas impessoais).

Palavras-chave: direito administrativo, impessoalidade, princípio, decisões administrativas, ponderação, conciliação, interesses. 
Tarcisio Vieira de Carvalho Neto. O princípio da impessoalidade nas decisões administrativas. Doutorado - Faculdade de Direito, Universidade de São Paulo, São Paulo, 2014.

\begin{abstract}
This essay intends to analyze the juridical concept of the principle of impersonality, embraced in the article 37 of the Constitution of 1988, in order to establish standards of parameterization, control and liability in the administrative decisions. The essay comprises three main fields of analysis: a) introductory concepts - preliminary approach to comprehend the theoretical and the political context in which is developed the scope and the enforcementof the principle of impersonality in the processes that lead to administrative decisions (postpositivism and neoconstitutionalism; the enforcement of principles; public interest; Administrative Law as a system; politic neutrality and the issue of Justice); b) the principle of impersonality within the Administrative Law - analysis of the scope of protection of the principle, aiming to demonstrate that its juridical concept must be considered in a wide open perspective in order to guarantee a strong protection of the constitutional values. In this part, it will be emphasized that the development of a impartial administrative conduct is closely related to the idea of a impartial administrative organization. (historical background; foreign legislation; Brazilian legal doctrine; the principle of the impersonality within the constitutional rules, the specific legislation and the judicial precedents; juridical concept of the principle); c) the enforcement of the principle of impersonality in administrative decisions - In this part it is developed the juridical concept of the principle in the field of the deliberative administrative proceedings. This juridical concept embraces the idea of balancing and conciliating all legitimate interests - public or private - involved in a determined situation that requires a administrative deliberation (distinctions between impersonal and impartial administrative decisions; standards to create a impersonal decision-making; specific implications of impersonal decisions; legal consequences arising from the disregard of the principle of impersonality in administrative decisions; legal techniques that lead to a impersonal administrative decision-making).
\end{abstract}

Key words: Administrative Law, Principle of Impersonality, administrative decisions, balancing, conciliation, interests. 
Tarcisio Vieira de Carvalho Neto. O princípio da impessoalidade nas decisões administrativas. Doutorado - Faculdade de Direito, Universidade de São Paulo, São Paulo, 2014.

\title{
RIASSUNTO
}

Il obbieto di questa tesi riguarda la comprensione giuridica del principio di impersonalitá nel ordenamento giuridico brasiliano, in vista del articolo 37 della Costituzione Federale di 1988, in particolare con la finalitá di stabilire standards di parametrizzazione, controllo e responsabilitá delle decisioni amministrativi. La tesi comprende tre parti principali: a) nozioni introduttive - idee basilari per comprendere il contesto e il concetto del principio di impersonalitá e la sua applicazione nel campo delle decisioni amministrative (postpositivismo, il nouove teorie costituzionali, costituzionalizzazione, l'importanza dei principi; la nozione di interesse publicco; dirrito amministrativo come un sistema; neutralitá politica e la questione della giustizia); b) impersonalitá nel diritto amministrativo - dimostrazione teorica che il principio di impersonalitá ha una struttura aperta per rendere maggiore protezione ai valori tutelati per l'ordine constituzionale, con particolare attenzione alla organizzazione amministrative impersonale per garantire un' azione amministrativa naturalmente impersonale (background storico; strumentalizzazione reciproca dei principi; dirrito di altre paesi (estero); dottrina giuridica brasiliana; il principio di impersonalitá nella Constituzione, nelle leggi e nella giurisprudenza; concetto di impersonalitá); c) il principio di impersonalitá nelle decisioni amministrativi - in questa parte lo intento é lo sviluppo di un concetto di impersonalitá specifico per le decisioni amministrativi. Questo concetto giuridico involge la idea di conciliare tutti gli interessi legitimi - publicco o privato - presenti in una data situazione que richiede una deliberazione amministrativa (distinzione tra decisioni amministrativi impersonali e imparziali; implicazioni delle decisioni impersonali; conseguenze giuridiche della violazione del dovere di osservare il principio di impersonalitá; tecniche per un processo decisionale impersonale).

\author{
Parole Chiave: Diritto Amministrativo, Principio di Impersonalitá, Decisioni \\ Amministrativi, conciliazione, interessi.
}




\section{SUMÁRIO}

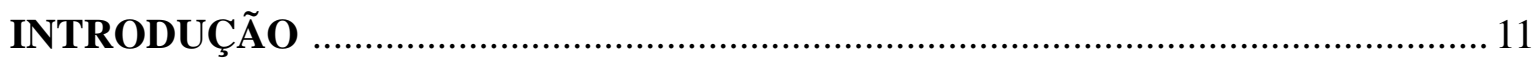

CAPÍTULO 1 - NOÇÕES INTRODUTÓRIAS ...................................................... 14

1.1 Pós-positivismo e neoconstitucionalismo ..................................................................... 14

1.2 Constitucionalização do Direito Administrativo ............................................................ 20

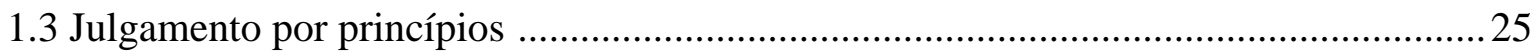

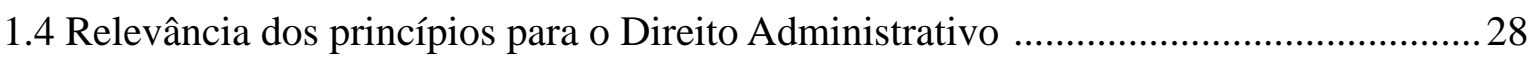

1.5 Direito Administrativo do interesse público ............................................................... 32

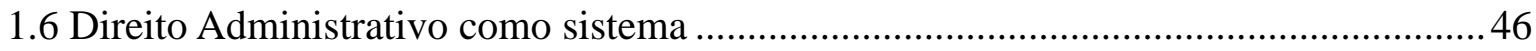

1.7 O mito da neutralidade política da decisão administrativa e a questão da justiça.......... 49

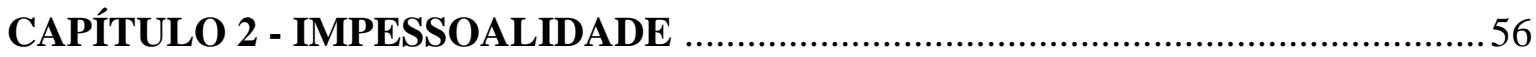

2.1 Instrumentalização recíproca dos princípios constitucionais administrativos ...............56

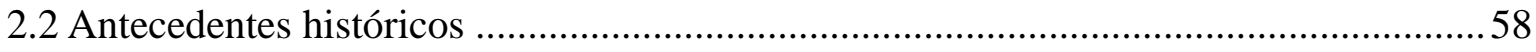

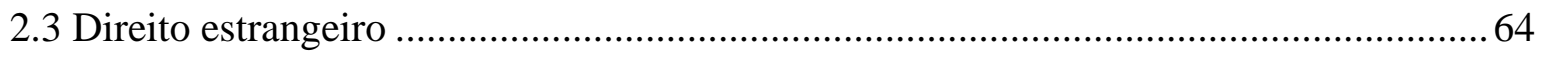

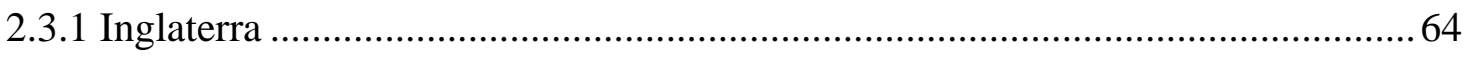

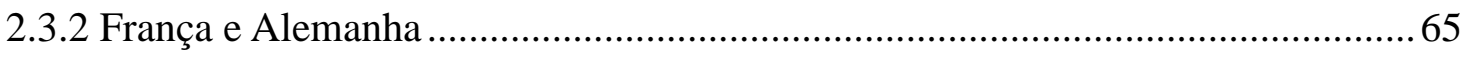

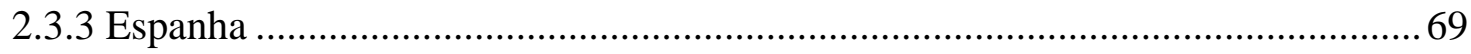

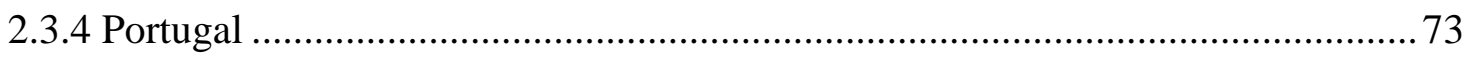

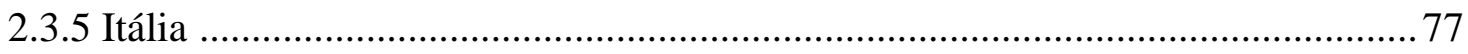

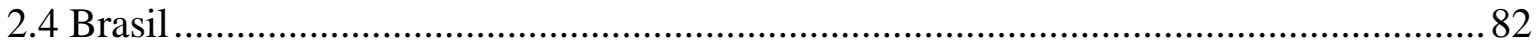

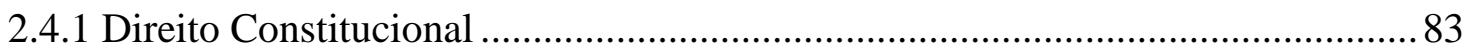

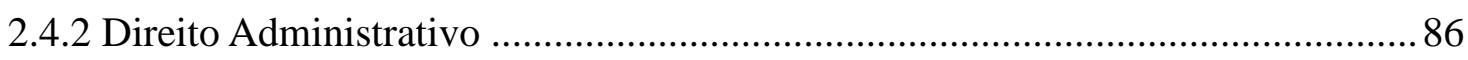

2.5 Constituição de 1988 (regra ou princípio?) ................................................................... 99

2.5.1 Art. 37, § $1^{\circ}$ (regra da proibição de promoção pessoal na publicidade

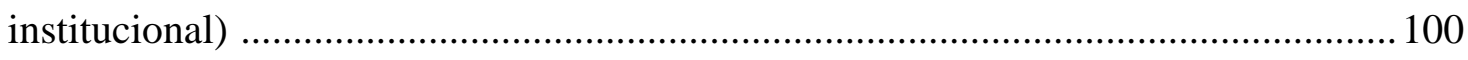

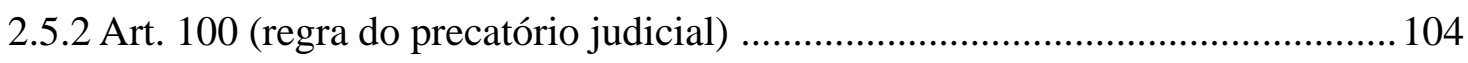

2.5.3 Art. 37, caput (princípio da impessoalidade administrativa) ............................. 107

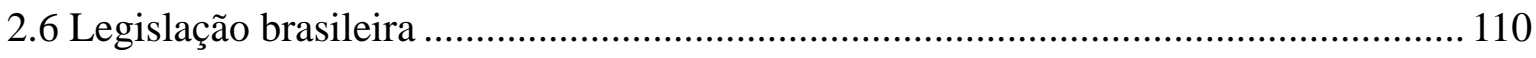

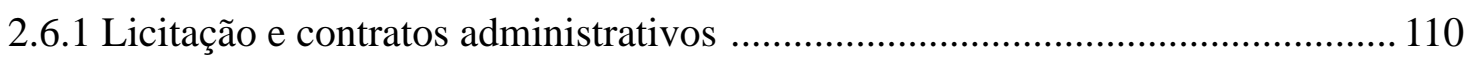




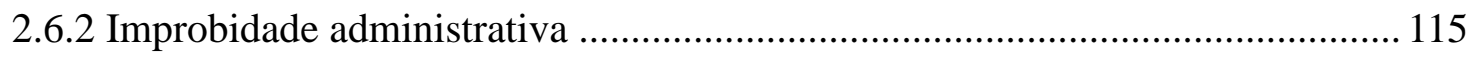

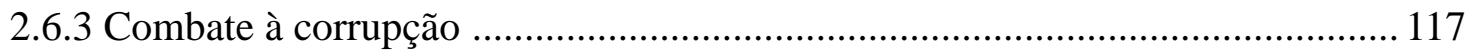

2.6.4 Concessões e permissões da prestação de serviços públicos .............................. 119

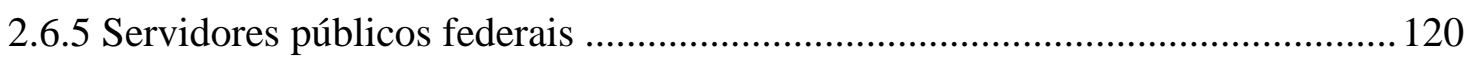

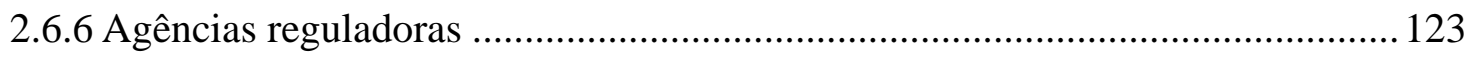

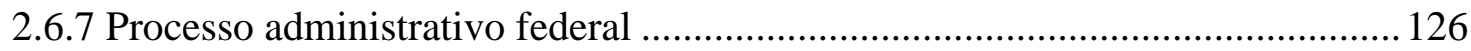

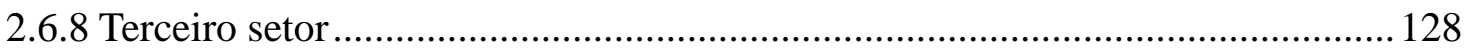

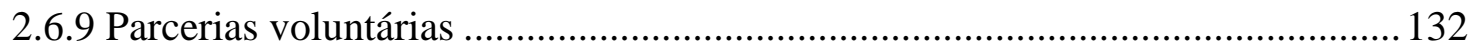

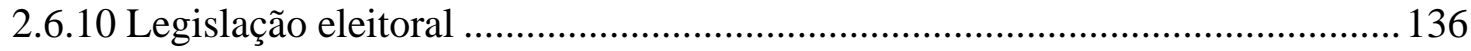

2.6.11 Vedação de atribuição de nome de pessoa viva a bem público ......................... 141

2.6.12 Ações de comunicação do Poder Executivo Federal ....................................... 144

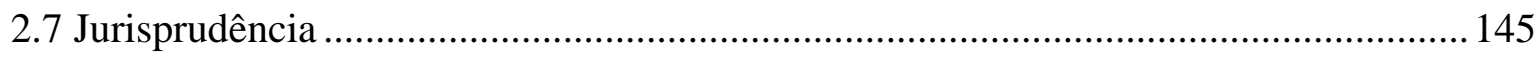

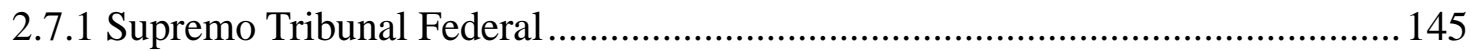

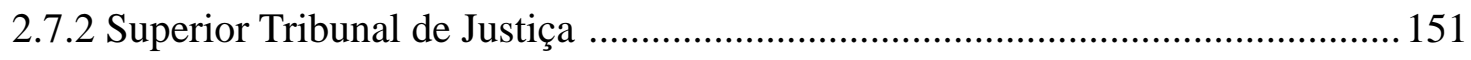

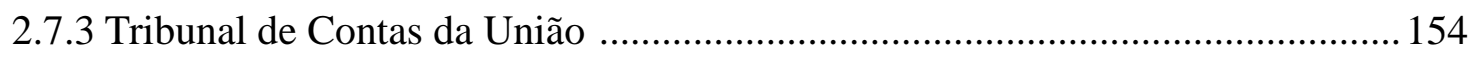

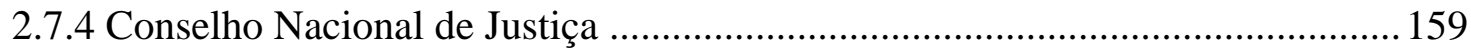

$2.8 \mathrm{O}$ policefático conceito de impessoalidade ................................................................ 164

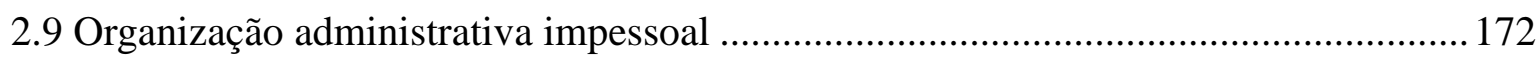

\section{CAPÍTULO 3 - IMPESSOALIDADE NA SEARA ADMINISTRATIVA}

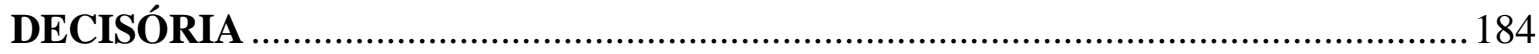

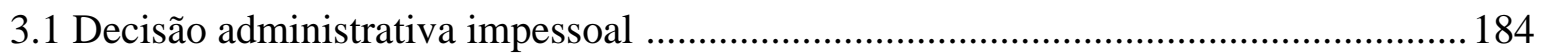

3.2 Decisão administrativa impessoal versus decisão judicial imparcial .......................... 189

3.3 Garantias e requisitos para adoção de decisões administrativas imparciais .................. 192

3.3.1 Dever de fundamentação (motivação) ................................................................. 198

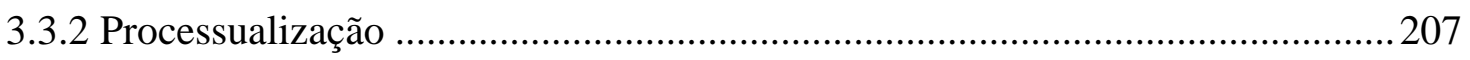

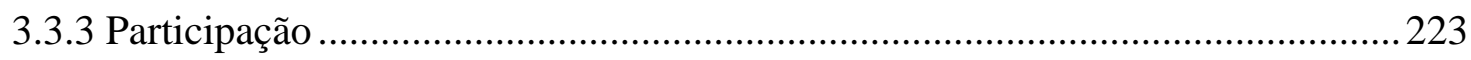

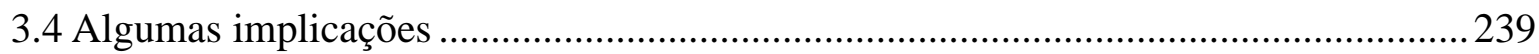

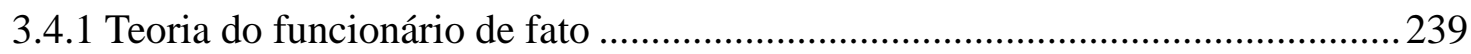

3.4.2 Diminuição da discricionariedade administrativa decisional ...........................243

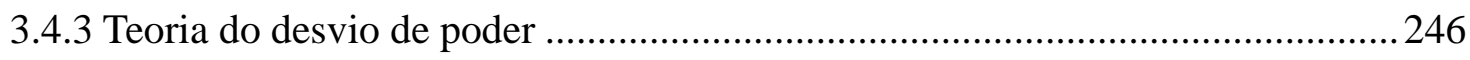

3.4.4 Necessidade de motivação na dispensa de empregados públicos ....................... 250 
3.4.5 Responsabilidade civil extracontratual objetiva do Estado ..............................253

3.4.6 Necessidade de reconhecimento dos direitos dos administrados.......................254

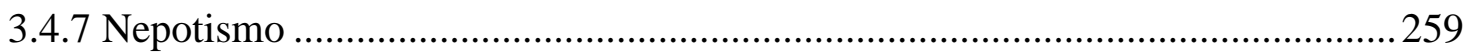

3.4.8 Revisitação da reformatio in pejus como regra do processo administrativo .....262

3.5 Consequências da quebra da impessoalidade nas decisões administrativas .................264

3.5.1 Anulação da decisão administrativa não impessoal ............................................266

3.5.2 Responsabilização civil extracontratual do Estado .......................................... 271

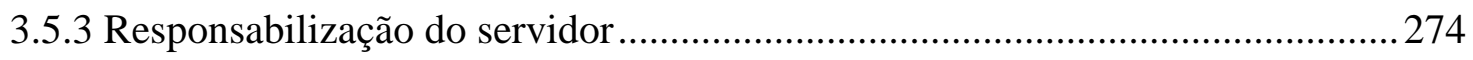

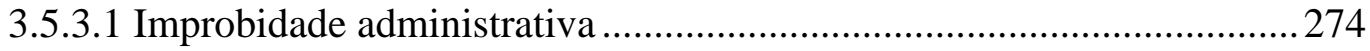

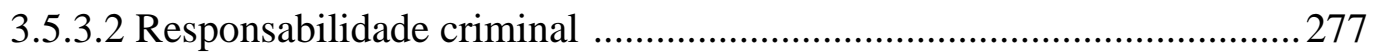

3.6 Técnicas para adoção de decisões administrativas impessoais - ponderação e

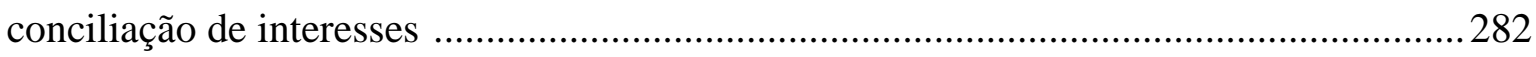

3.6.1 Objetos de ponderação - bens, interesses e valores ..........................................2. 288

3.6.2 Cenários de ponderação .................................................................................... 290

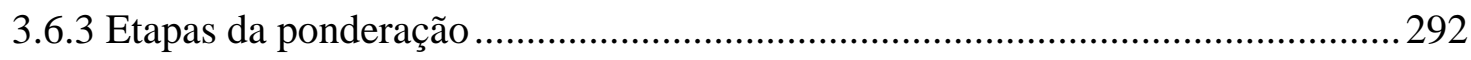

3.6.4 A ponderação decisória na Ciência da Administração ........................................ 296

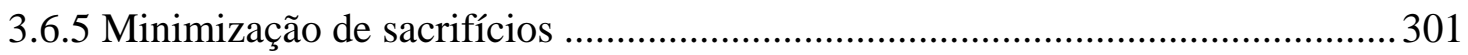

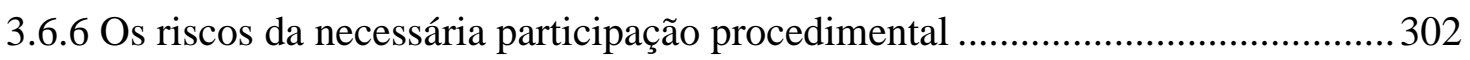

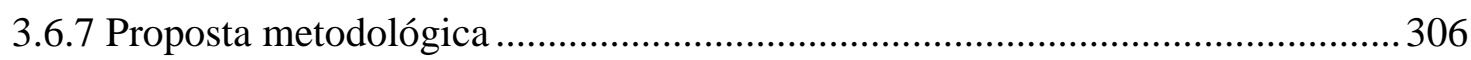

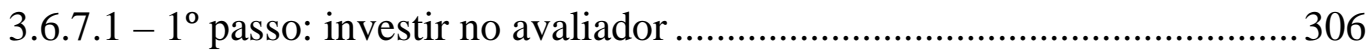

3.6.7.2 - $2^{\mathrm{o}}$ passo: decidir com impessoalidade ............................................. 306

3.6.7.3 - $3^{\circ}$ passo: exteriorizar a decisão ........................................................ 307

3.6.8 Escopo e efeitos da ponderação decisória ...........................................................307

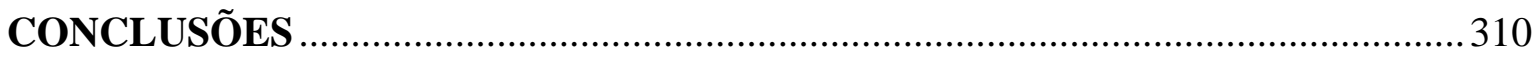

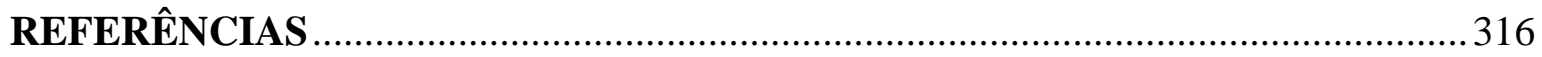




\section{INTRODUÇÃO}

Todos os dias a Administração Pública profere decisões - com impactos significativos na vida dos administrados - que no Estado Democrático de Direito devem primar por uma legalidade assentada em bases amplas, entendida como compatibilidade vertical em relação a uma ordem jurídica justa. Uma legalidade amalgamada com os demais princípios constitucionais, dentre os quais o da impessoalidade.

O princípio da impessoalidade, previsto na Constituição Federal de 1988, deve ser cada vez mais observado nas decisões administrativas.

Mas o que é impessoalidade? Existe uma impessoalidade específica para fins de parametrização, controle e responsabilidade nas decisões administrativas? Em caso positivo, como alcançá-la?

Para responder tais indagações é necessário circunscrever o princípio da impessoalidade num ambiente constitucional revigorado pela ética e pela moral, já que no pós-positivismo empresta-se ao princípio papel constitutivo marcante da ordem jurídica, em significado autoevidente. E a constitucionalização do Direito Administrativo implica não mais poder-se atribuir aos princípios papel secundário. Trata-se de compreender o fenômeno da irradiação dos efeitos dos valores constitucionais nos comportamentos administrativos, para conhecer suas consequências e conceber estruturas jurídicas hábeis a assegurar os resultados desejados.

Nas decisões administrativas julga-se cada vez mais com princípios e, no caso da impessoalidade, uma aplicação marcada pelas pechas do subjetivismo, da predileção, da perseguição, do favorecimento pessoal etc. pode descambar para o que se pretende evitar a todo custo: a impessoalidade às avessas.

A impessoalidade ganha maior relevo diante da sistematização recente e da falta de codificação do Direito Administrativo, sobretudo quando a dignidade humana e os direitos fundamentais reverberam nas atividades administrativas próprias de uma “boa administração”.

Para delimitar a impessoalidade decisória, imprescindível refazer a ideia de interesse público, insuscetível de ser concebido, no novel cenário constitucionalmente conformado, como o interesse unilateral da Administração, do erário, nem sempre conectado com o justo e com o que é conforme o Direito.

A impessoalidade demandará um interesse público plural? Obtido da conciliação de interesses legítimos variados, públicos e privados, em cada caso concreto?

E mais. Como o Direito Administrativo, como sistema (de estruturação e ação) da 
prossecução do interesse público, passará a servir-se da impessoalidade para atingir seus propósitos constitucionais?

São perguntas que merecem resposta.

Sem um princípio da impessoalidade que ostente arquétipo aberto, para conferir maiores cobertura e proteção aos valores tutelados pelo texto constitucional, parece impossível, de antemão, dar cabo da tarefa de julgar com equilíbrio e equidistância, buscando um interesse público que, muitas vezes, estará no reconhecimento do interesse particular.

Necessário será comparar impessoalidade com imparcialidade, objetividade e neutralidade, visões próprias do direito estrangeiro, para aferir se o princípio brasileiro em destaque confunde-se com os demais ou, diferentemente, assume feição original.

No trabalho, pretende-se deixar claro que os princípios, incluídos os regedores da atividade administrativa, se aplicam em bloco. E que o da impessoalidade, de caráter policefático, só pode ser bem compreendido com ênfase redobrada na questão da organização (estruturação) administrativa impessoal.

Ambiciona-se comprovar, a partir da constatação de um tratamento insuficiente na doutrina nacional, que a arquitetura administrativa faz toda a diferença. Deve ser tal que dela flua, naturalmente, um decidir impessoal, no realce da força de institutos como o do concurso público e o do merecimento e de premissas como a da profissionalização e a da qualificação da Administração Pública.

Em passo seguinte, fixada a premissa da estruturação interna impessoal, a tese se preocupará em estabelecer critérios para um agir decisório impessoal.

Como fazer isso? Em que medida a ponderação e a conciliação de todos os interesses legítimos - públicos e privados - envolvidos em cada caso concreto submetido à apreciação do julgador administrativo satisfaz a impessoalidade, como "justa solução do caso concreto”?

Para projetar a decisão ideal será preciso distinguir entre decisão administrativa impessoal e decisão judicial imparcial, remarcando a posição de “parte imparcial” de uma Administração que não pode ser neutra ou indiferente quanto a interesses legítimos envolvidos, mas que simultaneamente - para alcançar as finalidades espelhadas na ordem jurídica - deve julgar com equilíbrio, equidistância e imparcialidade.

A questão principal da tese está em revolver a seguinte inquietação: para além de uma estruturação (organização) administrativa impessoal, como assegurar decisões impessoais, a 
não ser a partir de requisitos e garantias, com destaque para os deveres de fundamentação (motivação), processualização e participação, que se predicam reciprocamente?

Diante de uma impessoalidade decisória assim cogitada, serão investigadas implicações da matéria em temas recorrentes do Direito Administrativo, tais como: funcionário de fato; diminuição da discricionariedade; desvio de poder; motivação na dispensa de empregados públicos; responsabilidade civil extracontratual do Estado; necessidade de reconhecimento dos direitos dos administrados; nepotismo e revisitação da reformatio in pejus. Em todos os tópicos serão estabelecidos liames diretos com a impessoalidade administrativa decisória.

Divisar-se-ão também as consequências da indesejável quebra da impessoalidade nas decisões administrativas, como anulação, responsabilização do Estado e do servidor, tanto por improbidade administrativa quanto criminalmente.

Finalmente, serão apresentadas e sugeridas técnicas para adoção de decisões administrativas impessoais, com rigor científico e método jurídico. Buscar-se-á demonstrar que uma (boa) decisão administrativa impessoal, como projeção de uma estruturação administrativa virtuosa, pressupõe comportamentos administrativos objetivados, obsequiosos da ponderação e da conciliação de todos os interesses legítimos em disputa. 


\section{CAPÍTULO 1 - NOÇÕES INTRODUTÓRIAS}

Neste capítulo serão abordados temas de fundamental importância para a compreensão do objeto da presente exploração científica. São “ideias de aproximação” necessárias à fixação do contexto e do conceito do princípio da impessoalidade e do alcance de sua projeção nas decisões administrativas.

Parte-se da consideração de que, no ambiente do neoconstitucionalismo, ou melhor, no do pós-positivismo, em que os princípios dispõem de força normativa e merecem aplicação concreta, o princípio da impessoalidade, extraído do texto constitucional, fundamenta um sem-número de decisões administrativas, mesmo sem a intermediação de leis. Há que frisar exageros hermenêuticos e consequentes injustiças por derivação de aplicação desmesurada do princípio.

\subsection{Pós-positivismo e neoconstitucionalismo}

Comunga-se do entendimento revelado por Luís Roberto Barroso ${ }^{1}$ de que o direito constitucional contemporâneo só pode ser bem compreendido a partir dos valores e da ética, deve ser lido pelas lentes da filosofia moral. Tal concepção é própria do pós-positivismo, sendo tributária da virada filosófica do direito constitucional e (por que não?) da virada kantiana do direito em geral.

Segundo Barroso, na pós-modernidade deparamos com o colapso dos projetos emancipatórios abrangentes, com a fragmentação de ideias e com uma onda de pragmatismo. A globalização tornou-se palavra de ordem, e o Estado soberano tradicional enfrenta adversidades externas - com a mitigação da ideia de soberania em face do direito comunitário e do direito internacional - e internas, com o questionamento de sua capacidade gerencial, assim como de agente econômico e social eficiente.

No quadro de erosão da dogmática tradicional do direito constitucional, cujos traços marcantes eram o formalismo e o positivismo, ganhou relevo a teoria crítica do direito², de base marxista, responsável, em grande medida, pela desmistificação do conhecimento con-

\footnotetext{
${ }^{1}$ O Novo Direito Constitucional Brasileiro: contribuições para a construção teórica e prática da jurisdição constitucional no Brasil. Belo Horizonte: Fórum, 2012, p. 99 e seguintes.

${ }^{2}$ Para Barroso (O Novo Direito Constitucional Brasileiro..., p. 110): “(...) sob a designação genérica de teoria crítica do direito, abriga-se um conjunto de movimentos e de ideias que questionam o saber jurídico tradicional na maior parte de suas premissas: cientificidade, objetividade, neutralidade, estabilidade, completude. Funda-se na constatação de que o Direito não lida com fenômenos que se ordenem independentemente da atuação do sujeito, seja o legislador, o juiz ou o jurista. Este engajamento entre sujeito e objeto
} 
vencional, que encobria, sob o discurso da imparcialidade do direito, forte carga ideológica em favor do status quo.

A teoria crítica, conquanto consistente, não logrou a substituição completa da dogmática jurídica legatária do Século XIX. Foi preciso “superar a visão cética e desconstrutiva da teoria crítica para redefinir o lugar do direito como um espaço de luta relevante-ainda que limitado - para o avanço social”.

A partir das insuficiências do jusnaturalismo ${ }^{3}$ e do positivismo jurídico ${ }^{4}$, ganhou contorno o pós-positivismo, e com ele a crença na normatividade dos princípios. E a ideia de justiça passou a fazer parte da essência do discurso jurídico ${ }^{5}$.

Por pós-positivismo deve ser compreendido um novo contexto constitucional em marcha de edificação. Como assinala Barroso, "é a designação provisória e genérica de um ideário difuso, no qual se incluem a definição da relação entre valores, princípios e regras, aspectos da chamada nova hermenêutica e a teoria dos direitos fundamentais”.

compromete a pretensão científica do direito e, como consequência, seu ideal de objetividade, de um conhecimento que não seja contaminado por opiniões, preferências, interesses e preconceitos”.

${ }^{3}$ Ensina Barroso (O Novo Direito Constitucional Brasileiro..., p. 114) que o termo jusnaturalismo identifica uma das principais correntes filosóficas que tem acompanhado o Direito ao longo dos séculos, fundada na existência de um direito natural. Para o autor: "sua ideia básica consiste no reconhecimento de que há, na sociedade, um conjunto de valores e de pretensões legítimas que não decorrem de uma norma jurídica emanada do Estado, isto é, independem do direito positivo. Esse direito natural tem validade em si, legitimado por uma ética superior, e estabelece limites a própria norma estatal. Tal crença contrapõe-se a outra corrente filosófica de influência marcante, o positivismo jurídico (...)”.

${ }^{4}$ Para Barroso (O Novo Direito Constitucional Brasileiro..., p. 118-119): “o positivismo jurídico foi a importação do positivismo filosófico para o mundo do Direito, na pretensão de criar-se uma ciência jurídica com características análogas a ciência exatas e naturais. A busca de objetividade científica, com ênfase na realidade observável e não na especulação filosófica, apartou o Direito da moral e dos valores transcendentes. Direito é norma, ato emanado do Estado com caráter imperativo e força coativa. A ciência do Direito, como todas as demais, deve fundar-se em juízos de fato, que visam ao conhecimento da realidade, em não em juízos de valor, que representam uma tomada de posição diante da realidade. Não é no âmbito do Direito que se deve travar a discussão acerca de questões como legitimidade e justiça".

${ }^{5}$ Como assinala Barroso (O Novo Direito Constitucional Brasileiro..., p. 119-120): “o positivismo pretendeu ser uma teoria do direito, na qual o estudioso assumisse uma atitude cognoscitiva (de conhecimento), fundada em juízos de fato. Mas resultou sendo uma ideologia, movida por juízos de valor, por ter se tornado não apenas um modo de entender o direito, como também de querer o Direito. O fetiche da lei e o legalismo acrítico, subprodutos do positivismo jurídico, serviam de disfarce para autoritarismos de matizes variados. A ideia de que o debate acerca da justiça se encerrava quando da positivação da norma tinha um caráter legitimador da ordem estabelecida. Qualquer ordem”.

${ }^{6}$ O Novo Direito Constitucional Brasileiro..., p. 120-121. Para o Autor: “o Direito, a partir da segunda metade do século XX, já não cabia mais no positivismo jurídico. A aproximação quase absoluta entre Direito e norma e sua rígida separação da ética não correspondiam ao estágio do processo civilizatório e as ambições dos que patrocinavam a causa da humanidade. Por outro lado, o discurso científico impregnava o Direito. Seus operadores não desejavam o retorno puro e simples a jusnaturalismo, aos fundamentos vagos, abstratos ou metafísicos de uma razão subjetiva. Nesse contexto, o pós-positivismo não surge com o ímpeto da desconstrução, mas como uma superação do conhecimento convencional. Ele inicia sua trajetória guardando deferência relativa ao ordenamento jurídico, mas nele introduzindo as ideias de justiça e legitimidade. $O$ constitucionalismo moderno promove, assim, uma volta aos valores, uma reaproximação entre ética e Direito". 
No pós-positivismo, valores (advindos de textos religiosos, filosóficos ou jusnaturalistas) condensam-se em princípios. E os princípios, agasalhados pelo texto constitucional, explícita ou implicitamente, revestem-se de normatividade $e^{7}$.

Gustavo Zagrebelsky ${ }^{8}$ ensina que a superação do “Estado de direito legislativo”, isto é, aquele em que havia a supremacia do Poder Legislativo, trouxe importantes consequências. E as “separações” da “lei”, seja em relação ao “direito”, seja em relação à “justiça”, dotaram de enorme relevância a distinção entre regras e princípios, não desconhecida no passado, mas que hoje, no Estado constitucional, deve ser muito mais valorizada.

Em sua obra "Direito dúctil”, Zagrebelsky9 ${ }^{9}$ revela que a literatura para se entender a diferença entre “regras” e “princípios” é muito extensa e constitui, por si, demonstração eloquente do caráter problemático e da relevância desta distinção com importância crescente. A seu ver, se o direito atual está composto de regras e princípios, cabe observar que normas legislativas normalmente são regras, enquanto que normas constitucionais sobre direitos e justiça são normalmente princípios. Por isso, distinguir os princípios das regras significa, em grande medida, distinguir “Constituição” e “lei”.

Na visão do constitucionalista italiano, quando a lei estabelece que os trabalhadores em greve devem garantir serviços públicos essenciais, está-se diante de uma regra, ao passo que quando a Constituição diz ser a greve um direito dos trabalhadores, está-se diante de um princípio. Sucede que a Constituição, além de princípios, contém regras. Assim, à luz do ordenamento jurídico italiano, quando se afirma que a detenção deve ser confirmada por um juiz no prazo de 48 (quarenta e oito) horas, está-se na presença de uma regra, mas quando se diz que a liberdade pessoal é direito inviolável, anuncia-se um princípio.

O mesmo raciocínio é desenvolvido por Virgílio Afonso da Silva ${ }^{10}$, com base nos estudos de Alexy, ao qualificar como “regras” os “princípios” do nulla poena sine lege, da legalidade e da anterioridade, entre outros.

\footnotetext{
${ }^{7}$ No pós-positivismo, como assinala Barroso (O Novo Direito Constitucional Brasileiro..., p. 122-123): “os princípios constitucionais, portanto, explícitos ou não, passam a ser a síntese dos valores abrigados no ordenamento jurídico. Eles espelham a ideologia da sociedade, seus postulados básicos, seus fins. Os princípios dão unidade e harmonia ao sistema, integrando suas diferentes partes e atenuando tensões normativas. De parte isso, servem de guia para o intérprete, cuja atuação deve pautar-se pela identificação do princípio maior que rege o tema apreciado, descendo do mais genérico ao mais específico, até chegar á formulação da regra concreta que vai reger a espécie"..

${ }^{8}$ El derecho dúctil: Ley, derechos, justicia. 6 ${ }^{a}$ Edición. Madrid: Editorial Trotta, 2005, p. 109.

${ }^{9}$ El derecho dúctil..., p. 109-110.

${ }^{10}$ A constitucionalização do direito: os direitos fundamentais nas relações entre particulares. São Paulo: Malheiros, 2005, p. 36.
} 
Para Zagrebelsky, as diferenças entre princípios e regras podem ser assim anunciadas, sinteticamente:

a) Somente os princípios desempenham um papel propriamente constitucional, “constitutivo” da ordem jurídica. As regras, ainda que escritas na Constituição, não são mais do que leis reforçadas por sua forma especial. As regras se esgotam em si mesmas, não tendo força constitutiva fora do que elas mesmas significam;

b) Só às regras são aplicáveis os variados métodos de interpretação jurídica que têm por objeto a linguagem do legislador. Nas formulações dos princípios, há pouco a ser interpretado. Em geral, seu significado linguístico é autoevidente. As fórmulas de princípios consubstanciam expressões um tanto quanto banais, mas nada menos veneráveis, que remetem a tradições históricas, contextos de significado etc. Mais do que interpretados por meio da análise de linguagem, os princípios devem ser entendidos em seu ethos. Em poucas palavras, às regras se obedece e, por isso, é importante determinar os preceitos que o legislador estabelece por meio das formulações que as contêm; aos princípios se presta adesão e, por isso, é importante compreender o mundo dos valores, as grandes opções de cultura jurídica;

c) As regras nos proporcionam os critérios de nossas ações, dizem como devemos e podemos atuar em determinadas situações específicas previstas por elas mesmas. Os princípios, diretamente, nada nos dizem a esse respeito, mas nos proporcionam critérios para tomarmos posição diante de situações concretas, não previamente determinadas. Princípios geram atitudes favoráveis ou contrárias, de adesão ou apoio ou de dissenso e repulsa a tudo o que possa estar implicado em sua salvaguarda em cada caso concreto, já que carecem de pressupostos de fato. Nas regras, diferentemente, só podem alcançar algum significado operativo quando relacionados a algum caso concreto. Seu significado não pode ser predeterminado, em abstrato, mas tão só nos casos concretos. Apenas num caso concreto pode ser entendido o alcance preciso de um princípio;

d) Somente as regras podem ser observadas e aplicadas mecânica e passivamente. Se o direito fosse composto apenas de regras, não seria insensato pensar na aplicação mecânica de simples correlação entre os fatos e a norma.

Para os fins do trabalho, impõe-se remarcar a importância dos princípios, posto que a 
respectiva ideia central é tratar, especificamente, da aplicação de um deles, o da impessoalidade administrativa.

- Qual é a importância dos princípios?

Zagrebelsky assinala que, segundo uma visão tradicional do positivismo jurídico, os princípios de direito desempenham uma importante função supletiva, integradora ou corretiva das regras jurídicas. Os princípios operariam para aperfeiçoar o ordenamento e entrariam em jogo quando as outras normas não estivessem em condições de desenvolver plenamente sua função.

Esse autor menciona que não há regra escrita que não apresente margem de ambiguidade ou que não se preste a alguma interpretação evasiva; que não são todos os casos que requerem uma regulação jurídica que sempre encontre a regra adequada, e que, frequentemente - e muito mais nos caóticos ordenamentos jurídicos da época atual - se produzem colisões entre os conteúdos das normas jurídicas (regras contra regras ou regras contra princípios) nem sempre fáceis de resolver com os instrumentos convencionais de eliminação de antinomias que os próprios ordenamentos preveem (prevalência da norma mais recente, de maior grau, mais especial etc.). Nestes casos - para superar as dúvidas interpretativas, colmatar as lacunas e resolver contradições de outros modos não solucionáveis - entrariam em ação os princípios de direito, com sua força diretiva tanto mais vinculante quanto venham reconhecidos na Constituição. E isso já é uma forma de assinalar um importante papel para os princípios, porque em todos os casos referidos, de carência de uma regra ou de somente uma regra, as teses positivistas mais restritivas se limitavam a afirmar a ausência de direito e a liberdade do intérprete para recorrer a critérios morais, em todo caso extrajurídicos. Aqui já não estaríamos diante de uma interpretação; abre-se margem para uma função criativa da jurisprudência.

São precisas as palavras de Zagrebelsky. Concebidos como aperfeiçoamento do ordenamento jurídico, os princípios desempenham uma função na prática do direito. Todavia, esta concepção não só é parcial, como também encerra a contradição intrínseca de sustentar que as normas de maior intensidade de conteúdo - os princípios - têm função puramente acessória em relação às outras normas cuja intensidade é menor - as regras. Isto deriva do persistente prejuízo de pensar que as verdadeiras normas são as regras, enquanto os princípios são um plus, só necessários como válvulas de segurança do ordenamento. Uma vez mais o positivismo revela-se uma ideologia distorcida no campo jurídico. 
Se considerarmos seriamente a diferença estrutural entre princípios e regras, é possível concluir pela impossibilidade de redução do alcance dos princípios a uma mera função acessória das regras. Os princípios não impõem uma ação conforme o pressuposto normativo, como ocorre com as regras, mas sim, como antes explicitado, uma tomada de posição conforme seu ethos em todas as situações concretas da vida. Os princípios não esgotam sua eficácia como apoio às regras jurídicas; colocam uma razão autônoma de ser frente à realidade.

A realidade, ao se colocar em contato com o princípio, se vivifica e, assim, adquire valor. Ao invés de se apresentar como matéria inerte, objeto passivo da aplicação de regras, a realidade iluminada pelos princípios aparece revestida de qualidades jurídicas próprias. O valor se incorpora ao fato e impõe a adoção de tomadas de posições jurídicas em relação a ele (ao legislador, à jurisprudência, à administração, aos particulares e, em geral, aos intérpretes do direito). O “ser” iluminado pelos princípios ainda não contém em si o “dever ser”, a regra, mas indica ao menos a direção em que se deveria colocar a regra para não contrariar o valor contido no princípio.

A incidência direta dos princípios sobre a realidade, ou seja, a possibilidade de que se confira aos fatos um valor normativo próprio, é algo não só não previsto, como também excluído pelo positivismo jurídico.

A doutrina do positivismo se baseia na mais rígida incomunicabilidade, no mais rígido dualismo entre “ser” e “dever ser” e acusa de incorrer na “falácia naturalista” toda e qualquer concepção que, como aquelas que remetem ao direito natural, pretendem estabelecer uma ponte entre a realidade e o valor, fazendo derivar o atuar do conhecer, a vontade da razão, os juízos de valor dos juízos de fato. O mundo jurídico, que é o mundo do dever ser, isto é, do valor, do atuar e da vontade, seria independente do mundo da realidade, do conhecimento, da razão. Seu critério de validade não seria a verdade, mas a competência. A norma jurídica válida seria aquela proveniente de uma vontade autorizada, com total independência dos conteúdos da mencionada vontade.

Ao princípio da impessoalidade o ordenamento jurídico constitucional atribui importante papel constitutivo da realidade. A ele se espera adesão. Por meio dele são denotados critérios para a tomada de decisões, não só pelos particulares, mas também e, principalmente, por parte do Estado Administração. 


\subsection{Constitucionalização do Direito Administrativo}

Por constitucionalização do direito, entenda-se, como faz Virgílio Afonso da Silva"1 a "irradiação dos efeitos das normas (ou valores) constitucionais aos outros ramos do direito".

Tal irradiação, como explica, é um processo, e, como tal, pode se revestir de variadas formas e pode ser executado por diferentes atores. Dentre os trabalhos sobre o tema, destaca como pioneiras as análises doutrinárias de Gunnar Folke Schuppert e Christian Bumke, de um lado, e a de Louis Favoreau, de outro.

Para Schuppert e Bumke, há cinco formas principais de "constitucionalização do ordenamento jurídico": (1) reforma legislativa; (2) desenvolvimento jurídico por meio da criação de novos direitos individuais e de minorias; (3) mudança de paradigma nos demais ramos do direito; (4) irradiação do direito constitucional - efeito nas relações privadas e deveres de proteção; (5) irradiação do direito constitucional - constitucionalização do direito por meio da legislação ordinária.

Esclarece Virgílio Afonso da Silva ${ }^{12}$ que algumas das fórmulas acima reveladas não podem ser simplesmente importadas para o sistema jurídico brasileiro, tanto porque a Constituição brasileira, em relação ao catálogo de direitos fundamentais, é mais abrangente do que a alemã, quanto porque, no Brasil, não há um antagonismo tão marcado entre jurisdição constitucional e jurisdição ordinária.

Guardadas as diferenças entre os ordenamentos jurídicos cotejados, importa ressaltar, no âmbito da análise Schuppert/Bumke, que a reforma legislativa, ao menos em tese, é a mais efetiva e a menos problemática forma de constitucionalização do direito. Por meio de reformas, mais ou menos abrangentes, é possível “adaptar a legislação ordinária às prescrições constitucionais e, nos casos de constituições de caráter dirigente, realizá-la por meio de legislação"13.

No entanto, o processo de constitucionalização operado pela via da reforma legislativa pode ser demorado. Virgílio Afonso da Silva ${ }^{14}$ lembra-nos da “lentidão com que os princípios da Constituição brasileira de 1988 e as tarefas que ela impõe são concretizados pela legisla-

\footnotetext{
${ }^{11}$ A constitucionalização..., p. 18.

${ }^{12}$ A constitucionalização..., p. 39.

${ }^{13}$ A constitucionalização..., p. 39.

${ }^{14}$ A constitucionalização..., p. 40.
} 
ção ordinária". E isso não é necessariamente um problema de falta de "vontade política”, mas sim, em todo o mundo, “uma característica inerente à lentidão do legislador para se adaptar a novos paradigmas"15.

Luís Roberto Barroso ${ }^{16}$ explica que a constitucionalização do direito está associada “a um efeito expansivo das normas constitucionais, cujo conteúdo material e axiológico se irradia, com força normativa, por todo o sistema jurídico". Desta forma, “os valores, os fins públicos e os comportamentos contemplados nos princípios e regras da Constituição passam a condicionar a validade e o sentido de todas as normas de direito infraconstitucional”.

Para Barroso, a constitucionalização irradia efeitos amplos. Repercute sobre a atuação dos três Poderes, inclusive nas suas relações com os particulares. No seu correto entender, a constitucionalização:

a) Relativamente ao Legislativo:

a.1) Limita sua discricionariedade ou liberdade de conformação na elaboração das leis em geral;

a.2) Impõe-lhe determinados deveres de atuação para a realização de direitos e programas constitucionais;

b) Relativamente ao Poder Judiciário:

b.1) Serve de parâmetro para o controle de constitucionalidade por ele desempenhado (incidental ou por ação direta);

b.2) Condiciona a interpretação de todas as normas do sistema;

c) No tocante à Administração Pública:

c.1) Limita a discricionariedade;

c.2) Impõe deveres de atuação;

c.3) Fornece fundamento de validade para a prática de atos de aplicação direta e imediata da Constituição, independentemente da interposição do legislador ordinário.

Em relação aos particulares, Barroso ${ }^{17}$ assinala que o fenômeno da constitucionalização

\footnotetext{
${ }^{15}$ Segundo Virgílio Afonso da Silva (A constitucionalização..., p. 40-41): “É possível perceber, portanto, que uma mudança de paradigma imposta pela Constituição e uma decorrente necessidade de adaptação da legislação ordinária por imposição constitucional, ainda que configurem, em tese, a forma mais segura e menos controvertida de constitucionalização do direito, não implicam mudanças rápidas quando o paradigma não muda para a sociedade e, também, para os operadores do direito".

${ }^{16}$ A Constitucionalização do direito e suas repercussões no âmbito administrativo. In: ARAGÃO, Alexandre Santos de; MARQUES NETO, Floriano Azevedo (Coord.). Direito administrativo e seus novos paradigmas. Belo Horizonte: Fórum, 2012, p. 32-33.

${ }^{17}$ A constitucionalização..., p. 33.
} 
“estabelece limitações à autonomia da vontade, em domínios como a liberdade de contratar ou o uso da propriedade privada, subordinando-a a valores constitucionais a direitos fundamentais".

Para Barroso ${ }^{18}$, o atual estágio de constitucionalização do direito teve como antecedentes (i) o movimento de aproximação entre constitucionalismo e democracia, (ii) a força normativa da Constituição e (iii) a difusão da jurisdição constitucional ${ }^{19}$. Explica:

"Nos Estados de democratização mais tardia, como Portugal, Espanha e, sobretudo, o Brasil, a constitucionalização do direito é um processo mais recente, embora muito intenso. Verificou-se, entre nós, o mesmo movimento translativo ocorrido inicialmente na Alemanha e em seguida na Itália: a passagem da Constituição para o centro do sistema jurídico. A partir de 1988, e mais notadamente nos últimos cinco ou dez anos, a Constituição passou a desfrutar já não apenas da supremacia formal que sempre teve, mas também de uma supremacia material, axiológica, potencializada pela abertura do sistema jurídico e pela normatividade de seus princípios. Com grande ímpeto, exibindo força normativa sem precedente, a Constituição ingressou na paisagem jurídica do país e no discurso dos operadores jurídicos”.

Tem-se, então, que a Constituição passou a ser a régua interpretativa de todos os ramos jurídicos, fenômeno indicado por parte da doutrina como "filtragem constitucional", consistente, ainda segundo Barroso ${ }^{20}$, “em que toda a ordem jurídica deve ser lida de modo a realizar os valores nela consagrados”. E mais:

“À luz de tais premissas, toda interpretação jurídica é também interpretação
constitucional. Qualquer operação de realização do direito envolve a apli-
cação direta ou indireta da Lei Maior. Aplica-se a Constituição:
a) Diretamente, quando uma pretensão se fundar em uma norma do próprio
texto constitucional. Por exemplo: o pedido de reconhecimento de uma

${ }^{18}$ A constitucionalização..., p. 33.

${ }^{19}$ Esclarece Barroso que o percurso histórico do fenômeno da constitucionalização não se desenvolveu de maneira simultânea ou uniforme em todos os sistemas jurídicos. Para um exame minucioso da evolução do fenômeno no Reino Unido, nos Estados Unidos, na Alemanha, na Itália, na França e também no Brasil, recomendável a leitura integral de seu artigo doutrinário “A constitucionalização do direito e suas repercussões no âmbito administrativo".

${ }^{20}$ A Constitucionalização..., p. 43. 
imunidade tributária (CF, art. 150, VI) ou o pedido de nulidade de uma prova obtida por meio ilícito (CF, art. 5, LVI);

b) Indiretamente, quando uma pretensão se fundar em uma norma infraconstitucional, por duas razões:

(i) Antes de aplicar a norma, o intérprete deverá verificar se ela é compatível com a Constituição, porque, se não for, não deverá fazê-la incidir. Esta operação está sempre presente no raciocínio do operador do direito, ainda que não seja por ele explicitada;

(ii) Ao aplicar a norma, o intérprete deverá orientar seu sentido e alcance à realização dos fins constitucionais”.

Barroso assinala que o mais decisivo para a constitucionalização do Direito Administrativo, em especial, foi a incidência nos seus domínios dos princípios constitucionais, não apenas os específicos, mas sobretudo os de caráter geral, que se irradiam por todo o sistema jurídico. A seu ver, a partir da centralidade da dignidade humana e da preservação dos direitos fundamentais, alterou-se a qualidade das relações entre Administração e administrado, com superação ou reformulação de paradigmas tradicionais, dentre os quais:

a) A redefinição da ideia de supremacia do interesse público sobre o interesse privado;

b) A vinculação do administrador à Constituição e não apenas à lei ordinária;

c) A possibilidade de controle judicial do mérito administrativo.

Contudo, a constitucionalização excessiva traz riscos sistêmicos. E Barroso aponta duas consequências negativas do fenômeno, uma de natureza política, a saber, o esvaziamento do poder das maiorias, pelo engessamento da legislação ordinária, e outra de natureza metodológica, justamente o decisionismo judicial, potencializado pela textura aberta e vaga das normas constitucionais. E, em meio aos esforços para coibir as duas disfunções referidas, e porque a Constituição "não pode pretender ocupar todo o espaço jurídico em um Estado Democrático de Direito”, o autor aponta dois parâmetros preferenciais a serem seguidos pelos exegetas:

a) Preferência pela lei: onde tiver havido manifestação inequívoca e válida do legislador, deve ela prevalecer, abstendo-se o juiz ou o tribunal de produzir solução diversa que lhe pareça mais conveniente;

b) Preferência pela regra: onde o constituinte ou o legislador tiver atuado, mediante a edição de uma regra válida, descritiva da conduta a ser seguida, deve ela preva- 
lecer sobre os princípios de igual hierarquia, que por acaso pudessem postular incidência na matéria ${ }^{21}$.

Alexandre Santos de Aragão ensina que para reduzir a esfera de subjetividade do juiz e do administrador e evitar a blindagem de determinados conceitos, ainda que com certos parâmetros estabelecidos pela doutrina, "não se pode aplicar a ponderação imoderadamente como técnica decisória quando houver REGRA expressa e razoável sobre a matéria, ainda mais quando a própria regra integrar a Constituição”. Assim:

\begin{abstract}
“A deferência aos enunciados normativos é pertinente e se justifica não por mero formalismo, mas porque a ponderação já foi realizada quando da edição da norma, pelo constituinte (quando se tratar de norma constitucional) ou pelo legislador (quando se tratar de norma infraconstitucional), e até mesmo pela Administração Pública. Logo, utilizar ponderação para decidir nos casos em que já há regra tutelando determinado direito seria reponderar valores já ponderados. ${ }^{22}$
\end{abstract}

Para Aragão ${ }^{23}$, longe de proclamarem um desapego aos valores ou um abandono da ponderação como técnica decisória, em um Estado de Democrático de Direito, “é preciso que sejam levadas a sério pelos órgãos julgadores e aplicadores do direito as ponderações previamente realizadas pelo legislador ou pelo constituinte, expressas por meio do texto normativo”. Ou, então, como observa Barroso, na mesma linha de pensamento, propugnando a preferência pela lei, para concretizar os princípios da separação de poderes, da segurança jurídica e da isonomia, o reconhecimento de que se pode atuar criativamente em determinadas situações não confere autorização de que haja sobreposição ao legislador, “a menos que este tenha incorrido em inconstitucionalidade. Vale dizer: havendo lei válida a respeito, é ela que deve prevalecer" 24 .

Tais balizas são importantes porque a impessoalidade administrativa está presente no texto constitucional e na legislação infraconstitucional, de variadas formas e com muitas

${ }^{21}$ Tudo conforme Luís Roberto Barroso (A constitucionalização..., p. 59-61).

${ }^{22}$ Subjetividade judicial na ponderação de valores - alguns exageros na adoção indiscriminada da teoria dos princípios. In: Almeida, Fernando Dias Menezes de; MARQUES NETO, Floriano de Azevedo; MIGUEL, Luiz Felipe Hadlich; SCHIRATO, Vitor Rhein (Coord.). Direito público em evolução: estudos em homenagem à Professora Odete Medauar. Belo Horizonte: Fórum, 2013, p. 71-72.

${ }^{23}$ Subjetividade..., p. 72.

${ }^{24}$ A constitucionalização..., p. 61. 
nuances. No texto constitucional, às vezes é regra e às vezes é princípio. E na lei também. Há leis que propugnam a aplicação da impessoalidade num sentido mais abstrato e outras que lhe dão delimitação mais concreta.

E num entrechoque de comandos normativos, no momento decisório, o administrador-julgador (decisor) deverá considerar tudo isto, priorizando as normas mais específicas, as constitucionais primeiro, em detrimento das mais gerais, sem o que incidirá em subjetivismo incompatível com a própria noção de impessoalidade.

\subsection{Julgamento por princípios}

Julgar com princípios não é tarefa fácil. Todavia, o julgamento por princípios é traço marcante da contemporaneidade jurídica.

Inúmeras situações concretas são equacionadas pelo Poder Judiciário e também pela Administração Pública a partir da invocação pura e simples de princípios jurídicos, notadamente os constitucionais.

Repete-se, como um mantra, que os princípios têm força normativa e dispõem de eficácia concreta.

Mas o que é um princípio? Até onde se pode chegar com ele? Na atualidade, deparamos com condenáveis exageros. No contexto do pós-positivismo, uma das maneiras mais comuns de conceituar um princípio se faz a partir da sua questionável diferenciação com as regras.

O presente trabalho não comporta um desenvolvimento exaustivo da diferenciação, mas é óbvio que tratar do princípio da impessoalidade nas decisões administrativas sem uma noção aceitável de princípio é algo cientificamente falho e reprovável. Forçoso, pois, retomar em parte as ideias do item 1.1 infra.

Para Barroso ${ }^{25}$, como corolário da adoção do pós-positivismo (onde a Constituição passa a ser encarada como um sistema aberto permeável a valores jurídicos suprapositivos, exercendo papéis centrais as ideias de justiça e a realização de direitos fundamentais) “ $a$ distinção qualitativa entre regras e princípios é um dos pilares da moderna dogmática constitucional, indispensável para a superação do positivismo legalista, onde as normas se cingiam a regras jurídicas”.

No trato do tema, segundo o mesmo autor ${ }^{26}$, a mudança de paradigma nessa matéria

${ }^{25}$ O Novo Direito Constitucional Brasileiro..., p. 123.

${ }^{26}$ O Novo Direito Constitucional Brasileiro..., p. 123. 
deve especial tributo à sistematização de Ronald Dworkin, já que a respectiva elaboração acerca dos diferentes papéis desempenhados por regras e princípios “ganhou curso universal e passou a constituir o conhecimento convencional na matéria”.

Nas palavras de Barroso, "regras são proposições normativas aplicáveis sob a forma de tudo ou nada (all or nothing)”, ao passo que “os princípios contêm, normalmente, uma carga valorativa, um fundamento ético, uma decisão política relevante, e indicam uma direção a seguir”. Daí porque, no caso das regras, “o comando é objetivo e não dá margem a elaborações mais sofisticadas acerca de sua incidência”, extraindo-se daí: (i) uma regra só deixará de incidir sobre a hipótese de fato que contempla se for inválida, se houver outra mais específica ou se não estiver em vigor; (ii) dá-se sua aplicação, predominantemente, mediante subsunção. Já no caso dos princípios:

\footnotetext{
“(...) em uma ordem pluralista, existem outros princípios que abrigam decisões, valores ou fundamentos diversos, por vezes contrapostos. A colisão de princípios, portanto, não só é possível, como faz parte da lógica do sistema, que é dialético. Por isso a sua incidência não pode ser posta em termos de tudo ou nada, de validade ou invalidade. Deve-se reconhecer aos princípios uma dimensão de peso ou importância. À vista dos elementos do caso concreto, o intérprete deverá fazer escolhas fundamentadas, quando se defronte com antagonismos inevitáveis (...). A aplicação dos princípios se dá, predominantemente, mediante ponderação.”
}

Observa Marcelo Neves ${ }^{27}$ que a tese de Dworkin surgiu como uma contundente crítica ao positivismo analítico de Hart. Para Hart, o ordenamento jurídico, formado por regras primárias de conduta e regras secundárias de organização, deixa ao juiz um campo de discricionariedade em que a escolha por uma das alternativas oferecidas não é suscetível de um enquadramento em regras, o que implicaria a textura aberta do direito. Para Dworkin, nas situações em que o caso não pode ser solucionado por regras, devem incidir os princípios jurídicos, fundados moralmente, que impediriam todo e qualquer espaço ou poder discricionário para o juiz Hércules.

Para Marcelo Neves ${ }^{28}$, no entanto, ocorre justamente o contrário. Alude ao ser mitológico com forma de serpente, hálito mortífero e muitas cabeças, as quais se regeneravam à

${ }^{27}$ Entre Hidra e Hércules: princípios e regras constitucionais como diferença paradoxal do sistema jurídico. São Paulo: Editora WMF Martins Fontes, 2013, p. XVI-XVII).

${ }^{28}$ Obra citada, p. XVII e seguintes. 
medida em que eram decepadas, os princípios têm caráter de Hidra e não prescindem das regras para o equacionamento dos casos jurídicos. Enquanto “os princípios abrem o processo de concretização jurídica, instigando à maneira de Hidra, problemas argumentativos, as regras tendem a fechá-lo, absorvendo a incerteza que caracteriza o início do procedimento de aplicação normativa".

A questão é mais relevante porque, na solução de muitos casos concretos interagem regras e princípios, sem que exista hierarquia linear entre eles ${ }^{29}$. Na sua visão, por um lado as regras dependem do balizamento ou da construção a partir de princípios. Por outro, estes só ganham significado prático se encontram correspondência em regras que lhes deem densidade e relevância para a solução do caso, somando-se a isso o fato de que a relação nem sempre é harmônica e, muitas vezes, é até mesmo conflituosa.

Por isso mesmo é que, para Marcelo Neves ${ }^{30}$, “a tendência a superestimar os princípios em detrimento das regras torna altíssimo o grau de incerteza e pode descambar em insegurança incontrolável”. Em contrapartida, “a tendência a superestimar as regras em detrimento dos princípios torna o sistema excessivamente rígido para enfrentar problemas sociais complexos”.

Tem-se como correta, então, a constatação inicial de Barroso de que o chamado póspositivismo afigura-se como obra inacabada. Como qualquer reação a um estado insuportável de coisas, pode descambar para exageros.

Para Jorge Galvão ${ }^{31}$, em interessante obra sobre os riscos (e exageros!) do chamado neoconstitucionalismo para o Estado de Direito:

\section{“(...)}

Se a constitucionalidade das normas for constantemente questionada pelos

\footnotetext{
${ }^{29}$ Para Marcelo Neves (obra citada, p. XIX): “só as regras viabilizam a transformação da incerteza do ponto de partida à certeza obtida com a decisão. Só as regras levam a redução de complexidade ou à seleção suscetível de determinar a solução do caso". Não obstante, prossegue: "as regras, na sua vinculação mais direta à situação concreta, são pouco adequadas a absorver a alta complexidade dos chamados 'casos difíceis'. Diante do grau reduzido de flexibilidade, de sua tendência ao rigor hercúleo, impõe-se às regras o balizamento por princípios, para que se enfrente a alta complexidade dos problemas a serem resolvidos. Poder dizer que, no processo de concretização normativa, enquanto os princípios jurídicos transformam a complexidade desestruturada do ambiente do sistema jurídico (valores, representações morais, ideologias, modelos de eficiência, etc.) em complexidade estruturável do ponto de vista normativo jurídico, as regras jurídicas reduzem seletivamente a complexidade já estruturável por força dos princípios, convertendo-a em complexidade juridicamente estruturada, apta a viabilizar a solução do caso. São dois polos normativos fundamentais no processo de concretização jurídica, cada um deles se realimentando circularmente na cadeia argumentativa orientada à decisão do caso".

${ }^{30}$ Obra citada, p. XX.

${ }^{31}$ O Neoconstitucionalismo e o Fim do Estado de Direito. São Paulo: Saraiva, 2014, p. 46.
} 
intérpretes - utilizando-se princípios e ponderação como técnica - elas perderão sua capacidade de guiar as condutas dos indivíduos, além de dar ensejo a uma atuação mais subjetiva por parte dos agentes públicos. Explicase: ao se constatar que os princípios constitucionais se irradiam por todo o ordenamento jurídico, torna-se possível argumentar, em qualquer caso, por mais ordinário que seja, a favor do resultado que se considera o mais correto, uma vez que o texto fundamental alberga uma infinidade de valores contraditórios em sua essência”.

Impende, pois, recolocar o julgamento por princípios no seu devido lugar. E se se pretende julgar (bem) com o princípio constitucional da impessoalidade, é preciso ter bastante cuidado. Uma aplicação altamente subjetiva do princípio, para fins decisórios, pode variar justamente para o mal que se pretende evitar: a impessoalidade às avessas.

\subsection{Relevância dos princípios para o Direito Administrativo}

Carlos Ayres Britto ${ }^{32}$, ao comentar o art. 37, caput, da Constituição da República, assinala que:

\footnotetext{
“(...), peculiarizando-se por atuar mediante órgãos e entidades, cumulativamente, e pelo desempenho da atividade administrativa enquanto meio e enquanto fim, indiferentemente, o Poder Executivo termina sendo a parte elementar do Estado que mais se faz presente no dia a dia da população. Noutros termos, é graças à ontologia e funcionalidade do Poder Executivo que o Estado-administração, mais que o Estado-legislação e o Estado-jurisdição, passa a compor o cotidiano de cada indivíduo e da população por inteiro”.
}

A despeito de sua já anunciada conceituação controvertida na doutrina especializada, não se discute a importância dos princípios para o Direito Administrativo.

Para Odete Medauar, no âmbito de um Direito Administrativo não codificado e de elaboração recente, os princípios revestem-se de grande importância porque auxiliam na compreensão e na consolidação de seus institutos. Além disso, muitas normas são editadas em vista de circunstâncias de momento, resultando em multiplicidade de textos, sem reunião

${ }^{32}$ Comentários à Constituição do Brasil. J.J. Gomes Canotilho... [et al.]. São Paulo: Saraiva/Almedina, 2013, p. 818 e seguintes. 
sistemática. Daí a importância dos princípios “sobretudo para possibilitar a solução de casos não previstos, para permitir melhor compreensão dos textos esparsos e para conferir certa segurança aos cidadãos quanto à extensão dos seus direitos e deveres”33.

A releitura do Direito Administrativo, desde a força normativa dos princípios constitucionais, que é própria do neoconstitucionalismo, impõe desafios ${ }^{34}$. E o primeiro deles diz com a reestruturação da ideia de legalidade, elementar na edificação da matéria.

Sobre os contornos contemporâneos da noção de legalidade, cobertura para toda e qualquer ação estatal, leciona Odete Medauar ${ }^{35}$ :

\begin{abstract}
"Embora permaneçam o sentido de poder objetivado pela submissão da Administração à legalidade e o sentido de garantia, certeza e limitação do poder, registrou-se evolução da ideia genérica de legalidade. Alguns fatores dessa evolução podem ser apontados, de modo sucinto. A própria sacralização da legalidade produziu um desvirtuamento denominado legalismo ou legalidade formal, pelo qual as leis passaram a ser vistas como justas por serem leis, independentemente do conteúdo. Outro desvirtuamento: formalismo excessivo dos decretos, circulares e portaria, com exigências de minúcias irrelevantes. Por outro lado, com as transformações do Estado, o Executivo passou a predominar sobre o Legislativo; a lei votada pelo Legislativo deixou de expressar a vontade geral para ser vontade de maiorias parlamentares, em geral controladas pelo Poder Executivo. Este passou a ter ampla função normativa, como autor de projetos de lei, como legislador por delegação, como legislador direto (por exemplo, ao editar medidas provisórias), como emissor de decretos, portarias e circulares que afetam direitos. Além do mais, expandiram-se e aprimoraram-se os mecanismos de controle de constitucionalidade das leis.”
\end{abstract}

\footnotetext{
${ }^{33}$ Direito Administrativo Moderno. $18^{\mathrm{a}}$ ed. São Paulo: Malheiros, 2014, p. 128-129.

${ }^{34}$ Jaime Rodríguez-Arana Muñoz (La Vuelta al Derecho Administrativo - A vueltas con lo privado y lo publico. In: Revista de Derecho de la Universidad de Montevideo, $n^{0}$ 7, 2005, p. 89 a 102) ensina que a caracterização do Direito Administrativo a partir da perspectiva do Direito Constitucional impõe a revisitação de antigos dogmas e critérios, dogmas e critérios esses que por haverem prestado grandes serviços devem ser substituídos de forma serena e moderada pelos princípios que presidem o novo Estado social e democrático de Direito. Na opinião do autor, a garantia do interesse geral é a principal tarefa do Estado e, em função dele, o Direito Administrativo deve levar em conta tal realidade e adequar-se, institucionalmente, aos novos tempos, pois, do contrário, perderá a ocasião de cumprir a função que justifica a sua existência, qual seja a de melhor ordenação e gestão da atividade pública com apego à justiça. Para ele, não se trata de banir elementos essências do Direito Administrativo, mas sim de repensá-los à luz do ordenamento constitucional. Para Rodríguez-Araña, o que está sendo modificado, insiste-se, é o papel do interesse público que, a partir dos postulados do pensamento aberto, plural e dinâmico, impõe a adequação das instituições tradicionais à realidade constitucional.

${ }^{35}$ Direito Administrativo Moderno. $18^{\mathrm{a}}$ ed. São Paulo: Malheiros, 2014, p. 141-142.
} 
Ante tal contexto, buscou-se assentar o princípio da legalidade em bases valorativas, sujeitando as atividades da Administração não somente à lei votada pelo Legislativo, mas também aos preceitos fundamentais que norteiam todo o ordenamento. A Constituição de 1988 determina que todos os entes e órgãos da Administração obedeçam ao princípio da legalidade (caput do art. 37); a compreensão desse princípio deve abranger a observância da lei formal, votada pelo Legislativo, e também aos preceitos decorrentes de um Estado Democrático de Direito, que é o modo de ser do Estado brasileiro, conforme reza o art. $1^{\circ}$, caput, da Constituição; e, ainda, deve incluir a observância dos demais fundamentos e princípios de base constitucional.

A República Federativa do Brasil, nos termos do art. $1^{\text {o }}$ da Constituição de 1988, constitui-se em Estado Democrático de Direito e tem como fundamento expresso, dentre outros de altíssima significação, a dignidade da pessoa humana (inciso III). Por conseguinte, a Administração Pública e o Direito Administrativo, para além de uma legalidade meramente semântica, têm a obrigação constitucional de, captando a ideologia subjacente à Carta Política Maior, dar concretude à ideia de que o ser humano ocupa papel de destaque maior na pauta de preocupações do Estado.

Enquanto destinatário maior das ações administrativas, o administrado não pode ser prejudicado por interpretações que ensejem a redução do alcance da esfera jurídica protetora da dignidade humana de que é titular. E devem ser prontamente refutadas interpretações que coloquem a dignidade humana do administrado em plano secundário.

Por imperativo constitucional, trata-se de considerar o administrado em sua condição humana, como começo e fim das preocupações e das ações do Estado-administrador que, relembre-se, nada mais é do que o produto das aspirações da Constituição dirigido à preservação dos direitos e das garantias fundamentais do ser humano.

A obrigatória aderência do Direito Administrativo à nova principiologia constitucional impõe a travessia de um Direito Administrativo conservador (tanto quanto autoritário) para o Direito Administrativo democrático, consensual e participativo. E daí, sem escalas, ao Direito Administrativo da Justiça Material, tendo na dignidade administrativa o alvo a ser mirado e o horizonte a ser descortinado ${ }^{36}$.

\footnotetext{
${ }^{36}$ De acordo com Gustavo Justino de Oliveira (Direito Administrativo Democrático. Belo Horizonte: Fórum, 2010, p. 164), "insta observar que a junção da noção de democracia à de Estado de direito, muito mais do que estabelecer um qualificativo do modo de ser do Estado, é responsável pela atribuição aos cidadãos do direito de participação nas decisões estatais".
} 
Na visão de Odete Medauar, a necessária participação administrativa descortina-se como técnica retificadora do distanciamento da organização administrativa em relação ao cidadão e à realidade ${ }^{37}$.

Também tem razão Gustavo Binenbojm ${ }^{38}$ quando assevera que a teoria do direito administrativo brasileiro sempre pareceu inconsistente do ponto de vista lógico-conceitual; autoritária, do ponto de vista político-jurídico; e ineficiente, de um ponto de vista pragmático. Dentre as inquietações referidas pelo autor, destaca-se a relacionada à pergunta "como enquadrar um princípio de supremacia de interesse público sobre os interesses particulares em um ambiente 'reconstitucionalizado', no qual se proclama a centralidade não do Estado ou da sociedade, mas do sistema de direitos fundamentais?”

Nesta perspectiva teórica, o sistema de direitos fundamentais e o princípio democrático cumprem papel fundamental tanto na estruturação e no funcionamento do Estado Democrático de Direito como da própria administração pública.

Não é apenas desejar uma “boa administração”, na expressão de Guido Falzone ${ }^{39}$, no sentido de um princípio regente da atividade administrativa no contexto contemporâneo, de administração pública leal, proba, justa, de boa-fé, que não surpreende o administrado com ações e inações despidas de razão e bom senso, mas sim ir além, dignificar o ser humano administrado nos seus posicionamentos mais cotidianos numa espécie de vocação sistêmica preventiva, própria de uma deontologia que previne o arbítrio e, por conseguinte, coroa a legalidade substancial.

Tratar o administrado como objeto inanimado de direito, como massa de manobra, é comportamento a ser erradicado em se tratando de Estado de Democrático de Direito. Ao contrário, o administrado deve ser visto com o devido respeito constitucional, como sujeito e destinatário de direitos, como protagonista de uma relação jurídica que se constrói na específica perspectiva de sua emancipação.

\footnotetext{
${ }^{37}$ Administração Pública ainda sem democracia. Problemas Brasileiros, v. 23, n. 256, p. 37-41, 44-53, mar./ abr.1986.

${ }^{38}$ Uma teoria do direito administrativo: direitos fundamentais, democracia e constitucionalização. $3^{\mathrm{a}}$ ed. Rio de Janeiro: Renovar, 2014, p. 2.

${ }^{39}$ Il Dovere di Buona Amnistrazione - Parte I. Milão: Giuffrè, 1953. Para o autor italiano (tradução livre), “Quando se fala em 'boa administração' somos induzidos a pensar, à primeira vista, que esta não se confunde com a noção de má administração e nem com a ideia de uma ótima administração, mas corresponde a uma categoria intermediária, constituída sobre um critério médio. Todavia, para que se possa entender tal expressão, deve-se, sobretudo, construir hipoteticamente um quadro daquilo que é de fato a administração e colher aspectos diversos do modo pelo qual se desenvolve a atividade administrativa: a ótima, a boa e a má administração, a fim de poder definir a noção de 'boa administração' como aquela que deve conduzir e padronizar a ação administrativa ."
} 
Deve ser superada a ideia de Direito Administrativo “do” Estado, “em favor” do Estado, à disposição da Administração Pública, em desfavor e “de costas” para o administrado.

Nesta quadra evolutiva, o Direito Administrativo passa a ser visto como valioso aparato instrumental, como remodelado meio para a obtenção de resultados mais significativos no âmago de um “Estado constitucional solidário”, integralmente comprometido com a igualdade e a justiça como valores supremos de uma sociedade fraterna ${ }^{40}$.

O foco não só de reflexão, mas de ação, se desloca, radicalmente, da Administração Pública - num sentido bolorento e desgastado, semântico, estático - para o da pessoa humana do administrado, num sentido dinâmico, ativo, vivo, ideal e substancialmente digno.

No panorama entreaberto, merecem revisão conceitos estáveis do Direito Administrativo tradicional, sendo mesmo possível falar, como o faz Oliveira ${ }^{41}$, que “o direito administrativo brasileiro encontra-se, em relação a suas categorias e institutos jurídicos tradicionais, em um processo acelerado de transformação" e que "isso implica considerar que as matrizes clássicas deste ramo jurídico necessitam passar, no dizer de Odete Medauar, por um 'controle de validade"”.

O princípio da impessoalidade, portanto, impõe um agir decisório cada vez mais comprometido com o justo, um justo que leve em consideração, substancialmente e sem tergiversação, a dignidade humana do administrado.

\subsection{Direito Administrativo do interesse público}

Postula-se pela identificação de um conteúdo autônomo para o princípio da impessoalidade no Brasil que sirva de parâmetro para uma atuação administrativa decisória juridicamente hígida e responsável.

\footnotetext{
${ }^{40}$ Para Michelle Carducci (Por um direito constitucional altruísta. Tradução de Sandra Regina Martini Vial, Patrick Lucca da Ros e Cristina Lazzaroto Fortes. Porto Alegre: Livraria do Advogado Editora, 2003, p. 57-59): “(...) o declínio progressivo do Estado-Nação como figura central da economia-mundo significou a desterritorialização da economia (do desenvolvimento e da divisão do trabalho), ou seja, o desaparecimento do espaço geográfico - e, ainda antes, cultural e político - do Estado como mecanismo fundamental ou 'motor' da 'máquina' do desenvolvimento. Como consequência, o mecanismo 'vitimário' que exclui povos e indivíduos do planeta do acesso aos 'bens fundamentais' é um problema relacionado com os direitos fundamentais de liberdade e que, no horizonte da 'globalização' do homem e do mundo, não pode ser delegado à soberania de cada Estado Nacional, mas à inteira comunidade internacional. (...) Daí a urgência de pensar a democracia como novo princípio político destinado a garantir a 'dignidade'humana no pluralismo e no 'moral disagreement'. E daí a urgência de um Direito Constitucional 'altruísta' como novo nomos da Terra, capaz de contestar o princípio da soberania e os interesses da razão de Estado como fundamento exclusivo da legitimidade e da liberdade".

${ }^{41}$ Obra citada, p. 233.
} 
A impessoalidade, a nosso sentir, será observada, pragmaticamente, quando alcançado o interesse público. Mas o que é interesse público? Ensina Alexandre Santos de Aragão ${ }^{42}$ que as concepções anglo-saxônicas e europeias sobre interesse público são distintas:

\begin{abstract}
“Enquanto nos EUA e no Reino Unido o interesse público é considerado como intrinsecamente ligado aos interesses individuais, sendo próximo do que resultaria de uma soma dos interesses individuais (satisfação dos indivíduos = satisfação do interesse público), nos Estados de raiz germânicolatina é tendencialmente considerado superior à soma dos interesses individuais, sendo superior e mais perene que eles, razão pela qual é protegido e perseguido pelo Estado, constituindo o fundamento de um regime jurídico próprio, distinto do que rege as relações entre os particulares”.
\end{abstract}

Para Carlos Vinícius Alves Ribeiro ${ }^{43}$, o interesse público (“conceito determinável”) dotado de supremacia é só aquele internalizado pela Administração, incluído entre os fins administrativos, cabendo à lei (instrumento normativo genérico e abstrato) adicionar objetivos à administração. Com apoio em Alessi, ensina que "não é a própria administração que diz onde existe e onde não existe interesse público como móvel do agir administrativo, mas somente a lei (instrumento jurídico genérico e anterior à prática do ato)”44.

Por isso mesmo, para Fernando Dias Menezes de Almeida ${ }^{45}$, a essência da impessoalidade está “no fato de o tratamento dado pelos agentes estatais aos casos individuais e concretos estar fundamentado numa decisão anterior geral e abstrata" ${ }^{46}$

Sucede que em nome da supremacia do interesse público, numa visão retrógrada,

\footnotetext{
${ }^{42}$ Curso de Direito Administrativo. Rio de Janeiro: Forense, 2012, p. 151-152.

${ }^{43}$ Interesse público: um conceito jurídico determinável. In: Supremacia do interesse público e outros temas relevantes do direito administrativo. São Paulo: Atlas, 2010, p. 103 a 119.

${ }^{44}$ Para o mesmo autor (Interesse..., p. 104): “...não basta que a administração diga que fará ou deixará de fazer algo, eventualmente atingindo interesses legítimos de indivíduos, por essa ação ou inação de interesse público. É preciso rechear o conceito, destrinchá-lo, dizer qual é efetivamente o interesse público naquele caso concreto e qual regra jurídica lhe atribui superioridade legítima".

${ }^{45}$ Princípio da impessoalidade. In: Princípios de direito administrativo: legalidade, segurança jurídica, impessoalidade, publicidade, motivação, eficiência, moralidade, razoabilidade, interesse público. Thiago Marrara (org.). São Paulo: Atlas, 2012, p. 114.

${ }^{46}$ Para Fernando Menezes Dias de Almeida (Princípio...., p. 115), é preciso enfatizar que: "Se uma regra geral comporta exceções, elas devem estar previstas, numa formulação hipotética, na própria norma que estabelece a regra geral, de modo que sua concretização, em cada caso, corresponda ainda assim a uma aplicação da norma geral e abstrata. O que não se pode admitir é a criação, em cada caso concreto, por decisões individuais, de exceções não antecipadas pela regra posta pela via legal. Não se quer sustentar que a norma geral e abstrata devesse prever hipóteses de exceções individuais e concretas; isso seria uma contradição em termos. Afirma-se, sim, que a norma geral e abstrata deve contemplar - sem abandonar o plano geral e abstrato - a possibilidade de haver exceções, com os seus delineamentos hipotéticos".
} 
reacionária e autoritária, absurdos têm sido $\operatorname{cometidos}^{47}$. E sendo certo que o interesse público não pode ser vislumbrado em abstrato ${ }^{48}$, mostra-se necessário remodelar o seu espectro de incidência.

De início, deve ser afastada, à luz da doutrina de Floriano Peixoto de Azevedo Marques Neto ${ }^{49}$, a noção, comum no âmbito da Administração Pública, de interesse público como universal, absoluto, singular, "como aquele que se contrapõe à perspectiva atomizada dos particulares”. Tal concepção não mais se sustenta, devendo ser substituída pela de “um elo de mediação de interesses privados dotados de legitimidade”.

No correto entender do autor, o interesse público não pode mais subsistir (nem na prática política, nem na formulação doutrinária) de forma absoluta e autoritária, justamente para evitar que ele se transforme numa cortina de fumaça para a prática de excessos e desvios de poder.

Para Floriano Peixoto de Azevedo Marques Neto ${ }^{50}$ deve-se conduzir o conceito de interesse público - e com ele, enfatizamos nós, o de impessoalidade - à ideia de que atualmente "interesses legítimos, mediatos ou imediatos, de um particular, não podem significar automaticamente um interesse contrário aos desígnios públicos”. Em muitos casos, o atendimento dos interesses dos particulares será, em si, a consagração do interesse público. Em suas palavras:

\footnotetext{
“Temos claro que atender a Administração Pública - com eficiência e diligência - a um interesse legítimo de particular, tendo por móvel as imposições ou princípios de ordem administrativa, não implica conduta que possa ser inquinada de reprovável pelo moderno Direito Administrativo. Afinal, (...), o atendimento do interesse privado (mormente quando este se reveste de caráter metaindividual), hodiernamente, é, no mais das vezes, forma única de consagração do interesse público”.
}

\footnotetext{
${ }^{47}$ Adverte Carlos Vinícius Alves Ribeiro (Interesse..., p. 105), com apoio em Alice Gonzales Borges, que é necessário distinguir a supremacia do interesse público de "suas manipulações e desvirtuamentos em prol do autoritarismo", sendo certo que "o problema não é do princípio: é, antes, de sua aplicação prática”.

${ }^{48}$ Carlos Vinícius Alves Ribeiro (Interesse..., p. 119), com apoio na Teoria dos Tipos de Carl Gustav Jung, sustenta ser o interesse público não um conceito, mas sim um "tipo", "uma noção quadro que, por mais que inicialmente, em abstrato, diretamente, não seja possível dizer, precisar, esquadrinhar o que seja, é possível, sem grandes dificuldades, chegar-se a um consenso do que não é, e com o complemento dado pela situação posta, ao que, naquele caso, é o interesse público”.

${ }^{49}$ Regulação estatal e interesses públicos. São Paulo: Malheiros, 2002, p. 148, 149 e 151.

${ }^{50}$ Regulação estatal e interesses..., p. 152.
} 
Coerentemente, o mesmo autor ${ }^{51}$ sustenta que em vista da falência da noção tradicional de interesse público, passa a ser necessário um novo estudo das formas de composição dos diversos interesses que convivem na sociedade "a partir de critérios de relevância sempre dependentes de uma avaliação conjuntural”.

O princípio da "supremacia do interesse público" deve adquirir a feição de "prevalência dos interesses públicos” e, depois, deve ser desdobrado em três subprincípios, balizadores da função administrativa: a) interdição do atendimento de interesses particularísticos (v.g., aqueles desprovidos de amplitude coletiva, transindividual); b) obrigatoriedade de ponderação de todos os interesses públicos enredados no caso específico; c) imprescindibilidade de explicitação das razões de atendimento de um interesse público em detrimento dos demais. Ademais, o clássico “princípio da indisponibilidade do interesse público” tem que ser reformulado "de modo a expressar a irrenunciabilidade à tutela dos interesses públicos difusos - o que importa dizer: no exercício da função administrativa, o agente público não pode se esquivar de proteger e fazer prevalecer os interesses hipossuficientes”.

Se o princípio da impessoalidade, como será demonstrado, se concretiza pela ponderação de todos os interesses legítimos em jogo, no momento da decisão é necessário remodelar a ideia de interesse público, a ser cotejado vis-à-vis com o interesse particular.

O interesse público, presente em todos os setores do Direito Administrativo, pode ser satisfeito pelo cumprimento do princípio da impessoalidade? Em que medida?

Héctor Jorge Escola ${ }^{52}$ chega ao ponto de assinalar que o interesse público é, em si, o fundamento do Direito Administrativo. Nas suas palavras, "es el concepto que da sustento a todo el derecho administrativo, que puede ser definido, sintéticamente, como el derecho del interés público". O autor relaciona interesse público com praticamente todas as matérias objeto de estudo científico do Direito Administrativo: (i) organização administrativa; (ii) função pública; (iii) serviços públicos; (iv) ato administrativo; (v) contrato administrativo; (vi) atividade de fomento; (vii) domínio público e limitações à propriedade privada; e (viii) responsabilidade do Estado. Ou seja, praticamente tudo o que se estuda no Direito Administrativo tem como fundamento o interesse público ${ }^{53}$.

Partindo de uma ideia de interesse público como a soma quantitativa de interesses

\footnotetext{
${ }^{51}$ Regulação estatal e interesses..., p. 165.

${ }^{52}$ El interés público como fundamento del Derecho Administrativo. Buenos Aires: Depalma, 1989, p. IX.

${ }^{53}$ Assinala Escola que "el verdadero fundamento del derecho administrativo es el interés público, que es éste que da sentido y comprensión a todas sus instituciones, y el que justifica y explica la singularidad de sus principios y de sus soluciones" (obra citada, p. 261).
} 
privados legítimos, Escola ${ }^{54}$ assinala que não é exato supor que o interesse público deva sempre prevalecer sobre o interesse individual, como se fossem duas coisas substancialmente diferentes, sendo uma (o interesse público) superior à outra. Também não é certo dizer que entre o interesse público e o interesse individual possa haver uma colisão ou contradição a ser revolvida sempre em favor do primeiro. No seu entendimento, interesse público não se confunde com interesse da Administração, do partido, de governantes, do hierarca etc.

Para Escola $a^{55}$, "solo cuando se identifica el interés público con el interés del propio Estado, de la administración, del partido, del soberano, del jerarca, etc., podría pretenderse que ese supuesto interés público - que ya hemos explicado que no es tal - llega no sólo a desplazar, sino a sacrificar u extinguir cualquier interés privado que se le opusiera, incluso sin ningún tipo de reparación, pues ambos tendrían una entidad sustancial diferente, siendo que la del primero superior e derogante de la del segundo”.

Interessante notar que o mesmo autor assinala que todo pretenso interesse público, para ser verdadeiro, deve estar conectado com as grandes finalidades elencadas no texto constitucional, especialmente no preâmbulo, fechando as portas para que se constituam, em verdade, "meros intereses sectorialies o de grupo, de partido o de ideologias que no se conjugan con las de nuestra organización político-social”56.

Ao tratar da constitucionalização do direito e suas repercussões no Direito Administrativo, Barroso ${ }^{57}$ anotou que, a partir da centralidade da dignidade humana e da preservação dos direitos fundamentais, alterou-se a qualidade das relações entre Administração e administrado, com a superação ou reformulação de paradigmas tradicionais, dentre os quais a ideia de supremacia do interesse público sobre o interesse privado, que precisa ser redefinida.

No seu entender cabe distinguir, de antemão, interesse público “primário” de interesse público “secundário”, o que pode ser feito desde a visão de Renato Alessi.

O interesse primário seria o interesse da sociedade, sintetizado em valores como justiça, segurança e bem-estar social. O secundário seria o interesse da pessoa jurídica de direito

\footnotetext{
${ }^{54}$ Ensina que: "el interés público sólo es prevaleciente, con respecto al interés privado, tiene prioridad o predominancia, por ser un interés mayoritario, que se confunde y asimila con el querer valorativo asignado a la comunidad". E que: esta prevalencia se funda, también, en el hecho de que el interés público, concebido de esa forma, y como lo acotara Gordillo, habrá de redundar en mayores derechos y beneficios para todos y cada uno de los individuos de la comunidad, que por eso, justamente, aceptan voluntariamente aquella prevalencia, que les es ventajosa" (obra citada, p. 243).

${ }^{55}$ Obra citada, p. 244.

${ }^{56}$ Obra citada, p. 261.

${ }^{57}$ A constitucionalização..., p.49.
} 
público (União, Estados e Municípios), identificando-se com o interesse da Fazenda Pública, isto é, o erário.

Para Barroso, o interesse público secundário jamais desfrutará de uma supremacia $a$ priori e abstrata em face do interesse particular. Se ambos entrarem em rota de colisão, caberá ao intérprete proceder à ponderação desses interesses, à vista dos elementos normativos e fáticos relevantes para o caso concreto ${ }^{58}$.

Tal visão não está imune a críticas porque a conceituação do que seja interesse primário pode conduzir a um excessivo subjetivismo, passível de ser manipulável de maneira autoritária.

Mais correto, então, conectar as noções de “interesse público (primário)” e “função pública”, notadamente no ambiente do princípio da impessoalidade, o que bem faz Odete Medauar. Confira-se ${ }^{59}$ :

\footnotetext{
“Com o princípio da impessoalidade, a Constituição visa obstaculizar atuações geradas por antipatias, simpatias, objetivos de vingança, represálias, nepotismo, favorecimentos diversos, muito comuns em licitações, concursos públicos, exercício do poder de polícia. Busca, desse modo, que predomine o sentido de função, isto é, a ideia de que os poderes atribuídos finalizam-se ao interesse de toda a coletividade, portanto a resultados desconectados de razões pessoais”.
}

Ao tratar do princípio do atendimento do interesse público ou princípio da finalidade, Odete Medauar ${ }^{60}$ é eloquente ao afirmar que “esse princípio vem apresentado tradicionalmente como o fundamento de vários institutos e normas do direito administrativo e, também,

${ }^{58}$ Na lição de Renato Alessi (La responsabilità della pubblica amministrazione. $3^{\text {a }}$ ed. Milano: Giuffrè, 1955, p. 197-198), mais uma vez (bem) invocado por Barroso, o interesse público se conecta com a ideia de função administrativa. Depois de tratar da primeira peculiaridade da posição jurídica da Administração Pública em relação aos particulares, qual seja a de que ela, normalmente, se apresenta como titular do poder soberano (poder de império), a ser exercitado, no Estado de Direito, de acordo com o princípio da legalidade, explica: “ $A$ segunda peculiaridade da posição da administração pública, a qual sintetiza a definição de administração mencionada alhures, diz respeito à própria noção de função: função, como posto em relevo, é o poder concebido em relação à realização de interesses - na espécie, tratando-se do poder soberano, à realização de interesses públicos, coletivos. Estes interesses públicos, coletivos, os quais a administração deve garantir a satisfação, não se confundem com os interesses da administração como aparato organizativo, mas correspondem ao chamado interesse coletivo primário, formado pelocomplexo dos interesses individuais que prevalecem numa determinada organização jurídica da coletividade, enquanto que o interesse próprio do aparato administratovo seria apenas um entre todos os interesses secundários da coletividade, e que somente podem ser realizados em casos de coincidência - e nos limites dessa coincidência - com o interesse coletivo primário. A peculiaridade da posição jurídica da administração pública está justamente nisso, que a sua função consiste na realização do interesse coletivo, público, primário”.

${ }^{59}$ Direito Administrativo Moderno..., p. 144.

${ }^{60}$ Direito Administrativo Moderno..., p. 148. 
de prerrogativas e decisões" e "por vezes, de modo errôneo, se invoca o atendimento do interesse público com o sentido de atendimento de interesse fazendário ou para justificar decisões arbitrárias”.

Forçoso notar que, pelo ângulo de uma Administração Pública eivada de vícios remanescentes de um passado arbitrário, descumprem-se direitos individuais sob o manto da fundamentação jurídica, ou melhor, revestida de aparente e superficial juridicidade, em que se proclama uma supremacia do interesse público que, na verdade, nada mais é do que a prevalência de uma posição unilateral do Estado nem sempre conectada com o justo. Em resumo, proclama-se uma falsa supremacia do interesse público mercê da quebra da impessoalidade.

Em importante obra coletiva ${ }^{61}$ sobre a desconstrução da visão tradicional do princípio da supremacia do interesse público, Alexandre Santos de Aragão, Daniel Sarmento, Gustavo Binenbojm, Humberto Ávila e Paulo Ricardo Schier revelam sua nova compreensão à luz da noção de Estado de Direito verdadeiro. E ao prefaciar a mesma obra, Barroso ${ }^{62}$ revela o sentido e o alcance esperados:

“(...) em um Estado democrático, assinalado pela centralidade e supremacia da Constituição, a realização do interesse primário muitas vezes se consuma apenas pela satisfação de determinados interesses privados.

(...)

Mesmo quando não esteja em jogo um direito fundamental, o interesse público pode estar em atender adequadamente a pretensão do particular. (...) O interesse público se realiza quando o Estado cumpre satisfatoriamente o seu papel, mesmo que em relação a um único cidadão.

(...). O interesse público secundário - i.e., o da pessoa jurídica de direito público, o do erário - jamais desfrutará de supremacia a priori e abstrata em face do interesse particular. Se ambos entrarem em rota de colisão, caberá ao intérprete proceder à ponderação adequada, à vista dos elementos normativos e fáticos relevantes para o caso concreto”.

Barroso $^{63}$ é expressivo ao esclarecer que o interesse público primário desfruta de supremacia porque não é passível de ponderação, justamente em razão de ser ele o parâmetro

\footnotetext{
${ }^{61}$ Interesses públicos versus interesses privados: desconstruindo o princípio da supremacia do interesse público. Rio de Janeiro: Editora Lumen Juris, 2005.

${ }^{62}$ Conforme prefácio, p. XIV e XV, da obra citada.

${ }^{63}$ Trecho do mesmo prefácio acima aludido, p. XVI.
} 
de ponderação. No seu entender: “o interesse público primário consiste na melhor realização possível, à vista da situação concreta a ser apreciada, da vontade constitucional, dos valores fundamentais que ao intérprete cabe preservar ou promover".

Odete Medauar ${ }^{64}$ refere-se a um "ultrapassado princípio da supremacia do interesse público sobre o interesse particular”. Diz que “se o princípio algum dia existiu”, merece pronta revisitação à luz das seguintes colocações:

a) A Constituição de 1988 prioriza os direitos fundamentais, direitos estes dos particulares;

b) Mostra-se pertinente à Constituição e à doutrina administrativa contemporânea a ideia de que à Administração cabe realizar a ponderação de interesses presentes numa determinada situação, para que não ocorra sacrifício a priori de nenhum interesse; o objetivo desta função está na busca de compatibilidade ou conciliação dos interesses, com a minimização de sacrifícios;

c) O princípio da proporcionalidade também matiza o sentido absoluto do preceito, pois implica, entre outras decorrências, a busca da providência menos gravosa, na obtenção de um resultado;

d) Tal "princípio” não vem sendo mais indicado na maioria maciça das obras contemporâneas.

Uma das passagens doutrinárias mais completas sobre a abordagem ora tida como a correta é a de Paulo Otero ${ }^{65}$. Explicita que a prossecução (condução) do interesse público e a satisfação das necessidades coletivas pela Administração Pública pode-se fazer atendendo-se ao seu relacionamento com as posições jurídicas subjetivas, à luz de três diferentes concepções:

a) Concepção de matriz totalitária - prevalência absoluta da prossecução do interesse público, justificando o sacrifício de quaisquer posições jurídicas subjetivas;

b) Concepção compromissória - harmonização entre a prossecução do interesse público e o respeito pelas posições jurídicas subjetivas dos administrados;

c) Concepção personalista - prevalência absoluta do núcleo essencial da dignidade da pessoa humana sobre qualquer prossecução do interesse público.

Em Portugal, a Constituição da República, dentre os princípios fundamentais, traz o

\footnotetext{
${ }^{64}$ Direito Administrativo Moderno..., p. 149.

${ }^{65}$ Manual de Direito Administrativo..., p. 309 e seguintes.
} 
primado da dignidade humana ${ }^{66}$ e, quando trata dos princípios fundamentais da Administração Pública, deixa claro que a condução do interesse público terá como pressuposto o "respeito pelos direitos e interesses legalmente protegidos dos cidadãos”. ${ }^{67}$

Do enlace entre "República fundamentada na dignidade humana” e o “interesse público revelado pela proteção aos direitos e interesses legalmente protegidos dos cidadãos”, Paulo Otero constrói uma teoria que pode ser reproduzida sem traumas para o contexto brasileiro, em que a Dignidade da Pessoa Humana é referida no texto constitucional como fundamento da República ${ }^{68}$.

Para Paulo Otero, a concepção personalista, a ser preferida e explorada, alicerça-se em duas vigas mestras, representadas pelas seguintes ideias:

a) O respeito à dignidade humana de cada pessoa viva e concreta é um postulado que nunca pode ceder perante a prossecução do interesse público ${ }^{69}$;

b) A prossecução do interesse público encontra na dignidade da pessoa humana o seu fundamento e o seu limite de relevância constitucional.

A concepção personalista traz a pessoa humana - como começo e fim das preocupações do Estado - para o centro da interpretação constitucional e deita consequências muito fortes na visão que se pode ter, à luz do quadro constitucional, sobre interesse público.

Partidário de tal constatação, Paulo Otero sentencia que a concepção personalista provoca "um descentrar da ideia de prossecução do interesse público para a pessoa humana e a sua dignidade o propósito central do bem comum e do agir da Administração Pública”. Por conseguinte:

\footnotetext{
${ }^{66}$ Artigo 1ㄹ da Constituição da República Portuguesa, de 1976: "Portugal é uma República soberana, baseada na dignidade da pessoa humana e na vontade popular e empenhada na construção de uma sociedade livre, justa e solidária”.

${ }^{67}$ Art. 266 , 1, da CRP/76: “A Administração Pública visa a prossecução do interesse público, no respeito pelos direitos e interesses legalmente protegidos dos cidadãos".

${ }^{68}$ Art. 1엉 da CFB/88: "A República Federativa do Brasil, formada pela união indissolúvel dos Estados e Municípios e do Distrito Federal, constitui-se em Estado Democrático de Direito e tem como fundamentos: (...) III - a dignidade da pessoa humana (...)”.

${ }^{69}$ Para ilustrar a força da tese, Paulo Otero (Manual de Direito Administrativo, p. 310, rodapé 1031) chega a deduzir a seguinte situação: "Nem perante casos de 'bomba-relógio' se mostra admissível o Estado recorrer à tortura contra os terroristas, isto no sentido de obter deles a confissão do local ou do momento da sua deflagração: a superioridade do Estado de Direito e da democracia encontra-se no respeito pela legalidade, pois não existe segurança jurídica sem lei ou à margem da lei (neste sentido, sem prejuízo da existência de votos de vencido, usando argumentação valorizadora da 'razão de estado', cfr. The Public Committee against Torture in Irrael v. The Government of Israel, Case n. HCJ 769/02, in http://elyon1. Court.gov.il e IsrLR, 2006, PP. 459 ss., em especial, PP. 516 ss.”
} 
a) A pessoa humana tem primado sobre as necessidades coletivas e materiais da sociedade, nela residindo o fundamento da Constituição e o alicerce da sua permanente e renovada legitimidade;

b) A concepção personalista perfilha uma construção antropocêntrica do poder, fazendo da dignidade humana o "ponto de Arquimedes do Estado constitucional”;

c) O personalismo administrativo, alicerçando-se na prevalência da dignidade humana, faz “honrar o princípio parametrizador em que se baseia a República”.

Correto Paulo Otero quando diz que o personalismo acolhe, numa verdadeira síntese reveladora da centralidade da pessoa humana e da sua dignidade, a tradição axiológica judaico-cristã ${ }^{70}$ e as relevantes contribuições de Pico della Mirandola ${ }^{71}$, de Kant ${ }^{72}$ e do pensamento existencialista ${ }^{73}$. E que "a concepção personalista é um ponto de chegada de uma longa tradição evolutiva de valorização da pessoa humana, enquanto realidade viva, concreta e irrepetível, dotada de uma dignidade sagrada e inviolável - o ser humano é digno porque é pessoa"74.

Daí que, segundo Otero, é em cada ser humano vivo e concreto que a Administração Pública encontra, enquanto instituição social e jurídica, o sujeito e o fim da sua atividade, sendo certo que:

a) É em função da pessoa humana e da sua dignidade inalienável que o interesse público existe e deve ser prosseguido;

b) Não há, nem pode existir, interesse público ou bem comum contra a dignidade humana ${ }^{75}$;

c) O respeito pela dignidade humana é o parâmetro de relevância jurídica do interesse público ou do bem comum;

\footnotetext{
${ }^{70} \mathrm{Na}$ tradição judaico-cristã, cada pessoa humana é um ser criado à imagem e semelhança de Deus, dotado de valor sagrado e único (Gênesis I, 26-7)

${ }^{71}$ Para Pico della Mirandela, renascentista, a partir das ideias-força de liberdade e soberania da vontade, cada pessoa é senhora de si e tem a capacidade de determinar seu próprio destino.

${ }^{72}$ No pensamento kantiano, a pessoa é sempre um fim em si mesma, não podendo ser tida como simples coisa ou objeto.

${ }^{73}$ No pensamento existencialista, aproveita-se a ideia de Hegel sobre o conceito de homem determinado como um ideal vivo e concreto.

${ }^{74}$ Manual de Direito Administrativo..., p. 312.

${ }^{75}$ Para Paulo Otero (Manual de Direito Administrativo..., p. 312, rodapé 1045), neste sentido, mostram-se "totalmente inadmissíveis, a título de exemplo, usando como justificação a defesa do interesse público da sobrevivência do Estado em cenários de luta ou 'guerra' contra o terrorismo, a elaboração pela Administração de regulamentos definindo 'técnicas reforçadas de interrogatório' ou manuais de tortura. Sobre o tema, cfr. James P. Pfiffner, Torture as Public Policy - Restoring UC Credibility on the Wold Stage, Colorado, 2010".
} 
d) A garantia e a proteção da dignidade humana não postulam apenas o respeito pela juridicidade, exigem também eficiência da gestão administrativa.

Tem-se, pois, que o interesse público não pode prevalecer sobre o núcleo indisponível da dignidade humana. E tal limite é inegociável.

Mesmo diante do interesse público relacionado à segurança nacional ou ínsito a uma forte emergência econômica ou financeira, não se pode justificar o sacrifício demasiado à dignidade humana. E dois casos recentes de Cortes constitucionais europeias bem ilustram tal posicionamento. No primeiro deles, conhecido como caso Luftsicherheitsgesetz, o Tribunal Constitucional alemão, em fevereiro de 2006, interpretando a lei de segurança aérea, em nome do direito à vida e do princípio da dignidade humana de passageiros e tripulantes, considerou inconstitucional norma que permitia às forças armadas o abate de aeronave sequestrada por terroristas para uso coativo contra alvos civis e militares. No segundo, o Tribunal Constitucional português, em abril de 2013, afirmou que "não se pode deixar de reconhecer-se que haverá sempre de ressalvar, ainda que em situação de emergência econômica, o núcleo essencial da existência mínima"76.

A adoção da concepção personalista de condução do interesse público implica que se até as forças armadas, num cenário de ataque terrorista, não estão habilitadas pelo legislador, em prol do interesse público “da segurança nacional”, a adotar conduta violadora do núcleo duro da dignidade humana, com maior razão, como afirma Otero77 “ “a Administração Pública civil, em cenários de normalidade constitucional, nunca poderá fazer prevalecer a prossecução do interesse público sobre o núcleo indisponível da dignidade humana”.

Abusando de sua qualificada capacidade de síntese, Paulo Otero revela um conjunto de corolários na articulação entre as duas realidades - próprias da subordinação da prossecução do interesse público pela Administração Pública pelo núcleo essencial da dignidade humana - ao nível da ação administrativa:

a) A dignidade humana mostra-se passível de contribuir para uma densificação positiva do conteúdo dos próprios interesses públicos cuja prossecução se encontra, por lei, a cargo da Administração Pública;

b) Nunca existem razões de interesse público que justifiquem ou habilitem que o

${ }^{76}$ Cfr. Acórdão do Tribunal Constitucional no 187/2013, de 5 de abril de 2013, processos nºs 2/2013, 3/2013, 8/ 2013 e 11/2013.

${ }^{77}$ Manual de Direito Administrativo..., p. 313-314. 
ser humano seja tratado com indignidade pela Administração Pública; antes esta se encontra vinculada a uma obrigação universal de respeito, garantia e proteção da dignidade de cada pessoa humana;

c) Os direitos fundamentais (pessoais e sociais) e as liberdades inerentes ao núcleo essencial da dignidade humana são insuscetíveis de ceder perante todo e qualquer interesse público;

d) A dignidade humana postula um espaço privado ou reservado de cada pessoa, excluindo ou limitando a existência de interesses públicos habilitadores de intervenção administrativa;

e) A dignidade de cada ser humano só pode sofrer limitações administrativas decorrentes de uma concorrencial ponderação alicerçada na dignidade de outro ser humano: só a dignidade humana limita ou condiciona a dignidade humana;

f) A dignidade humana envolve sempre uma prevalência do ser sobre o ter e das pessoas sobre as coisas: não pode existir prevalência de valorização administrativa de bens patrimoniais privados sobre bens de natureza pessoal;

g) O respeito pela dignidade humana constitui critério teleológico de interpretação e adequação da prossecução do interesse público;

h) O decisor administrativo (administrador-julgador) tem a obrigação de tomar em consideração os efeitos ou resultados (efetivos ou previsíveis) da decisão ao nível da garantia da dignidade humana;

i) Uma teleologia decisória fundada no respeito pela dignidade humana habilita um dever administrativo de revisão ou reformulação de decisões lesivas ou passíveis de gerar perigo à dignidade humana;

j) O respeito e a garantia da dignidade humana podem constituir causa legítima de inexecução administrativa de sentenças judiciais.

Implícita aos corolários referidos no "Decálogo de Paulo Otero” está a ideia de que se o homem veio antes, e é mais importante, deve o Estado humanizar-se. E se assim é, o interesse público tem de "se curvar perante a dignidade humana e não a dignidade humana que tem de se ajoelhar perante o interesse público"78.

Crê-se, porém, que uma subordinação cega do interesse público à dignidade humana

\footnotetext{
${ }^{78}$ Manual de Direito Administrativo..., p. 316.
} 
pode ensejar certa letargia impositiva da máquina pública, na perseguição de interesses vitais para a coletividade, o que não é recomendável.

Mais uma vez recorrendo a Paulo Otero, a paralisia ou o temor de agir por parte da Administração repugnam em razão do que:

a) Não será possível, numa desproporcional ou unidimensional ponderação da dignidade humana, privar as estruturas administrativas de eficácia de ação inerente à prossecução do bem comum da coletividade;

b) Se o respeito pela dignidade humana fundamenta e limita a prossecução do interesse público, a verdade é que não anula ou exclui essa prossecução, até porque a dignidade humana, se é fonte primeira de direitos fundamentais, também é alicerce primário de deveres fundamentais: não há direitos fundamentais sem deveres fundamentais;

c) O respeito pela dignidade humana de uns não pode impedir que a Administração Pública satisfaça a garantia da dignidade humana de outros que, numa conduta ilícita de terceiros, se encontram como alvo de uma agressão ou ameaça de tentativa de agressão.

E o próprio autor se incumbe de perguntar: “como garantir, em tais cenários de necessidade de atuação administrativa, a indispensável subordinação do interesse público ao respeito pela dignidade humana?” Eis o ponto nevrálgico da questão.

São quatro as recomendações de Otero ${ }^{79}$ para bem equacionar as coisas:

a) Ter presente a exata função da reserva de lei no habilitar da atuação administrativa: a.1) A reserva de lei traduz um instrumento de proteção preventiva da dignidade humana: a Administração encontra aqui uma definição da linha de fronteira entre o que pode, o que deve e o que não pode e não deve fazer;

a.2) A reserva de lei revela-se como área de ponderação entre a dignidade humana e o interesse público, à luz de um critério definido pelo legislador, que se impõe à Administração Pública;

b) A ponderação feita pelo legislador, ao abrigo da reserva de lei, entre a dignidade humana e a prossecução do interesse público goza de uma presunção de constitucionalidade que só excepcionalmente poderá ser afastada pelas estrutu-

${ }^{79}$ Manual de Direito Administrativo..., p. 318-319. 
ras administrativas - existe aqui um princípio in dubio pro dignitate secundum legem;

c) Haverá ainda a diferenciar duas situações radicalmente distintas em que a Administração se pode confrontar:

c.1) Se os particulares se colocam voluntariamente numa situação de perigo, suscetível de levantar sérios riscos a uma lesão da sua dignidade (v.g., a participação numa manifestação não autoriza a prática de ilícitos criminais, contravencionais ou disciplinares);

c.2) Aquela em que os particulares, sem qualquer vontade ou intenção, se encontram numa situação de perigo ou expostos (involuntariamente) a um risco.

Na hipótese c.1, diferentemente do que ocorre na hipótese c.2, a prevalência da dignidade humana encontra-se relativizada, porquanto o próprio particular se expôs voluntariamente ao risco de sofrer uma intervenção administrativa que, habilitada por lei e respeitado o princípio da proporcionalidade, interfira com a sua dignidade (v.g., coação policial, detenção, suspensão preventiva), sem nunca habilitar, todavia, uma lesão do seu núcleo sagrado (v.g., nunca permite sujeitar a tortura ou a sevícias);

d) Haverá, em quarto lugar, que atender se, no entendimento concreto do decisor existia (ou era razoável supor) uma situação de estado de necessidade ou, em alternativa, de legítima defesa de terceiros que, em nome de um interesse público imperioso e urgente, objetiva ou subjetivamente configurado, justificava, segundo as exigências do princípio da proporcionalidade, uma intervenção administrativa lesiva à dignidade humana. A teoria do erro sobre os pressupostos e a justificação decorrente da desculpabilidade da conduta do agente prolator da decisão administrativa podem completar o cenário traçado.

No momento da tomada de decisões administrativas, o administrador-julgador (o decisor) deverá levar em consideração todos os interesses legítimos em disputa, sejam eles públicos ou privados. Deverá medi-los e pesá-los, primeiro isoladamente e depois comparativamente. Só então, de maneira fundamentada, trilhará uma decisão justa e ponderada. A não ser assim, violará o princípio da impessoalidade. 


\subsection{Direito Administrativo como sistema}

No trato da teoria do "Direito Administrativo como sistema”, relevante para que se empreste à impessoalidade uma visão mais ampla, não só de ação, mas também de organização administrativa, destaca-se a obra do professor alemão Eberhard Schmidt-Assmann"80/81.

Em sua "Teoria geral do direito administrativo como sistema: objeto e fundamentos da construção sistemática”, o notável doutrinador alemão assinala pelo menos três traços metodológicos para a reconstrução da parte geral do direito administrativo, bem definidos por Javier Barnés ${ }^{82}$ :

a) Concepção de direito administrativo como "ciência de direção";

b) Compreensão mais ampla do sistema e dos objetivos da ciência do direito administrativo;

c) Ideia de "setores de referência”.

Por “ciência de direção” deve ser entendido um direito que tem por aspiração dirigir processos sociais. Assim, o direito administrativo não pode estar limitado à simples construção dogmática de regras jurídicas, categorias, institutos ou doutrinas, mas também deve se preocupar com a criação de condições e pressupostos que assegurem, ao Direito, eficácia e eficiência, em benefício do cidadão.

De outro lado, explica Bernés, enquanto o sistema jurídico que se inspira na dogmática tradicional estava centrado na interpretação das normas e na criação do Direito, a sistemática que se nutre da perspectiva científica que aporta da “doutrina de direção”, partindo da análise da realidade do Estado e da sociedade, tem por objeto, antes de tudo, o estudo da organização, o pessoal e o procedimento, na busca de uma maior eficácia.

Ademais, para determinar em que medida os institutos tradicionais do direito administrativo ainda cumprem sua função integradora, ou, ao revés, devem ser reformados, é necessário mergulhar em cada setor de sua parte especial e descer aos problemas concretos,

\footnotetext{
${ }^{80}$ La teoría general del derecho administrativo como sistema: objeto y fundamentos de la construcción sistemática. (tradução espanhola do original: Das Allgemeine Verwaltungsrecht als Ordnungs Idee). Madrid/ Barcelona: Marcial Pons, 2003.

${ }^{81}$ Para Javier Barnés, ao apresentar a tradução para o espanhol da obra referida (p. XVII): "no cabe duda de que este trabajo contiene una de las más notables reflexiones de la doctrina alemana del Derecho público de los últimos años y así es considerado en aquel país por no pocos iuspublicistas. Es una obra que se inscrebe y entronca con la mejor tradición del Derecho administrativo como disciplina sistemática, con pensadores como OTTO MAYER Y FRITZ FLEINER".

${ }^{82}$ Ao fazer a apresentação da tradução da obra para o idioma espanhol.
} 
aos interesses e aos objetivos específicos ali suscitados. A parte geral não pode ser fruto de abstração e generalização, mas sim algo mais.

Bernés afirma que o trabalho de Schmidt-Assmann condensa alguns fios condutores:

a) O sistema conceitual do Direito Administrativo tradicional, herdado do Estado liberal, se baseia em esquemas, postulados ou presunções que nem sempre resultam úteis para apreender por inteiro os novos fenômenos e realidades do nosso tempo. No particular, basta pensar, por exemplo, no próprio conceito de Administração, que não pode mais ficar preso à ideia de separação de poderes, mas sim à compreensão de que o exercício do poder público, do poder do Estado, está sujeito a exigências constitucionais específicas, atrativas das esferas de responsabilidade;

b) Tanto a Ciência do Direito Administrativo como as denominadas ciências da Administração têm o mesmo objeto de estudo e investigação: a Administração. Não há relação de subordinação ou preferência entre elas. Cada uma exerce ou cumpre uma função auxiliar em relação à outra. A identidade do objeto material (basta examinar a coincidência de temas em matérias entre tratados de Direito Administrativo e de Ciência da Administração) pode sugerir que, com o passar do tempo, tenha sido concebido um virtuoso sistema de comunicação, um fluido intercâmbio de conhecimentos específicos. Nada mais enganoso. Não se pode falar em interdisciplinaridade, a não ser a partir da soma dos distintos produtos científicos aportados por cada uma das ciências em questão de acordo com as respectivas ópticas, isto é, de multidisciplinaridade. Propõe-se, então, um “entendimento de base” sobre determinados conceitos ou parâmetros utilizados por ambas as ciências. Trata-se de promover a construção sistemática de conceitos “associativos” de caráter “interdisciplinar” que possam fazer uma “ponte” entre as disciplinas e que constituam “chaves interpretativas” de diálogo científico;

c) A parte geral do Direito Administrativo deve ser um lugar de reflexão e de recepção, para que se promovam revisões dos dogmas tradicionais e a construção de novas categorias, mormente na busca de uma Teoria Geral do Direito Administrativo Europeu. As funções e o objeto dessa reconstrução passam pelo cultivo de novos “setores de referência”, novos modelos de comunicação e novas estruturas administrativas. Em todos esses campos se encontra presente o "Direito Admi- 
nistrativo da informação”, que se converte, assim, não em um setor a mais, mas sim na coluna vertebral da reforma da teoria geral.

A força das ideias de Schimdt-Assmann perpassa, integralmente, a compreensão do que vem a ser impessoalidade. Para o autor:

“La parte general del Derecho administrativo, su Teoría general, constituye algo más que una disciplina académica capaz de poner en relación o de dar cierta unidad a determinados elementos o piezas aisladamente considerados, tales como las categorías y formas jurídicas, el procedimiento, la organización y la responsabilidad administrativas. Es una idea ordenadora, sobre la que luego se abundará, y cuyo objeto consiste en asegurar que cada institución o figura tenga un contexto cada vez más amplio; y en garantizar la evolución dogmática y la capacidad de adaptación de cada una de esas categorías con el resto del sistema. Ello exige y presupone un vigoroso y penetrante pensamiento racionalizador y analítico, susceptible de elevarse hacia categorías más generales. La clave de bóveda de esa 'idea ordenadora' consiste en la inducción de una teoría general a partir de las particularidades que presentan cada uno de los sectores del Derecho administrativo especial y en la reconducción de cada una de las piezas y soluciones singulares hacia principios generales del Derecho, entendidos ambos como procesos de interacción recíproca. Desde el punto de vista metodológico, tal idea ordenadora tiene por objeto la construcción de un sistema; se sirve a este propósito de un presupuesto o postulado sistemático”. ${ }^{83}$

Realçando a ideia (sistêmica) de uma “dupla função” para o Direito Administrativo, Schmidt-Assmann leciona que, se a relação entre Estado e indivíduo é, em toda a sua extensão, uma relação de caráter jurídico, resulta claro que o Direito Administrativo não pode se limitar a regras pontuais e concretas, ou seja:

“Si cualquier actuación del Estado se halla necesitada de una justificación o de un título legitimante, al Derecho administrativo no le bastará con ocuparse del estudio de las acciones administrativas singulares propias de ciertas relaciones marcadas por la idea de defensa o de protección. De ahí que el Derecho administrativo no se pueda circunscribir al estudio de las clásicas

${ }^{83}$ Obra citada, p. 1-2. 
relaciones de intervención o injerencia o a las de carácter prestacional, sino que habrá de ocuparse igualmente de todo lo relativo a la organización administrativa; de las cuestiones que se refieren a la obtención de información administrativa y a los procesos de toma de decisiones. El Derecho administrativo no se reduce, pues, a la perspectiva que proporciona la tutela judicial, sino que habrá de tener en cuenta también aquellos sectores a los que la sonda del control judicial no llega. No se trata sólo, por tanto, de racionalizar o limitar la acción administrativa desde el exterior, sino que es preciso ahormarla desde dentro, de acuerdo con los patrones del principio democrático y del Estado de Derecho. De la misma manera que la Constitución aspira a la juridificación del Estado en su globalidad, así habrá de operar el Derecho administrativo con la Administración pública, impregnando todas sus relaciones externas e internas, tanto en aquellos contactos puntuales o esporádicos con el ciudadano como en las relaciones sistemáticas e de mayor calado y extensión. No quiere decirse con ello que lo ‘exterior’ o lo ‘interior' deban disolverse necesariamente en una misma cosa, pues cada una de esas esferas puede tener sus propias leyes, unas peculiares inercias o necesidades y, en suma, explicarse a través de dogmáticas también distintas. Ahora bien, la esfera y los procesos ‘internos’ se hallan en la base misma, constituyen un importante fundamento para el entendimiento y la ordenación de cada una de las actividades con efectos hacia fuera". ${ }^{84}$

As esferas da Administração, a interna e a externa, devem estar harmonizadas, sendo papel do Direito Administrativo a busca de um necessário equilíbrio, dialogado com outras disciplinas, de modo que o agir impessoal, sobretudo na seara decisória, seja propiciado por uma organização administrativa voltada ao cumprimento do mesmo princípio constitucional.

\subsection{O mito da neutralidade política da decisão administrativa e a questão da justiça}

A Administração Pública tem sido escravizada por decisões político-partidárias, tomadas fora da esfera administrativa. Não obstante, no campo das decisões administrativas relevantes é necessário trilhar a "neutralidade política possível”.

Otero $^{85}$, ao tratar do tema da legitimação política em correlação com a colonização partidária, ensina que, num Estado pluralista, a politização da Administração Pública passa

${ }^{84}$ Obra citada, p. 23-24.

${ }^{85}$ Manual de Direito Administrativo..., p. 305 e seguintes. 
também pelo reforço da legitimidade política das diversas estruturas administrativas, segundo um modelo apoiado em quatro regras nucleares:

a) Fundamentação democrática dos critérios de decisão administrativa;

b) Representatividade político-democrática do prolator da decisão administrativa;

c) Responsabilidade política do prolator e da decisão administrativa;

d) Preferência pela maior legitimidade política do prolator e da decisão administrativa.

Tendo como foco o Estado parlamentar, o autor assinala que a Administração Pública dependente do Estado pode vir a ter a cor do partido governamental.

Paulo Otero conclui que não se encontra uma Administração legitimada democraticamente imune a um fenômeno de colonização administrativa pelos partidos políticos. São suas estas palavras:

“(...) a intervenção dos partidos políticos, fazendo de quase toda a máquina administrativa um palco da luta hegemônica do 'Estado do partido governamental', além de gerar um domínio informal das estruturas administrativas, determina também uma infiltração no próprio aparelho administrativo de boys ou fidèles du gouvernement, provocando uma transferência do centro decisório dos gabinetes administrativos para as salas dos diretórios partidários”.

Revela que:

\begin{abstract}
"Uma politização desordenada das estruturas da Administração Pública, envolvendo a sua colonização pelo 'partido governamental', poderá mesmo conduzir a uma quebra da neutralidade e da imparcialidade administrativas: a Administração politizada, gerando no seu seio verdadeiros lobbies de interesses particulares e tráfico de influências, será então 'coveira' das garantias dos administrados, desenvolvendo-se num processo de completa marginalidade face à ordem constitucional - será o exemplo de uma Administração ‘não oficial’ que vive paralela à Administração oficial”.
\end{abstract}

O raciocínio é poderoso. Mesmo focada no campo do parlamentarismo, a problemática pode ser transportada para a realidade do presidencialismo brasileiro, de coalizão, em que forças por vezes bem antagônicas celebram pactos políticos e morais muito débeis, em prol de uma governabilidade nem sempre comprometida com os valores republicanos. 
Fazendo uso dos ensinamentos de Otero ${ }^{86}$, tem-se que a politização da Administração contribui para que algumas das principais decisões administrativas revistam-se de conteúdo político. E assim é porque:

a) Em tais casos, as decisões administrativas, em vez de uma tradicional neutralidade política, mostram-se politicamente comprometidas, envolvendo uma escolha do interesse público ditada por puros critérios de oportunidade e valoração política - pode falar-se em politicidade da decisão administrativa;

b) Há aqui um espaço de liberdade política conformadora titulado pela Administração Pública, verdadeira área de indirizzo político, que lhe confere autonomia de orientação própria, criando novos pressupostos de conduta e, sob o seu próprio impulso, definindo inovativamente meios, critérios e objetivos que não possuem uma natureza predeterminada ou executiva da lei ou da Constituição.

Entretanto, mesmo que a politização da Administração seja uma realidade (verdade) eloquente, havendo campo fértil para a existência de decisões administrativas assentidas em pressupostos políticos e tendo um conteúdo político como objeto, há limites intransponíveis. E Paulo Otero arrola três:

a) Todas as decisões têm de visar sempre à prossecução do interesse público sem prejuízo da determinação deste assumir um inegável componente político. Nunca poderá esse componente político ser usado para habilitar derrogações à juridicidade;

b) Respeito pelas fronteiras decorrentes do princípio da separação de poderes, nunca habilitando o indirizzo político da Administração Pública a invadir a esfera do poder legislativo ou do poder judicial;

c) Proibição de gerar lesão a pessoas individualmente consideradas, devendo sempre respeitar direitos e interesses legalmente protegidos ${ }^{87}$.

Sabe-se muito bem que a neutralidade política no “agir” administrativo é um mito,

\footnotetext{
${ }^{86}$ Manual de Direito Administrativo..., p. 307.

${ }^{87}$ Paulo Otero, no particular, chega a formular exemplo interessante: “não se mostra admissível, neste contexto, por exemplo, que um órgão administrativo, usando um alegado ato de conteúdo ou propósito político (v.g., resolução, moção, declaração), possa lesar o bom nome ou a honorabilidade de pessoas individualizadas. Se o fizer, além da invalidade da deliberação, revela-se a mesma passível de gerar responsabilidade civil dos titulares que a votaram favoravelmente”. (Manual de Direito Administrativo..., p. 309, rodapé 1029).
} 
mas não deve ser (tanto) assim na “seara decisória”. Por óbvio, não se refuta a existência de uma forte relação entre Administração e Política, mesmo porque não se pode desconsiderar a percuciente observação de Odete Medauar ${ }^{88}$, forte em Sorace, para quem não há Administração sem política e vice-versa, sendo ilusório o objetivo de nítida separação, “ao invés do objetivo da organização da continuidade entre uma e outra em vista da obtenção de um equilíbrio razoavelmente aceitável e historicamente adequado”. Segundo a autora, "o verdadeiro problema consiste em especificar a justa relação entre orientação política e imparcialidade, no âmbito de uma discricionariedade administrativa inevitável, conotada pela tensão entre política e justiça e pela necessidade de compor, mais do que separar, os dois elementos”.

O que se sustenta, diferentemente, é que, nas decisões administrativas, não pode haver espaço para atuação política. A neutralidade aqui pressuposta, como pano de fundo da decisão administrativa, é a referida por J. Baptista Machado ${ }^{89}$ como a da justiça. Para esse autor:

“(...) é que, no plano superior da Justiça, estamos de regresso à perspectiva
da unidade do Estado, da integração de toda a comunidade em função do
valor do Direito e da Justiça - e a neutralidade afere-se agora por referência
a este valor e assume sob certos aspectos um significado idêntico ao de
imparcialidade”.

E prossegue:

“(...) neste sentido o Estado é neutro se, na resolução de qualquer conflito de interesses, assume uma posição valorativa de simultânea e igual consideração de todos os interesses em presença. A neutralidade não impõe aqui ao Estado atitudes de abstenção, mas mais propriamente atitudes de isenção na valoração dos interesses em conflito. O Estado é neutro quando faz vingar a Justiça e estabelece regras do jogo justas”.

Sérgio Sérvulo da Cunha ${ }^{90}$, de sua vez, observa com precisão que a constituição do poder implica a fixação dos seus fins e que “à dominação basta a ordem como fim do gover-

\footnotetext{
${ }^{88} \mathbf{O}$ direito administrativo em evolução. $2^{\text {a }}$ Ed. São Paulo, Editora Revista dos Tribunais, 2003, p. 139.

${ }^{89}$ Participação e descentralização - democratização e neutralidade na Constituição de 76. Coimbra: Almedina, 1982, p. 245.

${ }^{90}$ Uma deusa chamada justiça. São Paulo: Editora WMF Martins Fontes, 2009, p. 5.
} 
no, mas o Direito acrescenta-lhe a justiça”. Zagrebelsky ${ }^{91}$ assinala que três coisas regem o mundo: a justiça, a verdade e a paz. E que as três coisas são na realidade uma só: a justiça; porque de fato, apoiando-se a justiça na verdade, chega-se à paz.

A despeito de enorme controvérsia sobre a noção de justiça, notadamente em sua correlação com o ideário do Direito, é suficiente, para os fins deste trabalho, ter nela um valor correspondente ao justo. E por justo, a medida do bom ${ }^{92}$.

É de Zagrebelsky a escorreita observação de que a justiça é uma exigência que postula uma experiência pessoal, justamente a experiência da justiça, ou melhor, da aspiração à justiça que nasce da experiência da injustiça e da dor que dela deriva. Assim é que:

\begin{abstract}
"Si no disponemos de una fórmula de justicia que pueda poner a todos de acuerdo, es mucho más fácil convenir - a menos que se trate de conciencias desviadas - en la percepción de la injusticia contenida en la explotación, en la cosificación de los seres humanos por parte de otros seres humanos. Y es más fácil no verla o considerarla como algo remoto que permanecer insensibles una vez que se ha estado en contacto inmediato con ella”.
\end{abstract}

Para Sérgio Sérvulo da Cunha ${ }^{93}$, "o sentimento do justo e do injusto está à base de qualquer critério sobre o que é permitido ou proibido”, e o objetivo do Direito - enquanto arte, técnica e ciência - é a “institucionalização e materialização de relações de poder segundo a justiça, e não a mera reprodução de relações naturais, sociais ou econômicas de poder".

É também de Sérgio Sérvulo da Cunha ${ }^{94}$, ao tratar da justiça política, a lição de que:

\footnotetext{
“As múltiplas faces da justiça parecem estar contempladas ao definir assim o respectivo princípio: princípio segundo o qual, regente o bem de todos, as atribuições de direitos se fazem objetivando o maior bem individual possível. No princípio de justiça desfaz-se a pretensão oposição entre os interesses particulares (ou individuais) e o interesse geral. A realidade não é a parte
}

\footnotetext{
${ }^{91}$ La exigencia de justicia. ZAGREBELSKY, Gustavo. MARTINI, Carlo Maria. La exigencia de justicia. Madri: Trotta, 2006. Segundo o autor, "Hay tres cosas que rigen el mundo: la justicia, la verdad y la paz. Así lo entiende la Mishnah, que comenta: las tres cosas son en realidad una sola: la justicia. De hecho, apoyándose la justicia en la verdad, a lo que llega es la paz”.

${ }_{92}^{92}$ Para Sérgio Sérvulo da Cunha (Uma deusa..., p. 6), a justiça possui duas faces. Uma negativa, correspondente a evitar o mal; outra positiva, correspondente a fazer o bem.

${ }^{93}$ Uma deusa..., p. 7.

${ }^{94}$ Uma deusa..., p. 121.
} 
nem o todo, mesmo porque o todo nada é sem as partes, que, por sua vez, se definem como partes do todo. Decisão de justiça é a que traduz, concretamente, a fórmula dessa harmonia vital”.

Pode-se concluir, ainda com apoio em Sérgio Sérvulo da Cunha ${ }^{95}$, que o princípio da justiça é pré-jurídico, o que significa:

a) Que é uma exigência prévia ao ordenamento jurídico;

b) Que pode encontrar-se em processos sociais anteriores ao ordenamento jurídico, como a religião e a moral;

c) Que sua concretização não se pode esperar apenas do ordenamento jurídico.

José Renato Silva Martins ${ }^{96}$ concorda com o entendimento de que o ideal da justiça, a par de ser objetivo de todas as civilizações, no âmbito do Direito é algo que não se pode definir facilmente, mas indiscutivelmente o conceito de justiça é pressuposto para a existência do Direito e possui teor valorativo.

Com foco na figura do juiz, o mesmo autor ${ }^{97}$ assinala que "seria utópico pensar em um juiz absoluto e irremediavelmente neutro, cuja toga, suficientemente impermeável, o impedisse de sentir as pulsações do clamor da sociedade em que se insere”.

Sucede que neutralidade é uma coisa, imparcialidade é outra. A neutralidade judicial é mesmo um mito. A imparcialidade judicial, diferentemente, é exigência real, de todo necessária à perseguição da justiça ${ }^{98}$.

\footnotetext{
${ }^{95}$ Uma deusa..., p. 121.

${ }^{96}$ O dogma da neutralidade judicial: sua contextualização no Estado brasileiro contemporâneo. Rio de Janeiro: Editora Lumen Juris, 2007, p. 78 e 83.

${ }^{97} \mathbf{O}$ dogma..., p. 159.

${ }^{98}$ Segundo José Renato Silva Martins (O dogma..., p. 69-70), para o senso comum, muitas vezes, não há distinção entre neutralidade e imparcialidade, sendo ambos os termos utilizados como sinônimos, mas não são. Explica: “(...) ainda que se reconheça que tal distinção é feita por uma fronteira tênue, deve-se procurar a utilização de uma terminologia rigorosa, em nome de uma análise que se pretenda científica. A neutralidade (...) revela-se fruto de uma influência positivista da ciência. Mas, sobretudo o que se deve destacar nesta palavra é que, para que se possa realizar o que ela expressa, necessário seria estar isento de toda ideologia. Tal empreitada e impossível. No Direito, WOLKMER chega a falar em 'aspectos ideológicos da criação jurisprudencial do Direito'. Mas o que se torna essencial neste momento é definir neutralidade. A posição aqui assumida é que neutralidade é a possibilidade da manutenção da indiferença diante de um quadro que manifesta posições antagônicas; posições estas que precisam ser pacificadas no âmbito do intermediário social, que é o local privilegiado assumido pelo Direito. Uma vez adotada tal postura, deve-se buscar desbravar a definição de imparcialidade. A imparcialidade pode ser visualizada desde as origens do Poder Judiciário, quando da divisão do Estado, como pré-requisito da função do julgador. BLACKBURN define imparcialidade nos seguintes termos: 'virtude fundamental, associada à justiça e à equidade. Uma distribuição dos benefícios e das obrigações é feita imparcialmente se nenhuma consideração a influencia, exceto as que determinam o que é devido a cada indivíduo. Perspectivas diferentes quanto ao merecimento farão essa maneira diferente'.
} 
No Brasil, a Constituição de 1988, já em seu preâmbulo, assegura que o Estado democrático brasileiro é destinado a assegurar o exercício dos direitos sociais e individuais, a liberdade, a segurança, o bem-estar, o desenvolvimento, a igualdade e, finalmente, a "justiça”, como valores supremos de uma sociedade fraterna, pluralista e sem preconceitos.

Não bastasse, incluiu-se no texto constitucional, no art. $3^{\circ}$, inciso II, dentre os objetivos fundamentais da República brasileira, a construção de uma sociedade livre, justa e solidária.

A justiça também é presença constante nas entrelinhas do texto constitucional. Deveras, é consectário lógico da adoção do modelo social de Estado Democrático de Direito.

No Estado Social, persegue-se a todo custo, em todos os momentos, de mãos dadas com o desenvolvimento, a justiça social possível.

Ao bom exegeta descabe desconsiderar esse horizonte. E os raciocínios jurídicos serão incompletos e falhos se desconsiderarem tal premissa.

O dicionarista, porém, faz uma ressalva importante: 'uma das dificuldades na aplicação desse conceito é que na vida real as exigências das pessoas com que se está intimamente relacionado, como os amigos e a família, contrariam a imparcialidade estrita, fazendo com que esta pareça mais uma parte da moral pública do que da virtude privada'. (...) Mediante tais posições, pode-se afirmar que o juiz não pode e não deve ser indiferente, ou seja, neutro, mas deve ser imparcial, isto é, permitir que dentro do processo as partes tenham oportunidades iguais e julgar segundo o seu convencimento de causa, zelando assim pela lisura do processo e pela realização da justiça”. 


\section{CAPÍTULO 2 - IMPESSOALIDADE}

No presente capítulo pretende-se comprovar que o princípio da impessoalidade ostenta arquétipo aberto. E é bom que assim seja.

Comparável às noções de imparcialidade (Itália e Portugal), de objetividade (Espanha) e de neutralidade política (França), o Princípio da Impessoalidade, porém, com elas não se confunde. É o resultado da soma das ideias encetadas em cada uma das noções acima reveladas. E, por isso mesmo, em relação a cada uma, é mais completo e abrangente, conferindo maiores cobertura e proteção aos valores tutelados pelo texto constitucional.

Revelar sua textura aberta é comprovar sua natureza de princípio e permitir ao exegeta uma atuação construtiva de maior envergadura, compatível com os desafios hermenêuticos da contemporaneidade. Tratar a impessoalidade a partir de uma noção abrangente obtida da soma das ideias de imparcialidade, objetividade e neutralidade política, próprias do direito estrangeiro, é também celebrar a República, resgatar a necessidade de maior cuidado no trato da coisa pública.

Mas, o que é impessoalidade? Quais suas vertentes (ação e organização)? Quais os antecedentes históricos do instituto? Quais os atuais estágios doutrinário e jurisprudencial? Eis o temário deste capítulo.

\subsection{Instrumentalização recíproca dos princípios constitucionais administrativos}

Odete Medauar ${ }^{99}$ ensina que os princípios da impessoalidade, da moralidade e da publicidade apresentam-se intrincados de maneira profunda, sendo lícito falar na existência de uma "instrumentalização recíproca”. Em seu entendimento, “(...) a impessoalidade configura-se meio para atuações dentro da moralidade; a publicidade, por sua vez, dificulta condutas contrárias à moralidade e impessoalidade; a moralidade administrativa, de seu lado, implica observância da impessoalidade e da publicidade”.

Para Carlos Ayres Britto ${ }^{100}$, os cinco princípios regentes de qualquer das modalidades de administração pública (como atividade ou enquanto aparelho ou aparato de poder), previstos no caput, do art. 37, da CF/88, quais sejam, a legalidade, a impessoalidade, a moralidade, a publicidade e a eficiência, devem ser aplicados em bloco. É dizer:

\footnotetext{
${ }^{99}$ Direito Administrativo Moderno..., p. 143.

${ }^{100}$ Comentários..., p. 822.
} 
"Com aporte em tais princípios, a começar pelo da legalidade, a nossa Constituição atesta que toda atividade estatal-administrativa é um gravitar na órbita da lei. Lei formal do Poder Legislativo, em última análise (art. 48), mas sobre quatro específicas condições de aplicabilidade; quer dizer, não basta aplicar a lei, pura e simplesmente, mas aplicá-la por um modo impessoal, um modo moral, um modo público e um modo eficiente. Modos que são, de parelha com a própria lei, as primeiras condições ou os meios constitucionais primários de alcance dos fins para os quais todo poder administrativo é legalmente conferido. Tudo sob a ideia-força de que, para fins lícitos, meios igualmente lícitos”.

Dito de forma mais precisa, Ayres Britto ${ }^{101}$ assevera que:

“Ora, dizer que a lei é o primeiro dos princípios regentes da administração pública, mas não o único (óbvio), é também dizer que o Direito especificamente aplicável a esse tipo de administração começa com a lei, mas não termina com ela. O Direito ainda se manifesta em cada qual dos modos obrigatórios de aplicar a lei, que são os princípios da impessoalidade, moralidade, publicidade e eficiência. Princípios, então, de rigorosa compostura jurídico-positiva, e, nessa medida, também expressionais do Direito como sistema normativo. O chamado Direito Objetivo.

Cuida-se, em rigor de apreensão cognitiva, de uma nova dualidade básica. Dualidade expressa no princípio-continente da legitimidade administrativa e nos princípios-conteúdos da legalidade, da impessoalidade, da moralidade, da publicidade e da eficiência. É como dizer: a administração pública somente alcança o patamar da legitimidade plena quanto aos seus meios ou meios de atuação, se, impulsionada pela lei, a esta consegue imprimir o selo dos outros quatro princípios. Operando, estes, como fatores de legitimação conjunta da própria lei, do Direito como um todo e da atividade administrativa em especial”.

Alexandre Santos de Aragão ${ }^{102}$ revela que o princípio da impessoalidade “costuma incidir de forma simultânea com os princípios da moralidade e da finalidade, havendo um fortalecimento recíproco" e, segundo a jurisprudência, tem sido usado "para impedir que recursos públicos sejam instrumentalizados por interesses privados; para vedar a nomea-

${ }^{101}$ Comentários..., p. 822.

${ }^{102}$ Curso..., p. 70-71. 
ção para cargos de confiança por afinidade pessoal ou familiar etc.”, e que, em todos esses casos:

\begin{abstract}
“(...) há uma multiviolação de princípios do Direito Administrativo, porque, por exemplo, uma viagem privada paga pelo erário é, ao mesmo tempo, uma violação à finalidade de interesse público (Princípio da Finalidade), uma atuação imoral (Princípio da Moralidade), um desperdício de dinheiro público (Princípios da Eficiência e da Economicidade) e uma instrumentalização da coisa pública para interesses pessoais do agente público beneficiado (Princípio da Impessoalidade)”.
\end{abstract}

De fato, é muito difícil isolar a aplicação concreta individualizada dos princípios constitucionais, principalmente quando em jogo a impessoalidade, a moralidade e a publicidade. Para a solução adequada da maioria dos casos, os princípios revelados quase sempre somarão esforços.

Em suma: a resolução dos assuntos administrativos é obtida da interação de todos os princípios constitucionais regedores da atividade administrativa, num só jato. Esse entendimento reafirma a natureza jurídica de princípio de cada um deles: da impessoalidade e dos demais, o que não quer significar que cada um não tenha conteúdo autônomo, devassável cientificamente.

No caso da Impessoalidade, dado o seu arquétipo bastante amplo, seu conteúdo é de conceituação desafiadora.

Está certo David Duarte ${ }^{103}$ ao assinalar que "a enorme variabilidade de conteúdo e significado do princípio da imparcialidade, bem como a consequente indefinição do seu âmbito de densidade operativa, são causas justificativas da dificuldade, comumente verificada, de determinação dos seus momentos de evolução”.

\title{
2.2 Antecedentes históricos
}

As pesquisas em torno do instituto dão conta de que só existe impessoalidade no Brasil, ou melhor, só existe um Princípio da Impessoalidade, expresso, de índole constitucional, no ordenamento jurídico brasileiro, surgido na Constituição de $1988^{104}$.

${ }^{103}$ Procedimentalização..., p. 259.

${ }^{104}$ Conforme Maria Sylvia Zanella Di Pietro (Direito Administrativo. 27ª ed. São Paulo: Atlas, 2014, p. 68). 
O exame dos seus antecedentes históricos deve ser feito a partir dos exames dos antecedentes históricos dos seus correspondentes, tarefa que, adicionalmente, poderá revelar as diferenças entre impessoalidade, imparcialidade, objetividade e neutralidade política.

Diogo de Figueiredo Moreira Neto, ao prefaciar a obra de Ana Paula Oliveira Ávila ${ }^{105}$, assinala que a "imparcialidade”, um dos aspectos do “polifacético” princípio da impessoalidade, inicialmente foi confundida com o conceito de isonomia, “o que, até certo ponto, já justificaria a corrente doutrinária que prefere fundar o conceito de impessoalidade no tratamento igualitário que deve ser dispensado pela Administração Pública aos administrados”106.

Partindo da antiguidade clássica grega, Diogo de Figueiredo Moreira Neto, no mesmo prefácio, traça o seguinte itinerário do princípio em debate:

\begin{abstract}
"Recordo-me que insisti ter sido da antiguidade clássica grega que havia despontado e prosperado esse conceito de isonomia; a princípio, como uma ideia aristocrática, pois a igualdade era sinônima de justiça entre iguais, associada, por isso, à deusa Themis, atuando como uma condição de equilíbrio social, porque se referia à convivência necessariamente competitiva e conflitiva do homem, e, por isso, Themis era representada com uma balança nas mãos.

Nem por outro motivo, Sólon considerava a igualdade essencial à existência da polis, conformando seu esteio. Caminhavam juntas, portanto, igualdade e justiça, mas à época, no pensamento clássico, mantinham-se como conceitos em permanente tensão, pois era a dialética do eris (discórdia) e do filia (concórdia).

Essa competição, como fundamento e propulsora da vida na polis, revelase bem em Hesíodo (Os Trabalhos e os Dias) em que a igualdade vem concebida, por isso, como a necessária base para que fosse justa a competição entre rivais. Esta é a razão pela qual apenas os homoioi (semelhantes)
\end{abstract}

\footnotetext{
${ }^{105}$ O Princípio da Impessoalidade da Administração Pública: para uma Administração imparcial. Rio de Janeiro: Renovar, 2004.

${ }^{106}$ No particular, a visão de Diogo de Figueiredo Moreira Neto é completada pelo pensamento de David Duarte (Obra citada, p. 288), para quem: “(...) Existe, de facto, uma evidente relação histórica entre esta tradição de imparcialidade - isenção - e o princípio da igualdade, que é explicável pelo prisma diferenciado com que ambos os valores estiveram ao serviço do mesmo propósito: a igualdade como meio de abolição de privilégios e a imparcialidade como luta contra a vulnerabilidade do poder aos interesses individuais e de grupos. A eliminação de vantagens institucionalizadas ou de privilégios ocasionais tem resultado, assim, de suas frentes opostas: a igualdade, como estandarte revolucionário accionado pelo cidadão, e a imparcialidade, na perspectiva da Administração, através de neutralidade administrativa".
} 
e, por isso mesmo, tornados isoi (iguais), podiam se superar e alcançar a excelência esperada dos aristoi, os melhores. Assim, a origem da isonomia estava ainda muito longe do conceito de igualdade moderno, ligada que ficava à desigualdade aristocrática, que caracterizava os melhores na competição... Era uma igualdade agônica.

Mas só isso já era um conceito bastante difícil de absorver nesse tempo em que a monarquia e a tirania prevaleciam em todo o mundo. Mas era, ainda assim, um auspicioso começo, embora parecesse uma heresia... E como exemplo da estranheza, que mesmo essa aristocrática igualdade à antiga suscitava à época, está a passagem de As Suplicantes, de Eurípedes, em que o enviado de Tebas pergunta aos atenienses a quem deve entregar a mensagem do rei Creonte, e Teseu lhe responde ‘a qualquer um de nós’, referindose ao conceito ateniense de isonomia e escandalizando o arauto.

E não é outro senão Platão a confirmar esse pasmo em vários de seus diálogos, mas, pouco a pouco, já começava a ficar claro que estava nascendo à época uma nova forma de se compreender a sociedade política, mudando até mesmo o entendimento sobre a própria realidade, como se lê em Alcménon de Crotona (um dos protomédicos helênicos), que estendia o conceito de isonomia à medicina e, dela, ao cosmos, prenunciando milenarmente a moderna holística...

Mas a isonomia continuava a progredir, até entrar como parte do conceito de democracia em Heródoto - que foi o primeiro a usar esta palavra - ao narrar a estranha e curiosa proposta do rei persa Otanes de assegurar a seus súditos isonomia (igualdade ante a lei), isocratia (igualdade de poder para fazer a lei) e isagoria (igualdade de usar da palavra para convencer os pares na ágora política).

Coube, finalmente, a Aristóteles dar o passo decisivo na construção do conceito, ao confrontar igualdade e justiça (Política, 1280 a): 'Parece que a igualdade é o justo - e o é, mas não para todos, senão para os iguais; parece que a desigualdade é o justo - e o é, certamente, mas só para os desiguais'. Assim, com Aristóteles, separava-se a igualdade da justiça, o que permaneceria por muitos séculos.

Este foi este o longo percurso trilhado para se chegar à imparcialidade, pois, com a distinção aristotélica, justiça é imparcialidade, e não mais igualdade... Nascia, assim, o conceito de imparcialidade no berço helênico, surgindo a dikaios, o 'ser imparcial' - um atributo necessário da deusa Diké... e não mais da deusa Themis... Um atributo que, pelos séculos adiante estaria referido ao demos, ao povo, e não mais exclusivamente ao aristos, a elite...”. 
David Duarte ${ }^{107}$ aponta ser possível detectar a existência de uma condensação tradicional da ideia de imparcialidade que se afirma nas noções genéricas de isenção e neutralidade. Como valor, a imparcialidade "é tão antiga quanto o é a organização política de uma comunidade com a sua predeterminação de relações de poder público num enquadramento vertical”.

Segundo os ensinamentos do autor, as origens históricas da imparcialidade remontam a:

a) Platão - Na Antiguidade clássica, quando "relaciona o decaimento da democracia em tirania com base no problema do excesso de liberdade e na consequente negligência da acção governativa. Esta negligência é a causa de uma censurável imoralidade pública";

b) Aristóteles - quando assinala que, para além da determinação de quem governa, “integra um elemento valorativo que diz respeito exactamente ao tipo de interesses prosseguidos”. Também quando se refere à falta de virtude no exercício da política como responsável pelo declínio da democracia, à queda da oligarquia derivada da complacência dos magistrados relativamente ao povo e na elaboração de uma noção de justiça, virtude humana relativa à prática de atos justos, apurável por meio de uma ideia de equilíbrio entre extremos;

c) Tomás de Aquino - quando estabelece modelos de organização política com base na virtuosidade própria de cada um. E assim, “à luz do bonum comune, como fim supremo do Estado e da lei, que compreende o equilíbrio da satisfação do interesse geral com a satisfação dos interesses individuais”;

d) Maquiavel - quando promove a separação da moral individual e da moral política, fomentando a total independência do príncipe relativamente aos limites da ação humana e estimulando garantias para uma racional limitação do poder;

e) Montesquieu - ao conceber “uma forma de divisão do poder por classes sociais, que tanto se dirige a garantir a liberdade do cidadão como, em termos limitativos, a repartir o poder no sentido de impedir o excesso e de dissolver a corrupção que o poder absoluto tende a gerar". A doutrina da separação de poderes “tem, então, um alcance de revirtuosidade da acção política, embora as questões da disparidade de tratamento e da arbitrariedade estejam colocadas numa perspectiva social e no equilíbrio de estados”.

${ }^{107}$ Obra citada, p. 259. 
David Duarte ${ }^{108}$ diz com acerto, que é, aliás, “como resultado da inexistência de garantias individuais efectivas e da ênfase colocada nas grandes questões sociais e políticas, $o$ nível problemático em que se efectua a abordagem da isenção política, como antecedente remoto da imparcialidade, que é, em primeiro lugar, uma vertente da discussão filosófica sobre a moralidade na acção governativa”. Também digno de nota seu registro no campo da evolução histórica da imparcialidade, sobre a "imparcialidade administrativa liberal”:

\footnotetext{
“A neutralidade do liberalismo, embora diga respeito em primeira linha à relação entre o Estado e a Sociedade e à abstenção interveniente daquele, não deixa de ter resultados na revisão do âmbito em que se movem as questões relativas à isenção na atividade política. $\mathrm{O}$ isolamento do Estado relativamente à Sociedade, corolário da restrição do aparelho administrativo que se opera com a adopção das teses liberais, provoca que, ao nível governativo, seja o próprio compromisso político a afastar os Estados dos compromissos sociais. (...)

Independentemente da subsistência dessas magnas questões politicamente nucleares, das quais se retiram e se retiraram premissas de base da compreensão contemporânea da ideia de imparcialidade, é possível perceber, a partir do período liberal, um reforço concretizante daqueles temas iniciais na especificidade da actividade administrativa”.
}

Dos achados históricos de David Duarte ${ }^{109}$ pode-se concluir que embora exista alguma semelhança com a imparcialidade que é própria da seara jurisdicional, as noções de isenção, neutralidade e igualdade de tratamento como componentes da imparcialidade administrativa adquiriram “contornos próprios no capítulo dos deveres relacionais dos funcionários e titulares de órgãos administrativos”, sendo até mesmo possível encontrar, na literatura administrativista liberal, exemplos da exigência de isenção no cumprimento das tarefas públicas:

a) Proibição de integração de interesses particulares, como motivos inidôneos, no exercício dos cargos públicos ${ }^{110}$;

b) Proibição de usurpação de poderes jurisdicionais;

c) Proibição de comportamentos materialmente injustos provocados por negligência ou ignorância das questões relevantes.

\footnotetext{
${ }^{108}$ Obra citada, p. 263-264.

${ }^{109}$ Obra citada, p. 265-266.

${ }^{110}$ Art. $75^{\circ}$, da Carta Constitucional portuguesa de 1826, que expressamente responsabilizava os ministros por peita ou suborno.
} 
Diogo de Figueiredo Moreira Neto ${ }^{111}$ acentua que a marca democrática da imparcialidade acabou positivada na primeira Constituição europeia depois da Segunda Guerra Mundial, dando início a uma renovação do constitucionalismo em todo o mundo com a Carta da Itália, de 1948, nela se abrindo uma seção específica sobre a Administração Pública (Título II - O Governo - Seção II), com menção expressa a dois princípios: o da eficiência (bom andamento) e o da imparcialidade (art. 97). Em sequência declara:

\begin{abstract}
“(...) foram divulgados outros diplomas constitucionais com o mesmo destaque e no sentido, todos influentes sobre o nosso de 1988, como, por exemplo, a Carta de Portugal, de 1976, que dedica todo um Título (IX) à administração pública, estabelecendo cinco princípios fundamentais: a igualdade, a proporcionalidade, a justiça, a imparcialidade e a boa-fé (art. 266), e a da Espanha, de 1978, que é ainda o texto mais recente em vigor na Comunidade Europeia. Nela, o Título IV está dedicado ao Governo e a Administração, com um artigo definitório (art. 103) dos princípios que devem regê-la, em número de seis, destacando-se a imparcialidade, seguindose a ela a eficiência, a hierarquia, a descentralização, a coordenação e, inovativamente, o princípio da juridicidade, como uma superação da legalidade positivista (sic: ‘sujeita a lei e ao direito')”.
\end{abstract}

Interessante notar que, até aqui, as regras de imparcialidade dispunham de alcance predominante interno, no sentido da responsabilização do agente, ainda que para se avaliar a legitimidade das decisões. Eventualmente, cogitava-se de indenizações. Não se cogitava, ainda, de um parâmetro de avaliação da invalidade do ato pela verificação de motivos inidôneos ou pela preclusão ou privilégios de interesses secundários.

Ao que tudo indica, a teoria da invalidação dos atos administrativos praticados com quebra da imparcialidade começou a ser desenvolvida no quadro da abertura do desvio de poder. E mais uma vez assiste razão a David Duarte quando assinala que:

“À função que a imparcialidade incorpora, actualmente, como limite de
discricionariedade, correspondem, no período liberal, determinados elemen-
tos substantivos que fazem do desvio de poder um meio de controlo da
validade da decisão. Como vício dos actos que envolvem uma intervenção
subjectiva particularmente intensa, ao contrário dos outros casos de abertu-

${ }^{111}$ Do prefácio da obra de Ana Paula Oliveira Ávila (O Princípio da Impessoalidade da Administração Pública: para uma Administração imparcial. Rio de Janeiro: Renovar, 2004). 
ra - derivados de incompatibilidades entre o acto e a norma directamente verificáveis -, o desvio de poder vai reclamar para o contexto da actuação administrativa parâmetros que compreendem diferentes limites internos da discricionariedade, como as proibições de disparidade de tratamento e de favorecimento por motivos inconsideráveis”.

Foi da necessidade que a isenção administrativa passou a ser objeto de mecanismos preventivos criados pelo legislador, adaptados da longa tradição existente no campo jurisdicional. Surgiram, na disciplina administrativa, as garantias da imparcialidade. E sua positivação principiológica foi questão de tempo.

\subsection{Direito estrangeiro}

Do direito estrangeiro podem ser recolhidas nuances relevantes para a composição da visão do Princípio da Impessoalidade, genuinamente brasileiro, tido como a somatória das noções, típicas dos ordenamentos jurídicos europeus, de imparcialidade, objetividade e neutralidade política, com variações terminológicas.

Além de esgarçar os múltiplos aspectos de uma impessoalidade multifacetada, a descrição de outras realidades jurídicas realça e reforça os elementos históricos acima referidos.

\subsubsection{Inglaterra}

Tomando-se como base os ensinamentos de Maria Teresa de Melo Ribeiro ${ }^{112}$, é possível dizer que foi no direito inglês que o princípio da imparcialidade começou a se afirmar, surgindo como forma de assegurar a independência da Administração e a neutralidade política dos funcionários públicos.

Num primeiro momento, aplicava-se apenas às autoridades administrativas cujas atribuições fossem similares às das autoridades judiciais e tinha vocação restrita às atividades administrativas que envolvessem poderes de julgamento. Mais tarde, o princípio da imparcialidade do direito inglês, ou princípio da “justiça natural”, acabou por se estender para toda e qualquer atividade administrativa, como corolário de uma Administração pretensamente justa.

No ordenamento jurídico inglês, o princípio da "justiça natural” comporta duas regras fundamentais:

${ }^{112}$ O Princípio da Imparcialidade..., p. 65-66. 
a) Ninguém pode ser juiz em causa própria, em razão do que as autoridades administrativas devem de abster da tomada de decisões sobre assuntos em relação aos quais tenham interesse pessoal (nemo iudex in causa própria), também referida pela expressão rule against bias ou, então no man a judge in his own cause;

b) Os administrados têm o direito de ser ouvidos antes da tomada de uma decisão sobre assunto de seu interesse, pois a todo homem deve ser dada oportunidade de apresentar a sua defesa (audi et alteram partem ou the right to a fair hearing).

Lembra-nos Sabino Cassese ${ }^{113}$ que, normalmente, o princípio da imparcialidade é primeiro mencionado na lei e só mais tarde aplicado pela jurisprudência, mas na Inglaterra ocorreu o contrário, já que sua origem é consuetudinária e jurisprudencial.

David Duarte ${ }^{114}$ adere ao entendimento supracitado ao explicitar que:

“(...) no plano concreto das decisões, de forma pioneira nos sistemas anglosaxônicos (Grã-Bretanha), onde já em meados do século anterior se estabeleceu expressamente como princípio da imparcialidade a velha máxima de proibição de se decidir com interesse na questão (no Dimes v. Grand Junction Canal Co. Proprietors de 1852) Esta jurisprudência, particularmente vocacionada para a construção do bias nas situações em que o decisor tem interesses do tipo pecuniário na decisão (no R. v. Hammond de 1853, ficou estabelecido como ratio decidendi que o interesse pecuniário, por mais pequeno que seja, é sempre suficiente para o ultra vires da decisão) foi depois alargada a interesses de outra natureza”.

\subsubsection{França e Alemanha}

Maria Teresa de Melo Ribeiro ${ }^{115}$ leciona que o tema da imparcialidade administrativa, apesar de não ser desconhecido dos direitos francês e alemão, não tem suscitado grandes debates acadêmicos e jurisprudenciais. Em tais ordenamentos, a imparcialidade aparece mais como uma qualidade pessoal dos funcionários públicos, como forma de assegurar a sua independência, a sua neutralidade e a sua isenção, do que como um princípio geral da Adminis-

${ }^{113}$ Imparzialità amministrativa e sindicato giurisdizionale. Revista italiana per le Scienze giuridiche. Milano: Giuffrè, 1968, p. 109.

114 Obra citada, p. 265, rodapé 25. Perceba-se que a menção a "meados do século anterior" diz respeito ao ano de 1852, já que a obra de David Duarte data de 1996.

${ }^{115}$ Obra citada, p. 66. 
tração Pública. Crê que algumas razões militam para a constatação de um baixo interesse doutrinário na exploração científica do princípio da imparcialidade em ambos os ordenamentos:

a) Ausência de previsão constitucional expressa;

b) O fato de que, nesses países, muitos dos corolários reclamados para a imparcialidade administrativa são reconduzidos ao princípio da igualdade.

De acordo com David Duarte ${ }^{116}$, a atenção que tem o desvio de poder, como técnica de controle da discricionariedade, na doutrina e na jurisprudência francesas, também justifica o relativo subaproveitamento que é feito do princípio da imparcialidade, correspondente a uma simples limitação de intervenção nas decisões em que se tenha interesse pessoal. Na França, apenas em 1949 se desenvolveu a imparcialidade como princípio, nomeadamente no arrêt Trêbes. Esta a explicação do autor para que isso tenha acontecido:

"É que, ao contrário do que se tem verificado em Portugal - onde não se avalia o desvio de poder para além do motivo principalmente dominante -, em França, sempre se aferiu o détournement de pouvoir na pluralidade dos motivos da decisão, o que, tendo originado a teoria do motif surabondant para evitar ilegalidades no concurso de motivos válidos com motivos inidóneos de menor peso, leva a que não exista qualquer necessidade de relacionar o princípio da imparcialidade com a pluralidade de elementos que integram a construção da decisão".

Na França, o princípio da imparcialidade conota-se mais processual, tendo como principal vertente de atuação as regras relativas a impedimentos e suspeições.

Mesmo assim, é possível detectar um caráter principiológico, notadamente na avaliação das decisões tomadas ao desabrigo de regras sobre obligation de se récuser, já que o Conseil d'Etat tem anulado atos por entender que a autoridade prolatora da decisão deveria, de acordo com o princípio da imparcialidade, ter se afastado do processo ${ }^{117}$.

Maria Teresa de Melo Ribeiro ${ }^{118}$ chega a assinalar que, muito embora a doutrina

${ }^{116}$ Obra citada, p. 282 e seguintes.

${ }^{117}$ David Duarte ensina que, no Direito francês, não existe uma regulamentação genérica dos impedimentos e que "a técnica do afastamento de titulares de órgãos relativamente a decisões que lhes digam respeito ou nas quais tenham interesse (téchnique de la récusation) é um desenvolvimento feito no Conseil d’État a partir das equivalentes regras judiciais e que está apenas administrativamente prevista em diplomas avulsos com um

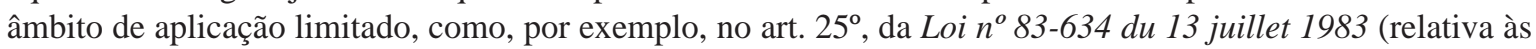
obrigações e deveres dos funcionários públicos do Estado” (Obra citada, p. 282, rodapé 86).

${ }^{118}$ Obra citada, p. 68. 
francesa não reflita qualquer preocupação de definição do seu conteúdo, a defesa da imparcialidade administrativa como princípio geral do direito já vem sendo feita por alguns autores, com alcance até mais geral do que o do princípio da igualdade, a exemplo de Waline e Vedel/Devolvé.

Benoît Delaunay ${ }^{119}$, ao comparar os sistemas francês e espanhol, esclarece que no direito administrativo francês, "el principio de objetividad casi no existe en si mismo, sino bajo diferentes apellidos: el princípio de imparcialidad, el principio de neutralidad, el principio de laicidad”. Em interessante artigo, assinala que:

\begin{abstract}
"Esta situación plantea el problema del valor jurídico que tiene el principio de objetividad. Pero, más allá, hay que poner de manifiesto las diferentes apariciones de la objetividad -que son numerosas- tanto en el estatuto de los funcionarios como en la acción administrativa cotidiana. Bajo esta perspectiva se construye el principio de objetividad a través de la elaboración de una deontología administrativa y de la sanción de la ilegalidad y de la responsabilidad en caso de falta de objetividad”.
\end{abstract}

Na França, segundo o mesmo autor, as manifestações do (implícito) princípio da objetividade podem ser resumidamente assim referidas:

a) Princípio da objetividade dos agentes da administração

a.1) A objetividade garantida pela imparcialidade dos agentes públicos;

a.2) A objetividade garantida pela neutralidade dos agentes públicos;

b) Princípio da objetividade da ação administrativa

b.1) A objetividade condicionada pela igualdade;

b.2) A objetividade como condição da legalidade.

Benoît Delaunay se refere à progressiva construção do princípio da objetividade tanto pelo viés preventivo quanto pelo viés repressivo, apoiado nos princípios “liberais” de anulação dos atos ilegais e de compromisso da responsabilidade dos agentes públicos franceses. Pelo ângulo da prevenção da falta de objetividade pela deontologia administrativa, refere-se à (i) prevenção da parcialidade e à (ii) prevenção dos conflitos de interesses. Já pela óptica da falta de objetividade por parte dos órgãos supervisores, alude: (i) à anulação dos

${ }^{119}$ El principio de objetividad en el Derecho Administrativo francés. In: DA. Revista Documentancíon Administrativa, $n^{\circ}$ 289, enero-abril 2011, p. 281-303. 
atos administrativos por falta de objetividade e (ii) ao compromisso da responsabilidade dos funcionários por falta de objetividade ${ }^{120}$.

Ainda com apoio nos ricos estudos empreendidos por David Duarte ${ }^{121}$, acerca do princípio da imparcialidade no direito comparado, é possível afirmar que a imparcialidade administrativa tem, no direito alemão (Unparteilichkeit der Verwaltung), um alcance que também “não transcende a proibição de tratamento preferencial ou prejudicial, corporizando a ideia de que as tarefas públicas devem ser efectuadas sem consideração de interesses individuais”.

Mesmo encarada a impessoalidade como princípio, os alemães limitam seu campo de incidência à prevenção de eventuais decisões parciais ${ }^{122}$.

Nikolaus Marsch ${ }^{123}$, traçando um paralelo entre os direitos administrativos espanhol e alemão, ensina que o ordenamento alemão não consagra expressamente o princípio da objetividade nem no nível constitucional nem no legal. Todavia, existem normas dirigidas a garantir a objetividade da Administração. Revela:

“Es el caso del principio de imparcialidad en el procedimiento administrati-
vo -que tiene su fundamento constitucional último en la cláusula de Estado
de Derecho- y de otras disposiciones de carácter sustantivo que regulan,
por ejemplo, el ejercicio de la discrecionalidad administrativa, la inclusión
de cláusulas accesorias en los actos administrativos y la celebración de los

${ }^{120}$ Para Bruno Miragem (A Nova Administração Pública e o Direito Administrativo. São Paulo: RT, 2011, p. 339), "no direito francês, de sua parte, embora não expressamente referido na Constituição, o princípio da imparcialidade é reconhecido e conformado na jurisprudência, como atesta mais recentemente o Caso Didier, de 1999, no esteio de jurisprudência afirmada ao longo de décadas de atuação do Conselho de Estado". A leitura do rico acórdão referido, representativo da influência do direito da União Europeia no direito administrativo francês, ou, em outras palavras, de como o ordenamento comunitário tem afetado e alterado o direito administrativo na França, permite perceber que está em franca construção a imposição de um padrão de conduta para a Administração Pública francesa a partir de normas comunitárias, em especial o disposto no art. $6^{\circ}$ da Convenção Europeia dos Direitos do Homem, que especificamente cuida dos juízos imparciais. A partir do acórdão, duas ilações podem ser feitas. A primeira, no sentido de que, tradicionalmente, não há no direito francês a garantia da imparcialidade da Administração Pública, a qual somente foi considerada a partir de um referencial normativo externo, oriundo da União Europeia. Nesse sentido, a decisão reforça aquele entendimento inicial de que esse tema, na raiz do direito administrativo francês, não existe. Ou melhor, é uma preocupação que não se coloca ou pelos menos não se colocava. Por outro lado, a partir do acórdão Didier, as autoridades administrativas devem doravante se adaptar à orientação nele encetada. Assim, ainda que não seja um princípio típico do direito administrativo francês, a imparcialidade se impõe como um referencial importante para aferição da regularidade dos atos administrativos, não podendo ser desprezada.

${ }^{121}$ Obra citada, p. 283.

${ }^{122}$ Para assegurar o exercício desinteressado da função administrativa e garantir a imparcialidade dos funcionários públicos, a Lei de Procedimento Administrativo de 25 de Maio de 1976, instituiu um regime de incompatibilidades para os funcionários, do qual resulta a obrigação de não participação em procedimentos nos quais tenham interesse pessoal, direto ou indireto.

${ }^{123}$ El principio de objetividad en Alemania. In: DA. Revista Documentación Administrativa, no 289, eneroabril 2011, p. 261-279. 
contratos administrativos, con el fin de asegurar que la Administración respete los fines previstos legalmente. También en algunas actividades administrativas, de policía y fomento, la jurisprudencia ha desarrollado algunos mandatos de actuación objetiva y neutral. Asimismo, la neutralidad del Estado juega un papel fundamental en el Derecho de la educación -al regular la presencia de crucifijos en las escuelas públicas o el uso del velo islámico por parte de las docentes- y en el Derecho de la función pública -en el que rigen el principio de mérito y capacidad y la obligación de los funcionarios de respetar la Constitución y de no involucrarse en asuntos políticos-.

\subsubsection{Espanha}

Diferentemente do que ocorre na França e na Alemanha, o ordenamento constitucional espanhol, relativo à Constituição de 1978, consagra expressamente certos princípios fundamentais da Administração Pública. E, de acordo com o disposto no art. 103.1, da Constituição espanhola, “la Administración Pública sirve con objetividad los intereses generales...”.

O princípio da objetividade guarda grandes semelhanças com o princípio da imparcialidade até aqui divisado. Sua evolução, no entanto, foi relativamente lenta. Inicialmente, seu conteúdo estava sobreposto ao conteúdo do princípio da igualdade ${ }^{124}$. Confira-se a evolução do princípio da objetividade da Espanha na obra de Davi Duarte ${ }^{125}$ :

“É relativamente consensual, em Espanha, estabelecer uma relação de aproximação entre o princípio da imparcialidade e o princípio da igualdade ou, de outro modo, apresentar a imparcialidade como um corolário da igualdade. A exigência de objectividade na actividade administrativa, que se contrapõe à parcialidade própria do partidarismo e do privilégio dos interesses sociais concretos distintos dos interesses definidos como gerais, projecta-se na ordenação procedimental através da imparcialidade como premissa na qual se fundamentam os mecanismos de abstenção e da recusação”. O princípio da imparcialidade tem no direito espanhol, assim, uma dimensão que se circunscreve à compreensão tradicional da imparcialidade como proibição de privilégio de interesses, cuja explicação valorativa se encontra na relação de concretização que se verifica da igualdade para a imparcialidade. A capacidade de actuação autónoma do princípio da imparcialidade, particular-

\footnotetext{
${ }^{124}$ A justificativa está revelada no item 2.2 supracitado.

${ }^{125}$ Obra citada, p. 284-285.
} 
mente como meio de controlo de decisões predominantemente discricionárias, está comprimida, também por isso e de forma algo nebulosa, pela operatividade conjunta do desvio de poder e do princípio da igualdade”.

No fim do século passado, a doutrina especializada ainda tecia críticas ferozes ao baixo patamar evolutivo do princípio da objetividade na Espanha.

Maria Teresa de Melo Ribeiro ${ }^{126}$, em 1996, anotou que muito embora resulte clara do texto constitucional a consagração do princípio da imparcialidade, chamado na Espanha de objetividade da Administração Pública, surpreendentemente a disposição constitucional não tem merecido dos administrativistas espanhóis a devida atenção.

Desde que foi publicada a obra de Maria Teresa de Melo Ribeiro, em 1996, a doutrina espanhola parece ter ouvido a sua crítica e então surgiram inúmeros estudos sobre a matéria no âmbito do Direito Administrativo espanhol.

Para Eduardo García de Enterría e Tomás-Ramon Fernández ${ }^{127}$, as ações administrativas devem visar ao interesse público, que não é o interesse próprio do aparato administrativo, mas sim o da comunidade. No âmbito do direito administrativo-constitucional espanhol contemporâneo está fortalecida a visão tradicional de imparcialidade.

Confira-se o atual posicionamento de Eduardo Gamero Casado e Severiano Fernándes Ramos $^{128}$, representativo de um conceito mui evoluído de objetividade, num viés convergente com o de imparcialidade:

“La objetividad es un estándar ético, que exige contrastar el ser con el deber
ser, la concreta actuacíon realizada por la Administración con su modelo
ideal de comportamiento (Morel OcAÑA). Exige que la ponderacíon de
intereses realizada por la Administración se limite a aplicar la voluntad de
la norma.
Objetividad no equivale a neutralidad: la Administración debe ser belige-
rante para atender el interés general, y esforzarse por articular aquélla
solución que mejor lo satisfaga, sin actuar en la aplicación del Derecho con
un mero automatismo. Por otra parte, la objetividad exige que la actuación
de la Administración no se encuentre condicionada por el color político del
Gobierno, limitándose a postular la solución más justa de conformidad con

${ }^{126}$ Obra citada, p. 69.

${ }^{127}$ Curso de Derecho Administrativo I. 12ª ed. Madrid: Civitas, 2004 (reimpresión, 2005), p. 453.

${ }^{128}$ Manual Básico de Derecho Administrativo. 10ª Edición. Madrid: Tecnos, 2013, p. 76. 
las normas actuantes, lo que ha sido calificado como eficacia indiferente (GARRido Falla).

La objetividad es un concepto opuesto a la subjetividad (HEIMENDAHL), o dicho de otro modo, a la arbitrariedad. Por ello el art. 103 CE guarda una estrecha conexión con el 9.3 CE, que establece da interdicción de arbitrariedad de los poderes públicos: son las dos caras de una misma moneda, pues cuando no hay objetividad se incurre en la arbitrariedad. Objetividad equivale entonces a conducta honesta, y proscribe las actuaciones caprichosas o carentes de justificación ética. La interdicción de la arbitrariedad constituye un medio especialmente idóneo para el control de la discrecionalidad administrativa, y precisamente a ese propósito fue proclamado este principio en la Constitución (L. Martín-Retortillo, Desdentado)”.

Enfocando a correlação entre objetividade e imparcialidade, os mesmos autores asseveram que:

"La objetividad de la Administración está en función de la conducta de los empleados públicos, pues las apreciaciones de éstos se convierten en apreciaciones de la Administración. Por consiguiente, existe una correlación necesaria entre objetividad de la Administración e imparcialidad de los funcionarios”.

E trazem à tona o ponto nodal da questão:

“Al exigir una valoración subjetiva de la realidad, el concepto de objetividad
adolece de una cierta indeterminación. Ello dificulta su control, especial-
mente en los casos en que la Administración cuenta con margen de
apreciación, como sucede con el ejercicio de las potestades discrecionales”.

Juan Alfonso Santamaría Pastor ${ }^{129}$ assinala que a Administração deve fidelidade à equipe de governo que detém o poder político, mas a Constituição espanhola assegura sua neutralidade mediante duas regras: (i) a primeira impõe a Administração (como organização, em seu conjunto) atuar com objetividade (art. 103.1: “la Administración sirve con objetividad los intereses generales...”); (ii) a segunda impõe a cada um dos membros da Administração uma atuação conforme um figurino legal de imparcialidade (art. 103.3, que ordena a lei regu-

\footnotetext{
${ }^{129}$ Principios de derecho administrativo general - I. 2a Edición. Madrid: Iustel, 2009, p. 82-84.
} 
lar, a respeito dos servidores públicos, “las garantias para la imparcialidad en el ejercicio de sus funciones”). É do mesmo autor a observação de que, por próximas que pareçam, as ideias de “objetividade” e “imparcialidade” detêm conteúdos diferentes.

Para Santamaría Pastor, a objetividade tem fins bem delineados. Confira-se:

"La objetividad, en primer término, constituye una directriz que se refiere a la actividad administrativa objetivamente considerada; esto es, al comportamiento de conjunto de la Administración, no de cada uno de sus miembros. Desde esta perspectiva la objetividad implica un doble orden de exigencias:

- Primero, que la actividad pública sea fiel a los fines que el sistema normativo atribuye a la potestad concreta que se ejerce en cada caso; la actuación administrativa debe perseguir la efectiva realización de dichos fines y no otros distintos; y

- Segundo, que la actividad de la Administración se desarrolle, y las decisiones respectivas se adopten previa una completa ponderación de todos los intereses en juego que la Ley ordena proteger en cada caso (p. ej., los de todos los aspirantes en un concurso), mediante el empleo de los criterios que la propia norma establezca; y, en otro caso, de acuerdo con criterios técnicos de congruencia o razonabilidad, generalmente admitidos y que sean adecuados al fin para el que la potestad concreta ha sido atribuida”.

Por seu turno, a imparcialidade diz respeito ao aspecto subjetivo da objetividade:

\footnotetext{
"La imparcialidad, en cambio, alude al aspecto subjetivo de este mismo principio: esto es, al deber de cada servidor público de actuar en la forma antes indicada, que se manifiesta, ante todo, en la prohibición de otorgar preferencias o disfavores, a unas u otras personas, que no se amparen en normas concretas o en directivas legítimamente dictadas por el Parlamento o por el poder ejecutivo. En este plano, la imparcialidad es un correlato o consecuencia del principio de igualdad en la aplicación de la ley (art. 14 CE).
}

Para o autor, os princípios da objetividade e da imparcialidade operam como parâmetros de valoração jurídica de qualquer ação administrativa, especialmente nas atividades materiais e técnicas, onde o princípio da legalidade não atua com toda a sua eficácia. Ao mesmo tempo, servem de fundamento para duas diretrizes coadjuvantes da realização efetiva dos mesmos princípios: 
- “de una parte, la opción constitucional por un sistema burocrático profesionalizado de corte clásico: esto es, el otorgamiento al núcleo central de los servidores públicos de un régimen estatutario singular, que comporta su selección con arreglo a criterios estrictamente objetivos de igualdad, mérito y capacidad (arts. 23.2 y 103.3 CEO así como un sistema privilegiado de ventajas (p. ej., la inamovilidad) y de limitaciones (p. ej., derecho de sindicación, así como el régimen de incompatibilidades, art. 103.3); y

- De otra, el establecimiento de un conjunto de reglas de comportamiento tendentes a asegurar el correcto uso de las potestades administrativas y la ponderación de todos los intereses sobre los que éstas han de incidir: tal es la funcionalidad básica del procedimiento administrativo, que la ley debe regular y al cual ha de acomodarse la actuación administrativa [art. 105.a) y c) CE], así como diversos trámites constitutivos del mismo, como los principios de contradicción o audiencia [art. 105. A) y c) CE] y el deber de abstención que pesa sobre las autoridades públicas en los supuestos en que su interés personal pueda influir en la decisión que haya de adoptarse (arts. 28 y 29 LRJAP).

De se ver que a atual abordagem espanhola acerca do Princípio da Objetividade caminha a passos largos para uma posição científica mais completa e adequada.

\subsubsection{Portugal}

A Constituição portuguesa atual, outorgada em 1976, em seu art. 266 arrola a imparcialidade dentre os princípios fundamentais da Administração Pública ${ }^{130}$. João Caupers ${ }^{131}$ assinala que o princípio da imparcialidade inscreve-se no relacionamento da Administração Pública com os cidadãos portugueses. Segundo o autor:

“procura, por um lado, assegurar que a tomada da decisão administrativa
leve em consideração todos os interesses, públicos ou privados, relevantes
- e só estes -, por outro, evitar que a prossecução de um interesse público se

${ }^{130}$ Art. $266^{\circ}$ - (Princípios Fundamentais)

1. A Administração Pública visa a prossecução do interesse público, no respeito pelos direitos e interesses legalmente protegidos dos cidadãos.

2. Os órgãos e agentes administrativos estão subordinados à Constituição e à lei e devem actuar, no exercício das suas funções, com respeito pelos princípios da igualdade, da proporcionalidade, da justiça, da impessoalidade e da boa-fé.

${ }^{131}$ Introdução ao Direito Administrativo. 9a Edição. Lisboa: Âncora, 2007, p. 88-9. 
confunda com quaisquer interesses privados com que a actividade administrativa possa contender ou se possa envolver”.

No seu entender:

\begin{abstract}
“o princípio da imparcialidade determina que a administração pública não deve favorecer nem prejudicar especialmente nenhum interesse privado; para reduzir os riscos de tal tratamento privilegiado - positiva ou negativamente -, impõe o afastamento dos titulares dos órgãos e agentes da Administração Pública da resolução de assuntos susceptíveis de afectarem os seus interesses privados enquanto cidadãos”.
\end{abstract}

Diogo de Freitas do Amaral ${ }^{132}$ revela que a origem da noção de imparcialidade, como "não tomar partido de nenhuma das partes em contenda", vem do direito processual e da prática dos tribunais. Assevera que não é por acaso que a estátua que costuma representar a justiça é uma figura humana que tem na mão uma balança com dois pratos e uma venda nos olhos. A balança representaria a ideia de igualdade, ao passo que a venda nos olhos mostra a ideia de que a justiça tem de ser cega, isto é, "não deve determinar-se em função da amizade para com qualquer das partes”. Hoje, pode-se dizer, no seu entender, que:

\footnotetext{
“o princípio da imparcialidade significa que a Administração Pública deve tomar decisões determinadas exclusivamente com base em critérios objectivos de interesse público, adequados ao cumprimento das suas funções específicas, não se tolerando que tais critérios sejam substituídos ou distorcidos por influência de interesses alheios à função, sejam estes interesses de indivíduos, de grupos sociais, de partidos políticos, ou mesmo interesses políticos concretos do Governo”.
}

Ou, então, numa formulação mais sintética, significa que “os órgãos e agentes administrativos ajam de forma isenta e equidistante relativamente aos interesses em jogo nas situações que devem decidir ou sobre as quais se pronunciem sem caráter decisório”.

De acordo com o respectivo entendimento, o princípio da imparcialidade teria duas vertentes: uma negativa, traduzindo a ideia de que os titulares de órgãos e os agentes da Administração estão impedidos de intervir em procedimentos, atos ou contratos que digam

\footnotetext{
${ }^{132}$ Curso de direito administrativo. $2^{\mathrm{a}}$ ed. $2^{\mathrm{a}}$ reimp. - $2^{\circ}$ v. Coimbra: Almedina, 2013, p. 152-9.
} 
respeito a questões do seu interesse pessoal ou de sua família, ou de pessoas com quem tenham relações econômicas, a fim de que não possa suspeitar-se da isenção ou da retidão da sua conduta; e outra positiva, como significado do dever, por parte da Administração Pública, de ponderar todos os interesses públicos secundários e os interesses privados legítimos, equacionáveis para o efeito de certa decisão, antes da sua adoção. Na vertente positiva “devem considerar-se parciais os actos ou comportamentos que manifestamente não resultem de uma exaustiva ponderação dos interesses juridicamente protegidos”.

José Eduardo Figueiredo Dias e Fernanda Paula Oliveira ${ }^{133}$, ao tratarem do tema da rica relação entre Administração e Direito ${ }^{134}$, procuram dar um sentido evolutivo ao princípio da legalidade e esculpem o princípio da juridicidade a partir da noção de subordinação ao Direito. E, no contexto do princípio da juridicidade, é que estaria revelado o princípio da imparcialidade, ao lado dos princípios da igualdade, da proporcionalidade, da boa-fé e da justiça. Sobre a imparcialidade, dizem ser “um princípio com especial relevo nas relações entre a Administração e os particulares, visando assegurar que nas decisões administrativas se tenham em consideração todos os interesses públicos e privados relevantes, e só estes (princípio da ponderação de interesses), de modo a evitar que a prossecução de um interesse público se confunda com quaisquer interesses privados com que a actividade administrativa possa contender ou possa se envolver".

Marcelo Rebelo de Sousa e André Salgado de Matos ${ }^{135}$ revelam que o conteúdo jurídico do princípio da imparcialidade, no ordenamento português, foi sendo ampliado e ganhou densidade com o tempo. Passou de uma noção simplória de "tratamento isento dos particulares pela administração, no sentido de que esta não os poderia favorecer ou desfavorecer por razões ligadas aos titulares dos órgãos ou agentes administrativos que estão em concreto na posição de decidir ou actuar" para uma noção moderna de "comando de tomada em consideração e ponderação, por parte da administração, dos interesses públicos e privados relevantes para cada concreta actuação sua”.

Assim como Diogo Freitas do Amaral, os autores acima citados focam o princípio da imparcialidade sob duas dimensões. A dimensão negativa proíbe de “a propósito de um caso

\footnotetext{
${ }^{133}$ Noções Fundamentais de Direito Administrativo. $2^{\text {a }}$ Edição. Coimbra: Almedina, 2011, p. 107 e seguintes. ${ }^{134}$ Exatamente, a nosso ver, no espectro de incidência da "Teoria Geral do Direito Administrativo como sistema”, de Eberhard Achmidt-Assmann, quanto à necessidade de diálogo interdisciplinar entre ciências que têm o mesmo objeto científico de exame.

${ }^{135}$ Direito Administrativo Geral - introdução e princípios fundamentais. Tomo I. $3^{\mathrm{a}}$ ed. Alfragide: Dom Quixote, 2008, p. 216.
} 
concreto, tomar em consideração e ponderar interesses públicos ou privados que, à luz do fim legal a prosseguir, sejam irrelevantes para a decisão”. De outro lado, a dimensão positiva impõe que, "previamente à decisão de um caso concreto, a administração tome em consideração e pondere todos os interesses públicos e privados que, à luz do fim legal a prosseguir, sejam relevantes para a decisão".

Marcelo Rebelo de Sousa e André Salgado de Matos comentam que da combinação das duas dimensões, a negativa e a positiva, resulta que "no exercício da sua margem de livre decisão, a administração tem que tomar em consideração e ponderar todos os interesses públicos e privados relevantes para a decisão e só estes”136.

Paulo Otero ${ }^{137}$ cataloga o princípio da imparcialidade no campo dos princípios gerais da atividade administrativa, ao lado de outros sete princípios: (i) Juridicidade; (ii) Prossecução do interesse público; (iii) Respeito pelas posições jurídicas ativas dos cidadãos; (iv) Igualdade, (v) Proporcionalidade, (vi) Justiça; (vii) Boa-fé. Antes dos princípios gerais da atividade administrativa, Otero descreve como sete os princípios gerais da organização administrativa: a) Subsidiariedade; b) Descentralização; c) Desconcentração; d) Unidade; e) Participação dos interessados na gestão da Administração; f) Aproximação dos serviços às populações; g) Desburocratização. Tanto os princípios gerais da organização administrativa quanto os princípios gerais da atividade administrativa têm previsão no texto constitucional português atual.

O princípio da imparcialidade, na visão de Paulo Otero ${ }^{138}$, pode ser assim divisado:

\begin{abstract}
"Numa primeira e nuclear acepção, a imparcialidade, envolvendo uma exigência de isenção e equidistância entre quem decide e o objeto ou o destinatário da decisão, expressa ainda uma ideia de justiça: a prossecução do interesse público deve ser feita sem o envolvimento de interesses subjetivos ou pessoais de quem decide, impedindo-se situações de favorecimento ou desfavorecimento por conflito ou colisão entre os interesses envolvidos.
\end{abstract}

\footnotetext{
${ }^{136}$ Os autores assinalam que não é tradicional na doutrina portuguesa a teorização da dimensão positiva do princípio da imparcialidade, muito embora ela já tenha acolhimento em alguma jurisprudência (Ac. STA 12/5/ 1988, Oliveira Fernandes e Ribeiro Ltda.). Também dão exemplos interessantes das duas dimensões. "A dimensão negativa do princípio da imparcialidade é violada caso um órgão administrativo determine o valor pecuniário de uma sanção contraordenacional ponderando a necessidade de arrecadar receitas (interesse público irrelevante) ou a imposição de um maior sacrifício ao infractor (interesse privado irrelevante); a dimensão positiva do princípio da imparcialidade é violada se, na mesma situação, o órgão administrativo não ponderar a gravidade da infracção (interesse público relevante) ou a situação econômica do infrator (interesse privado relevante)".
}

${ }^{137}$ Manual..., p. 373.

${ }^{138}$ Manual..., p. 373-374. 
Numa segunda dimensão, a imparcialidade aproxima-se da adequação ponderativa dos interesses relevantes para a decisão, devendo o decisor tomar sempre em consideração todos esses interesses, excluindo do seu âmbito, no entanto, todos os interesses que se mostram inapropriados ou irrelevantes face à situação concreta a decidir”.

Em nova investida, Otero revela o alcance exato do princípio da imparcialidade no contexto português:

“O princípio da imparcialidade comporta, neste sentido, uma dupla vertente:

(i) Em termos negativos, a imparcialidade envolve a neutralidade administrativa face a quaisquer interesses alheios ao interesse público, salvaguardando-se a independência e a isenção do prolator da decisão através de um conjunto de impedimentos, incompatibilidades, escusas e suspeições dos titulares das estruturas administrativas intervenientes;

(ii) Em termos positivos, a imparcialidade determina parâmetros racionais, objetivos, lógicos e transparentes de decisão, visando a que se tomem em consideração ponderativa todos os fatores ou elementos relevantes para a decisão, assim como excluir de ponderação quaisquer interesses alheios ou irrelevantes".

Cabe notar que mesmo antes da constitucionalização do princípio da imparcialidade, com a Constituição da República Portuguesa de 1976, vozes autorizadas como a de José Carlos Vieira de Andrade já sustentavam em trabalhos acadêmicos ${ }^{139}$ a necessidade premente de elevação ao status constitucional do princípio em tela.

Percebe-se que no regime português o princípio da imparcialidade não tem caráter meramente instrumental, acessório, adjetivo. De um lado está previsto no texto constitucional como princípio fundamental, regedor da Administração Pública como um todo; e de outro, a doutrina especializada lhe reserva desempenhar um papel bastante abrangente.

\subsubsection{Itália}

Atualmente, a versão italiana da impessoalidade, tratada como imparcialidade, assim como em Portugal, parece bem completa e refinada.

${ }^{139}$ A imparcialidade da Administração como princípio constitucional. In: Boletim da Faculdade de Direito da Universidade de Coimbra, Vol. L, 1974, p. 219 a 246. 
O estágio evoluído do tratamento conferido ao instituto talvez seja justificado, ao menos em parte, pelo fato de que foi a Itália o primeiro país na Europa a positivar, no texto constitucional, nos idos de 1948, o princípio da imparcialidade ${ }^{140}$. De acordo com David Duarte ${ }^{141}$ :

\begin{abstract}
“A evolução das referências que estão relacionadas com o significado corrente da imparcialidade administrativa demonstra que é da composição legislativa em torno da proibição de confusão, privilégio e prejuízo de interesses que se isolou a imparcialidade como princípio jurídico com incidência na actividade administrativa. Foi deste sentido e com objetivos de garantir a isenção administrativa que o texto constitucional italiano estabeleceu, numa disposição com projecções de diferente natureza, que a organização administrativa será estruturada de modo a assegurar a imparcialidade administrativa”.
\end{abstract}

Na Itália, o princípio da imparcialidade, no art. 97, da Constituição, é considerado princípio fundamental do Direito Administrativo e, segundo Sabino Cassese ${ }^{142}$, traz consequências relevantes, a exemplo da implantação de critérios de procedimento (concursos, por exemplo); da obrigação de a Administração examinar de modo acurado, completo e imparcial, todos os elementos relevantes das causas; da necessidade de avaliar e ponderar os interesses a fim de alcançar resultados relativos; e a abstenção da prática de ato da autoridade quando ela tiver interesse na decisão. Para o autor, o princípio da imparcialidade constitui a base das normas sobre inelegibilidades, incompatibilidades e conflitos de interesses na esfera pública.

Em verdade, o texto do art. 97 da Constituição italiana indica que a organização da Administração há de ser feita de modo a assegurar a imparcialidade administrativa e o bom andamento administrativo. E diferentes são as leituras doutrinárias a respeito do dispositivo, sendo dominante a perspectiva que vê no princípio do bom andamento uma determinação genérica de eficiência administrativa que se conecta, como cláusula de otimização, à função

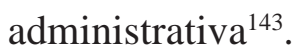

\footnotetext{
${ }^{140}$ Como referido no item 2.2 supracitado, a marca democrática da imparcialidade acabou positivada na Carta da Itália, de 1948, nela se abrindo uma seção específica sobre a Administração Pública (Título II - O Governo - Seção II), com menção expressa a dois princípios: o da eficiência (bom andamento) e o da imparcialidade (art. 97).

${ }^{141}$ Obra citada, p. 277-278.

${ }^{142}$ Il Diritto Amministrativo e i suoi principi (In: Corso di Diritto Amministrativo diretto da Sabino Cassese. 1. Instituzioni di Diritto Amministrativo a cura de Sabino Cassese. $4^{\mathrm{a}}$ ed. Milano: Giuffrè Editore, 2012, p. 1/22. ${ }^{143}$ Conforme, David Duarte (Obra citada, p. 278, rodapé 70).
} 
A introdução do princípio da imparcialidade no art. 97, da Constituição italiana, segundo David Duarte ${ }^{144}$, deveu-se à intenção de salvaguardar os particulares da disparidade de tratamento causada por diferentes opiniões políticas, que se explica na contraposição ao regime político que antecedeu o novo sistema constitucional. Para os constituintes de então, imparcialidade significava "irrelevância para a Administração da opinião política dos particulares e obrigação de agir sem qualquer influência política”.

Para Domenico Sorace ${ }^{145}$, de acordo com o princípio da imparcialidade, a Administração atua para satisfazer os interesses públicos primários, devendo estar atenta para todos os outros tipos de interesses relevantes públicos ou privados, a fim de que sua decisão corresponda a uma composição dos interesses em jogo, extraindo a máxima utilidade de todos e sem o descarte de qualquer um. O interesse público merece uma construção concreta, à luz dos diversos interesses envolvidos em cada caso.

De acordo com Francesco Merloni ${ }^{146}$, o princípio da impessoalidade pode ser considerado de vários modos. Pode implicar imparcialidade na “ação administrativa”, no sentido de que a Administração não pode discriminar algum interesse em prejuízo de outro, garantindo paridade de tratamento e dando concretude ao princípio da igualdade, formal e substancialmente considerada, como direito a um "justo procedimento" e a uma "boa administração". Pode resultar, noutro sentido, em imparcialidade “na organização”, seja do ponto de vista objetivo seja do ponto de vista subjetivo. Do ponto de vista objetivo, determinando competências, atribuições e responsabilidades, a fim de permitir resultados imparciais de ação. Do ponto de vista subjetivo, assegurando ao corpo administrativo a necessária independência, com reflexos na confiança do cidadão.

Maurizio Asprone ${ }^{147}$, em boa síntese, ensina que a imparcialidade na Administração Pública italiana está alicerçada nas premissas de que o princípio foi elevado a cânone do comportamento da Administração Pública, materializando regra que esta deve reproduzir em sua própria atividade. A imparcialidade alcança tanto a Administração Pública estática (organização administrativa) quanto a Administração Pública dinâmica (atividade/função administrativa).

Para o mesmo autor, o art. 97 da Constituição italiana estabelece a reserva de lei para a organização administrativa. E o dispositivo constitucional determina que a lei deve

\footnotetext{
${ }^{144}$ Obra citada, p. 278, rodapé 71.

${ }^{145}$ Diritto delle amministrazioni pubbliche - Una introduzioni. $6^{\mathrm{a}}$ ed. Bologna: Il Mulino, 2010, p. 67.

${ }^{146}$ Istituzioni di diritto amministrativo. Torino: G. Giappichelli Editore, 2012, p. 36-8.

${ }^{147}$ Il principio di imparzialità nel diritto comparato. Roma: Aracne editrice, 2011.
} 
assegurar a imparcialidade e o bom andamento da Administração. Nesse sentido, Asprone defende que a imparcialidade, assim como outros princípios, representa um elemento de conjunção (congiunzione) entre a vida/atividade dos órgãos constitucionais e a esfera dos aparatos administrativos, existindo íntima relação entre o princípio da imparcialidade e o endereçamento político.

A imparcialidade, para Asprone, exige que não haja “politização” da esfera administrativa e que se observe a necessária proibição de favoritismos. Instrumentalmente, tais exigências se materializariam em medidas como a predeterminação das modalidades de ação administrativa e a neutralidade (terzietá) do responsável pela condução do processo administrativo.

Para o mesmo autor, a imparcialidade não significa neutralidade ou indiferença em relação aos interesses envolvidos na atividade administrativa. Significa o uso correto do aparato administrativo para alcançar as finalidades previstas em lei, sem que haja a prevalência de um interesse que favoreça a Administração em confronto com a ordem jurídica e que, de antemão, condicione as escolhas administrativas. A Administração deve maximizar o interesse público entregue à sua tutela, conciliando-o com outros interesses públicos e privados envoltos na mesma seara administrativa (interesses secundários).

Asprone indica que o princípio da imparcialidade possui total conexão com o princípio democrático, não sendo possível conceber como pertencente a um regime democrático uma estrutura administrativa privada de conformações organizativas e operativas evidentemente imparciais.

Asprone alude, ainda, à difícil tarefa de definir o princípio. Revela que a Constituição italiana, para além do art. 97, não estabelece um conceito claro e preciso de imparcialidade. E ao se analisar a legislação, a conceituação se torna ainda mais difícil, na medida em que o legislador se utiliza quase sempre de aspectos específicos da imparcialidade, a depender do contexto particular e sobre qual setor da Administração esta incide.

Não há no seu entender amplitude genérica na aplicação do princípio da imparcialidade, que muitas vezes depende do confronto com o caso concreto e com a função administrativa a ser desenvolvida. Assim, materializam o princípio da imparcialidade tanto a obrigação do funcionário público de se abster diante de situações que impliquem conflitos de interesse quanto a predeterminação de critérios em procedimentos administrativos de escolha e a igualdade de tratamento dos administrados perante a Administração (concursos e licitações). 
Explana sobre a existência da corrente doutrinária italiana que compreende a imparcialidade como decorrente diretamente da legalidade. Essa ideia partiria da arquitetura do ordenamento jurídico delineada por Kelsen, segundo a qual a atividade administrativa é concebida como mera execução do trato normativo.

Asprone critica tal posicionamento com base na ausência de valoração por tal corrente doutrinária do conteúdo substancial e normativo do princípio. Assenta que, apesar da dificuldade de conceituação, a imparcialidade é valor fundante da Administração Pública e pode ser analisada a partir dos pontos de vista positivo e negativo. Sob a ótica negativa, o princípio da imparcialidade impõe à Administração Pública o dever de não realizar discriminações injustificadas com base em razões subjetivas. Do ponto de vista positivo, obriga os órgãos administrativos a agirem de acordo com as regras gerais que disciplinam a atividade administrativa.

É do mesmo autor a observação sobre ser pacífico na doutrina que a imparcialidade deve ter aplicação tanto na ação (atividade) quanto na organização da Administração Pública, de vez que o art. 97 da Constituição italiana atribui à Administração Pública o dever funcional de se organizar de modo a poder agir imparcialmente. E, nesse sentido, a Administração somente será imparcial, caso estruturada de modo que quem administra não tenha interesse pessoal nas decisões.

Com específica referência à atividade administrativa, o respeito ao princípio da imparcialidade requer da Administração Pública a predeterminação dos critérios a que deve se ater no desenvolvimento e na concretização de suas competências. A predeterminação de critérios estabelece um autolimite, o qual vincula os órgãos administrativos e os proíbe de atuar de forma diversa da previamente definida, consequentemente parcial. Em boa síntese, ora vertida para o português em tradução livre, Asprone ${ }^{148}$ assinala que:

\footnotetext{
"Em conclusão, portanto, do ponto de vista conceitual, a imparcialidade reflete tanto um dever de paridade de tratamento quanto uma proibição de favoritismo no exercício das prerrogativas discricionárias da Administração Pública e implica um certo grau de abstração da própria Administração, a fim de voltar a sua atividade à tutela do interesse público primário. Mas, por outro lado, deve também ser reconhecida uma acepção positiva, em razão da qual a Administração, no exercício do poder discricionário que
}

${ }^{148}$ Obra citada, p. 61. 
tipicamente a caracteriza, deve assegurar uma valoração completa de todos os interesses, a fim de poder garantir uma completa comparação dos interesses secundários em função do interesse público primário.”

Um olhar atento sobre o ordenamento jurídico europeu atual, como explicitado, revela que o tratamento conferido à imparcialidade na Itália parece despontar como o mais evoluído e, a partir desse traçado mais abrangente, parece conectar-se com a (mais ampla) visão que merece prevalecer entre nós, brasileiros, acerca do Princípio da Impessoalidade.

\subsection{Brasil}

A tese foca o exame do conteúdo jurídico do princípio da impessoalidade, especificamente considerado para a parametrização, o controle e a responsabilidade das decisões administrativas. Num tal contexto, investigará o porquê de não estar sendo bem atendido o princípio da impessoalidade.

Este trabalho parte da consideração de que uma das causas, talvez a principal, do descumprimento do princípio em evidência está na falta de explicitação normativa do seu conteúdo, seja no texto constitucional (art. 37, caput), seja no regime da legislação ordinária ou até mesmo a partir das leituras doutrinária e jurisprudencial.

Comprovando a acentuada constitucionalização do Direito Administrativo, a doutrina constitucional tem dedicado especial atenção ao princípio da impessoalidade. Para bem apreender o conteúdo jurídico do princípio, mister relacionar excertos doutrinários sobre a matéria, a fim de trilhar um conceito adequado de impessoalidade a ser empregado nas decisões administrativas.

O apanhado doutrinário será dividido em dois blocos: conceitos elaborados no Direito Constitucional e conceitos gerados no Direito Administrativo. Será enfocada apenas a literatura nacional, porque é nela que o princípio da impessoalidade assume o caráter de originalidade que se quer indicar, relativamente aos princípios (conteúdos) referidos no item 2.3.

O objetivo deste tópico é subsidiar a elaboração de um conceito de impessoalidade abrangente (continente), que sirva de norte à Administração, e depois aferir se o princípio da impessoalidade, no Brasil, está presente não só nas ações administrativas, mas como é de esperar, na organização administrativa. 


\subsubsection{Direito Constitucional}

Concebido no texto constitucional de 1988, ainda que como princípio cardeal do Direito Administrativo, natural que os constitucionalistas se dediquem ao estudo do Princípio da Impessoalidade.

José Afonso da Silva ${ }^{149}$, pioneiro no trato da matéria, respeitando a topografia constitucional, aborda o princípio da impessoalidade no contexto dos princípios (gerais) constitucionais da Administração Pública. Antes de tratar o assunto propriamente dito explica que a Administração Pública é informada por diversos princípios gerais, destinados, “de um lado, a orientar a ação do administrador na prática dos atos administrativos e, de outro lado, a garantir a boa administração”.

No seu entender, o princípio ou regra da impessoalidade da Administração Pública significa que os atos e provimentos administrativos são imputáveis não ao funcionário que os pratica, mas ao órgão ou entidade administrativa em nome do (a) qual age o funcionário, mero agente da Administração Pública, e que, portanto, não pode ser encarado como autor institucional do ato, mas como simples órgão formal de manifestação da vontade estatal.

Coerentemente, José Afonso da Silva anota que o administrado não se confronta com o funcionário (x ou y) que expediu o ato, porém com a entidade cuja vontade foi manifestada por ele, já que "a primeira regra de estilo administrativo é a objetividade, que está em estreita relação com a impessoalidade".

Diz que a Constituição dá uma consequência expressa a essa “regra”, quando, no § 1 , do art. 37, proíbe que constem nome, símbolo ou imagens que caracterizem promoção pessoal de autoridades ou servidores públicos em publicidades de atos, programas, obras, serviços e campanhas dos órgãos públicos. Por isso entende que a responsabilidade para com terceiros é sempre da Administração $0^{150}$.

A lúcida compreensão de José Afonso da Silva exibe que a impessoalidade, no contexto constitucional brasileiro, ora é regra, ora é princípio. Tanto que o autor se refere à “regra” do art. 37, § $1^{\circ}$, da CF/88, sobre a proibição de que constem da publicidade institucional nomes, símbolos ou imagens que caracterizem promoção pessoal de agentes públicos.

\footnotetext{
${ }^{149}$ Curso de Direito Constitucional Positivo. 35a Edição. São Paulo: Malheiros, 2012, p. 668-670.

${ }^{150}$ Não obstante a afirmação, José Afonso da Silva (Curso..., p. 670), cuidadosamente, alude ao fato de que a personalização, ou seja, a individualização do funcionário, pode ser recomendável, "quando atue não como expressão da vontade do Estado, mas como expressão de veleidade, capricho ou arbitrariedade pessoal”.
} 
Seu conceito de impessoalidade parece não alcançar o seu verdadeiro conteúdo, muito embora o autor tenha o cuidado de aproximá-lo da visão contemporânea de “objetividade”, própria do ordenamento espanhol, quando declara que “a primeira regra do estilo administrativo é a objetividade”. A sistematização do mestre tem o mérito de embutir no conceito antes traçado - impessoalidade como significado da abstração da pessoa do funcionário público - uma preocupação com os limites de atuação da administração pelo ângulo da “função pública”. No ponto, seu raciocínio se conecta com Odete Medauar, como será adiante demonstrado.

Para Gilmar Mendes ${ }^{151}$, a impessoalidade é um “comando constitucional” no sentido de que “à Administração não é permitido fazer diferenciações que não se justifiquem juridicamente, pois não é dado ao administrador o direito de utilizar-se de interesses e opiniões pessoais na construção das decisões oriundas do exercício de suas atribuições”. O autor esclarece que, obviamente:

“(...) as diferenciações são naturais em todo e qualquer processo, e não seria
razoável imaginar uma Administração que não fornecesse tratamento dife-
renciado a administrados sensivelmente diferentes”, sendo certo que “tais
diferenciações devem se submeter ao critério da razoabilidade e se justifi-
car juridicamente, pois do contrário estar-se-ia diante de uma discriminação
positiva ou negativa, que não se justifica no Estado de Direito, e mais ainda
no espaço público”.

Gilmar Mendes entende que a impessoalidade é corolário do princípio republicano e “manifesta-se como expressão de não protecionismo e de não perseguição, realizando, no âmbito da Administração Pública, o princípio da igualdade, previsto na Constituição Federal em seu art. 5, caput”. E que, em razão do “princípio” da impessoalidade, “não há relevância jurídica na posição pessoal do administrador ou servidor público, pois a vontade do Estado independe das preferências subjetivas do servidor ou da própria Administração”.

Alude à existência destas determinações concretas da impessoalidade administrativa no texto constitucional: a) obrigatoriedade do ingresso em cargo, emprego ou função pública por meio de concurso público, baseada no critério do conhecimento técnico para a contratação de futuros servidores públicos (art. 37, II, da CF/88); b) necessidade de certame licitatório

${ }^{151}$ Curso de Direito Constitucional. 6a Edição. São Paulo: Saraiva, 2011, p. 861-862. 
para a contratação com o Poder Público (art. 37, XXI); c) permissões e concessões de serviços públicos (art. 175, da CF/88).

A visão de Gilmar Mendes sobre a impessoalidade administrativa traz nuances interessantes. Há a preocupação inaugural de não rotular a impessoalidade como princípio, mas sim como “comando constitucional”. A expressão parece encerrar uma cláusula geral, a encampar "princípios e regras constitucionais”. O raciocínio se mostra adequado porque a impessoalidade, no texto constitucional, ora assume a máscara de regra, ora assume uma forma mais plástica de princípio. O autor nota que a impessoalidade é um corolário do princípio republicano. Concordamos às inteiras com tal pensamento. A ideia de gestão da “coisa pública” impõe ao administrador um comportamento impessoal inegociável.

Temos dúvidas, apenas, em atribuir à impessoalidade como “princípio” um papel coadjuvante, embora relevante, de "braço armado" da isonomia prevista no caput do art. $5^{\circ}$ do texto constitucional. Tal maneira de ver as coisas se aproxima de Celso Antônio Bandeira de Mello e nos parece, com todo respeito, leitura impeditiva de um maior alcance do princípio da impessoalidade, tanto porque não focado o seu âmbito de incidência pela leitura correta dos conceitos-chave de “interesse público” e de “função pública”, quanto porque não impõe, claramente, à maquina pública, a adoção impositiva de uma estrutura administrativa adequada para dar cabo das numerosas tarefas impostas pela impessoalidade, a chamada “organização administrativa impessoal”.

Cármen Lúcia Antunes Rocha ${ }^{152}$ assegura que “o princípio da impessoalidade administrativa tem como objeto a neutralidade da atividade administrativa, fixando como única diretriz jurídica válida para os comportamentos estatais o interesse público”. Explica que “à generalidade da lei corresponde a impessoalidade na Administração, e é isto que garante a resistência contra usos e abusos do Poder do Estado por pessoas ou grupos”. Em síntese precisa, assevera que "o princípio da impessoalidade impede e proíbe, assim, o subjetivismo na Administração Pública”, sendo certo que "a objetividade não permite que se mostre ou prevaleça a face ou a alma do administrador”.

Ao tratar especificamente dos vícios de pessoalidade na Administração Pública, Cármen Lúcia Antunes Rocha ${ }^{153}$ inclui a promoção pessoal ao lado do nepotismo, do partidarismo e da pessoalidade administrativa na elaboração normativa. Sobre a promoção pessoal explica que:

\footnotetext{
${ }^{152}$ Princípios constitucionais da Administração Pública. Belo Horizonte: Del Rey, 1994, p. 147-149.

${ }^{153}$ Obra citada, p. 155-169.
} 
“A impessoalidade administrativa tem sido acometida de grave afronta pelo recurso da promoção pessoal a que se oferecem alguns administradores. Valendo-se dos cargos públicos por eles ocupados, e que precisam ter as atividades a eles inerentes divulgadas para conhecimento da população, buscam aqueles agentes contornar o impedimento constitucional de personalizar o exercício da função pública e tirarem proveitos daquela difusão dos fatos, atos e serviços”.

Após revelar que a promoção pessoal pode ser indistintamente financiada com recursos públicos ou particulares, e que parece não ser exaustiva a listagem constitucional apresentada quanto ao que caracteriza a promoção pessoal - nomes, símbolos ou imagens - a autora verbera que:

“(...) Tudo o que caracteriza e personaliza a publicidade administrativa insere-se na vedação jurídica, pela agressão que ela carreia ao princípio da impessoalidade. Assim, a utilização de jingles de campanha política do candidato eleito, a tornar pessoal a publicidade dos atos por ele praticados, slogans que veicularam a sua marca pessoal de campanha, etc., são exemplos de comportamentos vedados constitucionalmente.”

E arremata:

"A impessoalidade administrativa impõe que o administrador não se valha de sua situação funcional ou como agente público para se promover ou para promover interesses benéficos ou maléficos a pessoas identificadas pela relação pessoal com ele mantida. Tudo o que desborde da neutralidade, objetividade e interesse público é inválido constitucionalmente pela agressão a este princípio”.

Embora extremamente rica, a posição externada por Cármen Lúcia também se ressente de um olhar mais direto para a organização administrativa impessoal, o que, a nosso sentir, se revela necessário, uma vez que sem uma organização administrativa impessoal torna-se difícil trilhar o agir impessoal ideal.

\subsubsection{Direito Administrativo}

Para Odete Medauar ${ }^{154}$, há ângulos diversos do princípio da impessoalidade, de

\footnotetext{
${ }^{154}$ Direito Administrativo Moderno..., p. 143-144.
} 
“instrumentalização recíproca” com a moralidade e a publicidade, mas todos convergem para "impedir que fatores pessoais, subjetivos, sejam os verdadeiros móveis e fins das atividades administrativas":

“(...) com o princípio da impessoalidade, a Constituição visa obstaculizar atuações geradas por antipatias, simpatias, objetivos de vingança, represálias, nepotismo, favorecimentos diversos, muito comuns em licitações, concursos públicos, exercício do poder de polícia. Busca, desse modo, que predomine o sentido de função, isto é, a ideia de que os poderes atribuídos finalizam-se ao interesse de toda a coletividade, portanto a resultados desconectados de razões pessoais. Em situações que dizem respeito a interesses coletivos ou difusos, a impessoalidade significa a exigência de ponderação equilibrada de todos os interesses envolvidos, para que não se editem decisões movidas por preconceitos ou radicalismos de qualquer tipo”.

A abordagem de Odete Medauar é simultaneamente completa e contemporânea. Chama-nos a atenção para vários ângulos da impessoalidade, ligados por uma unidade de escopo: “impedir que fatores pessoais, subjetivos, sejam os verdadeiros móveis e fins das atividades administrativas”. Ou seja, a impessoalidade como virtuoso conceito multifacetado, para que se aumente o seu raio de ação, de cobertura da ação administrativa, sem prejuízo de um foco bem delineado.

Reconduz a impessoalidade à ideia de “função”, deixando claro que os poderes administrativos hão de ser exercitados com apego aos interesses de toda a coletividade, desconectados de razões pessoais. O raciocínio vai ao encontro do que pensamos, porque situa a impessoalidade no contexto maior de “república” e denota atenção ao correto conceito de interesse público divorciado de visão unilateral (por vezes arbitrária) da Administração.

Coerentemente, a autora aborda o tema das decisões administrativas ao lecionar que a impessoalidade significa “a exigência de ponderação equilibrada de todos os interesses envolvidos”, de modo a banir preconceitos ou radicalismos de quaisquer espécies. Sua posição se harmoniza, no ponto, com a visão mais abrangente que se tem no ordenamento europeu acerca dos princípios da imparcialidade e da objetividade.

Na doutrina brasileira, também merece atenção a doutrina de Maria Sylvia Zanella di Pietro, que faz uma observação inicial que parece justificar um tratamento bastante aberto do princípio da impessoalidade. Diz que “este princípio, que aparece, pela primeira vez, com 
essa denominação, no art. 37 da Constituição de 1988, está dando margem a diferentes interpretações, pois, ao contrário dos demais, não tem sido objeto de cogitação pelos doutrinadores brasileiros" ${ }^{155}$.

No seu entendimento, a impessoalidade deve significar "que esse atributo deve ser observado em relação aos administrados como à própria Administração”. O primeiro significado, indicado para toda a atividade administrativa, estaria relacionado à "finalidade pública”, no sentido de que a Administração não pode atuar com vistas a prejudicar ou beneficiar pessoas determinadas, uma vez que é sempre o interesse público que tem que nortear o comportamento. No segundo, teria a mesma dimensão exposta por José Afonso da Silva, no sentido de que os atos administrativos são imputáveis não ao servidor, mas sim ao Estado.

Como exemplo do primeiro significado, a autora relaciona o art. 100, da CF/88, sobre os precatórios judiciais, aludindo ao fato de que o dispositivo proíbe a designação de pessoas ou de casos nas dotações orçamentárias e nos créditos adicionais abertos para esse fim. Como expressão do segundo significado, refere-se ao mesmo exemplo de José Afonso da Silva, ou seja, à questão da proibição de promoção pessoal em meio à publicidade institucional (art. 37, § $1^{\circ}$, da CF/88).

Pode o princípio da impessoalidade, dentro de seu caráter multifacetado, ser encarado como uma via de mão dupla. Está correta a autora. Isso porque, se de um lado a Administração se apresenta perante o administrado como uma realidade jurídica única, pouco importando a figura do servidor pessoalmente identificado, de outro lado ele, administrado, não pode ser prejudicado por interpretações tortuosas, vestidas de significados preconceituosos atentatórios ao interesse público.

Os exemplos referidos pela autora, todavia, não são exatos. A nosso sentir, tanto o art. 100, sobre os precatórios, quanto o art. 37, § 1º, ambos do texto constitucional, encerram aplicações da "regra” e não do “princípio” da impessoalidade e, assim, se aplicam na base do "tudo ou nada".

Diogo de Figueiredo Moreira Neto ${ }^{156}$, explorando o tema dos princípios gerais do Direito Administrativo, versa que o princípio da impessoalidade, expresso no caput do art. 37, da CF/88, tem tríplice acepção: $1^{a}$ ) veda à Administração distinguir interesses onde a lei não o fizer; $2^{\mathrm{a}}$ )veda a Administração de prosseguir interesses públicos secundários próprios,

\footnotetext{
${ }^{155}$ Direito Administrativo..., p. 68.

${ }^{156}$ Curso de Direito Administrativo. 14 ${ }^{\text {a }}$ Edição. Rio de janeiro: Forense, 2006, p. 95.
} 
desvinculados dos interesses públicos primários definidos em lei. (Neste caso, “enfatiza-se a natureza jurídica ficta da personalização do Estado, que, por isso, jamais deve atuar em seu exclusivo benefício, mas sempre no da sociedade"157). Na terceira, com ligeira diferença sobre a segunda, veda que a Administração dê precedência a quaisquer interesses outros em detrimento dos finalísticos.

Ensina que "as três acepções confluem para definir a correta atuação do Estado, enquanto administrador, relativamente à sua indisponível finalidade objetiva, que é aquela expressa em lei, ou seja, totalmente despido de qualquer inclinação, tendência ou preferência subjetiva, mesmo em benefício próprio, o que levou Cirne Lima a afirmar que a boa administração é a que prima pela ausência de subjetividade”"158.

A abordagem do Prof. Diogo tem o inegável mérito de realçar facetas do princípio da impessoalidade. Na primeira acepção, impessoalidade se aproximaria de isonomia. Na segunda, a nosso ver tributária da partição que é própria na Itália, em especial da doutrina de Alessi, entre interesses primários e secundários, afasta-se a possibilidade de a Administração prosseguir interesses públicos secundários próprios, desvinculados dos interesses públicos primários definidos em lei. Na terceira, abraça-se, a nosso ver, tese similar à de Hely Lopes Meirelles, invocando-se o princípio da finalidade, para dizer-se que a Administração não pode dar precedência a interesses outros, em detrimento dos finalísticos.

Quer nos parecer que o autor, principalmente na terceira acepção, ao fazer alusão à “preferência”, propõe implicitamente a consideração de interesses outros e todos os interesses envolvidos na decisão administrativa.

Outra respeitável análise é de Celso Antônio Bandeira de Mello, que ao tratar dos “princípios constitucionais do Direito Administrativo Brasileiro” arrola o princípio da impessoalidade ao lado de outros 13 (treze) princípios, sem a confessada preocupação maior de trilhar uma organização sistemática ideal. São eles, com as bases constitucionais respectivas: a) Princípio da supremacia do interesse público sobre o interesse privado - fundamentase na própria ideia de Estado; b) Princípios da legalidade (art. 5², II, 37, caput, e 84, IV); c) Princípio da finalidade (tem os mesmos fundamentos do princípio da legalidade); d) Princípio da razoabilidade (tem os mesmos fundamentos dos princípios da legalidade e da finalidade); e) Princípio da proporcionalidade (por ser aspecto específico da razoabilidade, também se apoia nos citados fundamentos); f) Princípio da motivação (arts. $1^{\circ}$, II e parágrafo único, e

157 Obra citada, p. 95.

${ }^{158}$ Obra citada, p. 95. 
50, XXXV); g) Princípio da publicidade (arts. 37, caput, e 5, XXXIII e XXXIV, “b”); h) Princípios do devido processo legal e da ampla defesa (art. 5, LIV e LV); i) Princípio da moralidade administrativa (art. 37, caput e $\S 4^{\circ}$, 85, V, e 5º LXXIII); j) Princípio do controle judicial dos atos administrativos (art. 5, $\mathrm{XXXV);} \mathrm{k)} \mathrm{Princípio} \mathrm{da} \mathrm{responsabilidade} \mathrm{do} \mathrm{Estado}$ por atos administrativos (art. 37, § $6^{\circ}$ ); l) Princípio da boa administração (para o autor, eficiência - art. 37, caput); m) Princípio da segurança jurídica (para o autor, não pode ser radicado em qualquer dispositivo constitucional específico, mas é da essência do Estado Democrático de Direito).

No entendimento de Celso Antônio Bandeira de Mello, o princípio da impessoalidade, tendo como base constitucional os arts. 37, caput, e 5, caput, "não é senão o próprio princípio da igualdade ou isonomia"159. E nele se traduz a ideia de que "a Administração tem que tratar a todos os administrados sem discriminações, benéficas ou detrimentosas”. Não pode haver nem favoritismos nem perseguições, e “simpatias ou animosidades pessoais, políticas ou ideológicas não podem interferir na atuação administrativa e muito menos interesses sectários, de facções ou grupos de qualquer espécie”.

Como aplicações concretas do princípio da impessoalidade no texto constitucional, o autor aponta: a) Art. 37, inciso II, ao exigir que o ingresso em cargo, função e emprego público depende de concurso público, exatamente para que todos possam disputar-lhes o acesso em plena igualdade; b) Art. 37, XXI, ao estabelecer, pelas mesmas razões, que os contratos com a Administração direta e indireta dependerão de licitação pública que assegure igualdade de todos os concorrentes; c) Art. 175, ao exigir licitação para permissões e concessões de serviços públicos, por similares razões.

Na obra de Bandeira de Mello, a questão em debate recebe os influxos do princípio da lealdade e da boa-fé, estribados no princípio constitucional da moralidade (art. 37, caput, da CF/88). Lealdade e boa-fé que, para Celso Antônio Bandeira de Mello ${ }^{160}$ dizem com a ideia de que a Administração, em todo o transcurso dos procedimentos administrativos, deve agir “de maneira lhana, sincera, ficando, evidentemente, interditados quaisquer comportamentos astuciosos, ardilosos, ou que, por vias transversas, concorram para entravar a exibição das razões ou dos direitos dos administrados”.

O que defende Celso Antônio Bandeira de Mello apoia-se na sobreposição do princípio da isonomia ao princípio da impessoalidade, mas não o entendemos da mesma forma. Pode

${ }^{159}$ Curso de Direito Administrativo..., p. 114.

${ }^{160}$ Curso de Direito Administrativo..., p. 508. 
haver enlaçamento dos espectros de incidência de ambos os princípios, porém existe espaço suficiente para que o princípio da impessoalidade tenha autonomia. Com o devido respeito, concluir que a impessoalidade é a isonomia é desprezar o apuro do legislador constituinte no que tratou dos temas em tópicos separados (art. $5^{\circ}$, caput, para a isonomia, e art. 37, caput, para a impessoalidade), e também deixar de fora de sua cobertura inúmeras situações incluídas na lida diária da Administração Pública. Em todo caso, essa visão encontra forte apoio em vários respeitáveis doutrinadores, a exemplo de Gilmar Mendes, como assinalado.

Já na obra de Hely Lopes Meirelles ${ }^{161}$ são apontados os seguintes “princípios básicos da administração": a) Legalidade; b) Moralidade; c) Impessoalidade ou finalidade; d) Razoabilidade e proporcionalidade; e) Publicidade; f) Eficiência; g) Segurança jurídica; h) Motivação; i) Ampla defesa e contraditório; j) Interesse público ou supremacia do interesse público.

Fica clara, de início, a posição do autor em promover a identidade das noções de impessoalidade e finalidade. Diz que “o princípio da impessoalidade, referido na Constituição de 1988 (art. 37, caput), nada mais é que o clássico princípio da finalidade, o qual impõe ao administrador público que só pratique o ato para o seu fim legal”. E o “fim legal”, para o autor, é "unicamente aquele que a norma de Direito indica expressa ou virtualmente como objetivo do ato, de forma impessoal”.

Para Hely Lopes Meirelles, o princípio deve outrossim ser entendido como a proibição de promoção pessoal na publicidade institucional (art. 37, § $1^{\circ}$, da CF/88). Completa seu raciocínio e confere-lhe coerência explicitando que “a finalidade terá sempre um objetivo certo e inafastável de qualquer ato administrativo: o interesse público”. Deste modo, “todo ato que se apartar desse objetivo sujeitar-se-á a invalidação por desvio de finalidade, que a nossa lei da ação popular conceituou como o 'fim diverso daquele previsto, explícita ou implicitamente, na regra de competência'do agente (Lei $n^{\circ} 4.717 / 65$, art. $2^{\circ}$, parágrafo único, 'e')”.

Interessante citar que Hely Lopes Meireles afirmou que “desde que o princípio da finalidade exige que o ato seja praticado sempre com finalidade pública, o administrador fica impedido de buscar outro objetivo ou de praticá-lo no interesse próprio ou de terceiro", sendo possível, entretanto, “o interesse público coincidir com o de particulares, como ocorre normalmente nos atos administrativos negociais e nos contratos públicos, casos em que é lícito conjugar a pretensão do particular com o interesse público”.

${ }^{161}$ Direito Administrativo Brasileiro. 37ª Edição. São Paulo: Malheiros, 2011, p. 93 e seguintes. 
Para tornar sua concepção ainda mais clara, asseverou que o "que o princípio da finalidade veda é a prática de ato administrativo sem interesse público ou conveniência para a Administração, visando unicamente a satisfazer interesses privados, por favoritismo ou perseguição dos agentes governamentais, sob a forma de desvio de finalidade”. E arrematou: "esse desvio de conduta dos agentes públicos constitui uma das mais insidiosas modalidades de abuso de poder".

Por fim, o autor constatou que "o princípio em foco está entrelaçado com o princípio da igualdade”, para ele previsto nos arts. $5^{\circ}$, I, e 19, III, da CF, o qual impõe à Administração Pública tratar igualmente a todos os que estejam na mesma situação fática e jurídica e significa, por conseguinte, que “os desiguais em termos genéricos e impessoais devem ser tratados desigualmente em relação àqueles que não se enquadram nessa distinção (RTJ 195/297)”.

Cremos serem importantes suas proposições sobre o princípio da impessoalidade. Conquanto não concordemos com a existência de uma identidade cabal entre as ideias de impessoalidade e finalidade, porque temos em mente que a impessoalidade desempenha um papel bem maior, não deixa de interessar a abordagem multifacetada feita pelo autor. Disse ele que na aplicação do princípio da impessoalidade o administrador não pode se descurar do fim legal, e que a finalidade terá um objetivo certo: o interesse público. Também mencionou que o art. 37, $\S 1^{\circ}$ (vedação de promoção pessoal em meio à publicidade institucional) é expressão da impessoalidade. E que se sujeita a invalidação, por desvio de finalidade, o ato praticado com quebra de impessoalidade (finalidade). Explicitou que o princípio não é igual, mas está “entrelaçado com o princípio da isonomia”.

A visão do autor, para nós, é rica e atual, sendo detectáveis apenas dois aparentes equívocos: a) a aproximação total do princípio da impessoalidade com a noção de finalidade; b) a não exploração de uma zona de aplicação do princípio voltada à necessidade de uma estruturação organizacional adequada da Administração para dar cabo das tarefas ditadas pela impessoalidade.

Caio Tácito expõe que o princípio da impessoalidade, regente de toda a atividade administrativa, condena comportamentos administrativos tendenciosos que traduzam ou impliquem uma pré-compreensão desfavorável ao administrado. Segundo Caio Tácito ${ }^{162}$ :

${ }^{162}$ O Princípio da legalidade: ponto e contraponto. In: BANDEIRA DE MELLO, Celso Antônio (org.). Estudos em Homenagem a Geraldo Ataliba-2 - Direito Administrativo e Constitucional. São Paulo: Malheiros Editores, 1987, p. 149. 
“O princípio da impessoalidade repele atos discriminatórios que importem favorecimento ou desapreço a membros da sociedade em detrimento da finalidade objetiva da norma de Direito a ser aplicada.

Não é indiferente, porém, à Administração Pública, a personalidade do administrado. O que se veda é a personificação de seus atos, na medida em que abandonem o interesse público para conceder favores ou lesar pessoas ou instituições.

Em síntese, a atividade administrativa pode, e em certos casos deve distinguir entre pessoas, em função de peculiaridades que a lei manda observar. Não poderá jamais discriminar entre elas, sobrepondo o juízo personalista à objetividade legal de tratamento.”

Tal posicionamento é relevante porque, muito embora deixe de lado a preocupação com a organização administrativa impessoal, voltada a um agir impessoal, remarca bem a ideia de que a Administração não só pode como deve levar em consideração, com seriedade, os legítimos interesses dos particulares no momento das decisões administrativas.

Merecem menção duas obras específicas no Direito Administrativo Brasileiro sobre o princípio da impessoalidade. Pioneiras numa sistematização maior e mais verticalizada, ambas estão revestidas de inegáveis méritos e as destacamos em separado.

Na obra de Lívia Zago, publicada em 2001, intitulada “O princípio da impessoalidade”163, demonstra-se ser a impessoalidade (i) um princípio ético e político, (ii) um direito e um dever fundamental e (iii) um princípio constitucional da Administração Pública. Como princípio ético e jurídico enfoca sua aplicação desde as noções na (i) titularidade de poder; (ii) no exercício do poder; (iii) como finalidade e interesse público; (iv) como neutralidade política. Como direito e dever fundamental, o princípio protegeria o cidadão contra a subjetividade, a arbitrariedade e o tratamento desigual e, ao mesmo tempo, exigiria do cidadão conduta conforme os direitos que lhe são assegurados. Como princípio constitucional, a impessoalidade é estudada nas Constituições do Brasil e é comparada como o princípio da “imparcialidade” na Inglaterra, na Itália, na Espanha e em Portugal.

Faz a autora exaustivo trabalho de desenvolvimento do significado e dos (muitos) significados do princípio da impessoalidade, entendido como: a) Neutralidade do órgão; b) Limite do poder discricionário; c) Óbice ao poder invisível e à “arcana práxis”; d) Coibição da improbidade; e) Garante da igualdade de condições; f) Forma de coibir a propaganda e a

${ }^{163}$ O Princípio da Impessoalidade. Rio de Janeiro: Renovar, 2001. 
publicidade dos agentes públicos e a personalização; g) Traço característico da burocracia; h) Princípio da eficiência do serviço público.

Busca um sentido absoluto (tomado em seus significados ético e político) e outro relativo (por admitir eventual flexibilização) para o princípio da impessoalidade. Nos sentidos ético e político "não admite a prevalência de qualquer outro princípio, já que concretiza as disposições preambulares da Constituição de 1988 e os objetivos fundamentais da República Federativa do Brasil, conforme disposto no artigo $3^{\circ}$ da Magna Carta". No sentido relativo, acaba por admitir “como a maioria dos princípios, e, certas hipóteses e sob certas circunstâncias, que ocorra a pessoalidade sem que isto signifique ofensa ao princípio em si mesmo considerado" ${ }^{\prime 64}$.

A autora esquadrinha a abrangência do princípio da impessoalidade debatendo a vinculação do legislador e o tormentoso tema da não aplicação da lei inconstitucional por quebra de impessoalidade. Também analisa a vinculação do juiz e a do particular ao mesmo princípio.

Além disso, faz referências sobre a matéria na doutrina e na jurisprudência. Quanto à doutrina brasileira, relaciona e compara o princípio com os conceitos de finalidade, igualdade, moralidade e neutralidade do órgão. Quanto aos excertos jurisprudenciais, indica posições bem e mal fundamentadas no princípio, em temas, dentre outros, como: a) Concurso público; b) Agentes públicos (b.1-Aumento/redução de salários; b.2- Represália por móvel de vingança ou político ou privilégio); c) Licitação; d) Desapropriação; e) Matéria tributária; f) Princípio da moralidade; g) Propaganda pessoal e personalização; h) Quebra de ordem cronológica.

Disposta a mais aprofundar-se, a autora compara o princípio com os outros princípios constitucionais da Administração Pública, nomeadamente, com os princípios da legalidade, da igualdade, da moralidade, da publicidade e da eficiência. E o compara com o princípio da imparcialidade.

Ao fim e ao cabo, para Lívia Zago ${ }^{165}$ o princípio da impessoalidade, de muitas facetas, constitui novidade no direito pátrio, pelo menos em termos constitucionais. Interpreta que a ciência política o conhece "no sentido e na aspiração de neutralidade do titular do poder e de objetividade no atuar da Administração, ambos retrato do Estado impessoal, gerido por leis impessoais e por uma organização administrativa isenta e burocrática”.

${ }^{164}$ Obra citada, p. 256.

165 Obra citada, p. 2. 
Segundo ela, “impõe-se, de um lado, a impessoalidade, como a exigência, dirigida sobretudo ao Poder Público, de comportamentos impessoais, objetivos, 'sine ira et studio', aos quais correspondem o direito de cidadão de ver a 'res publica' sempre na direção dos interesses públicos e objetivando o alcance do bem comum”.

Certo o ensinamento da autora de que " $a$ outra faceta da impessoalidade expõe as consequências negativas da neutralidade sem temperanças, que contribuiu para gerar, na seara da Administração Pública, a falta de eficiência do organismo burocrático, distante, impessoal, inacessível, insensível”, dando azo ao seguinte paradoxo:

\footnotetext{
“ao mesmo tempo em que a impessoalidade é condição de eficiência é, também, causa de deficiência do serviço público, ocasionando o trabalho anônimo, sem responsáveis, repetitivo, sem criatividade, ineficiente e ineficaz. A opção pela racionalização extrema, pelo excesso de burocracia e de regulamentação é, nas palavras de Roberto Dromi, ‘uma opção entre o bemestar geral e o mal-estar comum,”. ${ }^{166}$
}

Cumprindo o requisito de originalidade da tese, a autora projeta este conceito de impessoalidade:

\begin{abstract}
“O princípio da impessoalidade é o princípio da defesa da sociedade contra os desvios e excessos do poder. A impessoalidade na titularidade do poder é condição da existência do Estado Democrático de Direito; no exercício do poder, a impessoalidade é direito e dever fundamental do indivíduo, garantia a uma Administração Pública proba e eficiente, obtida pela imposição de condutas tendentes à realização do interesse público geral, caracterizado e valorado objetivamente, sem a ingerência de interesses públicos ou privados, admitida apenas a ressalva de outro interesse público específico e compatível”.
\end{abstract}

E também arrola, num quadro chamado de “princípio da impessoalidade - contrastes”, quatro aspectos perversos e quatro aspectos positivos do princípio. Como perversos: a) burocratização excessiva; b) dificuldade de responsabilização (pessoal); c) igualização (desmotivação); d) ineficiência. Como aspectos positivos, o princípio proporciona: a) administração neutra (objetiva); b) responsabilidade objetiva; c) igualização (respeito à isonomia); d) eficiência.

${ }^{166}$ Obra citada, p. 2-3. 
Já o trabalho de Ana Paula Ávila, intitulado “O princípio da Impessoalidade da Administração Pública: para uma administração imparcial”167, foi publicado em 2004 e propõe uma abordagem bastante distinta da concebida por Lívia Zago.

No prefácio do livro, da lavra de Diogo de Figueiredo Moreira Neto, registra-se a excelência do trabalho, cujos méritos são agora apontados.

Ana Paula Ávila ${ }^{168}$ inicia sua abordagem pelo ordenamento brasileiro. No particular, revela a posição tradicional da doutrina brasileira e adota o conceito de que "a noção de impessoalidade abarca as noções de objetividade, imparcialidade, neutralidade e transparência da Administração" e anota que a impessoalidade estará explicada como:

“(...) o princípio que impõe à Administração Pública o dever de respeitar o direito de igualdade dos Administrados e de não se valer da máquina pública para lograr proveito pessoal ou de outrem; o dever de proceder com objetividade na escolha dos meios necessários para a satisfação do bem comum; o dever de imparcialidade do administrador quando da prática de atos e decisões que afetem interesses privados ou que ponham termo a conflito de interesses privados perante a Administração, e, inclusive, na decisão sobre o conteúdo dos interesses públicos em concreto; o dever de neutralidade do administrador, que deve caracterizar a postura institucional da Administração e determinar aos agentes públicos o dever de não deixar que suas convicções políticas, partidárias ou ideológicas interfiram no desempenho de sua atividade funcional; e, ainda, na sua exteriorização, o dever de transparência”.

Em síntese, a autora indica que a impessoalidade é ponto de chegada de uma "faceta impositiva de deveres de conduta para a Administração Pública" e de outra "faceta limitadora da atividade administrativa”. Em razão disso, “surgem limites para a atividade discricionária, que fixam parâmetros decisórios para a determinação do interesse público, para a condução do processo administrativo e para a solução de conflitos entre interesses privados que se ponham perante a Administração".

O próximo passo foi delinear os fundamentos do princípio da impessoalidade, acolhendo-o no âmago dos princípios (i) do Estado Democrático de Direito; (ii) do Democráti-

${ }^{167}$ O princípio da Impessoalidade da Administração Pública: para uma administração imparcial. Rio de Janeiro: Renovar, 2004.

${ }^{168}$ Obra citada, p. 25-26. 
co; (iii) da proteção material dos Direitos Fundamentais (com ênfase na dignidade humana, na liberdade e na igualdade); d) do Republicano.

Então a autora extraiu deveres dedutíveis do princípio da impessoalidade: a) Objetividade ou Impessoalidade strictu sensu; b) Imparcialidade; c) Neutralidade; d) Transparência. E revelou vícios da impessoalidade: a) Parcialidade; b) Nepotismo; c) Partidarismo; d) Pessoalidade e elaboração normativa; e) Promoção pessoal.

Depois disso promoveu aproximação total entre o princípio da impessoalidade, próprio do direito brasileiro, e o princípio da imparcialidade, relativo a ordenamentos jurídicos da Europa continental. Chegou a trabalhar, adiante, a impessoalidade como imparcialidade, ou melhor, como “dever de imparcialidade”.

Em abordagem novidadeira, exibiu o dever de imparcialidade na atividade administrativa em geral, nos atos vinculados e nos atos discricionários. Também o fez no contexto dos processos administrativos, ao reafirmar, para a concretização do princípio, a necessidade das garantias do contraditório, da ampla defesa e do juiz natural.

Muito importa sua abordagem sobre o âmbito de incidência do dever de imparcialidade, seja o subjetivo, seja o objetivo, com reflexos: (i) na Administração Ordenadora (função de polícia: na atividade registral, no controle das atividades privadas e na intervenção sobre o domínio econômico); (ii) na Administração Prestadora de Serviços; (iii) na Administração Pública Promocional (ou Atividade de Fomento); (iv) na Administração em sua relação com a atividade de planejamento.

Por fim, Ana Paula Ávila trouxe implicações do dever de imparcialidade no direito administrativo brasileiro, sendo elas, nomeadamente: a) Na hierarquia e na independência do agente no âmbito decisório da Administração Pública; b) Sobre o poder de decisão de agentes exoneráveis ad nutum; c) Sobre a competência para a instauração e o julgamento de processo administrativo disciplinar; d) Sobre o sistema de impedimentos e suspeições do Código de Processo Civil e sua aplicabilidade no processo administrativo (com destaque para a Lei $\mathrm{n}^{\circ}$ 9.784, de 29 de janeiro de 1999, e para os impedimentos e suspeições no direito processual). Como principais conclusões, a autora assim se posicionou:

a) As noções tradicionalmente atribuídas pela doutrina ao princípio da impessoalidade não esgotam o seu conteúdo, que não extrapola a mera identificação com:

a.1) o princípio da isonomia; 
a.2) a teoria da imputação dos atos ao ente administrativo, e não às pessoas que o praticam;

a.3) com a necessidade do reconhecimento da validade dos atos praticados em exercício de fato.

b) A simples análise do sentido mais imediato do vocábulo "imparcialidade” aponta para outras significações, marcadas pela necessidade de desinteresse e objetividade nas avaliações e atividades procedidas pela Administração Pública;

c) Uma necessária nova concepção para o princípio da impessoalidade deve abarcar, para além das já consideradas pela doutrina, uma série de outras diretrizes, entre as quais a da imparcialidade, a da objetividade, a da neutralidade e a da transparência da Administração Pública;

d) O dever de imparcialidade é o mais importante aspecto do princípio da impessoalidade. E assim é porque impõe uma determinada postura aos agentes que lidam com a coisa pública a se portarem com necessário desinteresse e apego à isenção e à objetividade;

e) Dentre os mandamentos da imparcialidade destacam-se:

e.1) Dever de alheamento do agente em relação a interesses próprios, seus ou de outrem, que sejam irrelevantes para dar cumprimento às finalidades estabelecidas nas normas que permeiam a atividade política;

e.2) Dever de dar oportunidade de manifestação às pessoas afetadas pelas atividades administrativas;

e.3) Dever de equidistância em relação a todos os possíveis interessados nos atos praticados pela Administração Pública, com o que se mantém a isenção desejada para a função pública administrativa;

e.4) Dever de ponderação de todos os interesses - públicos e privados - envolvidos na execução das normas pelos entes administrativos;

e.5) Dever de afastamento dos agentes que, por quaisquer razões, possuam interesses próprios, diretos ou indiretos, nos feitos que realizam em nome da Administração.

f) O dever de imparcialidade tem lugar especial na seara decisória da Administração Pública;

g) O dever de imparcialidade tem lugar tanto na prática de atos vinculados quanto 
na de atos discricionários. No primeiro caso, não há falar em interesse próprio da Administração, pois os interesses a serem perseguidos estão fixados na norma posta pelo legislador. No segundo caso, exige-se a ponderação de todos os interesses envolvidos como conditio sine qua non para a determinação do próprio interesse público, a ser considerado como o "resultado concreto de todas as circunstâncias e vicissitudes das situações concretas que se coloquem ao administrador";

h) O dever de imparcialidade é garantia indissociável do processo administrativo e está ligado às garantias do contraditório, da ampla defesa e do juiz natural;

i) No caso de exploração de atividade econômica, cuja finalidade imediata é o lucro, e não a satisfação de uma necessidade pública, não é de ser aplicado o dever de imparcialidade, pela simples razão de que a própria Constituição determina a aplicação do mesmo regime aplicável à esfera privada;

j) O dever de imparcialidade pode ser considerado um postulado normativo e inspira deveres conexos, tais como o dever de neutralidade e de transparência. Também dá ensejo, porque o administrador desempenha função, ao manejo de todas as vedações de condutas que traduzam um mau desempenho, corroborando as hipóteses de impedimentos e suspeições.

As obras acima estudadas têm o mérito de descortinar cabalmente o princípio da impessoalidade, precisando-lhe conceito e alcance, sobretudo como ação administrativa. Na presente tese, partindo-se da infraestrutura produzida pelas obras, ambiciona-se ferir o tema da impessoalidade na organização administrativa e delinear a impessoalidade que deve ter lugar nas decisões administrativas, mormente como parâmetro para controle e responsabilização.

\subsection{Constituição de 1988 (regra ou princípio?)}

A impessoalidade, assim nominada, surgiu pela vez primeira na Constituição de $1988^{169}$. Está referida, de modo expresso, em várias passagens do texto. Exemplificativamente, é princípio geral, regedor de toda a atividade administrativa, tanto em termos de ação como de organização administrativa, no caput do art. 37. Vem revelada, como regra, no art. 100, na

\footnotetext{
${ }^{169}$ Conforme Maria Sylvia Zanella di Pietro (Direito Administrativo..., p. 68).
} 
exigência de precatório para pagamentos das dívidas do poder público e no $\S 1^{\circ}$, do mencionado art. 37, como forma de proibição de promoção pessoal na publicidade institucional.

No texto constitucional, portanto, a impessoalidade pode ostentar natureza jurídica ora de regra, ora de princípio.

Princípios, como explicitado, são normas que contêm exigências de justiça, equidade ou moralidade e que, ao contrário das regras, não se aplicam na base do "tudo ou nada”. Como ensinou Dworkin, em certas circunstâncias podem ceder em virtude da existência de outras razões ou de princípios que apontem para uma direção diferente. Os princípios ostentam dimensões e pesos e, na medida em que se chocam, eventualmente, é forçoso considerar, em casos concretos, a importância específica de cada um. Segundo a consagrada fórmula de Alexy, os princípios são mandados de otimização cuja aplicação varia em diferentes graus, estando sujeitos à ponderação e à proporcionalidade, sendo certo que sua pretensão normativa pode ceder, conforme as circunstâncias, a elementos contrapostos.

A partir das lições acima transcritas, é possível concluir que, por suas texturas fechadas, as normas de impessoalidade descritas nos arts. 37, § $1^{\circ}$, e 100 , ambos da CF/88, ostentam natureza jurídica de “regras” constitucionais.

Perceba-se que os respectivos conteúdos se esgotam em si mesmos e que elas ensejam a aplicação dos métodos comuns de interpretação. Implicam um conteúdo definido de submissão e propõem, claramente, critérios de ação, atraindo uma aplicação mecânica típica, bem distinta da que é própria dos princípios jurídicos.

Assim definidas como nítidas regras constitucionais, a impessoalidade de que cuidam os art. 37 , § $1^{\circ}$, e 100 , da CF/88 se aplica na base do “tudo ou nada”.

De outro lado, a referência à impessoalidade na cabeça do art. 37, por sua textura aberta, moldável diante das situações da vida, assume a confessada natureza jurídica de princípio constitucional.

\subsubsection{Art. 37 , § $1^{\circ}$, da CF/88 (regra da proibição de promoção pessoal na publicidade institucional)}

A regra do art. 37, § $1^{\circ}$, da CF/88, é produto da benfazeja interação entre os conteúdos jurídicos da impessoalidade e da publicidade. Publicidade que, para Norberto Bobbio ${ }^{170}$, faz ${ }^{170}$ O futuro da democracia. $11^{\text {a }}$ Edição. São Paulo: Editora Paz e Terra, 2009, p. 97-98. O autor revela que a
expressão de governo da democracia como “governo do poder público em público” traduz um aparente jogo de 
parte na democracia, passível de ser conceituada como "o governo do poder público em público”. Para Carlos Ari Sundfeld ${ }^{171}$, “a razão de ser do Estado é toda externa”, porque “tudo que nele se passa, tudo que faz, tudo que possui, tem uma direção exterior” e também porque "a finalidade de sua ação não reside jamais em algum benefício íntimo: está sempre voltado ao interesse público”.

É dever do administrador prestar contas de sua administração. Deveras, consoante o art. 15, da Declaração dos Direitos do Homem e do Cidadão, de 1789, “a sociedade tem o direito de pedir conta, a todo agente público, quanto à sua administração”.

O Estado de Direito repousa nas cláusulas do controle e da responsabilidade. De nada adianta submeter o Estado à ordem jurídica justa, à míngua de controles suficientemente hígidos para a detecção de desvios e de irregularidades nas ações e omissões estatais, umas e outras suscetíveis de acarretar as devidas responsabilidades. E para um controle eficaz, imprescindível a publicidade. Para Gilmar Mendes, a publicidade está intimamente ligada ao princípio democrático ${ }^{172}$ :

\begin{abstract}
“O princípio da publicidade está ligado ao direito de informação dos cidadãos e ao dever de transparência do Estado, em conexão direta com o princípio democrático, e pode ser considerado, inicialmente, como apreensível em duas vertentes: (1) na perspectiva do direito à informação (e de acesso à informação), como garantia de participação e controle social dos cidadãos (a partir das disposições relacionadas no art. $5^{\circ}$, da CF/ 88), bem como (2) na perspectiva da atuação da Administração Pública em sentido amplo (a partir dos princípios determinados no art. 37, caput, e artigos seguintes da CF/88).”
\end{abstract}

Partindo-se da ideia-força de que os princípios constitucionais estão em relação de “instrumentalização recíproca” ${ }^{173}$, o grande desafio do intérprete está em alcançar um ponto

\footnotetext{
palavras. Aparente porque "público" tem dois significados diversos, conforme venha contraposto a "privado", como exemplo da clássica distinção entre ius publicum e ius privatum, transmitida pelos juristas romanos, ou a "secreto", em cujo caso tem o significado não de pertencente à "coisa pública” ou ao "Estado", mas de "manifesto", "evidente”, mas precisamente de "visível".

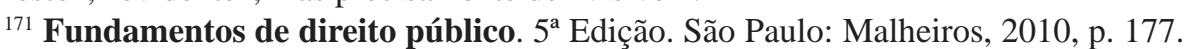

172 Obra citada, p. 863.

${ }^{173}$ Conforme o balizado magistério de Odete Medauar (Direito Administrativo Moderno..., p. 143), "os princípios da impessoalidade, moralidade e publicidade apresentam-se intrincados de maneira profunda, havendo, mesmo, instrumentalização recíproca; assim, a impessoalidade configura-se meio para atuações dentro da moralidade; a publicidade, por sua vez, dificulta medidas contrárias à moralidade e impessoalidade; a moralidade administrativa, de seu lado, implica observância da impessoalidade e da publicidade”.
} 
ótimo de equilíbrio, para que se assegure, com a máxima eficácia, de um lado, a publicidade, dever do Estado e direito do cidadão, e de outro a impessoalidade, a rechaçar, como afirma Odete Medauar ${ }^{174}$, em fórmula lapidar, “que fatores pessoais, subjetivos, sejam os verdadeiros móveis e fins das atividades administrativas”.

O Supremo Tribunal Federal já se posicionou sobre o tema em debate.

Inicialmente, é curioso perceber que, sobre a questão da quebra da impessoalidade na publicidade institucional, não há muitos acórdãos no Supremo Tribunal Federal com apreciação de mérito. A nosso ver, isso reforça a impressão de que a norma esculpida no art. 37, § $1^{\circ}$, da CF/88, tem natureza jurídica de regra. E assim é porque, como explicitado alhures, na sua aplicação, as regras ensejam atividade de subsunção entre a norma hipotética e a situação concreta da vida. É dizer: a aplicação de uma regra não prescinde de uma moldura fática específica. E como os tribunais superiores, em geral, resistem em reexaminar a prova dos autos ou, então, a rever a moldura fática dos acórdãos atacados pelos recursos de natureza extraordinária, há, naturalmente, uma abrupta diminuição de espaço para o conhecimento da questão de fundo, o que justifica uma profusão de julgados no sentido do não conhecimento dos recursos.

Não obstante isso, como “não conhecer” é uma forma de decidir, em muitos casos os tribunais superiores acabam por endossar as teses dos tribunais inferiores, tidas, ainda que silenciosamente, como as mais adequadas. No âmbito do Supremo Tribunal Federal destacam-se alguns acórdãos interessantes sobre o alcance do art. 37,§ $1^{\circ}$, da CF/88.

Ao julgar, por exemplo, o RE $n^{\circ} 191.668-1 / R S$, da relatoria do saudoso Ministro Menezes Direito, a $1^{\mathrm{a}}$ Turma do STF assentou que “o caput e o parágrafo $1^{\circ}$ do artigo $37 \mathrm{da}$ Constituição Federal impedem que haja qualquer tipo de identificação entre a publicidade e os titulares dos cargos alcançando os partidos políticos a que pertençam”. Esclareceu que “a possibilidade de vinculação do conteúdo da divulgação com o partido político a que pertença o titular do cargo público mancha o princípio da impessoalidade e desnatura o

\footnotetext{
${ }^{174}$ Direito Administrativo Moderno..., p. 144. Para a preclara autora: “com o princípio da impessoalidade, a Constituição visa obstaculizar atuações geradas por antipatias, simpatias, objetivos de vingança, represálias, nepotismo, favorecimentos diversos, muito comuns em licitações, concursos públicos, exercício de poder de polícia. Busca-se, desse modo, que predomine o sentido de função, isto é, a ideia de que os poderes atribuídos finalizam-se ao interesse público de toda a coletividade, portanto a resultados desconectados de razões pessoais. Em situações que dizem respeito a interesses coletivos ou difusos, a impessoalidade significa a exigência de ponderação equilibrada de todos os interesses envolvidos, para que não se editem decisões motivadas por preconceitos ou radicalismos de qualquer tipo".
} 
caráter educativo, informativo ou de orientação que constam do comando posto pelo constituinte dos oitenta"175/176.

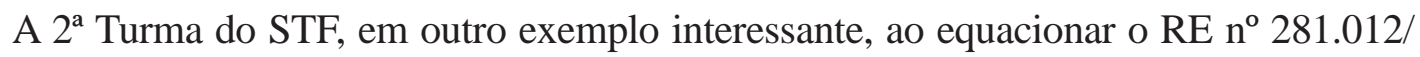
$\mathrm{PI}^{177}$, cujo relator originário era o Ministro Gilmar Mendes, mas cujo redator para o acórdão foi o Ministro Joaquim Barbosa, acabou por não conhecer de recurso interposto contra acórdão do Tribunal de Justiça do Piauí, que, em autos de ação popular, manteve condenação do então Prefeito da capital (Sr. Heráclito Fortes), que fez incluir símbolo e slogan político-pessoais em diversas formas de publicidade institucional e de divulgação de obras e eventos da Prefeitura ${ }^{178}$.

${ }^{175}$ Conforme ementa do julgado, publicada no DJe n ${ }^{\circ}$ 97, de 30.05.2008.

${ }^{176}$ No caso acima referido, o Município de Porto Alegre, em recurso extraordinário, buscava reverter condenação do Tribunal de Justiça do Rio Grande do Sul baseada no fato provado de que houve a inclusão de slogan na publicidade dos atos da Administração Pública, para fins de promoção pessoal ilícita. O Recorrente sustentou ofensa ao art. $37, \S 1^{\circ}$, da $\mathrm{CF} / 88$, porque, no seu entender a Constituição não proibiu, expressamente, a utilização de marcas, não sendo dado ao Judiciário atuar como legislador positivo. Também sustentou que a publicidade é necessária e está condicionada a limites formais, relacionados ao caráter informativo, educativo ou de orientação social, o que ocorre na divulgação de slogan sobre a "forma de governar". Ao rechaçar as teses do Município, o Ministro Menezes Direito, forte na visão de que se está diante de uma regra, a ser aplicada na base do "tudo ou nada", visão com a qual concordamos, elucidou que:

“(...) A regra constitucional do artigo 37, caput e parágrafo $1^{\circ}$, objetiva assegurar a impessoalidade da divulgação dos atos governamentais que devem voltar-se exclusivamente para o interesse social. Não quis o constituinte que os atos de divulgação servissem de instrumento para a propaganda de quem está exercendo o cargo público, espraiando com recursos orçamentários a sua presença política no eleitorado. O que o constituinte quis foi marcar que os atos governamentais objeto de divulgação devem revestir-se de impessoalidade, portanto, caracterizados como atos de governo e não deste ou daquele governo em particular. Não foi por outra razão que a redação do parágrafo $1^{\circ}$ do artigo 37 da Constituição de 1988, prestes a completar 20 anos, restringiu a publicidade ao caráter educativo, informativo ou de orientação social, 'dela não podendo constar nomes, símbolos ou imagens que caracterizem promoção pessoal de autoridades ou servidores públicos'. No momento em que existe a possibilidade de reconhecimento ou identificação da origem pessoal ou partidária da publicidade há, sem dúvida, o rompimento do princípio da impessoalidade determinada no caput, bem como configuração de promoção pessoal daquele que exerce o cargo público no padrão de sua vinculação com determinado partido político que ensejou a sua eleição. Assim, direta ou indiretamente, a vedação é alcançada toda vez que exista a menor possibilidade que seja de desvirtuar-se a lisura desejada pelo constituinte, sequer sendo necessário construir interpretação tortuosa que autorize essa vedação, nascida que é da simples leitura do texto da espécie normativa de índole constitucional”.

177 DJe 12.06.2012.

${ }^{178}$ No caso acima referido, o Tribunal de origem assentou, com base no acervo fático-probatório, tal como o fizera a sentença, que "nenhum teresinense, mesmo os menos avisados, em vendo o símbolo em forma de ' $H$ ' (inicial do prenome do ex-prefeito) e em lendo ou ouvindo o 'slogan' 'Unidos seremos mais fortes', deixaria de associá-los à pessoa do então administrador desta cidade”.

O Ministro Gilmar Mendes proferiu voto (vencido) no sentido da possibilidade da valoração da prova, algo excepcionalmente permitido, para concluir pela insuficiência destas como suporte da condenação, com o que deu como violado o art. 37, $\S 1^{\circ}$, da CF/88. O Ministro Joaquim Barbosa divergiu do relator, asseverando que o recorrente, em verdade, pretendia o reexame, pura e simples, dos fatos e provas, o que é vedado nas instâncias extraordinárias. Em pedido de vista, o Ministro Cezar Peluso, mesmo não conhecendo do apelo raro, adentrou e feriu a questão de fundo, com o seguinte elucidativo voto:

“O art. 37, § 1², da Constituição Federal, dispõe, na cláusula que interessa, que da publicidade dos atos, programas, obras, serviços e campanhas dos órgãos públicos, não podem constar nomes, símbolos, nem imagens que caracterizem promoção pessoal de autoridade ou servidores públicos. A questão, portanto, é saber se o símbolo e o slogan usados pela Prefeitura de Teresina configuram, ou não, promoção pessoal. Irretocável o raciocínio adotado pelo relator, na medida em que, deveras, é possível interpretar de forma 


\subsubsection{Art. 100, da CF/88 (regra do precatório judicial)}

De acordo com o art. 100, caput, da Constituição de 1988, “os pagamentos devidos pelas Fazendas Públicas Federal, Estaduais, Distrital e Municipais, em virtude de sentença judiciária, far-se-ão exclusivamente na ordem cronológica de apresentação dos precatórios e à conta dos créditos respectivos, proibida a designação de casos ou de pessoas nas dotações orçamentárias e nos créditos adicionais abertos para este fim”.

Segundo Fernando Facury Scaff e Luma Cavaleiro de Macedo Scaff ${ }^{179}$, “a norma constitucional em análise tem como finalidade assegurar a isonomia entre os credores da Fazenda Pública, impedindo qualquer espécie de favorecimento ou de privilégios, por razões políticas ou pessoais, em consonância com o Princípio Republicano, bem como os da Administração Pública, constantes do art. 37 da CF”.

O sistema de pagamento por precatório não consubstancia mero capricho do legislador constituinte. Diferentemente, diz com imperativos de ordem pragmática. Sem previsão orçamentária, é impossível a realização da despesa, por mais nobre que seja a sua origem. Daí porque os precatórios devem ser apresentados até julho de cada ano, para serem incluídos no próximo orçamento anual da entidade devedora.

Ao julgar a AC 254-QO, Rel. Min. Celso de Mello, o Supremo Tribunal Federal assentou, com absoluta precisão, verbis:

“A jurisprudência do STF (...) firmou-se no sentido de considerar imprescindível, mesmo tratando-se de crédito de natureza alimentícia, a expedição de precatório, ainda que reconhecendo, para efeito de pagamento do

impessoal o material produzido pela prefeitura, e, portanto, impossível afirmar que toda a população da cidade associou diretamente o símbolo e o slogan à pessoa do prefeito.

Inegável, porém, e tal fato é reconhecido no próprio voto do ilustre relator, que a evidente possibilidade de associação entre as metades de elos de uma corrente à letra ' $\mathrm{H}$ ', inicial do nome do ora recorrente, e do slogan 'unidos seremos mais fortes', ao seu sobrenome, permite, de maneira igualmente válida, interpretálos - como fez a decisão recorrida - como típicos de promoção pessoal.

Ora, a vedação expressa no art. 37, § $1^{\circ}$, da Constituição, não exige, nem poderia exigir, demonstração cabal de que a mensagem - quando disfarçada, como no caso - seja efetivamente compreendida por todos os cidadãos. A já referida impossibilidade prática de se obter tal comprovação reduziria e limitaria o âmbito da proibição constitucional ao caso de promoção pessoal direta, ostensiva e indisfarçada, como se dá, por exemplo, com o uso de fotografia ou o nome completo da autoridade.

O que releva estimar é apenas se a publicidade oficial apresenta indiscutível possibilidade de associação indevida ao titular do cargo, consoante já o reconheceu esta Corte (cf. RE n⿳ 191.668, Rel. Min. MENEZES DIREITO, DJ 30/05/2008). E, como visto, tal possibilidade parece inafastável na espécie.”

${ }^{179}$ Comentários à Constituição do Brasil. J.J. Gomes Canotilho... [et al.]. São Paulo: Saraiva/Almedina, 2013, p. 1.341. 
débito fazendário, a absoluta prioridade da prestação de caráter alimentar sobre os créditos ordinário de índole comum. (...) O sentido teleológico da norma inscrita no caput do art. 100 da carta Política - cuja gênese reside, no que concerne aos seus aspectos essenciais, na CF de 1934 (art. 1820 - objetiva viabilizar, na concreção do seu alcance, a submissão incondicional do Poder Público ao dever de respeitar o princípio de confere preferência jurídica a quem dispuser de precedência cronológica (prior in tempora, potior in jure).”

A ideologia subjacente ao texto constitucional revela que a "norma” em exame não consubstancia um “princípio”- sujeito a ponderação e proporcionalidade, podendo ceder, conforme as circunstâncias, a elementos contrapostos -, consubstancia uma "regra” que se aplica, de acordo com as balizadas visões de Dworkin, Alexy e Barroso, na base do “tudo ou nada”.

Tem-se, então, que mesmo diante de situações excepcionais, não é dado superar a exigência de precatório ${ }^{180}$.

${ }^{180}$ Não foi essa, entretanto, a posição levada a efeito pelo Tribunal de Justiça do Distrito Federal e Territórios em caso dramático do ponto de vista humanitário.

Em autos de ação de indenização por danos morais e materiais proposta em favor de menor sequelado por erro médico havido em hospital público, o TJDFT² assentou que se o conjunto probatório comprova a existência de graves e irreversíveis sequelas decorrentes de erro na escolha da técnica anestésica para a realização da cirurgia, evidencia-se o dever indenizatório, porquanto presente o nexo causal entre a conduta do agente público e o dano causado à vitima. E também que a intensidade do sofrimento causado pelo erro médico, consubstanciado em severas e irreversíveis sequelas, como tetraplegia e completa ausência de contato com o mundo exterior, autoriza a fixação de verba indenizatória a título de danos morais em quantia mais elevada.

O inusitado é que a Corte de Justiça do Distrito Federal foi além para deferir o pedido de antecipação de tutela formulado pelo Ministério Público e, assim, determinar o pagamento da verba arbitrada para reparar os danos morais sem o regime de precatório em face de situação qualificada como excepcionalíssima.

Na oportunidade, invocou-se precedente do Supremo Tribunal Federal, a saber, o RE no 495.740-0/DF, da Relatoria do em. Ministro Celso de Mello.

No caso do TJDFT, a providência de antecipação total da tutela, com dispensa de precatório, foi determinada ainda na instância ordinária, o que consubstancia risco bastante acentuado de irreversibilidade em caso de provimento dos apelos dirigidos às instâncias excepcionais.

Também é preciso assinalar que o Ministro Celso de Mello, no precedente indicado, ao proferir seu voto originário, deixou de acolher, num primeiro momento, com base na jurisprudência da Corte, o pedido de pagamento imediato da quantia arbitrada a título de danos morais justamente porque implicaria violação ao art. 100 da $\mathrm{CF} / 88$.

Tenha-se em mente, então, que o Supremo Tribunal Federal, muito diferentemente do que assentou o TJDFT, dispensou o precatório, depois de apreciar o recurso extraordinário, para que a indenização ficasse "depositada em juízo", a ser levantada apenas no trânsito em julgado ou em caso de interposição de recurso “manifestamente protelatório".

Verifica-se, portanto, que as situações são completamente distintas.

Repita-se: no RE no 495.740-0/DF, já havia decisão do Supremo Tribunal Federal acerca do recurso extraordinário interposto e o depósito seria levantado apenas no trânsito em julgado ou em caso de interposição de recurso manifestamente protelatório. Ao revés, no caso em exame, os recursos extremos ainda não foram sequer objeto de análise no juízo primeiro de admissibilidade e a quantia a ser depositada poderá ser movimentada, mediante justificação, pela representante legal do autor, por meio de requerimento nos autos do processo.

Nem mesmo a Suprema Corte, em seu aludido precedente, filho único na jurisprudência, foi tão avançada e liberal como a decisão proferida nos presentes autos. 
Além de violar a regra do art. 100 da CF/88, o entendimento de que se deva, em face das peculiaridades do caso, pagar a indenização independentemente de precatório, fere de morte um dos princípios constitucionais que lhe conferem vida, a saber, o da impessoalidade. Lembre-se de Cármen Lúcia Antunes Rocha ${ }^{181}$, para quem, verbis:

\begin{abstract}
“O princípio da impessoalidade impede e proíbe, assim, o subjetivismo na Administração Pública. A objetividade não permite que se mostre ou prevaleça a face ou a alma do administrador. Nem a do cidadão que a ela compareça ou com ela se relacione. Não há República, como se tem na própria denominação desta forma de governo, que não seja pública, e não há esta publicidade do Poder Público no Estado em que o subjetivismo presida as formas de atuação administrativa”.
\end{abstract}

Na mencionada dissertação de Ana Paula Oliveira Ávila ${ }^{182}$ apresentam-se, como deveres dedutíveis do princípio da impessoalidade, os deveres de (i) objetividade ou impessoalidade em sentido estrito; (ii) imparcialidade; (iii) neutralidade, e, como dever conexo, (iv) transparência. Aponta-se a parcialidade dentre os vícios da impessoalidade. E a pessoalidade, na autorizada visão da autora, tem lugar quando o administrador, no desempenho da função pública, deixa-se levar por influências externas ao serviço e passa a motivar subjetivamente a sua conduta. ${ }^{183} \mathrm{E}$ a violação do dever de imparcialidade ocorre quando a Administração Pública é parcial. Para a autora, verbis:

\footnotetext{
"Como se sabe, a Administração se move dentro de determinados regramentos e parâmetros. Entre essas regras determinantes e o atingimento concreto das finalidades públicas legalmente objetivadas deve aparecer o servidor público como um ser despido de vontade própria. O servidor nada deve fazer além de 'pôr em movimento', i.e., executar no plano fático um mandamento jurídico abstrato, exceção aberta unicamente às hipóteses de competências discricionárias - quando se fará algo mais do que simplesmente executar a lei, mas mesmo assim de forma limitada e por procedimento adequado.
}

Tal posicionamento contraria frontalmente a regra do art. 100, da CF/88.

Revela um dos exageros cada vez mais frequentes na adoção indiscriminada de “princípios”.

Desconsiderar valores já ponderados pelo constituinte não parece uma saída juridicamente hígida.

${ }^{181}$ Princípios Constitucionais da Administração Pública. Belo Horizonte: Del Rey, 1994, p. 148.

182 Obra citada, p. 45-80.

183 Obra citada, p. 81-2. 
Cada vez que o servidor faz intervir uma vontade que pouco ou nada tem a ver com o processo de aplicação da lei e com os atos que esta exige, adquire este uma vontade que não lhe foi permitida pelo ordenamento: ele se apropria da vontade que deve ser do ordenamento.

(...)."184

Toda a valoração possível, em termos de ponderação e proporcionalidade, foi feita soberanamente pelo legislador constituinte no momento da edição da norma. Ponderar a regra do art. 100 da Carta Magna, como bem explicitado por Alexandre Aragão, é “reponderar o que já foi ponderado pelo legislador”.

A dispensa casuística do precatório, norma de natureza ética, diante das “peculiaridades da causa”, representa risco jurídico de enorme expressão para o sistema do Estado de Direito. Reparações de inúmeras situações até mais graves do que a retratada no processo podem ser seriamente comprometidas com a manutenção do decisum.

\subsubsection{Art. 37, caput, da CF/88 (princípio da impessoalidade administrativa)}

No caput do art. 37, da CF/88, a Constituição elenca princípios constitucionais regedores da Administração Pública.

Aqui, indiscutivelmente, a impessoalidade assume a forma de princípio.

Não mais se aplica a partir de fórmulas textuais mais fechadas, à base do "tudo ou nada”. Diferentemente, exige aplicação ponderada, contextualizada, dialogada com as especificidades dos fatos da vida.

Além de a impessoalidade estar referida textual e expressamente como “princípio” no caput do art. 37, da CF/88, sua natureza jurídica é facilmente perceptível diante de sua moldura mais aberta e abrangente. O legislador constituinte não se preocupou em precisar seu alcance e conteúdo, deixando boa margem de liberdade para o exegeta (seja juiz ou administrador) fazer isso por ocasião de sua aplicação.

A natureza jurídica de princípio vem confirmada no substancioso rol de incisos do art. 37. Em muitos deles há clara conexão com a impessoalidade do caput, exigível em termos de organização e de ação administrativa.

Uma difusão ideológica assim, do caput para os incisos, apenas confirma que a

${ }^{184}$ Obra citada, p. 83. 
impessoalidade referida é mesmo um princípio, com consequências em todo o sistema de Direito Administrativo.

As normas dos incisos (algumas das quais regras outras, princípios específicos ou subprincípios) como as que preveem (i) acessibilidade ampla a cargos públicos (inciso I); (ii) concurso público (incisos II, III e IV); (iii) limitações ao exercício de funções de confiança e de parâmetros para o preenchimento de cargos em comissão (inciso V); (iv) reserva de cargos e empregos públicos para pessoas portadoras de deficiência (inciso VIII); (v) contratação por tempo determinado para atender necessidade temporária de excepcional interesse público (inciso IX); (vi) exigência de licitação para a contratação, pelo Poder Público, de obras, serviços, compras e alienações (inciso XXI) são, então, desdobramentos do princípio geral, de índole constitucional, da impessoalidade.

Perceba-se que os parágrafos do art. 37, da CF/88, também contêm desdobramentos importantes do princípio geral da impessoalidade previsto no caput. O $\S 2^{\circ}$, por exemplo, chega à minúcia de anunciar as consequências da quebra da regra do concurso público. Assinala que a não observância do disposto nos incisos II e III, do art. 37 implicará a nulidade do ato e a punição da autoridade responsável, nos termos da lei.

$\mathrm{O} \S 3^{\circ}$, orientado à atividade legislativa, induz uma progressiva participação do administrado, em especial do usuário na administração pública direta e indireta. Assinala que a lei deve regular, especialmente, (i) as reclamações relativas à prestação dos serviços públicos em geral, asseguradas a manutenção de serviços de atendimento ao usuário e avaliação periódica, externa e interna, da qualidade dos serviços (inciso I); (ii) acesso dos usuários a registros administrativos e a informações sobre atos de governo, observado o disposto no art. $5^{\circ}$, incisos X (inviolabilidade da intimidade, da vida privada, da honra e da imagem das pessoas, assegurado o direito a indenização pelo dano material ou moral decorrente de sua violação) e XXXIII (igualdade de todos quanto ao recebimento de informações de interesse particular, coletivo ou geral, dos órgãos públicos em determinados prazos e sob pena de responsabilidade, ressalvado o sigilo imprescindível à segurança da sociedade e do Estado); e (iii) a disciplina da representação contra o exercício negligente ou abusivo de cargo, emprego ou função na administração pública.

O $\S 4^{\circ}$ também verbera as contundentes consequências de atos de improbidade administrativa, a saber, a suspensão dos direitos políticos, a parda da função pública, a indisponibilidade dos bens e o ressarcimento ao erário, na forma e gradação previstas em lei, sem prejuízo da ação penal cabível. E lembre-se que, de acordo com a lei de improbidade 
administrativa (Lei $\mathrm{n}^{\circ}$ 8.429/92, art. 11), constituiu ato de improbidade administrativa violar princípios da administração pública, dentre os quais o da imparcialidade ${ }^{185}$.

O § $6^{\circ}$, do art. $37^{186}$, ao dar continuidade à tradição constitucional brasileira, iniciada na Constituição de 1946, de instituir a responsabilidade civil extracontratual objetiva do Estado por danos causados a terceiros, também reforça o princípio da impessoalidade. Note-se que a impessoalidade vem reforçada na ideia de que o Estado responde por “culpa anônima do serviço”, ou seja, independentemente da precisa identificação de um servidor que, agindo nessa qualidade, tenha causado danos a terceiros. O dolo e a culpa só são exigíveis para o exercício do direito de regresso, não mais na relação Estado/Administrado, mas sim relação Estado/Servidor. E o Estado indeniza a vítima (a fundo perdido!) independentemente de poder exercitar o regresso.

Também são dignos de nota o $§ 7^{\circ}$, no sentido de que “a lei disporá sobre os requisitos e as restrições ao ocupante de cargo ou emprego da administração direta e indireta que possibilite o acesso a informações privilegiadas" e o $\S 8^{\circ}$, no sentido de que a autonomia gerencial, orçamentária e financeira dos órgãos e entidades da administração direta e indireta pode ser ampliada mediante contrato a ser firmado entre seus administradores e o poder público, que tenha por objeto a fixação de metas de desempenho para o órgão ou entidade, cabendo à lei dispor sobre o prazo de duração do contrato, os controles e critérios de avaliação de desempenho, direitos, obrigações e responsabilidade dos dirigentes e remuneração do pessoal.

No $\S 7^{\circ}$, o texto constitucional parte da premissa de que informação é poder e se preocupa com uma maior objetivação da atividade administrativa. No § $8^{\circ}$, há clara preocupação de dotar a administração de meios jurídicos para imprimir um ritmo mais

${ }^{185}$ Art. 11, da Lei no 8.429/92: Constitui ato de improbidade administrativa que atenta contra os princípios da administração pública qualquer ação ou omissão que viole os deveres de honestidade, imparcialidade, legalidade e lealdade às instituições, e notadamente:

I - praticar ato visando ao fim proibido em lei ou regulamento ou diverso daquele previsto na regra de competência;

II - retardar ou deixar de praticar, indevidamente, ato de ofício;

III - revelar fato ou circunstância de que tem ciência em razão das atribuições e que deva permanecer em segredo;

IV - negar publicidade aos atos oficiais;

V - frustrar a licitude de concurso público;

VI - deixar de prestar contas quando esteja obrigado a fazê-lo;

VII - revelar ou permitir que chegue ao conhecimento de terceiro, antes da respectiva divulgação oficial, teor de medida política ou econômica capaz de afetar o preço de mercadoria, bem ou serviço.

${ }^{186}$ Art. 37, § $6^{\circ}$ As pessoas jurídicas de direito público e as de direito privado prestadoras de serviços públicos responderão pelos danos que seus agentes, nessa qualidade, causarem a terceiros, assegurado o direito de regresso contra o responsável nos casos de dolo ou culpa. 
profissionalizado, com foco em resultados, reconhecendo-se qualidade e mérito nas condutas e nos comportamentos dos servidores.

Em suma: a impessoalidade descrita no caput do art. 37 da CF/88 é um princípio propriamente dito, e em razão de sua inegável capilaridade informará o sistema de Direito Administrativo como um todo. Cobrirá seus recôncavos e será extremamente importante para que se exija da Administração Pública, em primeiro lugar, uma organização administrativa voltada a um agir naturalmente impessoal e a um agir impessoal despido de subjetivismos e preferências pessoais do administrador.

Fixar o alcance do princípio da impessoalidade é também necessário porque ele tem sido invocado e aplicado a casos concretos, independentemente de intermediação legislativa infraconstitucional. Na questão do nepotismo, por exemplo, tanto o Conselho Nacional de Justiça - CNJ quanto o Supremo Tribunal Federal retiram a proibição de nomeação de parentes para cargos e funções públicas diretamente do texto constitucional, com ênfase na impessoalidade.

\subsection{Legislação brasileira}

Há inúmeras referências à impessoalidade na legislação brasileira. Diretas e indiretas, explícitas e implícitas. Todavia, nada suficiente e satisfatoriamente sistematizado. E não há esforço maior em relacionar ação administrativa imparcial com organização administrativa voltada a uma agir naturalmente imparcial.

Neste tópico, a intenção é fazer um apanhado parcial, não exaustivo, de excertos legislativos relacionados ao tema da impessoalidade. A tarefa é importante na composição de um conceito que sirva de base à parametrização do uso da impessoalidade nas decisões administrativas.

\subsubsection{Licitações e contratos administrativos (Lei $\mathbf{n}^{0}$ 8.666/93)}

Dando concretude ao art. 37, inciso XXI, editada no exercício da competência privativa, constitucionalmente assegurada (art. 22, inciso XXVII, da CF/88, com a redação determinada pela EC n 19, de 04.6.1998) de legislar sobre “normas gerais de licitação e contratação, em todas as modalidades, para as administrações públicas diretas, autárquicas e fundacionais 
da União, Estados, Distrito Federal e Municípios, obedecido o disposto no art. 37, XXI, e para as empresas públicas e sociedades de economia mista, nos termos do art. $173, \S 1^{\circ}$, III”, a Lei $n^{0}$ 8.666/93 é fértil em dispositivos relacionados à impessoalidade administrativa.

A impessoalidade é uma das suas razões de ser, para que o Poder Público, na contratação de obras, serviços, compras e alienações, não se deixe levar por subjetivismos e preferências pessoais dos administradores.

É interessante notar que a lei em discussão contém dispositivos relacionados não só a um agir impessoal (impessoalidade na ação), mas também a uma organização administrativa (infraestrutura organizacional) voltada a propiciar o agir impessoal (impessoalidade na ação).

No art. $3^{\circ}$, a lei estabelece, sem tergiversação, que a licitação destina-se a garantir a observância do princípio constitucional da isonomia, a seleção da proposta mais vantajosa para a administração e a promoção do desenvolvimento nacional sustentável e será processada e julgada em estrita conformidade com os princípios básicos da legalidade, da impessoalidade, da moralidade, da igualdade, da publicidade, da probidade administrativa, da vinculação ao instrumento convocatório, do julgamento objetivo e dos que lhes são correlatos.

Ao se referir à isonomia, no sentido da necessidade de se conferir tratamento isonômico daqueles que desejam contratar com a Administração Pública, busca a lei assegurar a impessoalidade na ação administrativa.

Já quando se refere à seleção da proposta mais vantajosa, tem-se que a lei, afinada com a doutrina de Renato Alessi (sobre a distinção entre interesse primário e secundário), visa resguardar o interesse público primário e o secundário (proteção do erário). A norma de impessoalidade aqui disposta irradia efeitos em ambas as esferas: de ação e de organização administrativa.

Seguindo a mesma lógica do art. $3^{\circ}$ da Lei $n^{\circ} 8.666 / 93$ estão os artigos $1^{\circ}$, $\S 1^{\circ}$, inc. IV, e $3^{\circ}$ da Lei $n^{\circ} 12.462$, que institui o Regime Diferenciado de Contratações (RDC).

De acordo com o art. $3^{\circ}, \S 1^{\circ}$, da Lei $n^{\circ} 8.666 / 93$, é vedado aos agentes públicos:

I - admitir, prever, incluir ou tolerar, nos atos de convocação, cláusulas ou condições que comprometam, restrinjam ou frustrem o seu caráter competitivo, inclusive nos casos de sociedades cooperativas, e estabeleçam preferências ou distinções em razão da naturalidade, da sede ou domicílio dos licitantes ou de qualquer outra circunstância impertinente ou irrelevante para o específico objeto do contrato, ressalvado o disposto nos $\S \S 5^{\circ}$ a 12 deste artigo e no art. $3^{\circ}$ da Lei no 8.248, de 23 de outubro de 1991; 
II - estabelecer tratamento diferenciado de natureza comercial, legal, trabalhista, previdenciária ou qualquer outra, entre empresas brasileiras e estrangeiras, inclusive no que se refere a moeda, modalidade e local de pagamentos, mesmo quando envolvidos financiamentos de agências internacionais, ressalvado o disposto no parágrafo seguinte e no art. $3^{\circ}$ da Lei nº 8.248, de 23 de outubro de 1991.

Do ponto de vista do administrado, verifica-se direito subjetivo a não ser discriminado em procedimentos licitatórios. A norma aqui divisada opera efeitos no campo da ação administrativa.

Quanto à vedação aos agentes públicos de estabelecerem previsões discriminatórias em instrumentos convocatórios - sem justificativa legal - esta materializa a impessoalidade no campo da organização administrativa.

Grande foco de quebra de impessoalidade, no regime da Lei Geral de Licitações, ocorre nas chamadas contratações diretas ${ }^{187}$, isto é, aquelas realizadas sem licitação prévia.

Nas chamadas dispensas (art. 24) e inexigibilidades (art. 25) é que a casuística revela numerosos comportamentos írritos aos princípios da impessoalidade. Por detrás de alegadas situações propiciatórias de dispensas e inexigibilidades, há na verdade um jogo de cartas marcadas, recaindo a contratação sobre privilegiados dos administradores de plantão.

Daí a importância dos princípios também como parâmetros de controle da atividade administrativa.

Correto Marçal Justen Filho ${ }^{188}$ ao asseverar que "a contratação direta não significa que são inaplicáveis os princípios básicos que orientam a atuação administrativa". Não se está diante de uma zona livre e assim é porque:

“O administrador está obrigado a seguir um procedimento administrativo
determinado, destinado a assegurar (ainda nesses casos) a prevalência dos
princípios jurídicos fundamentais. Permanece o dever de realizar a me-

${ }^{187}$ Para Marçal Justen Filho (Comentários à Lei de Licitações e Contratos Administrativos. 16a Edição. São Paulo: Editora Revista dos Tribunais, 2014, p. 390): É usual afirmar que a "supremacia do interesse público" fundamenta a exigência, como regra geral, de licitação prévia para contratações da Administração Pública - o que significa, em outras palavras, que a licitação é um pressuposto do desempenho satisfatório pelo Estado das funções administrativas a ele atribuídas. No entanto, existem hipóteses em que a licitação formal seria impossível ou frustraria a realização adequada das funções estatais. O procedimento licitatório normal conduziria ao sacrifício dos fins buscados pelo Estado e não asseguraria a contratação mais vantajosa. Por isso, autoriza-se a Administração a adotar um outro procedimento, em que formalidades são suprimidas ou substituídas por outras.

${ }^{188}$ Comentários..., p. 390-391. 
lhor contratação possível, dando tratamento igualitário a todos os possíveis contratantes.

Portanto, a contratação direta não significa eliminação de dois postulados consagrados a propósito da licitação. O primeiro é a existência de um procedimento administrativo. O segundo é a vinculação estatal à realização de suas funções”.

Não é por outra razão que a lei, no parágrafo único do art. 26, estabelece que o processo de dispensa, de inexigibilidade ou de retardamento será instruído com (i) caracterização da situação emergencial ou calamitosa que justifique a dispensa, quando for o caso; (ii) razão da escolha do fornecedor ou executante; (iii) justificativa do preço; (iv) documento de aprovação dos projetos de pesquisa aos quais os bens serão alocados. Tais elementos são considerados por ocasião do controle do ato de dispensa e inexigibilidade.

Para reforço da regra que impõe a observância de processo administrativo formal e de fundamentação adequada, ainda existe o disposto no art. 25 , $\S 2^{\circ}$, no sentido de que nas hipóteses de inexigibilidade e também em qualquer dos casos de dispensa, "se comprovado superfaturamento, respondem solidariamente pelo dano causado à Fazenda Pública o fornecedor ou o prestador de serviços e o agente público responsável, sem prejuízo de outras sanções legais cabíveis”.

Mais uma norma relevante está no art. 44, da Lei nº 8.666/93. Por meio dele, “no julgamento das propostas, a Comissão levará em consideração os critérios objetivos definidos no edital ou convite, os quais não devem contrariar as normas em princípios estabelecidos por esta Lei”. Para confirmar a proibição de subjetivismos no julgamento (objetivo) das propostas, o legislador foi ainda mais enfático no $\S 1^{\circ}$, do mesmo dispositivo legal, segundo o qual "é vedada a utilização de qualquer elemento, critério ou fator sigiloso, secreto, subjetivo ou reservado que possa ainda que indiretamente elidir o princípio da igualdade entre os licitantes”.

Ao tratar do tema, Marçal Justen Filho ${ }^{189}$ assinala que a Administração, ao elaborar o edital, poderá discricionariamente eleger um, alguns ou diversos critérios para julgamento. E que a adoção de diversos critérios torna-os todos relevantes. A maior ou menor vantagem das propostas será avaliada pela conjugação de diversos aspectos, desde que previstos no instrumento convocatório, “mas essa pluralidade de critérios não pode acarretar sub-

${ }^{189}$ Comentários..., p. 820. 
jetividade no julgamento nem tornar incerta a operação através da qual a Administração selecionará a proposta”.

Para o autor 190 , "em termos amplos, a objetividade significa imparcialidade mais finalidade”. Assim, “o julgamento objetivo exclui a parcialidade (tomada de posição segundo o ponto de vista de uma parte)", o que é insuficiente. Em razão disso:

\footnotetext{
"Além da imparcialidade, o julgamento tem de ser formulado à luz dos valores protegidos pelo Direito. A tutela aos interesses supraindividuais não autoriza, contudo, ignorarem-se as disposições norteadoras do ato convocatório e da Lei. Não se admite que, a pretexto de selecionar a melhor proposta, sejam amesquinhadas as garantias e os interesses dos licitantes e ignorado o disposto no ato convocatório.”
}

Para sacramentar a tônica no controle sobre os julgamentos (objetivos) das propostas, o art. 45, da mesma lei, estabeleceu que a Comissão deve empreendê-los segundo "os critérios previamente estabelecidos no ato convocatório e de acordo com os fatores exclusivamente nele referidos, de maneira a possibilitar a sua aferição pelos licitantes e pelos órgãos de controle".

No art. 51, da Lei ${ }^{0}$ 8.666/93, também há regra importante sobre impessoalidade como organização administrativa. Confira-se que o legislador faz alusão à necessidade de que a comissão permanente ou especial de licitação seja composta por no mínimo três membros, "sendo pelo menos dois deles servidores qualificados pertencentes aos quadros permanentes dos órgãos da Administração responsáveis pela licitação”.

O fato de a lei prever órgão colegiado já diminui a possibilidade de personalização da conduta decisória. Reforça a regra a exigência de servidores qualificados, do quadro permanente, ou seja, de agentes menos infensos a ingerências de ordem política.

No mesmo sentido, explica Marçal Justen Filho ${ }^{191}$ :

“A lei estabelece número mínimo de membros. Não há número máximo. A pluralidade de membros visa a reduzir a arbitrariedade e os juízos subjetivos. Amplia-se a publicidade das decisões, na medida em que a pluralidade de membros dificulta o sigilo. Enfim, partilhase o poder entre diversas pessoas, na presunção de que essa solução reduz o arbítrio”.

Nos $\S \S 3^{\circ}$ e $4^{\circ}$, do mesmo art. 51, da Lei ${ }^{\circ}$ 8.666/93, há duas regras interessantes,

${ }^{190}$ Comentários..., p. 820.

${ }^{191}$ Comentários..., p. 909. 
também relacionadas à impessoalidade. No $\S 3^{\circ}$, a lei preconiza que “os membros das comissões de licitações responderão solidariamente por todos os atos praticados pela comissão, salvo se posição individual divergente estiver devidamente fundamentada e registrada em ata lavrada na reunião em que tiver sido tomada a decisão”. Está-se diante de dispositivo que reforça a indução a um julgamento impessoal.

No $\S 4^{\circ}$, o legislador estatuiu que " $a$ investidura dos membros das Comissões permanentes não excederá a 1 (um) ano, vedada a recondução da totalidade de seus membros para a mesma comissão no período subsequente”. Aqui, alia-se à ferramenta do mandato (de um ano) a técnica do desfazimento de um mesmo grupo. Privilegia-se a imparcialidade e o combate à feudalização.

Sobre a restrição à recondução dos membros da comissão, ensina Marçal Justen Filho ${ }^{192}$ que a lei busca evitar o continuísmo, refletindo preocupação em eliminar os riscos de desmandos. Assim, “a lei presume que a rotatividade na composição das comissões permanentes reduz a possibilidade de abusos ou atitudes reprováveis”.

Por fim, no $§ 5^{\circ}$, há uma regra sobre o julgamento das licitações na modalidade “concurso”. Será feito por uma “comissão especial integrada por pessoas de reputação ilibada e reconhecido conhecimento da matéria em exame, servidores públicos ou não”. Postula-se um julgamento que reconheça o mérito, e não preferências subjetivas dos julgadores.

\subsubsection{Improbidade administrativa (Lei ${ }^{0}$ 8.429/92)}

As normas previstas na Lei de Improbidade estabelecem punições para condutas de agentes públicos que: i) importem em enriquecimento ilícito; ii) causem danos ao erário; e/ ou iii) violem os princípios norteadores da Administração Pública. Tais normas buscam definir um padrão ético de atuação dos agentes públicos.

Para Odete Medauar ${ }^{193}$, a Constituição Federal de 1988, além de mencionar a moralidade como um dos princípios da Administração, aponta instrumento para sancionar sua inobservância, a exemplo da previsão de sanções a governantes e agentes públicos por atos ou condutas que impliquem improbidade administrativa. A seu ver, "na linguagem comum, probidade equivale a honestidade, honradez, integridade de caráter, retidão”. Ensina que "a improbidade administrativa tem um sentido forte de conduta que lese o erário públi-

192 Comentários..., p. 911.

${ }^{193}$ Direito Administrativo Moderno..., p. 145-146. 
co, que importe em enriquecimento ilícito ou proveito próprio ou de outrem no exercício de mandato, cargo, função, emprego público”. Contudo, esclarece a autora, a Lei nº 8.429/92 inseriu nos casos de improbidade administrativa condutas que não implicam necessariamente locupletamento de caráter financeiro ou material.

Conquanto relacionada diretamente ao princípio da moralidade, é certo que a quebra da impessoalidade e dos demais princípios constitucionais regedores da atividade administrativa pode, em tese, caracterizar improbidade administrativa.

A tal propósito, confira-se o teor do art. $4^{\circ}$, no sentido de que os agentes públicos de qualquer nível ou hierarquia são obrigados a velar pela estrita observância dos princípios de legalidade, impessoalidade, moralidade e publicidade no trato dos assuntos que lhe são afetos.

No art. 11 da mesma lei, inserido em seção intitulada “dos atos de improbidade administrativa que atentam contra os princípios da Administração Pública”, esclareceu o legislador, em linguagem clara e direta, que “constitui ato de improbidade administrativa que atenta contra os princípios da administração pública qualquer ação ou omissão que viole os deveres de honestidade, imparcialidade, legalidade, e lealdade às instituições (...)”.

A imparcialidade referida no dispositivo é aquela relativa à proibição de não tomar partido, de agir com subjetivismos prejudiciais ao interesse público primário. É englobada, pois, pelo conceito maior de impessoalidade.

José Antonio Lisbôa Neiva ${ }^{194}$, ao comentar o art. 11, da Lei de Improbidade Administrativa, traz importantes esclarecimentos sobre o alcance do desrespeito ao princípio da impessoalidade para fins de caracterização de improbidade:

“Os agentes públicos, em nosso País, parecem ter dificuldade, muitas ve-
zes, de compreender que devem agir com neutralidade e isenção na análise
de situações que envolvam os administrados. Muitos, no campo do Direito
Tributário, por exemplo, pensam que estão agindo na defesa do interesse
público e de modo correto, ao simplesmente desconsiderar as argumenta-
ções dos contribuintes quanto à interpretação da legislação aplicável, deci-
dindo formalmente a impugnação ou o recurso, mas envoltos em um espíri-
to de resguardar a arrecadação fiscal. Ou, ainda, na hipótese em que licitan-
te impugna decisão em procedimento licitatório, que beneficia outro con-
corrente, e a Administração, por seus agentes, mantém o resultado a fim de

${ }^{194}$ Improbidade administrativa: legislação comentada artigo por artigo: doutrina, legislação e jurisprudência. $3^{\text {a }}$ ed. Niterói,RJ: Impetus, 2012. p. 139. 
que prevaleça sua orientação administrativa, mesmo sendo relevante a alegação de equívoco”.

Para o autor ${ }^{195}$, esses comportamentos, embora reprováveis, não podem ser confundidos com improbidade administrativa, pois esta “exige algo mais no atuar do agente”. A seu ver, com apoio em Fábio Medina Osório, “a afronta à imparcialidade que enseja a improbidade seria aquela em que o agente público 'marque sua atividade administrativa pela perseguição de fins particulares, motivações egoístas, ambições pessoais que se sobreponham ao interesse público', em estreita harmonia com a quebra do dever de honestidade e de lealdade à Instituição à qual pertence”.

Os incisos do mesmo art. 11, da Lei nº 8.429/92, apresentados em enumeração meramente exemplificativa (confirmada pelo emprego do vocábulo “notadamente”!), desdobram o comando do caput. As condutas relativas a "praticar ato visando a fim proibido em lei ou regulamento ou diverso daquele previsto na regra de competência” (inciso I), "retardar ou deixar de praticar, indevidamente, ato de ofício" e "frustrar a licitude de concurso público", dentre outras, significam, em maior grau, atentados aos princípios regedores da Administração Pública, notadamente ao da impessoalidade.

\subsubsection{Combate à corrupção (Lei $\left.n^{0} 12.846 / 13\right)$}

A nova lei de combate à corrupção soma esforços no sentido de impulsionar o cumprimento pela Administração Pública dos princípios constitucionais, dentre os quais o da impessoalidade.

Lei n ${ }^{0}$ 12.846/13, “lei anticorrupção”, dispõe sobre a responsabilização administrativa e civil de pessoas jurídicas pela prática de atos contra a administração pública nacional ou estrangeira.

De acordo com o seu art. 5º , constituem atos lesivos à administração pública nacional ou estrangeira, para os fins da lei, todos aqueles praticados pelas pessoas jurídicas ${ }^{196}$ mencionadas no parágrafo único, do art. $1^{\text {}}$, que atentem contra o patrimônio público nacional ou

\footnotetext{
${ }^{195}$ Improbidade..., p. 139.

${ }^{196}$ Sejam elas sociedades empresárias, sociedades simples, personificadas ou não, independentemente da forma de organização ou do modelo societário adotado, bem como quaisquer fundações, associações de entidades ou pessoas, ou sociedades estrangeiras, que tenham sede, filial ou representação no território brasileiro, constituídas de fato ou de direito, ainda que temporariamente.
} 
estrangeiro, contra princípios da administração pública ou contra os compromissos internacionais assumidos pelo Brasil.

Os “atos lesivos à Administração Pública nacional ou estrangeira” (título do Capítulo II da Lei) estão definidos nos cinco incisos do art. $5^{\circ}$, assim dispostos:

I - prometer, oferecer ou dar, direta ou indiretamente, vantagem indevida a agente público, ou a terceira pessoa a ele relacionada;

II - comprovadamente financiar, custear, patrocinar ou de qualquer modo subvencionar a prática dos atos ilícitos previstos nesta Lei;

III - comprovadamente utilizar-se de interposta pessoa física ou jurídica para ocultar ou dissimular seus reais interesses ou a identidade dos beneficiários dos atos praticados;

IV - no tocante a licitações e contratos:

a) frustrar ou fraudar, mediante ajuste, combinação ou qualquer outro expediente, o caráter competitivo de procedimento licitatório público;

b) impedir, perturbar ou fraudar a realização de qualquer ato de procedimento licitatório público;

c) afastar ou procurar afastar licitante, por meio de fraude ou oferecimento de vantagem de qualquer tipo;

d) fraudar licitação pública ou contrato dela decorrente;

e) criar, de modo fraudulento ou irregular, pessoa jurídica para participar de licitação pública ou celebrar contrato administrativo;

f) obter vantagem ou benefício indevido, de modo fraudulento, de modificações ou prorrogações de contratos celebrados com a administração pública, sem autorização em lei, no ato convocatório da licitação pública ou nos respectivos instrumentos contratuais; ou

g) manipular ou fraudar o equilíbrio econômico-financeiro dos contratos celebrados com a administração pública;

V - dificultar atividade de investigação ou fiscalização de órgãos, entidades ou agentes públicos ou intervir em sua atuação, inclusive no âmbito das agências reguladoras e dos órgãos de fiscalização do sistema financeiro nacional.

$\mathrm{O}$ art. $5^{\circ}$ da Lei Anticorrupção visa à punição de diversas modalidades de condutas que atentam contra o patrimônio público e os princípios da Administração Pública. 
Percebe-se claramente que todos os tipos estabelecidos pela Lei $n^{0}$ 12.846/13 resguardam, em maior ou menor grau, o princípio da impessoalidade. Se a Lei de Improbidade pune agentes públicos pela prática de atos destes contra a Administração Pública, a Lei Anticorrupção responsabiliza integrantes da esfera privada (pessoas jurídicas) que lesam o patrimônio e a juridicidade administrativa.

Trata-se, portanto, de diploma normativo que tem como escopo garantir a ação (atuação) imparcial da Administração Pública. Todas as condutas elencadas no art. $5^{\circ}$ supratranscrito punem a busca por favorecimento de determinada sociedade empresária perante o Poder Público.

É possível dividir as condutas em três grandes grupos: atos de corrupção (incisos I e II); atos atentatórios contra os princípios de licitação e contratos administrativos (inciso IV); atos que dificultem ou burlem a fiscalização das autoridades públicas (incisos III e V).

Como a Lei é bastante recente, ainda não há jurisprudência sólida sobre os temas aqui tratados.

\subsubsection{Concessões e permissões da prestação de serviços públicos (Lei nº 8.987/95)}

Na Lei nº 8.987/95 (Lei do Regime Concessões e Permissões da Prestação de Serviços Públicos) há regras que materializam o princípio da impessoalidade.

Nos termos do seu art. $6^{\circ}$, “toda concessão ou permissão pressupõe a prestação de serviço adequado ao pleno atendimento dos usuários, conforme estabelecido nesta Lei, nas normas pertinentes e no respectivo contrato".

Serviço adequado, de acordo com o parágrafo $1^{\circ}$, do mesmo dispositivo legal, é aquele que "satisfaz as condições de regularidade, continuidade, eficiência, segurança, atualidade, generalidade, cortesia na sua prestação e modicidade das tarifas”.

O dever de generalidade se confunde com o princípio da universalidade na prestação dos serviços públicos. E o princípio da universalidade exige a prestação do serviço à coletividade como um todo, sendo uma atividade erga omnes e de forma indistinta. Para que esse princípio seja corretamente observado, necessário materializar o princípio da impessoalidade, o qual determina a prestação do serviço de forma impessoal, sendo vedada a discriminação entre os usuários. Da mesma forma, deve haver isonomia no tratamento dos usuários dos serviços, porque, desde que satisfaçam as condições legais, todos fazem jus à sua prestação, sem qualquer distinção de caráter pessoal. 
Tendo em vista que tais princípios são norteadores da prestação do serviço público, estes se materializam tanto na esfera da ação quanto da organização administrativa.

\subsubsection{Servidores públicos federais (Lei $\mathbf{n}^{\circ}$ 8.112/90)}

A Lei nº 8.112/90 dispõe de normas relevantes relativas à impessoalidade. No art. 10, por exemplo, está vertida a norma que impõe a realização de concurso público, como regra geral, na esteira do art. 37, inciso II, da CF/88.

Segundo o dispositivo mencionado, "a nomeação para cargo de carreira ou cargo isolado de provimento efetivo depende de prévia habilitação em concurso público de provas ou de provas e títulos, obedecidos a ordem de classificação e o prazo de sua validade”.

A regra do concurso público para provimento dos cargos na esfera do Poder Público materializa de forma plena o princípio da impessoalidade, na medida em que há o estabelecimento de critérios objetivos para o ingresso nas carreiras públicas. Afasta a possibilidade de favorecimentos na escolha de servidores e seleciona os indivíduos mais aptos à prestação do serviço. Constitui, portanto, regra que concretiza a impessoalidade na esfera da organização administrativa.

São exemplos de institutos voltados à obtenção de uma organização administrativa naturalmente mais impessoal, no regime da Lei $n^{\circ}$ 8.112/90:

a) Gratificação por encargo de curso ou concurso (arts. 76-A);

b) Licença para capacitação (art. 87);

c) Afastamento para estudo ou missão no exterior (arts. 95 e 96);

d) Afastamento para participação em programa de pós-graduação stricto sensu no país (art. 96-A);

e) Concessão de horário especial ao servidor estudante (art. 98);

f) Direito a matrícula em instituição congênere para o servidor estudante que mudar de sede no interesse da administração (art. 99).

O primeiro instituto (gratificação por encargo de curso ou concurso) estimula o servidor a se engajar em ambiente propício ao aprendizado em sentido amplo. Atuando como instrutor em cursos de formação, como membro de bancas examinadoras, na aplicação e na fiscalização de provas ou na logística de preparação e realização de concurso, o servidor 
convive e tem contato direto com pessoas que buscam valorização profissional e logram ganhos profissionais e pessoais, com reflexos na sua carreira e no seu dia a dia de servidor.

A licença para capacitação pode ser gozada pelo servidor após cada quinquênio de efetivo exercício de cargo efetivo, com a respectiva remuneração, por até 3 (três) meses, para participar de curso profissional. Além de prêmio pela assiduidade, o instituto permite ao servidor dar azo ao melhoramento de sua capacitação. Bem exercitado, o instituto traz reflexos na qualidade dos serviços ${ }^{197}$.

Na mesma linha de raciocínio, os afastamentos para estudo ou missão no exterior (item “c” supracitado) e para participação em programa de pós-graduação em sentido estrito. Por meio dos dois tipos de afastamento, para fins de estudos, o servidor carreia meios materiais de evoluir como pessoa e se tornar mais capacitado e habilitado para a prestação de serviço público de maior qualidade.

A concessão de horário especial para o servidor estudante é forma legislativa inteligente. Propicia a conciliação de interesses e, ao mesmo tempo, projeta uma atuação futura mais enriquecida pelos valores e ensinamentos angariados nos estudos.

Da mesma forma, há o direito a matrícula em instituição congênere para o servidor estudante que mudar de sede no interesse da administração. A interrupção dos estudos é prejudicial ao servidor e à administração. Resolve o dilema de, em nome do interesse público, pressuposto da mudança de sede, sacrificar-se outro interesse público no incremento que os estudos proporcionam na qualidade dos serviços públicos prestados pelo servidor que estuda e se mantém atualizado e mais bem preparado para o dia a dia da administração.

O princípio da impessoalidade, no âmbito da Lei $n^{\circ}$ 8.112/90, também se projeta no regime disciplinar. Há deveres e proibições voltadas ao desiderato constitucional. Podem ser referidos, por exemplo, entre os deveres (art. 116):

a) Levar as irregularidades de que tiver ciência em razão do cargo ao conhecimento da autoridade superior ou, quando houver suspeita de envolvimento desta, ao conhecimento de outra autoridade competente para apuração (inciso VI);

b) Tratar com urbanidade as pessoas (inciso XI);

c) Representar contra ilegalidade, omissão ou abuso de poder (inciso XII).

${ }^{197}$ Na redação original, ou seja, antes da redação determinada pela Lei 9.527/97, a licença era dada sema a exigência de submissão a curso de capacitação profissional. O dispositivo atual parece bem mais inteligente, fomentando benefícios para o servidor e também para a Administração. 
Dentre as proibições (art. 117), algumas têm clara conexão com a impessoalidade, como por exemplo as de:

a) Opor resistência injustificada ao andamento de documento e processo ou execução de serviço (inciso IV);

b) Promover manifestação de apreço ou desapreço no recinto da repartição (inciso V);

c) Coagir ou aliciar subordinados no sentido de filiarem-se a associação profissional ou sindical ou a partido político (inciso VII);

d) Manter sob sua chefia imediata, em cargo ou função de confiança, cônjuge, companheiro ou parente até o segundo grau civil (inciso VIII);

e) Valer-se do cargo para lograr proveito pessoal ou de outrem, em detrimento da dignidade da função pública (inciso IX).

As proibições acima transcritas buscam estabelecer um padrão ético de comportamento do servidor público. Nessa perspectiva, materializam o princípio da impessoalidade na esfera da ação administrativa.

Os deveres e proibições exemplificados convergem esforços para que a atuação administrativa seja moldada pelo interesse público primário. Para que não haja, no exercício das funções, espaço para atuações voltadas à satisfação de interesses outros, alheios àqueles plasmados em benefício da coletividade, banindo-se atuações, confessadas ou não, com base em subjetivismos, ódios, rancores, perseguições e preferências pessoais nada republicanas.

Ainda na Lei nº 8.112/90 é possível encontrar dispositivos voltados à impessoalidade em normas relativas ao processo administrativo disciplinar, como no instituto do afastamento preventivo (art. 147), que estimula uma apuração menos infensa a subjetivismos, livre de influências. No processo disciplinar propriamente dito, são relevantes os arts. 148 (sobre a processualização da apuração da responsabilidade), 149 (sobre a composição da comissão de sindicância ou inquérito, a ser composta de três servidores estáveis, dela não podendo participar cônjuge, companheiro ou parentes próximos do acusado) e 150, no sentido de que " $a$ Comissão exercerá suas atividades com independência e imparcialidade, assegurado o sigilo necessário à elucidação do fato ou exigido pelo interesse da administração".

Note-se que no campo disciplinar existe forte preocupação legislativa com a necessidade de que a apuração de responsabilidade se dê em ambiente processual, com objetividade, independência e imparcialidade. 


\subsubsection{Agências reguladoras}

Há forte conexão entre a impessoalidade e a ideologia que norteou a criação das agências reguladoras, as quais têm como funções primordiais: i) a profissionalização - e despolitização - da Administração Pública; ii) a instituição de marcos regulatórios específicos aos setores regulados e dotados de ampla tecnicidade ${ }^{198}$.

A autonomia e a independência das agências reguladoras são materializadas por instrumentos legais e institucionais como: i) nomeação de seus dirigentes por mandato determinado, durante o qual é vedada a exoneração ad nutum; ii) o poder normativo no setor regulado; iii) autonomia financeira e orçamentária ${ }^{199}$.

O princípio da impessoalidade está no cerne da ideologia que levou à consolidação das agências reguladoras no ordenamento jurídico pátrio. A busca em estabelecer uma atuação administrativa impessoal e imparcial - desvinculada de interesses momentâneos político-partidários - constitui o norte e o objetivo destas instituições. O princípio da impessoalidade, aqui, concretiza-se na esfera da organização administrativa ${ }^{200}$.

${ }_{198}$ Nesse sentido, confira-se a posição de Alexandre Santos de Aragão (Agências reguladoras...., p. 87-88):
"Profissionalização (Despolitizaçâo) da Administração Pública e Democracia - Estado Plural
"O grande risco da fluidez dos objetivos fixados na legislação é a possibilidade de, em razão da sua inevitável
generalidade, serem instrumentalizados politicamente pelas forças políticas momentaneamente dominantes.
Para evitar que os objetivos das normas sejam tomados por apenas uma parcela da sociedade, têm sido criados
órgãos ou entidades autônomas, cujos dirigentes não podem ser exonerados ad nutum e cuja composição é feita
de tal forma que tenda a ser heterogênea política e ideologicamente.
Veja-se, por exemplo, as agências reguladoras, cujos dirigentes são nomeados por mandatos certos não coin-
cidentes, propiciando a nomeação deles ao longo de diversos governos. A medida, longe de se afastar da
democracia, com um suposto afastamento destas instâncias das forças políticas majoritárias, assegura o
pluralismo no seio do Estado sem retirar totalmente o poder de controle do Chefe do Poder Executivo ou do
Poder Legislativo. São, destarte, uma fórmula apta a propiciar a necessária combinação entre o pluralismo e
o princípio majoritário.”
${ }^{199}$ Confira-se Alexandre Aragão, uma vez mais, sobre a autonomia e independência das Agências Reguladoras: (Agências reguladoras..., p. 218-219):

"As primeiras agências reguladoras independentes criadas entre nós guardaram pertinência com a retração da intervenção estatal em vastos setores da vida econômica, que teve como reverso a consciência de que o Estado não poderia deixar apenas ao alvedrio empresarial a gestão de atividades de indubitável interesse público, que deveriam, portanto, ficar sob o seu poder regulatório. Procurou-se, todavia, fazer com que a regulação de tais atividades não ficasse sujeita à variação dos humores político-partidários, dotando-se as entidades dela incumbidas de uma especial autonomia em relação ao Poder Executivo central.

(...)

Para evitar o déficit democrático destas instituições devemos ter sempre clara a sua vinculação às pautas estabelecidas pelo Legislador para as políticas públicas cuja implementação lhes é atribuída, assim como a necessária coordenação que devem possuir com o restante da Administração Pública, com o Poder Executivo central e com a rede composta do conjunto das demais instituições independentes. Vemos, assim, que a nomenclatura 'independente'é apenas um meio de denotar a sua autonomia reforçada, que, todavia é, como toda autonomia, por definição limitada".

${ }^{200}$ Nessa perspectiva, confira-se o entendimento de Alexandre Aragão (Agências reguladoras..., p. 217), com base na doutrina de Francesco Paolo Casavola: "um Estado que esteja dentro, não à frente dos processos 
Na legislação relativa às agências reguladoras, destacam-se institutos como o mandato e a quarentena. Ambos têm a ver com a impessoalidade.

O mandato fixo (com impossibilidade de exoneração ad nutum) dos Diretores das Agências Reguladoras e o período de quarentena após a saída deles dos respectivos cargos materializam, na essência, o princípio da impessoalidade.

Por um lado, buscam impedir que questões político-partidárias tenham influência marcante nas decisões das entidades reguladoras; por outro, a quarentena representa mecanismo que busca impossibilitar que antigo Diretor de Agência Reguladora use de sua influência para defender interesses privados no âmbito do setor regulado.

No regime da Lei n ${ }^{0}$ 9.986/2000 (dispõe sobre a gestão de recursos humanos das Agências Reguladoras), podem ser referidos dispositivos sobre mandatos dos dirigentes (arts. $6^{\circ}$ e $7^{\circ}$ ) e sobre os respectivos impedimentos para o exercício de atividades ou a prestação de qualquer serviço no setor regulado pela respectiva agência, por um período de quatro meses, contados da exoneração ou do término do seu mandato (art. $8^{\circ}$ ).

É interessante observar que para não impingir prejuízo não razoável ao ex-dirigente, a lei estipulou que durante o impedimento ele ficará vinculado à agência, fazendo jus a remuneração compensatória equivalente à do cargo de direção que exerceu e aos benefícios a ele inerentes (art. $8^{\circ}$, § $2^{\circ}$ ). O mesmo se aplica ao ex-dirigente exonerado a pedido, se este já tiver cumprido pelo menos seis meses do seu mandato.

O descumprimento da quarentena significa crime de advocacia administrativa, sujeitando o infrator (o ex-dirigente) às penas da lei penal, sem prejuízo das demais sanções cabíveis, administrativas e civis.

De acordo com a Lei n ${ }^{\circ}$ 9.427/96 (institui a Agência Nacional de Energia Elétrica ANEEL), art. 5º o Diretor-Geral e os demais Diretores serão nomeados pelo Presidente da República para cumprir mandatos não coincidentes de quatro anos.

Por força do art. $6^{\circ}$ da mesma lei, está impedida de exercer cargo de direção na ANEEL a pessoa que mantiver vínculos com qualquer empresa concessionária, permissionária, autorizada, produtor independente, autoprodutor ou prestador de serviço contratado dessas empresas sob regulamentação ou fiscalização da autarquia, como: (i) acionista ou sócio com participação individual direta superior a três décimos por cento no capital social ou superior

sociais, deve encontrar instrumentos que sejam independentes dos poderes originários e constitutivos da estatalidade - O Governo e o Parlamento. E deve encontrar pessoas eticamente independentes que não tenham ideologia ou interesse como parte nos processos sociais". 
a dois por cento no capital social de empresa controladora (inciso I); (ii) membro do conselho de administração, fiscal ou de diretoria executiva; ou (iii) empregado, mesmo com o contrato de trabalho suspenso, inclusive das empresas controladoras ou das fundações de previdência de que sejam patrocinadoras.

Em consonância com o parágrafo único, do art. $6^{\circ}$, da Lei n ${ }^{\circ}$ 9.427/96, também está impedido de exercer cargo de direção da ANEEL membro do conselho ou diretoria de associação regional ou nacional representativa de interesses dos agentes mencionados no caput (empresa concessionária, permissionária, autorizada, produtor independente, autoprodutor ou prestador de serviço contratado dessas empresas sob regulamentação ou fiscalização da autarquia), de categoria profissional de empregados desses agentes, bem como de conjunto ou classe de consumidores de energia.

Outro interessante instrumento vinculado ao princípio da impessoalidade é o contrato de gestão, concebido para a administração (impessoal) da ANEEL. De acordo com o art. $7^{\circ}$, caput, da lei de regência, uma cópia do instrumento deve ser encaminhada para registro no Tribunal de Contas da União, onde servirá de peça de referência em auditoria operacional. E consoante o $\S 1^{\circ}$ do mesmo dispositivo, o contrato de gestão será o instrumento de controle da atuação administrativa da autarquia e da avaliação do seu desempenho e elemento integrante da prestação de contas do Ministério de Minas e Energia e da ANEEL, a que se refere o art. $9^{\circ}$ da Lei $n^{\circ} 8.443$, de 16 de julho de 1992, sendo sua inexistência considerada falta de natureza formal, de que trata o inciso II do art. 16 da mesma lei.

Além de estabelecer parâmetros para a administração interna da autarquia, os procedimentos administrativos, inclusive para efeito do disposto no inciso V do art. $3^{\circ}$, o contrato de gestão deve estabelecer, nos programas anuais de trabalho, indicadores que permitam quantificar, de forma objetiva, a avaliação do seu desempenho $\left(\S 2^{\circ}\right)$. E tal contrato será avaliado periodicamente e, se necessário, revisado por ocasião da renovação parcial da diretoria da autarquia, sem prejuízo da solidariedade entre seus membros $\left(\S 3^{\circ}\right)$.

Já na Lei n 9.472/97 (dispõe sobre a organização dos serviços de telecomunicação e a criação e funcionamento da ANATEL), dignos de notas o art. 24, caput, segundo o qual o mandato dos membros do Conselho Diretor será de cinco anos, e o art. 25, no sentido de que os mandatos dos primeiros membros do Conselho Diretor serão de três, quatro, cinco, seis e sete anos, a serem estabelecidos no decreto de nomeação. Também pode ser referido o art. 30: “Até um ano após deixar o cargo, é vedado ao ex-conselheiro representar qualquer pes- 
soa ou interesse perante a Agência”. E o parágrafo único, do mesmo art. 30, estabelece ser vedado "ao ex-conselheiro utilizar informações privilegiadas obtidas em decorrência do cargo exercido, sob pena de incorrer em improbidade administrativa”.

Na Lei n ${ }^{\circ}$ 9.478/97, que instituiu a Agência Nacional de Petróleo - ANP, são relevantes, para os fins desta investigação, o art. $11, \S 3^{\circ}$, no sentido de que os membros da Diretoria cumprirão mandatos de quatro anos, não coincidentes, permitida a recondução, e o art. 14, sobre quarentena, assim redigido:

Art. 14. Terminado o mandato, ou uma vez exonerado do cargo, o ex-Diretor da ANP ficará impedido, por um período de 12 (doze) meses, contado da data de sua exoneração, de prestar, direta ou indiretamente, qualquer tipo de serviço a empresa integrante das indústrias do petróleo e dos biocombustíveis ou de distribuição.

$\S 1^{\circ}$ Durante o impedimento, o ex-Diretor que não tiver sido exonerado nos termos do art. 12 poderá continuar prestando serviço à ANP, ou a qualquer órgão da Administração Direta da União, mediante remuneração equivalente à do cargo de direção que exerceu.

$\S 2^{\circ}$ Incorre na prática de advocacia administrativa, sujeitando-se às penas da lei, o ex-Diretor que violar o impedimento previsto neste artigo.

Possuem previsões semelhantes as Leis 9.961/2000 (ANS), 9.984/2000 (ANA) e 11.182/2005 (ANAC).

\subsubsection{Processo administrativo federal (Lei $n^{0}$ 9.784/99)}

A Lei de Processo Administrativo Federal (Lei no 9.784/99), inspirada na legislação espanhola, embora não se refira expressamente ao princípio da impessoalidade, tem com ele grande afinidade. Há quem sustente, como Maria Sylvia Zanella di Pietro ${ }^{201}$, que ele está implicitamente contido no art. $2^{\circ}$, parágrafo único, inciso III, em dois sentidos possíveis (finalidade pública e proibição de promoção pessoal), quando se exige “objetividade no atendimento do interesse público, vedada a promoção pessoal de agentes ou autoridades”.

O Direito Administrativo contemporâneo não pode mais ser concebido sem apego a uma necessidade maior de fundamentação e de participação do administrado, sobrelevando, por isso mesmo, a importância da progressiva processualização.

\footnotetext{
${ }^{201}$ Direito Administrativo..., p. 69.
} 
Já no art. $2^{\circ}$, a lei em exame determina que a Administração obedeça a um leque de princípios $^{202}$ que, amalgamados, traduzem facetas ou ferramentas da impessoalidade, especialmente aos princípios da finalidade, motivação, proporcionalidade, ampla defesa, contraditório, segurança jurídica e interesse público. De acordo com o parágrafo único do art. $2^{\circ}$, estabeleceu o legislador a necessidade de observância, em meio aos processos administrativos, de critérios como a objetividade no atendimento do interesse público. E vedou a promoção pessoal de agentes ou autoridades.

A norma em destaque materializa um dos principais - senão o principal - mandamento de impessoalidade na realização e na concretização das atividades administrativas. O caráter abstrato e geral da Lei $\mathrm{n}^{0}$ 9.784/99 lhe confere status de norma padrão para todo ato decisório a ser tomado na esfera administrativa federal. Ao elencar como critério fundamental o de objetividade no atendimento do interesse público, sendo vedada a promoção pessoal dos agentes estatais, todas as esferas de poder, governamentais ou não, devem observar a impessoalidade, expressa na proibição de: i) discriminação subjetiva do administrado (por características a ele inerentes - como posição política ou posição social); ii) buscarem os agentes públicos vantagens e/ou benefícios pessoais em sua atuação.

Como meio de garantir a impessoalidade dos agentes públicos, principalmente no desenvolvimento de competências decisórias, a Lei de Processo Administrativo estabelece uma série de hipóteses de suspeição e impedimento desses agentes, no tocante à atuação concreta destes no campo processual. Confira-se:

Art. 18. É impedido de atuar em processo administrativo o servidor ou autoridade que:

I - tenha interesse direto ou indireto na matéria;

II - tenha participado ou venha a participar como perito, testemunha ou representante, ou se tais situações ocorrem quanto ao cônjuge, companheiro ou parente e afins até o terceiro grau;

III - esteja litigando judicial ou administrativamente com o interessado ou respectivo cônjuge ou companheiro.

${ }^{202}$ Art. $2^{\circ}$ A Administração Pública obedecerá, dentre outros, aos princípios da legalidade, finalidade, motivação, razoabilidade, proporcionalidade, moralidade, ampla defesa, contraditório, segurança jurídica, interesse público e eficiência.

Parágrafo único. Nos processos administrativos serão observados, entre outros, os critérios de:

(omissis)

III - objetividade no atendimento do interesse público, vedada a promoção pessoal de agentes ou autoridades; 
Art. 19. A autoridade ou servidor que incorrer em impedimento deve comunicar o fato à autoridade competente, abstendo-se de atuar.

Parágrafo único. A omissão do dever de comunicar o impedimento constitui falta grave, para efeitos disciplinares.

Art. 20. Pode ser arguida a suspeição de autoridade ou servidor que tenha amizade íntima ou inimizade notória com algum dos interessados ou com os respectivos cônjuges, companheiros, parentes e afins até o terceiro grau. Art. 21. O indeferimento de alegação de suspeição poderá ser objeto de recurso, sem efeito suspensivo.

Forçoso destacar a existência de um sistema bem articulado de impedimentos e suspeições, dando concretude, a nosso ver, ao aspecto procedimental da impessoalidade, próprio de uma das linhas da imparcialidade europeia, nomeadamente as chamadas "garantias formais".

Os artigos transcritos acima representam normas que materializam a impessoali-dade, tanto do ponto de vista da organização quanto da ação administrativa.

No plano abstrato, buscam assegurar a atuação imparcial do Poder Público, o qual deve se organizar de modo a fazer valer as vedações de seus agentes em casos de suspeição ou impedimento. Já sob a ótica da concretude fática, tais previsões legais possibilitam ao administrado questionar a idoneidade de determinado agente para atuar em seu processo, considerando os interesses em jogo e os vínculos de parentesco e amizade que este agente possua.

\subsubsection{Terceiro setor}

Também em tema de Terceiro Setor ${ }^{203}$, o princípio da impessoalidade se fez presente com força significativa.

As Organizações Sociais (OS), pessoas jurídicas de direito privado não integrantes da Administração Pública e sem fins lucrativos, cuja criação por particulares tem como objetivo a execução, por meio de parcerias, de serviços públicos não exclusivos do Estado (ensino,

${ }^{203}$ Consoante o magistério de Lucas Rocha Furtado (Curso de Direito Administrativo. $4^{\mathrm{a}}$ ed. Belo Horizonte: Fórum, 2013, p. 181):

"O terceiro setor corresponde a entidades privadas, necessariamente surgidas no âmbito privado, porém sem fins lucrativos ou econômicos. O seu nome (terceiro) surge por exclusão: o primeiro setor é o estatal; o segundo setor, o privado empresarial.

Em face de nosso vigente Código Civil, integram o terceiro setor as associações - que somente podem ser constituídas para fins 'não econômicos' (Cód. Civil, art. 53, caput) - e as fundações - que somente podem ser constituídas para desenvolver fins 'religiosos, morais, culturais, ou de assistência'(Cód. Civil, art. 62, par. único).” 
pesquisa, tecnologia, meio ambiente, cultura e saúde), atuam em nome próprio, sob regime de direito privado, mas recebem apoio estatal.

Na esfera federal, tais entidades são reguladas pela Lei n. 9.637/98.

$\mathrm{O}$ art. $5^{\circ}$ da lei em referência define o vínculo a ser firmado entre o Poder Público e a Organização Social. Tal vínculo é chamado pelo legislador de Contrato de Gestão. Verifique-se:

“Art. $5^{\circ}$ Para os efeitos desta Lei, entende-se por contrato de gestão o ins-
trumento firmado entre o Poder Público e a entidade qualificada como or-
ganização social, com vistas à formação de parceria entre as partes para
fomento e execução de atividades relativas às áreas relacionadas no art. ${ }^{\circ \text { ”. }}$

A elaboração do contrato de gestão deverá observar todos os princípios basilares da Administração Pública, em especial o princípio da impessoalidade. É o que determina o art. $7^{\circ}$ da Lei 9.637/98:

“Art. $7^{\circ}$ Na elaboração do contrato de gestão, devem ser observados os princípios da legalidade, impessoalidade, moralidade, publicidade, economicidade e, também, os seguintes preceitos:

I - especificação do programa de trabalho proposto pela organização social, a estipulação das metas a serem atingidas e os respectivos prazos de execução, bem como previsão expressa dos critérios objetivos de avaliação de desempenho a serem utilizados, mediante indicadores de qualidade e produtividade; II - a estipulação dos limites e critérios para despesa com remuneração e vantagens de qualquer natureza a serem percebidas pelos dirigentes e empregados das organizações sociais, no exercício de suas funções.

Parágrafo único. Os Ministros de Estado ou autoridades supervisoras da área de atuação da entidade devem definir as demais cláusulas dos contratos de gestão de que sejam signatários”.

Apesar de se submeterem ao regime de direito privado, as Organizações Sociais podem receber: i) dotações orçamentárias do Poder Público; ii) bens públicos por meio de permissão de uso; iii) cessão de servidores públicos. Esta é a previsão constante dos arts. 12 a 15 da Lei $n^{\circ} 9.637 / 98$.

As OS são qualificadas livremente pelo Ministro ou titular do órgão supervisor do seu ramo de atividade e pelo Ministro do Planejamento, Orçamento e Gestão. Art. $2^{\circ}$, inciso II, da Lei $n^{\circ} 9.637 / 98$. 
É justamente neste ponto que a doutrina critica severamente a Constituição e a qualificação de tais entidades. O art. 24, inciso XXIV da Lei nº 8.666/93 garante a dispensa de licitação para que a Administração contrate com Organizações Sociais:

\author{
“Art. 24. É dispensável a licitação: \\ XXIV - para a celebração de contratos de prestação de serviços com as \\ organizações sociais, qualificadas no âmbito das respectivas esferas de go- \\ verno, para atividades contempladas no contrato de gestão”.
}

A doutrina busca fazer uma leitura constitucional dessa hipótese de dispensa de licitação, no sentido de que somente é possível aplicá-la para a prestação de serviços posteriores à celebração do contrato de gestão (ou contrato-mãe). Para que haja a qualificação de organização social além da mera conveniência e oportunidade da Administração Pública há o dever de licitar, a fim de que se contrate a entidade mais apta e idônea para assumir os serviços de interesse público transmitidos pelo contrato de gestão ${ }^{204}$. Entretanto, para outra parte da doutrina não há como sanar tal inconstitucionalidade ${ }^{205}$.

É certo que a ampla dispensa de licitação para a qualificação de entidade privada como organização social ofende frontalmente o princípio da impessoalidade, tanto na esfera da ação quanto da organização administrativa ${ }^{206}$.

\footnotetext{
${ }^{204}$ Esse é o entendimento de Marçal Justen Filho (Comentários à Lei de Licitações e Contratos Administrativos. $10^{a}$ Ed. São Paulo: Dialética, 2004, p. 31.), ao asseverar que "há necessidade de prévia licitação para configurar o contrato de gestão e escolher a entidade privada que será contratada". Assim, "uma vez firmado o contrato de gestão, as futuras contratações de prestação de serviço - já previamente identificadas - serão pactuadas sem a necessidade de nova licitação".

${ }^{205}$ Nessa perspectiva, relevante destacar a crítica de Lucas Rocha Furtado (Obra citada, p. 182):

"A ideia de utilizar entidades privadas na prestação de serviços de utilidade pública é boa. Todavia, a absoluta falta de critérios de impessoalidade para a escolha da entidade que irá receber os recursos públicos tem sido fonte de constante questionamento quanto à sua constitucionalidade. A rigor, há situações em que entidades privadas são criadas com o único propósito de receberem esses recursos, em evidente violação aos princípios da moralidade e da impessoalidade. A absoluta discricionariedade - que por ser absoluta se converte em arbitrariedade - na escolha da entidade privada a ser qualificada como OS, aliada à falta de transparência nas prestações de contas, que são encaminhadas à própria entidade ou órgão que repassa referidos recursos, têm comprometido todo o processo de publicização. Urge aprimorar a legislação de modo a desenvolver mecanismos impessoais de escolha da entidade que irá receber os recursos e a definir o modo mais claro e transparente o processo de prestação de contas" (Grifo nosso).

${ }^{206}$ Nesse sentido, ressalte-se também o entendimento firme de Celso Antônio Bandeira de Mello (Curso..., p. 240):

"No caso, o tema se propõe porque a lei disciplinadora das organizações sociais pretendeu, inconstitucionalmente, permitir que travem contratos administrativos com o poder público sem licitação e sem qualquer cautela, mesmo a mais elementar, resguardadora dos princípios constitucionais da impessoalidade (prestante para assegurar o princípio da moralidade) garantidora dos interesses públicos.

(...)

A ausência de licitação é obviamente uma exceção que só pode ter lugar nos casos em que razões de indiscutível tomo a justifiquem, até porque, como é óbvio, a ser de outra sorte, agravar-se-ia o referido princípio
} 
Frise-se que está pendente de julgamento a ADI no 1923, ajuizada pelo Partido dos Trabalhadores (PT) contra o referido art. 24, inciso XXIV, da Lei 8.666/93 e a forma de qualificação das Organizações Sociais.

As Organizações da Sociedade Civil de Interesse Público - OSCIPs, de sua vez, foram introduzidas no ordenamento jurídico pátrio por meio da Lei $n^{\circ}$ 9.790/99. No que se refere à finalidade dessas entidades, há certa semelhança com o fim buscado pelas organizações sociais, qual seja, a execução de serviços públicos não privativos do Estado. A lei define diversas possíveis áreas de atuação das OSCIPs, tais como (i) assistência social; (ii) cultura; (iii) meio ambiente.

Para obterem a qualificação de OSCIPs, as entidades privadas não podem ter fins lucrativos e devem requerer habilitação junto ao Ministério da Justiça. Destaque-se que, ao contrário das Organizações Sociais, não se trata da constituição de uma entidade nova; é pessoa jurídica já constituída que ganha esse status temporário, durável enquanto houver parceria.

O vínculo entre o Poder Público e entidade privada para que haja a constituição de uma OSCIP materializa-se no denominado termo de parceria ${ }^{207}$.

A crítica da doutrina quanto à violação do princípio da impessoalidade na qualificação das Organizações Sociais se aplica de forma semelhante às Organizações da Sociedade Civil de Interesse Público.

Já as entidades de apoio são pessoas jurídicas de direito privado que exercem, sem fins lucrativos, atividade social e/ou serviços não exclusivos do Estado relacionados a ciência, pesquisa, saúde e educação. Essas entidades não integram os quadros da Administração Indireta. São cooperadoras do Estado, atuando normalmente junto a hospitais públicos e universidades públicas. Não possuem legislação específica quanto à sua constituição e qualificação.

A doutrina aponta inúmeras críticas a essas entidades, com razão. Deve-se alertar que

constitucional da isonomia. Por isto mesmo é inconstitucional a disposição do art. 24, inciso XXIV, da Lei de Licitações (8.666/93), ao liberar de licitações e contratos entre o Estado e as organizações sociais, pois tal contrato é o que ensancha a livre atribuição deste qualificativo a entidades privadas, com as correlatas vantagens; inclusive a de receber bens públicos em permissão de uso sem prévia licitação".

${ }^{207}$ Lucas Rocha Furtado (Obra citada, p. 184) aponta diferenças práticas entre o termo de parceria e o contrato de gestão:

"A prática tem revelado que a efetiva distinção se encontra no âmbito de alcance dos acordos firmados com essas entidades. $O$ contrato de gestão firmado com a OS vincula a entidade em toda a sua atuação. Toda a atuação, toda a atividade, enfim, tudo o que a entidade com a qual se celebra o contrato de gestão faz ou deixa de fazer é definido neste instrumento, assim como a OS passa a depender integralmente dos recursos públicos que lhe serão repassados. No caso da OSCIP, o termo de parceria irá igualmente permitir o repasse de recursos públicos, mas apenas para a execução de determinados projetos ou programas. Em outras palavras, o contrato de gestão vincula a OS em todas as suas atuações; o termo de parceria viabiliza o repasse de recursos públicos para projetos específicos, sem, todavia, comprometer a autonomia ou independência da OSCIP”. 
elas não seguem regime público, mas poderão receber dotação orçamentária, servidor e bens públicos. Como se percebe, possuem uma aparência material de entidade da administração pública, mas, formalmente, escapam aos deveres de licitar e de realizar concurso público ${ }^{208}$.

\subsubsection{Parcerias Voluntárias (Lei $\mathbf{n}^{0}$ 13.019/14)}

Recentemente foi publicada a Lei $\mathrm{n}^{0}$ 13.019/14, denominada Lei das Parcerias Voluntárias. Regula parcerias entre a Administração Pública e entidades do terceiro setor (chamadas pela Lei de organizações da sociedade civil). Todos os repasses de verbas públicas e benefícios a tais entidades deverão respeitar as diretrizes dessa lei. A lei deu ênfase maior a determinados princípios (dentre os quais o da impessoalidade) e deu vida ao instituto do chamamento público (espécie de procedimento licitatório). Ao contrário das Organizações Sociais, que podem ser contratadas sem licitação, as OSCIPs e demais entes do terceiro setor terão que se submeter a esse novo regramento.

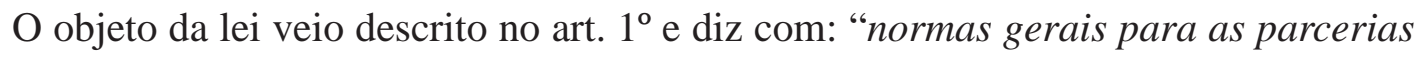
voluntárias, envolvendo ou não transferências de recursos financeiros, estabelecidas pela União, Estados, Distrito Federal, Municípios e respectivas autarquias, fundações, empresas públicas e sociedades de economia mista prestadoras de serviço público, e suas subsidiárias, com organizações da sociedade civil, em regime de mútua cooperação, para a consecução de finalidades de interesse público; define diretrizes para a política de fomento e de colaboração com as organizações da sociedade civil; e institui o termo de colaboração e o termo de fomento".

De se ver que a Lei $\mathrm{n}^{0}$ 13.019/14 se aplica a todas as esferas de governo (Federal, Estadual e Municipal), trabalha conceitos e, de acordo com o art. $2^{\circ}$, considera:

I - organização da sociedade civil: pessoa jurídica de direito privado sem fins lucrativos que não distribui, entre os seus sócios ou associados, conse-

\footnotetext{
${ }^{208}$ Lucas Rocha Furtado (Obra citada, p. 186-187) critica severamente as entidades de apoio: "Mais uma vez, o propósito subjacente à criação dessas entidades de apoio não tem nada de digno. A verdade, mais uma vez, é uma só: foram criadas as (mal)ditas fundações de apoio - como entidades privadas, porém com fundos que lhe foram ilegalmente transferidos pelas próprias universidades federais - para intermediar as contratações das universidades, burlando a lei de licitação.

(...)

São igualmente utilizadas para burlar regras de concurso público: em vez deste, a universidade firma convênio com sua fundação de apoio para fornecimento de mão de obra. Não bastassem essas irregularidades, são ainda utilizadas essas entidades para violar regimes de dedicação exclusiva a que se submetem inúmeros professores".
} 
lheiros, diretores, empregados ou doadores, eventuais resultados, sobras, excedentes operacionais, brutos ou líquidos, dividendos, bonificações, participações ou parcelas do seu patrimônio, auferidos mediante o exercício de suas atividades, e que os aplica integralmente na consecução do respectivo objeto social, de forma imediata ou por meio da constituição de fundo patrimonial ou fundo de reserva;

VII - termo de colaboração: instrumento pelo qual são formalizadas as parcerias estabelecidas pela administração pública com organizações da sociedade civil, selecionadas por meio de chamamento público, para a consecução de finalidades de interesse público propostas pela administração pública, sem prejuízo das definições atinentes ao contrato de gestão e ao termo de parceria, respectivamente, conforme as Leis $\mathrm{n}^{\text {os }} 9.637$, de 15 de maio de 1998, e 9.790, de 23 de março de 1999;

VIII - termo de fomento: instrumento pelo qual são formalizadas as parcerias estabelecidas pela administração pública com organizações da sociedade civil, selecionadas por meio de chamamento público, para a consecução de finalidades de interesse público propostas pelas organizações da sociedade civil, sem prejuízo das definições atinentes ao contrato de gestão e ao termo de parceria, respectivamente, conforme as Leis $\mathrm{n}^{\text {os }}$ 9.637, de 15 de maio de 1998, e 9.790, de 23 de março de 1999;

XI - comissão de monitoramento e avaliação: órgão colegiado da administração pública destinado a monitorar e avaliar as parcerias celebradas com organizações da sociedade civil nos termos desta Lei, composto por agentes públicos, designados por ato publicado em meio oficial de comunicação, sendo, pelo menos, 2/3 (dois terços) de seus membros servidores ocupantes de cargos permanentes do quadro de pessoal da administração pública realizadora do chamamento público;

XII - chamamento público: procedimento destinado a selecionar organização da sociedade civil para firmar parceria por meio de termo de colaboração ou de fomento, no qual se garanta a observância dos princípios da isonomia, da legalidade, da impessoalidade, da moralidade, da igualdade, da publicidade, da probidade administrativa, da vinculação ao instrumento convocatório, do julgamento objetivo e dos que lhes são correlatos;

Confira-se que a lei tem aplicação em relação às OSCIPs (Organizações da Sociedade Civil de Interesse Público). Sobre princípios e diretrizes relacionados à impessoalidade, merecem destaque estas normas da novel legislação: 
Art. $5^{\circ} \mathrm{O}$ regime jurídico de que trata esta Lei tem como fundamentos a gestão pública democrática, a participação social, o fortalecimento da sociedade civil e a transparência na aplicação dos recursos públicos, devendo obedecer aos princípios da legalidade, da legitimidade, da impessoalidade, da moralidade, da publicidade, da economicidade, da eficiência e da eficácia, além dos demais princípios constitucionais aplicáveis e dos relacionados a seguir:

IV - o direito à informação, à transparência e ao controle social das ações públicas;

Art. $6^{0}$ São diretrizes fundamentais do regime jurídico de fomento ou de colaboração:

II - a priorização do controle de resultados;

V - o estabelecimento de mecanismos que ampliem a gestão de informação, transparência e publicidade;

No texto legal sobressai o instituto do chamamento público. A administração pública pode fazer transferências voluntárias de recursos para organizações da sociedade civil com o objetivo de que sejam realizados planos de trabalho em regime de mútua cooperação.

A organização da sociedade civil que receberá tais transferências será selecionada por meio de um procedimento nominado “chamamento público” e, após escolhida, deverá celebrar um “termo de colaboração” ou um “termo de fomento” com a administração pública.

Guardadas as devidas diferenças, esse chamamento público funcionará como se fosse uma licitação, um processo seletivo (competitivo) para escolher a organização que melhor poderá executar o projeto.

Esse é o ponto mais importante da Lei, considerando que essa seleção pública busca evitar a escolha das ONGs qle irão receber os recursos com base em interesses pessoais e preferências políticas/ideológ cas.

Ao contrário das leis đue instituíram as Organizações Sociais e as Organizações da Sociedade Civil de Interesse Público, a Lei de Parcerias Voluntárias, ao estabelecer a regra do chamamento público, cria um novo marco de impessoalidade na organização e na ação administrativa.

Tal conclusão fica ma s clara quando focado o sistema de responsabilidades e sanções previsto na lei. As orga hizações da sociedade civil que descumprirem os termos da parceria firmada ou praticare $\mathrm{n}$ outros ilícitos poderão sofrer sanções administrativas e até responder por ato de improbid ade administrativa. 
Aliás, a Lei ${ }^{0}$ 13.019/14 acrescentou os seguintes incisos aos artigos da Lei de Improbidade Administrativa:

\section{Art. 10.}

VIII - frustrar a licitude de processo licitatório ou de processo seletivo para celebração de parcerias com entidades sem fins lucrativos, ou dispensá-los indevidamente;

XVI - facilitar ou concorrer, por qualquer forma, para a incorporação, ao patrimônio particular de pessoa física ou jurídica, de bens, rendas, verbas ou valores públicos transferidos pela administração pública a entidades privadas mediante celebração de parcerias, sem a observância das formalidades legais ou regulamentares aplicáveis à espécie;

XVII - permitir ou concorrer para que pessoa física ou jurídica privada utilize bens, rendas, verbas ou valores públicos transferidos pela administração pública a entidade privada mediante celebração de parcerias, sem a observância das formalidades legais ou regulamentares aplicáveis à espécie; XVIII - celebrar parcerias da administração pública com entidades privadas sem a observância das formalidades legais ou regulamentares aplicáveis à espécie;

XIX - frustrar a licitude de processo seletivo para celebração de parcerias da administração pública com entidades privadas ou dispensá-lo indevidamente;

XX - agir negligentemente na celebração, fiscalização e análise das prestações de contas de parcerias firmadas pela administração pública com entidades privadas;

XXI - liberar recursos de parcerias firmadas pela administração pública com entidades privadas sem a estrita observância das normas pertinentes ou influir de qualquer forma para a sua aplicação irregular.”

Art. 11.

VIII - descumprir as normas relativas à celebração, fiscalização e aprovação de contas de parcerias firmadas pela administração pública com entidades privadas.

A nova lei traduz uma mentalidade mais consentânea com a principiologia constitucional, sendo perceptíveis os influxos que recebeu do princípio da impessoalidade. 


\subsubsection{Legislação eleitoral}

A legislação eleitoral recebe forte influência do Direito Administrativo e condena comportamentos desconectados do princípio da impessoalidade administrativa.

A Lei n ${ }^{0}$ 9.504/97 (Lei das Eleições), em seu art. 74209, preconiza que o descumprimento da proibição constitucional de promoção pessoal, na publicidade institucional, configura abuso de autoridade e sujeita o responsável, se candidato, às drásticas penas de cancelamento do registro ou do diploma.

Pedro Roberto Decomain ${ }^{210}$ sustenta que a fórmula do art. 74, da Lei das Eleições, completa o disposto no art. 73, inciso VI, alínea "b”, do mesmo diploma legal e revela a inconstitucionalidade da propaganda institucional quando "mesmo não contendo nomes, símbolos ou imagens que caracterizem promoção pessoal de autoridades ou agentes públicos, não se revistam do caráter educativo, informativo ou de orientação social”.

Joel José Cândido ${ }^{211}$ ressalta que a regra do art. 74, da Lei das Eleições, “traz para o Direito Eleitoral infração que antes era punida fora dele, nos termos da Lei $n^{\circ}$ 8.429/1992, tão somente”. E que “agora, a promoção pessoal de autoridades ou servidores públicos, pela publicidade de atos, programas, obras, serviços e campanhas dos órgãos públicos, enseja a propositura da AIJE, e, também, da AIME e do RCD, ajuizados nas respectivas épocas e formas processuais".

José Jairo Gomes ${ }^{212}$ explica que a regra do art. 74, da Lei $\mathrm{n}^{0}$ 9.504/97, ligada que está ao art. 37, § $1^{\circ}$, da CF/88, tem em mira finalidade ética, moralizadora, de alto significado. Assim, “autoridades públicas não podem usar seus nomes, símbolos ou imagens para, no bojo de peça publicitária, custeada com dinheiro público, obter ou simplesmente pretender obter promoção pessoal, devendo a matéria veiculada pela mídia ter caráter eminentemente objetivo para que atinja sua finalidade constitucional de educar, informar ou orientar e não sirva, simplesmente, como autêntico marketing pessoal”. Todavia, lamenta o autor:

“A despeito disso, ainda é comum potenciais candidatos lançarem mão - na

\footnotetext{
${ }^{209}$ Art. 74. Configura abuso de autoridade, para os fins do disposto no art. 22 da Lei Complementar $n^{\circ}$ 64, de 18 de maio de 1990, a infringência ao disposto no $\S 1^{\circ}$ do art. 37 da Constituição Federal, ficando o responsável, se candidato, sujeito ao cancelamento do registro ou do diploma.

${ }^{210}$ Eleições: (comentários à Lei no 9.504/97). $2^{\text {a }}$ Edição. São Paulo: Dialética, 2004, p. 370-371.

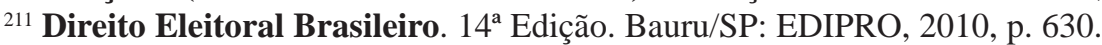

${ }^{212}$ Direito Eleitoral. $8^{a}$ Edição. São Paulo: Atlas, 2012, p. 390.
} 
propaganda institucional - de meios artificiosos para veiculares imagens e mensagens otimistas, penetrantes, fertilizando o terreno para futura propaganda eleitoral, que certamente virá. Ao chegar o tempo oportuno, corações e mentes encontrar-se-ão cevados, simpáticos ao agora candidato... Deveras, há administradores públicos que despendem fortunas do erário - dinheiro de impostos! - com a realização de suposta 'propaganda institucional'. Frequentemente, reservam-se no orçamento quantias muito superiores às destinadas às áreas sociais carentes de investimentos. Nesse jogo tresloucado e corrupto só há dois ganhadores: o candidato - cuja imagem é indiretamente promovida não à custa de seu eficiente trabalho, mas, sim, da mendaz publicidade 'institucional' - e as agências de publicidade... É preciso dar um basta nessa insólita sangria de recursos públicos! Exigem-no a moralidade pública, os princípios éticos mais elementares, a lei, a solidariedade social e a Justiça”.

O mesmo autor assinala que a situação piorou bastante com o instituto da reeleição, sobretudo se se atentar para a casuística regra que não impõe a desincompatibilização do candidato que pretende a renovação de seu mandato. Com isso, meses antes do período eleitoral é possível perceber a realização de maciça “propaganda institucional”, nos horários de picos de audiência, em desvio de finalidade, sem qualquer finalidade educativa, informativa ou de orientação social. Prossegue:

\footnotetext{
"Na verdade, tem-se assistido a verdadeiras propagandas eleitorais travestidas de 'institucionais', pagas, portanto, pelo contribuinte. A rigor, a maioria delas carece de caráter informativo, educativo ou de orientação social, constituindo pura exibição midiática. Muitas vezes, promessas são feitas. Um cenário maravilhoso é desenhado. Um futuro feliz e promissor é colocado em perspectiva, ao alcance de todos. Isso, é claro, se o governante em questão ou o seu afilhado político sagrar-se vitorioso nas urnas e for mantido na cadeira que ocupa. Invariavelmente, afirmações de fatos que não correspondem à realidade são feitas sem o menor constrangimento e com muita pompa. Enfim, todo arsenal do marketing político é mobilizado para criar artificialmente na opinião pública quadros mentais favoráveis ao potencial candidato”.
}

O tema da impessoalidade também repousa na proibição de propaganda institucional, qualquer que seja, no chamado “período crítico”, isto é, nos 3 (três) meses que antecedem o 
pleito. Trata-se da regra do art. 73, inciso VI, alínea “b”, da Lei n 9.504/97213, que foi erigida em prol da promoção de equilíbrio na disputa eleitoral.

De acordo com Pedro Roberto Decomain ${ }^{214}$, o dispositivo deve ser interpretado de forma extensiva, isto é, não é vedada apenas a autorização da publicidade institucional, mas, na realidade, a própria veiculação da publicidade. Para o reconhecido autor, o preceito legal faz duas ressalvas, verbis:

“(...) A primeira, da propaganda institucional relativa a produtos e serviços que tenham concorrência no mercado. As entidades da Administração Pública indireta, em particular as sociedades de economia mista e empresas públicas, estas podem fazer propaganda institucional relativas aos produtos que vendam, ou aos serviços que prestem, desde que estes tenham concorrência no mercado. Entes da Administração indireta que vendam produtos ou prestem serviços em regime de monopólio (como, por exemplo, a Petrobras, em relação a pesquisa, lavra e refino de Petróleo), não podem, nos três meses que antecedem o pleito, fazer propaganda institucional que diga respeito, direta ou indiretamente, a essas atividades. A segunda ressalva contida no dispositivo é a da publicidade destinada a atender grave e urgente necessidade pública. Esta deve, porém, ser reconhecida pela Justiça Eleitoral, o que a seu turno significa que tal publicidade deve ser por ela autorizada. Ocorrerá a hipótese, por exemplo, se for necessária publicidade pública para orientação aos atingidos por alguma calamidade pública, ou para a realização de campanha de vacinação urgente, destinada a prevenir mal que de modo epidêmico ameace alastrar-se. Nessas hipóteses a publicidade não poderia mesmo ser vedada. Mas a situação de gravidade e também de urgência deve ser analisada previamente pela Justiça Eleitoral. Se a publicidade for da União, ou entidade da Administração indireta por ela criada, a autorização caberá ao Tribunal Superior Eleitoral; se a publicidade for de Estado ou do Distrito Federal, a autorização caberá ao respectivo Tribunal Regional Eleitoral. Finalmente, se a publicidade for de âmbito munici-

${ }^{213}$ Art. 73. São proibidas aos agentes públicos, servidores ou não, as seguintes condutas tendentes a afetar a igualdade de oportunidades entre os candidatos nos pleitos eleitorais:

(omissis)

VI - nos três meses que antecedem o pleito:

(omissis)

b) com exceção da propaganda de produtos e serviços que tenham concorrência no mercado, autorizar publicidade institucional dos atos, programas, obras, serviços e campanhas dos órgãos públicos federais, estaduais ou municipais, ou das respectivas entidades da administração indireta, salvo em caso de grave e urgente necessidade pública, assim reconhecida pela Justiça Eleitoral.

${ }^{214}$ Obra citada, p. 357. 
pal, a autorização para ela, nos três meses anteriores ao pleito, caberá ao Juízo Eleitoral de primeira instância que abranja o Município interessado”.

Márlon Reis ${ }^{215}$ interpreta deste modo o mesmo texto legal:

“A utilização de campanhas publicitárias custeadas pelo Poder Público pode ter por meta a criação de estados psicológicos propícios à difusão da imagem do dirigente público como alguém capaz de alcançar realizações. Esse estado mental, fruto de propaganda indevida, concede a seu beneficiário condições privilegiadas de disputa, reforçando a ideia da força de sua campanha e transmitindo ao eleitor comum o receio de optar por candidaturas fadadas ao insucesso.

Por isso a norma proíbe a publicidade de programas, obras, serviços e campanhas dos órgãos públicos, com exceção dos que dependam de propaganda para favorecer sua concorrência no mercado, tal como ocorre com os produtos industriais decorrentes de intervenção do Estado no domínio empresarial. Outra exceção refere-se a transferências realizadas com o propósito de permitir o enfrentamento de situações emergenciais, de perigo ou de calamidade pública”.

Para o autor, “realizada a publicidade vedada, não se há de perquirir sobre a intensidade dos efeitos produzidos por ela no tocante ao resultado da eleição”, já que “a lei torna defesa a simples conduta, presumindo-se (praesumpio iuris et de iuris) a superveniência da quebra da isonomia entre os pretendentes ao mandato".

Permitimo-nos parcialmente discordar do culto autor, porque temos a conviç̧ão de que a intensidade dos efeitos da publicidade, dentre outros elementos fáticos condicionadores da infração, podem e devem ser levados em consideração não só para a fixação da multa pecuniária, escalonada de forma variável no $\S 4^{0216}$, do art. 73, mas também para aferição do eventual “benefício” do candidato, sem o que não só pode aplicar o $§ 5^{0217}$, do mesmo diploma legal, a não ser mediante a incidência, na esfera punitiva, de nula responsabilidade objetiva.

Note-se bem que a fim de evitar prejuízos econômicos para a Administração Pública,

${ }^{215}$ Direito Eleitoral Brasileiro. Brasília: Alumnus, 2012, p. 384-385.

${ }^{216}$ Art. 73, § $4^{\circ}$, da Lei no 9.504/97. O descumprimento do disposto neste artigo acarretará a suspensão imediata da conduta vedada, quando for o caso, e sujeitará os responsáveis a multa no valor de cinco a cem mil UFIR. ${ }^{217}$ Art. 73 , § $5^{\circ}$, da Lei n ${ }^{\circ} 9.504 / 97$. Nos casos de descumprimento do disposto nos incisos do caput e no $\S 10$, sem prejuízo do disposto no $\S 4^{\circ}$, o candidato beneficiado, agente público ou não, ficará sujeito à cassação do registro ou do diploma. 
o art. 73, inciso VI, alínea “b”, da LE, retira do âmbito da proibição de publicidade institucional, no período crítico, a propaganda “de produtos e serviços que tenham concorrência no mercado”. E, para não prejudicar a coletividade, permite que, “em caso de grave e urgente necessidade pública", possa a Justiça Eleitoral autorizar formalmente a "publicidade institucional de atos, programas, obras, serviços e campanhas dos órgãos públicos federais, estaduais ou municipais, ou das respectivas entidades da administração indireta”. Encaixam-se na última ressalva campanhas de vacinação obrigatória para contenção de epidemias, de mobilizações contra queimadas, etc.

Em ambos os casos (art. 74 e art. 73, VI, “b”, ambos da LE), estão em exame condutas vedadas aos agentes públicos em campanhas eleitorais, mas o tema é objeto de vultosa preocupação, por parte da Justiça Eleitoral, quando enfrentado o delicado assunto das propagandas eleitorais extemporâneas.

Sabe-se bem que a propaganda eleitoral somente é permitida após o dia 5 de julho do ano da eleição (art. 36, caput, da Lei n ${ }^{\circ}$ 9.504/97). Não obstante isso, candidatos inescrupulosos têm-se valido de propagandas (apenas) “formalmente” institucionais para se promoverem pessoalmente, sobretudo com fins eleitorais.

Por força da Lei $n^{\circ} 12.891 / 13$, acrescentou-se na Lei $n^{\circ}$ 9.504/97 o novel art. 36-B, que traz interessante hipótese de quebra de impessoalidade. Segundo o dispositivo, será considerada propaganda eleitoral antecipada e, pois, ilegal, “a convocação, por parte do Presidente da República, dos Presidentes da Câmara dos Deputados, do Senado Federal e do Supremo Tribunal Federal, de redes de radiodifusão para divulgação de atos que denotem propaganda política ou ataques a partidos políticos e seus filiados ou instituições”. E de acordo com o parágrafo único, do mesmo art. 36-B, da LE, “nos casos permitidos de convocação das redes de radiodifusão, é vedada a utilização de símbolos ou imagens, exceto aqueles previstos no $\S 1^{\circ}$ do art. 13 da Constituição Federal”.

O descumprimento das normas eleitorais referidas, por parte dos administradores públicos, revela um mau (para não dizer péssimo!) uso da publicidade institucional - dever do Estado e direito do cidadão - mercê de sua nítida deturpação para atingir finalidades alheias ao interesse público.

Interessa notar que o Tribunal Superior Eleitoral proíbe que candidatos usem nomes de órgãos públicos ${ }^{218}$. Um levantamento da Advocacia-Geral da União apontou que, nas elei-

${ }^{218}$ Conforme notícia no site Consultor Jurídico, de 07 de março de 2014. 
ções de 2012, mais de 200 (duzentas) pessoas utilizaram, nas campanhas eleitorais, denominações ligadas a órgãos federais, a exemplo de Jô Soares do INSS, Marcos Valério da UnB, Ivete da Funasa e Garrincha do Dnit. Para as eleições do corrente ano, de acordo com a Resolução/TSE nº 23.405/2014, isso não será mais permitido.

Por fim, registre-se que na lei de inelegibilidades (Lei Complementar $n^{\circ} 64 / 90$, com os acréscimos ditados pela Lei Complementar nº 135/10) há numerosas hipóteses de inelegibilidade decorrentes, em maior ou menor grau, da quebra da impessoalidade ${ }^{219}$.

\subsubsection{Vedação de atribuição de nome de pessoa viva a bem público}

Dando concretude especial ao princípio constitucional da impessoalidade, a Lei $n^{\circ}$ 6.454/77, com a (confusa) redação dada ao art. $1^{\circ}$ pela Lei $n^{\circ} 12.781 / 13$, proíbe, em todo o território nacional, “atribuir nome de pessoa viva ou que tenha se notabilizado pela defesa ou exploração de mão de obra escrava, em qualquer modalidade, a bem público, de qualquer natureza, pertencente à União e às pessoas jurídicas da administração indireta”. Proíbe também a inscrição dos nomes de autoridades ou administradores em placas indicadoras de obras ou em veículo de propriedade ou a serviço da Administração Pública direta ou indireta $\left(\right.$ art. $\left.2^{\circ}\right)$.

Todas as proibições até aqui mencionadas estendem-se às entidades que, a qualquer título, recebam subvenção ou auxílio dos cofres públicos federais (art. $3^{\circ}$ ) e a infração à lei acarreta ao responsável a perda do cargo ou função pública e, quando caso, a suspensão da subvenção ou auxílio (art. $4^{\circ}$ ).

A Lei Estadual da Paraíba (nº 5.998/94), em seu art. $1^{\circ}$, preconizou que “fica proibido atribuir nome de pessoa viva a bem público, de qualquer natureza, pertencente ao Estado da Paraíba ou às pessoas jurídicas da Administração indireta”. E pune com a perda do cargo ou da função pública os responsáveis pelo descumprimento da norma (art. $4^{\circ}$ ).

A Constituição da Bahia, no seu art. 21, veda expressamente "a utilização de nome, sobrenome ou cognome de pessoas vivas, nacionais ou estrangeiras, para denominar cidades, localidades, artérias, logradouros, prédios e equipamentos públicos de qualquer natureza”.

Em artigo ${ }^{220}$ sobre o tema, Antonio Pessoa Cardoso (Desembargador do TJ/BA), assi-

\footnotetext{
${ }^{219}$ Como por exemplo, as alíneas “e”, “g”, “h”, “j” e “l”, do inciso I, do art. $1^{\text {․ }}$

${ }^{220} \mathrm{http}: / /$ www.amb.com.br/index_.asp?secao=artigo_detalhe\&art_id=133\& (em 07.8.2014)
} 
nala que o desrespeito à impessoalidade, em casos que tais, implica improbidade administrativa, nos termos do art. 8.429/92. Confira-se:

“(...).

As regras constitucionais, artigo 37, foram incorporadas implícita ou explicitamente às leis estaduais, leis orgânicas dos municípios, leis de organizações judiciárias dos tribunais, buscando diluir a projeção da imagem individualista do administrador que insiste em trilhar o caminho oblíquo do golpe e da fraude com o uso de recursos do erário público para sua satisfação pessoal.

A impessoalidade e a moralidade inserem-se na ordem difusa e seu desrespeito aponta ato de improbidade administrativa, atrelado à sobrevivência da democracia; legitima, portanto, a atuação do Ministério Público, que, em muitos estados tem tomado a iniciativa de notificar os infratores ou ingressar com ação civil pública para obrigar os agentes públicos a respeitarem a Constituição federal, Constituições estaduais e leis ordinárias; o procedimento cinge-se a estrito zelo à ordem jurídica, art. $5^{\circ}$, inciso I, da Lei Complementar n. 75/93, aplicada subsidiariamente às promotorias dos estados, na forma do art. 80, Lei n. 8.625/93 (Lei Orgânica do Ministério Público dos Estados).

O uso de nomes de pessoas vivas em prédios públicos é típico ato de improbidade, porque atentatório à administração pública e cercado de maior gravidade, porque propaganda ostensiva e permanente. O descaso constitui preocupação de toda a instituição pública, porque os atos administrativos daí emanados não são imputáveis ao funcionário, mas ao órgão público, em nome de quem age o executivo.

A infração é punida expressamente pela Lei 8.429/92 e consubstancia-se na suspensão dos direitos políticos e perda da função pública, além de indisponibilidade dos bens e ressarcimento ao erário, sem prejuízo da ação penal.

(...)".

O autor registra o esforço desenvolvido pelo Ministério Público para a reversão do quadro de desrespeito ao princípio da impessoalidade na vertente específica de proibição do uso de nome de pessoa viva em bens públicos:

“(..).

Em muitos estados, o Ministério Público tem sido atuante: no Maranhão, a 
Justiça Federal, em ação civil pública requerida pelo Ministério Público, determinou que fosse removido o letreiro com o nome do Senador José Sarney do Fórum do Tribunal Regional do Trabalho/MA. A decisão alcança outros prédios, inclusive fóruns, com nomes de pessoas vivas no Estado. Em Sergipe, o juiz da Comarca de Japaratuba julgou procedente Ação Civil Pública que questionava a colocação dos nomes de políticos em prédios públicos do distrito de Pirambu. Determinou-se a remoção das inscrições, porque em afronta aos princípios constitucionais.

O Promotor das cidades de Sorriso, de Nobres e outros municípios de Mato Grosso, notificaram os prefeitos locais para substituírem os nomes de pessoas vivas em prédios públicos.

Em Santa Catarina, o município de Indaial teve de retirar os nomes de pessoas vivas de prédios públicos, resultado de sentença em ação civil pública requerida pelo Ministério Público.

Na Bahia, a Resolução do Tribunal de Justiça de n. 08/2002 estabelece no artigo $1^{\circ}$ : 'Fica proibido, em todo o âmbito estadual, dar nome de pessoas vivas a bem público, de qualquer natureza, pertencente ao Poder Judiciário’. Eventuais denominações dadas anteriormente continuam violando a Lei 6.545/77 e a Constituição de 1988.

Através de ação civil pública, no ano passado, a Promotoria da comarca de Iguaí conseguiu fosse retirado de um prédio público o nome de pessoa viva. No Rio de Janeiro, a pedido do Sindicato dos Advogados, o Corregedor Geral da Justiça do Trabalho, Ministro Rider de Brito, impediu, em abril/ 2004, a colocação do nome do presidente do TRT/RJ na inauguração do prédio da Justiça Trabalhista. A placa com o nome do homenageado foi encoberta com tarja e posteriormente retirada.

A motivação do Corregedor para o ato moralizador deu-se nos seguintes termos:

'Considerando o estatuído nos preceitos legais/constitucionais supratranscritos (art. 37, da Constituição e Lei 6454/77), tem-se que a Resolução Administrativa nº 6/2004 do Órgão Especial do TRT da Primeira Região, que conferiu o nome do atual Presidente daquela Corte ao novo prédio das Varas do Trabalho do Rio de Janeiro, vulnera o princípio da moralidade administrativa e contraria de forma inequívoca a norma prevista no $\S 1^{\circ}$ do artigo 37 CF/88, por importar manifesta promoção pessoal de autoridade vinculada ao Poder Judiciário Trabalhista."”

Em boa síntese, o mesmo autor arremata: 
“(...).

A entrega ao povo de qualquer obra, originada de um dos três Poderes, não justifica a fraude; afinal, os governantes devem submeter-se às leis e não servir-se delas para realização de ambições pessoais. O servidor é elevado à função pública exatamente para construir estradas, prédios, escolas, fóruns, monumentos, etc; a execução dessas tarefas implica no simples cumprimento do dever, sem significar favor algum ao cidadão; a lei não autoriza, mas, pelo contrário, proíbe autopromoção à custa do dinheiro público.

Os nomes de magistrados, de políticos e de profissionais vivos nas obras públicas tornam as leis descartáveis, profanadas pelo "jeitinho” brasileiro que só acomoda a vaidade dos poderosos.”

Tem-se, ainda, a Resolução nº 140/2011, que proíbe a atribuição de nomes de pessoas vivas aos bens públicos sob a administração do Poder Judiciário, a ser objeto de análise no item 2.7.4 (infracitado).

\subsubsection{Ações de comunicação do Poder Executivo Federal}

O tema da impessoalidade também pode ser relacionado às ações de comunicação dos Governos, que aliás investem fortunas no setor e, a pretexto de (bem) informar os administrados, não raras vezes descambam para escancarada promoção pessoal de governantes e de partidos políticos, em frontal ofensa ao que se contém no art. 37, § 1º da CF/88.

Segundo o art. $2^{\circ}$-B, incisos I e IV, da Lei no 10.683/03 (Dispõe sobre a organização da Presidência da República e dos Ministérios e dá outras providências), com as alterações feitas pela Lei no 11.497/07, compete à Secretaria de Comunicação Social da Presidência da República assistir direta e imediatamente ao Presidente da República, dentre outros assuntos, (i) formulação e implementação da política de comunicação e divulgação social do Governo (inciso I); (ii) na implantação de programas informativos; (iii) na coordenação da comunicação interministerial e das ações de informação e difusão das políticas de governo; (iv) na coordenação, normatização, supervisão e controle da publicidade e de patrocínios dos órgãos e das entidades da administração pública federal, direta e indireta, e de sociedades sob controle da União.

Na esteira da lei, a Presidência da República baixou o Decreto nº 6.555/08, cujo art. $2^{\circ}$ determina que no desenvolvimento e na execução das ações de comunicação nele previs- 
tas serão observadas, dentre outras, as diretrizes da (i) afirmação dos valores e princípios da Constituição (inciso I); (ii) atenção ao caráter educativo, informativo e de orientação social (inciso II); (iii) vedação do uso de nomes, símbolos ou imagens que caracterizem promoção pessoal de autoridades ou servidores públicos (inciso VII).

O Decreto $n^{\circ}$ 6555/08 revogou inteiramente, de maneira expressa (art. 14), o Decreto $n^{\circ}$ 4.799/03, que já continha em seu art. $1^{\text {}}$, parágrafo único, a regra segundo a qual “é vedada a publicidade que, direta ou indiretamente, caracterize promoção pessoal de autoridade ou de servidor público", agora reforçada pelo que contém o inciso VII, do art. $2^{\circ}$, do Decreto $\mathrm{n}^{\circ}$ 6.555/08 acima aludido.

O regramento tem o condão de parametrizar as ações do governo em matéria de comunicação social e, ao mesmo tempo, fornece aos órgãos de controle critérios para julgamento, em termos de higidez jurídica, de sua particular atuação.

\subsection{Jurisprudência}

Apresentado um panorama legal, a partir do qual foi possível vislumbrar o incrível alcance da impessoalidade, conveniente fornecer, a partir de um apanhado jurisprudencial do Supremo Tribunal Federal - STF e do Superior Tribunal de Justiça - STJ, a visão dos tribunais. Mostram-se relevantes alguns traços da matéria levados a efeito no âmbito do Tribunal de Contas da União - TCU e no Conselho Nacional de Justiça - CNJ.

Advirta-se desde logo que, nos órgãos mencionados, há inúmeros julgados centrados no tema da impessoalidade. Na impossibilidade de se fazer referência a todos eles ou a um número demasiadamente amplo, o que escaparia aos fins desta tese, foram selecionados alguns, tidos como representativos dos vários aspectos e das várias facetas do policefático princípio (ou regra) da impessoalidade.

\subsubsection{Supremo Tribunal Federal}

Natural que o princípio da impessoalidade ocupe lugar de destaque na jurisprudência do Supremo Tribunal Federal. Afinal de contas, é o STF o órgão do Poder Judiciário responsável pela guarda da Constituição, no bojo da qual está inserido. É dizer: o STF goza da prerrogativa de dar a última palavra em termos de impessoalidade. 
Fernando Dias Menezes de Almeida"21, após afirmar que “mesmo as leis formais, sejam as veiculadoras de norma individual e concreta, sejam as veiculadoras de norma geral abstrata, devem respeitar o princípio da impessoalidade”, faz interessante apanhado sobre este aspecto do princípio na jurisprudência do STF. Revela que, sob a invocação do princípio em questão, há acórdãos proferidos nas seguintes ações:

a) $\mathrm{ADI} 3795^{222}$, na qual se julgou inconstitucional lei do Distrito Federal que vedava a realização de processo seletivo para a contratação de estagiários junto a certos órgãos distritais;

b) $\mathrm{ADI} 4259^{223}$, na qual se julgou inconstitucional lei da Paraíba que singularizava de tal modo os beneficiários de certo programa de incentivo fiscal que apenas uma pessoa beneficiar-se-ia de mais de 75\% dos valores incluídos no programa;

c) ADI $4125^{224}$, na qual se julgou inconstitucional lei do Tocantins que criara milhares de cargos em comissão, mediante vulneração do princípio da impessoalidade implícito no concurso público;

d) ADI 4178 REF-MC 225 , na qual se julgou inconstitucional lei de Goiás que dava valor excessivo, em termos de pontuação em concurso público para provimento de serviços notariais e registrais, à atuação anterior dos candidatos na atividade em questão.

Para esse mesmo autor, por vezes a impessoalidade é utilizada, na jurisprudência do Supremo, para balizar a interpretação de outros dispositivos constitucionais, como ocorre nos seguintes casos:

a) MS 28279226, no qual se sustentou a autoexecutoriedade do art. 236, § $3^{\circ}$, da Constituição Federal, que se refere a concurso público para provimento de serviços notariais e registrais;

b) $\mathrm{ADI} 3462^{227}$, na qual se destacou o sentido de impessoalidade contido no art.

\footnotetext{
${ }^{221}$ Princípio da impessoalidade. In: Princípios de Direito Administrativo: legalidade, segurança jurídica, impessoalidade, publicidade, motivação, eficiência, moralidade, razoabilidade, interesse público / Thiago Marrara, (organizador). São Paulo: Atlas, 2012, p. 109 a 118.

${ }^{222}$ Rel. Min. Ayres Britto, Pleno, v.u., j. 24.2.2011.

${ }^{223}$ Rel. Min. Ricardo Lewandowski, Pleno, v.u., j. 23.6.2010.

${ }^{224}$ Rel. Min. Carmén Lúcia, Pleno, v.u., j. 10.6.2010.

${ }^{225}$ Rel. Min. Cezar Peluso, Pleno, v.u., j. 4.2.2010.

${ }^{226}$ Rel. Min. Ellen Gracie, Pleno, v.u., j. 16.12.2010.

${ }^{227}$ Rel. Min. Cármen Lúcia, Pleno, v.u., j. 15.9.2010.
} 
150, § $6^{\circ}$, da Constituição Federal, que vincula à lei a concessão de benefícios tributários, coibindo assim o uso desses instrumentos como elemento de barganha por vantagens pessoais dos agentes da Administração.

Dora Maria de Oliveira Ramos ${ }^{228}$ preocupou-se em estudar a jurisprudência do Supremo Tribunal Federal acerca do princípio da impessoalidade. Além de alguns dos achados já referidos na sistematização levada a efeito por Fernando Dias Menezes de Almeida, a autora fez referência aos seguintes julgados:

a) $\mathrm{ADI} 3.853^{229}$, sobre a proibição de concessão de pensão vitalícia aos ex-ocupantes do cargo de Governador de Estado, assinalando, em resposta ao argumento de que por meio de lei poderia o Estado conceder o benefício que entendesse apropriado, que a destinação dos recursos públicos está condicionada à sua conformidade com os preceitos constitucionais;

b) $\mathrm{RE} 351142^{230}$, em que se teve como irregular a concessão de nova oportunidade para o candidato que se lesionou durante prova física integrante de concurso público ${ }^{231}$;

c) RE $191.668^{232}$, em que se teve como violado o princípio da impessoalidade na faceta referida no art. 37, § $1^{\circ}$, do CF/88, ou seja, promoção pessoal de administrador em meio à publicidade institucional;

d) $\mathrm{ADI} 3305^{233}$, em que ao apreciar a constitucionalidade de regra da lei eleitoral

${ }^{228}$ Notas sobre o princípio da impessoalidade e sua aplicação no direito brasileiro. In: Princípios de Direito Administrativo: legalidade, segurança jurídica, impessoalidade, publicidade, motivação, eficiência, moralidade, razoabilidade, interesse público / Thiago Marrara, (organizador). São Paulo: Atlas, 2012, p. 119 a 132 .

${ }^{229}$ Rel. Min. Cármen Lúcia que, em seu voto, afirmou que a condição pessoal do beneficiado não pode ser considerada para a concessão de benesses com o dinheiro público, assim, “a forma republicana de governo [...] não possibilita ao legislador personalizar o que não é condição personalista e, o que é mais, com recursos públicos”. E acrescentou: “O princípio constitucional da impessoalidade administrativa tem como objetivo a neutralidade da atividade pública, fixando como única diretriz jurídica válida para os comportamentos estatais o interesse público. A impessoalidade no trato da coisa pública garante exatamente esta qualidade da res gerida pelo Estado: a sua condição de ser pública, de todos, patrimônio de todos, voltada à concretização do bem de todos e não de grupos ou de algumas pessoas [...] traduz-se (o princípio da impessoalidade) na ausência de marcas pessoais e particulares correspondentes ao administrador que, em determinado momento, esteja no exercício da atividade administrativa, tornando-a, assim, afeiçoada a seu modelo, pensamento ou vontade”. ${ }^{230}$ Rel. Min. Ellen Gracie, 2a Turma, DJ 1º.7.2005.

${ }^{231}$ Ao julgar o RE 630.733, Rel. Min. Gilmar Mendes, j. 15.5.2013, o Plenário do STF reafirmou o entendimento de que, à luz dos postulados da impessoalidade e da supremacia do interesse público, inexiste direito constitucional à remarcação de provas em razão de circunstâncias pessoais dos candidatos. No caso, em nome da segurança jurídica, o STF firmou, ainda, a compreensão de que são válidas as provas de segunda chamadas realizadas até a data da conclusão do julgamento, isto é, 15.5.2013.

${ }^{232}$ Rel. Min. Menezes Direito, $1^{\text {a }}$ Turma, DJ 30.5.2008.

${ }^{233}$ Rel. Min. Eros Grau, Pleno, DJ 24.11.2006. 
que veda a participação de candidatos a cargos do Poder Executivo em inaugurações de obras públicas nos três meses que precedem a eleição, o Min. Ayres Britto apontou como fundamento para a constitucionalidade da norma a observância do princípio da impessoalidade, importando para marcar " a distinção nítida entre o espaço público e o espaço privado, ou seja, não há confundir a administração com o administrador”;

e) $\mathrm{ADI} 2472^{234}$, ao cuidar da publicidade dos atos de governo, o Min. Ayres Britto, em seu voto, assinalou que o princípio em questão implica “vedação de vedetismo, de estrelismo, para que às custas do erário, a autoridade não faça autopromoção ou marketing pessoal”235.

Para a autora, além dos acórdãos acima referidos, nos quais a impessoalidade se aproxima da noção de igualdade ou de proibição de promoção pessoal, podem ser referidos outros julgados nos quais o STF se refere à impessoalidade como preservação da imparcialidade do juiz. Ei-los:

a) HC $95009^{236}$, no qual se decidiu que a imparcialidade do juiz, como representação da impessoalidade, é necessária para que o magistrado fique livre de “influências provenientes das partes nos processos judiciais a ele submetidos”, de forma a julgar “com ausência absoluta de prevenção a favor ou contra alguma das partes”;

b) MS $21814^{237}$, no qual se decidiu ser nula a nomeação de Juiz para integrar Tribunal se irregular a sua inserção em lista tríplice, de cuja votação participou pai de candidato que deveria ter se dado por impedido, porque, segundo o voto do Min. Neri da Silveira, ao contrário do princípio da moralidade, o princípio da impessoalidade é de "objetiva noção, pois independe de critérios temporais ou espaciais e, ao contrário, [está] jungido, unicamente, à ocorrência de pressupostos situados no mundo dos fatos”.

Além dos julgados acima referidos nos trabalhos de Fernando Menezes Dias de Almeida e de Dora Maria de Oliveira Ramos, podem ser apontados outros:

\footnotetext{
${ }^{234}$ Rel. Min. Maurício Corrêa, Red. p/ o acórdão Min. Marco Aurélio, Pleno, DJ 9.3.2007.

${ }^{235} \mathrm{Na}$ mesma linha de raciocínio, confira-se o AG. REG. NO RE 631.448, Rel. Min. Roberto Barroso, $1^{\mathrm{a}}$ Turma, j. 24.6.2014, em que o STF assentou, com base em precedente, que veiculação de propagandas institucionais que ultrapassam limites informativos, servindo de promoção pessoal de governo atual, colidem com o princípio da impessoalidade.

${ }^{236}$ Rel. Min. Eros Grau, Pleno, DJ 19.12.2008.

${ }^{237}$ Rel. Min. Neri da Silveira, Pleno, DJ 10.6.1994.
} 
a) RE 598099 238 , sobre o direito à nomeação dos candidatos aprovados em concursos públicos, em que o STF assentou que dentro do prazo de validade do concurso, a Administração poderá escolher o momento em que se realizará a nomeação, mas não poderá dispor sobre a própria nomeação ${ }^{239}$;

b) SEGUNDO AG. REG. NO RE 503436²40, em que se teve como válida lei de criação de Tribunal Regional do Trabalho no sentido de que funções gratificadas, diferentemente de cargos em comissão, não podem ser ocupadas por pessoas estranhas ao quadro permanente de servidores ${ }^{241}$;

c) $\mathrm{ADI} 3745^{242}$, em que a Corte teve como inconstitucional, por ofensa ao princípio da impessoalidade, lei do Estado de Goiás que criou exceções ao óbice da prática do nepotismo;

d) ADI $1.521^{243}$, em que a Corte entendeu que a proibição da prática de nepotismo atinge, indistintamente, a nomeação para cargos em comissão de cônjuges ou companheiros e parentes consanguíneos, afins ou por adoção, até o segundo grau;

e) ROMS 26029244, em que a Corte teve como irregular uma mesma pessoa, embora ocupando cargos distintos, julgar validamente o pedido de reconsideração e o recurso administrativo interposto em autos de processo administrativo relativo a revogação de permissão para execução de serviço especial de retransmissão simultânea de televisão ${ }^{245}$;

\footnotetext{
${ }^{238}$ Rel. Min. Gilmar Mendes, Pleno, DJe 03.10.2011.

${ }^{239}$ Com base no voto do Min. Gilmar Mendes, assentou o STF que "o princípio constitucional do concurso público é fortalecido quando o Poder Público assegura a observa as garantias fundamentais que viabilizam a efetividade desse princípio. Ao lado das garantias da publicidade, isonomia, transparência, impessoalidade entre outras, o direito à nomeação representa também uma garantia fundamental da plena efetividade do princípio do concurso público".

${ }^{240}$ Rel. Min. Luiz Fux, $1^{\text {a }}$ Turma, j. 16.4.2013.

${ }^{241}$ Seguindo o voto do Min. Luiz Fux, a $1^{\text {a }}$ Turma do STF sufragou o entendimento de que "funções públicas ou de confiança são plexos unitários de atribuições, criados por lei, correspondentes a encargos de direção, chefia ou assessoramento, a serem exercidas por titular de cargo efetivo, da confiança da autoridade que as preenche", sendo certo que "ditas limitações ao preenchimento de cargos e funções na Administração visam conferir efetividade aos princípios constitucionais da moralidade, da impessoalidade e da eficiência administrativa".

${ }^{242}$ Rel. Min. Dias Toffoli, Pleno, j. 15.5.2013. No caso, entendeu o STF, com esteio no voto do Min. Dias Toffoli, que "a previsão impugnada, ao permitir (excepcionar), relativamente a cargos em comissão ou funções gratificadas, a nomeação, a admissão ou a permanência de até dois parentes das autoridades mencionadas no caput do art. $1^{\circ}$ da Lei estadual no 13.145/1997 e do cônjuge do Chefe do Poder Executivo, além de subverter o intuito moralizador inicial da norma, ofende irremediavelmente a Constituição Federal".

${ }^{243}$ Rel. Min. Ricardo Lewandowski, Pleno, j. 19.6.2013.

${ }^{244}$ Rel. Min. Cármen Lúcia, 2a Turma, j. 11.3.2014.

${ }^{245}$ Em seu voto, a Min. Cármen Lúcia assentou que: "De nada adiantaria ter o legislador assegurado o direito de reexame e o acesso a até três instâncias administrativas se essas garantias pudessem ser desvirtuadas pela
} 
f) MS 32176 ${ }^{246}$, em que a Corte entendeu que "a divulgação de resultado para fins de convocação para a fase subsequente do concurso deve diferenciar e classificar os candidatos apenas quanto ao desempenho no certame segundo os critérios de avaliação divulgados no edital, ressalvada a divulgação sub judice no resultado final, quando encerrado o processo avaliativo" ${ }^{247}$;

g) SEGUNDO AG. REG. NO RE 773.774248, em que o STF fixou o entendimento de que a despedida de empregado de conselho profissional admitido por concurso público deverá ser motivada para assegurar “que os princípios da impessoalidade e da isonomia, observados no momento da admissão, sejam também respeitados por ocasião da dispensa”249.

Especificamente sobre o instituto do concurso público, em sua correlação com o princípio da impessoalidade, são dignos de nota recentes julgados do STF que reconhecem a inconstitucionalidade do (i) preenchimento de cargos públicos mediante concurso interno ${ }^{250}$ e (ii) a imposição de discrímen de gênero injustificados para fins de participação em concurso público ${ }^{251}$.

realização de dois julgamentos pela mesma pessoa física, ainda que ocupando cargos diversos. É que, nesse caso, haveria afronta ao princípio da impessoalidade, previsto expressamente no caput do art. 37 da Constituição da República, pois o julgador careceria da isenção necessária para a tomada de decisão".

${ }^{246}$ Rel. Min. Dias Toffoli, $1^{\mathrm{a}}$ Turma, j. 18.3.2014.

${ }^{247}$ Neste caso, entendeu o STF que ainda que não se deva presumir a existência de má-fé ou de irregularidades, nem mesmo a interferência da condição "sub judice" nas avaliações realizadas pela Comissão de Concurso nas fases subsequentes do certame, "a divulgação dos resultados para convocação de candidatos para a fase subsequente com a inserção de expressão, símbolo ou termo" que os identifique impetrantes de mandado de segurança "não se coaduna com os princípios constitucionais da isonomia e da impessoalidade". De acordo com o voto proferido pelo Min. Dias Toffoli, os candidatos devem ser diferenciados e classificados a partir dos "critérios de avaliação" divulgados no edital e não com base em resultado de mandado de segurança, critério esse não relacionado com a aptidão técnica e os conhecimento apresentados. Em todo caso, ficou ressalvada a inserção da expressão "sub judice" na divulgação do resultado final, quando encerrado o processo avaliativo. ${ }^{248}$ Rel. Min. Ricardo Lewandowski, $2^{\mathrm{a}}$ Turma, j. 5.8.2014.

${ }^{249}$ Alguns pormenores do rico tema da necessidade de fundamentação do ato de dispensa de empregados de conselhos profissionais serão abordados no item 3.5.4 infra, com base no leading case do STF sobre a matéria, a saber, o RE 589.998/PI, Pleno, Rel. Min. Ricardo Lewandowski, j. 20.3.2013.

${ }^{250}$ Essa espécie de "promoção interna" viola o princípio da ampla acessibilidade aos cargos públicos e, consequentemente, consiste em afronta ao princípio da impessoalidade. STF. Plenário. ADI917/MG, rel. orig. Min. Marco Aurélio, red. Para o acórdão Min. Teori Zavascki, julgado em 6/11/2013.

${ }^{251}$ Para o STF, a discriminação por gênero somente é compatível com a Constituição nos excepcionais casos em que demonstradas a fundamentação proporcional e a legalidade da imposição, sob pena de ofensa ao princípio da isonomia, e, consequentemente, da impessoalidade. STF. $2^{a}$ Turma. RE 528684/MS. Rel. Min. Gilmar Mendes, julgado em 3/9/2013. 


\subsubsection{Superior Tribunal de Justiça}

O Superior Tribunal de Justiça também se ocupa com muita frequência do tema da impessoalidade.

Mesmo não detendo a competência constitucionalmente assegurada para conhecer e julgar recursos extraordinários em sentido estrito (art. 102, inciso III, da CF/88), por violação direta ao texto constitucional, que é do Supremo Tribunal Federal, o Superior Tribunal de Justiça interpreta a impessoalidade tanto no contexto da exegese da legislação infraconstitucional quanto no âmbito de outros processos tendentes à veiculação de matéria constitucional, a exemplo do mandado de segurança.

Confiram-se alguns balizamentos hermenêuticos do princípio da impessoalidade na jurisprudência do STJ:

a) A revogação de outorga de permissão de execução de serviço de radiodifusão sonora, sem motivação, ato ou processo administrativo que decline as razões pelas quais não se pode prosseguir na execução do serviço fere o princípio da impessoalidade (Mandado de Segurança nº 16.616/DF, Rel. Min. Arnaldo Esteves Lima);

b) A Comissão de Concurso, posteriormente à publicação do edital, não pode alterar os critérios de definição da pontuação de títulos, principalmente após a apresentação dos mesmos (Recurso em Mandado de Segurança nº 40.956/MG, Rel. Min. Mauro Campbell Marques);

c) Diante de investidura precária, tabelião que se investiu no cargo por delegação do poder público não tem direito à exclusão da serventia do rol das vagas dispostas no edital de concurso público (Agravo Regimental em Mandado de Segurança $\mathrm{n}^{\circ}$ 39.822/SC, Rel. Min. Herman Benjamin);

d) Caracteriza ato de improbidade administrativa a promoção pessoal em propaganda institucional, sendo necessária a presença de dolo ao menos genérico e dispensável a demonstração da ocorrência de dano para a Administração Pública ou enriquecimento ilícito do agente, nos termos do art. 11, da Lei n ${ }^{\circ} 8.429$ / 92 (Agravo Regimental no Recurso Especial n ${ }^{\circ}$ 1.368.125/PR, Rel. Min. Humberto Martins);

e) Padece de nulidade insuscetível de convalidação o ato de remoção ex officio de servidora aprovada e nomeada em concurso público para localidade específica, 
sem a devida motivação (Recurso em Mandado de Segurança nº 29.206/MG, Rel. Min. Campos Marques - Desembargador Convocado do TJ/PR);

f) Em tema de licitação, o princípio da impessoalidade obsta que critérios subjetivos ou anti-isonômicos influam na escolha dos candidatos exercentes da prestação de serviços públicos (Recurso Especial nº 1.384.138/RJ, Rel. Min. Humberto Martins);

g) Não havendo previsão editalícia para a realização de novo teste de aptidão física, no caso de incapacidade temporária, fica obstada a pretensão de realização de segundo exame (Agravo Regimental em Mandado de Segurança $n^{\circ}$ 28.375/MS, Rel. Min. Rogério Schietti Cruz);

h) Em matéria de concurso público, o sigilo e a subjetividade do exame psicológico tornam-no nulo (Agravo Regimental em Mandado de Segurança nº 29.645/AC, Rel. Min. Rogério Schietti Cruz);

i) Ilegítimo o pedido de submissão a nova prova oral em concurso público porque isso equivaleria a conferir privilégio a candidato reprovado, em detrimento de outros com notas individuais até melhores, mas que também não lograram êxito (Recurso em Mandado de Segurança n ${ }^{\circ}$ 41.785/RS, Rel. Min. Humberto Martins);

j) A alegação de suspeição requer comprovação prévia e evidente de vínculos pessoais (Recurso em Mandado de Segurança n 43.800/ES, Rel. Min. Humberto Martins);

k) Se não há lei ou regulamento impondo que, na licitação na modalidade convite, deva ser enviada Carta-Convite às pessoas que participaram de procedimento anterior (Tomada de Preços), com objeto semelhante, não há falar em ofensa ao princípio da impessoalidade (Agravo Regimental no Recurso Especial $n^{\circ}$ 1.306.817/AC, Rel. Min. Napoleão Nunes Maia Filho).

Sobre a questão do nepotismo, interessante a tese fixada no Agravo Regimental em Mandado de Segurança $n^{\circ}$ 44.242/MA, Rel. Min. Mauro Campbell Marques, em que a Segunda Turma do STJ, na esteira da Resolução/CNJ nº 07 e da Súmula Vinculante ${ }^{0}$ 13, do STF, asseverou que:

\footnotetext{
“a vedação ao nepotismo decorre da interpretação dos princípios constitucionais da moralidade, impessoalidade, isonomia e eficiência, norteadores da
} 
temática dos provimentos dos cargos públicos, não requerendo regra explícita de qualquer esfera federativa (cf. REsp 1200125/RS, Rel. Ministro HERMAN BENJAMIN, SEGUNDA TURMA, DJe 15/06/2012; ADI 3745, Rel. Min. DIAS TOFFOLI, Tribunal Pleno, DJe 01/08/2013), o que desaconselha, por si só, a criação de outras formas de se permitir (excepcionar) a nomeação para cargo comissionado de pessoa com relação próxima de consanguinidade com magistrado já investido, sob pena de subverter o intuito moralizador das normas aplicáveis, em ofensa irremediável à Constituição Federal”.

Já no Mandado de Segurança $n^{0}$ 16.179/DF, da relatoria do Min. Ari Pargendler, a Primeira Seção do STJ, propugnando total transparência da Administração Pública quanto à concessão de passaportes diplomáticos, entendeu que o nome de quem recebe um passaporte diplomático emitido por interesse público não pode ficar escondido do público.

Ao julgar o Recurso Especial n ${ }^{0}$ 1.286.466/RS, da relatoria da Min. Eliana Calmon, a Segunda Turma do STJ entendeu que a prática de assédio moral - “mais do que provocações no local do trabalho (sarcasmo, crítica, zombaria e trote), é campanha de terror psicológico pela rejeição” - enquadra-se na conduta prevista no art. 11, caput, da Lei $\mathrm{n}^{\circ}$ 8.429/92, “em razão do evidente abuso de poder, desvio de finalidade e malferimento à impessoalidade, ao agir deliberadamente em prejuízo de alguém”. Segundo o acórdão, a partir do enquadramento de assédio moral como ofensa à impessoalidade, objetiva-se “coibir, punir e/ou afastar da atividade pública os agentes que demonstrem caráter incompatível com a natureza da atividade desenvolvida”252.

Ao julgar o Recurso Especial n 1.114.254/MG, da relatoria do Min. Sérgio Kukina, a Primeira Turma do STJ entendeu que desde que caracterizado o dolo, “no mínimo genérico”, na irregular veiculação de propaganda institucional em que atreladas as realizações do Município ao seu então Prefeito, é de ser considerado ofendido o princípio da impessoalidade, com configuração de ato doloso de improbidade administrativa, nos termos do art. 11 da Lei $n^{0} 8.429 / 92$.

Já está enfocada na jurisprudência do Superior Tribunal de Justiça a distinção entre interesse público primário e secundário. A Corte faz uso da diferenciação para justificar,

\footnotetext{
${ }^{252}$ Segundo o voto da Ministra Eliana Calmon, o então Prefeito de Canguçu/RS, motivado por sentimento de vingança, em razão de denúncia feita por servidora pública municipal ao Ministério Público, acerca da existência de dívida municipal, teria imposto a ela "castigo" consubstanciado no afastamento de suas funções e na obrigatoriedade de permanecer por três dias na sala de reuniões.
} 
por exemplo, a atuação do Ministério Público como custus legis, cabível apenas em face do primeiro.

\subsubsection{Tribunal de Contas da União}

No âmbito do Tribunal de Contas da União, também há farta jurisprudência sobre a impessoalidade administrativa, em seus múltiplos aspectos.

Afinal de contas, tendo o TCU atribuições constitucionais amplas, naturalmente tem oportunidade de colaborar na construção jurisprudencial do Direito Administrativo.

Para se ter uma ideia, podem ser localizados e referidos, a partir de sua jurisprudência, em torno do tema da impessoalidade, dentre outras, as seguintes matérias:

a) Nepotismo e "transnepotismo” (troca de favores entre dirigentes de órgãos públicos, de poderes e/ou esferas distintos);

b) Admissão de pessoal sem concurso público em conselho de fiscalização profissional;

c) Irregularidades em cessão de terreno de propriedade da União;

d) Provimento de cargo de professor sem concurso público;

e) Contratação de empresa cujo sócio-gerente é dirigente da entidade contratante (relacionamento entre gestor e empresa contratada);

f) Inexigibilidade (indevida) de licitação na terceirização de serviços administrativos ligados à atividade fim;

g) Inexigibilidade (indevida) de licitação na contratação de fundação de apoio por instituição federal de ensino superior;

h) Processo seletivo para contratação de pessoal do sistema "s";

i) Contratação, sem concurso público, de pessoas ligadas a funcionários e a dirigentes de conselho de fiscalização profissional;

j) Restrições ao caráter competitivo de licitações;

k) Direcionamento de licitações;

l) Conluio entre licitantes;

m) Despesas irregulares com diárias e passagens;

n) Aquisição direta de gêneros alimentícios junto a empresa pertencente a dirigente de entidade do sistema "s"; 
o) Aquisições e contratações à custa de recursos federais por organizações não governamentais (ONGs) e organizações de sociedade civil de interesse público (OSCIPs);

p) Requisição de servidores;

q) Confusão entre OSCIP e dirigentes de empresas que executavam serviços para a entidade, à conta de serviços públicos;

r) Celebração e pagamento de acordos extrajudiciais;

s) Não emissão e preterição de pagamentos de precatórios;

t) Inaplicabilidade da Lei ${ }^{\circ}$ 8.666/93 às OSCIPs;

u) Celebração de acordos coletivos de trabalho incluindo a concessão de vantagens excessivamente onerosas para os cofres da entidade (conselho de fiscalização profissional) além de não condizentes com a realidade de mercado e com a finalidade da lei;

v) Existência de grau de parentesco entre membro da Comissão Permanente de Licitação e proprietário de firma participante de certames;

w) Descumprimento de prazo de permanência de servidores requisitados.

As matérias acima reveladas, colhidas (propositalmente) a esmo da jurisprudência do TCU, para a confecção de um rol exemplificativo, podem ser assim condensadas: i) Nepotismo; ii) Indevidas dispensa ou inexigibilidade de licitação; iii) Fracionamento indevido de despesas para fugir do processo licitatório; iv) Repasses de verbas a empresas de parentes sem quaisquer critérios objetivos; iv) Uso de bens públicos para satisfazer interesses particulares; v) Submissão de entidades paraestatais (principalmente Sistema “S”) aos princípios regentes da Administração Pública; vi) contratação sem concurso público; vii) conflitos de interesse em concursos públicos.

Ao julgar caso em que foi contratada empresa terceirizada de parentes de funcionários da empresa pública contratante (INFRAERO), a Primeira Turma do TCU, no Acórdão nº 1.680/2005, teve oportunidade de assentar que, verbis:

"De fato, as normas relativas à terceirização de serviços pela Administração Pública não preveem proibição de as empresas terceirizadas contratarem parentes de funcionários do órgão licitante. Porém, a intervenção direta perante a contratada com o intuito de direcionar suas contratações de pessoal é claramente irregular, por afrontar princípios da boa administração, sobretudo os da impessoalidade e da moralidade. 
A identificação dessas falhas é de extrema dificuldade, pois a existência de parentes desempenhando serviços terceirizados apenas indica a possibilidade da ilegalidade. Nesse contexto, uma determinação com conteúdo impeditivo mostra-se a melhor solução para evitar que funcionários da administração, com poder de influência, beneficiem parentes nos contratos de terceirização de serviços, em consonância com o supratranscrito Acórdão 926/2003 - Plenário.”

Mostra-se assaz interessante a decisão prolatada pela Primeira Câmara do TCU no Acórdão no 3139/05, em caso que envolvia nepotismo no Tribunal Regional Eleitoral de Sergipe - TRE/SE, no sentido de que “... de fato, a questão abordada nos autos, pertinente à possibilidade de nomeação, no âmbito da jurisdição dos tribunais ou juízos, de servidores ocupantes de cargo em comissão/função comissionada que detenham vínculo de parentesco até o terceiro grau, inclusive, ou que sejam cônjuges ou companheiros, dos respectivos membros ou juízes vinculados, já foi exaustivamente debatida no âmbito desta Corte, cujo entendimento é no sentido de considerar tal prática condenável, por configurar ofensa aos princípios que regem a Administração Pública, sobretudo os da moralidade, impessoalidade e finalidade administrativa".

Também merece destaque o Acórdão nº 562/2009 (Primeira Câmara), oriundo do Município de Passo de Camaragibe/AL, em que o TCU teve como irregulares aquisições, sem licitação, efetuadas em postos de gasolina pertencentes a parentes da Prefeita e do Secretário de Finanças do Município.

Já no Acórdão nº 5290/2008 (Segunda Câmara), em caso oriundo de Paranatinga/MT, o TCU assentou que a colocação, em locais de obras custeadas com recursos federais, de placa de agradecimento a autoridades políticas, configura promoção pessoal de tais autoridades, em contrariedade aos princípios constitucionais da impessoalidade e da moralidade e ao disposto no art. $2^{\circ}$ da Lei 6.454/77 e no art. 37, § $1^{\circ}$, da Constituição da República.

Digna de nota a referência ao Acórdão nº 2485/2008, em que o Plenário do TCU teve como ilegal concurso público promovido pelo Tribunal Regional do Trabalho da $1^{\text {a }}$ Região porque a organização do certame foi realizada por servidor público que também era candidato a uma das vagas em disputa. Afirmou que “em observância aos princípios da moralidade, da impessoalidade e da transparência, deve o órgão jurisdicionado adotar providências pertinentes, no sentido de coibir que servidor, ocupante de cargo efetivo ou comissionado ou ainda de função de confiança, acumule atribuições relacionadas à condução de concurso 
público para provimento de cargos com a sua própria participação no certame como candidato a uma das vagas oferecidas”.

O TCU, em tema de licitações e contratos, vislumbrados pelo ângulo da impessoalidade

administrativa, em sua instrumentalização recíproca com a legalidade, a publicidade e a isonomia, tem ricas orientações ${ }^{253}$.

${ }^{253}$ De que são exemplos: a) O princípio que refuta a restrição ao caráter competitivo não é absoluto, representando essencialmente a expressão sintetizada de uma orientação vista em caráter de generalidade, a admitir, por óbvio, excepcionalidades que sejam conduzidas por circunstâncias ensejadoras de determinada feição fora do comum. Não se admite a discriminação arbitrária na seleção do contratante, sendo insuprimível o tratamento uniforme para situações uniformes, tendo em vista que, nos termos do art. $3^{\circ}$, caput, da Lei no 8.666/1993, a licitação destina-se a garantir não só a seleção da proposta mais vantajosa para a Administração, e também a observância do princípio constitucional da isonomia. Acórdão 1631/2007 Plenário (Sumário); b) A restrição à competitividade, causada pela ausência de informações essenciais no instrumento convocatório, é causa que enseja a nulidade da licitação. Acórdão 1556/2007 Plenário (Sumário); c) É inconstitucional e ilegal o estabelecimento de exigências que restrinjam o caráter competitivo dos certames. Acórdão 539/2007 Plenário (Sumário); d) Devem ser evitadas exigências que comprometam o caráter competitivo da licitação. A licitação deve ser processada e julgada em estrita conformidade com os princípios básicos. Acórdão 112/2007 Plenário (Sumário); e) As exigências editalícias devem limitar-se ao mínimo necessário para o cumprimento do objeto licitado, de modo a evitar a restrição ao caráter competitivo do certame. Acórdão 110/2007 Plenário (Sumário); f) Inclua, quando contratar manutenção de sistemas, descrição sumária de suas funcionalidades, estimativa de tamanho e complexidade de suas operações, em atenção ao princípio da isonomia, referido no art. 3 da Lei n 8.666/1993. Acórdão 2220/2008 Plenário; g) Observe as disposições contidas no parágrafo único do art. $4^{\circ}$ do Decreto n ${ }^{\circ} 3.555 / 2000$, especialmente no que tange à interpretação das normas disciplinadoras da licitação em favor da ampliação da disputa entre os interessados, desde que não comprometam o interesse da Administração e os princípios que regem o processo licitatório. Acórdão 1046/2008 Plenário; h) Abstenha-se de aceitar propostas de bens com características diferentes das especificadas em edital, em respeito ao princípio de vinculação ao instrumento convocatório, consoante o art. $3^{\circ}$ da Lei no 8.666/1993. Acórdão 932/2008 Plenário; i) A Lei n ${ }^{\circ} 8.666 / 1993$ estabelece, no seu art. $3^{\circ}$, os princípios que devem nortear os procedimentos licitatórios, dentre eles o da publicidade e o da isonomia. O princípio da publicidade consagra o "dever administrativo de manter plena transparência em seus comportamentos”. O TCU, ao analisar esse princípio, assim o explicou: "Qualquer interessado deve ter acesso às licitações e seu controle, mediante divulgação dos atos praticados pelos administradores em todas as fases da licitação". Acórdão 204/2008 Plenário (Relatório do Ministro Relator); j) Zele para que não sejam adotados procedimentos que contrariem, direta ou indiretamente, o princípio básico da vinculação ao instrumento convocatório, de acordo com os arts. $3^{\circ}$ e 41 da Lei no 8.666/1993. Acórdão 2387/2007 Plenário; k) Observe os princípios da transparência, do julgamento objetivo, da vinculação ao instrumento convocatório e da escolha da proposta mais vantajosa para a Administração, conforme regem os arts. $3^{\circ}$, art. 40, VII, art. 41, caput, 43, IV, art. 44, § $1^{\circ}$ e art. 45, da Lei no 8.666/1993. Acórdão 1286/2007 Plenário; l) Observe, especialmente em relação à interpretação em favor da ampliação da disputa entre os interessados, desde que não comprometam o interesse da Administração e os princípios que regem o processo licitatório, as regras estabelecidas no parágrafo único do art. $7^{\circ}$ do Decreto $n^{\circ} 3.555 / 2000$, e no art. $5^{\circ}$, caput e parágrafo único, do Decreto $n^{\circ}$ 5.450/2005. Acórdão 536/2007 Plenário; m) Atente para o princípio da vinculação ao instrumento convocatório, bem assim abstenha-se de efetuar exigências que comprometam o caráter competitivo do certame, em desacordo com o art. $3^{\circ}$, caput e $\S 1^{\circ}$, inciso I, da Lei $n^{\circ}$ 8.666/1993. Acórdão 112/2007 Plenário; n) Ao examinar o assunto no primeiro momento (...), compreendi como adequadas as proposições então formuladas (...), uma vez que as irregularidades noticiadas nos autos configuram risco de inobservância, no processo licitatório, dos princípios da competição e da isonomia, além da possibilidade de frustração da escolha da proposta mais vantajosa, entendendo oportuna, desse modo, a manifestação do gestor. Acórdão 1162/2006 Plenário (Voto do Ministro Relator); o) Observe rigorosamente as disposições contidas no art. 37, caput, da Constituição Federal de 1988 c/c o art. $3^{\circ}$ da Lei no 8.666/1993, obedecendo aos princípios constitucionais da publicidade, da igualdade, da isonomia e da impessoalidade, de modo a impedir restrições à competitividade. Acórdão 819/2005 Plenário; p) A violação de princípios básicos da razoabilidade, da economicidade, da legalidade e da moralidade administrativa, e a desobediência às diretrizes fundamentais da 
Há também vasta construção jurisprudencial no TCU acerca da delicada questão da impessoalidade no Terceiro Setor.

A Primeira Câmara do TCU, no Acórdão n 3434/2012 (Processo nº 018.016/2006-0), em caso relativo a Serviço de Apoio às Micro e Pequenas Empresas de Mato Grosso do Sul SEBRAE/MS, detectou irregularidades na celebração de avenças com diversas entidades, notadamente com a Fundação de Apoio da Universidade Federal de Mato Grosso do Sul UFMS, com destaque para a "relação existente entre suas cúpulas diretivas”. Aludiu à falta de pertinência entre os objetos e as finalidades institucionais do SEBRAE, com violação aos princípios da Impessoalidade e da Moralidade.

Já no Acórdão nº 2.575/2012 (Processo nº 027.265/2006-4), o Plenário do TCU, em feito que envolveu o Fundo Nacional de Desenvolvimento da Educação - FNDE/MEC, a Petróleo Brasileiro S/A - Petrobras e a Secretaria de Educação Continuada, Alfabetização e Diversidade/MEC, encontrou indícios de irregularidades, diante da falta de critérios claros e objetivos, em repasses de recursos efetivados pela Petrobras, sob a forma de patrocínios, convênios e outros meios assemelhados, para ações de caráter social.

Ao julgar o Processo n ${ }^{\circ}$ 025.031/2008-2, oriundo de Tomada de Contas Especial, o Plenário do TCU, em mais um caso que envolveu o SEBRAE/MS, teve oportunidade de fixar o entendimento de que fere a impessoalidade a circunstância de uma mesma pessoa sustentar, em dada relação jurídica, interesses contrapostos de mais de uma entidade.

É também do Plenário do TCU (Processo nº 026.269/2007-7 - Acórdão nº 2922/2013), em caso que envolveu a Prefeitura Municipal de Betim/MG, a compreensão de que convênios celebrados entre municipalidades e organizações não governamentais, relativos a recursos do Fundo Nacional de Assistência Social - FNAS, devem zelar pelo cumprimento dos desígnios constitucionais.

Finalmente, merece destaque julgado do Plenário do TCU (Processo nº 007.670/20125 - Acórdão nº 696/2014), oriundo de Tomada de Contas Especial, no interesse do Município de Pinhais/PR, em que a Corte de Contas detectou irregularidades na aplicação de recursos repassados a organizações da sociedade civil de interesse público - OSCIPs, na condição de meras intermediárias de mão de obra, com burla ao concurso público.

licitação pública, no caso, a isonomia entre licitantes, o julgamento objetivo, a vinculação ao instrumento convocatório, bem como o caráter competitivo do certame constituem vícios insanáveis que ensejam a fixação de prazo para exato cumprimento da lei, no sentido de declarar a nulidade do certame. Acórdão 6198/2009 Primeira Câmara (Sumário); q) Observe o princípio da vinculação ao instrumento convocatório, de acordo com as disposições exaradas especialmente no art. $3^{\circ}$ da Lei 8.666/1993. Acórdão 330/2010 Segunda Câmara. 


\subsubsection{Conselho Nacional de Justiça}

Criado pela Emenda Constitucional n 45/04 (Reforma do Judiciário), o Conselho Nacional de Justiça - CNJ, órgão do Poder Judiciário (art. 92, inciso I-A, da CF/88), foi considerado constitucional pelo Supremo Tribunal Federal na ADI 3.367, como órgão interno de controle administrativo, financeiro e disciplinar da magistratura nacional.

De acordo com o art. 103-B, $\S 4^{\circ}$, da CF/88, compete ao CNJ o controle da atuação administrativa e financeira do Poder Judiciário e do cumprimento dos deveres funcionais dos juízes, cabendo-lhe, dentre outras, as atribuições de "zelar pela observância do art. 37 e apreciar, de ofício ou mediante provocação, a legalidade dos atos administrativos praticados por membros ou órgãos do Poder Judiciário, podendo desconstituí-los, revê-los ou fixar prazo para que se adotem as providências necessárias ao exato cumprimento da lei, sem prejuízo da competência do Tribunal de Contas da União” (inciso II).

Desde a sua criação, o CNJ se destaca no exercício de poder normativo, editando resoluções muitas das quais polêmicas. No exercício do poder de editar resoluções, o CNJ tem construído uma sólida doutrina sobre impessoalidade.

Uma de suas maiores conquistas diz respeito a uma pioneira sistematização do combate ao nepotismo, no Poder Judiciário, com reflexos posteriores na jurisprudência do Supremo Tribunal Federal e, a partir daí, na legislação federal e de diversos Estados e Municípios.

Do portal do CNJ na internet ${ }^{254}$ recolhe-se o seguinte conceito de nepotismo:

\footnotetext{
Nepotismo é o favorecimento dos vínculos de parentesco nas relações de trabalho ou emprego. As práticas de nepotismo substituem a avaliação de mérito para o exercício da função pública pela valorização de laços de parentesco. Nepotismo é prática que viola as garantias constitucionais de impessoalidade administrativa, na medida em que estabelece privilégios em função de relações de parentesco e desconsidera a capacidade técnica para o exercício do cargo público. O fundamento das ações de combate ao nepotismo é o fortalecimento da República e a resistência a ações de concentração de poder que privatizam o espaço público.
}

No portal do CNJ é possível colher um resumo da (rica) marcha que redundou na fixação do entendimento atual sobre os contornos da configuração do nepotismo:

"Em 18 de outubro de 2005, o Conselho Nacional de Justiça editou a Resolução $n^{\circ}$ 07, banindo definitivamente as práticas de nepotismo do Poder 
Judiciário brasileiro. A norma especifica os casos em que o favorecimento de parentes na nomeação para cargos de provimento em comissão ou função gratificada representam nepotismo, salvaguardando situações nas quais o exercício de cargos públicos por servidores em situação de parentesco não viola a impessoalidade administrativa, seja pela realização de concurso público, seja pela configuração temporal das nomeações dos servidores.

O nepotismo está estreitamente vinculado à estrutura de poder dos cargos e funções da administração e se configura quando, de qualquer forma, a nomeação do servidor ocorre por influência de autoridades ou agentes públicos ligados a esse servidor por laços de parentesco. Situações de nepotismo só ocorrem, todavia, quando as características do cargo ou função ocupada habilitam o agente a exercer influência na contratação ou nomeação de um servidor. Dessa forma, na nomeação de servidores para o exercício de cargos ou funções públicas, a mera possibilidade de exercício dessa influência basta para a configuração do vício e para configuração do nepotismo.

A posterior edição de Enunciados Administrativos e a consolidação de interpretações realizadas pelo Plenário do Conselho também compõem o conjunto normativo que dispõe sobre o nepotismo no Conselho Nacional de Justiça. O nepotismo cruzado, o nepotismo entre Poderes da República e aquele realizado por via da requisição de servidores são formas sutis de identificação da utilização de cargos públicos para manifestações de patrimonialismo e privatização do espaço público.

Após três anos da edição da Resolução nº 07, o Supremo Tribunal Federal, no julgamento da Ação Declaratória de Constitucionalidade $n^{\circ}$ 12, consolidou o entendimento de que a proibição do nepotismo é exigência constitucional, vedada em todos os Poderes da República (STF, Súmula Vinculante $n^{\circ} 13,29$ de agosto de 2008).

Interessante notar que o CNJ retirou a proibição do nepotismo diretamente do princípio da impessoalidade, em conexão com o conceito de República. Também fez alusão direta ao fato de que institutos como o do concurso público combatem a nefasta prática. Com isso, reforça-se a tese de que uma administração impessoal na sua organização, que valorize o mérito e a igualdade de oportunidades, que não faça distinções a partir de subjetivismos ou preferências pessoais dos governantes, habilita-se para um agir naturalmente impessoal. É dizer: a impessoalidade da organização administrativa conduz a ações administrativas impessoais.

${ }^{254}$ http://www.cnj.jus.br/component/content/article/356-geral/13253-o-que-e-nepotismo (em 07.08.2014) 
Não ficou bem resolvida, contanto, na compreensão do CNJ, a natureza jurídica da modalidade “impessoalidade como proibição de nepotismo”. Se regra ou princípio. Com as consequências correlatas.

Parece que o órgão tem inclinação para o entendimento de que a proibição de nepotismo é regra de impessoalidade. Tanto é que, paulatinamente, vem radicalizando na eleição de hipóteses que, a seu ver, seriam de todo proibidas pelo texto constitucional, a partir da “força normativa” do princípio da impessoalidade.

Confira-se que o CNJ, a partir do mesmo entendimento (quebra da impessoalidade) firmou a conclusão de que estagiários de tribunais devem ser escolhidos por processo seletivo. A decisão do Conselho foi proferida, por maioria, na 159ª sessão plenária (27.11.12), na análise do Processo de Controle Administrativo n ${ }^{\circ}$ 0006121-88.2011.2.00.0000. Segundo o órgão, o processo seletivo é a forma que melhor atende ao princípio constitucional da impessoalidade na Administração Pública, ou, nas palavras do Conselheiro Wellington Saraiva, "é mais republicano e democrático o processo seletivo, que atende melhor ao princípio da impessoalidade”. Segundo o mesmo Conselheiro, há preferência da doutrina administrativista pela seleção impessoal dos cidadãos interessados "no usufruto de direito ou gozo de vantagens” na Administração Pública, como ocorre nas licitações, por exemplo. De acordo com Saraiva, a exigência de processo seletivo para estagiários em tribunais evitaria a prática do apadrinhamento, o que, para o Ministro Joaquim Barbosa, à época Presidente do CNJ, confirmava a máxima de que "quando se faz uma seleção, têm-se candidatos mais bem qualificados”.

A preocupação do CNJ com a impessoalidade também é objeto de Resolução específica sobre precatórios (resolução nº 115/10). Por meio dela foi criado o Sistema de Gestão de Precatórios - SGP, um banco de dados de caráter nacional, poderoso artifício para que os pagamentos sejam feitos a partir de regras mais claras e objetivas, conforme os desígnios constitucionais. Na mesma Resolução, são definidos critérios para a elaboração de listagem de precatórios e para o pagamento de preferências justificadas a partir de discriminações positivas, bem toleradas pelo ordenamento jurídico vigente.

Percebe-se esforço significativo do CNJ quanto à necessidade de progressiva objetivação de concursos públicos para ingresso na magistratura. A matéria é objeto de sistematização maior na Resolução $n^{0} 75 / 09$, que define critérios sólidos para que sejam minimizadas as hipóteses historicamente comuns de quebra de impessoalidade. No mesmo 
contexto, são reforçadas as medidas de publicidade para que o concurso possa ser fiscalizado em maior amplitude (art. 12 e seguintes). Também são delineadas regras sobre a composição e o funcionamento das comissões de concurso, a fim de que sejam rechaçados impedimentos e suspeições (art. 20 e seguintes). Autorizam-se, ainda, a celebração de convênio e a contratação de serviços de instituição especializada para a execução da primeira ou de todas as etapas do concurso (art. 29). Com isso, são afastadas influências subjetivas de membros e servidores do próprio tribunal. Mesmo para as fases subjetiva e oral, há normas que impõem e asseguram um controle maior sobre a banca, arrefecendo ânimos e medidas de índole subjetiva ${ }^{255}$.

Merece destaque a Resolução/CNJ nº 106 que trata da promoção de magistrados. A norma passou a prever critérios objetivos para a escolha do magistrado, a fim de acabar com o subjetivismo nas promoções por merecimento. A Resolução considerou um passado de processos de promoção por merecimento marcados tradicionalmente por avaliações baseadas em questões de ordem pessoal, amizades, favoritismos e alinhamento ideológico dos candidatos.

A Resolução/CNJ no 106/2010 estabelece que a promoção por merecimento deve adotar, como ponto de partida, a atribuição de notas para critérios objetivos de aferição da capacidade profissional dos magistrados, rechaçando subjetivismos e casuísmos.

Destaca-se a Resolução nº 140/2011, que proíbe a atribuição de nomes de pessoas vivas aos bens públicos sob a administração do Poder Judiciário. Ao baixar a resolução em questão, o CNJ considerou, expressamente, o disposto no art. 37, $\S 1^{\circ}$, da CF/88 e na Lei $\mathrm{n}^{\circ}$ 6.454/77 (veda a atribuição de nome de pessoa viva a bem público). Também invocou o princípio da impessoalidade, esclarecendo que o comando constitucional tem como intuito “evitar a promoção pessoal de autoridades ou servidores públicos”.

No campo repressivo, a atuação do CNJ é também marcante. Anulou, por exemplo, o XVIII Concurso para ingresso na magistratura estadual de Rondônia, por violação aos princípios da impessoalidade e da imparcialidade, porque candidatas eram assessoras de dois Desembargadores membros da comissão organizadora. Por ocasião do julgamento, o então Conselheiro Paulo Lobo assentou que mesmo diante da ausência dos mencionados Desembargadores na fase de entrevistas e na avaliação oral, constatou-se reprovável parcialidade.

O CNJ também suspendeu concurso para cartórios, em Santa Catarina (objeto do

\footnotetext{
${ }^{255}$ Frise-se que, no CNJ, há proposta de alteração da Resolução 75 (concurso de magistrado) em pauta, aguardando julgamento.
} 
Edital $n^{\circ}$ 176/2012 - TJSC), porque a comissão designada para conduzir o certame, com ofensa ao princípio da impessoalidade, convocou seguidas vezes e nominalmente concorrentes que ainda não tinham entregado documentos exigíveis.

Quanto à aplicação da Resolução/CNJ nº 106 - que trata da promoção de magistrados, segundo critérios menos subjetivos - pode ser referido o Procedimento de Controle Administrativo $\mathrm{n}^{0}$ 0005003-09.2013.2.00.0000, da lavra da Conselheira Maria Cristina Irigoyen Peduzzi, oriundo do Tribunal de Justiça do Amazonas, em que o CNJ assentou: “....a ampliação da concorrência é válida e legítima quando realizada previamente à realização das provas. Na presente hipótese, o ato que majorou número de candidatos habilitados a participar da segunda fase do concurso é de idoneidade questionável, pois beneficiou candidatos que não lograriam aprovação se respeitados os limites da Resolução, em violação ao princípio da impessoalidade״"256.

Em outro caso significativo (Procedimento de Controle Administrativo nº 000452569.2011.2.00.0000, da relatoria do Conselheiro Jorge Hélio Chaves de Oliveira), de interesse do Tribunal de Justiça do Estado de Goiás, conferindo a correta interpretação à Resolução/ CNJ n ${ }^{0} 106$, sobre critérios (mais objetivos) para a promoção de magistrados por merecimento, o órgão fixou tais entendimentos, verdadeiras balizas hermenêuticas, a fim de evitar escolhas meramente discricionárias e até mesmo arbitrárias.

E ao julgar a Consulta ${ }^{\circ}$ 0007159-04.2012.2.00.0000, também da relatoria do Conselheiro Jorge Hélio Chaves de Oliveira, formulada pela Associação dos Magistrados da Bahia - AMAB, sobre o tema na necessidade de objetivação da nomeação por merecimento de magistrados, à luz da Resolução/CNJ n 106, o CNJ firmou a compreensão de que “na formação das listas tríplices para fim de promoção de magistrados pelo critério do merecimento, o Tribunal deve indicar os três candidatos que obtiveram maior pontuação após a aferição das notas dos concorrentes nos quesitos objetivos previstos no artigo $4^{\circ}$ da Resolução $n^{\circ}$ 106, de 2010, do CNJ”.

\footnotetext{
${ }^{256}$ No mesmo julgado, lembrou-se que "o Princípio da Proteção da Confiança Legítima também não autoriza a convalidação do edital retificador" porque, "a despeito do crescente reconhecimento do Princípio pela doutrina, este Eg. CNJ já se posicionou no sentido que atos que afrontem diretamente a Constituição não se beneficiam do Princípio e são insuscetíveis de convalidação". E assim é porque, ainda de acordo com o julgado, "o princípio da confiança legítima não pode ser visto como valor absoluto, de forma a engessar a ordem jurídica, impedindo a Administração de anular os atos praticados em violação à lei”.
} 


\subsection{O policefático conceito de impessoalidade}

Temos como correta a posição de Carlos Ayres Britto acerca da Administração Pública enquanto noção oposta à de Administração Privada ${ }^{257}$ e cremos que o princípio da impessoalidade remarca tais fronteiras.

Se impessoalidade, imparcialidade, objetividade e neutralidade política fossem círculos, teriam tamanhos distintos. A impessoalidade seria o círculo maior, abrangente dos demais.

Em interessante estudo, fincado na comparação entre os sistemas italiano e espanhol e no cotejo entre imparcialidade e objetividade, Massimo Monteduro ${ }^{258}$ explora o caráter multidimensional da matéria e, a nosso ver, acaba por conceber um campo de incidência que pode ser aproveitado para a realidade brasileira na designação do princípio da impessoalidade.

No texto, Monteduro identifica a imparcialidade como um princípio multidimensional, um “princípio de princípios”. Metaforicamente, seria um “polítopo” multidimensional que apresenta diversos lados axiológicos e prescritivos, com várias dimensões:

$1^{\text {a }}$ Dimensão: i) imparcialidade estrutural ou organizativa: impõe o dever à Administração Pública de se estruturar de forma a conduzir uma ação objetiva e imparcial. Nessa perspectiva, o autor entende que essa dimensão da imparcialidade permite estabelecer critérios para distinguir a atividade política da atividade administrativa; ii) imparcialidade funcional: desenvolve-se na ação administrativa. Essa concepção se aplica a um espectro amplíssimo de cânones, tais como transparência, igualdade de trato, motivação etc. ${ }^{259}$.

\footnotetext{
${ }^{257}$ Para o autor (Comentários..., p. 822):

“Também de se ver que a objetiva atividade estatal de administração 'pública'é assim designada por oposição ao fraseado administração privada. Vale dizer, no círculo da fisiologia estatal, 'administração'é gerenciamento da coisa pública. Não da coisa ou dos assuntos privados, porque nós sabemos que há uma administração privada nas empresas, nas ONGs, nas famílias, nas igrejas, em todos os setores da sociedade dita civil, enfim. Como contraponto é que surge a administração pública, a significar gerência de tudo que é de todos. Ou 'atividade de quem não é senhor de coisa própria, mas gestor de coisa alheia', como insuperavelmente cunhou Rui Cirne Lima.

(...)

Cuida-se de dicotomia que traduz a nítida diferenciação entre administrador e administração pública. Que éa clara distinção entre espaço público e espaço privado, este sim, regido pelo princípio da vontade pessoal ou do mero querer subjetivo dos atores sociais. Distinção sem a qual, enfatize-se, a triste herança portuguesa do patrimonialismo persistirá como a principal base de inspiração dos acordos que, pelas bandas de cá, não cessam de urdir os que açambarcam o poder econômico e o poder político".

${ }^{258}$ El carácter multidimensional de la imparcialidad administrativa y el principio de objetividad: reflexiones sobre la experiencia italiana. In: DA. Revista Documentación Administrativa n 289, enero-abril 2011, p. 305-366.

${ }^{259}$ Apesar da separação teórica entre imparcialidade organizativa e funcional, estas estão interconectadas de forma inseparável, como faces da mesma moeda.
} 
2a Dimensão: i) imparcialidade subjetiva: conjunto de normas que condicionam e limitam o comportamento e as atividades de titulares de funções públicas; ii) imparcialidade objetiva: ação e organização administrativas consideradas em si mesmas, independentemente das pessoas físicas que intervenham em concreto ${ }^{260}$.

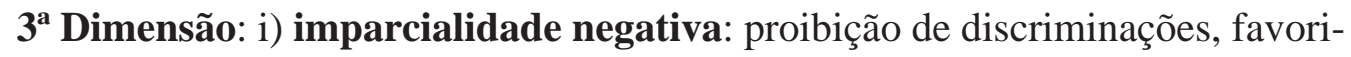
tismos, preferências e/ou desigualdades injustificadas; ii) imparcialidade positiva ou inclusiva: abertura institucional da Administração Pública para considerar e comparar todos os interesses envolvidos e protegidos pela ordem jurídica em concreto. Busca de equilíbrio e composição de interesses. Tal aspecto da imparcialidade é instrumentalizado pela participação dos interessados na esfera do processo administrativo.

A Imparcialidade também é referida por Monteduro como critério de distinção entre política (direção) e administração (gestão). As escolhas político-partidárias, tomadas no plano abstrato, possuem o filtro em concreto da imparcialidade. As escolhas políticas não devem levar a discriminações nem a favoritismos na esfera pública. Os problemas, nessa seara, residem em questões como as relativas a cargos comissionados e escolhas de entidades para cooperarem com o Poder Público.

Relevante considerar a participação procedimental como corolário do princípio da imparcialidade, com foco na ideia de justo procedimento administrativo, a qual abrange: i) participação procedimental como garantia de contraditório e ampla defesa do administrado; ii) participação procedimental como colaboração com o Poder Público, a fim de que este tenha uma ampla percepção dos interesses em jogo e possa tomar uma decisão com maior legitimidade após a análise e avaliação de todos eles.

Para Monteduro, “em virtude dos princípios em questão, os órgãos administrativos encarregados da instrução e decisão devem conhecer, comprovar e valorar todos os interesses pertinentes, na medida em que sejam significativos para o interesse público concreto que se deve satisfazer, de modo a permitir a mais ampla compreensão possível de todos os aspectos relativos ao caso".

\footnotetext{
${ }^{260}$ Em outros termos, a imparcialidade em sentido subjetivo gera normas sobre quem, de forma legítima, deve tomar as decisões administrativas e a imparcialidade em sentido objetivo regula como devem ser tomadas as referidas decisões.
} 
Correlato ao princípio da participação procedimental é o dever de motivação dos atos administrativos. Segundo o autor, não é possível haver efetiva participação procedimental dos cidadãos se o Poder Público não fundamenta e motiva suas decisões. Ao proteger quaisquer interesses in concretu, a Administração deve demonstrar, à luz da proporcionalidade e da razoabilidade, o porquê da escolha de um interesse específico em detrimento de outros. Tal explicitação dos motivos confere transparência à ação administrativa e permite eventuais impugnações por parte dos cidadãos prejudicados pelo ato.

A imparcialidade, na visão mais alargada de Monteduro, que se aproxima da nossa ideia de impessoalidade, tem forte relação com publicidade e transparência. Sob a sua óptica, o fundamento constitucional primário dos princípios da transparência e da publicidade está justamente na imparcialidade. Um e outra são garantias indispensáveis à possibilidade e à efetividade da participação procedimental e, portanto, da imparcialidade em sua dimensão positiva.

Imparcialidade também diz respeito a integridade na ação administrativa. A integridade ganha relevo como conjunto de medidas de combate à corrupção na esfera pública, não no plano punitivo, mas no preventivo como meios de controle (vocação preventiva do controle). A integridade, nessa perspectiva, também se mostra como corolário da imparcialidade.

Ao comparar a imparcialidade (contexto italiano) com a objetividade (contexto espanhol), Monteduro arrola traços comuns e traços diferenciados. Considerando que a impessoalidade (contexto brasileiro) é abrangente das duas, convém tecer considerações sobre a segunda, com base nos estudos desenvolvidos pelo mesmo autor.

Eis as diferentes compreensões do princípio da objetividade pela doutrina italiana, segundo Monteduro:

$1^{\text {a }}$ Forma de Compreensão: Objetividade é um corolário do princípio da legalidade. Nessa perspectiva, o administrador público está vinculado à finalidade geral estabelecida na lei. Ao atuar conforme tal finalidade estará realizando uma conduta objetiva.

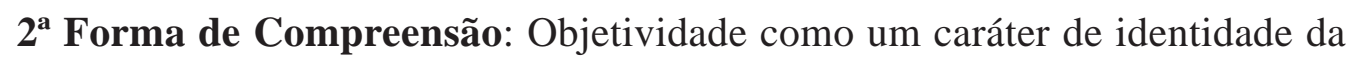
Administração Pública em sua organização e ação. Nessa perspectiva, objetividade e imparcialidade se confundem (planos estrutural e funcional da imparcialidade), no sentido de estabelecer a "forma de dever ser da Administração Pública”. 


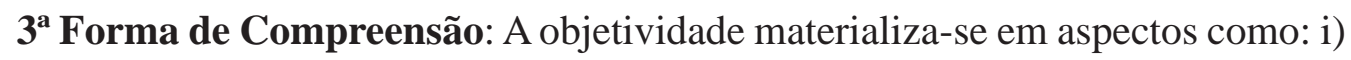
fixação de parâmetros de referência para a ação administrativa; ii) critérios para limitação da discricionariedade administrativa.

A objetividade da ação administrativa pode então ser considerada como princípio derivado da imparcialidade. Para Monteduro, a atuação objetiva do Poder Público representa apenas uma das facetas do "polítopo" multidimensional do princípio da imparcialidade e, portanto, mais próxima da $3^{\mathrm{a}}$ forma de compreensão.

A objetividade pode ser vista como uma técnica de redução da parcialidade, ao estabelecer parâmetros para a dessubjetivização das valorações discricionárias realizadas pela Administração Pública. De acordo com Monteduro, não se trata de abstrair das escolhas do administrador toda e qualquer valoração subjetiva, mas definir, do ponto de vista dos destinatários da decisão ou ato administrativos, critérios que não os julguem ou qualifiquem por suas características ou atributos pessoais. Para tanto deve haver um estabelecimento prévio dos métodos e cânones que levarão à formação do juízo discricionário. Nas suas palavras, eis uma síntese da ideia: “Dessa forma, a Administração Pública, ao se caracterizar como parte interessada entre sujeitos interessados, não privilegiará quaisquer destes e não será privilegiada, encontrando seus critérios de objetividade numa abertura plena e integral a intersubjetividade, segundo um modelo que encontra sua fórmula conceitual mais acertada na expressão "parte imparcial”.

Como explicitado por ocasião das incursões históricas, a visão italiana de imparcialidade, bastante moderna, aberta e abrangente, se conecta com o alcance que se quer conferir ao princípio da impessoalidade, próprio do regime constitucional brasileiro.

No particular, forçoso revisitar alguns autores italianos cujas lições acerca da imparcialidade que existe na Itália se amoldam, como mão à luva, à impessoalidade brasileira.

Para Domenico Sorace ${ }^{261}$, o art. 97 da Constituição italiana estabelece como princípios norteadores da função administrativa a imparcialidade e o bom andamento da administração, os quais devem nortear a organização e as atividades desenvolvidas pelo poder público. Em outros termos, o mandamento constitucional determina que a Administração Pública tem o dever de se organizar e atuar de modo a dar concretude aos princípios da imparcialidade e do bom andamento.

${ }^{261}$ Diritto delle amministrazioni pubbliche - una introduzione. 6a ed. Bologna: Il Mulino, 2010, p. 65-68. 
Ao tratar dos muitos significados e do alcance do Princípio da Imparcialidade, o autor assinala que a imparcialidade é um princípio intimamente vinculado à atividade jurisdicional, pela qual o julgador, ao apreciar controvérsia entre partes com interesses contrapostos, deve decidir sem qualquer sentimento de preferência ou favoritismo. Entretanto, questiona-se: Como é possível enquadrar a Administração Pública como “parte imparcial”, tendo em vista que esta deve perseguir o interesse público, o qual, muitas vezes, não coincide com os diversos interesses da sociedade? É necessário explicar, portanto, o conteúdo do dever de imparcialidade do Poder Público, em face de sua atuação como parte interessada (na busca do interesse público), dando azo a alguns sentidos:

$\mathbf{1}^{\mathbf{0}}$ sentido: Imparcialidade e atividade vinculada - Neste caso, para ser imparcial, o administrador deve atuar o mais próximo possível do comportamento de um juiz. Deve buscar a aplicação plena da lei ao caso concreto.

$\mathbf{2}^{\mathbf{o}}$ sentido: Imparcialidade e Organização Administrativa - Para garantir a imparcialidade dos órgãos que compõem o aparato administrativo é necessário garantir a máxima independência entre a esfera administrativa e a esfera política. Também, do ponto de vista subjetivo, faz-se necessário garantir a neutralidade “terzietá” - dos agentes públicos, a fim de impedir conflitos de interesses e favoritismos.

$3^{\mathbf{0}}$ sentido: Imparcialidade se confunde com igualdade - Neste sentido, é vedado à Administração Pública realizar discriminações entre situações jurídicas e interesses, sem que haja um fundamento justificativo, pois a imparcialidade seria a concretização da igualdade no âmbito da função administrativa.

$4^{0}$ sentido: Imparcialidade e Composição de Interesses - Quando a Administração Pública atua no caso concreto para satisfazer o interesse público primário (resultante da identificação e disposição política - indirizzi politici), deve também estar atenta a todos os outros interesses envolvidos, sejam eles públicos ou privados. Assim, as decisões tomadas pelo Poder Público devem materializar a composição dos diversos interesses em jogo, a fim de serem efetivamente úteis a todos eles (sem descartar a priori nenhum dos interesses em jogo).

Nas palavras de Sorace, “naturalmente, se o interesse público deve, em definitivo, ser construído em concreto, tendo em conta os diversos possíveis interesses em jogo, tais interesses devem ser apreciados de forma adequada”. 
O posicionamento de Sorace inspira questionamentos: - A imparcialidade está na abertura participativa da Administração Pública, a fim de que sejam trazidos ao seu conhecimento os diversos interesses da coletividade? Ou está na apreciação e na valoração objetiva dos interesses sociais? Ou em ambas as hipóteses?

Surgem, então, um $5^{\circ}$ e um $6^{\circ}$ sentidos:

$5^{0}$ sentido: Imparcialidade, Procedimento e Participação - A abertura procedimental permite a participação da coletividade, na medida em que se abre um caminho para que sejam levados à Administração Pública os diversos interesses em jogo, para a tomada de qualquer decisão administrativa. No entanto, há limitação dessa abertura procedimental pelo princípio do bom andamento administrativo. Assim, é preciso estabelecer critérios de pertinência e de relevância dos interesses, para que não se comprometa o desenvolvimento da atividade administrativa de modo eficiente.

$6^{0}$ sentido: Imparcialidade e Justo Procedimento - O contraditório é um corolário constitucionalmente necessário para a concretização da imparcialidade, à luz do justo procedimento (fair proceeding, due process of Law).

Também merece destaque a posição doutrinária de Sabino Cassese ${ }^{262}$, para quem a concepção tradicional de imparcialidade aponta para a necessidade de corrigir e ter sob controle a politização da Administração Pública, em face da presença de agentes políticos na esfera administrativa. Segundo Cassese, esta é a parte negativa da imparcialidade. Nessa perspectiva, são vedados o favoritismo, a preferência e a discriminação injustificada.

Na sua visão, eis as consequências da aplicação da imparcialidade pela jurisprudência e pela legislação: a) obrigação de estabelecer critérios e parâmetros objetivos anteriores ao procedimento administrativo; b) obrigação da Administração Pública de analisar de modo preciso, completo e imparcial todos os elementos relativos à “fattisspecie” (hipótese legal); c) obrigação de realizar, de modo objetivo, uma análise comparativa dos interesses em jogo, levando em conta os efeitos e possíveis resultados de sua tutela; d) obrigação do agente público de se abster de agir e atuar quando tenha interesses pessoais na decisão, a fim de assegurar a imparcialidade (neutralidade - terzietá) da função administrativa.

${ }^{262}$ Il diritto amministrativo e i suoi principi. In: Corso di Diritto Amministrativo diretto da Sabino Cassese. 1. Instituzioni di Diritto Amministrativo a cura de Sabino Cassese. $4^{a}$ ed. Milano: Giuffrè Editore, 2012, p. 13- 14. 
Cassese ressalta que o princípio da imparcialidade constitui o fundamento das normas sobre inelegibilidade, incompatibilidade e conflitos de interesse no âmbito da Administração Pública.

Giampaolo Rossi ${ }^{263}$ também tem contribuições significativas na matéria. Entende que o significado do princípio da imparcialidade deve ser estabelecido à luz do critério dos interesses tutelados. Para ele, não é possível comparar a imparcialidade da Administração Pública com a imparcialidade de um juiz, na medida em que a ação daquela é voltada ao alcance de um objetivo específico (interesse público), e não puramente à solução de controvérsias.

Para que se vislumbre a imparcialidade típica da Administração Pública é preciso ter em conta que ela atua como parte interessada na busca de concretização do interesse público. A Administração Pública deve ser imparcial no sentido de assegurar a tutela de um determinado interesse - considerado interesse público - sem deixar de apreciar outros interesses públicos e privados envolvidos. Isso se traduz na proibição de favoritismos e preferências, ou seja, na obrigação do Poder Público de tutelar e promover os interesses de forma objetiva, sem quaisquer discriminações indevidas.

Para Rossi, o princípio da imparcialidade se realiza por meio de instrumentos diversos, quando consideradas as esferas de: i) atividade; e de ii) organização da Administração Pública. Confira-se:

i) Quanto à atividade, devem-se distinguir os procedimentos administrativos submetidos ao direito público e ao direito privado.

Direito Público - Quando a atividade administrativa se realiza por meio de um provimento unilateral, o critério de imparcialidade determina que seja dada a todos os interessados a possibilidade de participar do procedimento, e que a Administração conheça os interesses e elementos úteis para a tomada de uma decisão ponderada.

Direito Privado - Princípio do concurso. A Administração deve escolher o contratante privado da forma mais idônea e transparente possível.

ii) Quanto à organização administrativa, o princípio da imparcialidade se desenvolve em duas perspectivas:

a) independência da atuação administrativa perante os órgãos políticos;

b) obrigação dos agentes públicos de se absterem de agir ou atuar quando houver conflito de interesses na decisão a ser tomada.

\footnotetext{
${ }^{263}$ Principi di diritto amministrativo. Torino: G. Giappichelli Editore, 2010, p. 95-97.
} 
Já para Francesco Merloni ${ }^{264}$, os sentidos do princípio da imparcialidade são os seguintes: $\mathbf{1}^{0}$ sentido: Imparcialidade na Ação Administrativa - Decorre do princípio da igualdade. No desenvolvimento da função administrativa, a imparcialidade é garantida pela: i) participação do interessado no procedimento administrativo; ii) necessária valoração pelo Poder Público dos interesses públicos e privados em jogo; iii) obrigação de motivar; iv) predeterminação de critérios que a Administração seguirá em sua atuação.

$2^{\mathbf{o}}$ sentido: Imparcialidade na Organização Administrativa:

- Do ponto de vista objetivo: distinção entre as funções política e administrativa. Independência funcional dos agentes públicos.

- Do ponto de vista subjetivo: independência do agente público, tanto em relação a influências políticas quanto no tocante à neutralidade (ausência de interesses particulares). Também tem grande importância a confiança que os cidadãos depositam nos agentes públicos, razão pela qual estes, além de serem imparciais, também devem aparentar/demonstrar imparcialidade.

Merloni faz importante análise em relação ao conflito entre os princípios da imparcialidade e do bom andamento administrativo e, neste ponto, diverge de Sorace. Para Merloni:

\begin{abstract}
"No eventual conflito entre os princípios do bom andamento e da imparcialidade, sempre este deve prevalecer (por estar em posição de superioridade no ordenamento jurídico). Assim, um ato que satisfaça plenamente o critério da eficiência e economicidade, mas seja viciado sob a ótica da imparcialidade, por ter discriminado ilegitimamente algum interesse em jogo, é anulável por causar lesão a uma situação jurídica subjetiva tutelada”.
\end{abstract}

Por fim, merece destaque a doutrina de Elio Casseta ${ }^{265}$, para quem a imparcialidade pode ser vislumbrada dos pontos de vista positivo e negativo. Sob a ótica positiva, o princípio da imparcialidade estabelece um comportamento ativo voltado à concretização de relações jurídicas imparciais por parte da Administração Pública. No negativo, o princípio impõe o dever de a Administração Pública não discriminar ilegitimamente os sujeitos relacionados à sua atividade.

${ }^{264}$ Istituzioni di diritto amministrativo. Torino: G. Giappichelli Editore, 2012, p. 36-38.

${ }^{265}$ Compendio di Diritto Amministrativo. $3^{\mathrm{a}}$ ed. Milano: Giufreè, 2003, p. 16-18. 
Segundo Casseta, para que seja possível conceber o conceito de imparcialidade é necessário ter em mente que a Administração Pública deve perseguir os interesses públicos que a lei determina e define. Portanto, neste sentido, a Administração é parcial.

Assim, a imparcialidade impõe, sobretudo, que a Administração Pública seja estruturada de modo a assegurar uma condição objetiva imparcial.

Na esfera de organização administrativa, a imparcialidade se materializa no dever de abstenção dos funcionários públicos em decisões que impliquem conflito de interesses; no critério de concurso público.

Já quanto à ação administrativa, o aspecto primordial para garantir a imparcialidade é a predeterminação de critérios e modalidades em que a Administração se baseará para um processo de escolha. Representa um autolimite à ação administrativa.

É de Casseta a lúcida afirmação de que a predeterminação dos critérios garante a igualdade perante a Administração, na medida em que permite a valoração dos interesses envolvidos na ação administrativa. Há, no princípio em questão, a exigência abstrata de que todos esses interesses sejam considerados.

No direito brasileiro, não tem havido uma preocupação maior em retirar uma ação administrativa impessoal de uma organização administrativa naturalmente voltada a tal desiderato.

É imperioso relacionar as duas dimensões do princípio da impessoalidade a partir das lições antes assinaladas sobre o princípio da imparcialidade.

O princípio da impessoalidade, em sua correta acepção, impõe à Administração Pública uma dupla preocupação. Em primeiro lugar, a Administração Pública deve se organizar, do ponto de vista de sua estrutura, para ser impessoal. De outro lado, a Administração Pública, devidamente organizada, deve ser impessoal em suas ações.

Entrelaçam-se, então, garantias instrumentais e substanciais de impessoalidade. As garantias instrumentais estão ligadas ao primeiro aspecto, de organização administrativa impessoal, ao passo que as garantias substanciais estão relacionadas ao agir administrativo impessoal, incluído o agir decisório.

\subsection{Organização administrativa impessoal}

Ao focar-se a impessoalidade como organização ${ }^{266}$ administrativa, estuda-se a Administração Pública num sentido estático.

${ }^{266}$ O termo “organização" é utilizado no trabalho no sentido (vulgar) de "estruturação”, de “arrumação” interna, na linha do tratamento conferido à matéria especialmente na Itália e na Espanha. 
Para ser impessoal e para agir impessoalmente, a Administração Pública deve ser estruturada de forma ideal. Sua organização deve ser tal que dela flua, naturalmente, o agir impessoal.

Héctor Jorge Escola ${ }^{267}$ assinala que a Administração “es el centro vital del cual emana uma vasta y compleja actividad, una acción concreta e continuada, para cuyo cumplimiento es imprescindible contar com uma organización adecuada”. Leciona ainda que:

\footnotetext{
“La noción de ‘organización’ se extiende, como es sabido, a la formulación de una serie de principios y de reglas sistemáticas que concurren a coordinar de manera adecuada un complejo de medios, de muy diversa naturaleza, encaminados al logro de un fin o de un conjunto de fines, sobre la base de una correcta división del trabajo.

Con la organización se busca la más adecuada ordenación y el mejor empleo de los elementos y medios que son necesarios para alcanzar un fin presupuesto, mientras que, desde otro punto de vista, puede entendérsela como aquella voluntad ordenadora por medio de la cual se habrá de determinar el lugar así como las posibles interrelaciones que corresponden a cada uno de los elementos componentes de una empresa dada, y el de las tareas que cada uno de éstos deberá desarrollar, dentro de un conjunto que debe actuar con armonía”.
}

Juan Alfonso Santamaría Pastor ${ }^{268}$ evidencia que a Administração deve atuar com sujeição às diretrizes emanadas do Governo, enquanto veículo representativo da legitimidade democrática, “pero no es un puro apéndice ejecutor de las decisiones políticas”. No seu entender:

\begin{abstract}
"La Administración es una organización de carácter profesional, cuya actuación debe sujetarse a criterios de racionalidad técnica, ajenos a los intereses ideológicos de la pugna política: es, en suma, una organización fiel, pero neutral, debiendo servir con igual eficacia y dedicación al Gobierno que en cada momento haya sido investido por el Parlamento. Fidelidad no es lo mismo que adhesión”.
\end{abstract}

O Princípio da Impessoalidade obriga a Administração Pública a adotar, como regra, institutos jurídicos como: concurso público, licitação, processo administrativo, regras de impe-

267 Obra citada, p. 63.

${ }^{268}$ Principios de derecho administrativo general - I. $2^{\text {a }}$ Edición. Madrid: Iustel, 2009, p. 82. 
dimento e suspeição etc. Em todos os casos há unidade de propósitos. Tais institutos têm outros objetivos próprios, mas em grande medida convergem para a ideia maior de impessoalidade.

- Como ser impessoal sem concurso público? O Administrador que não é nomeado por concurso público tem, em tese, a mesma isenção política do que o é?

No direito brasileiro, Raquel Dias da Silveira ${ }^{269}$ se ocupou do tema da profissionalização da função pública, revelando que, ao contrário do que pode parecer, "desde a criação do Departamento Administrativo do Serviço Público (Dasp), em 1938, e, mais tarde, com as pesquisas realizadas pela Comissão Especial de Estudos de Reforma Administrativa (Comestra) (que culminaram na edição do Decreto-Lei $n^{\circ}$ 200/67), o Estado mostra-se preocupado com a deterioração do mérito no serviço público”. E que a Constituição de 1988 (art. 39, caput), já na sua redação originária, também concedeu especial atenção ao dever do Estado de promover, por meio da carreira, a profissionalização do servidor.

A autora salienta que a concepção de burocracia formulada por Weber teve como fundamento a criação de um Estado forte, dotado de servidores públicos profissionalizados. Para Weber, o avanço em relação ao capitalismo dependia do progresso do funcionalismo burocrático, caracterizado pelo formalismo na divisão funcional do trabalho, na estabilidade, no salário, no treinamento especializado e na promoção, no sentido amplo da carreira ${ }^{270}$.

Esclareça-se, como faz Raquel Dias Silveiraa ${ }^{271}$, que, a despeito das críticas que serviram de base à promulgação da Emenda Constitucional nº 19/98, a burocracia, no seu sentido puro e técnico, "foi inspirada no propósito de se alcançarem a eficiência e a eficácia na gestão pública, para fim de projeção política e econômica do Estado”.

Enfatiza que, no Brasil, o paradigma da profissionalização veio da organização administrativa ditada pela Constituição imperial de 1824, caracterizada pelo modelo essencialmente patrimonialista, quando, mesmo assim, já se cogitava mérito mínimo como condição de ingresso no serviço público.

A autora trabalha então fortemente a noção de mérito, sob três sentidos diversos, mas complementares, a saber: a) O mérito objetivo atual, apurado pela Administração quando do ingresso de indivíduos no serviço público, por meio de concurso público de provas ou de provas e títulos; b) O mérito objetivo potencial que o servidor adquirirá ao longo de sua trajetória funcional, por intermédio de cursos de capacitação e aperfeiçoamento e que deverá

\footnotetext{
${ }^{269}$ Profissionalização da função pública. Belo Horizonte: Fórum, 2009.

${ }^{270}$ Obra citada, p. 24.

${ }^{271}$ Obra citada, p. 24.
} 
ser verificado pela Administração mediante processo de avaliação de desempenho; c) O mérito subjetivo, presente no provimento dos cargos em comissão, que se refere ao elo de confiança entre o servidor comissionado e a autoridade que o nomeou.

Raquel Dias da Silveira sustenta que a profissionalização da função pública pelo sistema de mérito é mesmo um direito subjetivo do servidor e direito fundamental dele e da sociedade. Por outro lado, corresponde à obrigação imposta pelo constituinte ao Estado brasileiro.

Interessante notar que a autora ${ }^{272}$, ao arrolar os princípios que informam a "função pública profissionalizada”, refere-se, primeiramente, à impessoalidade. Os demais princípios seriam a eficiência (mais compreendida no sentido de eficácia ou de boa administração), a segurança jurídica, a justiça, a proibição do retrocesso dos direitos sociais, a dignidade da pessoa humana e a valorização do trabalho do servidor.

No que se refere ao princípio da impessoalidade, a autora ${ }^{273}$ defende que uma "função pública profissionalizada” independe de mudanças na política ou nas diretrizes de governo. A seu ver, “a independência política dos servidores aos quais cumpre a gestão de serviços públicos ou de atividades de interesse público deve-se, primeiramente, à investidura mediante concurso público de provas ou de provas e títulos” e, assim, “o servidor é integrado à 'função pública' por seu próprio mérito, sendo independente em relação àqueles que se encontram momentaneamente no poder”. Após a investidura objetiva e meritória por concurso público, para a autora, a impessoalidade da função pública gera “a continuidade no desenvolvimento das atividades administrativas e na prestação de serviços adequados e de qualidade ao público”. Para Raquel Dias da Silveira:

\footnotetext{
“A impessoalidade é característica do Estado de Direito antagônica à ideia de que os governantes ou os servidores possam deduzir da investidura em cargos e empregos públicos uma conquista pessoal ou particular. Trata-se de um múnus, um encargo exercido por quem gere coisa alheia, e, na gestão de coisa alheia, não interessa a personalidade a que serve.

Por isso, afirma Romeu Felipe Bacellar Filho que a finalidade pública insere-se no princípio da impessoalidade administrativa. 'Sua observância pela Administração previne o ato praticado em qualquer sentido de individualismo, posicionando-se em conformidade com o bem comum””.
}

${ }^{272}$ Obra citada, p. 25.

${ }^{273}$ Obra citada, p. 71-72. 
Segundo a autora, o fundamento constitucional do princípio da impessoalidade para a profissionalização da função pública pelo sistema de mérito radica no art. 37, caput, e nos seus incisos I, II, III, IV e V da Constituição de 1988, dispositivos esses que “destinam-se a promover a neutralidade na realização do interesse público por servidores objetivamente investidos na aludida tarefa".

Romeu Felipe Bacellar Filho, ao prefaciar a obra acima aludida correlacionou o tema da profissionalização da Administração Pública aos princípios da isonomia e da eficiência. Confira-se:

\begin{abstract}
“Tenho sustentado que, no Direito Brasileiro, o tema da profissionalização da função pública encontra-se intimamente relacionado aos postulados constitucionais. Como pano de fundo a lembrança, sempre presente, que a Administração Pública é um aparelhamento do Estado que se encontra voltado, por excelência, à satisfação cotidiana das necessidades coletivas - aliás, seu indispensável referencial.

Com efeito, a Administração Pública legitima-se quando age em conformidade com o interesse público. Neste contexto, a profissionalização da função pública constitui instrumento de legitimação da Administração Pública brasileira perante o povo: (i) primeiro, para garantir a observância do princípio da igualdade na escolha de seus agentes, a partir de critérios que possibilitem a aferição daqueles mais preparados (em todos os sentidos) para o exercício da profissão, e não num status atribuído em razão de um direito de nascença ou pela proximidade pessoal com os governantes; (ii) segundo, para dar cumprimento ao princípio da eficiência, de uma Administração capacitada a responder aos anseios coletivos mediante a prestação de serviços adequados.”
\end{abstract}

Para Romeu Bacellar²74, a profissionalização do servidor público deveria ter consubstanciado um ponto forte da reforma administrativa levada a efeito pela Emenda Constitucional no 19/98, já que “o preparo técnico para o desempenho de cargo, emprego ou função pública é condição sine qua non para avaliar a eficiência do servidor público". Daí porque a implementação de um sistema de mérito no funcionamento público é emergencial. A profissionalização exige não somente o fortalecimento do instituto do concurso público (e a necessidade de se privilegiar interpretações restritivas quanto aos cargos em comissão que

${ }^{274}$ Conforme o prefácio da obra "Profissionalização da função pública”, de Raquel Dias da Silveira. 
constituem exceção à regra do concurso), mas também um adequado plano legislativo de carreira, em todos os níveis da Federação (União, Estados, Distrito Federal e Municípios). Para o Professor:

\begin{abstract}
“(...) a Administração Pública legitima-se quando age em conformidade com o interesse público, sendo imperioso realçar que, para dar cumprimento ao princípio da eficiência, faz-se indispensável que a Administração esteja capacitada a responder aos anseios coletivos mediante a prestação de serviços adequados, através de profissionais comprometidos com a causa pública e esperançosos de ver seus esforços adequadamente retribuídos. Neste quadro, a implementação do sistema de mérito revela-se fundamental.”
\end{abstract}

De acordo com Florivaldo Dutra de Araújo 275 , “um dos mais renitentes traços do patrimonialismo em nosso país é o da utilização dos ofícios públicos como mercadoria de barganha política, insumo do clientelismo e formação de patrimônio familiar”. Para ele, o concurso público está longe de ser perfeito na aferição do mérito, mas “é insubstituível como meio de se buscar a impessoalidade e a moralidade no preenchimento dos cargos e empregos públicos, valorizando as aptidões de cada cidadão e buscando evitar os desvios patrimonialistas apontados”. É do mesmo autor a crítica observação de que:

\footnotetext{
"Lamentavelmente, a criatividade e a desfaçatez continuam inesgotáveis na administração pública brasileira, quando se trata de desconhecer o mérito e burlar a isonomia de tratamento no ingresso e no desenvolvimento profissional da função pública. As contratações formalmente ‘temporárias', mas de fato permanentes, o desvio de função e as abusivas terceirizações de mão de obra são alguns dos expedientes corriqueiros para não se cumprir o direito fundamental do cidadão à valorização do mérito na função pública. Outro grave problema tem sido o abuso na criação de cargos em comissão, de livre nomeação e exoneração, a despeito do comando constitucional do art. 37, $\mathrm{V}$, da CF, restritivo no tocante a tais cargos, que somente devem ser criados na medida da efetiva necessidade de exercício de tarefas de direção, chefia e assessoramento".
}

Para Florivaldo Dutra de Araújo, “o desafio de efetivar a impessoalidade e a moralidade

${ }^{275}$ Do prefácio da obra de Leonardo Carneiro Assumpção Vieira, intitulada Merecimento na administração pública: concurso público, avaliação de desempenho e política pública de pessoal. Belo Horizonte: Fórum, 2011. 
na função pública brasileira, por meio da valorização do mérito, apurado mediante critérios isonômicos, é trabalho árduo, por se chocar diretamente com os mais empedernidos 'valores'do patrimonialismo renitente".

Para o autor, o mérito no acesso e no desenvolvimento profissional da questão pública é tema a merecer maior reflexão jurídica, muito embora alguns avanços possam ser registrados, dentre os quais:

a) No campo constitucional - (i) a enunciação da impessoalidade e da moralidade como princípios constitucionais; (ii) a explicitação de que não apenas os cargos de regime estatutário, mas também os empregos públicos, devem ser preenchidos mediante concurso público; (iii) a previsão de punição às autoridades infratoras do dever de realização do certame público; (iv) o direito à carreira, segundo normatização legal, ex vi do art. 39, da CF/88;

b) No campo jurisdicional - (i) a extensão das hipóteses em que se reconhece o direito à nomeação do candidato aprovado em certame público; (ii) a proliferação de pronunciamentos coibidores de condutas subversivas da regra do concurso; (iii) o reconhecimento do nepotismo como prática atentatória a diversos princípios constitucionais, com a consequente edição da Súmula Vinculante ${ }^{0} 13$, do STF.

c) No campo doutrinário - a sistematização de diversas ideias e institutos que devem nortear os aplicadores do direito no sentido da aplicação prática das regras e dos princípios constitucionais relativos à ocupação dos cargos, empregos e funções públicas, bem quanto ao desenvolvimento profissional do servidor.

No Brasil, Leonardo Carneiro Assumpção Vieira ${ }^{276}$ dedicou-se ao tema do merecimento da Administração Pública, com foco nas questões do concurso público, na avaliação de desempenho e como política pública de pessoal.

Para o autor, o merecimento é, sob o prisma antropológico, apenas um dos vários critérios de diferenciação, hierarquização social e organização dos agrupamentos humanos. Há outros, tais como (i) a maturidade e (ii) a linhagem familiar. Ensina que "seja na Grécia antiga, nas quase extintas civilizações indígenas da América, na Ásia ou na África, o problema da organização do grupo relaciona-se diretamente com o sucesso competitivo

\footnotetext{
${ }^{276}$ Merecimento na Administração Pública: concurso público, avaliação de desempenho e política pública de pessoal. Belo Horizonte: Fórum, 2011.
} 
deste, com a ambição de cada indivíduo e com as representações sociais”. E que o merecimento individual objetivo, apurado nos diversos institutos jurídicos, com destaque para o concurso público e para a avaliação de desempenho, encontra seu desenvolvimento fundamental na Europa, entre os séculos XVII a XIX, e “corresponde à pretensão de organização da sociedade conforme os padrões reclamados pela classe burguesa de então e cristalizados pelas noções iluministas de igualdade, impessoalidade, bem como pela distinção entre o público e o privado" 277.

Para Leonardo Carneiro Assumpção Vieira:

“(...) o merecimento é princípio jurídico acolhido pelo sistema constitucio-
nal brasileiro e que implica na justa distribuição e manutenção de oportuni-
dades profissionais, conforme procedimentos objetivos voltados à compro-
vação do desempenho pessoal, que visam ao equilíbrio entre interesses dos
candidatos, da organização de caráter público e da comunidade interessada
em seus serviços. No âmbito da função pública, é possível perceber dois
subprincípios derivados deste que acabamos de anunciar: o princípio do
merecimento objetivo no provimento de cargos públicos; e o princípio do
merecimento no desempenho dos cargos públicos”.

Perceba-se que do merecimento objetivo no provimento de cargos públicos deflui naturalmente uma atuação impessoal tendente à consolidação do merecimento no desempenho dos cargos públicos. É dizer: O servidor que vem a ocupar um cargo público por mérito ingressa no serviço público com um cabedal de independência voltado a um agir mais impessoal. E, por consequência de um agir impessoal, é mais provável venha a ter novo merecimento objetivamente reconhecido no desempenho das respectivas funções públicas.

Para Leonardo Carneiro Assumpção Vieira ${ }^{278}$, muito embora não seja referido expressamente no texto constitucional, o princípio do merecimento se revela a partir da análise sistêmica de outros princípios e de algumas regras. Dentre os princípios, ocupam papéis de destaque:

a) Princípio da igualdade (art. 5º art. 37) - previsto não apenas em sua dimensão formal, mas também por intermédio de mecanismos com finalidade maior de contraposição às diferenças entre cidadãos, garantindo a dignidade de todos e, de modo especial, a igualdade de oportunidades;

\footnotetext{
277 Obra citada, p. 17.

278 Obra citada, p. 140.
} 
b) Princípio da impessoalidade (art. 37; e art. $3^{\circ}$, IV) - segundo o qual o Estado ou seus agentes não estabelecerão preferência entre cidadãos, indicativo de que os critérios a serem adotados, quando diferenciações forem adotadas, hão de consistir em dados tão objetivos quanto possíveis, em acordo com o interesse público;

c) Princípio da eficiência (art. 37) - baliza a atuação do administrador público, que deve proceder sempre visando ao ótimo e pressupõe equilíbrio entre a economicidade e o atingimento de metas vinculadas a demandas sociais.

Para o mesmo autor ${ }^{279}$, os princípios acima enumerados “convergem no princípio do merecimento que, por sua vez, se densifica em diversas regras, algumas delas, é verdade, no âmbito do direito da função pública (concurso, avaliação de desempenho)”. Para ele, no âmbito da função pública, é possível perceber os dois subprincípios antes assinalados: (i) merecimento objetivo no provimento dos cargos públicos e (ii) merecimento no desempenho dos cargos públicos.

\section{Relativamente ao princípio do merecimento objetivo no provimento dos cargos}

públicos, tem-se que a Constituição se ocupa de delinear as hipóteses diante das quais é possível ou não promover uma valoração subjetiva quanto à pessoa de um candidato a cargo público. Obviamente, sempre haverá algum espaço para a subjetividade em relação a determinados cargos, até mesmo porque, “mesmo a definição dos critérios ocorre cercada de juízos pessoais sobre o que deve ou não ser exigido”, sendo certo que “a diferença encontrase sobre o momento e o objeto da valoração subjetiva: se sobre o candidato ou sobre os critérios de escolha deste" ${ }^{280}$.

\footnotetext{
279 Obra citada, p. 141.

${ }^{280}$ Para Nelson Lopes de Figueiredo (O Estado infrator. Belo Horizonte: Fórum, 2012, p. $67-70$ e 73-74), "o preenchimento das funções de confiança e dos cargos em comissão, devido ao desrespeito ou à má-fé das autoridades públicas competentes para provê-los, sempre se constituiu em fonte de irregularidades e ilegalidade”. E mais: “(...) Frequentemente, a Administração Pública vale-se dos cargos em comissão, das contratações temporárias e outros expedientes para protelar a realização de concursos públicos ou frustrar a nomeação de concursados aprovados para os setores contemplados com tais improvisações 'legais', gerando anomalias que reclama a correção judicial mesmo nos domínios antes reservados à intocabilidade da discricionariedade administrativa. (...) Mais lesivo do que a criação desnecessária de cargos em comissão é o abuso que deles fazem as autoridades competentes para o provimento ou preenchimento dos mesmos, 'cujo único interesse é atender os que lhes são mais próximos', como é o caso de alguns parentes. (...) Mas não se esgota nas 'contratações por tempo determinado'irregulares ou anômalas 'consultorias'o degradante catálogo de ilegalidades perpetradas pelo Estado no acesso às funções públicas, algumas de inquestionável relevância. Restam ainda, nesta lista negra, as terceirizações, que são precedidas de licitação regularmente realizada para a contratação de firma fornecedora de mão de obra. Escolhida a firma especializada, é ela que vai selecionar o pessoal para o contrato. Nessa fase surgem todas as espécies de favorecimento, nepotismo, clientelismo, enfim. Porque os titulares do órgão detentor do contrato 'indicam' sutilmente, sem qualquer 'pressão'é claro, pesso-
} 
Saliente-se que mesmo em relação aos cargos de natureza política e aqueles outros de direção, chefia e assessoramento, regidos pela confiança entre agente público e superior hierárquico, o ideal é que se promova um "juízo de adequação entre a capacidade do candidato e as exigências do cargo", mesmo que o critério de merecimento seja valorado subjetivamente.

Em todos os demais casos, o merecimento objetivo deve ser interpretado como regra, seja para provimentos originários seja para provimentos derivados, salvo nas hipóteses excepcionais de livre designação. E assim é porque o merecimento objetivo, imperativo na ordem constitucional brasileira, não permite subjetivismos quanto à pessoa do candidato, atendendo apenas critérios impessoais preestabelecidos.

O merecimento objetivo no provimento dos cargos públicos se relaciona, em primeiro lugar, com a exigência geral de concurso público, instituto no qual está subjacente a ideia de disputa, não só para a seleção dos melhores candidatos, mas também para a correta distribuição dos aprovados nos quadros das administrações públicas conforme os méritos individuais objetivamente avaliados. Em segundo lugar, o princípio diz com a ideia de amplo acesso aos cargos públicos, sendo certo que, em linha de princípio, qualquer cidadão pode almejar um cargo público, desde que preencha os critérios objetivos de seleção, a fim de participar da gestão da coisa pública.

Em resumo, como assinalado por Leonardo Carneiro Assumpção Vieira, “o merecimento é tradução jusadministrativista de critério de organização social, e sua objetividade é instrumental da igualdade e impessoalidade nos provimentos originários ou derivados, de cargos públicos”281.

\section{Relativamente ao princípio do merecimento no desempenho dos cargos públicos,} adverte o mesmo autor, não se permite que o desempenho dos cargos públicos seja tratado como se fosse res derelicta. Cabe deixar transbordar no desempenho das funções públicas as potenciais habilidades verificadas quando do exame de seleção. Deveras, “a finalidade do concurso público não é eleger uma casta de pseudomeritocratas a ser sustentada pelo Esta-

as para serem contratadas para os empregos que vão desde copeiro, auxiliar de limpeza, telefonista, auxiliar administrativo, até advogados ou 'assistentes jurídicos'. Consuma-se pela porta larga da licitação pública, aberta pela ala dos fundos do direito e com finalidades escusas, em escancarada violação aos princípios do concurso público, da legalidade, da moralidade e da impessoalidade, para ficar só nos mais diretamente afrontados, outra aviltante injuridicidade estatal. (...) Aí está a profunda contradição. Por um lado, a onipresença estatal interferindo com técnicas e sofisticação aprimoradas em todos os momentos da vida individual; por outro, o comando do poder e todo esse aparato entregue, nos postos mais elevados dos centros de decisão, a pessoas que possuem a titularidade de qualificações altamente subjetivas: a amizade, o parentesco; o respaldo partidário ou ideológico ou companheirismo político.”

${ }^{281}$ Obra citada, p. 144. 
do a todo custo", e o cargo público "não é monopólio nem daquele que nele se encontra investido, nem da pessoa jurídica na qual se encontra encartado”, sendo conveniente a criação de critérios definidores de hipóteses de perda de cargos públicos, mesmo porque “o respeito ao merecimento implica, também, no respeito à oportunidade que todos os cidadãos possuem de desempenhar um cargo público”282.

Para Leonardo Carneiro Assumpção Vieira, com o advento da hipótese de perda de cargo público por insuficiência de desempenho, inscrita no bojo do art. 41, do Texto Constitucional, bem como com a explicitação do princípio da eficiência no caput do art. 37, seguiram-se algumas esparsas manifestações sobre o dever de desempenho eficiente dos cargos públicos, mas é chegada a hora de perceber que "Estado e servidor não são os únicos polos do merecimento no desempenho dos cargos públicos”, sendo certo que "os cidadãos nesta relação comparecem não como sujeitos passivos destinatários de eventuais serviços, mas como sujeitos de direitos, capazes de atuar juridicamente para conformar a ação estatal garantindo a eficácia dos princípios juridicamente albergados”283.

Com apego à ideia de direito administrativo como sistema em constante diálogo, inclusive, com outras disciplinas do saber humano, mormente as voltadas ao estudo da administração pública, é imperioso pesquisar, no campo das ciências da administração, o tratamento conferido à matéria da impessoalidade como organização administrativa.

Para Mariano Baena del Alcázar ${ }^{284}$, ao tratar da Administração na atual Constituição espanhola, mais especificamente sobre o que chamou de “a Administração do Estado-Organização”, é fato que a Administração depende do Governo, sendo até mesmo possível dizer que no regime anterior se dava uma autêntica confusão entre ambos. Hoje, não. Governo e Administração são tratados em tópicos apartados do texto constitucional espanhol. Segundo os arts. 97 a 102, o Governo dirige a administração civil e militar, o que significa que há um Governo dirigente, distinto da Administração dirigida. A Administração, de acordo com os arts. 103 a 107, de sua vez, é constituída pela “organização subordinada”. E há um elo entre Governo e Administração quando fincadas as figuras dos titulares dos Ministérios, os quais detêm a condição simultânea de membros do Governo e de ocupantes de altos cargos da Administração do Estado.

Também para as ciências da administração, a configuração constitucional repercute,

\footnotetext{
${ }^{282}$ Obra citada, p. 145.

283 Obra citada, p. 146.

${ }^{284}$ Curso de Ciencia de la Administración. Volumen I. 3ª Edición. Madrid: Tecnos, 1993, p. 198-199.
} 
claramente, na organização e na atuação administrativa. Interessa-nos, sobremaneira, a articulação entre ordenação da Administração e princípios constitucionais. Para o autor em questão, à luz do ordenamento espanhol, tem muita importância o disposto no art. 103.1 da Constituição. No seu contexto estão englobadas distintas matérias, tais como a finalidade da Administração Pública, seus critérios de atuação, os princípios de organização e, por último, o princípio fundamental de submissão à lei e ao Direito. ${ }^{285}$ Para ele:

“Junto a las precisiones relativas al fin de la Administración hay que referirse
a los criterios de actuación de la misma. El artículo 103.1 destaca principal-
mente el carácter objetico de la actuación de la Administración pública al
declarar que el servicio a los intereses generales debe hacerse con objetividad.
Esta idea puede interpretarse de modo primario e directo en el sentido de
que la Administración, integrada por funcionarios profesionales según se
desprende del número 3 del artículo 103, debe ser neutral y actuar con
imparcialidad política. Es decir, los administradores públicos no deben
dejarse llevar por criterios partidistas. Sin embargo, una reflexión sobre el
tema demuestra que la objetividad no se reduce ni mucho menos a esto.
Incluye, desde luego, la imparcialidad política pero tiene connotaciones más
amplias. En realidad debe relacionarse precisamente con la profesionalidad
de los administradores. Hay que servir los intereses generales sin atender
criterios de preferencia personal de cualquier índole, sin establecer
discriminación alguna entre los ciudadanos y los grupos, y ateniéndose a
una racionalidad que tenga en cuenta los hechos objetivos, las necesidades
sociales y la línea política que se haya establecido para resolverlas. La
objetividad, por tanto, trasciende ampliamente la neutralidad política de la
Administración pública”.

Em boa síntese, Maria Teresa de Melo Ribeiro ${ }^{286}$ assinala que o respeito pelo princípio da imparcialidade (aqui entendida como impessoalidade) pressupõe que a Administração Pública esteja organizada de modo a permitir o exercício imparcial (lemos: impessoal) da função administrativa e pressupõe que existam condições legais e institucionais capazes de garantir e de promover o desenvolvimento imparcial (impessoal) da função administrativa.

\footnotetext{
${ }^{285}$ Para o autor espanhol da ciência da administração (obra citada, p. 199): "Debe insistirse algo más en el primer punto, que no se refere sólo a la dependencia de la Administración respecto al Gobierno. Es claro que además de ser dirigida por este y por ese mismo hecho, la Administración pública no existe por sí misma, no cumple unos fines que sean exclusivamente los propios. Es una instancia subordinada que no puede existir sino en función de los intereses y necesidades de toda la colectividad. Se trata, por tanto, de un complejo orgánico que articula al conjunto de medios necesarios para que la colectividad subsista".

${ }^{286}$ Obra citada, p. 283.
} 


\section{CAPÍTULO 3 - IMPESSOALIDADE NA SEARA ADMINISTRATIVA DECISÓRIA}

Nesta fase do trabalho a ideia é conceber uma impessoalidade específica para fins de parametrização das decisões administrativas, o que só se entremostra possível mediante a cogitação de garantias e requisitos necessários para um decidir administrativo impessoal.

Também é escopo do capítulo apresentar implicações da impessoalidade nas decisões administrativas e as consequências da quebra do princípio. Finalmente, o capítulo concebe uma tentativa de sistematização da matéria a partir de técnicas para a adoção de decisões administrativas impessoais.

\subsection{Decisão administrativa impessoal}

A identificação de um conteúdo autônomo para o princípio da impessoalidade no Brasil - que sirva de parâmetro para uma atuação administrativa decisória juridicamente hígida e responsável - passa pelo reconhecimento do interesse público em cada caso concreto.

Ana Paula Oliveira Ávila ${ }^{287}$, com apoio em Humberto Ávila, esclarece que “o interesse público somente restará definido após um processo de ponderação concreta e sistematicamente orientada, com padrões de decisão flexíveis e adaptáveis a cada caso concreto, dos interesses públicos com todos os demais interesses individuais que residam nas circunstâncias do caso concreto". Em percuciente observação, a autora revela que "sendo o interesse público o resultado dessa operação de ponderação, produzido, portanto, ao final, sua determinação ocorre sempre a posteriori $e$ in concreto, e nunca a priori $e$ in abstrato”.

Decisão administrativa impessoal é, pois, aquela que se apresenta como produto de uma criteriosa iteração entre os interesses envolvidos numa disputa.

Mais uma vez recorrendo ao escólio de Ana Paula Oliveira Ávila ${ }^{288}$, alicerçado em Humberto Ávila, “a interpretação dos casos concretos deve ser direcionada não para uma principal prevalência, mas para a máxima realização dos interesses envolvidos”.

A propósito, Humberto Ávila ${ }^{289}$ refere-se a um caso do STF em que o Min. Luiz

\footnotetext{
${ }^{287}$ Obra citada, p. 132.

${ }^{288}$ Obra citada, p. 132.

${ }^{289}$ Repensando o “Princípio da Supremacia do Interesse Público sobre o Particular”. In: Interesses públicos versus interesses privados: desconstruindo o princípio da supremacia do interesse público. Rio de Janeiro: Editora Lumen Juris, 2005, p. 193.
} 
Galloti, decidindo sobre a suspensão de obra pela autoridade administrativa, reconheceu a importância de terceiros de boa-fé, em função dos quais "é necessária uma ponderação multipolar, precisamente porque os interesses devem ser preservados por meio de uma decisão unitária”290. Correto Humberto Ávila ${ }^{291}$ quando assinala, a respeito de não existir uma regra geral, hipotética, de prevalência de interesses públicos, que:

“Da constatação de que os órgãos administrativos possuem em alguns casos
uma posição privilegiada relativamente aos particulares não resulta, de modo
algum, na corroboração da supremacia do interesse público sobre o interes-
se particular. Essa posição indica, tão só, que os órgãos administrativos exer-
cem uma função pública, para cujo ótimo desempenho são necessários de-
terminados instrumentos técnicos, devidamente transformados em regras
jurídicas. E essas regras procedimentais (não regras que instituem finalida-
des) decorrem tanto das normas constitucionais como do desinteresse pes-
soal que define a função administrativa ('Selbstlösigkeit'). ISENSEE bem
o afirmou: ‘À liberdade dos cidadãos corresponde a vinculação normativa
dos funcionários públicos’. Isso tudo não tem nada a ver com uma regra
geral de prevalência”.

A nosso sentir, em vínculo direto com a ideia de impessoalidade como ponderação dos interesses envolvidos em disputas concretas, com interdição do querer subjetivo do julgador (decisor), Humberto Ávila ${ }^{292}$ é cortante:

“A constatação de que os funcionários não representam interesses outros
além do público não resulta do interesse público propriamente dito (defini-
do, aliás, pela finalidade), mas do desinteresse, por sua vez reconduzido à
função pública e ao princípio republicano. E é o princípio republicano que
estrutura o bem público, a ser constatado no direito positivo”.

O desinteresse do funcionário público referido tem o nítido sentido de impessoalidade. Não é o desinteresse na "justa solução do caso concreto”, mas sim no encaminhamento de decisões dotadas de subjetivismos, predileções e preferências pessoais do julgador.

${ }^{290}$ Confira-se o voto do Min. Gallotti, acima citado por Humberto Ávila: “Os parágrafos do citado artigo 305 (CPC), embora referentes à hipótese de demolição, claramente traduzem o espírito da lei, no sentido de conciliar o interesse público com os demais interesses em causa, ordenando que a construção não seja demolida, mesmo quando contrária às condições legais, se por outro meio se puder evitar o dano ao bem comum".

${ }^{291}$ Repensando..., p. 201.

${ }^{292}$ Repensando..., p. 201. 
Floriano de Azevedo Marques Neto 293 assinala que “não passa de um dogma a formulação de que exista um só interesse público a motivar, no caso concreto, a atuação estatal”. Com apoio em Gaspar Ariño, ensina que:

\begin{abstract}
“Há sempre uma miríade de interesses relevantes, muitas vezes conflitantes, a disputar a ação estatal. Se é possível um controle negativo (ou seja, a verificação de que a um dado interesse não corresponde uma relevância justificadora de uma ação estatal - portanto, a verificação de que se trata de um interesse não público), de outro lado não é possível se aferir o que ou qual seja o interesse público único, singular, que justifique a intervenção estatal na esfera privada. Mas o discurso do interesse público é dependente dessa noção de singularidade, pois sem ela teria de assumir que toda ação do poder público demanda, previamente, uma arbitragem de interesses. O que enfraqueceria a sua função legitimadora e operacional”.
\end{abstract}

Assume especial relevância, no particular, a rememoração da distinção que é própria da doutrina portuguesa, entre as vertentes negativa e positiva do princípio da imparcialidade ${ }^{294}$.

Na vertente positiva, relembre-se a lição de Diogo de Freitas do Amaral ${ }^{295}$, com significado de dever, por parte da Administração Pública, de ponderar todos os interesses públicos secundários e os interesses privados legítimos, equacionáveis para o efeito de certa decisão, antes da sua adoção. Ou seja, “devem considerar-se parciais os actos ou comportamentos que manifestamente não resultem de uma exaustiva ponderação dos interesses juridicamente protegidos".

Merece nova menção a posição de José Eduardo Figueiredo Dias e Fernanda Paula Oliveira ${ }^{296}$, para os quais o princípio da imparcialidade visa “assegurar que nas decisões administrativas se tenham em consideração todos os interesses públicos e privados relevantes, e só estes (princípio da ponderação de interesses), de modo a evitar que a prossecução de um interesse público se confunda com quaisquer interesses privados com que a actividade administrativa possa contender ou possa se envolver”.

\footnotetext{
${ }^{293}$ Interesses públicos e privados na atividade estatal de regulação. In: Princípios de direito administrativo: legalidade, segurança jurídica, impessoalidade, publicidade, motivação, eficiência, moralidade, razoabilidade, interesse público. Thiago Marrara (org.). São Paulo: Atlas, 2012, p. 425.

${ }^{294} \mathrm{~V}$. item 2.3.5 infra.

${ }^{295}$ Curso, p. 152-159.

${ }^{296}$ Obra citada, p. 107 e seguintes.
} 
E também a interpretação de Marcelo Rebelo de Souza e André Salgado de Matos ${ }^{297}$, no sentido de que, modernamente, imparcialidade deve ser entendida como "comando de tomada em consideração e ponderação, por parte da administração, dos interesses públicos e privados relevantes para cada concreta actuação sua”.

Uma decisão administrativa impessoal precisa considerar o que Paulo Otero ${ }^{298}$ chamou de “adequação ponderativa dos interesses relevantes para a decisão”, devendo o decisor “tomar sempre em consideração todos esses interesses, excluindo do seu âmbito, no entanto, todos os interesses que se mostram inapropriados ou irrelevantes face à situação concreta a decidir”. E mais: “em termos positivos, a imparcialidade determina parâmetros racionais, objetivos, lógicos e transparentes de decisão, visando a que se tomem em consideração ponderativa todos os fatores ou elementos relevantes para a decisão, assim como excluir de ponderação quaisquer interesses alheios ou irrelevantes”.

Devem ser rememoradas, nesta ocasião, sem desdouro para outras, as contribuições dadas à matéria pela doutrina italiana ${ }^{299}$.

Relembre-se Domenico Sorace ${ }^{300}$, de acordo com quem o princípio da imparcialidade merece construção concreta, à luz dos diversos interesses envolvidos em cada caso. E para quem a Administração atua para satisfazer os interesses públicos primários, devendo estar atenta para todos os outros tipos de interesses relevantes, sejam públicos ou privados, a fim de que a sua decisão corresponda a uma composição dos diversos interesses em jogo, extraindo a máxima utilidade de todos eles e sem o descarte de qualquer um. Nas palavras de Sorace, “naturalmente, se o interesse público deve, em definitivo, ser construído em concreto, tendo em conta os diversos possíveis interesses em jogo, tais interesses devem ser apreciados de forma adequada".

E também Merloni ${ }^{301}$, para quem a Administração não pode discriminar algum interesse em prejuízo de outro, garantindo paridade de tratamento e dando concretude ao princípio da igualdade, formal e substancialmente considerada, como direito a um "justo procedimento” e a uma "boa administração".

E Maurizio Asprone ${ }^{302}$, para quem a imparcialidade, longe de significar neutralidade ou

\footnotetext{
${ }^{297}$ Obra citada, p. 216.

${ }^{298}$ Manual..., p. 373-374.

${ }^{299} \mathrm{~V}$. Itens 2.3.6 e 2.8, infra.

${ }^{300}$ Obra citada, p. 67.

${ }^{301}$ Obra citada, p. 36-8.

302 Obra citada, p. 61.
} 
indiferença em relação aos interesses envolvidos na atividade administrativa, quer dizer o uso correto do aparato administrativo para alcançar as finalidades previstas em lei, sem que haja a prevalência de um interesse que favoreça a Administração em confronto com a ordem jurídica e que, de antemão, condicione as escolhas administrativas. Em razão do que a Administração deve maximizar o interesse público entregue à sua tutela, conciliando-o com outros interesses públicos e privados envoltos na mesma seara administrativa (interesses secundários).

Relembre-se ainda Monteduro ${ }^{303}$, que, ao tratar das dimensões da imparcialidade, incluiu na imparcialidade positiva ou inclusiva uma abertura institucional da Administração Pública para considerar e comparar todos os interesses envolvidos e protegidos pela ordem jurídica em concreto, na busca de equilíbrio na composição de interesses.

Merece destaque retrospectivo a posição doutrinária de Sabino Cassese ${ }^{304}$, para quem a Administração, ao decidir, tem a obrigação de realizar, de modo objetivo, uma análise comparativa dos interesses em jogo, considerando os efeitos e possíveis resultados de sua tutela.

Decisão administrativa impessoal só se obtém assim: mercê de uma mui criteriosa avaliação, por parte do julgador, de todo e qualquer interesse legítimo, público e/ou privado, envolvido na espécie. Sem preconceitos e pré-compreensões. Sem preferências ou predileções prévias. Em suma, sem subjetivismos. Tudo a ser apurado com seu peso e com a sua importância. Com método e cientificidade.

Em síntese lapidar, consolidando ideias até aqui reveladas, Humberto Ávila alcança a seguinte conclusão, com a qual concordamos às inteiras:

“...se o ordenamento jurídico regula justamente uma relação de tensão ('Spannungsverhältnis') entre o interesse público e o particular, bem exemplificada pela repartição de competências nos vários níveis estatais e pelo contraponto da instituição de direitos fundamentais, por sua vez só ajustável - com a ajuda de formas racionais de equidade - por meio de uma ponderação concreta e sistematicamente orientada, então a condição racional para o conhecimento do ordenamento jurídico deve ser outra, precisamente consubstanciada no 'postulado da unidade da reciprocidade de interesses ('Gegenseitigkeitspostulat'). Ou nas palavras de LAUDER:

'Ponderação de bens é uma figura dogmática que não mais submete os di-

\footnotetext{
${ }^{303}$ Obra citada, p. 305-366.

${ }^{304}$ Il diritto amministrativo e i suoi principi. In: Corso di Diritto Amministrativo diretto da Sabino Cassese. 1. Instituzioni di Diritto Amministrativo a cura de Sabino Cassese. $4^{\mathrm{a}}$ ed. Milano: Giuffrè Editore, 2012, p. 13- 14.
} 
reitos e limites imanentes e explícitos, isto é, a regras de preferências estáveis (p. ex. em favor do interesse público), mas procura trabalhar situativa e estrategicamente um complexo, uma conexão de interesses de generalização limitada, sobretudo por meio da formulação de standards ou de valores flexíveis"”. 305

\subsection{Decisão administrativa impessoal versus decisão judicial imparcial}

Antes de trilhar o tema das garantias e dos requisitos para a adoção de decisões administrativas impessoais, necessário fazer uma distinção - sumária que seja - entre julgamentos realizados no Poder Judiciário e no Poder Executivo.

Na seara decisória, a impessoalidade administrativa não é idêntica à impessoalidade jurisdicional, mais comumente chamada de imparcialidade judicial. E assim é porque, no processo administrativo, a Administração é parte. No processo judicial, o juiz não é parte, mas sim terceiro (sujeito imparcial), totalmente desinteressado do objeto da disputa, do litígio propriamente dito.

Isso não quer significar que a Administração, porque é parte, deva julgar a causa segundo os seus interesses unilaterais, nem sempre conectados com o justo, com o interesse primário. Muito ao contrário, guardando subserviência ao princípio da impessoalidade, a decisão administrativa, como se disse, deve ser fruto de uma conciliação ponderada de todos os interesses, legítimos e relevantes, públicos ou privados, envolvidos num dado processo administrativo.

No processo administrativo, muito embora a Administração seja simultaneamente parte e julgadora, é necessário que a Administração assuma uma condição de "parte imparcial”, sem o que a impessoalidade administrativa restará afrontada.

Na doutrina do Direito Público parece insuperável o trabalho desenvolvido por Umberto Allegretti ${ }^{306}$ sobre o papel da Administração Pública como “parte imparcial”. Ao tratar da situação da Administração Pública como parte, frente ao dever de imparcialidade (impessoalidade para nós), o autor revela que sua atuação está relacionada à busca de concretizar as finalidades públicas (interesse público primário).

Segundo Allegretti, é necessário compreender o sentido da aparente contradição que

${ }^{305}$ Repensando..., p. 202-203.

${ }^{306}$ L'imparzialità amministrativa. Padova: CEDAM, 1965. 
se manifesta na visão da Administração como, ao mesmo tempo, parte e ente que tem na imparcialidade um dever de conduta. A contradição está expressa na constatação de que com a atribuição à Administração do caráter de imparcialidade, há hipoteticamente a renúncia da manutenção de todo rigor da posição de parte. Isso porque tal posição implica, ao menos idealmente, a orientação de perseguir os seus próprios interesses.

Allegretti defende que, na condição de parte, não é possível falar em Administração Pública desinteressada. O que dá azo à seguinte questão central: - Como compatibilizar a ideia de atuação parcial (como parte) com o dever de imparcialidade?

De acordo com o autor, a imparcialidade administrativa, nesse contexto, representa a qualificação da posição da Administração Pública frente à pluralidade de partes intervenientes em relação a um dado ato administrativo, atribuindo a estas uma paridade de situação. Em tal perspectiva, a Administração Pública deve portar-se como uma "parte garantidora da igualdade”, em respeito à situação recíproca dos vários sujeitos privados. É imparcial porque não deve direcionar sua conduta com base em favoritismos ou subjetivismos, mas, ao contrário, "deve avaliar e sopesar todos os interesses concorrentes para a conformação de sua função de concretizar o interesse público (primário)”.

Ao ferir especificamente o tema da evolução e da aplicação da imparcialidade na atuação administrativa, revela Allegretti que a mais tradicional e remota aplicação do princípio da imparcialidade diz respeito à separação entre os interesses privados do agente público e as finalidades públicas. Nesse contexto, faz-se necessário o desenvolvimento de instrumentos jurídicos de controle que impeçam a subjetivização da atividade administrativa.

E a segunda aplicação do princípio da imparcialidade, mais ampla, volta-se à necessidade de eliminação da politização da Administração Pública. Para o autor, trata-se de um dos maiores problemas do Estado contemporâneo. O sentido da imparcialidade nessa perspectiva é o de salvaguardar a atuação administrativa na busca pelas finalidades públicas, ou seja, o de evitar que a Administração Pública se ponha a serviço de interesses particulares (partidos políticos, grupos econômicos etc.).

Allegretti tem posição bastante interessante quanto à neutralidade política da Administração Pública. De acordo com o autor, a Administração deve se manter neutra diante dos interesses particulares de grupos e indivíduos. Entretanto, “tal neutralidade não pode ser confundida com inércia ou indiferença, mas deve ser compreendida como uma abertura que permita aos particulares terem suas posições subjetivas avaliadas e valoradas pela Adminis- 
tração na busca pela conformação do interesse público”. Para tanto, a abertura desse “caminho de participação” dos administrados na organização administrativa é fundamental.

Allegretti compreende, em síntese, que ao contrário das outras partes que integram o jogo sociopolítico (partidos, empresas, grupos), a Administração Pública deve ter uma preocupação maior com sua atuação de forma justa (o que o autor chama de justiça da parte), em consonância com os valores que formam o ordenamento jurídico, devendo conceber critérios para garantir a imparcialidade administrativa, dentre os quais: (i) paridade de tratamento; (ii) proporcionalidade; (iii) motivação suficiente; (iv) controle dos motivos; (v) exata cognição dos fatos etc.

Em sistematização incomparável, Allegretti afirma que Administração Pública como “parte imparcial” significa que ela deve buscar concretizar o interesse público, agindo de forma unilateral e direta, orientando-se pelos fins estabelecidos pelo ordenamento jurídico. Entretanto, o caráter imparcial atribuído à função administrativa impõe o dever de a Administração Pública não se fechar em si, mas, ao contrário, atentar para todos os outros interesses envolvidos em sua atividade.

O autor também ressalta que a atuação administrativa tem de ser comprometida com a justiça e com os fins da ordem jurídica. Em suas palavras, em tradução livre:

\footnotetext{
“A imparcialidade não indica uma posição superior àquela de parte; a condição de imparcialidade da Administração Pública, como comando normativo, revela a 'justiça de parte’ e a solidariedade na proteção dos fins gerais do ordenamento e das posições legítimas de outras partes. Na essência, a imparcialidade não implica a ausência de fins ou da posição de parte, mas veda o comportamento parcial” (favoritismo, subjetivismo, etc.).
}

Allegretti defende que os fins gerais da Administração Pública estão previstos pela ordem jurídica. E considerando que esta protege uma pluralidade de situações jurídicas legítimas, a atuação administrativa deve se pautar pela composição da complexa variedade de interesses e posições diversas.

Assim, o interesse público primário é reflexo de tal composição, sendo fundamental para a concretização do princípio da justiça, qual seja, fazer prevalecer em concreto os interesses de maior valor.

Para o autor, "bom andamento” e "imparcialidade” são princípios norteadores da atividade administrativa. O primeiro refere-se à vinculação da Administração ao seu fim primá- 
rio. Já a imparcialidade impõe o dever de respeito e proteção aos interesses secundários, de forma concomitante à busca de materializar o interesse público (fim primário).

Allegretti identifica como importantes implicações de tal concepção de parte imparcial: a) Limitação e condicionamento da discricionariedade administrativa: ponderação, de forma objetiva, das situações jurídicas envolvidas pela ação administrativa; b) Procedimentalização da atuação administrativa: meio de controle dos atos da Administração e abertura à participação do administrado.

Ao traçar as (pálidas) fronteiras entre "imparcialidade administrativa” e "imparcialidade judicial”, o autor ressalta que tanto a atividade jurisdicional quanto a atividade administrativa têm no ordenamento jurídico sua conformação, seu condicionamento, sua limitação.

Todavia, o juiz deve atuar como terceiro desinteressado (terzietá). A imparcialidade judicial repousa na identificação do juiz como sujeito estranho aos interesses e direitos das partes. Ele não atua na realidade concreta, mas a examina e a aprecia de fora e ex post.

E a Administração Pública, por sua vez, é responsável institucionalmente por iniciativas e resultados concretos. Diante desse quadro, não é possível falar que a atividade administrativa seja marcada pelo desinteresse e pela neutralidade. A sua atuação na busca pelo interesse público primário a reveste da característica de parte no jogo sociopolítico. Isso não significa que a Administração deva se fechar em si mesma. Dito mais uma vez, o caráter de imparcialidade a ela atribuído impõe o dever de avaliar e sopesar os interesses e posições subjetivas envolvidos na atuação administrativa.

O autor assegura que a concepção ampla de imparcialidade a que está submetido o poder jurisdicional não se confunde, portanto, com a imparcialidade administrativa, já que a Administração Pública possui finalidades concretas a serem alcançadas. E na busca de concretizar suas finalidades a Administração Pública deve atuar de forma imparcial, que deve ser entendida como atuação com base em critérios objetivos e solidária com os demais interesses em jogo.

\subsection{Garantias e requisitos para adoção de decisões administrativas impessoais}

Como asseverado por Marcelo Rebelo de Sousa e André Salgado de Matos ${ }^{307}$, a mera

${ }^{307}$ Direito Administrativo Geral - Tomo I - Introdução e princípios fundamentais. $3^{\mathrm{a}}$ ed. Alfragide (Portugal): D. Quixote, 2010, p. 217. 
prescrição do princípio não chega a garantir o seu acatamento, como sucede com qualquer outra norma jurídica. No caso da imparcialidade (ora lida como impessoalidade), a violação “tem como traços característicos a dificuldade de prova e, sobretudo, na sua dimensão negativa, o facto de depender frequentemente de circunstâncias relativas, não à administração em sentido orgânico, mas às pessoas singulares que em concreto são agentes ou titulares de órgãos administrativos”.

Cogita-se, assim, de garantias preventivas de impessoalidade, de mecanismos tendentes a assegurar que os titulares de órgãos ou agentes administrativos não se comportem de modo parcial. As garantias implicam impedimentos e suspeições. David Duarte ${ }^{308}$, propugnando por uma maior concretização do princípio da imparcialidade, no trabalho tomado como impessoalidade, como parâmetro decisório, realça a importância da procedimentalização, da participação e da fundamentação.

O ordenamento jurídico deve dotar a Administração Pública de garantias e requisitos para uma natural adoção de decisões administrativas impessoais. Já se disse que um decidir naturalmente impessoal passa, necessariamente, por uma organização administrativa inteligente, por uma Administração Pública estruturada de forma a permitir que decisões impessoais sejam decisões corriqueiras, comuns.

Para que isso ocorra é necessário, por exemplo, que o julgador (decisor) seja uma pessoa qualificada e motivada. De preferência, servidor efetivo, menos infenso a pressões ilegítimas. Por outro lado, o decisor não pode nutrir interesse primário sobre o objeto do litígio, isto é, não pode ser suspeito ou impedido.

Tanto quanto possível, também devem ser estabelecidas rotinas administrativas estáveis, baseadas em critérios objetivos. Procedimentos ad hoc e critérios subjetivos conduzem mais facilmente a resultados vedados e, por isso mesmo, devem ser rechaçados.

Se possível, devem ser produzidas súmulas administrativas sobre matérias repetitivas. E devem ser trilhados procedimentos para a eliminação de burocracias inúteis ou despropositadas.

Um bom instrumento para a parametrização de decisões administrativas é o parecer normativo. Segundo Odete Medauar ${ }^{309}$, os pareceres vinculantes "são emitidos em casos em que a norma exige consulta prévia a órgão jurídico ou técnico, cuja manifestação, expressa

\footnotetext{
${ }^{308}$ Procedimentalização, participação e fundamentação: para uma concretização do princípio da imparcialidade administrativa como parâmetro decisório. Coimbra: Almedina, 1996.

${ }^{309}$ Direito Administrativo Moderno..., p. 437.
} 
em parecer, deve nortear obrigatoriamente a decisão a ser tomada”. Neste caso, leciona a Professora, “a autoridade somente poderá decidir no sentido do parecer, restando-lhe a alternativa de não editar o ato, se for possível, ou solicitar novo parecer". No seu balizado entender, "além da função consultiva, o órgão que emite o parecer vinculante exerce, assim, função de controle preventivo”.

Além das garantias acima reveladas, a decisão administrativa impessoal depende de alguns outros requisitos, tão ou mais importantes.

Na doutrina de Juan Alfonso Santamaría Pastor ${ }^{310}$, as bases constitucionais do direito administrativo espanhol estão relacionadas a 4 (quatro) cláusulas: a) Estado de Direito; b) Estado Social; c) Estado Democrático; e d) Estado Autônomo.

Na cláusula do Estado de Direito (“a”, supra), estão inseridos os princípios da (i) legalidade e da (ii) tutela judicial. Na cláusula do Estado Social (“b”, supra), (i) o princípio da eficiência e (ii) os poderes públicos. Na cláusula de Estado Democrático (“c”, supra), estão contidas as matérias relativas: (i) à submissão às instâncias públicas; (ii) organização hierárquica; (iii) os critérios de objetividade e imparcialidade; (iv) outras diretrizes constitucionais de alcance limitado, dentre as quais: a) o princípio da publicidade; b) a ideia de participação. Finalmente, na cláusula do Estado Autônomo (“d”, supra), os princípios: (i) da autonomia; (ii) da unidade; (iii) da solidariedade.

Para os fins desta tese, interessa-nos a cláusula do Estado Democrático. Importa tratar das “outras diretrizes” constitucionais da cláusula em questão, nomeadamente, sobre o princípio da publicidade e sobre a ideia de participação. Isto porque, para a ideal aplicação do princípio da impessoalidade, são imprescindíveis publicidade e participação.

Na obra de Santamaría Pastor ${ }^{311}$, ambas as diretrizes são rotuladas como de alcance limitado, o que, a nosso ver, não desnatura a força das suas ideias.

Para o autor, "en nuestros días, las ideas de publicidad y secreto evocan, de forma intuitiva, las instituciones políticas democráticas y autocráticas, respectivamente”. Porque:

\footnotetext{
"La democracia es un sistema que se presupone, por definición, transparente: el poder y sus órganos, se piensa, no deben tener apenas secretos para los ciudadanos, por lo mismo que éstos son los auténticos titulares y 'propietarios' de aquél. Es notorio, por otra parte, que los sistemas autoritarios
}

${ }^{310}$ Obra citada, p. 51 a 107.

${ }^{311}$ Obra citada, p. 84. 
o totalitarios tienden naturalmente a levantar un velo impenetrable de misterio sobre la actuación de sus poderes: el secreto y la opacidad, ciertamente, incrementan la eficacia de las técnicas de dominación e control social”. ${ }^{312}$

Sobre a ideia de participação, mais uma vez demonstrando ceticismo, o autor ensina que:

“La defensa de una ‘participación ciudadana en la Administración’ fue un
auténtico lema defendido con entusiasmo por determinadas fuerzas políti-
cas de algunos Estados europeos durante la segunda mitad del siglo XX: un
banderín ideológico que trató de abrirse paso los en los textos constitucionales
y en la legislación ordinaria presentándose como el principal vehículo de
‘democratización’ y ‘revitalización’ de las estructuras administrativas”.

Para Santamaría Pastor:

“No es fácil describir cuál fuera el contenido práctico de este lema, en el que durante muchos años cupo todo o casi todo. Su propuesta básica consistía en la inserción de determinadas organizaciones privadas (pero mayoritariamente controladas e dirigidas por grupos políticos: sindicatos, asociaciones de vecinos, asociaciones de consumidores, grupos ecologistas) en las organizaciones administrativas, promoviendo su participación activa en determinados tipos de procedimientos; en ambos casos, con objeto de tomar parte en los procesos de toma de decisiones públicas, complementando la actividad desarrollada por los políticos y los miembros de la burocracia profesional, y con el objetivo final, más o menos declarado, de sustituir a unos y otros”.

O ceticismo advindo da leitura crítica da realidade espanhola não impediu o autor de ter a isenção doutrinária necessária para reconhecer que, na pureza teórica, o movimento de ampliação da participação do cidadão na tomada de decisões tinha razão de ser. Confira-se:

"Es necesario reconocer que el fundamento teórico de este movimiento era impecable. Desde un planteamiento estrictamente democrático, se partía de indiscutible fenómeno de obsolescencia de los esquemas clásicos de la democracia liberal: la representación del pueblo se había confiado originariamente a unas instituciones (los parlamentos) que se bien habían sido los detentores reales del poder en los primeros tiempos, se hallaban sumidos en 
una profunda crisis, consecuencia del desplazamiento efectivo de dicho poder a los Gobiernos, a las Administraciones y, dentro de ellas, a la alta burocracia, seleccionada de acuerdo con criterios de mérito y competencia técnica, pero supuestamente alejada de las necesidades y aspiraciones del pueblo al que decían servir. La ‘devolución del poder al pueblo’ parecía exigir, pues, la participación de nuevas organizaciones sociales ‘espontáneas’ en los centros de decisión real de la vida política, las estructuras administrativas”.

Para o autor, não há uma relação exaustiva de mecanismos de participação, sendo mais relevantes: a) Fórmulas orgânicas, mediante a incorporação de membros representantes das organizações sociais nos órgãos administrativos, consultivos ou mesmo decisórios; b) Fórmulas de participação procedimental que garantam a oitiva das organizações antes da tomada de certas decisões e, se possível, com a substituição da forma clássica de decisão unilateral por técnicas de consenso, negociação e conciliação coletiva; c) Fórmulas de participação processual, conferindo às associações legitimidade para bater as portas do Judiciário questionando atos produzidos em procedimentos administrativos revestidos de significação coletiva.

No seu entender, a participação do cidadão não pode ser elencada como princípio constitucional. Em primeiro lugar porque o próprio texto constitucional espanhol se mostrou bastante cauteloso ao não se referir expressamente ao princípio que, deveras, não aparece mencionado no art. 103 nem em qualquer outro preceito de caráter geral. O legislador constituinte aceitou-o apenas em âmbitos organizativos ou funcionais concretos das Administrações Públicas, como: a) Art. 20.3 - meios de comunicação social dependentes do Estado; b) Art. 27.7 gestão de centros educativos sustentados com recursos públicos; c) Art. 51.2 - questões relativas a consumo; d) Art. 105.a - procedimento de elaboração de regulamentos; e) Art. 129.1 gestão da seguridade social; f) Art. 131.2 - projetos de planificação econômica.

A seu ver não se pode falar, no ordenamento espanhol, de um princípio constitucional de participação administrativa como uma diretiva vinculante de alcance geral, que obrigue os poderes públicos a implantarem técnicas participativas em todos os âmbitos das Administra-

\footnotetext{
${ }^{312}$ Para o autor espanhol, disso não se tira a conclusão simplista de que as Administrações dos países democráticos não possam guardar algum tipo de segredo diante dos cidadãos. A solução está no equilíbrio. Há coisas que podem ser divulgadas e outras que não podem. E há coisas que podem ser públicas para certas pessoas e para outras não. No caso espanhol, segundo afirma, a necessária regulação do tema, bastante complexo em si mesmo, é fragmentária e deficiente (Obra citada, p. 85).
} 
ções Públicas, mas pode-se dizer que a participação é, sim, “una línea de actuación posible y lícita en el marco de un Estado democrático”.

Cremos que, no direito brasileiro, a participação do cidadão na tomada de decisão pode ser recebida com menos ceticismo. Do contrário, o princípio da impessoalidade sofrerá algum abalo na sua concretização ideal.

Para assegurar a impessoalidade nas decisões administrativas, devem ser observados ao menos três deveres fundamentais: a) Fundamentação; b) Processualização; c) Participação do administrado.

Tais deveres se vinculam reciprocamente. A fundamentação de decisões relevantes deve ter lugar em ambiente processual no qual é assegurada a participação do administrado. A processualização, de sua vez, existe para assegurar participação do administrado e fundamentação. E a participação do administrado implica processo e fundamentação.

Em alguns setores, impensável a tomada decisões sem a observância dos três deveres fundamentais acima referidos. Pense-se, por exemplo, em atos administrativos decisórios de cunho sancionador. Embora considerando que tais deveres são relevantes para todas as decisões administrativas significativas, nos procedimentos voltados à imposição de sanções parece haver importância maior.

Em artigo intitulado “O Estado de Democrático de Direito e os seus castigos: uma reavaliação do ato sancionador”, Demian Guedes ${ }^{313}$ destaca a importância da processualidade, do contraditório participativo e da motivação. Assinala que "a análise da legitimidade dos castigos oficiais não se limita ao contraste do ilícito com a legalidade”. Segundo ele, “passa também pela forma como a pena é aplicada pelo Estado, i.e., por uma avaliação do processo utilizado para identificar a ocorrência do ilícito, atribuir responsabilidades e aplicar sanções”314.

E assim é porque, conforme manifesta o autor, "na contemporaneidade, o direito administrativo não pode ser ocupar apenas com os resultados da ação administrativa, deve alcançar os seus instrumentos de atuação" 315 . No campo da aplicação de sanção administrativa, "um mal imposto conscientemente pelo Estado a um particular", ensina Demian Guedes ${ }^{316}$, “a relação entre Administração e cidadão se encontra em crise, com pretensões

${ }^{313}$ In: Os caminhos do ato administrativo/ Odete Medauar, Vitor Rhein Schirato (organizadores). São Paulo: RT, 2011, p. 285-308.

${ }^{314}$ Obra citada, p. 297.

315 Obra citada, p. 297.

${ }^{316}$ Obra citada, p. 299. 
diametralmente opostas”, prejudicando-se a desejável composição harmônica dos litígios e abrindo-se margem, por conseguinte, à incidência de garantias voltadas à preservação do primado dos direitos fundamentais. Por tais razões explica que "hoje é livre de divergências a impossibilidade de sanções sem processo - sem que se estabeleça entre Estado e particular um diálogo acerca da pretensão punitiva, sua validade e consequências”.

- E nas decisões administravas em geral? É diferente?

A nosso ver, não. Pelo menos nas decisões relevantes incidentes sobre interesses de administrados individual ou coletivamente considerados.

\subsubsection{Dever de fundamentação (motivação)}

A decisão administrativa relevante, para ser impessoal, deve conter fundamentação suficiente. Tal exigência, como consectário lógico do Estado Democrático de Direito, é inegociável.

Tanto quanto possível, a decisão administrativa deve ser convincente em relação às partes e em relação a terceiros. Ao mesmo tempo, serve para demonstrar que o decisor não nutriu interesse pessoal sobre o objeto do litígio.

Em tema de fundamentação das decisões, parece lícito aproveitar a excelência do desenvolvimento da matéria à luz da doutrina do processo judicial. Mesmo diferentes entre si, há aproximações relevantes entre a decisão administrativa e a decisão judicial.

Em obras de Teoria Geral do Processo, como um dos requisitos formais da sentença a fundamentação (ou motivação) ocupa lugar de destaque. Para Carreira Alvim¹7, a fundamentação "é a parte da sentença onde o juiz examina e conhece da pretensão das partes litigantes; as questões de fato e as questões de direito que lhes socorrem; enfim, exterioriza as razões que o convenceram do acerto ou desacerto das teses sustentadas pelas partes”. Noutras palavras, por meio da sentença "o juiz dá os fundamentos de fato e de direito que lhe formaram a convicção".

Interessante notar, na Teoria Geral do Processo, que a motivação também é um pressuposto objetivo do recurso. Ao recorrer, é fundamental apontar as razões de fato e de direito que implicam discordância em relação aos termos da decisão recorrida ou que justificam a pretensão de reforma.

${ }^{317}$ Elementos de teoria geral do processo. $7^{a}$ Ed. Rio de Janeiro: Forense, 1997, p. 259. 
E assim é porque o recurso só pode ter como fundamento um error in iudicando ou um error in procedendo. O primeiro erro, relacionado a uma má apreciação dos fatos ou da regra jurídica correspondente, conduz a uma decisão “injusta”. O segundo, ligado à violação de norma processual em acepção ampla, conduz a uma decisão “errada”. Em face de um “erro de julgamento” pleiteia-se, no recurso, a “reforma” da decisão “injusta”. Em caso de erro de procedimento postula-se a “cassação” da decisão "errada”.

Em trabalho sobre o dever de fundamentar as decisões judiciais sob o ângulo do direito processual civil, Sérgio Nojiri ${ }^{318}$ assinala que tal obrigação é também uma garantia. Para o autor, “quando o jurisdicionado suspeitar que o magistrado decidiu contra a lei, desrespeitando direitos fundamentais ou extrapolando suas funções institucionais, deverá buscar na fundamentação subsídios para aferir a qualidade da atividade jurisdicional prestada”.

Ao mencionar as consequências da falta de fundamentação da decisão judicial, Nojirii ${ }^{319}$ assinala como defeitos correntes na atividade jurisdicional decisória: (i) ausência de fundamentação; (ii) deficiência de fundamentação; (iii) ausência de correlação entre fundamentação e decisório. Afirma, contanto, que tais vícios são redutíveis ao conceito genérico de “ausência de fundamentação”, de vez que "fundamentação deficiente”, em rigor, não é fundamentação, e “fundamentação que não tem relação com decisório” não é fundamentação: pelo menos não a “daquele decisório”.

De ser ver que não se deve exigir apenas “fundamentação", mas “fundamentação adequada”, ou melhor, “devidamente adequada”.

No processo judicial, reina alguma controvérsia sobre as consequências dos vícios de fundamentação dos decisórios. Segundo Nojiri ${ }^{320}$, para alguns autores a ausência de fundamentação gera nulidade. Para outros, está-se diante de hipótese de inexistência. Para o autor, seguindo as lições de Kelsen, “a decisão judicial sem fundamentação, apesar de conter vício de extrema gravidade, é válida, até ser declarada nula”. Por isso, no seu entender, "as decisões judiciais com vícios ligados à fundamentação são anuláveis (não nulas ou inexistentes!), até que escoe o prazo definitivo previsto para o recurso cabível ou para a propositura da ação rescisória, conforme o caso”, já que “decorrido o lapso temporal, a decisão não mais poderá ser modificada, passando a integrar definitivamente o ordenamento jurídico positivo”.

\footnotetext{
${ }^{318} \mathbf{O}$ dever de fundamentar as decisões judiciais. $2^{\mathrm{a}}$ Ed. São Paulo: Editora Revista dos Tribunais, 2000, p. 70. ${ }^{319}$ Obra citada, p. 108 e seguintes.

${ }^{320}$ Obra citada, p. 109.
} 
A solução acima preconizada - de que sejam apenas anuláveis (não nulas ou inexistentes!) as sentenças com vícios de fundamentação - pode soar contraditória com a afirmação de que o dever de fundamentar decorre da ideia de Estado Democrático de Direito, mas não se pode desconsiderar também o princípio da segurança jurídica, sobretudo na perspectiva de que os litígios devem ter fim. É de Nojiri ${ }^{321}$ a afirmação, com a qual concordamos, de que "a necessidade de se estabelecerem parâmetros de estabilidade das relações interpessoais requer limites temporais para que as demandas postas à apreciação do Poder Judiciário encontrem um fim, mesmo que o resultado possa, eventualmente, não ser o mais justo”.

Uma fundamentação insuficiente ou ausente pode comprometer um controle eficaz sobre a decisão.

Relativamente ao processo administrativo, o raciocínio é similar. A explicação primária para a necessidade de fundamentação advém da premissa de que decisões administrativas são atos de poder estatal, poder que se exerce, no Estado Democrático de Direito, em nome do povo, seu verdadeiro titular, nos termos do parágrafo único, do art. $1^{\text {o }}$, da CF/88 22 .

Se a autoridade administrativa responsável pela prática do ato decisório ostenta natureza jurídica de representante do titular do poder, mais do que exigível a demonstração de que se fez dele bom uso.

Interessante notar que mesmo antes de uma decisão final (substancial) em processo administrativo, a autoridade profere decisões intermediárias, de índole processual e perfil interlocutório. Em relação a tais decisões, também se mostra razoável a exigência de fundamentação, ainda que sucinta, à moda do que ocorre no âmbito dos processos judiciais.

Sem acesso aos caminhos mentais perseguidos pelo prolator da decisão administrativa, dificultado estará o acesso à instância recursal. Em outras palavras: difícil será recorrer à míngua de fundamentação na decisão recorrida.

Fácil concluir que a exigência de fundamentação se conecta claramente com o Princípio do Contraditório e da Ampla Defesa, com os meios e recurso a ela inerentes, nos exatos termos do art. $5^{\circ}, \mathrm{LV}$, da $\mathrm{CF} / 88^{323}$.

O dispositivo acima referido, como se sabe, se aplica às inteiras não só ao processo

321 Obra citada, p. 113.

${ }^{322} \mathrm{CF} / 88$ : Art. $1^{\circ}$, parágrafo único - Todo poder emana do povo, que o exerce por meio de representantes eleitos ou diretamente, nos termos desta Constituição.

${ }^{323} \mathrm{CF} / 88$ : Art. $5^{\circ}, \mathrm{LV}$ - aos litigantes, em processo judicial ou administrativo, e aos acusados em geral são assegurados o contraditório e a ampla defesa, com os meios e recursos a ela inerentes. 
judicial, mas também ao processo administrativo, além de constituir direito dos “acusados em geral”.

No art. 93, inciso IX, da CF/88, com a redação dada pela EC nº 45/04, preconizou-se que “todos os julgamentos dos órgãos do Poder Judiciário serão públicos, e fundamentadas todas as decisões, sob pena de nulidade (...)”. E de acordo com o disposto no inciso X, do mesmo art. $5^{\circ}$, a Constituição exige que “as decisões administrativas dos tribunais serão motivadas e em sessão pública (...)”.

Note-se, pois, a eloquente preocupação do legislador constituinte de dotar a decisão, seja ela judicial ou administrativa, de maior carga de convencimento. Interessa, ainda que nos dois dispositivos constitucionais referidos há a preocupação maior de casar "fundamentação” e “publicidade”, numa parelha de instrumentalização recíproca, como convém.

Talvez por isso Ana Paula Oliveira Ávila ${ }^{324}$, ao tratar dos deveres dedutíveis do princípio da impessoalidade (Objetividade ou impessoalidade stricto sensu; Imparcialidade; e Neutralidade), tenha se preocupado em apresentar um “dever conexo”, qual seja o “dever de transparência”. É por meio da transparência, explica Ana Paula Oliveira Ávila, que se exterioriza a impessoalidade na atividade administrativa, “constituindo o elemento que possibilita o controle das condutas da Administração". E a transparência, prossegue, “é também pressuposto para a imparcialidade, pois é o fator que viabiliza a participação dos administrados: principal meio pelo qual o administrador toma conhecimento da quantidade e do conteúdo dos interesses que devem ser ponderados na sua atuação concreta”.

As sessões dos tribunais, jurisdicionais ou administrativas, serão públicas, e as motivações serão exteriorizadas em público.

À semelhança do que ocorre no cenário jurisdicional, no cenário administrativo não se contenta o sistema com a livre convicção do decisor, mas sim com o livre convencimento, que assume a forma de princípio.

Por convencimento, entenda-se a convicção externada, exteriorizada.

É o convencimento, e não a convicção, que permite um maior controle pelas partes, pelo corpo social e pelos órgãos de controle.

Tomadas as decisões em sessões públicas, tanto melhor ${ }^{325}$.

\footnotetext{
${ }^{324}$ Obra citada, p. 75-76.

${ }^{325}$ Lembre-se que, no Brasil, além de serem públicas, as Sessões do Plenário do Supremo Tribunal Federal e do Tribunal Superior Eleitoral são transmitidas ao vivo pela TV Justiça, criada pela Lei $n^{\circ} 10.461 / 02$, o que aumenta sobremaneira o controle social sobre a atuação do Poder Judiciário. Sobre alguns aspectos da problemática que deriva da transmissão ao vivo, pela televisão, dos julgamentos levados a efeito nas Cortes acima referidas,
} 
A Lei n ${ }^{\circ}$ 9.784/99, que regula o processo administrativo no âmbito da Administração Pública Federal, em seu art. $2^{\circ}$ estabelece que se deva obedecer, dentre outros, ao "princípio" da motivação.

Emprestar à motivação a natureza jurídica de princípio é remarcar a sua importância, no contexto dos processos administrativos em geral.

Não bastasse, no parágrafo único, do mesmo art. $2^{\circ}$, a Lei $n^{\circ} 9.784 / 99$, exige-se a observância nos processos administrativos de critérios como: (a) atuação conforme a lei e o Direito (inciso I); (b) atendimento aos fins de interesse geral (inciso II); (c) objetividade no atendimento do interesse público; (d) atuação segundo padrões éticos de probidade, decoro e boa-fé; (e) adequação entre meios e fins, vedada a imposição de obrigações, restrições e sanções em medida superior àquelas estritamente necessárias ao atendimento do interesse público (inciso VI); (f) indicação dos pressupostos de fato e de direito que determinarem a decisão (inciso VI); (g) observância das formalidades essenciais à garantia dos direitos dos administrados (inciso VIII); (h) interpretação da norma administrativa da forma que melhor garanta o atendimento do fim público a que se dirige (inciso XIII).

- Como demonstrar o atendimento de tais critérios a não ser por uma consistente fundamentação?

Não bastasse a alusão à motivação como princípio e não fosse suficiente a menção aos critérios acima revelados, indutores da fundamentação como natural dever da autoridade incumbida da decisão, a lei federal de processo administrativo se preocupou em destacar um capítulo específico para a motivação.

No Capítulo XII, materializado pelo art. 50, caput, o legislador foi enfático (e até redundante!) ao preceituar que em determinadas matérias “os atos administrativos deverão ser motivados, com indicação dos fatos e dos fundamentos jurídicos” (grifos nossos).

- E que matérias foram referidas pelo legislador como de fundamentação indiscutivelmente obrigatória?

Os atos que: (i) neguem, limitem ou afetem direitos ou interesses; (ii) imponham ou agravem deveres; (iii) decidam processos administrativos de concurso ou seleção pública; (iv) dispensem ou declarem a inexigibilidade de processo licitatório; (v) decidam recursos administrativos; (vi) decorram de reexame de ofício; (vii) deixem de aplicar jurisprudência 
firmada sobre a questão ou discrepem de pareceres, laudos, propostas e relatórios oficiais; (viii) importem anulação, revogação, suspensão ou convalidação de ato administrativo.

Um exame atento sobre esse extenso rol de atos que requestam motivação denota que pouquíssimas decisões administrativas ficarão de fora da benfazeja exigência. Em relação ao administrado, nenhuma relevante. Talvez decisões mais simples, desde que não afetem sua esfera jurídica.

Além de explicitar, nos incisos do art. 50, os atos administrativos que impõem motivação, o legislador conseguiu ser ainda mais explícito quando, nos parágrafos, descreveu minuciosamente de que tipo de motivação exigível se está a falar.

No $\S 1^{\circ}$, do art. 50, da Lei $n^{\circ} 9.784 / 99$, o legislador esclareceu, para além de qualquer dúvida, que “a motivação deve ser explícita, clara e congruente”, ainda que, por razões pragmáticas, possa consistir em “declaração de concordância com fundamentos de anteriores pareceres, informações, decisões ou propostas, que, neste caso, serão parte integrante do ato" ${ }^{326}$.

Por força do $\S 2^{\circ}$, rendendo-se à burocracia e abrindo-se às tecnologias, diz-se que “na solução de vários assuntos da mesma natureza pode ser utilizado meio mecânico que reproduza os fundamentos das decisões, desde que não prejudique direito ou garantia dos interessados".

Por fim, no $\S 3^{\circ}$, tem-se que “a motivação das decisões dos órgãos colegiados e comissões ou de decisões orais constará da respectiva ata ou termo escrito”.

Diego Zegarra Valdivia' 327 tem na motivação um elemento essencial do ato administrativo. Ensina que a preocupação com a motivação do ato administrativo esteve presente no Congresso de Ciências Administrativas de Varsóvia (1947), no Congresso da Comissão Internacional de Juristas de Nova Déli (1959) e no Congresso de Direito Comparado de Pescara (1970). E que, posteriormente, em 1977, o Conselho da Europa aprovou a Resolução no 77/31, sobre a proteção do indivíduo diante dos atos administrativos, com a expressa recomendação de que os Estados ampliem e generalizem a obrigação de motivação de atos administrativos que afetem direitos ou interesses dos administrados ${ }^{328}$.

\footnotetext{
${ }^{326}$ A declaração de concordância com fundamentos de anteriores pareceres, informações, decisões ou propostas, que, neste caso, serão parte integrante do ato, dá azo ao que os processualistas chamam de "motivação indireta". ${ }^{327}$ La motivación como elemento esencial del acto administrativo. In: Os caminhos do ato administrativo. MEDAUAR, Odete; SCHIRATTO, Vitor Rhein (organizadores). São Paulo: Editora Revista dos Tribunais, 2011, p. 145 a 177.

${ }^{328}$ Obra citada, p. 146.
} 
Conforme o autor, a motivação do ato administrativo é obrigatória para que sejam anunciados os critérios da decisão, diminuindo-se o risco de arbitrariedade no agir estatal:

\footnotetext{
“(...) la motivación de la decisión es indispensable para marcar diferencia entre lo discrecional y lo arbitrario, y ello, porque de no existir motivación que la sostenga, el único apoyo de la decisión será la voluntad de quien la adopta, apoyo insuficiente en un Estado de Derecho en el que no hay margen, por principio, para el poder puramente personal”.
}

Prossegue o mesmo autor ${ }^{329}$ dizendo que a obrigação de motivar as decisões não só contribui para fazê-las aceitáveis, mas também para que o Direito possa cumprir a sua função de guia da conduta humana. O dever de motivar é uma exigência de uma Administração democrática, de vez que o conjunto de cidadãos pode pretender conhecer as razões pelas quais foram tomadas as decisões. Como derradeiro aspecto, tem-se que a motivação aproxima a Administração dos cidadãos. Para ele: “la Administración que motiva sus decisiones es una administración 'pedagogica', que transforma en gran parte la simple imposición autoritaria de sus criterios por un intento de persuasión, considerando al administrado no tanto como 'sudito' cuando ciudadano”.

Odete Medauar ${ }^{330}$ esclarece que, no âmbito do direito administrativo, motivo significa "as circunstâncias de fato e os elementos de direito que provocam e precedem a edição do ato administrativo” e que a enunciação dos motivos recebe o nome de motivação (ou exposição de motivos). E que, durante muito tempo, vigou a regra da não obrigatoriedade da motivação, salvo imposição explícita da norma. A partir de meados da década de 1970, essa tendência vem se invertendo, "no sentido da predominância da exigência de motivação dos atos administrativos, principalmente naqueles que restrinjam o exercício de direitos e atividades, apliquem sanção, imponham sujeições, anulem ou revoguem uma decisão, recusem vantagem ou benefício qualificado como direito, expressem resultado de concursos públicos”.

A autora ensina ${ }^{331}$ que alguns ordenamentos constitucionalizaram a obrigatoriedade de motivação, como o português, na revisão de 1982. No Brasil, não deu certo a tentativa de tornar obrigatória a motivação para os atos administrativos em geral, na Constituição Federal, a não ser para as decisões administrativas dos tribunais, o que, a seu ver, não afasta a

\footnotetext{
${ }^{329}$ Obra citada, p. 148 e 149.

${ }^{330}$ Direito Administrativo Moderno..., p. 159.

${ }^{331}$ Direito Administrativo Moderno..., p. 159.
} 
exigência de motivar, pois esta encontra respaldo na característica democrática do Estado brasileiro (art. $1^{\circ}$ da CF), no princípio da publicidade (art. 37, caput) e, tratando-se de atuações processualizadas, na garantia do contraditório (inc. LV do art. $5^{\circ}$ ). No Estado de São Paulo, todavia, a Constituição de 1989, no art. 111, menciona a motivação como um dos princípios da Administração.

Para Odete Medauar, “a Administração Pública é sempre obrigada a motivar, e, nos casos em que houver discricionariedade na escolha do motivo, este, explicitado, deve realmente ser procedente sob pena de o ato ser inválido por vício no seu motivo" ${ }^{332}$, sendo certo que "não se exigem requisitos formais excessivos para a motivação, podendo a autoridade emitente do ato fazer remissão a outros atos administrativos, pareceres, laudos etc.”. O que se faz necessário, a seu ver, é que “a motivação seja clara, consistente, pertinentes àquilo que se está praticando (art. 50, § $1^{\circ}$, Lei do Processo Administrativo Federal)”333.

José Carlos Vieira de Andrade ${ }^{334}$, em importante obra sobre o dever de fundamentação expressa dos atos administrativos, explica que a fundamentação pode ser entendida como uma "exposição” enunciadora das razões ou motivos da decisão, ou então como uma “recondução” do decidido a um parâmetro valorativo que o justifique: no primeiro sentido, privilegia-se o “aspecto formal” da operação, associando-a à transparência da perspectiva decisória; no segundo, dá-se relevo à “idoneidade substancial” do ato praticado, integrandoo num sistema de referência em que encontre bases de legitimidade.

O mesmo autor anuncia que, no direito português, diante de norma constitucional preconizando o dever de fundamentação expressa, como já referido em Odete Medauar, a motivação obrigatória deve incluir ambas as dimensões, a “formal” e a "substancial”.

Ao tratar especificamente do conteúdo da fundamentação obrigatória e os problemas da sua suficiência, Vieira de Andrade sustenta que para a concretização da modalidade de fundamentação desejável interessam considerações qualitativas (relativas ao quid) e quantitativas (relativas ao quantum).

\footnotetext{
332 Ato administrativo: origem, concepções, abrangência. In: Os caminhos do ato administrativo. MEDAUAR, Odete; SCHIRATO, Vitor Rhein (coordenação). São Paulo: Editora Revista dos Tribunais, 2011, p. 50. A professora adverte que "malgrado a regra da obrigatoriedade da motivação, os atos de mero expediente e ordinatórios, de feição exclusivamente interna, sem qualquer conteúdo decisório - por exemplo, um despacho de 'junte-se aos autos a petição'-, e alguns atos que já têm sua motivação autocompreensiva em sua própria expedição, não precisam ser fundamentados. Essas exceções devem, contudo, ser sempre vistas com cautela e apreciadas a cada caso" (Obra citada, p. 50).

${ }_{333}$ Ato administrativo: origem, concepções, abrangência..., p. 51.

${ }^{334} \mathbf{O}$ dever da fundamentação expressa de actos administrativos. Coimbra: Almedina, 2003.
} 
Com base nos ensinamentos de Vieira de Andrade, exige-se que a fundamentação seja clara, congruente e suficiente.

A clareza da declaração apresenta-se como o requisito mais simples, por ser aquele, segundo o autor, “que está mais intimamente ligado à existência física de uma fundamentação”. Assim, “se as formulações utilizadas são confusas ou indistintas, se a argumentação é dubidativa, ambígua ou obscura, então não se pode saber ou compreender sequer o que determinou o agente a praticar aquele acto ou a escolher aquele conteúdo”. Para Vieira de Andrade, “uma declaração obscura não é uma fundamentação, porque não contém sequer um discurso, faltando-lhe o conteúdo semântico".

Por congruência, entenda-se, com apoio no mesmo autor, base em “processo lógico, coerente e sensato”, de maneira que só se possa aceitar como fundamentação “um discurso racional, pelo menos um que não contenha erros de raciocínio evidentes”. Para Vieira de Andrade, é necessário notar que a congruência se refere especialmente à "relação entre a fundamentação e o conteúdo do ato, devendo este ser uma consequência lógica daquela, e não tanto à coerência dos diversos fundamentos entre si: uma eventual contradição entre os fundamentos invocados implica antes a falta de clareza ou a incompreensibilidade da fundamentação apresentada”. Por tal razão, “uma declaração incongruente também não é uma fundamentação, porque não pode ser um discurso justificativo, faltandolhe a racionalidade, que é uma condição necessária de toda a decisão pública de autoridade num Estado de Direito".

Por fim, a fundamentação deve ser suficiente, em sentido estrito (ou residual), isto é, “deve conter os elementos bastantes, capazes ou aptos a basear a decisão”. Segundo Vieira de Andrade, "interessa em primeira linha garantir que haja uma verificação ou uma ponderação, por parte do autor do acto, das circunstâncias da realização do interesse público que visa prosseguir; ora, para satisfazer essa finalidade, a fundamentação deve ser concreta quanto baste para que se revele a existência de uma reflexão deliberativa sobre os interesses em jogo, em especial na medida em que caiba à Administração a complementação dos pressupostos legais com motivos autoescolhidos”. Para o autor, uma fundamentação insuficiente não é aceitável, porque não é um discurso apto a justificar a decisão tomada, faltando-lhe “densidade funcional mínima exigida pela racionalidade teleológica que caracteriza a decisão administrativa”. 


\subsubsection{Processualização}

Para serem impessoais, decisões administrativas relevantes demandam processo administrativo justo.

Consoante o magistério de Marçal Justen Filho ${ }^{335}$, “é quase impossível configurar hipóteses em que determinado ato administrativo poderia ser produzido de modo desvinculado de um procedimento ou fora do desenvolvimento da atividade administrativa”. Ensina que, por mais que os procedimentos concretamente sejam variados, "é ponto comum submeter o exercício da função administrativa à observância de limitação do poder estatal e garantia de respeito aos valores democráticos". Num tal contexto, "salvo situações excepcionais, todo e qualquer ato administrativo deve ser produzido no bojo de um procedimento".

Para o mesmo autor ${ }^{336}$, "não apenas os atos administrativos têm de ser examinados no contexto de um conjunto de atividades, mas essas atividades se desenvolvem necessariamente sob forma procedimentalizada", mesmo porque, não o “formalismo inútil”, mas sim “a forma jurídica é um instrumento de controle do exercício das competências estatais”, e a procedimentalização “impede a concentração decisória num ato imediato e único”, com o benefício de assegurar "oportunidade de manifestação para todos os potenciais interessados, a qual deverá ser promovida (em princípio) previamente a qualquer decisão".

Especificamente no contexto do ato administrativo decisório, acrescenta o autor ${ }^{337}$ que “o procedimento configura uma fragmentação da competência decisória, a qual é pulverizada em uma pluralidade de atos formalmente diversos, mas logicamente inter-relacionados”, ou seja, “há um ato decisório final, mas seria juridicamente impossível dissociar esse ato daqueles que o antecederam”, sendo certo que "o ato final é o resultado das etapas anteriores, de modo inclusive a impedir que a validade dele seja avaliada sem considerar o conjunto dos atos praticados".

Dentre os fins visados pela procedimentalização, Marçal Justen Filho ${ }^{338}$ indica quatro virtudes: (i) o controle; (ii) a democracia, (iii) a isenção de defeitos e (iv) a redução dos encargos de Poder Judiciário. Tomando-se a expressão controle no sentido de fiscalização, “o processo permite a verificação dos atos decisórios”. Também seria “uma solução de

\footnotetext{
${ }^{335}$ Curso de Direito Administrativo. $7^{\text {a }}$ Ed. Belo Horizonte: Fórum, 2011, p. 304.

${ }^{336}$ Curso..., p. 305.

${ }^{337}$ Curso..., p. 306.

${ }^{338}$ Curso..., p. 307-308.
} 
vinculação do ocupante do poder político ao respeito à vontade presumível dos cidadãos”. Ademais, a procedimentalização aperfeiçoa a ação estatal, "partindo do pressuposto de que o ato decisório será resultado lógico dos eventos apurados ao longo do processo”, sendo certo que a dialética processual "impede uma visão limitada e parcial dos fatos". Finalmente, a procedimentalização reduz os encargos do Poder Judiciário por dois motivos: a) “a participação dos potenciais interessados e a instrução minuciosa propiciam a melhor composição possível para interesses contrapostos, o que reduz a necessidade de recorrer ao Judiciário”; b) "a procedimentalização evidencia de modo objetivo a correção (ou incorreção) da atividade administrativa, o que diminui o risco de aventuras judiciárias”.

De acordo com o texto constitucional de 1988, art. 5, LV, “aos litigantes, em processo judicial ou administrativo, e aos acusados em geral são assegurados o contraditório e a ampla defesa, com os meios e recursos a ela inerentes".

Para Odete Medauar 339 , “sem dúvida, no momento, o processo administrativo se mostra como um dos temas fortes do direito administrativo, representando significativo indicador da evolução deste ramo jurídico, nos últimos quarenta anos, focalizada no cidadão e no atendimento dos seus direitos”.

Acrescenta Odete Medauar ${ }^{340}$ que "o ato administrativo, nos dia de hoje, vê contestada a sua centralidade no Direito Administrativo". E se defronta “com dois principais 'concorrentes': o processo administrativo, já apontado por vários autores como o novo tema central do Direito Administrativo; e o contrato administrativo".

Marçal Justen Filho ${ }^{341}$ assinala que o conceito de ato administrativo perdeu relevância como instrumento de compreensão e organização do direito administrativo. E que “o fundamental está em considerar a atuação administrativa de modo global, não cada ato administrativo isoladamente", mesmo porque “o Estado pós-moderno é uma estrutura organizacional vocacionada a produzir atos em massa, não a promover atos isolados”342.

No âmbito da Teoria Geral do Processo, a despeito da existência de um sem- número de teorias sobre a natureza jurídica do processo $^{343}$, mostra-se relevante a que vislumbra no

\footnotetext{
339 Trecho inicial da apresentação da obra Atuais Rumos do Processo Administrativo. MEDAUAR, Odete; SCHIRATO, Vitor Rhein (organização). São Paulo: Editora Revista dos Tribunais, 2010, p.5.

${ }^{340}$ Ato administrativo: origem, concepções, abrangência..., p. 33.

${ }^{341}$ Curso..., p. 302.

342 Curso..., p. 303.

${ }^{343}$ Entre as inúmeras teorias concebidas pela doutrina acerca da natureza jurídica do processo, ainda tem prestígio a que foi edificada por Bülow ("processo como relação jurídica”), em 1868, em seu famoso livro Teoria dos pressupostos processuais e das exceções dilatórias, tido como a primeira obra científica sobre direito processual. Para Bülow, há uma relação entre as partes e o juiz, que não se confunde com a relação jurídica de direito material controvertida.
} 
processo a natureza jurídica de “procedimento em contraditório”. Araújo Cintra, Ada Grinover e Cândido Dinamarco ${ }^{344}$ ensinam que:

“Em tempos mais recentes, na Itália surgiu o novo pensamento de Elio Fazzalari, repudiando a inserção da relação jurídica processual no conceito de processo. Fala do 'módulo processual' representado pelo procedimento realizado em contraditório e propõe que, no lugar daquela, se passe a considerar como elemento do processo essa abertura à participação, que é constitucionalmente garantida.

Na realidade, a presença da relação jurídico-processual no processo é a projeção jurídica e instrumentalização técnica da exigência político-constitucional do contraditório.

(...)

É lícito dizer, pois, que o processo é o procedimento realizado mediante o desenvolvimento da relação entre seus sujeitos, presente o contraditório. Ao garantir a observância do contraditório a todos os 'litigantes em processo judicial ou administrativo e aos acusados em geral’, está a Constituição (art. 5, inc. LV) formulando a solene exigência política de que a preparação de sentenças e demais provimentos estatais se faça mediante o desenvolvimento da relação jurídica processual”.

Colhe-se da Teoria Geral do Direito Público a ideia de que o processo é o modo normal de agir do modelo democrático de Estado de Direito. Como revela Carlos Ari Sundfeld ${ }^{345}$, o poder jurídico de o indivíduo produzir atos, decorrendo do valor liberdade, é um valor em si mesmo, ou seja, “não se justifica por qualquer finalidade de agir”. Em razão disso, “ninguém interfere na formação da vontade de outrem: seria imiscuir-se na vontade alheia”. Com o direito público ocorre justamente o inverso. No Estado Democrático de Direito, “o exercício das diferentes funções estatais - e, em consequência, a produção dos atos de direito público exige a observância de processo perfeitamente regulado pelas normas jurídicas”.

Com razão Norberto Bobbio ${ }^{346}$, trilhando concepção processual de democracia, quando aduz que "o único modo de se chegar a um acordo quando se fala de democracia, entendida como contraposta a todas as formas de governo autocrático, é o de considerá-la caracterizada por um conjunto de regras (primárias ou fundamentais) que estabelece quem está

\footnotetext{
${ }^{344}$ Teoria Geral do Processo. 22 ${ }^{\text {a }}$ Ed. São Paulo: Malheiros, 2006, p. 303.

${ }^{345}$ Fundamentos de Direito Público. $5^{a}$ ed. São Paulo: Malheiros, 2010, p. 89 e seguintes.

${ }^{346} \mathbf{O}$ futuro da democracia..., p. 30.
} 
autorizado a tomar as decisões coletivas e com quais procedimentos”. E em obra insuperável sobre o tema - legitimação pelo procedimento - Niklas Luhmann ${ }^{347}$ aduz:

"É que o poder é também um mecanismo de transmissão de resultados de seleção e até mesmo de obras de seleção produzidas pela decisão. Quem tem o poder pode motivar outros a adotar as suas decisões como premissas de procedimento, portanto, a aceitar como compulsiva uma seleção dentro do âmbito de possíveis alternativas de comportamento. A transmissão intersubjetiva tem, pois, aqui, fundamentos diferentes dos que tinha no caso da verdade. Não pode ser apresentada como consequência da razão de ser do mundo contra a qual uma pessoa se possa absurdamente revoltar. Ela constitui a atenção desejada de uma decisão.

A adoção de resultados de uma seleção baseados apenas em decisões é fato que carece de motivos mais especiais. A verdade de certas premissas de decisão, só por si, não é suficiente para isso. Portanto, tem de se partir da hipótese de que, no procedimento se criem essas razões adicionais para aprovação das decisões e de que, neste sentido, o poder gere a decisão e a torne legítima, isto é, que se torne independente, pelo imperativo exercido concretamente. Visto desta forma, o objetivo do procedimento juridicamente organizado consiste em tornar intersubjetivamente transmissível a redução de complexidade - quer com a ajuda da verdade, quer através da criação do poder legítimo da decisão”348.

${ }^{347}$ Legitimação pelo procedimento. Tradução de Maria da Conceição Côrte-Real. Brasília: Editora Universidade de Brasília, 1980, p. 26-27.

${ }^{348}$ Tércio Sampaio Ferraz Jr., ao apresentar o livro de Lumann, na versão da Editora Universidade de Brasília, cujo trecho restou acima transcrito, em necessário aporte para a contextualização da obra e de seu autor, observou que:

“(...).

O tratamento que dá Luhmann ao problema da legitimidade se põe no terreno puramente fático. Uma estrutura jurídica é para ele legítima na medida em que é capaz de produzir uma prontidão generalizada para aceitação de suas decisões, ainda indeterminadas quanto ao seu conteúdo concreto, dentro de certa margem de tolerância.

A posição de Luhmann se insere, até certo ponto, dentre as chamadas concepções decisionistas da legitimidade. Normas jurídicas concebidas como decisões só podem ser fundadas em outras decisões, havendo, então, uma decisão última que estabelece inapelavelmente a legitimidade da série. Como as decisões normativas são proposições deônticas, de dever-se, a elas não cabe a alternativa verdadeiro/falso Com isso, a possibilidade de se fundar a legitimidade em valores supremos é rechaçada. Isto porque, na série regressiva das decisões, sempre topamos com um plurarismo de valores que não se fundam em verdade, mas são, ao contrário, atos de crença, admitidos como fatos.

Luhmann, contudo, é um decisionista mais arguto. Sem eliminar o caráter decisório da legitimidade, ele evita o problema do regresso a uma decisão última, no início da série, mostrando que a legitimidade não está ali, mas no próprio processo, que vai do ponto inicial do procedimento de tomada de decisão até a própria decisão tomada. É, assim, o procedimento mesmo que confere legitimidade, e não uma de suas partes componentes.

Procedimentos são para ele sistemas de ação, através dos quais os endereçados das decisões aprendem a aceitar uma decisão que vai ocorrer, antes da sua ocorrência concreta. Trata-se de sistemas no sentido acima 
Acrescenta Sundfeld ${ }^{349}$ que a exigência de que os atos estatais sejam fruto de processo advém do fato de que os agentes públicos exercitam poder em nome de finalidade que lhe é estranha. Em outras palavras: o agente público desempenha função. E função é o poder outorgado a alguém para o obrigatório atingimento de bem jurídico disposto na norma. Além disso, a lei, a sentença e o ato administrativo são unilaterais, sua produção independe da concordância dos particulares atingidos. Para o autor, essas duas características das atividades públicas - constituírem função e gerarem atos unilaterais invasivos da esfera jurídica dos indivíduos - exigem a regulação do processo formativo da vontade que expressam.

Para o mesmo autor ${ }^{350}$, o processo simultaneamente "infunde ao ato racionalidade, imparcialidade, equilíbrio; evita que o agente o transforme em expressão de sua personalidade”. Sem ele, prossegue o autor, “o agente fatalmente excederia seu papel de intermediário entre o Direito (a Constituição, a lei) e o ato a ser produzido". Assim, conclui, “o processo é, então - em perfeita coerência com a ideia central do direito público, de realizar o equilíbrio entre liberdade e autoridade -, a contrapartida assegurada aos particulares pelo fato de serem atingidos por atos estatais unilaterais”.

Para Odete Medauar ${ }^{351}$, “o processo administrativo representa instrumento de objetivação do poder para evitar ou dificultar que motivos e fins subjetivos informem a tomada de decisões, pois nele se contrapõem argumentos, dados e fatos, que permanecem registrados; se móveis subjetivos, mesmo assim, afetarem a decisão, torna-se mais fácil o controle administrativo e jurisdicional”.

Araújo Cintra, Ada Grinover e Cândido Dinamarco ${ }^{352}$, em tratamento doutrinário útil ao processo administrativo, revelam que “investigações sociológicas e sociopolíticas sobre o processo levaram a doutrina a afirmar que a observância do procedimento constitui fator de legitimação do ato imperativo proferido afinal pelo juiz”. Asseveram que:

\footnotetext{
“(...). Como o juiz não decide sobre negócios seus, mas para outrem, valendo-se do poder estatal e não da autonomia da vontade (poder de autorregulação de interesses, aplicável aos negócios jurídicos), é compre-
}

mencionado, pelos quais os diferentes motivos a que alguém possa sentir-se obrigado ou não a aceitar decisões são reduzidos e especificados num limite de alta probabilidade, de tal modo que o endereçado da decisão se vê na contingência de assumi-la, sem contestá-la, ainda que lhe seja, no caso, desfavorável”.

${ }^{349}$ Obra citada, p. 92.

${ }^{350}$ Obra citada, p. 93/94.

${ }^{351}$ A processualidade no direito administrativo. São Paulo: Editora Revista dos Tribunais, 1993, p. 90.

352 Teoria Geral do Processo..., p. 303-304. 
ensível a exigência de legalidade no processo, para que o material preparatório do julgamento final seja recolhido e elaborado segundo regras conhecidas de todos. Essa ideia é uma projeção da garantia constitucional do devido processo legal.

Por outro lado, só tem sentido essa preocupação pela legalidade na medida em que a observância do procedimento constitua meio para a efetividade do contraditório no processo. É assegurando às partes os caminhos para participar e meios de exigir a devida participação do juiz em diálogo que o procedimento estabelecido em lei recebe sua própria legitimidade e, ao ser devidamente observado, transmite ao provimento final a legitimidade de que ele necessita”.

Para os mesmos autores ${ }^{353}$, tudo isso corresponde a uma "reabilitação do procedimento" na teoria processual, "especialmente mediante seu retorno ao conceito de processo, do qual estivera banido desde quando formulada a teoria da relação jurídica".

No Brasil, Odete Medauar ${ }^{354}$ certamente escreveu uma das mais respeitáveis obras sobre processo administrativo. Expôs que há notas predominantes da processualidade jurídica, presentes nos vários âmbitos em que se expressa e que “a partir de um núcleo de identidade mínima irradiam-se pontos de diversidade, em grande parte decorrentes das características da função que a processualidade traduz e do ato final a que tende”. Segundo a autora, "há peculiaridades na processualidade administrativa que a distinguem da processualidade jurisdicional e da legislativa”.

Marçal Justen Filho ${ }^{355}$ revela a tendência de identificar processo administrativo e processo jurisdicional, o que parece um erro, na exata medida em que desconsideradas algumas regras peculiares do segundo, ligadas à posição do juiz. Ensina que enquanto no processo jurisdicional o juiz personifica o Estado-jurisdição e não é titular dos interesses sobre os quais decide, sendo imparcial, no processo administrativo o sujeito encarregado da função de julgar “integra” a própria Administração, salvo, obviamente, nos países que adotam o Contencioso Administrativo.

Segundo o seu pensamento, com o qual concordamos, “apenas seria possível aludir a processo administrativo como uma categoria idêntica ao processo jurisdicional se houvesse

\footnotetext{
353 Teoria Geral do Processo..., p. 304.

${ }^{354}$ A processualidade..., p. 23.

355 Curso..., p. 311.
} 
órgãos independentes com competência para conduzir a solução da controvérsia na via administrativa" ${ }^{356}$.

Para Vitor Rhein Schirato ${ }^{357}$, o tema do processo administrativo vem ganhando cada vez mais espaço nos estudos de direito administrativo. Na sua concepção, sobretudo a partir da consolidação da democracia como um dos valores do Estado contemporâneo, “o ato administrativo - dantes ocupante de lugar de honra na estruturação sistemática do estudo de direito administrativo - passa a perder espaço para o processo administrativo, do qual o ato administrativo é parte".

No entender do autor, essa mudança de paradigma é uma decorrência lógica da alteração da forma de atuação do Estado na consecução das suas missões, cada vez mais desapegada de uma visão autoritária e verticalizada da Administração Pública em relação aos particulares, própria do período compreendido desde fins do séc. XIX e a primeira metade do séc. XX.

Para Schirato, no momento atual, ligado a um cenário de consolidação do Estado de Direito e das boas práticas democráticas, não há lugar para a imposição de decisões unilaterais e ilimitadamente autoritárias. A seu ver, "valores democráticos passam a exigir que o Estado não somente produza resultados conforme a lei, mas que siga o caminho legalmente disciplinado para produzir tais resultados, de forma concertada com aqueles direta e indiretamente interessados no conteúdo do ato a ser exarado”.

Na mesma linha, Floriano de Azevedo Marques Neto ${ }^{358}$ propugna pela superação do “ato administrativo autista”, que vem a ser um ato administrativo revestido de "um brutal déficit de comunicação com o meio ambiente cultural, social, econômico”, produzido com "absoluta indiferença para com os administrados e com a sociedade que, em última instância, são destinatários e razão de ser da prática destes atos”.

Na lúcida visão de Floriano de Azevedo Marques Neto ${ }^{359}$, a exacerbação da autonomia do ato administrativo, que tem como premissa a ideia de que todos os elementos para a sua existência, validade e eficácia "são encontráveis internamente ao sistema jurídico administra-

\footnotetext{
${ }^{356}$ Conforme Marçal Justen Filho (In Curso de Direito Administrativo. $7^{a}$ Ed. Belo Horizonte: Fórum, 2011, p. 311).

${ }^{357}$ O processo administrativo como instrumento do Estado de Direito e da Democracia. In: Atuais novos rumos do processo administrativo / organizadores Odete Medauar, Vitor Rhein Schirato. São Paulo: Editora Revista dos Tribunais, 2010. P. 9 a 51.

${ }^{358}$ A superação do ato administrativo autista. In: Os caminhos do ato administrativo. MEDAUAR, Odete; SCHIRATO, Vitor Rhein (coordenação). São Paulo: Editora Revista dos Tribunais, 2011, p. 96

${ }^{359}$ A superação do ato administrativo autista...., p. 96-97.
} 
tivo”, implica uma “absoluta indiferença em relação ao meio”. Assim, “aquilo que num primeiro momento procura imunizar o ato das interferências da política, da economia, da cultura" acaba por colocar o administrado na condição de mero espectador e destinatário do ato.

Para o autor ${ }^{360}$, o “ato administrativo autista” expressa uma visão positivista do direito administrativo e confere "uma ampla margem de autonomia para a Administração intervir na esfera de direitos dos indivíduos, sem franquear a estes indivíduos a possibilidade de intervir e interferir na formação do ato e sem obrigar a Administração a sopesar, de forma transparente, as diversas alternativas de ação, para selecionar aquela que reúna as melhores condições de efetividade com o menor sacrifício de direitos”.

Ainda em Floriano de Azevedo Marques Neto ${ }^{361}$, o “ato administrativo autista” entra em choque com desafios contemporâneos. A partir da submissão da atuação administrativa ao princípio da motivação e da teoria dos motivos determinantes começa-se a questionar a viabilidade de tais presunções. Pergunta o autor:

- Como combinar a presunção de legitimidade e de veracidade com o dever do administrador, prévia ou concomitantemente à prática do ato (portador da suposta presunção), expor suas premissas de fato e de direito, sujeitando tal motivação ao escrutínio do juízo em sede de questionamento pelo interessado?

- Como combinar estas presunções com os deveres de transparência e publicidade impostos pela Constituição?

Dentre os “vetores de transformação paradigmática” para a superação do "ato administrativo autista”, o autor salienta: a) Processualidade administrativa; b) Consensualidade; c) Controle ampliado da Administração Pública.

Quanto à processualidade administrativa, objeto de nosso interesse maior, o entendimento do autor ${ }^{362}$ é deveras relevante. Além de dizer que a prescrição constitucional (art. $5^{\circ}$, LV) assegura o "direito a um processo administrativo como um direito fundamental do cidadão”, vai além para vislumbrar “um efeito colateral que se revelou ainda mais importante”, a saber, a consagração da ideia de que "a atividade administrativa, o exercício da função administrativa, não é atividade que se realize isolada dos interesses e pretensões dos administrados”. Confira-se o sedutor raciocínio lógico do autor:

\footnotetext{
${ }^{360}$ A superação do ato administrativo autista..., p. 98-99.

${ }^{361}$ A superação do ato administrativo autista..., p. 104-105.

${ }^{362}$ A superação do ato administrativo autista..., p. 108-109.
} 
"Se a Carta admite a existência de litigantes em processo administrativo (é dizer, em processos vocacionados à edição de um ato administrativo), é porque pressupõe haver pretensão resistida (lide, conflito, antagonismo) no processo de produção do ato. Logo, seja ontologicamente, seja operativamente, a edição de atos administrativos não pode ser mais concebida de forma autista, infensa à participação e à consideração de diversos interesses envolvidos. Para além das consequências diretas da sujeição da atividade administrativa ao processo (participação dos interessados, contraditório, direito a aduzir suas razões e produzir provas, direito a uma manifestação de outra autoridade no curso do manejo recursal), tem-se que a prescrição constitucional cria um dever em si para a Administração Pública de conduzir a prática dos atos administrativos em permanente comunicação com os setores potencialmente atingidos, de forma positiva ou negativa, pelo ato a ser praticado ao fim do processo necessário”.

O mesmo autor assinala a existência de uma revolução em curso, “para a qual o direito administrativo tradicional não atentou totalmente”. A seu ver, sob o pálio do direito fundamental ao processo administrativo, o ato administrativo deverá ser, em regra, resultado de um processo administrativo. E prossegue, em providencial advertência:

\footnotetext{
"Note-se que o que se extrai do art. 5, LV, da CF/88, não é apenas uma restrição à prerrogativa da Administração em editar atos administrativos de forma unilateral e autoritária. Se fosse assim, teríamos a permanência do ato administrativo autista apenas interditado quando, a contragosto, o administrador tivesse que admitir a participação de um interessado, colocando então a prática do ato dentro do processo administrativo. O sentido que extraímos da prescrição constitucional vai muito além. Ao nosso ver, ela obriga que todo ato seja praticado no ambiente da processualidade. Estabelece um dever para a Administração de promover e facilitar a participação processual dos interessados. Isso se verifica, por exemplo, no dever de promover audiências e consultas públicas para a edição de certos atos, independentemente de solicitação prévia por parte de interessados”.
}

A submissão do ato administrativo a uma processualidade ampla conduz, segundo Floriano de Azevedo Marques Neto ${ }^{363}$, a consequências desafiadoras do "ato administrativo autista":

${ }^{363}$ A superação do ato administrativo autista..., p. 110. 
a) O percurso do ato administrativo mostra-se "permeável aos interesses dos administrados” potencialmente colhidos pelos seus efeitos, o que significa que "todos os diversos ângulos de mirada, todas as contraposições e os conflitos deverão ser conhecidos e considerados";

b) O agir administrativo vocacionado à produção do ato administrativo "não poderá ser referenciado apenas nas balizas editadas ex ante (fundamento legal), tornando-se necessária também a consideração do olhar prospectivo (forwardlooking), mediante a ponderação de impactos, comparação de alternativas, fundamentação da melhor escolha, juízos de ponderação”. É dizer: “o ato administrativo tomado no ambiente processual tende a se pautar por uma maior responsividade";

c) Não há como se preservar a unilateralidade como pressuposto da prática do ato administrativo, o que significa que "no ambiente da processualidade as posições conflitantes têm de ser consideradas (v.g., levadas em conta inclusive para fins de fundamentação) no momento de produção do ato (ou seja, no curso do necessário processo administrativo)”. Emerge uma “unilateralidade reflexiva”, em que "o exercício da autoridade não se desvanece, mas se sofistica, perdendo o seu viés autoritário”.

O processo administrativo ${ }^{364}$, de acordo com o balizado magistério de Odete Medauar 365 - que, inclusive figurou como relatora do anteprojeto que deu origem à Lei $n^{0}$ 9.784/99, o estopim da evolução mais acentuada da matéria no Brasil - ostenta as seguintes finalidades:

a) Finalidades de garantia - O processo tutela direitos dos administrados que 0 ato administrativo pode afetar. É o “primeiro círculo” de garantias das posições jurídicas dos administrados. Assim, “no esquema processual o cidadão não encontra ante si uma Administração livre, e sim uma Administração disciplinada na sua atuação". Além disso, o processo administrativo completa a proteção dada pelo processo judicial e "se direitos dos administrados obtêm reconhecimento, evitam-se os ônus da ação em juízo”.

\footnotetext{
${ }^{364}$ Como ensina Odete Medauar (A processualidade..., p. 41): "a despeito do difundido uso do termo 'procedimento' no âmbito da atividade administrativa, mais adequada se mostra a expressão 'processo administrativo', de vez que "a resistência ao uso do vocábulo 'processo' no campo da Administração Pública, explicada pelo receio de confusão com o processo jurisdicional, deixa de ter consistência no momento em que se acolhe a processualidade ampla, isto é a processualidade associada ao exercício de qualquer poder estatal".

${ }^{365}$ A processualidade..., p. 61 a 69.
} 
b) Melhor conteúdo das decisões - A contribuição dos interessados amplia os pressupostos objetivos da decisão administrativa. Essa finalidade, sob o ângulo do administrado e dos cidadãos em geral representa uma garantia, "em virtude do embasamento correto da decisão administrativa, ante os elementos de instrução reunidos no processo".

c) Eficácia das decisões - A decisão tomada em ambiente processual, a partir da colaboração dos interessados, é “mais suscetível de aceitação e de cumprimento, do que outra, oriunda, praticamente, do nada e que se pretende impor aos indivíduos”.

d) Legitimação do poder - a imperatividade do ato "apresenta-se como resultado de um processo que viu o confronto de muitos interesses, direitos e deveres e chegou a um ponto de convergência; é possível, então, falar de nova imperatividade, pois é construída e buscada, superando a ideia de imperatividade unilateral”.

e) Correto desempenho da função - O processo leva ao equilíbrio entre a autoridade do sujeito público e os direitos dos particulares, objetiva as decisões, restringe o arbítrio e promove um conhecimento mais amplo de dados relevantes às soluções administrativas.

f) Justiça na Administração - Estende-se a ideia de justiça, como produto exclusivo da atuação jurisdicional, para o campo administrativo. Tal postura “importa em mudança das condutas administrativas inertes ou negligentes, movidas por má-fé ou não, no atendimento de direitos (muitas vezes cristalinos) de cidadãos ou funcionários”. O processo administrativo “direciona-se à realização da justiça não só pelo contraditório e a ampla defesa vistos do ângulo do indivíduo, mas também por propiciar o sopesamento dos vários interesses que envolvem uma situação".

g) Aproximação entre Administração e cidadãos - rompe-se a ideia de Administração contraposta à sociedade, já que o processo impõe colaboração entre todos os sujeitos da relação processual. Assim, “muda a perspectiva do cidadão visto em contínua posição de defesa contra o poder público que age de modo autoritário e unilateral; quebra-se a tradição de interesse público oposto a interesse privado". O esquema processual "representa um dos meios para que a vontade do administrador e a vontade dos administrados se encontrem na mesma decisão". 
h) Sistematização de atuações administrativas - o processo impõe organização racional da edição de muitos atos administrativos, com reflexos na sistematização das próprias atividades. Para a Administração representa meio de simplificação de práticas. Para o administrado, permite o conhecimento do modo de exercício da função administrativa, em contraste com funções não processualizadas, cujo modo de exercício dificilmente se dá a conhecer. Com isso, confere melhores condições para o administrado pleitear o reconhecimento dos seus direitos.

i) Facilitar o controle da Administração - o esquema processual, com a colaboração dos sujeitos e o conhecimento do modo de atuação administrativa, facilita o controle por parte da sociedade, do Poder Judiciário e de todos os demais entes que fiscalizam a Administração Pública.

j) Aplicação dos princípios e regras comuns da atividade administrativa-como ponto de convergência entre princípios e regras relativas à atuação administrativa, o processo se torna "campo propício à concretização de tais parâmetros, muitos dos quais consagrados constitucionalmente”.

Rafael Wallbach Schwind ${ }^{366}$ chama-nos a atenção para fortes traços evolutivos da própria noção de processo administrativo, dentre os quais: (i) a compreensão do processo administrativo como figura relevante para os direitos fundamentais; (ii) a questão da aceleração do processo administrativo; (iii) a atuação concertada de órgãos e entidades administrativas; (iv) a problemática da processualidade na atuação consensual da Administração Pública; (v) a participação de particulares como parciais condutores de determinados atos inseridos no processo administrativo; (vi) a questão das atuações mecanizadas.

No entender do autor ${ }^{367}$, a evolução do processo se dá em uma série de direções e com os mais diversos conteúdos, sendo certo que o processo administrativo "não é uma realidade estanque, mas mutável, que evolui à medida que se desenvolve o próprio Direito Administrativo”. Daí falar-se num “processo administrativo em evolução”.

Para Rafael Wallbach Schwind ${ }^{368}$ é inequívoca a relevância do processo administrativo para os direitos fundamentais, tema que nos interessa mais de perto. No seu entender, o

${ }^{366}$ Processo administrativo em evolução. In: ALMEIDA, Fernando Dias Menezes de; MARQUES NETO, Floriano de Azevedo; MIGUEL, Luiz Felipe Hadlich; SCHIRATO, Vitor Rhein (Coord.). Direito público em evolução: estudos em homenagem à Professora Odete Medauar. Belo Horizonte: Fórum, 2013, p. 375 a 387. 367 Obra citada, p. 386.

${ }^{368}$ Obra citada, p. 377. 
processo administrativo não é nada menos do que "uma das formas de manifestação dos direitos fundamentais”.

Com mestria, subdivide o tema em três: a) A dimensão procedimental dos direitos fundamentais; b) Direitos fundamentais e as normas reguladoras do processo administrativo; c) A variabilidade procedimental.

Quanto ao primeiro, com base no escólio de Schmidt-Assman, revela Rafael Schwind ${ }^{369}$ que “uma das facetas dos direitos fundamentais é justamente a sua dimensão procedimental”. E que:

\begin{abstract}
“O processo administrativo, portanto, não consiste num mecanismo de participação apenas do Estado de Direito, nem se resume a uma forma de controle e organização da praxis da Administração Pública. Para além disso, o processo administrativo somente é compreendido em toda a sua plenitude à medida que é visto como uma técnica garantista respaldada nos direitos fundamentais. Trata-se de mecanismo que impõe que os atos administrativos, inclusive aqueles que afetam os cidadãos de modo mais direto e imediato, sejam praticados depois de percorrido um caminho direcionado pela lógica, pela racionalidade e pela ponderação de interesses. Daí a menção por Peter Häberle, ainda em 1971, do status activus processualis justamente como uma manifestação da teoria dos direitos fundamentais. A observância do processo administrativo legalmente previsto é, assim, um direito fundamental dos cidadãos”.
\end{abstract}

O mesmo autor ${ }^{370}$ assinala que inserir o processo administrativo, a partir de uma noção de processualidade ampla, no rol de direitos fundamentais dos cidadãos no Estado contemporâneo, é algo elementar, na medida em que é ele, a um só tempo: a) Método de atuação racional; b) Instrumento de legitimação; c) Mecanismo de transparência; d) Possibilitador de controle; e) Garantia de segurança jurídica.

Ao tratar dos direitos fundamentais e das normas reguladoras do processo administrativo, o autor ${ }^{371}$ esposa que a relevância do processo administrativo pode ser verificada no estabelecimento dos direitos subjetivos processuais:

“(...). É nesse contexto que se pode falar no direito ao contraditório e à

\footnotetext{
${ }^{369}$ Obra citada, p. 378.

${ }^{370}$ Obra citada, p. 378.

${ }^{371}$ Obra citada, 378 e 379.
} 
ampla defesa (e, de modo mais amplo, no direito do cidadão de influir na tomada das decisões administrativas), no direito a que se observe a publicidade do processo administrativo (direito de acesso aos autos, direito de ser comunicado acerca dos atos praticados e inclusive de ser informado previamente acerca de atos de natureza instrutória), direito à interposição de recurso para a autoridade superior (duplo grau administrativo), necessidade de proteção à segurança jurídica e à confiança legítima (por meio de uma finalidade certa e determinada, de modo que não haja surpresa acerca dos rumos do processo)".

Além disso, esclarece que a perspectiva jusfundamental do processo administrativo também se revela "na divisão de ônus, no estabelecimento de prazos, nas normas de preclusão que fazem o processo prosseguir e se desenvolver, no estabelecimento de uma estrutura procedimental especialmente clara, entre outros fatores".

Por fim, ao tratar no último item - variabilidade procedimental - da relevância do processo administrativo para os direitos fundamentais, Rafael Schwind ${ }^{372}$ assinala que "múltiplas são as formas que podem adotar um procedimento e diversas são as conexões entre os componentes desse procedimento, de modo que não existe uma solução única e acabada de procedimento administrativo ideal”. No seu entender, "a imposição de um modelo procedimental único seria ofensiva à concepção do instituto como instrumento protetor e realizador dos direitos fundamentais”.

A identificação do processo administrativo como instrumento catalisador dos direitos fundamentais "consiste num importante elemento significativo da evolução do processo administrativo, do ponto de vista epistemológico”. Segundo Rafael Schwind ${ }^{373}$ :

“(...). Possibilita-se uma melhor compreensão dos desdobramentos do processo administrativo sobre a esfera de direitos dos cidadãos, sendo este o motivo pelo qual o devido processo legal administrativo foi alçado ao status de direito constitucional fundamental. Não é por outro motivo que o Prof. Caio Tácito, na exposição de motivos que acompanhou o anteprojeto da atual Lei $n^{\circ}$ 9.784/99, afirmou estar enviando proposta que assegurava justamente os direitos fundamentais dos cidadãos, que viria a se transformar precisamente em um verdadeiro código da cidadania”.

372 Obra citada, p. 379.

${ }^{373}$ Obra citada, p. 379. 
Ao tratar do processo administrativo em correlação com os princípios constitucionais da Administração, Odete Medauar ${ }^{374}$ fere o tema da impessoalidade. Para a autora, “o processo administrativo representa instrumento de objetivação do poder para evitar ou dificultar que motivos e fins subjetivos informem a tomada de decisões, pois nele se contrapõem argumentos, dados e fatos, que permanecem registrados; se móveis subjetivos, mesmo assim, afetarem a decisão, torna-se mais fácil o controle administrativo e jurisdicional”.

Para Marçal Justen Filho ${ }^{375}$, como antes explicitado, há um grande problema em vislumbrar no processo administrativo um equivalente do processo jurisdicional, com a única peculiaridade de ser conduzido pela própria Administração Pública. Para ele, a disputa sobre a distinção se traduz de modo mais evidente na controvérsia sobre o princípio do juiz natural, que significa "a vedação à criação de regras de competência e de jurisdição específicas para um caso concreto". O juiz natural "é aquele que, segundo as regras gerais e abstratas, editadas antes do surgimento do litígio, foi investido da competência para decidir a controvérsia”376.

Para Marçal Justen Filho ${ }^{377}$, aqui reside um problema. A exigência de observância do juiz natural não é típica da atividade administrativa decisória. Diz ele que "mesmo que a Administração Pública seja investida do dever de julgar - muito similar, em alguns casos, à função jurisdicional -, isso não conduz, usualmente, à existência de um corpo permanente de servidores encarregados da função decisória”. Conclui que “não cabe aludir à aplicação do princípio do juiz natural no âmbito do processo administrativo”, mas que podem ser feitas ressalvas:

a) Sempre que existir uma estrutura estável e permanente, na via administrativa, de servidores encarregados da função julgadora, será aplicável o princípio do juiz natural;

b) A ausência de uma garantia de juiz natural nos processos administrativos não equivale a autorizar o abuso ou a eliminar a garantia da imparcialidade, inserida na cláusula do devido processo administrativo.

As aludidas ressalvas vão ao encontro das ideias até aqui desenvolvidas e, com a licença do Prof. Marçal, se não dão azo à existência do instituto do juiz natural no processo

\footnotetext{
${ }^{374}$ A processualidade..., p. 90.

${ }^{375}$ Curso..., p. 310-311.

${ }^{376}$ Curso..., p. 312.

${ }^{377}$ Curso..., p. 312-313.
} 
administrativo, pelo menos remarcam, para além de qualquer dúvida razoável, a importância das garantias da impessoalidade.

Ao tratar dos princípios norteadores do procedimento administrativo, Marçal Justen Filho $^{378}$ destaca princípios gerais (do direito administrativo) e princípios específicos, quais sejam: (i) utilidade; (ii) imparcialidade; (iii) publicidade; (iv) contraditório; (v) motivação; (vi) objetividade e (vii) celeridade. ${ }^{379}$ Sobre o princípio (específico) da imparcialidade, anota ${ }^{380}$ :

“O princípio da imparcialidade impõe que a autoridade encarregada de de-
cidir e todos os demais agentes estatais envolvidos no processo estejam em
condições de formar a sua vontade e manifestá-la sem preferência ou oposi-
ção aos interesses envolvidos.
O procedimento administrativo é um instituto jurídico orientado a reduzir o
subjetivismo e a irracionalidade na decisão administrativa. Como decorrên-
cia inafastável, é vedado que o procedimento administrativo seja conduzido
por um sujeito que tenha formado previamente o seu convencimento, orien-
tando a sua conduta e a condução da atividade à obtenção de um resultado
predeterminado. A imparcialidade impõe o afastamento de todas as autoridades que se encontrem em posição de conflito de interesses em face do objeto a ser decidido. O conflito de interesses pode configurar-se em termos explícitos, o que se passa quando o resultado do procedimento for apto a afetar de modo necessário uma situação jurídica de que participe a autoridade. Tal configura a hipótese denominada de impedimento no âmbito do direito processual. (...)

Mas o princípio da imparcialidade também alcança os casos em que o conflito de interesses decorre das circunstâncias do caso concreto. São aqueles casos em que o procedimento envolve sentimentos, propostas ou outros posicionamentos subjetivos da autoridade administrativa. É evidente que todo e qualquer indivíduo professa certas convicções e que tal não configura qualquer ilicitude. Mas isso não autoriza que a autoridade administrativa ignore a sua condição de ‘servidor da comunidade’ e pretenda impor a outrem uma convicção própria”.

\footnotetext{
${ }^{378}$ Obra citada, p. 316 e seguintes.

${ }^{379}$ Perceba-se que o processo administrativo deve casar "impessoalidade", como princípio geral, e "imparcialidade" como princípio específico, bem na linha que reputamos adequada de diferenciação de conteúdos, sendo a impessoalidade mais ampla, representada por um círculo maior, e a imparcialidade menor, mas deveras importante.

${ }^{380}$ Curso..., 2011, p. 317.
} 
Para exemplificar a primeira situação (impedimento), o autor traz a hipótese em que a autoridade seja proprietária de imóvel que pode ser abrangido em processo de desapropriação por utilidade pública, ficando proibida de conduzir o procedimento.

Para exemplificar a segunda situação, de caracterização menos objetiva, o autor ${ }^{381}$ enfoca uma hipotética decisão sobre aquisição de merenda escolar, para dizer que se o sujeito responsável pela decisão for vegetariano, nem por isso pode haver restrição à compra de carne como alimento. Assim, “a escolha da dieta envolve uma margem insuprimível de liberdade pessoal”, mas isso não quer significar possa a autoridade, mercê de preferência pessoal, “impor a aquisição apenas de alimentos de origem vegetal - o que configuraria violação à imparcialidade, além de uma severa infração à natureza democrática do sistema político”.

\subsubsection{Participação}

A processualização da decisão administrativa tem como uma das suas maiores virtudes proporcionar ao administrado a possibilidade de participar da construção da decisão administrativa impessoal.

A participação, como ensina J. Baptista Machado 382 , “considerada como democratização da democracia - e também como democratização da sociedade - traduz na intensificação da intervenção dos indivíduos e dos grupos no processo de decisão de assuntos de interesse público" ${ }^{383}$.

Carlos Ari Sundfeld ${ }^{384}$, ao ter no processo o modo normal de agir do Estado Democrático de Direito, assinala que "sem que a decisão do Estado (a lei, a sentença, o ato administrativo) deixe de ser ato de autoridade, protege-se o indivíduo a ser afetado; condicionando a produção do ato a um processo do qual ele possa participar”.

O terceiro pilar sobre o qual se funda o desenvolvimento de uma atuação administrativa eminentemente impessoal é, portanto, o da ampla democratização da Administração Pública.

${ }^{381}$ Curso..., p. 317-318.

${ }^{382}$ Participação e descentralização - democratização e neutralidade na Constituição de 76. Coimbra: Almedina, 1982, p. 115.

383 Para J. Baptista Machado (obra citada, p. 117): “Fala-se indistintamente em 'democratização da democracia' e 'democratização da sociedade' mediante uma intensificação da participação dos indivíduos e dos grupos nos processo de decisão. Isto corresponderia a um aumento do input democrático e, consequentemente, a um aumento da legitimidade democrática nas decisões da publica potestas”.

${ }^{384}$ Obra citada, p. 94. 
Para além do sistema jurídico de liberdades formais estabelecido após o advento das Revoluções Liberais, em que a representação política por meio do sufrágio era tida como suficiente para fundamentar escolhas legítimas dos administradores, os novos paradigmas que norteiam a gestão e a implementação das funções administrativas apontam para a necessidade premente de construção, na esfera pública, de decisões amparadas num critério mais amplo de legitimidade, baseado na participação efetiva dos cidadãos nas deliberações sociais e políticas realizadas pelo Poder Público.

José Afonso da Silva ${ }^{385}$ arrola 10 (dez) blocos de princípios constitucionais da Administração Pública: a) legalidade e finalidade; b) impessoalidade; c) moralidade e probidade administrativa; d) publicidade; e) eficiência; f) licitação pública; g) prescritibilidade dos ilícitos administrativos; h) responsabilidade civil da Administração; i) participação; j) autonomia gerencial.

Quanto ao princípio da participação, o autor invoca, com precisão, o enunciado do art. 37, § $3^{\circ}$, da CF/88, com a redação dada pela EC $n^{\circ} 19 / 88$, do seguinte teor:

$\S 3^{\circ}$ A lei disciplinará as formas de participação do usuário na administração pública direta e indireta, regulando especialmente:

I - as reclamações relativas à prestação dos serviços públicos em geral, asseguradas a manutenção de serviços de atendimento ao usuário e a avaliação periódica, externa e interna, da qualidade dos serviços;

II - o acesso dos usuários a registros administrativos e a informações sobre atos de governo, observado o disposto no art. $5^{\circ}$, X e XXXIII;

III - a disciplina da representação contra o exercício negligente ou abusivo de cargo, emprego ou função na administração pública.

Destaque-se no trato do tema a Lei $n^{0} 12.527$, que regula o acesso a informações previsto no inciso XXXIII do art. $5^{\circ}$, no inciso II do $\S 3^{\circ}$ do art. 37 e no art. 216 da Constituição Federal.

Diante desse quadro, a democratização das instâncias e esferas administrativas, associada à motivação e à processualização das tomadas de decisão pela Administração Pública, representa aspecto essencial para aferir a aplicação normativa do princípio da impessoalidade como fundamento da ação/organização administrativa.

A fim de compreender o conteúdo e o alcance desse fenômeno de democratização -

${ }^{385}$ Curso de Direito Constitucional positivo..., p. 675 e seguintes. 
cada vez mais sensível nas diversas ordens constitucionais - importa analisar as transformações substanciais que a concepção de democracia tem assumido ao longo dos períodos históricos, até atingir sua conformação contemporânea manifesta na ideia complementar de representação/participação.

O marco teórico adotado, à luz das finalidades específicas do presente trabalho, voltar-se-á à definição dos aspectos mais relevantes para a construção hodierna da noção de Administração Pública democrática.

Por muito tempo, as correntes teóricas que se debruçavam sobre os questionamentos acerca dos regimes ditos democráticos estavam imersas na discussão polarizada entre as concepções de democracia direta, de um lado, e democracia representativa, de outro.

Os autores contratualistas de tradição liberal, tais como John Locke, manifestavam o pensamento de que o sistema de eleições de representantes por meio do voto configurava um modelo idealmente democrático ${ }^{386}$, na medida em que as assembleias legislativas eleitas possuíam a legitimidade necessária para alcançar, em concreto, o bem público ${ }^{387}$. Alexis de Tocqueville, séculos depois, defendeu o mesmo entendimento em sua obra clássica “A Democracia na América”, onde pela primeira vez o emprego do termo democracia passou a ser utilizado para caracterizar regimes políticos contemporâneos fundados nos ideais de representação política e liberdades públicas (no caso específico, o dos Estados Unidos da América).

Em contraposição, o também contratualista Jean-Jacques Rousseau, como crítica a essa visão, exprimia a ideia de que a soberania não poderia ser representada, tendo em vista a intangibilidade e a inalienabilidade da vontade geral, a qual somente se manifestaria pela participação direta em assembleia de todos os cidadãos que compunham a sociedade civil. Pela relevância, impende citar textualmente o posicionamento de Rousseau:

“A soberania não pode ser representada pela mesma razão que a torna
inalienável; ela reside essencialmente na vontade geral, e a vontade não
admite representação... Os deputados do povo, portanto, não são e não po-

${ }^{386}$ Conforme John Locke (Dois Tratados sobre o Governo. In: MORRIS, Clarence. Org. Os Grandes Filósofos do Direito. São Paulo: Martins Fontes, 2002. p. 151). Cumpre salientar que apesar das concepções de John Locke levarem à compreensão da formação de um regime democrático pelas assembleias legislativas eleitas, o autor não usava o termo democracia de forma expressa para designar o sistema político parlamentarista. Tal referência à democracia como característica de um regime político contemporâneo foi iniciada com a obra de Alexis de Tocqueville, em 1835.

${ }^{387}$ Ressalte-se que o bem público no âmbito do Estado Liberal era visto como a intervenção mínima estatal na esfera econômica e social, a fim de deixar os cidadãos livres para usufruírem da liberdade privada. Os objetivos centrais do Estado, nesse modelo, eram garantir a segurança nacional e manter a paz pública. 
dem ser seus representantes; são seus meros procuradores e não podem levar a efeito atos definitivos. Toda lei que o povo não ratificou em pessoa é nula e vazia... O povo da Inglaterra se considera livre, mas trata-se de um enorme equívoco; ele só é livre durante a eleição dos membros do Parlamento. Tão logo estes são eleitos, a escravidão sobrevém e ele nada é” ${ }^{388}$.

A aludida dicotomia entre democracia direta e democracia representativa foi detalhada de forma precisa na obra de Norberto Bobbio, na qual o autor, com base no pensamento de Benjamin Constant, contrapôs a liberdade dos modernos à liberdade dos antigos. Segundo Bobbio, liberdade e democracia são conceitos que caminham lado a lado, mas correspondem a realidades diferentes a depender do contexto histórico e sociopolítico em que estão inseridos. Nesse sentido, “o objetivo dos antigos era a distribuição do poder político entre todos os cidadãos de uma mesma pátria”. Por outro lado, “o objetivo dos modernos é a segurança nas fruições privadas: eles chamam de liberdade as garantias acordadas pelas instituições para aquelas fruições" ${ }^{389}$.

À luz da constatação de Bobbio, a compreensão do conteúdo substancial do significado da democracia está vinculada às concepções sociais, políticas e culturais que vigoram em determinada sociedade em certo período. Assim, enquanto a igualdade de condições e de voto dos cidadãos gregos na idade antiga representava o cerne do modelo democrático, os pensadores liberais pós-revolucionários passaram a identificar a garantia da liberdade privada e a oposição aos regimes monárquicos autocráticos por meio da eleição de representantes políticos como o ápice da realização democrática, materializado em máximas como "no taxation without representation".

Todavia, não tardou para que o sistema de representação política estabelecido com o advento do Estado Liberal apresentasse os primeiros sinais de crise. Embora se constatasse a ampliação do direito de voto - até o alcance do sufrágio universal - a restrição da participação política dos cidadãos ao depósito da cédula na urna engendrou inúmeros problemas institucionais no âmbito desse modelo.

\footnotetext{
${ }^{388}$ Conforme Jean-Jacques Rousseau (O Contrato Social. In: MORRIS, Clarence. Org. Os Grandes Filósofos do Direito. São Paulo: Martins Fontes, 2002. p. 231). Apesar de defender que a democracia somente se realizaria de forma plena com a participação direta dos cidadãos nas deliberações públicas, Rousseau estava convencido que uma verdadeira democracia não é capaz de existir, haja vista que requer muitas condições difíceis de serem reunidas, tais como um Estado demasiadamente pequeno e uma grande igualdade de oportunidades e fortunas entre os cidadãos.

${ }^{389}$ Liberalismo e Democracia. 6a ed. São Paulo: Ed. Brasiliense, 2000. p. 8.
} 
Marcos Augusto Perez ${ }^{390}$, em obra de referência sobre o tema, elenca problemas vivenciados pela democracia participativa: i) oligarquização dos partidos políticos; ii) incapacidade dos parlamentares para identificar e resolver as complexas dificuldades inerentes à atuação estatal no domínio social e econômico; iii) personalização excessiva do processo eleitoral; iv) desprestígio da lei enquanto instrumento normativo; v) concentração de poderes nas mãos da burocracia do Executivo; vi) falta de educação política dos eleitores, levando-os a optar mais emotiva do que racionalmente, no momento de escolha dos governantes; dentre outros.

Como bem havia ressaltado Jean-Jacques Rousseau em sua crítica ao sistema democrático representativo, a liberdade política não pode estar circunscrita ao momento de escolha dos representantes parlamentares e executivos, sob pena de verdadeira submissão política da sociedade civil aos governantes eleitos. Com base nesse pressuposto amplo, as diversas ordens constitucionais passaram a adotar instrumentos de participação direta do cidadão na gestão e no controle das finalidades públicas ${ }^{391}$, para além da garantia plena do direito de voto. Essa nova conformação política, em que há a conciliação entre a representação e a participação do cidadão na esfera pública, passou a ser compreendida como um sistema de democracia participativa.

Norberto Bobbio, em obra específica sobre os desafios da democracia contemporânea, identifica de modo magistral as origens dos influxos e pressões político-sociais que levaram à assunção da democracia participativa, à efetiva proteção e garantia constitucional. De acordo com o autor, o processo de democratização nas últimas décadas passou a transcender a esfera das relações políticas para alcançar o campo muito mais amplo das relações sociais, as quais abrangem não só o vínculo entre cidadão e Estado, mas todas as conexões entre indivíduos na sociedade civil, a exemplo das relações entre empregado e empregador, professor e aluno, pai e filho, produtor e consumidor etc. Diante desse quadro, a democracia participativa configura de forma mais acurada não o retorno da democracia representativa para a democracia direta, mas a passagem da democracia política em sentido estrito para a democracia social. Nesse ponto, é fundamental conferir ipsis litteris o pensamento de Bobbio:

“(...) podemos dizer que o que acontece hoje quanto ao desenvolvimento da

${ }^{390}$ A Administração Pública Democrática. Belo Horizonte: Ed. Fórum. 2009. p. 31.

${ }^{391}$ Tomamos como exemplos a Constituição Portuguesa de 1976, a Constituição Espanhola de 1978 e a Constituição Brasileira de 1988. 
democracia não pode ser interpretado como a afirmação de um novo tipo de democracia, mas deve ser entendido como a ocupação, pelas formas ainda tradicionais de democracia, como é a democracia representativa, de novos espaços, isto é, de espaços até agora dominados por organizações de tipo hierárquico ou burocrático.

Deste ponto de vista, creio que se deve falar justamente de uma verdadeira reviravolta no desenvolvimento das instituições democráticas, reviravolta esta que pode ser sinteticamente resumida numa fórmula do seguinte tipo: da democratização do Estado à democratização da sociedade”392.

Na perspectiva adotada por Bobbio, o ideal democrático passa a ser um dos pilares centrais das práticas e decisões tomadas no campo da sociedade civil, que cada vez mais se encontra permeada pela participação política (latu sensu) dos cidadãos. Ampliaram-se os questionamentos em torno da democracia para além do direito formal de eleitor. A aferição da maturidade democrática de uma sociedade passou a pressupor o alcance e a efetiva aplicação dos valores democráticos nas diversas esferas e instâncias sociais. Para o ilustre pensador:

\footnotetext{
“(...) hoje, se se deseja apontar um indicador do desenvolvimento democrático, este não pode mais ser o número de pessoas que têm o direito de votar, mas o número de locais, diferentes dos locais políticos, nos quais se exerce o direito de voto; sintética mas eficazmente: para dar um juízo sobre o Estado da democratização num dado país, o critério não deve mais ser o de ‘quem' vota, mas o do 'onde' se vota” ${ }^{393}$.
}

Nessa afirmação, Bobbio ressalta expressamente que o "direito de voto" deve ser compreendido de modo amplo, no sentido de alcançar a participação concreta do cidadão nas escolhas e decisões feitas no seio social, que também abarca o meio político.

No âmbito da ordem constitucional, em particular, os poderes constituintes dos regimes democráticos contemporâneos conferiram à democracia densidade normativa de princípio, o qual se expande tanto na esfera da ação estatal - como elemento informador das práticas e condutas assumidas pelo Poder Público - quanto no campo da organização do Estado - a partir da criação de instrumentos e meios de participação e formação democrática dos cidadãos na esfera pública. Esse é o pressuposto teórico fundamental do qual parte

${ }^{392}$ O Futuro da Democracia..., p. 67.
${ }^{393}$ O Futuro da Democracia..., p. 68. 
Marcos Augusto Perez ${ }^{394}$ em sua obra, extraído da elaboração doutrinária de J. J. Canotilho. Confira-se:

\begin{abstract}
“Como diz Canotilho, a democracia é um princípio normativo não somente informador do Estado, mas também, o que nos interessa primordialmente, um princípio de organização que 'implica a estruturação de processos que ofereçam aos cidadãos efectivas possibilidades de aprender a democracia, participar nos processos de decisão, exercer controlo crítico na divergência de opiniões, produzir inputs políticos democráticos.

(...)

Não se objetiva, portanto, que o Estado continue a atuar solitariamente, mas que conte com a colaboração de 'entidades da sociedade civil, entidades privadas ou afins' para o desenvolvimento de atividades que importem na ‘efetivação de direitos econômicos, sociais e culturais”.
\end{abstract}

Em face desse entendimento, evidencia-se que o paradigma do Estado Democrático de Direito, expressamente definido pelo poder constituinte originário da Constituição Federal de 1988 como o modelo estatal em que se organiza e se constituía a República brasileira, é fundado nas noções sólidas de res publica e de democracia, tanto no viés representativo como no participativo.

O parágrafo primeiro do art. $1^{\circ}$ da CF de 1988 materializa ambas as concepções de República e de democracia participativa, ao asseverar que "todo o poder emana do povo, que o exerce por meio de representantes eleitos ou diretamente, nos termos desta Constituição”.

Segundo Carlos Ari Sundfeld, a concepção de res publica, tal como consagrada pelo texto constitucional, "implica fazer dos agentes políticos que exercem diretamente o poder político representantes diretos do povo, por ele escolhidos e renovados periodicamente"395. Desse modo, a chancela popular dos mandatos políticos configura instrumento efetivo de controle dos cidadãos das atividades realizadas pelos representantes eleitos. Porém, como bem ressalta Sundfeld, “a renovação dos mandatos não é o único controle do povo sobre os exercentes do poder. Estes podem ser responsabilizados (punidos e destituídos de seus cargos) quando violam seus deveres, excedendo ou descumprindo os termos do mandato que receberam 396 . Nesse sentido, o autor destaca, baseado na obra de Geraldo Ataliba, que caracteriza o sistema republicano, a eletividade, a periodicidade e a responsabilidade.

\footnotetext{
${ }^{394}$ Obra citada, p. 36.

${ }^{395}$ Fundamentos de Direito Público..., p. 50.

${ }^{396}$ Fundamentos de Direito Público..., p. 50.
} 
É preciso acrescer a essa visão, no entanto, que conforme consta manifestamente do parágrafo primeiro do dispositivo constitucional anteriormente transcrito, a escolha de governantes eleitos não esgota o poder democrático do povo. Este também possui ampla legitimidade para exercer diretamente os direitos políticos assegurados pela Constituição. Nessa perspectiva, o fortalecimento institucional de instrumentos de participação popular efetiva e direta nas tomadas de decisão na esfera pública foi erigido pelo constituinte como pilar de legitimação dos poderes constituídos, em face do aludido fenômeno de democratização das relações sociais.

Nesse contexto, é nítido que a Constituição consagrou, de modo irmanado ao princípio democrático, o princípio da participação. Manoel Gonçalves Ferreira Filho, em texto de vanguarda sobre o referido princípio, apreciou de forma precisa o que aqui se pretende demonstrar. Destaque-se:

\footnotetext{
“O voto é, sem dúvida, uma das manifestações da participação popular que reclama a Democracia. Essa participação, contudo, não pode ser resumida ao rito do voto, portanto não deve ser medida em termos de extensão do direito de voto e de elegibilidade. Tem ela outro parâmetro, seguramente mais significativo - a intensidade dessa participação. Não é por mera coincidência que nos países considerados mais democráticos fervilham as associações cívicas, e é grande a preocupação do cidadão com o que é comum a todos, com a 'res publica'. Só a participação intensa fortalece a Democracia, o rito do voto pode muitas vezes apenas travesti-la"397.
}

O princípio da participação é a pedra angular da democracia participativa. Quando se garantem aos cidadãos meios para atuar concretamente na gestão e no controle das atividades e finalidades púbicas, está-se viabilizando plenamente a determinação constitucional de exercício direto do poder pelo povo. A participação, logo, está diretamente vinculada à legitimidade consubstanciada na fórmula do Estado Democrático de Direito ${ }^{398}$.

\footnotetext{
${ }^{397}$ A Democracia Possível. São Paulo: Saraiva, 1972. p. 32.

${ }^{398}$ Nesse sentido, confira-se o posicionamento do professor Diogo de Figueiredo Moreira Neto (Quatro Paradigmas do Direito Administrativo Pós-Moderno - Legitimidade, Finalidade, Eficiência e Resultados. Belo Horizonte. Ed. Fórum. 2009. p. 21): “Realmente, os tradicionais e necessários vínculos de legalidade - que caracterizavam suficientemente o Estado de Direito - cederam espaço para a inclusão de novos vínculos de legitimidade - sem os quais não se viabilizaria a sua caracterização como Estado Democrático de Direito. Assim, o referencial de legitimidade, para cuja satisfação o modernismo democrático se havia limitado a exigir um novo conteúdo no pós-modernismo democrático, passando a demandar, além da investidura legítima no poder (legitimidade pelo título), também um exercício legítimo do poder (legitimidade pelo exercício) e, ainda, um resultado legítimo do emprego do poder (legitimidade pelo resultado). Para tornar efetiva essa tríplice
} 
A ampla conformação constitucional do princípio da participação - como não poderia deixar de ser - alcança inteiramente a esfera administrativa do Estado. Diante desse quadro, não há como pensar a Administração Pública fora dos novos contornos políticos e institucionais desenvolvidos a partir da consolidação da democracia participativa. Como se disse antes, o princípio geral democrático (o qual abrange a participação) deve embasar tanto a ação quanto a organização do Poder Público, de modo a estabelecer vias eficazes para a manifestação do cidadão nos processos de decisão administrativa e de elaboração das políticas públicas.

Segundo Marcos Augusto Perez, “passamos a falar, assim, da democracia no sentido de 'democracia de funcionamento', isto é, da adoção de instrumentos que interferem no modo de atuar da Administração, de maneira a torná-la mais aberta à influência externa de inputs dos administrados, mais 'responsiva', enfim”399.

Na mesma perspectiva, Odete Medauar defende tal orientação, ao entender que o modelo de democracia contemporâneo impõe a necessidade de aproximação entre as concepções políticas de democracia que vigoram na ordem constitucional e a atuação concreta do Poder Público, superando o vetusto paradigma de submissão total do administrado à autoridade da Administração. Importa destacar o posicionamento da professora Medauar, em excerto que capta de forma ímpar a transição da Administração autoritária para a Administração democrática ${ }^{400}$ :

“A partir da metade da década de 50 do século XX, começa a surgir a preo-
cupação com uma democracia mais completa, com a democracia que trans-
põe o limiar de eleição de representantes políticos para expressar-se tam-
bém no modo de tomada de decisão dos eleitos. Emergiu a ideia de que o
valor da democracia depende também do modo pelo qual as decisões são
tomadas e executadas. Verificou-se que havia, com frequência, grande
distanciamento entre as concepções políticas de democracia vigentes num
país e a maneira com que ocorriam as atuações da Administração: perante
esta, o indivíduo continuava a ser considerado como súdito, não como cida-
dão dotado de direitos. Passou a haver, então, uma pregação doutrinária em
favor da democracia administrativa, que pode ser incluída na chamada de-

legitimação estatal referida a seus agentes, o próprio conceito de democracia se transformaria, passando de uma acepção nada mais que formal a uma acepção material, com a introdução de três robustos princípios, aos poucos explícita ou implicitamente constitucionalizados: o da participação, o da eficiência e o do controle, que serão considerados nestes estudos".

${ }^{399}$ Obra citada, p. 37.

${ }^{400}$ Direito Administrativo Moderno..., p. 40-41. 
mocracia de funcionamento ou operacional. Em vários ordenamentos estrangeiros e também no brasileiro muitas normas e medidas vêm sendo implantadas para que a democracia administrativa se efetive. Isso porque o caráter democrático de um Estado, declarado na Constituição, deve influir sobre o modo de atuação da Administração, para repercutir de maneira plena em todos os setores estatais”.

Diante desse quadro, é interessante apreciar o novo arranjo institucional constituído no âmbito da Administração Pública à luz dessa realidade de participação direta do cidadão na esfera administrativa.

No início da conformação do regime jurídico-administrativo, estabelecido sob a égide do Estado Liberal, a estrutura normativa que regulava os poderes da Administração fundavase em dois pressupostos fundamentais: i) a submissão do Poder Público à lei, numa perspectiva formalista, em que ao administrador somente era dado fazer o que o comando legal determinava; ii) a conferência à Administração Pública de poderes exorbitantes, voltados instrumentalmente à concretização do interesse público. Neste contexto é que se formaram as noções centrais da atividade administrativa, nomeadamente a imperatividade, a unilateralidade e a autoexecutoriedade ${ }^{401}$.

A percepção em abstrato da existência de um interesse público, definido em lei, a ser implementado a todo custo pela Administração, representava o ponto central de sustentação do regime jurídico-administrativo. Em sua formação original, tal regime era plenamente compreendido como um complexo de prerrogativas e poderes que permitiam ao Estado desenvolver e materializar a finalidade pública expressa no texto legal. Nessa seara, interesses particulares e públicos eram vistos como realidades contrapostas, devendo os primeiros sucumbir em prol dos segundos quando entrassem em conflito.

No modelo liberal de Estado, a concepção de supremacia do interesse público sobre o particular embasava os atos unilaterais e imperativos (e por que não autoritários) da Administração Pública, instrumentalizados pelos poderes exorbitantes a esta, conferidos pelo regime legal. Em síntese, munia-se o Poder Público de prerrogativas especiais para que este alcançasse da melhor forma o interesse público estabelecido a priori pelo legislador.

No paradigma liberal, um aparato administrativo fundado na supremacia e na

${ }^{401}$ Conforme Vitor Rhein Schirato (O Processo Administrativo como Instrumento do Estado de Direito e da Democracia. In: Atuais Rumos do Processo Administrativo. Org. Vitor Rhein Schirato e Odete Medauar. São Paulo: Ed. Revista dos Tribunais. p. 12). 
indisponibilidade do interesse público se adequava perfeitamente ao modo de atuação e gestão da máquina administrativa. A figura estatal eminentemente absenteísta somente intervinha na ordem econômica e social para garantir e proteger a plena fruição das liberdades privadas. Nessa senda, com o fundamento de assegurar a ordem pública e a paz social, eram claramente justificáveis as prerrogativas do Poder Público para fazer valer a noção abstrata de interesse público, compreendido numa ótica formal-negativa (garantia de segurança para o desempenho dos direitos e liberdades individuais).

Entretanto, como ressalta de forma precisa a professora Odete Medauar, o regime jurídico administrativo “não flutua num espaço vazio, mas liga-se ao quadro social, político, econômico e institucional do País" ${ }^{02}$. Desse modo, as mudanças estruturais, políticas, econômicas e sociais que alcançaram a formação do Estado a partir do início do séc. XX impõem a necessária redefinição dos pressupostos e fundamentos do Direito Administrativo, a fim de adequá-lo às novas diretrizes normativas e axiológicas assumidas pela ordem constitucional.

Os princípios da democracia e da participação, em específico, estão vinculados à assunção de uma nova postura do Poder Público frente ao administrado. Um Estado Democrático de Direito não pode conviver com a concepção de uma Administração Pública autoritária, que se coloca em posição de distanciamento do cidadão. A perspectiva deve, necessariamente, ser outra. A autoridade da Administração deve ser buscada, em seu fundamento de legitimidade, na própria participação do administrado na gestão e no controle das finalidades públicas.

A autoridade permanece - como tem de ser - com o Poder Público, sendo modificada apenas sua fonte de legitimidade. Enquanto no Direito Administrativo de tradição liberal o poder legítimo derivava da atribuição legal ao administrador de concretização do interesse público (definido a priori em lei), no paradigma democrático atual a ordem jurídica deve fornecer instrumentos para que o cidadão integre a esfera administrativa, influindo nas tomadas de decisões e na determinação em concreto do interesse público. Nesse arranjo institucional, escolhas e deliberações definitivas são da própria Administração, mas ao cidadão deve ser dada ampla possibilidade de manifestar e de ter seus pleitos e contribuições realmente apreciados pelo administrador.

Conforme bem observa Marcos Augusto Perez, a participação do cidadão no desenvolvimento das atividades administrativas "não desvirtua a repartição constitucional de po-

${ }^{402}$ Direito Administrativo Moderno, p. 39. 
deres. A decisão continua sendo tomada pela Administração, em nada sendo usurpada a divisão constitucional de poderes e funções estatais”. Com efeito, “há, isto sim, uma estruturação aberta do processo de construção da decisão administrativa, de modo a possibilitar ao cidadão exercitar, como que em devolução, os poderes que ele próprio delegou constitucionalmente à Administração" "403. Conclui-se que "não existe positivamente a atribuição de poderes à Administração sem participação popular”404.

Diante dessas premissas, a densidade normativa dos princípios democráticos (democracia e participação) impõe a criação de instrumentos de abertura institucional da Administração Pública para que o administrado possa participar efetivamente das atividades administrativas, mormente aquelas de cunho deliberativo. Nesse contexto, figura que ganha grande destaque é a do processo administrativo.

Como já discutido, o fortalecimento da processualidade no regime jurídico administrativo, no presente momento, ater-se-á à necessária postura democrática a ser assumida pelo Poder Público no âmbito do processo administrativo, de modo a se concretizar a atuação impessoal dos administradores.

A transição do modelo de Administração Pública autoritária para a Administração Pública Democrática tem como aspecto primordial a perda do referencial único acerca da concepção do interesse público. A ordem constitucional fundada na democracia abarca e protege inúmeros interesses legítimos, muitas vezes conflitantes quando considerados concretamente. Em face desse quadro, a abertura da esfera administrativa à participação dos cidadãos que representam tais interesses, num procedimento logicamente encadeado e organizado, é sem dúvida meio eficaz de democratização da Administração, na medida em que possibilita a ampla e necessária apreciação das demandas dos diferentes grupos sociais.

Segundo a professora Odete Medauar, “com a participação forma-se ponte entre um mundo administrativo fechado e cidadãos muito enfraquecidos, ocorrendo, portanto, ruptura da imagem clássica de uma dualidade radical entre Administração e administrado e decréscimo da oposição entre autoridade e liberdade" ${ }^{405}$. Diante dessa nova conformação organizativa do Poder Público legitimada pela participação do cidadão, rompe-se a vetusta oposição entre Estado e sociedade, fazendo com que a balança entre autoridade e liberdade em constante tensão no direito administrativo - penda mais para o lado dessa última.

${ }^{403}$ Obra citada, p. 139.

404 Obra citada, p. 140.

${ }^{405}$ O Direito Administrativo em Evolução. 2a Ed. São Paulo: Ed. Revista dos Tribunais. 2003. p. 229. 
Considerando o vasto espectro de interesses que dão ensejo ao surgimento de um processo administrativo, o papel da Administração Pública passa a ser o de uma verdadeira mediadora e gestora de pretensões no seio administrativo, devendo aferir, em concreto, aquelas posições fáticas e jurídicas que merecem a tutela do Poder Público ${ }^{406}$. Nessa perspectiva, o interesse público passa a ser visto como uma construção à luz das circunstâncias e dos direitos envolvidos concretamente no caso particular e demonstrados no curso do processo administrativo.

Relevante destacar novamente o entendimento de Odete Medauar. De acordo com a ilustre professora, "a participação liga-se à identificação do interesse público de modo compartilhado com a população; associa-se ao decréscimo da discricionariedade; propicia atenuação da unilateralidade na formação dos atos administrativos; liga-se também às práticas contratuais baseadas no consenso, na negociação, na conciliação de interesses" ${ }^{407}$.

Cumpre à Administração gerir e confrontar todos os interesses em jogo para chegar, de forma motivada, a uma decisão que concretize o interesse público evidenciado dos elementos materiais e formais materializados no processo.

Retratando a aludida postura da Administração, de gestora e mediadora de interesses, impende destacar o posicionamento de Vitor Rhein Schirato:

\footnotetext{
“Desta releitura da noção de interesse público e do dogma da supremacia do interesse público a priori e em qualquer caso, imperativa na atual conjuntura do direito administrativo, emerge uma profunda alteração na forma de atuação da Administração Pública. Na medida em que se considera não mais caber à Administração Pública realizar um interesse público previamente definido em lei - ou estabelecido pela própria Administração por delegação legal -, mas sim caber, por meio de um exercício de ponderação dos diversos interesses coletivos legítimos existentes no caso concreto, adotar a medida considerada mais adequada ao caso concreto, escolhendo um ou alguns dos interesses públicos subjacentes, tem-se como clara a noção de que a função administrativa nada mais é do que uma função de arbitramento,
}

\footnotetext{
${ }^{406}$ Mais uma vez, recorre-se aos ensinamentos de J. Baptista Machado (Participação..., p. 118), para quem: “É claro que a Administração ou, em geral, o Executivo, não pode servir-se do poder que exerce para falsear o jogo da concorrência entre formações políticas ou para dominar o 'mercado da opinião'(meios de comunicação social pertencentes ao Estado - cfr. Art. $39^{\circ} \mathrm{da}$ Constituição). Neste aspecto, o Executivo tem de ser neutro ou imparcial. Em todo caso, ele tem por missão executar o seu programa político, um programa sem dúvida assente em certa concepção da sociedade e dos factos sociais".

${ }^{407}$ Idem, p. 230.
} 
pois implica um papel de mediação, confiado a seu titular, entre a norma e seu efeito jurídico, conforme ensina Sabino Cassese”408.

Em face do arranjo institucional democrático da Administração Pública contemporânea, é possível perceber que a abertura à participação do cidadão por meio do processo administrativo é instrumento vital para a atuação impessoal do administrador público.

Do ponto de vista da organização administrativa, o processo administrativo representa um meio eficaz de estruturação democrática do Poder Público para receber e apreciar concretamente as manifestações e demandas sociais relacionadas à prática de determinada atividade pela Administração. Com o alcance do processo a todos os grupos interessados em certa decisão administrativa, a efetiva consideração dos interesses em jogo pela autoridade competente confere grande legitimidade democrática à deliberação tomada ao final do trâmite processual, nos moldes da democracia participativa.

Quanto à ação administrativa, é certo que uma decisão que levou em conta os interesses envolvidos na hipótese específica e identificou, de forma motivada, o interesse público a ser perseguido no caso concreto, encontra perfeita consonância com o princípio da impessoalidade. Nessa perspectiva, em particular, a atuação impessoal do Estado materializa a concepção da doutrina italiana de impessoalidade como tratamento isonômico dos cidadãos. É também o que se extrai entendimento de Vitor Schirato ao afirmar que "valores democráticos passam a exigir que o Estado não somente produza resultados conforme a lei, mas que siga o caminho legalmente disciplinado para produzir tais resultados, de forma concertada com aqueles direta e indiretamente interessados no conteúdo do ato a ser exarado" 409 .

A legislação brasileira que rege o processo administrativo na esfera federal (Lei $n^{\circ}$ 9.784/99) é fortemente imbuída dos aludidos princípios democráticos, não só do ponto de vista formal - com a garantia do contraditório e da ampla defesa - mas também sob a ótica material. Exemplos das garantias materiais estão expressos nos artigos $3^{\circ}$, inciso III, 32 e 33 da Lei ${ }^{0}$ 9.784/99. Constate-se a redação desses dispositivos:

\footnotetext{
"Art. $3^{\circ}$. O administrado tem os seguintes direitos perante a Administração, sem prejuízo de outros que lhe sejam assegurados:
}

${ }^{408}$ O processo administrativo...., p. 16.

${ }^{409}$ O processo administrativo..., p. 10. 


\section{(...)}

III - formular alegações e apresentar documentos antes da decisão, os quais serão objeto de consideração pelo órgão competente;

Art. 32 - Antes da tomada de decisão, a juízo da autoridade, diante da relevância da questão, poderá ser realizada audiência pública para debates sobre a matéria do processo;

Art. 33. Os órgãos e entidades administrativas, em matéria relevante, poderão estabelecer outros meios de participação de administrados, diretamente ou por meio de organizações e associações legalmente reconhecidas”.

Como se pode depreender da leitura dos dispositivos legais transcritos, a Administração Pública tem o dever de ampliar a participação dos cidadãos no âmbito do processo administrativo, a fim de que estes possam influir de modo efetivo na tomada de decisão pela autoridade administrativa competente. Para além de mero formalismo, a referida participação popular é aspecto que confere legitimidade e validade às decisões administrativas. Nesse ponto, vale mais uma vez mencionar a doutrina de Vitor Schirato:

\footnotetext{
“A garantia do direito de participação no processo decisório do Estado não é, neste contexto, apenas um formalismo decorrente da concepção de democracia, mas sim é um elemento essencial para que a decisão tomada reflita a ponderação de todos os interesses existentes e que são manifestados no exercício de direitos democráticos. Tem o processo administrativo, destarte, um papel fundamental no atual contexto democrático consagrado na Constituição Federal, estando intimamente ligado à noção de efetiva democracia que acima propugnamos. É, sem dúvidas, um dos instrumentos pelo qual o povo exerce seu poder, visto que uma ponderação viciada dos interesses subjacentes, ou falha na garantia do contraditório, levará ao vício da decisão exarada” ${ }^{410}$.
}

Além do processo administrativo, há na legislação pátria outros instrumentos eficazes que possibilitam a efetiva participação do cidadão nas deliberações e nos atos realizados na esfera pública. Dentre estes, ressaltem-se as figuras das audiências públicas - inclusive referidas na Lei nº 9.784/99 -, dos conselhos participativos, das consultas públicas nas agências reguladoras, dos orçamentos participativos e das ouvidorias públicas (ombudsman). É

\footnotetext{
${ }^{410}$ O processo administrativo..., p. 40.
} 
certo que cada um desses institutos mereceria um detalhamento maior, mas, a fim de não fugir dos objetivos aqui pretendidos, por ora apenas os mencionaremos.

Com a consolidação na legislação pátria dos aludidos instrumentos de democratização da atividade administrativa, fortaleceu-se na doutrina a defesa da consensualidade na Administração Pública. De acordo com esse modelo de atuação consensual, amparado na participação popular e na concepção de boa administração, substitui-se a noção de atividade administrativa unilateral e imperativa pelo fomento de práticas negociais acordadas entre o Poder Público e os cidadãos. Inserem-se nessa perspectiva teórica a ampliação dos contratos administrativos, os acordos referentes aos valores de indenizações (ex. desapropriação amigável) e inclusive a arbitragem na esfera pública.

O efetivo desenvolvimento da consensualidade pela Administração Pública representa uma virada paradigmática no modelo de atuação e de gestão pública. As tradicionais prerrogativas do Poder Público que eram tidas como elementos caracterizadores do regime jurídico administrativo cedem frente à efetividade e, principalmente, à legitimidade democrática das decisões consensuais. Nesse sentido, confira-se a orientação perfilhada por Juliana Bonacorsi de Palma, uma das principais autoras na matéria em questão:

“A consensualidade é caracterizada pela negociação da prerrogativa impe-
rativa, seja para especificar a forma de exercício da imperatividade, seja
para substituir um comando imperativo por outro inteiramente consensual.
Antípoda à decisão unilateral e imposta verticalmente, a consensualidade
demanda a aquiescência da decisão administrativa tanto pelo Poder Público
quanto pelo particular. Sem essa concordância previamente estabelecida em
uma negociação, o acordo torna-se inócuo. O particular tem o direito de
celebrar acordos administrativos na exata medida de sua aquiescência, nem
menos e nem mais. As obrigações traduzidas a termo que o particular deve
satisfazer para terminação consensual do processo necessitam necessaria-
mente corresponder àquelas previamente ajustadas com o Poder Público e
com base nas quais o particular manifestou o seu 'aceite’ em transacionar”411.

Verifica-se que a tomada de decisões consensuais com base na construção realizada ao longo do processo administrativo fortalece mais o movimento de democratização da Administração Pública. Acordos efetivos entre cidadão e gestor administrativo diminuem consi-

${ }^{411}$ A Teoria do Ato Administrativo e a Prática da Consensualidade. In: Os Caminhos do Ato Administrativo. Org. Odete Medauar e Vitor Rhein Schirato. São Paulo: Ed. Revista dos Tribunais. 2011. p. 254. 
deravelmente o déficit histórico existente entre liberdade e autoridade, concretizando de modo amplo a democracia participativa.

Considerando todos os elementos delineados no presente tópico, constata-se que motivação, processualização (procedimentalização) e participação democrática do cidadão na esfera administrativa emergem como fundamentos sólidos para a adoção pelo Poder Público de práticas eminentemente impessoais.

\subsection{Algumas implicações}

No presente tópico serão apresentadas correlações interessantes entre a impessoalidade nas decisões administrativas e algumas matérias tradicionais do Direito Administrativo.

\subsubsection{Teoria do funcionário de fato}

Uma das implicações do princípio da impessoalidade, na vertente de que os atos administrativos são imputáveis não ao funcionário que os pratica, mas à Administração Pública, é a teoria do "exercício de fato” ou do "servidor de fato”.

Pelo ângulo do Direito Constitucional, Dirley da Cunha Júnior ${ }^{412}$ assinala que uma das aplicações do princípio da impessoalidade “encontra-se em matéria de exercício de fato, quando se reconhece validade aos atos praticados por agente irregularmente investido no cargo ou função, sob o fundamento de que os atos são do órgão, e não do agente público”.

Oswaldo Aranha Bandeira de Mello ${ }^{413}$ apontou que agentes públicos de fato ${ }^{414}$ são “gentes públicos putativos”. Assim, “embora a sua investidura se dê, sob aspecto material, irregularmente, sob o aspecto formal, de título de provimento, tal ocorre de maneira regular”. Possuem, então, na dicção do autor, “color of title, o título de agente público”. Em

${ }^{412}$ Curso de Direito Constitucional. $7^{\text {a }}$ ed. São Paulo: Editora Jus Podium, 2013, p 915.

${ }^{413}$ Princípios Gerais de Direito Administrativo. Volume II. Rio de Janeiro: Forense, 1969, p. 280 e 281.

${ }^{414}$ Para o autor (Princípios..., p. 281), podem ser apontadas diferenças entre (i) agentes públicos de fato; (ii) agentes públicos revolucionários e (iii) agentes usurpadores. Um agente público revolucionário ocupa, sem qualquer título, cargo público, apossando-se dele. Trata-se de situação de fato que se torna legítima por ato posterior e de efeito retroativo, nos casos de os vencedores de golpe de Estado conseguirem manter-se no governo e atuar em nome dele como titulares legítimos dos cargos públicos. Essa situação de governo de fato se legitima pela força, que se institucionaliza, e os atos por ele praticados, nesse período, são considerados legítimos, válidos. Já os usurpadores, apontados como tais pelo Código Penal, são estranhos à função pública, que, dolosamente, passam a exercer mediante ato de simples autoassunção, sem terem sido nela investidos. Também se consideram usurpadores aqueles que continuam, dolosamente, a exercer funções dos cargos públicos tendo deixado de ser agentes públicos, por exonerados ou demitidos regularmente. 
consequência, “como a investidura se deu por título formalmente satisfatório, apesar de materialmente inválido, os atos lícitos praticados pelos agentes públicos de fato se têm como do próprio Estado, no desempenho das suas atividades, pois se é plausível terceiro o considere agente público, não pode ser prejudicado na sua boa-fé”.

Fazendo correlação direta com a impessoalidade, O. A. Bandeira de Mello ${ }^{415}$ explica que o aproveitamento dos atos administrativos praticados pelos agentes públicos de fato é medida que se impõe porque "os atos jurídicos, como as atividades materiais, atos de ofício público ou de encargo público, são do órgão estatal, do qual o agente público participa apenas como elemento ativo, como instrumento para a sua ação".

Interessante perceber que o mesmo autor, no início da segunda metade do século passado, também fazia alusão à necessidade de aproveitamento de tais atos também à luz do interesse público. Dizia que "em última análise, esses atos são do organismo moral, do qual o órgão participa, isto é, da pessoa jurídica ou coletiva, Estado”. E que “o próprio interesse público, outrossim, pede a sua validade”.

O.A. Bandeira de Mello ensina que no Direito Romano já se encontrava resolvido tal problema, embora divirjam os autores quanto ao fundamento da validade do ato do agente público de fato. Aponta que Barbário Filipe, escravo fugitivo, pediu e obteve a função de pretor em Roma, cuja situação de escravo era ignorada, e os atos por ele praticados como pretor foram considerados válidos no Direito dos Imperadores ${ }^{416}$.

Maria Sylvia Zanello di Pietro ${ }^{417}$ chega a assinalar ser essa uma aplicação específica do princípio da impessoalidade, “quando se reconhece validade aos atos praticados por funcionário irregularmente investido no cargo ou função, sob fundamento de que os atos são do órgão e não do agente público”.

Celso Antônio Bandeira de Mello, ao tratar do tema dos agentes públicos, anota que dois são os requisitos para a sua caracterização: a) um de ordem objetiva - a natureza estatal da atividade desempenhada; b) outro de ordem subjetiva - a investidura nela. E, invocando a teoria do "funcionário de fato" ${ }^{118}$ (ou "agente público de fato”) adverte que "o defeito

\footnotetext{
${ }^{415}$ Princípios..., p. 281.

${ }^{416}$ Princípios..., p. 281.

${ }^{417}$ Direito Administrativo..., p. 69.

${ }^{418}$ Para Celso Antônio Bandeira de Mello, funcionário de fato é “aquele cuja investidura foi irregular, mas cuja situação tem a aparência de legalidade”, e a teoria aludida postula que "em nome do princípio da aparência, da boa-fé dos administrados, da segurança jurídica e do princípio da presunção de legalidade dos atos administrativos” reputem-se válidos os atos praticados, se por outra razão não forem viciados (Curso de Direito Administrativo, p. 245).
} 
invalidante da investidura de um agente não acarreta, por si só, a invalidade dos atos que este praticou"419. E que, uma vez invalidada a investidura do funcionário de fato, "nem por isso ficará ele a repor aos cofres públicos aquilo que percebeu até então", porque "tendo trabalhado para o Poder Público, se lhe fosse exigida a devolução dos vencimentos auferidos haveria um enriquecimento sem causa do Estado, o qual, dessarte, se locupletaria com trabalho gratuito".

Também para Hely Lopes Meirelles ${ }^{420}$, baseado em precedentes do Supremo Tribunal Federal, são válidos os atos praticados pelo “servidor de fato”, ou seja, “por aquele que teve sua nomeação declarada insubsistente por anulação ou inconstitucionalidade da norma que a amparou”, justamente em razão “da presunção de legitimidade daqueles atos e do princípio da segurança jurídica, conjugados com a teoria da investidura aparente”.

Odete Medauar trata da questão do funcionário de fato especificamente à luz da impessoalidade. Para a autora ${ }^{421}$, em muitos conceitos de ato administrativo aparece a locução “manifestação de vontade” do Estado. E isso de deve ao fato de que, no Direito Civil, utiliza-se a mesma expressão para a definição de ato de negócio jurídico nas relações entre particulares. No seu correto entender, no âmbito do Direito Administrativo a expressão pode levar à (falsa) ideia de vontade como fator subjetivo, quando, na verdade, as decisões administrativas não são tomadas sob um enfoque particularizado, para produzir efeitos sobretudo entre as partes. Uma das características das decisões administrativas encontra-se na avaliação mais ampla dos interesses em confronto e no sentido de efeitos no todo, mesmo naquelas que, aparentemente, repercutem em âmbito restrito.

Ainda de acordo com Medauar, “hoje se deve entender a 'vontade', que se exprime no ato administrativo, não como um fato psíquico, de caráter subjetivo, mas como um momento objetivo". Segundo ela, "é uma das consequências do princípio da impessoalidade que norteia as atividades da Administração brasileira (art. 37, caput, da CF)”.

Nessa linha de raciocínio, Bernardo Strobel Guimarães ${ }^{422}$ assinala que “o princípio

${ }^{419}$ Celso Antônio Bandeira de Mello, invocando lições de Oswaldo Aranha Bandeira de Mello lastreadas no escólio de Fernando Henrique Mendes de Almeida, lembra que, na antiguidade, firmou-se o entendimento, no Direito dos Imperadores, sobre a validade dos atos de Barbário Filipe, escravo fugitivo que chegou a exercer a função de pretor em Roma. (Curso de Direito Administrativo, p. 245-6, rodapé 1).

${ }^{420}$ Direito Administrativo Brasileiro, p. 466.

${ }^{421}$ Direito..., 2014, p. 156

${ }^{422}$ Reflexões acerca do princípio da impessoalidade. In: Princípios de direito administrativo: legalidade, segurança jurídica, impessoalidade, publicidade, motivação, eficiência, moralidade, razoabilidade, interesse público. Thiago Marrara (org.). São Paulo: Atlas, 2012. Para o autor: "Neste sentido, é evidente que o princípio vai ser densificado por inúmeras normas a ele referidas. Não faltam em nosso ordenamento jurídico 
da impessoalidade diz respeito a algo que é inerente à atuação administrativa: a passagem da vontade institucionalizada, posta pela ordem jurídica (portanto, potência) para atos concretos, que dão substância ao programa que se põe à Administração". E que "como tal procedimento só pode ser levado a cabo por pessoas que interpretam as normas, avaliam os fatos, tomam as decisões e garantem a sua observância, o princípio da impessoalidade serve de proteção para que nesse iter não haja qualquer desvio indevido, decorrente da subjetividade do agente".

O autor ${ }^{423}$ assegura que o princípio da impessoalidade "é a garantia maior da concepção da atividade administrativa como uma função". E que "como o regime administrativo se caracteriza pela satisfação de interesses tomados como públicos pela ordem jurídica, é a impessoalidade que assegura que haverá a persecução isenta dessas metas”. Para Bernardo Strobel Guimarães ${ }^{424}$ :

“Embora não seja possível desumanizar a Administração, podem-se criar mecanismos institucionais que garantam que os fins verdadeiramente desejados pela coletividade sejam perseguidos. Assim, nada obstante os outros princípios também concorram para a definição do papel reservado à Administração Pública pela nossa ordem jurídica, fato é que a impessoalidade traz uma garantia verdadeiramente essencial a ela. Daí porque reputarmos que o princípio da impessoalidade é elemento de definição da própria função administrativa, como atividade orientada à satisfação de interesses públicos”. ${ }^{425}$

preceitos que venham a impedir tal sorte de procedimento, bem como que estipulem salvaguardas que permitam seu controle. Apenas para pontuar, pense-se nas normas que em matéria processual impedem determinado agente de conhecer determinadas matérias, pois a ordem jurídica não lhes reconhece a isenção necessária para tanto. É o que se dá com as normas processuais contidas na Lei n $n^{\circ}$ 9.784/1999 que tratam das figuras do impedimento e da suspeição (arts. 18 a 21). Na mesma categoria estão as normas que exigem procedimentos objetivos para as escolhas administrativas (tais como as que tratam de concursos e licitações), que também são informadas pelas ideias referentes ao princípio da impessoalidade. Procedimentos objetivos visam, justamente, neutralizar as preferências do administrador, remetendo a escolha a critérios previstos em lei. Por outro lado, as regras que exigem motivação e publicidade dos atos administrativos visam a permitir que a vontade do agente seja sindicada, de modo a possibilitar que a sociedade conheça as razões que levaram à prática de determinado ato, tachando-o de pessoal, se for o caso. É dizer, o valor contido no princípio é tratado por diversas normas, que lhe dão feição específica. Todavia, nada obstante haja preceitos que cuidem de dar espessura à ideia de impessoalidade, fato é que a simples previsão da impessoalidade como princípio cardeal da Administração basta para interditar atos timbrados pela pessoalidade, não se exigindo lei expressa que trate do tema".

${ }^{423}$ Obra citada, p. 147.

${ }^{424}$ Obra citada, p. 147.

${ }^{425}$ Bernardo Strobel Guimarães (Obra citada, p. p. 139-141) assinala que: "O princípio da impessoalidade visa precipuamente a impedir qualquer desvio que possa permitir que um determinado agente venha a se beneficiar pessoalmente do exercício das competências previstas em prol da coletividade. E note-se que o benefício pessoal não se associa exclusivamente a uma vantagem direta ao servidor. Interesses partidários ou de grupos de pressão (lobbies) também caracterizam modalidades em que há uma afirmação indevida da subjetividade do agente no exercício da função administrativa, conforme adverte Umberto Allegretti, Ou seja, o thelos é 
Num tal contexto, parece fora de dúvida possam ser aproveitados, a partir do princípio da impessoalidade, atos administrativos decisórios levados a efeito por servidores de fato.

\subsubsection{Diminuição da discricionariedade administrativa decisional}

Anota Eduardo García de Enterrìa ${ }^{426}$ que a necessária demolição sistemática dos círculos de imunidades do poder, a grande obra do século XX, é travada em três frentes: a) no poder regulamentar; b) nos chamados atos políticos ou de governo; c) no poder discricionário.

Para o mesmo autor ${ }^{427}$, o terceiro é o círculo mais resistente, já que a liberdade de eleição entre várias soluções possíveis, todas igualmente legítimas, no que consiste a discricionariedade, foi considerada durante todo o século XIX como área interditada ao controle judicial ${ }^{428}$, diferentemente do que ocorre hoje em dia, em que fala num “direito universal ao juiz”.

- De que forma o princípio da impessoalidade repercute na discricionariedade administrativa decisória?

De certa forma, a impessoalidade - no que implica uma atuação administrativa despida de subjetivismos e predileções pessoais - reduz significativamente a margem de liberdade conferida por lei ao administrador para trilhar a solução que melhor atenda o interesse público (primário) ${ }^{429}$.

\footnotetext{
a proteção do interesse institucional, que é posto em causa não só pelo desejo de apropriação individual dos agentes, mas também pela captura da Administração Pública por objetivos que lhe são alheios".

${ }^{426}$ Problemas del derecho público al comienzo de siglo. Madri: Civitas, 2001, p. 40.

${ }^{427}$ Problemas..., p. 43.

${ }^{428}$ Para Eduardo García de Enterrìa (obra citada, p. 44), o primeiro vício de legalidade na decisão discricionária percebido pelo Conselho de Estado francês foi o desvio de poder, no sentido da persecução de um fim privado na decisão pública discricionária, vício que se converteu, assim, numa nova “abertura” do recurso por excesso de poder. Mais tarde, o controle por meio dos princípios gerais do Direito (como a proporcionalidade, a boa-fé, a interdição da arbitrariedade, a proteção da confiança legítima, etc.) abriu novas vias de controle. E o que se chamou na França de "erro na apreciação dos fatos" e na Alemanha e na Espanha de "conceitos jurídicos indeterminados”, tradicionalmente confundidos com a discricionariedade, foi o passo decisivo. Hoje, sem prejuízo do respeito que se deva ter pela capacidade de eleição que a lei confere ao administrador, a discricionariedade está submetida ao ordenamento jurídico, e, assim, ao juiz, como de resto toda a atividade administrativa.

${ }^{429}$ Para Bernardo Strobel Guimarães (Obra citada, p. 139-140), "contribui para a dificuldade do exame da impessoalidade o fato de que não raramente o Direito Administrativo supõe uma vontade com vistas a operacionalizar a atuação da Administração". Para o autor: "O primeiro campo em que isto se evidencia é a discricionariedade, em que intencionalmente a regra de competência não se apresenta completa, devendo ser atualizada pela vontade do agente competente, a partir de critérios de oportunidade e conveniência. Ou seja, a relação entre previsão abstrata e implementação de uma providência passa, necessariamente, por uma escolha do agente, que é expressamente pressuposta pela norma. Aqui se agrava a questão da impessoalidade, pois se está em um campo em que se exige a vontade do agente, que é tomada como sendo à da própria Administração".
} 
O administrador deve decidir sem arranhar o princípio da impessoalidade.

Bruno Miragem ${ }^{430}$, ao estabelecer necessária correlação entre impessoalidade e eficiência, opina que:

“Neste ponto se afirma o critério da objetividade como parte do conteúdo da impessoalidade administrativa. Note-se que a adoção de critérios objetivos e constitucionalmente adequados para a conformação da ação administrativa e de seus resultados afina-se aos princípios da impessoalidade e da eficiência, tendo em vista um duplo resultado: impedir discriminações antijurídicas e promover a otimização dos recursos disponíveis à consecução das finalidades públicas. Comprova-se esta afirmação examinando o exercício de poder discricionário pelo agente público.

Não há dúvida de que o princípio da impessoalidade constitui limite ao exercício do poder discricionário do agente público. Neste sentido, no espaço de escolha que se percebe ao agente público, não pode este ferir a impessoalidade estabelecendo discriminação antijurídica ou preferências subjetivas.

Para o mesmo autor ${ }^{431}$ :

“O princípio da impessoalidade limita nesse sentido tanto o exercício do poder discricionário, mediante interpretação/concreção de conceitos discricionários, quanto a concreção de conceitos indeterminados descritivos e normativos, tendo em vista que a indicação de significado a tais conceitos deve se dar mediante critério de objetividade e razoabilidade (adesão à realidade), de modo a melhor conformar a finalidade da ação administrativa (inclusive mediante otimização dos recursos existentes: princípio da eficiência). (...)

A impessoalidade considerada na perspectiva de vínculo absoluto com a finalidade pública respeita tanto a atos característicos do exercício de poder vinculado, quanto de poder discricionário, devendo ser em relação a estes últimos, requisito de validade do ato discricionário, e dando causa à invalidade quando violado na sua formação. De rigor, diga-se: é critério para exame da validade do ato administrativo a ausência absoluta da finalidade de beneficiar ou prejudicar determinadas pessoas, ou seja, sem causa objetiva e razoável de diferenciação, tanto em relação ao motivo indicado

${ }^{430}$ A Nova Administração Pública e o Direito Administrativo. São Paulo: RT, 2011, p. 342-343.

${ }^{431}$ A Nova Administração..., p. 344. 
no ato (situação de direito e de fato que o autoriza), quanto, com mais razão, ao seu móvel (a finalidade subjetiva do agente que o promove).”

O cenário é desafiador, difícil e complexo, mas absolutamente necessário para que se confirme a fórmula do verdadeiro Estado de Direito.

Ao decidir, o administrador deverá observar a impessoalidade administrativa por inteiro, o que demanda uma solução de equilíbrio, caso a caso, em concreto ${ }^{432}$.

No contexto contemporâneo, como ensina e adverte Odete Medauar ${ }^{433}$, embora persista a ideia de lei como "simples" garantia contra abusos, novos influxos se fazem sentir e não podem ser desprezados pelo estudioso fiel, dentre os quais, a “sacralização da legalidade”, com reflexos na criação do chamado "legalismo" e o agigantamento do Poder Executivo.

Percebe-se certo desgaste da clássica doutrina da Separação dos Poderes, pedra de toque do chamado Estado de Direito, ou, pelo menos, descortina-se a necessidade de um novo olhar sobre a divisão de tarefas entre Executivo, Legislativo e Judiciário, mormente no ambiente do chamado Estado Social.

No mundo de hoje, com foco na realidade brasileira, o Executivo predomina sobre o Legislativo, e a lei deixou de representar a vontade geral para se transformar na vontade de parlamentares “garroteados” pelo Executivo. A fórmula originária da Separação de Poderes, então, magistralmente sistematizada por Montesquieu, já não se ajusta, numa espiral crescente, à realidade político-institucional dos Estados hodiernos. Tampouco à do Brasil!

Com o advento do Executivo eleito diretamente, não mais se justifica a supremacia do Legislativo. Há choque de legitimações, ambas advindas das mesmas urnas. Ademais, a ampliação das funções do Estado, cada vez mais numerosas e complexas, inclusive no âmbito social e econômico, colocou na forca a lentidão do processo legislativo. O Executivo passou, inclusive, a ter atividade legislativa (normativa) intensa.

Qualquer tema de Direito Administrativo, inclusive o do controle sobre a atividade administrativa discricionária, só pode ser divisado quando bem compreendida a noção contemporânea de Estado de Direito, com maior respeito pela Administração a princípios e valores de índole constitucional, sobretudo na mira do reconhecimento de direitos fundamentais.

\footnotetext{
${ }^{432}$ Consoante José Cretella Jr. (Anulação do ato administrativo pode desvio de poder. Rio de Janeiro: Forense, 1978, p. 105), "se o administrador exerce os poderes discricionários de que está investido, quer num fim pessoal, quer num fim político, quer num fim religioso, está caracterizado, de modo insofismável, o desvio de poder".

${ }^{433}$ Extremamente convincentes, no ponto, as lições, aqui resumidas, da lavra de Odete Medauar (Direito Administrativo Moderno, $18^{a}$ ed. São Paulo, Editora Revista dos Tribunais, 2014, p. 141-142).
} 
Toda e qualquer atividade administrativa levada a efeito não pode retirar sua legitimidade de uma legalidade meramente aparente, retórica, semântica. O administrador, mais do que nunca, é escravo não da lei, mas sim da ordem jurídica justa.

E o princípio da impessoalidade soma esforços no sentido de parametrizar o (bom) exercício da discricionariedade administrativa, inclusive para fins de controle e responsabilização.

Para Gustavo Binenbojm ${ }^{434}$, fazem parte da rotina do administrador público demandas por decisões investidas, não raro, de larga margem de discricionariedade. E, nessas situações, não é livre o agente para decidir por um ou outro caminho, devendo ele, “à luz das circunstâncias peculiares ao caso concreto, bem como dos valores constitucionais concorrentes, alcançar solução ótima que realize ao máximo cada um dos interesses em jogo”.

De acordo com Binenbojm ${ }^{435}$, o que se pode chamar de “melhor interesse público”, ou seja, “o fim legítimo que orienta a atuação da Administração Pública” é consequência da ponderação como técnica de controle da discricionariedade administrativa e de racionalização dos processos de definição do interesse público prevalente ${ }^{436}$.

\subsubsection{Teoria do desvio de poder}

No campo do desvio de poder, a impessoalidade também está presente.

Gustavo Binenbojm ${ }^{437}$ assegura, com acerto, que “a realização de interesses particulares quando em confronto com interesses públicos não constitui desvio de finalidade para a Administração, pois aqueles são também fins públicos”. Assim, “a proteção de um interesse privado constitucionalmente consagrado, ainda que parcialmente, pode representar, da mesma forma, a realização de um interesse público”.

Muito ao contrário, a quebra da impessoalidade administrativa no agir decisório é que representa, indiscutivelmente, desvio de poder ou de finalidade.

Odete Medauar aponta 5 (cinco) possíveis defeitos (ou vícios) que afetam os elemen-

\footnotetext{
${ }^{434}$ Da supremacia do interesse público ao dever de proporcionalidade: um novo paradigma para o direito administrativo. In: Interesses públicos versus interesses privados: desconstruindo o princípio da supremacia do interesse público. Rio de Janeiro: Editora Lumen Juris, 2005, p. 150-151.

${ }^{435}$ Da supremacia..., p. 151.

${ }^{436}$ Ensina Binenbojm (Da supremacia..., p. 151) que a técnica de ponderação como forma de controle da discricionariedade administrativa e de racionalização dos processos que envolvem a definição do interesse público encontra aplicação recente tanto nos países da common law, como no sistema constitucional europeu.

${ }^{437}$ Da supremacia..., p. 142.
} 
tos dos atos administrativos: (i) incompetência; (ii) ilegalidade do objeto; (iii) defeito de forma; (iv) defeito de motivo; (v) defeito do fim.

O defeito do fim, também denominando de “desvio de poder” ou “desvio de finalidade”, nos termos da Lei no 4.717/65 - Lei de Ação Popular, art. 2º parágrafo único, alínea “e”, ocorre "quando o agente pratica ato visando a fim diverso daquele previsto, explícita ou implicitamente, na regra de competência”.

Com razão Alexandre Santos de Aragão quando assinala que todo ato administrativo deve atender à finalidade expressa ou implícita na norma atributiva da competência, e, caso não a atenda, estar-se-á diante do vício conhecido como desvio de poder, que ocorre "não apenas quando o ato não visa a qualquer interesse público - no exemplo clássico da desapropriação para prejudicar um inimigo político -, mas, também, nos casos em que a lei fixa determinada finalidade pública a ser atingida e o ato visa a outra, ainda que ambas sejam de ‘interesse público”’.

Odete Medauar ${ }^{438}$ ensina que a teoria em questão, de origem francesa, "representou importante passo no sentido de direcionar o exercício do poder discricionário aos fins de interesse público, explícitos ou implícitos, em razão dos quais esse poder foi conferido ao agente administrativo”. Fazendo inequívoca conexão com o princípio da impessoalidade, assim se posiciona a autora:

\footnotetext{
“Os poderes atribuídos aos agentes visam ao atendimento do interesse público pertinente à matéria em que esses agentes atuam. Não se destinam tais poderes à satisfação de interesses pessoais, de grupos, de partidos, nem são instrumento de represália, vingança ou favorecimento próprio ou alheio. Exemplo: usar o poder de expropriar em represália a declarações formuladas na imprensa por um administrado”.
}

Ao tratar dos “móveis” do desvio de finalidade, José Cretella Jr. ${ }^{439}$ ensina que:

\footnotetext{
“Todo ato administrativo tem por escopo o interesse geral. É a regra a que está sujeita toda autoridade administrativa. Disto resulta que o desvio de poder é causa de ilegalidade suscetível de afetar todos os atos administrativos, sem exceção alguma.
}

${ }^{438}$ Direito Administrativo Moderno..., p. 175.

${ }^{439}$ Anulação do ato administrativo por desvio de poder. Rio de Janeiro: Forense, 1978, p. 105. 
Mesmo que nenhum fim específico seja atribuído a uma competência determinada, sempre tal competência poderá ser acusada de desvio de poder, quando atuar na persecução de fim que não seja de interesse público. É o que se costuma exprimir algumas vezes, dizendo-se que, em matéria de fim, não existe nunca poder discricionário (Laubadère, Traité élémentaire de droit administratif, 1953, p. 390).”

No campo dos atos discricionários, incluídos os decisórios, a matéria ganha relevo maior, inclusive em conexão com o tema da impessoalidade.

Cretella Jr. assinala que "se o administrador exerce os poderes discricionários de que está investido, quer num fim pessoal, quer num fim político, quer num fim religioso, está caracterizado, de modo insofismável, o desvio de poder" ${ }^{440}$. Revela:

\footnotetext{
"Waline, dando como exemplo o interesse econômico, cita o caso na França, de um Prefeito que regulamentava bailes e 'dancings' do município, para combater concorrência que faziam à sua hospedaria (Traité élémentaire de droit administratif, 6a Ed., 1952, p. 142, nota 2).

O móvel político é decisão da autoridade para prejudicar ou eliminar adversário que pensa de modo diferente, em matéria governamental. O móvel religioso é qualquer medida favorável ou contrária a determinada religião, em confronto com outra, atingida pelos reflexos diretos do ato, como, por exemplo, ocorreu em certa ocasião, no Brasil, quando Igreja Evangélica foi desapropriada, não por utilidade pública, mas por motivos religiosos, o que tornou ilegal o ato administrativo expropriatório, eivado de vício de finalidade (Cf. Revista dos Tribunais, 129/689).”
}

Esclarece Cretella Jr. ${ }^{441}$ que também configura vício de finalidade decisão destinada a favorecer um particular em detrimento de outro, o que não quer dizer que a decisão favorável não possa ocasionalmente coincidir com o interesse coletivo, caso em que, de modo algum, incrimina 0 ato.

Evidente que, em termos processuais, verifica-se enorme dificuldade prática de comprovação do desvio de poder. Como revela Alexandre Santos de Aragão ${ }^{442}$, tal se dá por ser “predominantemente uma questão subjetiva interna ao administrador que praticou o ato",

\footnotetext{
${ }^{440}$ Obra citada, p. 105.

${ }^{441}$ Obra citada, p. 105-106.

${ }^{442}$ Curso de Direito Administrativo..., p. 153.
} 
em razão do que há forte tendência na aceitação de indícios de sua ocorrência, desde que verossímeis.

Uma das questões mais problemáticas diz com o tema da prova do “desvio de poder”, inclusive por quebra de impessoalidade.

É de Cretella Jr. a lúcida visão de que a caracterização não só pode como deve ser feita a partir de "sintomas denunciadores”. Segundo o seu pensamento, os indícios (“qualquer coisa” ou “fato sensível”) adquirem muita relevância na comprovação do desvio de poder, mormente "quando se sabe quão difícil é encontrar prova, absolutamente irrefutável, que comprometa o editor do ato, autoridade administrativa, regra geral, esclarecida e astuta para incriminarse, deixando vestígios, mesmo leves, de sua intenção 'distorcida”. Nesse caso, acrescenta, “os sintomas é que revelarão o 'mal', inserido num quadro clínico indiscutível”.

Por “sintoma” deve ser entendido qualquer traço, interno ou externo, direto, indireto ou circunstancial, qualquer indício que revele a “distorção” da vontade do agente público ao editar o ato, praticando-o não por motivo alheio ao interesse público.

Para Odete Medauar ${ }^{443}$, “a dificuldade na prova do desvio de poder ou de finalidade levou a doutrina a mencionar os chamados indícios denunciadores do desvio de poder, que são alguns dados que permitem concluir pela ocorrência dessa ilegalidade, tais como: contradição entre fatos invocados a título de motivo e o conteúdo do ato; desproporção entre meios e fins; contradição entre os motivos expostos; ocultação de fatos relativos à situação etc.”.

Para Cretella Jr. ${ }^{444}$, internamente, o sintoma se revela na própria motivação do ato. Então, “se a motivação é excessiva, insuficiente, deficiente, inexistente ou contraditória, o desvio de poder é caracterizado pelo próprio exame dos elementos constantes do bojo do ato”. Assim, os próprios motivos alegados permitem que se perceba a presença do “dominus”. Nesse caso, prossegue o autor, “a própria autoridade ('pela boca morre o peixe') é que fornece a prova da ocorrência do desvio”. Em outros casos, expõe:

a) A motivação conflita com a que fundamenta outros atos, anteriores ou posteriores à edição do ato ou se choca com fatos, ocorrentes antes ou depois da prática do ato, e aí o desvio se denuncia "pelo choque entre essas circunstâncias inconciliáveis";

${ }^{443}$ Direito Administrativo Moderno..., p. 175.

${ }^{444}$ Anulação do ato administrativo por desvio de poder..., p. 106. 
b) O desvio também pode ser comprovado a partir de um "feixe convergente de indícios” (expressão de Rivero), já que cada um desses indícios, de per si, isoladamente, seria insuficiente para tipificar a “aberratio finis legis”;

c) Assumem relevo também as “circunstâncias” (Parafraseando Ortega e Gasset: “eu sou eu e minhas circunstâncias”) em que o ato veio a ser praticado, quando por exemplo a autoridade demonstra "precipitação em praticar o ato".

Cretella Jr. ${ }^{445}$ assegura que tais “sintomas” têm sido bem identificados e sistematizados pelas doutrinas francesa e italiana, principalmente com apoio em decisões pretorianas do Conselho de Estado dos respectivos países. Entre esses índices, indícios, sintomas ou pautas, podem ser referidos os consagrados nas seguintes expressões ${ }^{446}$ : a) Contradição do ato com atos posteriores e/ou com atos anteriores; b) Motivação exagerada, contraditória e/ou insuficiente; c) Alteração dos fatos; d) Ilogicidade manifesta; e) Manifesta injustiça; f) Disparidade de tratamento; g) Derrogação de norma interna; h) Precipitação com que o ato foi editado; i) Inexistência, de fato, dos motivos apresentados pelo administrador para justificar a decisão tomada; j) Desigualdade de tratamento dispensada aos interessados; k) Caráter sistemático de certas proibições; l) Caráter geral atribuído a medida que deveria permanecer particular; m) Circunstâncias locais que antecederam a edição do ato; n) Feixe convergente de indícios.

Em todos esses casos e a partir dos parâmetros assinalados, deve estar atenta a Administração para trilhar decisões administrativas indiscutivelmente impessoais.

\subsubsection{Necessidade de motivação na dispensa de empregados públicos}

Uma particular projeção do princípio da impessoalidade no Direito Administrativo está na exigência de motivação para a dispensa de empregados públicos.

Sabe-se bem que o empregado público não tem direito à estabilidade, garantia prevista pelo Texto Constitucional (art. 41, § $1^{\circ}$, da CF/88 ${ }^{447}$ ) tão só para o servidor público ocupante de cargo efetivo.

\footnotetext{
445 Anulação do ato administrativo por desvio de poder, p. 108.

${ }^{446}$ Cretella Jr. examina uma a uma a expressões às fls. 109 a 123 do sua excelente obra Anulação do ato administrativo por desvio de poder.

${ }^{447}$ Confira-se o texto constitucional:

Art. 41. São estáveis após três anos de efetivo exercício os servidores nomeados para cargo de provimento efetivo em virtude de concurso público.

$\S 1^{\circ} \mathrm{O}$ servidor público estável só perderá o cargo:
} 
É verdade que muito se discutiu sobre o tema na Justiça do Trabalho e que o Tribunal Superior do Trabalho chegou, inclusive, a cristalizar em sua jurisprudência, não apenas a inexistência de direito à estabilidade, como também a desnecessidade de motivação do ato de demissão (OJ n ${ }^{\circ}$ 247/SDI-I:).

Ocorre que o Supremo Tribunal Federal pôs fim à discussão, ao julgar o RE nº 589.998 (Rel. Min. Ricardo Lewandowski), em 20/03/2013, sob a sistemática da repercussão geral, assentando que o empregado público concursado não tem direito à estabilidade, mas sua demissão deve ser motivada, em respeito aos princípios da impessoalidade e da isonomia.

A análise do julgado revela que o Supremo Tribunal Federal retirou a exigência de motivação diretamente do princípio constitucional da impessoalidade.

Para o relator (Min. Ricardo Lewandowski), embora as “empresas estatais” tenham natureza jurídica de direito privado, elas se submetem a um regime jurídico no mínimo "híbrido”, ou seja, “sujeitam-se a um conjunto de limitações que têm por escopo a realização do interesse público”. Para o relator, ocorre "derrogação parcial das normas de direito privado em favor de certas regras de direito público”, a exemplo das regras relativas à submissão ao teto remuneratório, à proibição de acumulação de cargos, empregos e funções e à exigência de concurso público para ingresso nos quadros.

Assim, prossegue o Min. Ricardo Lewandowski, "o objetivo maior da admissão de empregados das estatais por meio de certame público é assegurar a primazia dos princípios da isonomia e da impessoalidade, privilegiando-se a meritocracia em detrimento de escolhas de índole pessoal ou de caráter puramente subjetivo no processo de contratação”.

Como consequência de uma contratação impessoal, calcada no concurso público, a dispensa deve rechaçar exagerados subjetivismos, o que não quer significar estabilidade, mas sim garantias jurídicas no procedimento de dispensa, o qual deve respeitar, por igual, os princípios da impessoalidade e da isonomia.

Com isto, explica o Min. Lewandowski, “objetiva-se coibir a ocorrência de abusos, a perpetração de arbitrariedades ou a concessão de privilégios por parte do empregador público, garantindo-se aos servidores em particular e aos administrados em geral um maior controle dos critérios de demissão”.

veitado em outro cargo ou posto em disponibilidade com remuneração proporcional ao tempo de serviço. $\S 3^{\circ}$ Extinto o cargo ou declarada a sua desnecessidade, o servidor estável ficará em disponibilidade, com remuneração proporcional ao tempo de serviço, até seu adequado aproveitamento em outro cargo. $\S 4^{\circ}$ Como condição para a aquisição da estabilidade, é obrigatória a avaliação especial de desempenho por comissão instituída para essa finalidade. 
Inteiramente correto o Relator quando assinala que a obrigação de motivar os atos também decorre do fato de que os agentes estatais lidam com a coisa pública, porquanto o capital das empresas estatais - integral, majoritária ou mesmo parcialmente - pertence ao Estado, ou seja, a todos os cidadãos, sendo certo que esse dever, ademais, “está ligado à própria ideia de Estado Democrático de Direito, no qual a legitimidade de todas as decisões administrativas tem como pressuposto a possibilidade de que seus destinatários as compreendam e o de que possam, caso queiram, contestá-las”. Em síntese perfeita: “no regime político que essa forma de Estado consubstancia, é preciso demonstrar não apenas que a Administração, ao agir, visou ao interesse público, mas também que agiu legal e imparcialmente”.

No mesmo acórdão, sustentou o Min. Teori Zavascki, com sua lógica característica, que "se a Constituição exige concurso público para a contratação, não se poderia admitir que a dispensa pudesse ocorrer sem motivação idônea, sob pena de abrir-se (sic) as portas para a fraude à norma constitucional”.

Merece destaque o voto proferido pela Min. Cármen Lúcia, no mesmo julgado, para quem a motivação é imprescindível “porque o princípio da finalidade ordena todos os comportamentos da administração pública indireta, e não há como se verificar e se controlar a finalidade se não houver a motivação”, já que a motivação, prossegue, “compõe o próprio regime administrativo constitucionalmente estabelecido para a administração pública direta e indireta”.

Franqueia-se, assim, a partir da exigência de motivação, em clara correlação com a impessoalidade, um controle (muito) mais efetivo sobre as dispensas e, mais do que isso, sobre os móveis da dispensa.

É dizer: a partir de uma exigível motivação plenamente vinculante, permite-se aos órgãos de controle, notadamente aos jurisdicionais, uma investigação muito mais completa e verticalizada sobre as reais e verdadeiras razões de uma dispensa nem sempre justa, o que equivale a concluir sobre ter havido ou não desvio de finalidade por parte da Administração Pública.

Interessante notar que o Tribunal Superior do Trabalho, após a aludida decisão do Supremo, já adaptou a sua jurisprudência, passando a exigir motivação na dispensa de empregado público ${ }^{448}$.

448 Seguindo essa orientação, confira-se: RR - 756-21.2010.5.04.0002, Relator Ministro: Cláudio Mascarenhas Brandão, Data de Julgamento: 12/02/2014, $7^{a}$ Turma, Data de Publicação: 14/02/2014). 


\subsubsection{Responsabilidade civil extracontratual objetiva do Estado}

Um dos aspectos da impessoalidade está na aplicação da responsabilidade civil extracontratual objetiva do Estado.

É em função da impessoalidade que se responsabiliza pela chamada "culpa anônima”, ou seja, aquela que prescinde da identificação precisa de um servidor identificável, com nome, endereço e CPF, que tenha agido com dolo ou culpa.

Não interessa quem praticou o ato danoso em nome do Estado, mas sim que o Estado, como um todo, lesou a vítima e deve indenizá-la.

Veja-se que, coerentemente, mesmo quando não se faz possível a identificação de um servidor que tenha agido com dolo ou culpa, para fins de direito de regresso, ainda assim à vítima se assegura a devida indenização.

José Afonso da Silva ${ }^{449}$ assinala que “a personalização, ou seja, a individualização do funcionário, pode ser recomendável, quando atue não como expressão da vontade do Estado, mas como expressão de veleidade, capricho ou arbitrariedade pessoal” e, então, “a personalização vale assim para imputar ao funcionário uma falta e responsabilizá-lo perante a Administração Pública, a fim de que esta lhe imponha a punição cabível”.

Considerando que a nossa Constituição, no art. 37, § $6^{\circ}$ estatuiu duas ordens de responsabilidade por ação, uma objetiva (independentemente de dolo ou culpa), própria da relação Estado-vítima, e outra subjetiva (dependente da comprovação de dolo ou culpa por parte de servidor identificável), relativa à relação (regressiva) servidor-Estado, parece claro que a responsabilidade objetiva, típica da primeira relação jurídica aludida, também retira a sua condição constitucional de validade do Princípio da Impessoalidade, mesmo porque os incisos e parágrafos do art. 37, da CF/88, inclusive o $§ 6^{\circ}$, recebem os influxos dos princípios gerais previstos no seu caput.

Alexandre Santos de Aragão ${ }^{450}$, ao tecer considerações sobre o princípio da impessoalidade, no contexto dos princípios do direito administrativo, capta bem a relação existente com a responsabilidade civil extracontratual objetiva. Diz que em uma das acepções possíveis, "pode se considerar a impessoalidade à luz da organização administrativa; ela impõe que os atos da Administração Pública sejam imputados ao Estado, não ao agente/ pessoa física que o praticou”. Assim, “o princípio da impessoalidade nessa linha seria fun-

449 Curso..., p. 677.

${ }^{450}$ Curso..., p. 70. 
damento da Teoria dos Órgãos (...) e, indiretamente, da responsabilidade civil do Estado por atos praticados por seus agentes”.

A impessoalidade se relaciona com a responsabilidade civil extracontratual do Estado quanto às consequências da quebra da impessoalidade nas decisões administrativas, o que será objeto de exame no tópico próprio ${ }^{451}$.

\subsubsection{Necessidade de reconhecimento dos direitos dos administrados}

Atualmente, no Brasil, o Estado-Administração frequenta com assiduidade as barras do Poder Judiciário, normalmente no polo passivo de relações jurídico-processuais iniciadas pelo particular-administrado que não vê reconhecido, na via administrativa - como era de se esperar - direito seu.

Odete Medauar ${ }^{452}$, ao tratar dos controles internos incidentes sobre a atividade administrativa, chega a assinalar o seguinte:

\footnotetext{
“Embora na Administração Pública brasileira, em geral, o pedido de reconsideração seja desprezado pelas autoridades, com o pensamento de que o interessado, se quiser, 'vá reclamar seus direitos na Justiça', é um excelente meio para propiciar o autocontrole, para ouvir os interessados, para buscar atender aos anseios da população e, mesmo, para realizar a Justiça, visto que não somente o Poder Judiciário deve concretizá-la, mas também e sobretudo a Administração Pública, cada vez mais ampla, cada vez mais afetando mais direitos dos indivíduos”.
}

É fato que o Estado, em processos judiciais, sucumbe repetidas vezes em causas que poderiam ser bem resolvidas seguindo critérios de justiça material, na própria via administrativa.

A Advocacia-Geral da União, as Procuradorias Estaduais e do Distrito Federal e as Procuradorias dos Municípios consomem uma fortuna de dinheiro público na manutenção de aparatos jurídicos voltados à movimentação de feitos judiciais inúteis em termos de resultados efetivos para o interesse público.

A realidade revela um abismo entre o discurso teórico e a prática diuturna da Admi-

${ }^{451}$ Vide item 3.5.2, infra.

${ }^{452}$ Controle da Administração Pública. $2^{\text {a }}$ ed. São Paulo: Editora Revista dos Tribunais, 2012, p. 53. 
nistração que, muitas vezes, embora proclame a legalidade como algo inerente ao seu pensar e ao seu agir, como inflexível padrão comportamental, prefere não se comprometer de antemão com a missão de fazer justiça no caso concreto, optando, como se pudesse dispor de direitos alheios, caros à ordem jurídica, por remeter algumas questões jurídicas nada complexas ao Poder Judiciário.

A Administração Pública, mesmo diante de temas jurídicos judicialmente estabilizados, teima em não reconhecer direitos dos administrados, o que além de não encontrar justificativa no verdadeiro Estado Democrático de Direito tem o condão de gerar a anulação do ato decisório e a responsabilidade do Estado e do servidor recalcitrante.

No Brasil, tem-se a forte impressão de que se está diante de um discurso vazio ou, o que é pior, falso, demagógico, cínico, de que a Administração Pública deve cega subserviência à legalidade plena, mas tal subserviência não é revelada em suas práticas diárias, corriqueiras, comuns.

Estudos recentes, datados de 2011, do Conselho Nacional de Justiça ${ }^{453}$ e da Fundação Getúlio Vargas (Rio) ${ }^{454}$ revelaram dados alarmantes para o bom entendedor.

Tinha-se, por exemplo, que o grande usuário do Judiciário, em especial do Supremo Tribunal Federal (doravante STF), era o próprio governo. No STF, 85 (oitenta e cinco) partes concentravam mais de 75\% (setenta e cinco por cento) dos processos. E mais: $90 \%$ (noventa por cento) das partes eram públicas (contra 7\% privadas, 2\% mistas e 1\% privatizadas); $87 \%$ (oitenta e sete por cento) das causas tinham origem no Poder Executivo; 68\% (sessenta e oito por cento) tinham origem na esfera federal.

Os mesmos estudos revelaram que o grande cliente recursal do STF era de natureza pública, o Executivo Federal. Nominalmente, as principais partes nos recursos junto ao STF eram: a) Caixa Econômica Federal - CEF; b) União; c) Instituto Nacional do Seguro Social - INSS; d) Estado de São Paulo; e) Banco Central do Brasil; f) Estado do Rio Grande do Sul; g) Município de São Paulo; h) Telemar Norte Leste S/A; i) Banco do Brasil S/A; j) Estado de Minas Gerais; l) Instituto de Previdência do Estado do Rio Grande do Sul - IPERGS; m) Distrito Federal.

Na frieza dos números, entre os 12 (doze) maiores litigantes em recursos no STF, apenas um não era do setor público, a saber, a Telemar Norte Leste S/A, no oitavo lugar. Nos

\footnotetext{
453 Justiça em Números, 2011.

${ }^{454}$ Relatório Supremo em Números, 2011.
} 
mesmos estudos, apenas três entes concentravam mais de 50\% (cinquenta por cento) dos processos (recursais) no Supremo, a saber: CEF (18,87\%), União (16,48\%) e INSS (14,87\%). Certo que atores como CEF e Banco Central se destacavam pela alta "taxa de litigância ativa”, beirando os $100 \%$ (cem por cento), ou seja, na quase totalidade dos casos levados ao STF, tais entes vinham, da origem, de derrotas judiciais e buscavam reformas nas decisões.

Em 2013 sobreveio um novo estudo da Fundação Getúlio Vargas, referente ao ano de $2012^{455}$. Governos municipais e estaduais tiveram queda significativa no número dos processos em que litigam. A média nacional foi de 44\% de redução da litigiosidade desses entes federados.

Também há modificação no rol dos 10 maiores litigantes. Percebe-se que a Caixa Econômica Federal - CEF não está mais entre eles. Em 2012, os maiores litigantes foram: INSS, União, Estado de SP, Estado do RJ, STJ, DPU, MPF, Estado de MG e Banco Santander.

Houve redução também no percentual do número de processos em que figuram os 10 maiores litigantes. Em 2006, esse percentual era de 64\%, e em 2012 passou a ser de 42\%.

Tema que foi objeto de particular atenção no estudo foi o do número de processos envolvendo questões atinentes aos servidores públicos. Em 2012, 21\% dos processos julgados pelo STF versavam sobre tais questões (ex. remuneração, aposentadoria, concurso público etc.).

Percebe-se que o Supremo Tribunal Federal continua afogado em recursos de algumas partes, quase todas do setor público. De causas que têm origem no Poder Executivo. Vale notar, com base em tais estudos, a "taxa de derrota” do Poder Público. Isto é, em sua grande maioria, os recursos interpostos pelo Poder Público para o STF são desprovidos.

Para o Estado-Administração não tem qualquer sentido a produção de estímulos à litigiosidade, montados, muitas vezes, em letargias burocráticas impositivas inúteis e despropositadas. Estando o Estado submetido à ordem jurídica justa, na acepção mais autorizada de legalidade, não pode ele deixar de reconhecer direitos legítimos dos administrados. Deve-se trilhar uma ruptura comportamental da Administração Pública, estimulando-se, impositivamente, a partir da correta leitura do princípio da impessoalidade, comportamentos públicos obsequiosos daquilo que é certo e justo, o que propiciaria maior aproximação, ou melhor, uma virtuosa redução do distanciamento entre Estado e cidadão, permanente detentor da legítima aspiração de que o Poder Público exista para proporcionar-lhe paz e bem-estar social.

${ }^{455}$ Eis o link do relatório: http://supremoemnumeros.fgv.br/sites/supremoemnumeros.fgv.br/files/attachment/ ii_relatorio_supremo_em_numeros_-_o_supremo_e_a_federacao_entre_2010_e_2012.pdf. 
Odete Medauar"456 leciona que "a autoridade administrativa deve deixar de lado a recalcitrância ante direitos claramente identificados, muitas vezes já reconhecidos pelo Poder Judiciário em casos semelhantes, e rever, reexaminar decisões e medidas espontaneamente ou mediante recurso administrativo do interessado, o que permitirá maior confiança na Administração Pública, atuação mais justa, atendimento ao interessado da coletividade, evitando, por outro lado, sobrecarga do Poder Judiciário”.

É fato que o próprio Judiciário tem sido muito tímido na efetivação de direitos legítimos dos administrados, frequentemente sob o pálio da argumentação de que não está ele autorizado a governar, o que tem despertado vozes autorizadas no sentido de propugnar uma percepção judicial mais acurada do que seja "fazer justiça”".

Carlos Ayres Britto ${ }^{457}$ ensina que uma coisa é governar, algo que o Judiciário não pode fazer; outra bem diferente é "impedir o desgoverno (que o Judiciário pode e tem que fazer)”. Segundo o autor, “é como falar: o Judiciário não tem do governo a função, mas tem do governo a força. A força de impedir o desgoverno, que será tanto pior quanto resultante do desrespeito à Constituição”. É que, prossegue:

“(...) o Sistema Jurídico brasileiro tem virtualidades emancipatórias que há
muito estão à espera de aplicadores que se disponham a auscultá-lo como o
termômetro da consciência. Consciência que tem como ponto de partida,
não o Congresso Nacional, não o Palácio do Planalto, mesmo ainda a Casa
Branca ou o Palácio de Buckingham, mas o sensível e ao mesmo destemi-
do coração de cada juiz. Esta a razão pela qual Martin Luther King, ao
visitar um país estrangeiro e ser informado da excelência do Direito Le-
gislado ali produzido, responde: não quero saber das suas leis. Quero sa-
ber dos seus intérpretes”.

O mesmo raciocínio deve ser empreendido na seara administrativa decisória. Afinal de contas, a decisão administrativa não está submetida ao regime de princípios e regras obsequiosas do que é bom e justo, segundo valores e cânones constitucionais?

Não é favor ou liberalidade, atentatórios à impessoalidade, mas dever jurídico real e concreto, não protelar o efetivo cumprimento da lei sob o falso pretexto de que não lhe é dado dispor do interesse público, como se ele, interesse público, também não estivesse, precisa e justamente, no reconhecimento de legítimos interesses dos administrados.

${ }^{456}$ Controle da Administração Pública, p. 53.

${ }^{457}$ O humanismo como categoria constitucional. Belo Horizonte: Fórum, 2007, p. 117-119. 
A Administração Pública tem promovido uma leitura ineficaz do princípio da impessoalidade administrativa. Não se sabe se por má compreensão do valor normativo da Constituição ou se por conveniente leniência, o certo é que o administrador comum ainda relaciona decisões marcadas com a pecha da pessoalidade com ausência de consequências jurídicas.

O tema é importante porque este aspecto concreto da impessoalidade, como mote para a anulação de atos administrativos maculados e a deflagração de responsabilidades, não vem bem explorado em termos doutrinários e jurisprudenciais, e sua abordagem contribui para o fortalecimento de uma crescente cultura de zelo no trato da coisa pública.

AAdministração Pública, quando decide lides administrativas, conflitos de interesses com referibilidade ao Direito Administrativo, já juridicamente estabilizados, deve reconhecer, sem temor, administrativamente, direitos legítimos dos administrados, repudiando comportamentos administrativos decisórios que remetam ao Poder Judiciário questões perfeitamente suscetíveis de serem equacionadas de antemão, no próprio seio do Poder Executivo, com sabor de definitividade.

A técnica pressupõe autoridades administrativas imparciais, que não se deixem levar “por cualquier influencia 'de arriba’, en interés de una justicia vinculada sólo al Derecho”458.

Sempre que se alcance a compreensão, com boa margem de segurança, de que é justo o pleito administrativamente formulado, é dever da Administração Pública, na trilha proposta, para além de qualquer dúvida razoável, empreender posturas concretas de reconhecimentos de direitos individuais.

O juízo administrativo, embora provisório e precário, plenamente controlado que é pelo Judiciário (CF, art. 5, $\mathrm{XXXV}$ ), este sim definitivo e prioritário, pode se transmudar de singelo adereço em posição final eloquente, acerca daquilo que pode ser denominado, a partir de então, de "Direito Administrativo Justo". Sem rodeios, a ideia é transformar o julgamento administrativo, a partir da correta leitura do princípio da impessoalidade, em "posto avançado” de um julgamento jurisdicional nem sempre necessário.

A partir da impessoalidade, as decisões administrativas não mais poderão ser tidas como formas legais de promoção de injustiças, mas sim como um campo fértil à realização material dos postulados constitucionais de construção de uma sociedade justa e solidária.

${ }^{458}$ Conforme Karl Larenz. Derecho Justo - Fundamentos de Etica Juridica. Madrid: Editorial Civitas, 1985, p. 182. 


\subsubsection{Nepotismo}

A questão da proibição do nepotismo é uma das que merecem equacionamento a partir de uma correta aplicação do Princípio da Impessoalidade.

Muitas decisões administrativas tratam do tema. Em certos casos, nomeações atentatórias à proibição de nepotismo podem ser revistas à luz da impessoalidade. Em outros, podem ser questionadas decisões provenientes de autoridades administrativas nomeadas com desrespeito ao princípio.

Sem pretender desenvolver o tema para além das finalidades do trabalho, algumas considerações devem ser externadas.

Verifica-se tendência a uma proibição generalizada quanto à nomeação de parentes para cargos públicos, o que pode conduzir a injustiças de toda ordem. Em alguns casos, o interesse público não se perfaz pela proibição, mas sim pela nomeação.

A edição da Súmula Vinculante nº 13, pelo E. Supremo Tribunal Federal, foi resultado de intensos debates sobre a necessidade da existência de lei expressa, em sentido formal, que vedasse a figura do nepotismo na Administração Pública.

Os debates tiveram desenvolvimento, notadamente, a partir do julgamento da $\operatorname{ADC~} \mathrm{n}^{\circ}$ 12, que veiculou discussão quanto à constitucionalidade do conteúdo da Resolução $\mathrm{n}^{\circ}$ 07/ 2005, editada pelo Conselho Nacional de Justiça, que dispunha acerca da vedação da prática do nepotismo no seio do Poder Judiciário.

Nas sessões realizadas em 20.08.2008 e 21.08.2008, o Plenário do Supremo Tribunal Federal discutiu intensamente a abrangência e a redação da súmula, de modo a evitar, ao máximo, dúvidas exegéticas a respeito do verbete marcado pelo caráter vinculante.

A proposta inicial, apresentada ao Plenário pelo Ministro Ricardo Lewandowski, estava assim redigida, verbis:

\footnotetext{
“A proibição do nepotismo na Administração Pública, direta e indireta, em qualquer dos Poderes da União, dos Estados, do Distrito Federal e dos Municípios, independe de lei, decorrendo diretamente dos princípios contidos no artigo 37, caput, da Constituição Federal”.
}

Após os debates iniciais - que sequer envolveram o direcionamento da proibição aos cargos em comissão e função de confiança - foi apresentada esta proposta, no início da sessão do dia 21.08.2008, verbis: 
“A proibição da nomeação em cargo comissionado ou função de confiança de cônjuge, companheiro ou parente de autoridade nomeada e investida em cargo de direção, chefia ou assessoramento, na Administração Pública direta e indireta, em qualquer dos Poderes da União, dos Estados e dos Municípios, independe de lei, decorrendo diretamente dos princípios contidos no artigo 37, caput, da Constituição”.

Prosseguindo-se nos debates, com a fixação das diversas premissas jurídicas fixadas pela E. Suprema Corte, chegou-se à redação do texto final da Súmula Vinculante $n^{0} 13$, verbis:

\footnotetext{
"Súmula Vinculante n 13 . A nomeação de cônjuge, companheiro ou parente em linha reta, colateral ou por afinidade, até o terceiro grau, inclusive, da autoridade nomeante ou de servidor da mesma pessoa jurídica investido em cargo de direção, chefia ou assessoramento, para o exercício de cargo em comissão ou de confiança ou, ainda, de função gratificada na administração pública direta e indireta em qualquer dos poderes da União, dos Estados, do Distrito Federal e dos Municípios, compreendido o ajuste mediante designações recíprocas, viola a Constituição Federal.”
}

O verbete é expresso ao consignar que o nepotismo tem vez quando se tiver em mira nomeação "para o exercício de cargo em comissão ou de confiança ou, ainda, de função gratificada” na Administração Direta e Indireta.

Trata-se de delimitação clara e precisa, ostentando o inequívoco sentido de que a proibição não atinge outros cargos que não aqueles cuja natureza foi especificamente referida, certo que, nos moldes de conhecida regra de hermenêutica, a norma não traz palavras e expressões inúteis.

Verifica-se, de plano, a inviabilidade de o intérprete conferir maior abrangência ao verbete sumular, do que o que veio aquilatado pelo E. STF, sob pena de flagrante desnaturação da regra, em desrespeito à autoridade das decisões da Suprema Corte e o caráter vinculante do verbete $\mathrm{n}^{0} 13$, autorizando-se até mesmo a abertura da via da reclamação constitucional.

E o preciso direcionamento da norma é inteiramente justificável, eis que a regra, buscando a realização do princípio da impessoalidade (e também da moralidade!), visa evitar que a autoridade pública nomeie livre e desembaraçadamente seus parentes para cargos e funções públicas. 
Tal liberdade de nomeação se faz presente apenas nos cargos em comissão e nas funções gratificadas, ex vi do disposto no art. 37, II, da Constituição Federal ${ }^{459}$.

Tal compreensão vem reforçada pela Resolução n ${ }^{\circ}$ 07/2005, do CNJ, na qual se assenta, com precisão, que "semelhantes vedações configuram-se como exceções ao art. 37, II, da CF, que contempla o princípio da livre nomeação de servidores para cargos em comissão.”

Assentado o objetivo da norma, consubstanciado no controle do nepotismo para nomeação de cargos em comissão ou funções de confiança, marcados pelo caráter da livre nomeação (art. 37, II, da CF/88), forçoso reconhecer que a proibição do nepotismo não pode se estender generalizadamente, sob pena até mesmo de se conceber uma “impessoalidade às avessas” ${ }^{\prime 40}$.

É fato que a Súmula Vinculante no 13/STF não esgota os casos em que, por imposição do princípio da impessoalidade, se aperfeiçoa a prática nefasta do nepotismo, mas é forçoso ter em mente que a súmula somente se aplica a funções administrativas ${ }^{461}$.

O STF, aliás, já decidiu pela inaplicabilidade da Súmula Vinculante ${ }^{0}$ 13/STF, em decisão monocrática proferida na Reclamação 14.316 (Rel. Min. Gilmar Mendes, DJe de 11.10.2012), em caso que envolvia a nomeação de agentes políticos (Secretários Municipais) parentes de Prefeito Municipal.

${ }^{459}$ E para que não fique dúvida quanto ao efetivo direcionamento da regra aos cargos comissionados e funções de confiança, vale observar o que decidido pelo Pleno do E. STF no julgamento do RE no 579.951/RN (Rel. Min. Ricardo Lewandowski, DJe de 24.10.2008).

${ }^{460}$ Em caso interessante, o Conselho Federal da Ordem dos Advogados do Brasil validou decisão do Conselho Seccional do Maranhão que assentara a proibição de determinado advogado, cunhado da Governadora, participar de processo seletivo voltado à escolha de membro do Tribunal de Justiça local pela representação do quinto constitucional de advogados.

Eis as razões pelas quais não reputamos correta a posição da entidade.

A nosso sentir, a entidade se equivocou porque se estava diante de cargo permanente, de membro do Poder Judiciário, necessariamente remunerado por subsídio, nos termos art. 39, § 4º da CF/88. E o magistrado, mais do que um servidor efetivo, que alcança a estabilidade, goza da prerrogativa da vitaliciedade, nos exatos moldes do art. 95, I, da Constituição Federal.

O Desembargador, portanto, egresso do Quinto Constitucional, ocupa o cargo em caráter vitalício, já a partir de sua posse, tal como deixa claro o art. 22 da LC nº 35/79.

Não há, pois, respaldo técnico e jurídico para que seja dispensado ao cargo vitalício de Desembargador do Tribunal de Justiça o tratamento e as restrições incidentes especificamente para os cargos comissionados ou em confiança.

${ }^{461}$ Tal como se observa da redação emprestada à súmula Vinculante ${ }^{\circ} 13$ do E. STF, caracteriza-se o nepotismo quando se cuida de nomeação "para o exercício de cargo em comissão ou de confiança ou, ainda, de função gratificada na administração pública direta e indireta em qualquer dos poderes da União, dos Estados, do Distrito Federal e dos Municípios (...)”.

A referência ao exercício das atribuições na “Administração Direta ou Indireta” traz em si um relevante fator de delimitação. Isto porque, parte-se do pressuposto de que a nomeação está necessariamente ligada ao exercício de funções administrativas, ainda que no âmbito de qualquer dos Poderes, o que não abrangeria, sob o ponto de vista técnico, funções jurisdicionais ou legislativas típicas, como no caso do Desembargador do Tribunal de Justiça Estadual. 
Merece registro que, no julgamento do agravo regimental na Reclamação Constitucional $n^{\circ}$ 6702/PR, o STF sinalizou para a inviabilidade de nomeação de Conselheiro de Tribunal de Contas Estadual por irmão de Governador, mas naquela oportunidade o Tribunal fez constar da própria ementa do julgado entendimento quanto à "natureza administrativa do cargo".

\subsubsection{Revisitação da reformatio in pejus como regra do processo administrativo}

Dentre os dogmas do Direito Administrativo brasileiro está o da não proibição da reformatio in pejus no processo administrativo, entendida esta como a possibilidade de vir a ser agravada a situação jurídico-processual do recorrente no âmbito de seu próprio recurso. Para haver reformatio in pejus é necessário que a decisão proferida em sede recursal seja mais desfavorável que a recorrida do ponto de vista prático.

Relembra Carreira Alvim que a proibição de reforma em prejuízo do recorrente, no âmbito de seu próprio recurso, foi elevada à categoria de princípio processual e domina tanto o processo penal, quanto o civil e o trabalhista ${ }^{462}$.

No processo administrativo, ganha destaque o tema da reformatio in pejus, que também ocupa a pauta de preocupações do Direito Administrativo quando em exame o controle da Administração Pública.

Para Odete Medauar ${ }^{463}$, que trata do tema dentro dos chamados controles internos da Administração Pública, é fato que o interessado, ao interpor recursos administrativos, busca benefícios, melhorias, vantagens, reconhecimento de direitos, satisfação de interesses e, num tal sentido, cabem as perguntas: (i) o recurso limitaria o poder de decisão da autoridade somente aos termos aí contidos?; (ii) pode a administração, ao decidir o recurso, piorar a situação do interessado?; (iii) ou melhorá-la? - Para a autora ${ }^{464}$ :

\footnotetext{
"se o recurso administrativo for considerado sob ângulo subjetivo, como instrumento de defesa de direitos e interesses do indivíduo ou de grupos, a Administração seria obrigada a apreciá-lo nos termos em que foi interposto, não podendo agravar a situação do recorrente. Sob prisma objetivo, o recurso configura um meio de assegurar a legalidade e a correção da atividade
}

\footnotetext{
${ }^{462}$ Elementos de Teoria Geral do Processo. $7^{\text {a }}$ Ed. Rio de Janeiro: Forense, 1997, p. 277.

${ }^{463}$ Curso..., p. 403.

${ }^{464}$ Curso..., p. 403.
} 
administrativa, cabendo à autoridade apreciar não só as alegações do recurso administrativo, mas reexaminar, no seu conjunto, as circunstâncias do ato impugnado - o recurso desencadeia o controle, mas não condiciona a extensão do controle. Surgindo a necessidade de reformar para pior, emerge o conflito entre o aspecto subjetivo e o aspecto objetivo do recurso".

Odete Medauar alerta: “a tendência geral faz prevalecer o aspecto objetivo sobre o aspecto subjetivo, admitindo-se a reformatio in pejus, excepcionada em algumas hipóteses por exemplo: ao tratarem da revisão do processo disciplinar, os Estatutos de servidores, de regra, vedam o agravamento da pena como consequência. Ensina que no direito espanhol a jurisprudência fixada a partir de 1972 proíbe a reformatio in pejus de atos objeto de recurso, devendo as exceções ser previstas em lei. E que “na Administração Federal brasileira, em geral, se da decisão do recurso puder decorrer gravame à situação do interessado, este deverá ser cientificado para que formule suas alegações antes da decisão (v. art. 64, parágrafo único, da Lei 9.784/99)”465.

A autoridade não deve apenas considerar “as alegações do interessado” antes de proferir decisão de que possa resultar gravame ao particular, numa espécie de contraditório formal, ou de devido processo legal “de fachada”, mas sim reconhecer desde logo, na via administrativa, legítimos direitos e interesses particulares, ainda que discrepantes de políticas públicas em execução.

Compete destacar que em trabalho que escrevemos em obra coletiva em homenagem à Professora Odete Medauar ${ }^{466}$, tivemos a oportunidade de cotejar o princípio da non reformatio in pejus com o tema do controle de legalidade no processo administrativo.

Na ocasião, dissemos que ao rejeitarem a possibilidade, como regra, da reformatio in pejus, no âmbito do processo administrativo, Sérgio Ferraz e Adilson de Abreu Dallari467 ensinam, com acerto, que “a tutela da ampla defesa envolve a possibilidade de, sem ser surpreendida, a parte rebater acusações, alegações, argumentos ou interpretações tais como dialeticamente postos, para evitar sanções e prejuízos”. E que “ver sua posição agravada sem contraditório, quando sequer houve recurso da parte contrária, é validar a restrita defesa, e não a ampla defesa de que cuida a Constituição”. E é, também, “fazer letra morta dos princípios da isonomia e da boa-fé”.

\footnotetext{
${ }^{465}$ Curso..., p. 403-404.

${ }^{466}$ Direito Público em evolução..., p.389 a 404.

${ }^{467}$ Processo Administrativo. 2 ${ }^{\mathrm{a}}$ Edição. São Paulo: Malheiros, 2007, p. 196.
} 
Guardamos a convicção de que restringir o alcance da reformatio in pejus é algo não só desejável, mas imperativo à luz da aproximação sistêmica promovida pelo atual texto constitucional entre processo judicial e administrativo, claramente identificada desde a leitura entrelaçada dos incisos LIV e LV, do art. 5º da Constituição da República de 1988.

E isto não quer significar, absolutamente, risco acentuado de consolidação de ilegalidades absolutas ou até mesmo uma fuga da verdade real, posto que ao Estado-Administração será sempre lícito recorrer administrativa e judicialmente ${ }^{468}$. Sustentar a impossibilidade, como regra, no processo administrativo, da reformatio in pejus, diferentemente do que pode parecer, não significa sacrificar o controle administrativo.

Para “realizar” a Constituição, elevação máxima dos limites de operatividade e eficácia, não se prescinde do controle da atividade administrativa, baseado na observância de princípios constitucionais que orientam a Administração Pública, dentre os quais o da impessoalidade.

Note-se que uma reforma para pior, sem critérios objetivos, lastreada em subjetivismos e predileções pessoais do administrador responsável pelo julgamento do recurso administrativo pode tisnar o princípio e manchar a decisão de maneira irreversível. No julgamento do recurso deverão ser ponderados todos os interesses envolvidos na espécie, trilhando-se a decisão, devidamente fundamentada, que melhor atenda ao interesse público.

\subsection{Consequências da quebra da impessoalidade nas decisões administrativas}

A constitucionalização dos princípios que regem a atuação administrativa representa um dos marcos paradigmáticos na conformação do Direito Administrativo contemporâneo. A expressa previsão constitucional das bases principiológicas de ação e organização da Administração Pública, para além da mera relevância teórica e institucional, leva à necessária adoção e implementação de tais princípios nas escolhas concretas e tomadas de decisão dos diversos agentes públicos.

Nessa perspectiva, verifica-se de forma nítida o fenômeno da ampliação material da concepção de legalidade administrativa, que passa a estabelecer não mais um vínculo formal

468 É o que sustentam Sérgio Ferraz e Adilson Abreu Dallari (obra citada, p. 196). Confira-se: “(...) o que se defende é a impossibilidade do agravamento, sem recurso (ao menos adesivo) da Administração, na relação processual administrativa; mas a decisão do Estado-juiz poderá indicar o cabimento do enquadramento mais severo, daí podendo o Estado-administração vir a praticar os atos que entenda necessários e/ou convenientes, sem sacrifício das tutelas constitucionais básicas, antes lembradas." 
entre a ação do Poder Público e o texto legal, mas a conformação de toda a atuação administrativa à ordem constitucional, manifesta na noção de juridicidade ou bloco de legalidade, em que os princípios constituem o núcleo essencial. A lei, nesse contexto, configura um dos pilares da ação/organização administrativa, mas não consiste propriamente no seu fim imediato. A lógica de proporcionalidade que impera na órbita constitucional e a eficácia concreta dos princípios estabelecem um marco jurídico mais amplo que abrange todo o sistema de normas a que está sujeita a Administração. Verifique-se o posicionamento de Gustavo Binenbojm:

\footnotetext{
“A constitucionalização do direito administrativo convola a legalidade em juridicidade administrativa. A lei deixa de ser o fundamento único e último da atuação da Administração Pública para se tornar apenas um dos princípios do sistema de juridicidade instituído pela Constituição. (...)
}

Assim, o agir administrativo pode encontrar espeque e limite diretamente em regras ou princípios constitucionais dos quais decorrerão, sem necessidade de mediação do legislador, ações ou omissões da Administração” ${ }^{469}$.

Diante desse quadro, percebe-se que na nova ordem constitucionalmente conformada os princípios possuem força normativa para determinar in concreto a ação administrativa, sendo cogente a sua observância a fim de que sejam legítimas e válidas as decisões e deliberações tomadas pelo Poder Público.

As consequências jurídicas decorrentes da quebra dos deveres impostos pelo complexo de princípios emergem como elementos de fulcral relevância. A necessidade de reafirmar a força normativa dos princípios ante a violação de seus preceitos é fator indispensável para a recomposição da ordem jurídica e a manutenção da confiança legítima nas regras do jogo democrático. Seja por meio da sanção, seja sanando diretamente o vício, as consequências jurídicas da inobservância das normas extraídas dos princípios pelo Poder Público consubstanciam garantias que asseguram os direitos do cidadão e da coletividade frente às ações e omissões estatais lesivas.

No presente trabalho, três consequências jurídicas das decisões administrativas não impessoais merecem especial destaque: i) a anulação da decisão; ii) a responsabilidade civil

${ }^{469}$ Uma Teoria do Direito Administrativo. Direitos Fundamentais, Democracia e Constitucionalização. $2^{\mathrm{a}}$ Edição. Rio de Janeiro: Renovar. 2008. p. 70. 
do Estado; iii) a responsabilização do agente público. Quanto à última, serão abordadas as responsabilidades (i) por improbidade e (ii) penal.

O princípio da impessoalidade, em particular, foi erigido como uma das diretrizes mestras da atuação do Poder Público, tanto do ponto de vista da ação quanto da organização administrativa (art. 37 caput da CF). Nesse ponto, importa analisar, em específico, como as aludidas consequências jurídicas incidem nas hipóteses concretas para afastar e reprimir a quebra do dever de impessoalidade pelo agente público.

\subsubsection{Anulação da decisão administrativa não impessoal}

Irrecusável seja reconhecida a nulidade dos atos administrativos decisórios praticados com quebra de impessoalidade.

Bernardo Strobel Guimarães ${ }^{470}$ assinala, à luz do princípio da impessoalidade, que “se extrai diretamente da previsão da Constituição a descrição de condutas proscritas (como o nepotismo, e.g.)”. Assim, prossegue, “a previsão contida na Constituição fixa de modo direto modelos de conduta a serem seguidos, sob pena de nulidade dos atos”. Por conta disso "ficam interditadas quaisquer condutas que impliquem a apropriação da função pública por interesses alheios ao sistema".

Ao tratar do tema dos efeitos de atos da Administração Pública praticados contra o princípio constitucional da impessoalidade, notadamente a invalidade, Cármen Lúcia Antunes Rocha ${ }^{471}$ lança a interessante questão da subsistência, ou não, de seus efeitos, pois “o fim público domina a Administração, e o interesse que é, assim, objetivado pode impor que se mantenham os efeitos do ato, mesmo quando esta não possa sobreviver juridicamente em face do gravame ao sistema jurídico que nele se contenha”.

De acordo com Odete Medauar, “a anulação consiste no desfazimento do ato administrativo, por motivo de ilegalidade, efetuada pelo próprio Poder que o editou ou determinada pelo Poder Judiciário"

A concepção do desfazimento do ato envolve sua total retirada da esfera jurídica, anulando-se todos os seus efeitos e repercussões concretas. A decisão que declara nulo o ato

${ }^{470}$ Reflexões acerca do princípio da impessoalidade. In: Princípios de direito administrativo: legalidade, segurança jurídica, impessoalidade, publicidade, motivação, eficiência, moralidade, razoabilidade, interesse público. Thiago Marrara (org.). São Paulo: Atlas, 2012.

${ }^{471}$ Princípios constitucionais da administração pública. Belo Horizonte: Del Rey, 1994, p. 169.

472 Direito Administrativo Moderno..., p. 178. 
praticado pelo Poder Público possui eficácia ex tunc, fazendo com que as situações jurídicas por ele afetadas retornem ao status quo ante, como se este nunca tivesse sido produzido ${ }^{473}$.

A anulação justifica-se, como salienta Odete Medauar, por motivo de ilegalidade, ou seja, por contrariedade às disposições legais. A compreensão do conceito de ilegalidade, nesse ponto, deve ser estabelecida a partir da ampliação material do parâmetro de controle da atuação administrativa, o qual deve abranger não só a lei em sentido puramente formal, mas também - e principalmente - os princípios fundantes da ordem constitucional.

Busca-se então assentar a legalidade "em bases valorativas, sujeitando as atividades da Administração não somente à lei votada pelo Legislativo, mas também aos preceitos fundamentais que norteiam todo o ordenamento" ${ }^{474}$.

Desse modo, quaisquer atos ou decisões que contrariem ou não observem o conjunto de normas que compõem a ordem jurídica - compreendida de forma harmônica à luz da juridicidade - devem ser declarados nulos, seja pela própria Administração Pública seja pelo Poder Judiciário.

O amplo poder conferido ao Judiciário para anular decisões e atos administrativos eivados de vícios decorre de suas atribuições constitucionais inerentes, que possuem por base o princípio máximo da inafastabilidade da jurisdição, segundo o qual nenhuma lesão ou ameaça de lesão a direito pode ser excluída de sua apreciação (art. $5^{\circ}$, inc. XXXV da CF). Ações constitucionais como o mandado de segurança e o habeas data consistem em fundamentais instrumentos de proteção do administrado frente a atos ilegais e arbitrários do Poder Público. Não é dado ao Poder Judiciário, todavia, atuar de ofício para anular atos ilegais, devendo sempre ser previamente provocado para que se busque tal finalidade.

Importa destacar que o ordenamento jurídico brasileiro adotou expressamente o sistema de jurisdição una, manifesto na concepção de inafastabilidade da jurisdição. Em países em que vigora o modelo de jurisdição dúplice - em que há a separação entre a justiça comum e a justiça administrativa - o Poder Judiciário, como regra, não possui competência jurisdicional para anular os atos e decisões dos entes estatais, sendo tal atribuição exclusiva dos órgãos que compõem os quadros da jurisdição administrativa. No Brasil, a inafastabilidade da apreciação jurisdicional é um direito fundamental, não podendo ser suprimida ou condicionada por quaisquer previsões legais ou administrativas. Sempre a via judicial estará aberta ao administrado para questionar a validade das decisões proferidas pelos poderes públicos.

${ }^{473}$ A não ser diante de situações em que seja impossível retornar ao estado anterior à produção do ato (fato consumado), ou quando já transcorrido o prazo decadencial para a Administração Pública anular seus atos.

${ }^{474}$ Direito Administrativo Moderno..., p. 141. 
A anulação de atos e decisões ilegais efetuada pela Administração, por sua vez, configura um poder-dever decorrente da autotutela dos poderes públicos sobre os seus próprios atos. Isso porque a atuação administrativa in concreto deve se vincular aos parâmetros legais e constitucionais que condicionam e conferem legitimidade e validade aos atos e decisões dela advindos.

A anulação feita pelo Poder Público independe de provocação, não obstante tenha de observar os princípios do contraditório e da ampla defesa, quando se verificar que haverá prejuízos aos cidadãos com a retirada do ato ou da decisão. O STF, em relevantes precedentes, vem firmando sólida orientação no sentido de que é dever da Administração possibilitar aos administrados que serão afetados por eventual anulação de determinado ato que se manifestem na esfera administrativa processual, a fim de possibilitar a ampla percepção dos interesses envolvidos ${ }^{475}$.

Do ponto de vista histórico, a construção teórica do poder da Administração de anular seus próprios atos eivados de ilegalidade iniciou-se na primeira metade do séc. XX, instituída pela jurisprudência do Conselho de Estado francês. No Brasil, o Supremo Tribunal Federal também teve protagonismo nessa construção, principalmente após aprovação pela Corte da Súmula n 346, a qual dispõe que “a Administração Pública pode declarar a nulidade de seus próprios atos”. Posteriormente foi editada a Súmula nº 473 do STF, segundo a qual “ $a$ Administração pode anular seus próprios atos, quando eivados de vícios que os tornem ilegais, porque deles não se originam direitos, ou revogá-los, por motivo de conveniência ou oportunidade, respeitados os direitos adquiridos e ressalvada, em todos os casos, a apreciação judicial”" ${ }^{476}$.

Com a promulgação da Lei n. 9.784/99 (Lei de Processo Administrativo), a ordem jurídica pátria passou a prever expressamente o regime geral a que se submete o poder-dever da Administração Pública de anulação de atos e decisões ilegais. Conforme dispõe o art. 53 deste diploma legal, “a Administração deve anular seus próprios atos, quando eivados de vício de legalidade”. A lei também determina que, nos casos em que do ato ou decisão administrativa decorrerem efeitos favoráveis aos destinatários, decai em 5 (cinco) anos o prazo para a sua respectiva anulação pelo Poder Público.

\footnotetext{
${ }^{475}$ Nesse sentido, confira-se o seguinte julgamento paradigmático: RE n ${ }^{0}$ 158.543/RS, Segunda Turma, Relator o Min. Marco Aurélio, DJ de 6/10/95.

${ }^{476}$ Impende destacar que após a edição da Súmula n ${ }^{\circ} 473$ do STF resolveu-se antiga divergência doutrinária quanto à correta compreensão dos conceitos de revogação e anulação. A Súmula define expressamente o conteúdo e o alcance de cada um desses poderes conferidos à Administração Pública.
} 
Há grande discussão doutrinária acerca da imperatividade da anulação dos atos ilegais pela própria Administração Pública. Parte da doutrina entende que a decisão pela anulação do ato pertence ao campo de discricionariedade do agente público competente, sendo-lhe facultado anular ou não o ato conforme juízo de oportunidade e conveniência, à luz da supremacia do interesse público sobre o particular. Há doutrinadores, porém, que defendem arduamente ser a anulação um dever da Administração, ante a estrita observância do princípio da legalidade.

Não obstante a divisão estanque entre tais orientações teóricas, têm se fortalecido na doutrina posicionamentos intermediários, pautados pela razoabilidade e pela proporcionalidade na atuação administrativa e na busca efetiva das finalidades públicas. Nesse sentido ${ }^{477}$, ressalte-se o entendimento da professora Odete Medauar:

\begin{abstract}
"Embora o poder e o dever de anular permaneçam plenos para qualquer ato eivado de ilegalidade, é possível que, em determinadas circunstâncias e ante a pequena gravidade do vício, a autoridade administrativa deixe de exercêlos, em benefício do interesse público, para que as consequências do desfazimento em si e sua repercussão não acarretem maior prejuízo que a subsistência do ato - em tais casos, a autoridade deverá sopesar as circunstâncias e as repercussões, até mesmo sociais, do desfazimento no caso concreto, para decidir se o efetua ou se mantém o ato" ${ }^{478}$.
\end{abstract}

Em face de tal concepção teórica - em que deve prevalecer o sopesamento dos interesses em jogo para que se decida pela anulação do ato ilegal ou sua manutenção diante das circunstâncias concretas - a compreensão e a definição da gravidade dos vícios e a possibilidade da convalidação dos atos e decisões emergem como fatores de grande relevância no campo de atuação do Poder Público.

Quanto aos vícios que atingem as decisões e atos administrativos, a doutrina, com base nos elementos que compõem a atividade da Administração, os divide de acordo com o aspecto de incidência da ilegalidade. Os eventuais vícios dos atos emanados do Estado podem ser relativos: i) à incompetência ou à incapacidade do sujeito; ii) à finalidade; iii) à forma; iv) ao objeto; v) aos motivos expostos para sua prática. Segundo a doutrina, a depender da gravidade do vício e da possibilidade de praticar o ato novamente de forma legítima,

477 Ressalte-se que a professora Maria Sylvia Zanella Di Pietro também defende esse mesmo posicionamento. Vide: Direito Administrativo. 27ª Edição. São Paulo: Atlas, 2014, p. 248.

${ }^{478}$ Direito Administrativo Moderno..., p. 179. 
será viável - e até mesmo um dever como defende Celso Antônio Bandeira de Mello $^{479}$ - a convalidação do ato ou decisão.

A quebra do princípio da impessoalidade em decisões e atos administrativos pode, em tese, atingir quaisquer dos elementos acima mencionados, sendo, portanto, passíveis de anulaçã $0^{480}$. Nesse aspecto, os vícios quanto aos motivos e à finalidade do (a) ato/decisão merecem destaque. A inexistência e a falsidade dos motivos expostos em determinada prática administrativa e o desvio de finalidade estão intimamente relacionados à violação da impessoalidade na ação do Poder Público.

Dois exemplos clássicos auxiliam o entendimento do que aqui se pretende demonstrar. O primeiro deles diz respeito à utilização da desapropriação com o intuito de prejudicar determinada pessoa. Nessa hipótese específica, a autoridade administrativa responsável pelo ato expropriatório desvirtua de forma nítida o propósito do instituto em questão, que é o emprego do bem desapropriado na concretização do interesse público. Ao buscar lesar um indivíduo específico com a desapropriação de um bem de seu patrimônio, o agente público responsável atua em claro desvio de finalidade, valendo-se muitas vezes de falsos motivos para justificar a legitimidade do ato de expropriação. Nesse caso, a atuação administrativa que deveria destinarse, de modo impessoal, às finalidades públicas, visa nitidamente a atingir e lesar um administrado. Uma vez constatados os referidos vícios, deve ser considerado nulo o ato expropriatório por contrariedade expressa à impessoalidade. O segundo exemplo refere-se à remoção ex officio de funcionário público por interesses particulares e íntimos da autoridade administrativa competente para a prática do ato. Nesse caso, não obstante possa apresentar motivação baseada no interesse público, o ato possui claro desvio de finalidade, violando frontalmente o princípio da impessoalidade. De modo semelhante ao caso anterior, a busca de interesses privados pelo administrador público que busca prejudicar outro servidor com remoção indevida reflete claramente uma postura desvinculada das finalidades públicas e do dever mínimo de atuação impessoal. A declaração de nulidade do ato é, portanto, medida que se impõe.

Marçal Justen Filho ${ }^{481}$, com razão, assegura que “o ato estatal inválido não é protegi-

${ }^{479}$ Curso..., p. 479.

${ }^{480}$ De acordo com Bruno Miragem (A Nova Administração Pública e o Direito Administrativo. São Paulo: RT, 2011, p. 345): “Na práxis jurisprudencial brasileira, o princípio da impessoalidade vem sendo aplicado para invalidar atos administrativos que estabeleçam favorecimentos discriminatórios favoráveis ou contrários a determinados interesses parciais/individuais. Da mesma forma, serve como critério para controle de constitucionalidade de leis que visando ofertar/distribuir benefícios a determinados indivíduos, categorias ou grupos, o fazem de modo a desconsiderar um critério objetivo que assegure o respeito à finalidade pública".

${ }^{481}$ Curso ..., p. 1.241. 
do como meio de realizar o interesse público”, já que “a simples constatação da ilicitude do ato torna inaplicável a invocação ao interesse público”. Aliás, acrescenta, “a realização do interesse público apenas pode significar que o Estado tem o dever de observar o direito”. Se não o fizer, arremata, “a supremacia do interesse público impõe o dever de o Estado responder pelas ações e omissões indevidas”.

É ainda de Marçal Justen Filho 482 a precisa observação de que “somente regimes autoritários e não democráticos adotam a concepção de que a supremacia do interesse público acarreta a impossibilidade de tutela do interesse privado". A seu ver, "a mera leitura da Constituição de 1988 comprova a rejeição desse enfoque”.

\subsubsection{Responsabilização civil extracontratual do Estado}

A segunda consequência jurídica que decorre da quebra do dever de impessoalidade nos atos e decisões administrativos concerne à possibilidade de responsabilização patrimonial do Estado pelos danos e prejuízos advindos da conduta ilegítima de seus agentes.

Conforme a doutrina especializada, a responsabilização patrimonial dos entes de direito público deve ser entendida como a obrigação que lhes incumbe de reparar economicamente os danos lesivos à esfera juridicamente garantida de outrem e que lhes sejam imputáveis em decorrência de comportamentos unilaterais, lícitos ou ilícitos, comissivos ou omissivos, materiais ou jurídicos ${ }^{483}$.

O caráter extracontratual refere-se à necessária exclusão deste campo da responsabilidade advinda de relações contratuais assumidas pelo Estado, cuja regulamentação está na esfera legal dos contratos administrativos.

Os fundamentos da responsabilidade civil do Estado, em específico, foram delineados a partir da consolidação do Estado de Direito. Com a queda dos Estados Absolutistas e a construção política do paradigma da superioridade da lei ${ }^{484}$, principalmente após a Revolução Francesa, todas as pessoas - públicas ou privadas - passaram a se sujeitar aos princípios e regras da ordem jurídica. O Estado deixou de ser compreendido como instância superior e

${ }^{482}$ Curso..., 1.241.

483 Por todos: Odete Medauar (Direito Administrativo Moderno..., p. 415 e seguintes); Celso Antônio Bandeira de Mello (Curso de Direito Administrativo..., p. 1001 e seguintes); Maria Sylvia Zanella Di Pietro (Direito Administrativo..., p. 715 e seguintes).

${ }^{484}$ Manifesto no corolário de que ninguém é obrigado a fazer ou deixar de fazer alguma coisa a não ser em virtude de lei. 
intangível de soberania e poder - realidade manifestada nas expressões "the king can do no wrong” e “quod principi placuit habet legis vigorem”485 - para assumir a posição de pessoa jurídica e, como tal, titular de direitos e obrigações.

Foi lenta a evolução dos contornos jurídicos e institucionais da responsabilidade civil dos entes de direito público perante os administrados. Para Michel Paillet, numa retrospectiva histórica, a responsabilidade do Poder Público é relativamente linear, com progressiva consagração jurisprudencial de soluções favoráveis às vítimas. Evolução que experimentou etapas. Migrante da irresponsabilidade plena - fundada na concepção de soberania - para responsabilidade limitada pela noção privatística de culpa, tal limitação paulatinamente cedeu e fez vislumbrar-se a “culpa anônima do serviço”"486. Posteriormente, diversos ordenamentos jurídicos, visando aumentar a proteção do administrado frente aos atos e omissões do Poder Público, consagraram a responsabilidade objetiva dos entes estatais.

Os pressupostos da responsabilidade objetiva do Estado foram desenvolvidos, fundamentalmente, com base na teoria do risco administrativo. De acordo com esse modelo de responsabilização, a comprovação da culpa é prescindível para a configuração do dever de indenizar. Deve-se somente demonstrar o dano (específico e anormal), a conduta estatal e o nexo de causalidade entre estes. Supera-se, nessa perspectiva, a conformação tradicional de responsabilidade civil fundada na culpa, para centrar-se no risco. O risco administrativo, concretizado em resultado danoso, passou a ser o fundamento da responsabilidade, e não mais a conduta dolosa ou negligente do agente público ou até mesmo a falha na prestação do serviço.

Na ordem jurídica brasileira, especificamente, a teoria da irresponsabilidade do Estado nunca foi adotada. O Código Civil de 1916 - primeira codificação civil brasileira - positivou a teoria da responsabilidade civil subjetiva dos entes de direito público ${ }^{487}$. No âmbito constitucional, a evolução do modelo de responsabilização do Estado brasileiro foi mais célere. A Constituição de 1946 já previa expressamente a responsabilidade objetiva das pessoas jurídi-

\footnotetext{
${ }^{485}$ Aquilo que agrada ao príncipe tem força de lei.

${ }^{486}$ Nesse sentido, confira-se o que escrevemos no livro Responsabilidade Civil Extracontratual do Estado por Omissão. Brasília: Gazeta Jurídica. 2014. p. 51-56. A teoria da culpa anônima do serviço considera como danos indenizáveis pelo Estado os eventos causados por mau funcionamento - funcionamento tardio ou omissão - dos serviços públicos. Na hipótese, buscou-se desvincular a responsabilidade do Estado da ideia de culpa do funcionário.

${ }^{487}$ Não obstante alguns doutrinadores defenderem que a abertura semântica gerada pela expressão "procedendo de forma contrária ao direito ou faltando a dever prescrito por lei”, contida no referido dispositivo legal, possibilitasse o enquadramento da regra no campo da responsabilidade objetiva.
} 
cas de direito público. As Constituições seguintes também mantiveram a regra, com acréscimos normativos ${ }^{488}$.

O quadro normativo atual, estabelecido pela Constituição de 1988, tem como fundamento o art. 37, $\S 6^{\circ}$ do texto constitucional. Preceitua o dispositivo em tela que "as pessoas jurídicas de direito público e as de direito privado prestadoras de serviços públicos responderão pelos danos que seus agentes, nessa qualidade, causarem a terceiros, assegurando o direito de regresso contra o responsável nos casos de dolo ou culpa”.

No dispositivo constitucional estão compreendidas duas regras: i) a responsabilidade objetiva do Estado; ii) a responsabilidade subjetiva do agente público.

Considerando o caráter protetivo da norma constitucional expressa no art. $37, \S 6^{\circ}$ da $\mathrm{CF}$, constata-se que esta se reveste da natureza de garantia do cidadão frente aos atos e omissões estatais lesivos. O alcance da responsabilidade patrimonial atinge todas as esferas do Estado, sendo passíveis de indenização não só os danos decorrentes de atos da Administração Pública, como os prejuízos advindos de atos jurisdicionais e atos legislativos ilegítimos (contrários à noção de juridicidade).

Sendo ampla a proteção conferida pelo art. 37, § $6^{\circ}$ da CF, a quebra do dever de impessoalidade pelo agente público que acarretar danos concretos ao administrado é fator perfeitamente capaz de ensejar a responsabilização patrimonial do Estado.

De acordo com a teoria do órgão, proposta pelo doutrinador alemão Otto Gierke, a pessoa jurídica de direito público manifesta a sua vontade por meio de agentes devidamente investidos em cargos nos seus respectivos órgãos. A relação entre agente e órgão público é estabelecida pela imputação (e não pela mera representação como outrora se defendia), sendo todos os atos dos agentes, quando praticados em função dessa qualidade, diretamente atribuídos ao ente estatal ao qual está vinculado.

A atribuição aos entes estatais dos atos e decisões de seus agentes que violem o princípio da impessoalidade faz nascer a pretensão indenizatória contra o Estado de todos os cidadãos afetados e prejudicados pela conduta ilegítima. Tendo em vista o caráter preventivo e até mesmo punitivo da responsabilização patrimonial, o instituto da responsabilidade civil extracontratual do Poder Público consiste em instrumento de grande relevância para a recomposição da ordem jurídica e como meio de controle da atuação administrativa ${ }^{489}$.

\footnotetext{
${ }^{488}$ A título de exemplo, a Constituição de 1967, que estabeleceu a ação regressiva em caso de culpa ou dolo do agente público.

${ }^{489}$ De acordo com Bruno Miragem (A Nova Administração Pública e o Direito Administrativo. São Paulo: RT, 2011, p. 361-362):
} 


\subsubsection{Responsabilização do servidor}

A adoção de decisões administrativas marcadas pela pecha da quebra da impessoalidade atrai a eventual responsabilização do servidor ${ }^{490}$.

Num tal contexto, pode ter lugar a improbidade administrativa e até mesmo a caracterização dos crimes previstos nos arts. 319 (prevaricação) e 320 (condescendência criminosa), do Código Penal.

\subsubsection{Improbidade Administrativa}

A Lei n. 8.429/92 - que estabelece os preceitos e as sanções por atos de improbidade administrativa na ordem jurídica brasileira - tem como objeto central a definição de um padrão ético de conduta e atuação dos agentes públicos.

A lei em questão disciplina o art. 37, § $4^{\circ}$ da Constituição Federal, dividindo o universo de condutas qualificadas como ímprobas em três grandes grupos: i) as que importem em enriquecimento ilícito (art. 9º); ii) as que causem danos ao erário (art. 10); iii) as que impliquem em violação aos princípios norteadores da atuação administrativa (art. 11).

“O princípio da impessoalidade como princípio informador da Administração Pública é de destacada vinculação e utilidade com a proteção da finalidade pública da ação administrativa, de resto identificada com o princípio da finalidade. Associa-se, igualmente, à imparcialidade administrativa, especialmente com o desenvolvimento que o princípio em questão observa no direito comparado, convergindo seu significado com a proibição de discriminação antijurídica como fim, móvel ou resultado da atividade da Administração Pública.

A eficácia jurídica da impessoalidade traduz, em grande medida, um novo perfil da Administração Pública a partir da Constituição de 1988, especialmente por permitir mais claramente o controle da ação administrativa tendo como base a exigência de critérios objetivos na formulação de escolhas ou planejamento do Estado em relação à destinação e fruição de bens e serviços públicos, por intermédio da formulação e execução de políticas públicas, e da prática de atos administrativos em geral.”

490 Tratando do tema em parecer intitulado "Conceito e classificação - Responsabilidade de quem atende ou desatende parecer técnico - Responsabilidade de quem o emite - Administração contenciosa: dever de imparcialidade - Responsabilidade por violá-la”, Celso Antônio Bandeira de Mello (Pareceres de Direito Administrativo. São Paulo: Malheiros, 2011, p. 323-324) ensina que os órgãos administrativos contenciosos, aos quais compete, em posição de absoluta imparcialidade, o julgamento de situações controversas, tais como os tribunais de impostos e taxas ou as comissões processantes de funcionários, que devem apurar eventual cometimento de infrações por eles e, sendo o caso, aplicar as correlatas sanções, com direito de ampla defesa dos servidores acusados, devem agir em posição substancialmente similar à do Poder Judiciário.”

${ }^{1}$ Tratando do tema em parecer intitulado "Conceito e classificação - Responsabilidade de quem atende ou desatende parecer técnico - Responsabilidade de quem o emite - Administração contenciosa: dever de imparcialidade-Responsabilidade por violá-la”, Celso Antônio Bandeira de Mello (Pareceres de Direito Administrativo. São Paulo: Malheiros, 2011, p. 323-324) ensina que os órgãos administrativos contenciosos, aos quais compete, em posição de absoluta imparcialidade, o julgamento de situações controversas, tais como os tribunais de impostos e taxas ou as comissões processantes de funcionários, que devem apurar eventual cometimento de infrações por eles e, sendo o caso, aplicar as correlatas sanções, com direito de ampla defesa dos servidores acusados, devem agir em posição substancialmente similar à do Poder Judiciário.” 
Como salienta Fábio Medina Osório ${ }^{491}$, a concepção ética na esfera pública é bastante distinta da ética da vida privada, uma vez que essa última está vinculada unicamente à moral crítica, sendo suas sanções exclusivamente internas e autônomas. Segundo o autor, a natureza institucional da função pública cria um conjunto de problemas éticos diferentes, diante das finalidades públicas a serem concretizadas pela ação dos agentes estatais, e ética pública e responsabilização andam lado a lado, devendo ser corrigidos e punidos os desvios de conduta (nepotismo, corrupção, mau uso do dinheiro público etc.).

A Lei de Improbidade Administrativa, nessa perspectiva, visa a estabelecer um marco normativo que delimite de forma clara o conteúdo e o alcance do dever de probidade do agente público, sob pena de aplicação in concreto das sanções expressamente previstas em seus dispositivos legais.

Apesar das previsões específicas da Lei n. 8.429/92, existe grande debate na doutrina acerca da concepção conceitual de probidade administrativa. Para a corrente majoritária, a probidade situa-se no âmbito da moralidade administrativa, sendo aquela corolário desta. Marcelo Figueiredo expõe de modo preciso o que aqui se pretende analisar:

“o princípio da moralidade administrativa é de alcance maior, é conceito
mais genérico, a determinar a todos os poderes e funções do Estado, atua-
ção conforme o padrão jurídico da moral, da boa-fé, da lealdade, da hones-
tidade. Já a probidade, que alhures denominamos ‘moralidade administrati-
va qualificada', volta-se a particular aspecto da moralidade administrativa.
Parece-nos que a probidade está exclusivamente vinculada ao aspecto da
conduta do administrador. Assim, em termos gerais, diríamos que viola a
probidade o agente público que em suas ordinárias tarefas e deveres atrita
os denominados tipos legais. A probidade, desse modo, seria o aspecto 'pes-
soal-funcional’ da moralidade administrativa. Nota-se de pronto substanci-
al diferença. Dado agente pode violar a moralidade administrativa e nem
por isso violará necessariamente a probidade, se na análise de sua conduta
não houver a previsão legal típica por ato de improbidade”492.

Evidencia-se que o dever de probidade possui relação íntima com a atuação concreta dos agentes públicos na gestão e na condução da máquina administrativa. Enquanto a

\footnotetext{
${ }^{491}$ Teoria da Improbidade Administrativa. $3^{\text {a }}$ Ed. São Paulo: Revista dos Tribunais. 2013. p. 26 a 28.

${ }^{492}$ Probidade Administrativa - Comentários à Lei 8.429/92 e Legislação Complementar. $4^{\mathrm{a}}$ ed. São Paulo: Malheiros. 2000. p. 22.
} 
moralidade administrativa consiste num princípio basilar e informativo da Administração Pública - determinando tanto a organização quanto a ação do Poder Público - a probidade é uma decorrência lógica deste princípio, refletindo a aferição ética e valorativa da própria atividade dos servidores e funcionários que agem em nome do Estado.

A Constituição Federal, no art. 37, § $4^{\circ}$ delimitou de forma específica as consequências jurídicas sancionadoras de condutas que violem diretamente a probidade administrativa. São elas a suspensão dos direitos políticos, a perda da função pública, a indisponibilidade dos bens e o ressarcimento ao erário, a serem aplicadas na forma e na gradação previstas na Lei de Improbidade, sem prejuízo da ação penal cabível.

Especificamente quanto ao princípio da impessoalidade na atuação administrativa, a Lei n. 8.429/92 dispõe, no art. 11, que "constitui ato de improbidade administrativa que atenta contra os princípios da administração pública qualquer ação ou omissão que viole os deveres de honestidade, imparcialidade, legalidade e lealdade às instituições”. De acordo com a doutrina majoritária, o enquadramento da conduta do agente público a esse tipo legal só ocorre quando constatado o dolo, manifesto na vontade deliberada de atingir os fins ilícitos previstos no dispositivo.

Emerson Garcia e Rogério Pacheco Alves ressaltam que, tendo em vista a impossibilidade de se ter a certeza quanto à vontade e à consciência do agente que praticou o ato ímprobo, “o seu elemento subjetivo há de ser individualizado de acordo com as circunstâncias periféricas ao caso concreto, como o conhecimento dos fatos e das consequências, o grau de discernimento exigido para a função exercida e a presença de possíveis escusas, como a longa repetitio e a existência de pareceres embasados na técnica e na razão" ${ }^{493}$.

No campo da individualização da conduta por atos de improbidade e da consequente atribuição das sanções previstas na Lei n. 8.429/92, questão desafiadora reside na distinção no caso concreto entre a má-fé e a incompetência do agente público. O mero agir incorreto do agente em face de padrões de eficiência e qualidade não enseja a aplicação das sanções da lei em referência. Para que seja legítima a imputação dos atos de improbidade ao administrador público é necessária a comprovação do dolo deste in concreto, sendo insuficiente a demonstração de sua inabilidade ${ }^{494}$.

\footnotetext{
${ }^{493}$ Improbidade Administrativa. 6 ${ }^{\text {a }}$ Ed. Rio de Janeiro: Lumen Juris. 2011. p. 331.

${ }^{494}$ Essa orientação é pacífica na jurisprudência do STJ, a exemplo do julgado no REsp no 213.994/MG, Rel. Min. Garcia Vieira, julgamento em 17/08/1999, DJU de 27/09/1999.
} 
No tocante às violações dos princípios da Administração Pública previstas no aludido art. 11, a Lei de Improbidade impõe as seguintes sanções, a fim de reprimi-las:

Art. 12. Independentemente das sanções penais, civis e administrativas previstas na legislação específica, está o responsável pelo ato de improbidade sujeito às seguintes cominações, que podem ser aplicadas isolada ou cumulativamente, de acordo com a gravidade do fato:

III - na hipótese do art. 11, ressarcimento integral do dano, se houver, perda da função pública, suspensão dos direitos políticos de três a cinco anos, pagamento de multa civil de até cem vezes o valor da remuneração percebida pelo agente e proibição de contratar com o Poder Público ou receber benefícios ou incentivos fiscais ou creditícios, direta ou indiretamente, ainda que por intermédio de pessoa jurídica da qual seja sócio majoritário, pelo prazo de três anos.

Parágrafo único. Na fixação das penas previstas nesta lei o juiz levará em conta a extensão do dano causado, assim como o proveito patrimonial obtido pelo agente.

Como se depreende da leitura do dispositivo, as penalidades por atos de improbidade não se confundem com sanções de outros ramos do direito, inclusive as aplicadas na esfera administrativa. Na Lei $\mathrm{n}^{\circ}$ 8.429/92, a tutela jurídica é específica da probidade do administrador público, sendo as penas nela determinadas voltadas à preservação do padrão ético de conduta no âmbito da Administração.

Destarte, a quebra da impessoalidade decorrente de ato doloso que se enquadre nas disposições da Lei no 8.429/92 tem como consequência jurídica direta a aplicação ao administrador ímprobo das penalidades previstas nesta lei.

\subsubsection{Responsabilidade criminal}

Além da caracterização de improbidade administrativa, a quebra da impessoalidade nas decisões administrativas pode implicar consequências criminais para o julgador.

O Código Penal brasileiro dispõe de um rol bastante amplo de crimes praticados por funcionário público contra a administração em geral. Cogita-se dos crimes de: a) Peculato (art. 312); b) Peculato mediante erro de outrem (art. 313); c) Modificação ou alteração não autorizada de sistema de informações (art. 313-B); d) Extravio, sonegação ou inutilização 
de livro ou documento (art. 314); e) emprego irregular de verbas ou rendas públicas (art. 315); f) Concussão (art. 316); g) Corrupção passiva (art. 317); h) Facilitação de contrabando ou descaminho (art. 318); i) Prevaricação (art. 319); j) Condescendência criminosa (art. 320); k) Advocacia administrativa (art. 321); l) Violência arbitrária (art. 322); m) Abandono de função (art. 323); n) Exercício funcional ilegalmente antecipado ou prolongado (art. 324); o) Violação de sigilo funcional (art. 325); p) Violação do sigilo de proposta de concorrência (art. 326).

Para efeitos penais, de acordo com o art. 327, caput, do Código Penal, considera-se funcionário público “quem, embora transitoriamente ou sem remuneração, exerce cargo, emprego ou função pública”. E, de acordo com o $\S 1^{\circ}$, do mesmo dispositivo, “equipara-se a funcionário público quem exerce cargo, emprego ou função em entidade paraestatal e quem trabalha para empresa prestadora de serviço contratada ou conveniada para a execução de atividade típica da Administração Pública”. Em consonância com o § $2^{\circ}$ do mesmo artigo, a pena será aumentada da terça parte quando os autores dos crimes forem “ocupantes de cargos em comissão ou de função de direção ou assessoramento de órgão da administração direta, sociedade de economia mista, empresa pública ou fundação instituída pelo poder público”.

O exame do Código Penal demonstra que por um lado o legislador se preocupou em preordenar como ilícitos criminais uma série muito ampla de comportamentos praticados por funcionários públicos em desfavor da Administração Pública em geral e, por outro, cuidou de conceber um conceito alargado de funcionário público para abarcar crimes praticados não só por funcionários públicos no sentido estrito, como por quaisquer outras pessoas físicas que ajam em nome do Estado ${ }^{495}$. - O que isso quer dizer? Que o legislador quis proteger, com inegável zelo, o interesse público, que é pressuposto da atuação administrativa.

Forçoso registrar que na doutrina especializada o conceito (largo) de funcionário público tem aplicação ampla. Para Celso Delmanto, ao tratar do respectivo alcance, o art. 327,

\footnotetext{
${ }^{495}$ Segundo Celso Delmanto, Roberto Delmanto, Roberto Delmanto Júnior e Fábio M. de Almeida Delmanto (Código Penal Comentado. $8^{a}$ ed. São Paulo: Saraiva, 2010, p. 928):

"Embora seja importante o conceito administrativo, para efeitos penais, o conceito de funcionário público é um pouco diverso do que lhe dá o Direito Administrativo. Para o CP, é funcionário público quem, embora transitoriamente ou sem remuneração, exerce cargo, emprego ou função pública. Para a caracterização do conceito penal, portanto, é desnecessária a permanência ou remuneração pelo Estado. Ao mencionar função pública, a lei 'quis deixar claro que basta o simples exercício de uma função pública para caracterizar, para os efeitos penais, o funcionário público (HeLeno Fragoso, Jurisprudência Criminal, 1979, v. II, $n^{\circ}$ 250). Assim, ainda que a pessoa não seja empregada nem tenha cargo no Estado, ela estará incluída no conceito penal de funcionário público, desde que exerça, de algum modo, função pública”.
} 
do CP, consubstancia "regra de caráter geral, aplicável a todo o CP e à legislação penal extravagante"

Dentre os inúmeros crimes suscetíveis de serem praticados por funcionários públicos contra a Administração Pública há conexão maior em relação ao princípio da impessoalidade, para os fins deste trabalho, dos tipos previstos nos arts. 319 (prevaricação) e 320 (condescendência criminosa), do Código Penal ${ }^{497}$.

De acordo com art. 319 do Código Penal, consubstancia prevaricação "retardar ou deixar de praticar, indevidamente, ato de ofício, ou praticá-lo contra expressa disposição de lei, para satisfazer interesse ou sentimento pessoal”. A infração da regra atrai a pena de detenção de 3 (três) meses a 1 (um) ano e multa.

Ora, "satisfazer interesse ou sentimento pessoal" significa agir com quebra da impessoalidade. O interesse ou sentimento pessoal é essencial à tipificação. Exige-se dolo específico. E, assim, não cabe punição a título de culpa.

Rogério Greco 498 salienta que “a Administração Pública é regida por uma série de princípios, sendo que muitos deles foram previstos expressamente em nossa Constituição Federal”. E que:

\begin{abstract}
"O administrador ou servidor público deve atuar, sempre, com os olhos voltados para o bem comum, não podendo utilizar os poderes que lhe foram conferidos a fim de prejudicar aqueles que não lhe são muito caros, ou mesmo beneficiar os que lhe são próximos. Deve agir, portanto, de maneira impessoal, não permitindo que seus sentimentos se sobreponham aos interesses da própria Administração Pública. Todos têm o direito de ser tratados isonomicamente, não importando serem pessoas cultas e/ou ilustres, ou mesmo ignorantes e/ou desconhecidas, tenham amizade ou conflitos pessoais com algum funcionário público”.
\end{abstract}

Estabelecendo conexão entre o tipo de prevaricação e o princípio da impessoalidade, Rogério Greco ${ }^{499}$ ensina que:

${ }^{496}$ Código Penal Comentado. $8^{\mathrm{a}}$ ed. São Paulo: Saraiva, 2010, p. 928.

${ }^{497}$ A quebra da impessoalidade pode ser a tônica de crimes previstos fora do Código Penal, a exemplo do que se dá no regime da Lei de Licitações em relação aos arts. 89 (dispensar ou inexigir licitação), 90 (frustrar ou fraudar a licitação), 91 (patrocinar interesse privado) e 97 (licitar ou contratar com inidôneo. Nos quatro casos assinalados, pode ter havido quebra da impessoalidade, atentatória ao atingimento do interesse público primário. Para maior detalhamento dos crimes referidos, confira-se a obra de Diógenes Gasparini (Crimes na Licitação. $4^{\mathrm{a}}$ ed., São Paulo: Editora NDJ, 2011).

${ }^{498}$ Curso de Direito Penal: parte especial, volume IV. 9a ed. Niterói, RJ: Impetus, 2013, p. 457.

${ }^{499}$ Curso de Direito Penal..., p. 457. 
"No que diz respeito ao princípio da impessoalidade, previsto no caput do art. 37 da Constituição Federal, Nagib Slaibi Filho o vislumbra sob dois aspectos, a saber:

1) Sua finalidade coletiva, transcendendo o interesse individual e buscando atingir o interesse coletivo - é a finalidade pública como elemento essencial de seus atos, o que decorre dos princípios republicano e democrático;

2) A atuação igualitária perante os próprios servidores e os administrados que devem ser considerados como indivíduos iguais em um todo coletivo - é o princípio da isonomia, já afirmado no art. $5^{\circ}$ da Constituição, decorrente do regime democrático de poder;

Com a finalidade de evitar a prática, infelizmente muito comum, de retaliações ou favoritismos no funcionalismo público, foi criado o delito de prevaricação, tipificado no art. 319 do Código Penal. Pela redação constante do mencionado tipo penal, podemos apontar os elementos que lhe são característicos: a) a conduta de retardar ou deixar de praticar, indevidamente, ato de ofício; b) ou praticá-lo contra disposição expressa de lei; c) para satisfazer interesse ou sentimento pessoal.

$(\ldots)$.

Para $G r e c 0^{500}$, o traço marcante do crime de prevaricação é mesmo a intenção de satisfazer interesse ou sentimento pessoal. O interesse pessoal pode ser de qualquer espécie (patrimonial, material ou moral). E, com apoio em Heleno Fragoso, relata que "o sentimento pessoal diz com a afetividade do agente em relação às pessoas ou fatos a que se refere a ação a ser praticada, e pode ser representado pelo ódio, pela afeição, pela benevolência etc.”. E que " a eventual nobreza dos sentimentos e o altruísmo dos motivos determinantes são indiferentes para a configuração do crime, embora possam influir na medida da pena”.

Para Cezar Bitencourt ${ }^{501}$ a prevaricação é a infidelidade ao dever de ofício e à função exercida; é o descumprimento das obrigações que lhe são inerentes, movido o agente por interesses ou sentimentos próprios. Para o autor, “dentre os deveres inerentes ao exercício da função pública, o mais relevante deles é o que consiste no cumprimento pronto e eficaz das atribuições do ofício, que deve ser realizado escrupulosa e tempestivamente para lograr a obtenção dos fins funcionais”. Assim, “o sentimento do funcionário público não pode ser outro senão o do dever cumprido e o de fazer cumprir os mandamentos legais”.

${ }^{500}$ Curso de Direito Penal..., p. 458.

${ }^{501}$ Tratado de Direito Penal, 5: parte especial: dos crimes contra a administração pública e dos crimes praticados por prefeitos. $7^{\mathrm{a}}$ ed. São Paulo: Saraiva, 2013, p. 133. 
Entende-se caracterizado o crime de condescendência criminosa, de acordo com o art. 320, do Código Penal, quando “deixar o funcionário, por indulgência, de responsabilizar subordinado que cometeu infração no exercício do cargo ou, quando lhe falte competência, não levar o fato ao conhecimento da autoridade competente”. Em ambos os casos, a pena é de 15 (quinze) dias a 1 (um) mês de detenção ou multa.

No crime do art. 320 do CP, podem ser sujeitos ativos o funcionário público infrator ou seu superior hierárquico. O tipo objetivo diz respeito à conduta omissiva. E a omissão deve ser por indulgência, tolerância, condescendência. Ser indulgente, tolerante ou condescendente quanto ao cometimento de uma infração é se deixar levar por interesses alheios ao interesse público primário. É se deixar levar pela quebra da impessoalidade.

No crime de condescendência criminosa, a quebra da impessoalidade se liga ao elemento subjetivo, a saber, o dolo (genérico) consistente na vontade de se omitir. Não há forma culposa. Trata-se de crime formal. E por se tratar de crime omissivo próprio, a tentativa é inadmissível. Todavia, se a omissão é para satisfazer interesse ou sentimento pessoal, pode restar caracterizado o crime de prevaricação (art. 319, do CP), e, além disso, tratando-se de omissão em relação ao crime de tortura, aplica-se o disposto no art. $1^{\circ}$, $\S 2^{\circ}$, da Lei $n^{\circ}$ 9.455/97502.

Cezar Bitencourt ${ }^{503}$ esclarece que a condescendência criminosa é uma modalidade de prevaricação que recebeu tratamento diferenciado do legislador, por considerar a menor desvalia da ação criminalizada que envolve relação pessoal/funcional. Para ele ${ }^{504}$, “a criminalização desse tipo de conduta é uma demasia, ante a existência de outros mecanismos de controle formalizado, particularmente o Direito Administrativo, que podem ocupar-se melhor desse tipo de relacionamento omissivo na esfera da Administração Pública”. Leciona:

“(...) Em verdade, na prática, tal previsão dificilmente ganha aplicação, não que tais fatos não aconteçam, ao contrário, ocorrem, mas, normalmente, o

${ }^{502}$ Conforme Celso Delmanto, Roberto Delmanto, Roberto Delmanto Júnior e Fábio M. de Almeida Delmanto (Código Penal Comentado. 8a ed. São Paulo: Saraiva, 2010, p. 918).

${ }^{503}$ Tratado de Direito Penal, 5: parte especial: dos crimes contra a administração pública e dos crimes praticados por prefeitos. $7^{\text {a }}$ ed. São Paulo: Saraiva, 2013, p. 148. Ensina Cezar Bitencourt que o Código Criminal do Império disciplinava essa infração como espécie de prevaricação (art. 129, § 4 ${ }^{\circ}$ ), caminho também seguido pelo Código Penal de 1890 (art. 207, § 6º). Todavia, o Código Penal de 1940 preferiu destacar a prevaricação como figura autônoma para dar-lhe tratamento mais adequado, proporcional a sua menor gravidade. E o Anteprojeto de Reforma do Código Penal, por sua vez, descriminaliza essa modalidade de infração penal, entendendo, provavelmente, que minimis non curat praetor.

${ }^{504}$ Tratado de Direito Penal, 5: parte especial: dos crimes contra a administração pública e dos crimes praticados por prefeitos. $7^{\mathrm{a}}$ ed. São Paulo: Saraiva, 2013, p. 149. 
chefe do chefe, isto é, a 'autoridade competente' que toma conhecimento da omissão do funcionário faltoso também adota indulgência semelhante, omitindo-se, igualmente. Apenas por exceção poder-se-á chegar à punição, e, nesse caso, normalmente, a motivação não é mais nobre que a indulgência punida, pelo contrário, é movida por sentimento negativo, vingança, perseguição etc. Convenhamos, falando sério e sem meias palavras, somente motivações do gênero animarão colegas de trabalho a buscar a criminalização de uma ação indulgente sem maiores consequências”.

Em todo caso, gostemos ou não, o crime existe e, ao existir, amplia a proteção que decorre da impessoalidade administrativa.

\subsection{Técnicas para adoção de decisões administrativas impessoais - ponderação e conciliação de interesses}

Uma (boa) decisão administrativa impessoal pressupõe a adoção de comportamentos administrativos obsequiosos da ponderação e da conciliação de interesses legítimos em disputa.

Segundo Vieira de Andrade ${ }^{505}$, “a legalidade condiciona cada vez menos positivamente a actuação administrativa, transformando-se, em muitos casos, em programação vaga de fins, e não satisfaz as exigências, mais latas, da justiça como ideia normativa”. Prossegue: "a razão de ser constitucional do princípio da imparcialidade vai deste modo entroncar na ideia-mestra do bem público”. Com isso, “a liberdade contra o arbítrio, a igualdade real dos cidadãos e dos grupos nas condições concretas da sociedade técnica, a justiça como ideia condutora resumem-se na imparcialidade como acentuação eficaz do caráter público da actividade administrativa"506.

Maria Teresa de Melo Ribeiro ${ }^{507}$ chama-nos a atenção para o fato de que "numa época de forte intervenção do Estado na vida privada dos cidadãos e num momento de forte afirmação dos poderes administrativos de conformação do tecido social, o princípio da imparcialidade da Administração Pública representa um importante instrumento de garantia da prossecução exclusiva do interesse público por parte das autoridades administrativas e, simultaneamente, um instrumento de protecção dos direitos e interesses dos cidadãos”.

\footnotetext{
${ }^{505}$ Obra citada, p. 220.

${ }^{506}$ Obra citada, p. 221.

${ }^{507}$ O princípio da imparcialidade da administração pública. Coimbra: Almedina, 1996, p. 11.
} 
Para a autora, "ao mesmo tempo que se torna necessário assegurar a subordinação total da actividade administrativa ao Direito, acentua-se a necessidade de reforçar os vínculos de subordinação da Administração ao interesse público definido por lei: o princípio da imparcialidade afigura-se ser o meio mais adequado para alcançar esta dupla exigência vinculativa”. Acrescenta que "a dilatação da função administrativa exige, por outro lado, a imposição de novos critérios e padrões de conduta que prendam a Administração nas malhas da [legalidade]”. Assim, “princípio da imparcialidade e princípio da juridicidade são, por isso, duas realidades indissociáveis" ${ }^{508}$.

De acordo com Diogo Freitas do Amaral ${ }^{509}$, ao tratar da vertente positiva do princípio da imparcialidade, a necessidade de exaustiva ponderação de todos os legítimos interesses juridicamente protegidos implica um apreciável limite à discricionariedade administrativa, não só "pela exclusão que comporta de qualquer valoração de interesses estranhos à previsão normativa”, mas sobretudo porque “o real poder de escolha da autoridade pública só subsiste onde a protecção legislativa dos vários interesses seja de igual natureza e medida”. $\mathrm{Na}$ "vertente positiva” da imparcialidade, o juiz administrativo português encontrará a via para anular os atos praticados sem a devida ponderação de interesses.

Assim, uma inadequada ponderação dos diferentes interesses em disputa, suscetível de medição pela fundamentação, traduz um vício de decisão.

Assiste inteira razão a Diogo Freitas do Amaral ${ }^{510}$ ao dizer que:

\footnotetext{
"A ausência de ponderação dos diferentes interesses em jogo - a qual, na maioria dos casos, é detectada pela fundamentação - é, pois, o vício em que o princípio da imparcialidade aparece a suportar, ao lado dos restantes princípios jurídicos, a injunção de racionalidade decisória, caracterizando-se, justamente, 'por não reflectir a decisão que não é sustentada numa ponderação. A ausência de ponderação é, portanto, um vício da decisão que traduz a realização de um processo de decisão aleatório, no qual não são ponderados os interesses’ em jogo".
}

Marcelo Rebelo de Sousa e André Salgado de Matos ${ }^{511}$ confessam que o princípio da imparcialidade não permite dizer o resultado correto da ponderação de interesses, nem se-

\footnotetext{
${ }^{508}$ Obra citada, p. 341.

${ }^{509}$ Obra citada, p. 144.

510 Obra citada, p. 145.

${ }^{511}$ Obra citada, p. 217.
} 
quer se contém os critérios de tal ponderação. Mostram que "os critérios e resultados de ponderação decorrerão de outras normas, designadamente do princípio da proporcionalidade, mas não pelo princípio da imparcialidade”, já que dele resulta “apenas uma proibição da ponderação dos interesses irrelevantes e uma prescrição da ponderação dos interesses relevantes”. Acrescem que a afirmação do princípio da imparcialidade não contradiz a parcialidade como característica inerente do agir administrativo, já que ambas atuam em planos diferentes. Assim, “a administração é necessariamente parcial na prossecução do interesse público, mas é também necessariamente imparcial na ponderação dos interesses públicos e privados sobre os quais a sua actuação repercute”.

Em duas palavras, o julgador administrativo deve ponderar e conciliar interesses.

A decisão administrativa impessoal requesta ponderação e conciliação dos vários interesses relevantes e legítimos, públicos e/ou privados, envolvidos numa situação concreta ${ }^{512}$.

Adverte Humberto Ávila ${ }^{513}$, merece revisão a própria análise do Direito Administrativo desenvolvida sob o influxo da contraposição entre o Estado e o cidadão e entre o interesse público e o interesse privado. Diferentemente, a realidade do Direito Administrativo se projeta sobre uma multiplicidade de relações jurídicas, também definidas como “relações jurídicas multipolares ('multipolare Verwaltungsrechtsverhältnisse')”. Num tal contexto, novidadeiro e desafiador:

\begin{abstract}
"Em vez de uma relação bipolar, esclarece SCHMIDT-PREUSS sobre a relação administrativa, 'direciona-se esta para a forma de [relações administrativas poligonais], nas quais direitos subjetivos se defrontam entre si ('untereinander in Frontstellung stehen'). A seguir aumentam as vozes que partem da orientação global do Direito Administrativo baseada na relação bipolar-clássica Estado-cidadão e de seus decorrentes limites para referirem-se à compreensão de relações multipessoais'. A contraposição de ambos os interesses não ocorre nesses casos, muito menos, e por consequência, uma relação de prevalência.”514
\end{abstract}

\footnotetext{
${ }^{512}$ Como assinala Humberto Ávila (Repensando..., p. 207-208): “...na definição de interesse público estão também contidos interesses privados. ISENSEE esclarece: 'na prática política é bastante discutido o que proporciona o interesse público numa concreta situação, se ele obtém primazia frente a interesses particulares colidentes ou como deve ser obtido um ajuste. Mas não se trata de medidas inconciliáveis ou antinômicas. Então o bem comum inclui o bem de suas partes (...) Interesses provados podem transformar-se em públicos. Bonum commune $e$ bonum particulare exigem-se reciprocamente. Essa principal coordenação exclui uma irreconciliável contraposição. A tensão entre ambos é, no entanto, evidente”".

${ }^{51513}$ Repensando..., p. 209.

${ }^{514}$ Na mesma trilha exegética, confira-se o pensamento de Paulo Otero (Manual..., p. 429): “A existência de
} 
Em sentido amplo, ponderar é medir e pesar, para equilibrar. E conciliar é extrair a máxima efetividade possível - com o mínimo sacrifício - de todos os interesses envolvidos em uma decisão administrativa.

Como adverte José $\mathrm{M}^{\mathrm{a}}$ Rodríguez de Santiago ${ }^{515}$, a ponderação não é só um método jurídico, mas uma forma de pensar e de atuar, em geral. Qualquer um que tenha de decidir se vê obrigado, muitas vezes, a ponderar. Em comum têm os conceitos vulgar e jurídico de ponderar serem, antes de tudo, uma "forma de decidir". Assim: “un órgano estatal (en sentido amplio) tiene que ponderar cuando debe adoptar una decisión en la que ha de tener en cuenta dos o más principios, bienes, valores, intereses, eventuales perjuicios, etc., contrapuestos”.

Paulo Otero ${ }^{516}$ aponta os traços da Administração Pública contemporânea: (i) Personalização (Administração Pública Personalizada); (ii) Complexificação (Administração Pública Gestora de Conflitos); (iii) Ponderação (Administração Pública de Balanceamento); (iv) Especialização (Administração Pública Técnico-Científica); (v) Privatização (Administração Pública Privatizada); (vi) Informatização (Administração Pública Eletrônica).

Interessa-nos neste trabalho o traço $\mathrm{n}^{\circ}$ 03. Ao tratar da “Administração Pública de Balanceamento” o autor assinala que, cada vez mais, é preciso ponderar. Por ponderação, na visão de Otero, entenda-se:

\footnotetext{
“A ponderação - ou balancing, na terminologia norte-americana -, envolvendo um contrapesar, um balanceamento ou um equilibrar equitativo do peso relativo de realidades jurídicas conflituais em presença (: bens, interesses ou valores), pode-se dizer que é um método, estabelecendo um enunciado racional de preferência e afastando a radicalidade de um 'tudo ou nada'. A ponderação surge como uma forma de decidir com um duplo significado:

(i) A ponderação é um procedimento decisório, traduzindo uma metodologia de construir, por via argumentativa e mediante fundamentação adequada, decisões jurídicas de prioridade alicerçadas em bens, interesses ou valores conflituantes;

(ii) A ponderação é também o resultado ou conteúdo da solução decisória alcançada, sabendo-se que quanto maior for o grau de contração
}

uma relação administrativa multipolar ou poligonal, envolvendo conflitos de interesses tendencialmente inconciliáveis protagonizados por privados perante a Administração Pública, gera uma decisão assente numa verdadeira relação trilateral ou triangular, expressa num 'triângulo jurídico' que compreende a autoridade administrativa decisória, o destinatário da decisão e um (ou vários) terceiro (s)”.

${ }^{515}$ La ponderación de bienes e intereses en el derecho administrativo. Madrid/Barcelona: Marcial Pons, 2000, p. 9-10.

${ }^{516}$ Manual de Direito Administrativo, p. 409-496. 
aplicativa ou não satisfação do bem, interesse ou valor sacrificado, maior será a importância da satisfação ou cumprimento do outro bem, interesse ou valor que, por isso, assume prevalência ponderativa”.

A ponderação, explica Otero ${ }^{517}$, ultrapassando a sua origem judicial em torno de conflitos entre privados ou de colisões normativas envolvendo direitos fundamentais, transformou-se numa técnica decisória comum às diversas áreas do ordenamento jurídico positivo, podendo dizer-se que todo o Direito é ponderação, já que, segundo o seu pensamento: (i) pondera-se a solução abstrata a adotar na feitura da norma ${ }^{518}$; (ii) pondera-se na determinação do sentido interpretativo da norma ${ }^{519}$; (iii) pondera-se no momento da aplicação da norma ao caso concreto ${ }^{520}$.

Se assim é, não pode a Administração Pública, subordinando-se ao Direito, ficar imune à ponderação ${ }^{521}$. A ponderação na atividade administrativa, mormente na decisória, é tributária da adoção do Estado de Direito.

Ponderar é difícil. Porque difícil é eleger o interesse público em cada caso concreto submetido ao descortino do decisor (julgador). Por duas razões: (i) o interesse público não é sequer determinável objetivamente ${ }^{522}$; (ii) o julgador é uma pessoa humana, dotada de razão e emoção.

${ }^{517}$ Manual..., p. 432-433.

${ }^{518}$ Eis os exemplos de Paulo Otero: “deve preferir-se uma diminuição das despesas públicas através da redução dos salários dos funcionários públicos ou da redução do montante das reformas dos aposentados e reformados? Face à ausência de verbas para a contratação de novo pessoal docente para a Faculdade de Direito, deve reduzir-se o numerus clausus ou aumentar o número de alunos em aulas práticas?”

${ }^{519}$ Para Paulo Otero, como exemplos de ponderação interpretativa, dentre muitos outros: "o conceito constitucional de 'ambiente familiar normal', nos termos do art. $69^{\circ}, n^{\circ} 2$, compreende casais homossexuais? O conceito constitucional de 'casamento' compreende a união de duas pessoas do mesmo sexo ou o designado casamento poligâmico?”

${ }^{520}$ Eis os exemplos de Paulo Otero: "o exame oral realizado pelo aluno A merece a classificação de aprovado ou de reprovado e, em qualquer dos casos, qual a classificação entre zero e vinte valores? Deve a polícia dispersar a manifestação ilegal e violenta que está a ocorrer junto à A.R. usando uma simples ordem verbal, recorrer a canhões de água ou avançar com bastonadas e disparar balas de borracha?”

${ }^{521}$ Para Paulo Otero (Manual..., p. 433-434): “Se todo o Direito assenta numa metodologia de ponderação, a Administração Pública - subordinando-se ao Direito, criando Direito, interpretado Direito e aplicado Direito - não pode deixar de também usar uma metodologia decisória assente em ponderações: (i) Tal como se diz existir um "Estado de ponderação", pode falar-se numa Administração Pública de balanceamento ou de ponderação; (ii) A normatividade reguladora da Administração Pública encontra-se "minada" de "cláusulas de ponderação", tal como o resultado da atividade administrativa assenta em procedimentos e decisões de ponderação; (iii) A ponderação administrativa de interesse assume-se como exigência decorrente do próprio Estado de Direito".

${ }^{522}$ É de Humberto Ávila (Repensando..., p. 211-212) a seguinte lição: “(...) é importante lembrar que 'o' interesse público não é determinável objetivamente. Há muitas dificuldades para a determinação do significado de 'interesse': ele representa, antes de tudo, um fenômeno psíquico, cuja descrição deve ser necessariamente feita com referência ao ordenamento jurídico. Igualmente a expressão 'público'. (...) A possibilidade de uma definição abstrata mínima sem o recurso à concretização das normas constitucionais apresenta-se da mesma forma questionável. A mesma dificuldade apresenta-se na aplicação das normas (...)”. 
Para ponderar, necessário ter em mente que não há uma norma-princípio da supremacia do interesse público sobre o interesse particular, ou melhor, como revela Humberto Ávila ${ }^{523}$, “a Administração não pode exigir um comportamento do particular (ou direcionar a interpretação das regras existentes) com base nesse 'princípio"”, sobretudo em relação às atividades que imponham restrições ou obrigações. Segundo o autor:

\begin{abstract}
“(...) a única ideia apta a explicar a relação entre interesses públicos e interesses particulares, ou entre o Estado e o cidadão, é o sugerido postulado da unidade da reciprocidade de interesses, o qual explica uma principal ponderação entre interesses reciprocamente relacionados (interligados) fundamentada na sistematização das normas constitucionais”.
\end{abstract}

Não se trabalha com um cenário ideal, de cientificidade induvidosa, mas com o pano de fundo possível, mormente com uma impessoalidade de propósito multifacetada, para dar maior cobertura aos valores constitucionalmente protegidos e, por isso mesmo, dada a algumas imprecisões, juridicamente toleráveis, se exercitada com critérios e procedimentos objetivados.

Impõe-se considerar uma metodologia decisória baseada em "ponderações possíveis" ${ }^{524}$. E só se pondera em casos concretos $^{525}$.

No trato da matéria, são extremamente proveitosos os ensinamentos de Paulo Otero. Está correto ao assinalar que a proliferação de um sistema constitucional de adoração aos princípios, próprio do neoconstitucionalismo ou do pós-positivismo, “conduzindo a uma progressiva transformação da normatividade vinculativa da Administração Pública, substituiu um predominantemente 'Direito de regras' por um 'Direito de princípios' regulador da ação administrativa”. Fez-se, assim, da ponderação ou do balanceamento, uma metodologia decisória comum.

\footnotetext{
${ }^{523}$ Repensando..., p. 214.

${ }^{524}$ Para Paulo Otero (obra citada, p. 433-434): "Se todo o Direito se assenta numa metodologia de ponderação, a Administração Pública - subordinando-se ao Direito, criando Direito, interpretando Direito e aplicando Direito - não pode deixar de também usar uma metodologia decisória assente em ponderações: (i) Tal como se diz existir um 'Estado de ponderação', pode falar-se numa Administração Pública de balanceamento ou de ponderação; (ii) A normatividade reguladora da Administração Pública encontra-se 'minada'de 'cláusulas de ponderação', tal como resultado da atividade administrativa assenta em procedimentos e decisões de ponderação; (iii) A ponderação administrativa de interesses assume-se como exigência decorrente do próprio Estado de Direito".

${ }^{525}$ Correto Gustavo Binenbojm (Da Supremacia..., p. 143) quando afirma que "não há como conciliar no ordenamento jurídico um 'princípio' que, ignorando as nuances do caso concreto, preestabeleça que a melhor solução consubstancia-se na vitória do interesse público”.
} 
Para Otero 526 , “a ponderação, visando à resolução de conflitos normativos envolvendo bens, interesses e valores em colisão, procura sempre, atendendo ao 'peso' específico de tais realidades, determinar a medida em que cada um tem de ceder perante a outra ou cada uma entre si, tendo como propósito último o restabelecimento da paz jurídica: a ponderação só começa, porém,quando as antinomias normativas não possam ser solucionadas através dos critérios normais, revestindo natureza residual”.

\subsubsection{Objetos de ponderação - bens, interesses e valores}

- Quais os objetos de ponderação, para fins decisórios, à luz da impessoalidade? Ponderam-se bens, interesses e valores ${ }^{527}$. - E a dignidade humana? É também ponderável? ${ }^{528}$

\footnotetext{
${ }^{526}$ Obra citada, p. 437.

${ }^{527}$ Paulo Otero (Manual..., p. 438-439) explica e situa cada um dos objetos de ponderação. Confira-se:
}

“(a) Ponderação de bens

Sabendo-se que um bem é todo o elemento apto à satisfação de uma necessidade, o conceito de bem jurídico é dotado de considerável amplitude: ele compreende toda a realidade possuidora de relevância social e protegida pela ordem jurídica - bem é ‘tudo o que sirva para o homem atingir qualquer fim’. Naturalmente, a proteção que a ordem jurídica confere aos diversos bens não é toda igual: há, desde logo, uma diferença estruturante que separa entre (i) bens protegidos pela Constituição - podendo aqui ainda distinguir-se aqueles que gozam de uma proteção direta e expressa e os que apenas possuem uma proteção indireta , implícita ou reflexa - e (ii) os bens sem proteção constitucional. A existência de bens jurídico-constitucionais ou bens jusfundamentais, numa situação de colisão ou conflito face a bens sem proteção constitucional, nunca pode deixar de ser tomada em conta numa metódica ponderativa, envolvendo a presença dos primeiros face a estes últimos uma óbvia prevalência.

(b) Ponderação de interesses

O interesse é todo o bem jurídico subjetivado, enquanto ‘relação entre um sujeito e um determinado bem’ ou, numa linguagem sugestiva, o interesse é um bem jurídico capturado ou reivindicado por um sujeito sendo possível traçar uma dicotomia nuclear entre (i) interesses que a ordem jurídica configura como direitos subjetivos e (ii) interesses que apesar de protegidos pela ordem jurídica, não se reconduzem a direitos subjetivos. Não obstante qualquer destes interesses pode ter tutela constitucional, falando-se, no caso de interesses reconduzíveis a direitos subjetivos em direitos fundamentais (v.g., direito à vida, direito à integridade física, direito ao livre desenvolvimento da personalidade), e, no caso de interesses não identificáveis como direitos subjetivos, em interesses tutelados constitucionalmente (v.g., prossecução do interesse público, segurança pública, redistribuição da riqueza), igualmente aqui existem reflexos ao nível da ponderação administrativa, vislumbrando-se dois cenários:

- Conflitos entre o interesse público e interesses jurídicos privados à luz de uma relação bilateral ou de uma relação multipolar ou poligonal;

- Conflitos entre interesses públicos protagonizados por diferentes entidades da Administração Pública. (c) Ponderação de valores

Os valores são critérios de avaliação ou valoração de bens ou de condutas, traduzindo um juízo axiológico de bondade, superioridade ou quantificação: o valor como que encarna num bem ou numa conduta, envolvendo uma tomada de posição de um sujeito, numa "rotura de indiferença” face à realidade que é avaliada. Podendo ter ou não consagração constitucional, os valores são passíveis de uma ordenação hierárquica e que, em caso de conflito axiológico, se projeta no momento de sua ponderação: os valores de nível superior têm primado sobre os valores hierarquicamente inferiores.

${ }^{528}$ Paulo Otero (Manual..., p. 439) faz a mesma indagação: Será que a dignidade da pessoa humana, enquanto valor fundamental da ordem jurídico-constitucional, goza de uma prevalência absoluta em caso de ponderação face a outros bens, interesses ou valores constitucionais? 
Paulo Otero responde que, no contexto português, na concepção personalista de interesse público ${ }^{529}$, a resposta é negativa. Ponderação tem limites, um dos quais é o núcleo essencial da dignidade humana. Ainda assim, podem ser feitas três ilações:

(i) O núcleo indisponível da dignidade humana nunca pode deixar de prevalecer numa situação de ponderação face ao interesse público;

(ii) Por identidade de razões, a dignidade humana prevalece ante quaisquer ponderações envolvendo outros bens, interesses ou valores objeto de tutela constitucional que, sendo conflitantes, não convoquem a dignidade da pessoa humana, e, por maioria de razão, se estamos diante de bens, interesses ou valores que carecerem de tutela constitucional.

(iii) A dignidade humana mostra-se passível de, num procedimento ponderativo, ser limitativamente condicionada pela presença de uma concorrencial pretensão conflitual que também se alicerce na dignidade de outro ser humano, devendo dar-se proeminência àquela que maior conexão, intensidade ou proximidade revele face à dignidade humana, salvo se ambas gozarem de igual “peso”, hipótese em que, não podendo uma prevalecer sobre a outra - nem se conferir uma proteção insuficiente - têm de ter igual proteção.

Conforme Humberto Ávila, a (boa) ponderação deve, primeiro, determinar quais os bens jurídicos envolvidos e as normas a eles aplicáveis e, segundo, “procurar preservar e proteger, ao máximo, esses mesmos bens”, o que representa caminho bastante diverso de “direcionar, de antemão, a interpretação das regras administrativas em favor do interesse público, o que quer que isso possa vir a significar”. Isto quer dizer:

\begin{abstract}
"Não se está a negar a importância jurídica do interesse público. Há referências positivas em relação a ele. O que deve ficar claro, porém, é que, mesmo nos casos em que ele legitima uma atuação estatal restritiva específica, deve haver uma ponderação relativamente aos interesses privados e à medida de sua restrição. É essa ponderação para atribuir máxima realização aos direitos envolvidos o critério decisivo para a atuação administrativa. E antes que esse critério seja delimitado, não há cogitar sobre a referida supremacia do interesse público sobre o particular”.
\end{abstract}

${ }^{529}$ Segundo a qual há prevalência absoluta do núcleo essencial da dignidade da pessoa humana sobre qualquer prossecução do interesse público. V. item 1.5 infra. 
Gustavo Binenbojm ${ }^{530}$ propugna que “em vez de uma regra de prevalência, impõe-se ao intérprete/aplicador do Direito um percurso ponderativo que, considerando uma pluralidade de interesses jurídicos em jogo, proporcione solução capaz de realizá-los ao máximo”. Num tal contexto:

\begin{abstract}
“(...) De modo análogo às Cortes Constitucionais, a Administração Pública deve buscar utilizar-se da ponderação para superar as regras de preferência estáticas atuando situativa e estrategicamente com vistas a certos standards de decisão. Tais standards permitem a flexibilização das decisões administrativas de acordo com as peculiaridades do caso concreto, mas evitam o mal reverso, que é a incerteza jurídica total provocada por juízos de ponderação discricionários produzidos caso a caso”.
\end{abstract}

\title{
3.6.2 Cenários de ponderação
}

E quais são os cenários propícios à ponderação?

Mais uma vez recorrendo a Paulo Otero ${ }^{531}$, tem-se que a ponderação administrativa pode ocorrer em dois cenários radicalmente distintos:

(i) ponderação abstrata, correspondendo à figura norte-americana do definitional balancing, permitindo alcançar uma fórmula normativa de futura resolução de conflitos envolvendo bens, interesses e valores.

(ii) ponderação no caso concreto, reconduzível ao ad hoc balancing do ordenamento norte-americano, decidindo-se qual o bem, o interesse ou o valor que prevalece face à situação individual em causa que cumpre resolver.

Segundo Otero, a ponderação abstrata, sem desrespeitar a margem de liberdade conferida pelo legislador, nunca deixa de ter presente a preferência ponderativa feita pela lei, já que:

(i) O legislador goza de um primado de ponderação, competindo- lhe, em primeira linha, o exercício de uma tal tarefa, relativamente a todos os demais poderes constituídos. Em alguns casos, a Constituição reservou para si essa mesma ponderação, excluindo o legislador de intervenção decisória;

${ }^{530}$ Da supremacia..., p. 146.

${ }^{531}$ Manual..., p. 441-442. 
(ii) No que respeita a todos os restantes conflitos de bens, valores ou interesses constitucionais cuja resolução ponderativa não é reservada à própria Constituição, a exigência de reserva de lei significa exclusão de ponderação primária a favor da Administração Pública: a ponderação administrativa assume um estatuto subordinado, complementar e subsidiário face à ponderação legislativa de natureza abstrata;

(iii) A ponderação abstrata legislativa ou administrativa nunca pode conduzir a uma aplicação subsuntiva aos casos concretos, existindo sempre uma margem possível de ponderações $a d$ hoc, atendendo às especificidades e circunstâncias de fato e de direito subjacentes a cada situação concreta.

No que pertine à ponderação concreta ou ad hoc feita pela Administração Pública, cumpre sublinhar, de acordo com Otero ${ }^{532}$ :

(i) A conflitualidade subjacente à multilateralidade da atividade administrativa, aliada a uma normatividade principalista, reforçada pela vinculação à aplicabilidade direta das normas constitucionais sobre direitos fundamentais, fazem da ação administrativa trivial uma permanente ponderação de bens, interesses e valores "administrar é hoje ponderar face a casos concretos";

(ii) A atribuição de poderes discricionários de decisão administrativa, bem assim a utilização de conceitos indeterminados na normatividade reguladora da conduta administrativa, reforçam o apelo a ponderações entre bens, interesses e valores "trata-se de criar, por decisão do legislador, uma reserva de ponderação a cargo da Administração Pública";

(iii) A existência de ponderações abstratas ou normativas, se de um lado facilitam a tarefa ponderativa, face a casos concretos, de outro lado nunca a excluem - “ $a$ aplicação de ponderações abstratas é feita através de ponderações concretas”;

(iv) Em situações de invalidade do agir administrativo, uma colisão entre princípios gerais (v.g., tutela da confiança, legalidade, interesse público) pode justificar, estando em causa uma atuação unilateral ou bilateral, uma ponderação modeladora de efeitos ad hoc por parte da Administração Pública;

(v) A realização de ponderações concretas ou ad hoc não pode deixar de assumir, à

${ }^{532}$ Obra citada, p. 443-444. 
luz dos princípios da igualdade e da imparcialidade, caráter autovinculativo para o decisor diante de casos idênticos ou semelhantes, dando azo à formação de precedentes ponderativos em relação a um mesmo quadro fático-jurídico.

Para Paulo Otero, “em qualquer dos cenários de ponderação, os tribunais exercem uma função tendencialmente repressiva, acessória e a posteriori, controlando as ponderações antes feitas pelo legislador e pela Administração Pública”, numa dupla vertente que controla (i) o procedimento de ponderação e (ii) o resultado da ponderação ${ }^{533}$.

\subsubsection{Etapas da ponderação}

- E quais são as fases da ponderação?

Segundo Otero 534 , “a ponderação, sendo um método, não se reconduz a um sentimento, antes se afirma como um processo racional, apesar de impregnado de considerável discricionariedade, dotado de um método argumentativo e fundamentador das suas decisões”. Não obstante, podem ser vislumbradas fases procedimentais não rígidas: (i) identificação das realidades em colisão; (ii) atribuição do peso a cada uma das realidades em conflito; (iii) Decisão sobre a prevalência entre a realidade em colisão.

Para o autor, a identificação das realidades em colisão demanda recorte exato dos bens, interesses ou valores que se encontram em conflito, sendo o primeiro pressuposto de qualquer ponderação. Pode contar com a participação procedimental dos interessados, levando ao conhecimento da Administração Pública interesses que importa ter em conta, sem esquecer que nunca pode permitir (i) que se tomem em consideração ponderativa realidades que não se encontram em verdadeira colisão ou, em alternativa, (ii) que se deixem de considerar realidades que se encontram em efetiva colisão: o erro na identificação das realidades em conflito para efeitos de ponderação, seja por via de (i) falsos problemas de ponderação ou de (ii) omissão ponderativa, determina, inevitavelmente, a invalidade da ponderação.

\footnotetext{
${ }^{533}$ Para Paulo Otero (Curso..., p. 444): “Não se pode excluir que, invalida judicialmente uma ponderação, por ausência de tomada em consideração de determinado bem, interesse ou valor pelo decisor legislativo ou administrativo - numa manifestação de proibição do excesso ou de proibição de insuficiente proteção ponderativa -, se vislumbre um verdadeiro efeito aditivo na decisão judicial: o tribunal, em tais casos, poderá predeterminar a ponderação administrativa, nunca lhe sendo admissível, no entanto, à luz do princípio da separação de poderes, se existirem diversas soluções ponderativas juridicamente possíveis, substituir aquela que foi adotada por sua".

${ }^{534}$ Curso..., p. 445-449.
} 
Recortados os bens, interesses ou valores em colisão ante a situação cuja ponderação se encontra em causa, há agora que, tendo em vista as circunstâncias factuais subjacentes, proceder à definição da importância ou do peso de cada um de tais bens, interesses ou valores em conflito: há que comparar, utilizando uma argumentação racional, e encontrar uma fundamentação que permita avaliar e “pesar” cada uma das realidades em colisão, procurando saber, atendendo às diversas soluções possíveis do conflito, o grau de realização de um bem, interesse ou valor sacrificado - a ponderação ad hoc expressa sempre um procedimento aberto à factualidade das circunstâncias do caso concreto.

Finalmente, ainda segundo Otero, equacionadas argumentativamente as diversas soluções possíveis do conflito, encontra-se o decisor apto a solucioná-lo, nos seguintes termos:

(i) Se estiver em causa um conflito entre bens, interesses ou valores de igual "peso”, reconduzíveis a uma situação de “empate ponderatório”, deverá procurar obterse a sua concordância prática, harmonizando-os, em termos de conferir a ambos um espaço de operatividade, sem embargo de, à luz do princípio da necessidade, ser admissível que um “ceda” perante o outro, contraindo-se o espaço de eficácia deste a favor daquele, mas sem que exista um aniquilar do sacrificado;

(ii) Se, em sentido diverso, os bens, interesses ou valores em conflito revelam a existência de “pesos” diferentes, a ponderação conduz, nos termos da lei de Alexy, à prevalência ou ao primado daquele bem, interesse ou valor que, segundo a argumentação antes usada, tendo presente o princípio da proporcionalidade e as circunstâncias concretas, justifica o sacrifício total ou parcial do bem, interesse ou valor contrário - trata-se, porém, de uma hierarquização ponderativa móvel, ou, na visão de Canotilho, "instável, que é válida para um caso concreto, podendo essa relação inverter-se noutro caso".

José $\mathrm{M}^{\mathrm{a}}$ Rodríguez de Santiago ${ }^{535}$, de sua vez, assinala que, com o objetivo de se afastar das críticas mais frequentes dirigidas à ponderação - imprevisibilidade de resultados, insegurança jurídica, alusão à justiça do caso concreto, possíveis agressões à separação de poderes, dentre outros - é necessário conceber uma metodologia, tanto quanto possível, mais rigorosa e disciplinada. Salienta o autor que um “método matemático” para resolver os problemas da ponderação não será possível formular, como é fácil supor. Como também não

${ }^{535}$ La ponderación de bienes e intereses em el derecho administrativo, p. 117 e seguintes. 
será possível um método que permita chegar a soluções únicas, para todos os casos, “a través de cadenas argumentativas conectadas con necesidad de tipo lógico-deductivo”, algo que parece impróprio em se tratando de método jurídico.

Para o autor, o que se deve trilhar é uma "forma ordenada de proceder", com a qual se pode identificar "o que” e “como” há que se argumentar, o que excluiu a ideia de “fórmula mágica”, de todo carente de racionalidade.

Para tanto, Rodríguez de Santiago, em trabalho respeitável, sugere três fases de ponderação. Na primeira, promove-se a identificação dos princípios (bens, valores e interesses) em conflito. Na segunda, atribuem-se pesos ou importâncias a cada um dos princípios (bens, valores e interesses) em conflito, atendendo as circunstâncias do caso. E, finalmente, na terceira fase, promove-se uma decisão de prevalência conforme o critério de "quanto maior seja o grau de prejuízo a um dos princípios, maior deve ser a importância do cumprimento do seu contrário”, trilhando-se a formulação de uma regra de "prevalência condicionada”.

O raciocínio desenvolvido pelo autor é precioso e convém conhecê-lo melhor.

Na primeira fase, a simples identificação dos princípios (bens, valores e interesses) em conflito já permite chegar a um primeiro juízo de valor sobre dados da realidade em correlação com enunciados normativos, em clara ordenação de consequências jurídicas.

Uma primeira observação colocará dados da realidade submetidos a preceitos normativos, que em princípio predeterminam consequências contrárias, revelando tensões, ou seja, a situação fática subsumida a uma das normas levaria a uma determinada consequência jurídica, e submetida à outra - que protege ou garante o princípio, valor, direito etc. - conduziria a consectários diversos.

Nesta primeira etapa há um “quê” de método de subsunção e se deve prestar muita atenção para evitar a explicação incorreta de “falsos problemas de ponderação" 536 . Deve-se ficar atento para evitar um segundo tipo de conduta indevida: evitar a ponderação mediante a negação da existência do conflito.

\footnotetext{
${ }^{536}$ A esse respeito, em tom crítico, o autor se refere a um caso resolvido pelo Tribunal Constitucional alemão, de 1957, que utilizou o método de ponderação para resolver um pretenso conflito (na realidade, inexistente) entre a liberdade de opinião de um inquilino e a propriedade do locador. O inquilino havia colocado um cartaz de propaganda eleitoral no exterior do imóvel. Para o autor, parece incorreto resolver o caso pela ponderação, já que a liberdade de opinião não autoriza a utilização da propriedade alheia como meio de manifestação de opinião política pessoal. Identificou-se incorretamente um princípio ponderável (a liberdade de expressão) quando a situação fática não se subsumia ao âmbito de proteção da liberdade, não constitucionalmente assegurada para a proteção do uso injustificado da propriedade alheia. Para o autor, um exame mais atento nesta fase de ponderação deveria ter conduzido à exclusão do conflito entre dois (ou mais) princípios, que, como é evidente, é o pressuposto de qualquer ponderação.
} 
Na segunda fase, uma vez identificados os princípios, direitos ou interesses considerados relevantes e merecedores de inclusão na ponderação, devem ser atribuídos pesos e importâncias a cada um deles, em função das circunstâncias correspondentes.

Segundo o autor, trata-se, nesta fase, de "formular argumentos sobre o grau de cumprimento de um princípio e sobre o grau de compromisso ou prejuízo do seu contrário” para cada uma das soluções possíveis do conflito. É imperioso argumentar com o peso e a importância de cada um dos princípios em conflito. A ideia é formular proposições sobre o grau de prejuízo de cada um dos princípios e o grau de cumprimento dos contrários.

Para a formulação de tais proposições, é possível fazer uso de argumentos de variadas espécies: a) dados de fato extraídos das circunstâncias do caso; e b) argumentos de Direito que apoiem um ou outro princípio.

Assim se responde a “como” argumentar. E isso constituirá o núcleo da fundamentação de prevalência que se adotará como resultado da ponderação.

Interessante notar que são objeto de ponderação princípios, direitos, valores ou interesses protegidos pelo ordenamento jurídico, isto é, “princípios, direitos, valores e interesses legítimos” e não propriamente “circunstâncias do caso”, entendidas apenas como dados fáticos dos quais se extraem argumentos para a concessão de prevalência no juízo ponderativo. Para o autor, "los hechos, como tales, ni se ponderan, ni pueden ponderarse".

Em síntese, na segunda fase se trata de formular argumentos sobre o grau de cumprimento do princípio que, na terceira fase, retrocederá, e sobre a importância do cumprimento do princípio ao qual se outorgará primazia, para o que devem ser arrecadados dados fáticos e jurídicos relevantes para a fundamentação da decisão.

Na terceira e última fase se chega à decisão de fazer prevalecer um direito, princípio, interesse etc. frente a outro (ou outros), que retrocede (m), decisão que encontra fundamentação argumentativa nas duas fases anteriores, especialmente na segunda, em que se argumentou de forma separada, com todos os tipos de dados disponíveis, sobre a importância que, no caso concreto, merece cada um dos princípios confrontados.

A solução do conflito deve atender ao critério de "lei de ponderação", de quanto maior seja o grau de prejuízo do princípio que retrocede maior deve ser a importância do que prevalece no caso determinando. Esta “lei de ponderação” não se aplica como critério único para todos os casos nem contém conteúdo material de decisão. É tão somente “un apoyo que hace ganar al método de la ponderación en racionalidad”. 
Como resultado de cada ponderação é possível formular uma "regra de prevalência condicionada”, na qual se expressam as condições de acordo com as quais foi dada prevalência a um princípio em detrimento de outro. A “regra de prevalência condicionada” será obtida a partir da argumentação utilizada para a decisão de cada caso concreto, mas se for correta, permite-se um certo grau de generalização ou de abstração que facilite a sua aplicação a conflitos futuros de perfil semelhantes.

Impõe-se destacar, como faz o autor, que as três fases de ponderação não se apresentam em separação rígida, como se fossem expedientes isolados. Na ponderação parece claro que para realizar adequadamente a argumentação sobre a importância do cumprimento ou do descumprimento de cada um dos princípios em conflito (segunda fase) há que se questionar sobre os possíveis resultados da ponderação (eventuais soluções da terceira fase).

Enfatiza Rodríguez de Santiago que, nas duas primeiras fases, se produzirá o “ir y venir de la mirada” da norma ao fato, e do fato (o caso ou a situação real) à norma (o enunciado normativo que contém o princípio, bem, valor ou interesse de que se trata). Na primeira fase de identificação dos princípios em conflito, segue o autor, já deve começar a se “formar” o fato, segundo o que, à vista das normas, seja relevante.

Até que se conclua a segunda fase continua esse "peregrinar de ida y vuelta” do fato à norma e da norma ao fato. E até então, o fato (a situação fática ou real à qual se vai aplicar o Direito) não está completamente “formado”.

Num tal contexto, ao processo de aplicação do Direito não interessa o “fato bruto”, mas sim a “formação do fato”. O fato originário, como sucede na realidade, é em parte abreviado e em parte complementado até que se concretize em uma formulação que contenha todas as circunstâncias - e somente estas - que devam ser levadas em consideração para a aplicação a ele das normas correspondentes.

Para o autor, é marcante a peculiaridade da ponderação segundo a qual, em princípio, “todas as circunstâncias podem ser potencialmente relevantes”, o que atribui especial importância à tarefa de elaboração ou formação do fato.

\subsubsection{A ponderação decisória na Ciência da Administração}

A Ciência da Administração, em necessário diálogo com o Direito Administrativo, fruto da visão de "Direito Administrativo como Sistema" 537 , tem grande contribuição a dar ao tema das decisões administrativas impessoais.

${ }^{537}$ V. item 1.6 infra. 
Mesmo fora das ciências jurídicas é possível perceber acentuada preocupação em dotar a Administração Pública de fórmulas que emprestem à sua atividade uma legitimidade maior. Na Ciência da Administração, por exemplo, fala-se na necessidade de relacionar atividades administrativas a bons procedimentos.

Confira-se a esse respeito o entendimento de João Caupers, em sua obra “Introdução à Ciência da Administração Pública”538, para quem a complexidade crescente da atividade administrativa pública, "presente em quase todas as áreas da prática social através de intervenções multifacetadas, destinadas a satisfazer os mais variados interesses públicos, torna cada vez mais difícil a definição destes e o traçado de uma fronteira clara entre eles e os interesses privados”. Para o autor ${ }^{539}$ :

\begin{abstract}
“A ritualização ou procedimentalização da actividade administrativa pública, ou seja, o seu condicionamento por regras estritas relativas aos modos de actuação da administração, procura fazer face a esta dificuldade, compensando, de alguma forma, o esbatimento da distinção entre interesses públicos e interesses privados, ao mesmo tempo que procura garantir o respeito pelos interesses dos cidadãos, canalizando, de forma transparente, as influências dos interessados para a formação da decisão administrativa”.
\end{abstract}

Para João Caupers ${ }^{540}$, a procedimentalização representa mais-valia como fator de legitimação da decisão, porque:

\begin{abstract}
“(...) na verdade, perante as mencionadas diversidade e falta de clareza dos interesses públicos, a procedimentalização, consubstanciando-se numa série de diligências e providências destinadas a lançar luz e ordem sobre o aparente "caos” motivacional da decisão, tende a tornar esta mais racional e, por isso, menos controversa e mais aceitável”.

Tudo se passa como se, para compensar a incerteza quanto à boa qualidade da decisão administrativa, se procurasse fazer sufragar esta pelos representantes do maior número de interesses diferenciados envolvidos. Bem vistas as coisas, não é esta a grande regra da democracia representativa?”
\end{abstract}

Assinalar o direito de participação procedimental como fator de legitimação da deci-

\footnotetext{
${ }^{538}$ Lisboa: Âncora, 2002, p. 145.

${ }^{539}$ Introdução à Ciência da Administração Pública. Lisboa: Âncora, 2002, p. 145.

${ }^{540}$ Introdução..., p. 145.
} 
são administrativa é uma das preocupações da ciência da administração. João Caupers ${ }^{541}$ explica que participar é ter a oportunidade de influenciar no processo de tomada de decisão e que a generalização da “administração participada” encontrou justificação em três ordens de razões, a saber:

a) A participação dos cidadãos na formação das decisões administrativas (participação procedimental) e nas próprias estruturas da administração pública (participação orgânica) é forma de aprofundamento da democracia, que se convola de democracia formal, limitada às eleições periódicas, sem posterior participação na vida pública, em democracia participada, em que cada cidadão se empenha diretamente na resolução dos problemas que o afetam;

b) A participação garante a ponderação de todos os interesses relevantes na tomada da decisão administrativa imparcial;

c) A participação contribui para o aumento da qualidade da decisão administrativa.

Para Caupers ${ }^{542}$, não obstante existam fundadas justificativas para a participação do administrado no processo de tomada de decisão administrativa, "não se pense que esta conta com a boa vontade irreversível da administração pública”. Entende:

\footnotetext{
"Bem ao contrário: muito embora os detractores da participação raramente se assumam como tais - preferindo denegrir a participação, nomeadamente enfatizando o arrastamento temporal da tomada de decisão por que ela seria responsável - eles existem e continuam saudosos dos tempos em que as decisões administrativas eram tomadas sem ter na menor conta as posições dos cidadãos interessados”.
}

Caupers $^{543}$, em crítica fundada, assinala que apesar de a participação dos cidadãos na atividade administrativa ser uma medida desejável pela maioria das pessoas, qualquer participação que seja interpretada como desafiadora da autoridade administrativa é bloqueada pelos mesmos agentes que propagandeiam a necessidade de participação. Imperam, pois, no trato do tema, cinismo e demagogia. É do mesmo autor este (triste) diagnóstico:

"Não se fique, porém, com a ideia de que a mera possibilidade de participa-

\footnotetext{
${ }^{541}$ Introdução..., p. 156-157.

542 Introdução..., p. 157.

${ }^{543}$ Introdução..., p. 157-158.
} 
ção, ainda que constitucional ou legalmente garantida, assegura, por si só, uma efectiva capacidade de influenciar as decisões tomadas pela administração pública.

Na verdade, um mundo crescentemente complexo não é suficiente para assegurar a possibilidade de participar - ainda que formatando esta possibilidade como um direito subjectivo ou, mesmo, como um direito fundamental - para que tal participação seja efectiva. Como bem sublinha DENHARDT, a participação dos cidadãos, para ser realmente efectiva, exige frequentemente a posse de conhecimentos e o domínio de técnicas e instrumentos que não se encontram ao alcance de todos, nem sequer de uma maioria de cidadãos. Como assegurar então que aqueles que participam detêm as capacidades necessárias para formar e manifestar um vontade esclarecida?”.

Quanto à participação orgânica, diversa da procedimental, e que se concretiza, por exemplo, por meio da criação e do funcionamento de órgãos colegiados, de natureza consultiva, com a participação dos administrados, Caupers ${ }^{544}$ revela que, pelo menos no contexto português, "infelizmente, esta espécie de participação tem se chocado com inúmeras dificuldades, não podendo considerar-se uma experiência positiva”. Com base em estudos desenvolvidos por Maria Manuel Leitão Marques e respectiva equipe de investigação, para o Conselho Econômico e Social de Portugal, João Caupers arrola os obstáculos encontrados quanto a uma proveitosa participação orgânica: a) Excessiva proliferação; b) Sobrerrepresentação de serviços públicos, comparativamente com as estruturas da sociedade civil; c) Demasiado peso do Estado; d) Não funcionamento quase generalizado.

Fala-se mesmo, segundo Caupers, numa "natureza semântica de grande parte da administração consultiva".

No campo da Ciência da Administração Pública existem estudos virtuosos sobre procedimentos decisórios e sobre a decisão administrativa propriamente dita.

Com apoio em João Caupers ${ }^{545}$, é possível revelar que no campo do Direito impera certa impotência quanto à definição precisa do que venha a ser uma decisão administrativa. No campo das ciências da administração, não. Estudioso do tema em ambos os campos do saber, explana:

“Na verdade, não se pode estranhar que, num quadro fortemente marcado

\footnotetext{
${ }^{544}$ Introdução..., p. 159.

${ }^{545}$ Introdução..., p. 161 a 176.
} 
pela presença do direito, a decisão da administração se confundisse com a definição unilateral do direito aplicável a uma situação concreta. O conceito de decisão nunca entrou, por isso, no vocabulário corrente dos jusadministrativistas portugueses.

A decisão, todavia, é de interesse fundamental para a ciência da administração, visto que é à volta daquilo que se decide - ou não decide - e do modo que se decide que se jogam a maior parte dos factores susceptíveis de influenciar e condicionar a actividade administrativa pública: interesses e grupos de pressão, cultura organizacional, identificação, relações com o meio social, influência política, constrangimentos financeiros, relações de poder, são tudo realidades voltadas para a decisão administrativa. Não é de estranhar, pois, a atenção que muitos autores lhe dedicaram”.

Quanto ao processo de decisão, João Caupers" ${ }^{546}$ ensina que "se decidir não é, em regra, fácil, na administração pública é quase sempre difícil: lento, hesitante, amargurado”. Para o autor, “o processo decisional encontra-se eivado de escolhos, uns reais outros virtuais, todos ‘fazendo força' no sentido da não decisão”. Arremata, com bom humor, que “quase é de admirar que a administração pública ainda tome algumas decisões, que os decisores não se resignem, definitivamente, a que o verdadeiro factor determinante da decisão é o tempo: basta deixá-lo passar e tudo há-de resolver”.

Também ensina que o processo de decisão é constituído de diversas etapas, que no modelo de gestão por objetivos - o que mais tem sido defendido e estimulado - são: a) Definição do objetivo; b) Elaboração de uma proposta relativa à forma de o atingir; c) Em alternativa: (i) aceitação da proposta pelos responsáveis da organização; (ii) substituição por proposta alternativa; (iii) discussão das objeções levantadas à proposta; d) Abandono da decisão ou reformulação da proposta; e) Tomada da decisão; f) Execução da decisão.

Quanto à tomada da decisão, que nos interessa mais de perto, Caupers ${ }^{547}$ assinala que, também no âmbito das ciências da administração, convém realçar a importância das noções de fundamentação e de discricionariedade. No campo das ciências da administração decerto se tem a consciência de que "ao contrário do que muitos julgam, a decisão administrativa não consiste, nem poderia consistir, na aplicação automática da lei”. E assim é porque "a norma jurídica não é um algoritmo, e a aplicação do direito pela administração pública não é uma operação meramente lógica”, sendo impossível “apreciar a

${ }^{546}$ Introdução..., p. 171.

${ }^{547}$ Introdução..., p. 174. 
conformidade legal de uma actuação administrativa como quem corrige uma equação". Nas lúcidas palavras do autor:

\footnotetext{
"O que a lei administrativa faz é estabelecer os parâmetros da decisão: em função da verificação das circunstâncias tais e tais, deverá ser tomada a decisão $A, B$ ou $C$, conforme o que for mais conveniente ao interesse $X$. Por outras palavras, a lei condiciona mas não determina as decisões administrativas. E é justamente por esta razão que, por um lado, os jusadministrativistas se ocupam do complexo tema da discricionariedade administrativa; por outro lado, que as questões relativas à fundamentação das decisões administrativas (por que razão se fez A, quando se poderia feito B ou C?) assumem tão grande relevo".
}

Do ponto de vista da Ciência da Administração, assevera Caupers ${ }^{548}$, a discricionariedade, definida como espaço de liberdade da decisão, “é uma característica intrínseca da própria actividade administrativa: uma decisão administrativa pode ser mais ou menos discricionária, mas comporta sempre alguma dose de discricionariedade”. De outra parte, a exigência de fundamentação da decisão interessa à Ciência da Administração não como condição de aferição de validade jurídica (aspecto que releva no plano do direito administrativo), mas sim como susceptibilidade de avaliação. Assim, "é ela que possibilita a apreciação do lugar que a decisão escolheu no espaço de liberdade que lhe estava reservado”.

\subsubsection{Minimização de sacrifícios}

Odete Medauar ${ }^{549}$, ao tecer considerações sobre o que chamou de “ultrapassado princípio da supremacia do interesse público sobre o interesse particular”, anotou que “mostrase pertinente à Constituição de 1988 e à doutrina administrativa contemporânea a ideia de que à Administração cabe realizar a ponderação de interesses presentes numa determinada situação, para que não ocorra sacrifício a priori de nenhum interesse”. Diz, mais, que "o objetivo desta função está na busca de compatibilidade ou conciliação dos interesses, com a minimização de sacrifícios”.

Quando tratou de "parâmetros do poder discricionário”, a autora ${ }^{550}$, comprovando a

\footnotetext{
${ }^{548}$ Introdução..., p. 176.

${ }^{549}$ Direito Administrativo Moderno, p. 149.

${ }^{550}$ Direito Administrativo Moderno, p. 131.
} 
natureza jurídica do princípio que se quer conferir à matéria da impessoalidade, revelou que além dos requisitos de competência, forma, motivo, fim, em geral verificados após a edição de medidas, a doutrina contemporânea redireciona seu interesse para o "processo formativo da decisão" 551 . Daí resulta “o cuidado com normas organizacionais e instrumento pelos quais a autoridade possa conhecer e ponderar os diversos interesses envolvidos em cada situação”.

Dentre os tipos de parâmetros de dificílima sistematização, para a limitação do poder discricionário, Odete Medauar ${ }^{552}$ chama a nossa atenção para as “garantias organizacionais”, tais como: “a composição e o modo de funcionamento interno dos órgãos, em especial dos colegiados que decidem ou atuam no processo de decisão; e as regras de abstenção ou relativas a impedimentos, ligadas ao princípio da impessoalidade”. E ao tratar do "conceito de ato administrativo”, Odete Medauar leciona que em muitas conceituações de ato administrativo aparece a locução “manifestação de vontade” do Estado, o que pode levar à (falsa) ideia de vontade como fator subjetivo. Nada mais enganoso. Explica:

\begin{abstract}
“(...) Na verdade, as decisões administrativas não são tomadas sob um enfoque particularizado, para produzir efeitos sobretudo entre partes; uma das características das decisões administrativas encontra-se na avaliação mais ampla dos interesses em confronto e no sentido de efeitos no todo, mesmo naquelas que, aparentemente, repercutem em âmbito restrito. Hoje se deve entender a 'vontade', que se exprime no ato administrativo, não como um fator psíquico, de caráter subjetivo, mas como um momento objetivo. É uma das consequências do princípio da impessoalidade que norteia as atividades da Administração brasileira (art. 37, caput, da CF)”.
\end{abstract}

Uma avaliação mais ampla dos interesses em confronto, para a tomada de uma decisão administrativa impessoal, pressupõe participação procedimental efetiva.

\title{
3.6.6 Os riscos da necessária participação procedimental
}

Uma necessária participação procedimental, para que se assegure uma forçosa avali-

\footnotetext{
${ }^{551}$ Na mesma linha de raciocínio, confira-se a lição de Eduardo García de Enterrìa (Problemas..., p. 58-59), para quem "parece resultar una clara línea tendencial hacia la maduración plena del contencioso-administrativo como una vía judicial plenaria y efectiva para que la Administración, como gestor fiduciario que es del pueblo, haga efectiva su responsabilidad o dación de cuente ante los ciudadanos, eliminando todos los viejos obstáculos radicados en la tradición de exención de la justicia del viejo poder público, lejano y absoluto, y demoliendo todas las sucesivas y tenaces técnicas de impedir, limitar o condicionar la plenitud del conocimiento judicial que durante dos siglos han ido sucesivamente apareciendo".

${ }^{552}$ Direito Administrativo Moderno, p. 133.
} 
ação dos interesses particulares legítimos, traz riscos consideráveis. E a boa ponderação deve estar atenta a eles. Dentre os riscos postos pela participação procedimental efetiva, segundo Luísa Cristina Pinto e Netto ${ }^{553}$, podem ser apontados os relativos a:

(i) Eficiência - a participação promove o alargamento do iter procedimental, impondo deveres à Administração que postergam a decisão e implicam custos; a participação pode fragilizar a racionalização dos meios, levando a procedimentos caros e desproporcionais, acarretando formalismos excessivos e contribuindo para a protelação das decisões administrativas;

(ii) Igualdade/impessoalidade - os particulares que participam do procedimento não estão no mesmo patamar, em posição de paridade, podendo haver desequilíbrios potencializados pela participação que levem a resultados desiguais; além disso, a proximidade gerada entre Administração e particulares pode implicar o afastamento da busca, pautada por critérios objetivos, pela finalidade essencialmente pública;

(iii) Interesse público - pode haver a fragilização do interesse público seja pela captura por interesses privados, setoriais, em virtude da insuficiência de meios da Administração, seja por força de uma visão hipostasiada da atuação administrativa consensual, acarretando um déficit de autoridade em prejuízo do interesse público.

De acordo com José Manuel Sérvulo Correia ${ }^{554}$, a participação procedimental traz riscos até mesmo para a própria finalidade do procedimento administrativo, ligada à racionalidade e à eficiência da Administração. Nas suas palavras:

\footnotetext{
“A conduta dos participantes pode não primar ela própria pela racionalidade. A ausência de informação ou de preparação qualificada, o défice de motivação, o rígido alinhamento segundo egoísmos individuais ou de grupo podem retirar utilidade objectiva às intervenções e apenas contribuir para complicar e atrasar o cumprimento da tarefa administrativa. Poderá mesmo assistir-se ao abuso do direito de participação, com a articulação de operações obstrutivas com o faseamento legal do procedimento”.
}

${ }^{553}$ Participação administrativa procedimental: natureza jurídica, garantias, riscos e disciplina adequada. Belo Horizonte: Fórum, 2009, p. 180-181.

${ }^{554}$ Trecho do prefácio feito à obra de Luísa Cristina Pinto e Netto (ob. cit., p. 18-19). 
Para Luísa Cristina Pinto e Netto ${ }^{555}$, quanto ao item (ii) supracitado, a abertura procedimental gerada pela participação pode comprometer a impessoalidade, porque "podem ser trazidos para o procedimento e inadequadamente incorporados no material de ponderação interesses e fatos que são irrelevantes para a decisão”.

Considerando que a atividade administrativa está condicionada por finalidades públicas, definidas objetivamente, a autora ${ }^{556}$ sustenta que devem ser afastadas "condutas regidas por critérios pessoais e subjetivos, baseadas em preferências, favores e ódios pessoais”, impondo-se uma “atuação objetiva, regida por critérios impessoais, abstrata e genericamente concebidos para atender a finalidades públicas e não privadas”. Ao mesmo tempo, a participação e a proximidade entre a Administração e os particulares, se não houver cuidado, "pode levar a que se comprometam a igualdade e a impessoalidade, passando a atuação administrativa, essencialmente pública, voltada para a busca do bem comum, a atividade privatizada, voltada para a busca de interesses privados, de indivíduos ou grupos de particulares".

Para José Manuel Sérvulo Correia ${ }^{557}$, a proximidade ensejada pela participação procedimental entre os agentes públicos responsáveis pela decisão e os demais sujeitos interessados “pode dificultar a objectividade, mesmo que se trate apenas de um facto psicológico que em nada belisque a probidade do decisor”. Essa era, segundo o autor, em outros tempos, “a justificação adiantada para regras ou praxes de segredo e distanciamento que, hoje, a transparência e a participação procedimental, impostas pelo princípio democrático e pela garantia dos direitos, não permitem mais”.

Na seara decisória, a atividade administrativa deve estar revestida de técnica e de cautela. Quanto mais efetiva a participação procedimental, maiores os riscos de captação de interesses ilegítimos ou irrelevantes e, por conseguinte, de contaminação da decisão pela quebra da impessoalidade.

E a própria atividade de seleção de todos os interesses legítimos e relevantes, com a exclusão dos demais, precisa primar, de per si, pelo cumprimento do princípio da impessoalidade. Do contrário, a atividade administrativa de seleção do material a ser ponde-

\footnotetext{
${ }^{555}$ Participação administrativa procedimental: natureza jurídica, garantias, riscos e disciplina adequada. Belo Horizonte: Fórum, 2009, p. 128-129.

${ }^{556}$ Participação administrativa procedimental: natureza jurídica, garantias, riscos e disciplina adequada..., p. 130-131.

557 Trecho do prefácio feito à obra de Luísa Cristina Pinto e Netto (ob. cit., p. 19).
} 
rado no momento da decisão poderá estar corrompida pela inobservância da impessoalidade e, comprometidos estarão, como consectários lógicos, os resultados da ponderação.

Mais uma vez tem inteira razão Luísa Cristina Pinto e Netto quando afirma que nem todo interesse legalmente protegido é relevante para um determinado procedimento e que pela participação podem ser trazidos ao procedimento indiscriminadamente interesses que não devem ser ponderados na decisão. Assim, ensina, “a Administração, pelo princípio do inquisitório, tem o dever de guiar a atividade instrutória, balizada pela imparcialidade, pela eficiência, pela igualdade e impessoalidade, tem que fazer a filtragem da informação".

José Manuel Sérvulo Correia, ao prefaciar a obra de Luísa Cristina Pinto e Netto, sentencia que os maiores riscos a uma generalizada participação procedimental dizem respeito mesmo à preservação da imparcialidade da Administração e da autoridade do Estado em sentido amplo. Para o publicista português:

“(...). Para os órgãos da Administração, sobretudo quando se trata do exercício de margem de livre decisão administrativa, coloca-se aí um imperativo de só levar à ponderação os interesses juridicamente relevantes mas, ao mesmo tempo, de não deixar de ponderar todos os que o sejam. Por outro lado, a ponderação não poderá decorrer sob critérios inapropriados, normalmente canal de entrada para interesses que não podem relevar, como aqueles que tenham a ver com abuso de poder ou corrupção. No tocante aos titulares dos órgãos ou servidores da Administração, a imparcialidade impõe também soluções preventivas de impedimento ou suspeição, tendendo a barrar o exercício de funções no procedimento àquelas que, directamente, ou nas pessoas de familiares ou amigos e inimigos, possam ter alguma conexão com a decisão em causa”.

Segundo Luísa Cristina Pinto e Netto ${ }^{558}$, os riscos decorrentes da participação procedimental e a busca de meios para minimizá-los colocam em destaque "a tensão essencial que traveja a construção do Direito Administrativo, a busca por uma adequada equação entre interesses públicos e privados, entre autoridade e liberdade”.

Para a autora, os riscos podem ser minimizados por meio de uma disciplina legal adequada, que deve prever a obrigatoriedade de publicidade e transparência, fundamentação e imparcialidade. E tal disciplina deve proporcionar racionalidade procedimental, “o que

${ }^{558}$ Participação administrativa procedimental: natureza jurídica, garantias, riscos e disciplina adequada. Belo Horizonte: Fórum, 2009, p. 180. 
passa pela convivência de uma disciplina geral com disciplinas específicas para o procedimento administrativo e por disciplina não exaustiva - variando o grau de formalização segundo os direitos e deveres envolvidos, a espécie, função e objeto do procedimento, o tipo de decisão a ser tomada e seus efeitos e os custos envolvidos no procedimento - de modo a conferir discricionariedade à Administração para adequar racionalmente o rito procedimental às circunstâncias concretas”.

No seu entender, “a racionalidade também deve contar com a previsão de prazos e deveres de decidir, com a indicação clara dos responsáveis pela condução e conclusão do procedimento e a previsão de sanções e com a consagração de deveres de boa-fé e colaboração para os particulares, com sanções proporcionais por tratar-se de exercício de direito fundamental”.

\subsubsection{Proposta metodológica}

Afigura-se possível propugnar por uma metodologia para uma tomada de decisão administrativa impessoal alicerçada nos seguintes passos:

\subsubsection{1 - $\mathbf{1}^{\mathrm{o}}$ passo: investir no avaliador}

Em primeiro lugar, antes mesmo de invadir a seara decisória propriamente dita, impende verificar se o avaliador, isto é, a pessoa que, em nome da Administração Pública, proferirá a decisão administrativa relevante, com reflexos sobre interesses de terceiros, está cabalmente habilitada para a realização da importante tarefa.

A organização (estruturação) administrativa impessoal deverá ter sido orientada a destacar um decisor com características de virtuosidade. Esse julgador administrativo deverá ser, tanto quanto possível, um servidor: a) Estável; b) Não impedido ou suspeito; c) Profissionalizado; d) Qualificado; e) Motivado.

\subsubsection{2 - $2^{\circ}$ passo: decidir com impessoalidade}

Depois de selecionado o servidor mais habilitado para o agir decisório, impende adotar as seguintes condutas, em ambiente processual: a) Identificar, arrolar e fazer um inventá- 
rio de todos os interesses em jogo; b) Isolar e destacar em campos diferentes cada um dos interesses, públicos e privados, para serem observados de per si; c) Avaliar a juridicidade (compatibilidade com o Direito) de cada um dos interesses; d) Fundamentadamente, eliminar (descartar) os interesses ilegítimos, não amparados pela ordem jurídica; e) Medir e pesar, isoladamente, cada um dos interesses legítimos em disputa; f) Promover cotejo rigorosamente fundamentado entre os interesses legítimos em disputa; g) Com foco na “conciliação possível”, dar maior valia aos interesses mais relevantes (mais pesados); h) Trilhar o “menor sacrifício possível” do interesse menos relevante (menos pesado).

\subsubsection{3 - $3^{\circ}$ passo: exteriorizar a decisão}

A decisão administrativa deve ser clara, objetiva e primar pela justiça material ${ }^{559}$. Seus fundamentos devem ser perfeitamente inteligíveis, não só por letrados, mas também pelo comum do povo. Sua legitimidade deve estar conectada à aceitação social.

\subsubsection{Escopo e efeitos da ponderação decisória}

Com a ponderação, a Administração ambiciona alcançar - e muitas vezes alcança uma maior justiça (material) nas decisões concretas, reiterando não só a impessoalidade, mas os demais princípios constitucionais a ela amalgamados (legalidade, eficiência, etc.). Não obstante, como antes explicitado, a atividade de ponderação decisória como subproduto da atividade humana está sujeita a falhas e tem dado azo a críticas.

Quanto aos efeitos da ponderação administrativa, compete reproduzir a visão (crítica) de Paulo Otero ${ }^{560}$, para quem parece haver certo paralelismo entre as críticas que são feitas às ponderações judicial e administrativa:

(i) A ponderação aumenta o risco de incerteza e de insegurança do agir administrativo face aos cidadãos, pois torna imprevisíveis as decisões aplicativas da normatividade - não se pode esquecer, todavia, o efeito autovinculativo que cada

\footnotetext{
${ }^{559}$ Para Eduardo García de Enterrìa (Problemas..., p. 50-51), “el último y capital punto de llegada de la evolución del sistema contencioso-administrativo ha sido, pues, su reconfiguración resuelta como una justicia subjetiva. En un panorama general dominado por la preeminencia de los derechos fundamentales en la escena política, el derecho a la protección del propio círculo vital de intereses cuando la Administración, infringiendo la legalidad, menoscaba tales intereses, es un derecho fundamental más, y no por cierto de los menores o secundarios”.

${ }^{560}$ Manual..., p. 447-448.
} 
ponderação acarreta para o seu autor e o progressivo surgimento, “ao longo do tempo, de uma malha ou rede de regras de prevalência";

(ii) A ponderação gera redução ou subversão do papel garantístico da lei, dissolvida num modelo casuístico de aplicação ponderativa ad hoc, assistindo-se a uma desvalorização da própria força normativa da lei. - Não será esse, no entanto, um problema geral de todo o Direito, atendendo à complexidade de interesses antagônicos existentes nas modernas sociedades? Não estarão alguns deles obtendo acolhimento constitucional, e tanto maior, mais a ordem jurídica recorre a princípios gerais e a conceitos vagos e indeterminados?;

(iii) A ponderação redefine o papel do princípio da separação dos poderes, debilitando o protagonismo de legislador e a inerente legitimidade político-democrática, a favor da Administração Pública e, em última análise, dos tribunais, a quem estaria confiada a última palavra em matéria de ponderações. - Não será esse, porém, um efeito garantido pelo princípio da interdependência de poderes que reorienta ou limita, por efeito ponderativo, o princípio da separação de poderes?

Paulo Otero explica que a Administração Pública da ponderação ou do balanceamento entre bens, interesses e valores determina a substituição de um sistema tendencialmente fechado de juridicidade por um sistema predominantemente aberto, com consequências geradoras de desconfiança e receio:

(i) Remete-se para o aplicador administrativo do Direito um poder suplementar de proceder a ponderações, conferindo-se à Administração Pública um impensável protagonismo na realização do Direito; Direito que não é aquilo que a norma diz, Direito que será aquilo que a Administração Pública, recorrendo a uma metodologia de ponderação, diz ser Direito, salvo se os tribunais anularem essa ponderação administrativa;

(ii) Observa-se, simultaneamente, que a lei deixou de servir de instrumento de certeza e segurança jurídicas na atuação administrativa, rompendo com toda a tradição jurídica liberal, que via na lei um meio de proteção da liberdade dos particulares face ao poder, confiando-se agora ao poder judicial, exclusivamente, a proteção dos cidadãos e a defesa deste novo modelo de juridicidade administrativa aberta;

(iii) O modelo alimenta a conflitualidade social e jurídica: quem ficou insatisfeito com 
a ponderação administrativa efetuada, procurando sempre alicerçar sua pretensão em preceitos constitucionais, tenderá a abrir litígios judiciais, arrastando os tribunais para uma discussão político-constitucional, contribuindo para ampliar a crise na concretização jurisdicional da justiça.

Paulo Otero ${ }^{561}$ chega a dizer que não deixa de ser verdadeira a crítica de que " $a$ ponderação exige acordos excessivos em torno das suas premissas e permite desacordos excessivos nos seus resultados”, mas nos acalma a todos ao garantir que:

Todavia, pode bem questionar-se se essa não será uma característica típica de uma sociedade aberta a uma pluralidade de interpretações da sua ordem jurídica, incluindo ao seu texto constitucional. No limite, excesso de acordos nas suas premissas e desacordos excessivos nos seus resultados poderá será a melhor síntese de uma postura procedimental crítica à democracia”.

A partir de tais técnicas, se ainda não é possível trilhar decisões administrativas impessoais imaculadas, pelo menos se faz viável, em boa medida, diminuir o grau de incerteza quanto à aplicação do princípio em debate em prol de resultados cada vez mais idôneos, juridicamente mais hígidos, conectados à consecução do verdadeiro interesse público, razão de ser do Direito Administrativo.

${ }^{561}$ Manual..., p. 449. 


\section{CONCLUSÕES}

A constitucionalização dos direitos, no cenário do pós-positivismo, implica a irradiação dos princípios constitucionais, com efeitos amplos, a todos os ramos do direito, inclusive na regência das atividades dos particulares, com força normativa e eficácia concreta.

No campo do Direito Administrativo não é diferente. A Constituição é a régua interpretativa de todas as atividades intelectivas de cunho jurídico. Toda a ordem jurídica extrai sua legitimidade dos programas da Carta Política Maior.

Todos os dias, em nome do interesse público, a Administração julga com princípios, o que não é tarefa simples. O julgamento com princípios, marca da contemporaneidade jurídica, impõe desafios colossais, sendo forçoso evitar exageros decorrentes do subjetivismo e do casuísmo.

No Direito Administrativo, de sistematização recente e à míngua de codificação, os princípios têm importância redobrada, assumem papel de destaque. Não só auxiliam na compreensão e na consolidação de institutos jurídico-administrativos, mas também dão cobertura a um sem-número de operações jurídicas. A própria legalidade, lastro do Direito Administrativo, passa a ser vislumbrada com espectro de incidência dilatado.

No (novel) Direito Administrativo, o administrado (não súdito!) deve ser considerado em sua dimensão humana, como princípio e fim das preocupações do Estado. Num tal contexto impõe-se reconfigurar, juridicamente, a plataforma tradicional do interesse público. Em nome dele - e em nome de uma vazia suposta supremacia em relação a legítimos interesses dos particulares - foram e são cometidos abusos pela Administração.

Por interesse público já não se pode entender o interesse unilateral do Estado, do erário, do fisco, mas sim o resultado de uma equação, de uma ponderação bem feita, no âmbito da qual devem ser sopesados, com razão e método, os diversos interesses legítimos em disputa, públicos ou privados. O interesse público se dá em casos concretos e pode estar no reconhecimento dos direitos dos particulares.

O Direito Administrativo do interesse público verdadeiro, concebido como sistema, dialogado com disciplinas irmãs, como a Ciência da Administração, deve alinhar duas esferas, uma interior e outra exterior. A estruturação (organização) administrativa passa a ser aliada da ação administrativa, sem espaço para “atuações” políticas divorciadas da impessoalidade estatal.

A impessoalidade, núcleo essencial do Direito Administrativo, desempenha papel 
fundamental nas decisões administrativas. Em instrumentalização recíproca com os demais princípios, confere significativa cobertura e proteção aos valores tutelados pelo texto constitucional. É noção que supera a imparcialidade, a objetividade e a neutralidade política próprias de ordenamentos estrangeiros.

O Princípio da Impessoalidade, genuinamente brasileiro, tem recebido diversas leituras, algumas das quais reprováveis. Ganham força e prestígio abordagens que a relacionam às ideias de função pública e de finalidade pública, em forte correlação com um interesse público reconfigurado, obtenível a partir da ponderação e da conciliação de interesses legítimos. Também começa a ser lançado olhar mais penetrante sobre a questão da estruturação (organização) administrativa impessoal.

Há impessoalidade na Constituição e em numerosas leis, ora com o figurino de regra, ora de princípio, inspirando interpretações ricas e criativas. Em outros casos, revelando incompreensões, num rosário desejoso de sistematização.

Uma impessoalidade que se preste a dar cabo das numerosas tarefas estatais endereçadas no texto constitucional não pode desconsiderar o seu caráter abrangente, policefático, multifacetado. A não ser assim, sua cobertura seria irrisória.

A impessoalidade só pode ter a forma de círculo grande, abrangente de círculos menores, não menos dignos, consubstanciados nas noções de imparcialidade, objetividade e neutralidade política da Administração Pública. Uma impessoalidade de muitas dimensões e compreensões, articuladas, entrelaçadas, arquitetadas na revelação de um "princípio de princípios”, como um norte, um ponto cardeal para a Administração Pública, a reger não só as suas atividades cotidianas, das mais sofisticadas às mais simples, mas também a sua arrumação interna propiciatória de um agir decisório conectado com o justo e com o que é caro ao Direito.

O princípio da impessoalidade impõe à Administração uma dupla preocupação. Deve se organizar, do ponto de vista da sua estrutura, para ser impessoal. Demais disso, desde que devidamente organizada, deve ser impessoal em suas ações, em seu relacionamento jurídico com os administrados.

Para se organizar bem, impessoalmente, deve se estruturar de forma inteligente, adotando, como regra, institutos jurídicos como: concurso público, licitação, processo administrativo, balizas normativas de impedimento e suspeição etc. Deve investir na profissionalização e na qualificação dos agentes públicos. Deve reconhecer méritos, no acesso e no desempenho 
de cargos públicos. Deve banir nepotismos, patrimonialismos e outros comportamentos administrativos atentatórios à impessoalidade que serve (e ao mesmo tempo se serve!) do interesse público.

Imprescindível ter na decisão administrativa impessoal o resultado final, o produto de uma criteriosa iteração entre os interesses envolvidos numa disputa. Só pode ser fruto de uma mui criteriosa avaliação, por parte do julgador, de todo e qualquer interesse legítimo, público e/ou privado. Livre de preconceitos e pré-compreensões. Sem preferências ou predileções prévias. Em suma, sem subjetivismos. Tudo apurado com seu peso e importância. Com método e cientificidade.

Ao invés de, em nome de uma visão bolorenta e desgastada de supremacia do interesse público, perseguir os seus próprios “interesses públicos”, unilateralmente fixados, sem apego maior ao substrato ideológico do Direito Administrativo justo, deve-se sempre sopesar todos os direitos legítimos concorrentes para cumprir a função de concretizar o "interesse público” de base constitucional. A não ser assim, “interesses públicos” serão falácias, armadilhas. Prestarão desserviço ao Estado de Direito.

Decisões administrativas impessoais precisam observar ao menos três deveres fundamentais, implicados reciprocamente. Deve haver fundamentação (motivação), deve eclodir em ambiente processual (processualização) e pressupor-se a contribuição do interessado (participação).

Para ser impessoal, a decisão deve conter fundamentação suficiente e adequada. Tal exigência é consectário lógico do Estado Democrático de Direito. Deve ser convincente, sob pena de comprometimento do controle e de malferimento do desígnio de justiça da decisão. Também deve haver transparência, publicidade, por meio da qual se exterioriza a impessoalidade.

Decisões impessoais relevantes demandam ambiente processual. Concepções processuais e procedimentais da própria democracia, para fins de legitimação dos atos de poder, rechaçam decisões tomadas sem racionalidade, imparcialidade e equilíbrio, denotados pelo processo administrativo. Promove-se, assim, “dessubjetivação” do poder, evitando-se que motivos espúrios, obscuros, de índole pessoal e fins alheios ao interesse público contaminem a decisão impessoal tomada pelo Estado.

A participação, como direito, advém do princípio democrático. É pedra angular da democracia participativa. Sem participação não há impessoalidade decisória. O administrado 
tem direito de fazer os seus aportes. De somar esforços na edificação de uma decisão que leve em consideração todos os interesses legítimos, inclusive os seus.

A impessoalidade decisória assim alicerçada traz reflexos em vários temas tradicionais do Direito Administrativo.

Uma das implicações diz respeito à teoria do funcionário de fato. Podem ser aproveitados os atos administrativos levados a efeito por servidores de fato, justamente em decorrência da impessoalidade. Os atos são imputados à Administração, não ao servidor.

A impessoalidade reduz a discricionariedade decisória. No que implica atuação administrativa despida de subjetivismos e predileções pessoais, reduz a margem de liberdade do administrador conferida pela lei para que se atenda o interesse público verdadeiro. Ao decidir, o administrador deverá observar a impessoalidade por inteiro, o que demanda um arranjo de equilíbrio em cada caso concreto.

A teoria do desvio de poder também se nutre da impessoalidade decisória. Sintomas e indícios da decisão podem identificar decisões proferidas em desfavor do interesse público. Nestes casos, a impessoalidade estará ferida. A vontade do agente público direcionada a finalidades outras, alheias ao interesse público, mancha o princípio e abre ensejo à aplicação da teoria com máximo vigor.

A impessoalidade impõe a motivação do ato de demissão de empregados públicos. Como consequência de uma contratação impessoal, calcada em concurso público, a dispensa deve estar livre de subjetivismos.

De igual, a impessoalidade pode ser vista como fundamento da responsabilidade civil objetiva extracontratual da Administração. É em função da impessoalidade que se responsabiliza a “culpa anônima”, do serviço, ou seja, aquela que prescinde da precisa identificação de um servidor cuja conduta, dolosa ou culposa, tenha causado dano à vítima.

A impessoalidade também estimula o reconhecimento dos direitos dos administrados na via administrativa. Se a Administração teima em reconhecer administrativamente direitos dos administrados, remetendo questões ao crivo do Judiciário, sem necessidade, está aí configurada lesão à impessoalidade. Não é favor ou liberalidade, mas dever concreto da Administração empreender posturas facilitadoras do reconhecimento. As decisões administrativas não podem ser formas legais de produção de injustiças.

O nepotismo é um dos males fortemente combatidos pelo princípio da impessoalidade. Em muitos casos, nomeações casuísticas podem ser revertidas com apego ao princípio. Em 
outros, podem ser questionadas, em termos de juridicidade, decisões eivadas de grave vício de origem, já que provenientes de agentes públicos nomeados em desrespeito ao princípio.

Uma última implicação da impessoalidade pode ser destacada quanto à necessidade de revisitação da reformatio in pejus como regra do processo administrativo. Uma reforma para pior, sem critérios objetivos, lastreada em subjetivismos e predileções, pode tisnar o princípio e macular decisões tomadas em grau de recurso de maneira irreversível.

A quebra da impessoalidade administrativa decisória tem consequências jurídicas palpáveis, jungidas às possibilidades de anulação do ato decisório e responsabilização do Estado e do servidor. A anulação da decisão não impessoal parece irrecusável, já que se está diante de ilegalidade material, ou melhor, de uma flagrante inconstitucionalidade. A responsabilização civil extracontratual do Estado, de sua vez, é consectário imediato do art. 37, § 6º da Constituição Federal de 1988. E a responsabilização do servidor, outra consequência natural. O servidor que não age com impessoalidade no campo decisório comete improbidade administrativa, sem prejuízo de poder ser punido criminalmente.

A impessoalidade administrativa decisória atrai a necessidade de adoção de técnicas. Descortinam-se as técnicas da ponderação e da conciliação. Uma inadequada avaliação dos interesses em disputa traduz um vício da decisão.

Ponderar é medir e pesar, para equilibrar. E conciliar é extrair a máxima efetividade possível - com o mínimo de sacrifício - de todos os interesses envolvidos em uma decisão administrativa. A ponderação não é apenas um método, mas uma forma racional de atuar e de decidir.

Embora seja tarefa complexa, a ponderação administrativa pode ser determinável circunstancialmente, desde que executada com critérios e procedimentos objetivados. As ponderações administrativas são as “ponderações possíveis” e só se revelam em casos concretos.

À moda de proposta metodológica, pugna-se por uma caminhada em três passos. No primeiro, investe-se no avaliador, para saber se está habilitado para a importante tarefa de decidir em nome do Estado. No segundo passo, adotam-se condutas de identificação, arrolamento e inventário dos interesses em jogo; isolamento e destaque dos interesses confrontáveis; avaliação da juridicidade; eliminação fundamentada de interesses ilegítimos; medição e pesagem isolada de cada um dos interesses em disputa; cotejo dos interesses legítimos; conciliação possível para dar maior valia aos interesses mais relevantes com o menor sacrifício possível dos demais. No terceiro passo, exterioriza-se a decisão, com clareza e objetividade, primando-se pela justiça material e pela inteligibilidade dos fundamentos adotados. 
Concretiza-se, assim, com as técnicas de ponderação e conciliação, a impessoalidade administrativa decisória.

Eis a única solução constitucionalmente ajustada. 


\section{REFERÊNCIAS}

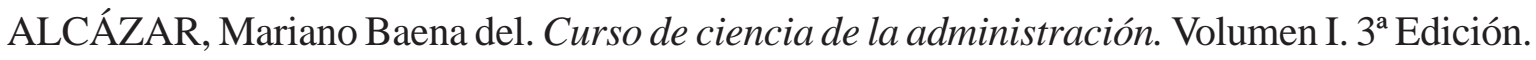
Madrid: Tecnos, 1993.

ALLEGRETTI, Umberto. L’imparzialità amministrativa. Padova: CEDAM, 1965.

ALESSI, Renato. La responsabilità della pubblica amministrazione. $3^{\mathrm{a}}$ ed. Milano: Giuffrè, 1955.

ALMEIDA, Fernando Dias Menezes de. Princípio da impessoalidade. In: Princípios de direito administrativo: legalidade, segurança jurídica, impessoalidade, publicidade, motivação, eficiência, moralidade, razoabilidade, interesse público. Thiago Marrara (org.). São Paulo: Atlas, 2012.

AMARAL, Diogo Freitas do. Última lição. Coimbra, Almedina, 2007.

. Curso de direito administrativo. $2^{\mathrm{a}}$ ed. $2^{\mathrm{a}}$ reimp. - $2^{\mathrm{o}} \mathrm{v}$. Coimbra: Almedina, 2013.

ANDRADE, José Carlos Vieira de. A imparcialidade da administração como princípio constitucional. Boletim da Faculdade de Direito da Universidade de Coimbra. Vol. L, 1974.

O dever de fundamentação expressa de actos administrativos. Coimbra: Almedina, 2003.

ANDRÉ, Adélio Pereira. A justiça administrativa. 12ª ed. Coimbra: Almedina, 2012.

ANTUNES, Luís Felipe Colaço. A tutela dos interesses difusos em direito administrativo: para uma legitimação procedimental. Coimbra: Almedina, 1989.

. Para um direito administrativo de garantia do cidadão e da administração. Coimbra:

Almedina, 2000.

ARAGÃO, Alexandre Santos de. Curso de Direito Administrativo. Rio de Janeiro: Forense, 2012.

Subjetividade judicial na ponderação de valores - alguns exageros na adoção indiscriminada da teoria dos princípios. In: ALMEIDA, Fernando Dias Menezes de; MAR- 
QUES NETO, Floriano de Azevedo; MIGUEL, Luiz Felipe Hadlich; SCHIRATO, Vitor Rhein (Coord.). Direito público em evolução: estudos em homenagem à Professora Odete Medauar. Belo Horizonte: Fórum, 2013.

A “supremacia do interesse público" no advento do Estado de Direito e na hermenêutica do direito público contemporâneo. In: Interesses públicos versus interesses privados: desconstruindo o princípio da supremacia do interesse público. Rio de Janeiro: Editora Lumen Juris, 2005.

ARAÚJO CINTRA, Antônio Carlos; GRINOVER, Ada Pellegrini; DINAMARCO, Cândido Rangel. Teoria Geral do Processo. 22ª Ed. São Paulo: Malheiros, 2006.

ASPRONE, Maurizio. Il principio di imparzialità nel diritto comparato. Roma: Aracne Editrice, 2011.

ATALIBA, Geraldo. República e Constituição. 2a ed. São Paulo: Malheiros, 2001.

ÁVILA, Ana Paula Oliveira. O princípio da impessoalidade da administração pública: para uma administração imparcial. Rio de Janeiro: Renovar, 2004.

ÁVILA, Humberto. Teoria dos princípios: da definição à aplicação dos princípios jurídicos. $12^{\mathrm{a}}$ ed. São Paulo: Malheiros, 2011.

"Neoconstitucionalismo: entre a "ciência do direito" e o "direito da ciência". In: Revista Eletrônica de Direito do Estado - ReDE. Número 17 - janeiro/fevereiro/março de 2009 - Salvador - Bahia.

. Repensando o “princípio da supremacia do interesse público sobre o particular”. In: Interesses públicos versus interesses privados: desconstruindo o princípio da supremacia do interesse público. Rio de Janeiro: Editora Lumen Juris, 2005.

BACELLAR FILHO, Romeu Felipe. Processo administrativo disciplinar. $4^{\mathrm{a}}$ ed. São Paulo: Saraiva, 2013.

BANDEIRA DE MELLO, Oswaldo Aranha. Princípios Gerais de Direito Administrativo. Volume II. Rio de Janeiro: Forense, 1969. 
BANDEIRA DE MELLO, Celso Antônio. Curso de Direito Administrativo. 28ª ed. São Paulo: Malheiros, 2011.

BARCELLOS, Ana Paula de. A eficácia jurídicas dos princípios fundamentais: princípio da dignidade da pessoa humana. Rio de Janeiro: Renovar, 2002.

BARROSO, Luís Roberto. O direito constitucional e a efetividade de suas normas: limites e possibilidades da Constituição Brasileira. 7ª ed. Rio de Janeiro: Renovar, 2003.

. A constitucionalização do direito e suas repercussões no âmbito administrativo. In: ARAGÃO, Alexandre Santos de; MARQUES NETO, Floriano Azevedo (Coord.). Direito administrativo e seus novos paradigmas. Belo Horizonte: Fórum, 2012.

. “Aqui, lá e em todo lugar": a dignidade humana no direito contemporâneo e no discurso transnacional. Separata da Editora Revista dos Tribunais. Ano 101 - vol. 919 maio de 2012.

. O novo direito constitucional - contribuições para a construção teórica e prática da jurisdição constitucional no Brasil. Belo Horizonte: Fórum, 2012.

BIELSA, Rafael. Principios de derecho administrativo. $3^{\text {a }}$ ed. Buenos Aires: Depalma, 1963. BINENBOJM, Gustavo. Uma teoria do direito administrativo: direitos fundamentais, democracia e constitucionalização. Rio de Janeiro: Renovar, 2006.

O sentido da vinculação administrativa à juridicidade no direito brasileiro. In: ARAGÃO, Alexandre Santos de; MARQUES NETO, Floriano Azevedo (Coord.). Direito administrativo e seus novos paradigmas. Belo Horizonte: Fórum, 2012, p. 145-204.

. Da supremacia do interesse público ao dever de proporcionalidade: um novo paradigma para o direito administrativo. Interesses públicos versus interesses privados: desconstruindo o princípio da supremacia do interesse público. Rio de Janeiro: Editora Lumen Juris, 2005.

BITENCOURT, Cezar Roberto. Tratado de Direito Penal, 5: parte especial: dos crimes contra a administração pública e dos crimes praticados por prefeitos. $7^{\mathrm{a}}$ ed. São Paulo: Saraiva, 2013. 
BOBBIO, Norberto. O futuro da democracia. $11^{\mathrm{a}}$ ed. Tradução de Marco Aurélio Nogueira. São Paulo: Paz e Terra, 2009.

. BOBBIO, Norberto. Liberalismo e Democracia. 6a ed. São Paulo: Ed. Brasiliense. 2000.

BRAGA, Carlos Eduardo Faraco. O princípio da verdade material no processo administrativo. http://rocadvogados.com.br/artigos/artigo2.pdf

BRITTO, Carlos Ayres. Teoria da Constituição. Rio de Janeiro: Forense, 2003.

. O humanismo como categoria constitucional. Belo Horizonte: Fórum, 2007.

. Comentários à Constituição do Brasil. J.J. Gomes Canotilho... [et al.]. São Paulo:

Saraiva/Almedina, 2013.

CÂNDIDO, Joel José. Direito Eleitoral Brasileiro. 14 Edição. Bauru/SP: EDIPRO, 2010.

CANOTILHO, J.J. Gomes. Direito constitucional e teoria da constituição. $3^{\mathrm{a}}$ ed. Coimbra: Almedina, 1999.

Estado de direito. Lisboa: Fundação Mario Soares, 1999.

O problema da responsabilidade do Estado por actos lícitos. Coimbra: Almedina, 1974.

CARBONELL, Miguel. (coord.) Teoría del neoconstitucionalismo: ensayos escogidos. Madri: Trotta, 2007.

CARDUCCI, Michele. Por um direito constitucional altruísta. Tradução de Sandra Regina Martini Vial, Patrick Lucca da Ros e Cristina Lazzaroto Fortes.Porto Alegre: Livraria do Advogado Editora, 2003.

CARREIRA ALVIM, J. E. Elementos de teoria geral do processo. $7^{\text {a }}$ Ed. Rio de Janeiro: Forense, 1997.

CARRILHO LOPES, Bruno Vasconcelos. A reformatio in peius no direito processual civil. In: Aspectos polêmicos e atuais dos recursos cíveis e de outros meios de impugnação às 
decisões judiciais/ coordenação Nelson Nery Jr., Teresa Arruda Alvim Wambier - São Paulo: Editora Revista dos Tribunais, 2005.

CARVALHO, Carlos Eduardo Vieira de. Regulação de serviços públicos na perspectiva da Constituição Econômica Brasileira. Belo Horizonte: Del Rey, 2007.

CARVALHO FILHO, José dos Santos. Manual de direito administrativo. 27a ed. São Paulo: Atlas, 2014.

. Processo administrativo federal: comentários à Lei $n^{\circ}$ 9.784, de 29.1.1999. $5^{\mathrm{a}}$ ed. São Paulo: Atlas, 2013.

CARVALHO NETO, Tarcisio Vieira de. Responsabilidade civil extracontratual do Estado por omissão. Brasília: Gazeta Jurídica, 2014.

. Controle jurisdicional da Administração Pública - algumas ideias. In: Revista de Informação Legislativa - RIL, nº 199, julho/setembro de 2103, p. 121 a 141.

O princípio da non reformatio in pejus e o controle de legalidade no processo administrativo. In: Almeida, Fernando Dias Menezes de; MARQUES NETO, Floriano de Azevedo; MIGUEL, Luiz Felipe Hadlich; SCHIRATO, Vitor Rhein (Coord.). Direito público em evolução: estudos em homenagem à Professora Odete Medauar. Belo Horizonte: Fórum, 2013, p. 389-404.

. Melhor a verborragia da TV Justiça do que a mudez. Artigo publicado na revista eletrônica Consultor Jurídico de 26.11.2012. http://www.conjur.com.br/2012-nov-26/tarcisiocarvalho-neto-melhor-verborragia-tv-justica-mudez

CASADO, Eduardo Gamero. RAMOS, Severiano Fernándes. Manual Básico de Derecho Administrativo. 10a Edición. Madrid: Tecnos, 2013

CASETTA, Elio. Compendio di Diritto Amministrativo. $3^{\mathrm{a}}$ ed. Milano: Giufreè, 2003.

CASSAGNE, Juan Carlos. Los principios generales del derecho en el derecho administrativo. Buenos Aires: Abeledo-Perrot, 1992.

Neoconstitucionalismo y acto administrativo. In: Almeida, Fernando Dias Menezes 
de; MARQUES NETO, Floriano de Azevedo; MIGUEL, Luiz Felipe Hadlich; SCHIRATO, Vitor Rhein (Coord.). Direito público em evolução: estudos em homenagem à Professora Odete Medauar. Belo Horizonte: Fórum, 2013.

CASSESE, Sabino. Imparzialità amministrativa e sindicato giurisdizionale. Revista italiana per le Scienze giuridiche. Milano: Giuffrè, 1968.

. A crise do Estado. Campinas/SP: Saberes Editora, 2010.

. Il diritto amministrativo e i suoi principi. In: Corso di Diritto Amministrativo diretto da Sabino Cassese. 1. Instituzioni di Diritto Amministrativo a cura de Sabino Cassese. $4^{\text {a }}$ ed. Milano: Giuffrè Editore, 2012.

CAUPERS, João. Introdução ao direito administrativo. 9ª ed. Lisboa: Editora Âncora, 2007. . Introdução à ciência da administração. Lisboa: Editora Âncora, 2002.

CAVALCANTI, Themistocles Brandão. Curso de direito administrativo. $9^{\mathrm{a}}$ ed. Rio de Janeiro: Freitas Bastos, 1971.

CERRI, Augusto. Imparcialità ed indirizzo político nella pubblica amministrazione. Padova: CEDAM, 1973.

CRETELLA Jr., José. Anulação do ato administrativo por desvio de poder. Rio de Janeiro: Forense, 1978.

CUNHA, Sérgio Sérvulo da. Princípios constitucionais. São Paulo: Saraiva, 2006. . Uma deusa chamada justiça. São Paulo: Editora WMF Martins Fontes, 2009.

DAROCA, Eva Desdentado. La crisis de identidad del derecho administrativo: privatización, huida de la regulación pública y administraciones independientes. Valencia: Tirant lo Blanch, 1999.

DEBBASCH, Charles. Institutions el droit administratifs. Tome 1. Les structures administratives. $4^{\text {a }}$ Édition. Paris: Presses Universitaires de France - puf, 1991.

DECOMAIN, Pedro Roberto. Eleições: (comentários à Lei no 9.504/97). $2^{\mathrm{a}}$ Edição. São Paulo: Dialética, 2004. 
DELMANTO, Celso; DELMANTO, Roberto; DELMANTO JÚNIOR, Roberto; DELMANTO, Fábio Fábio M. de Almeida. Código Penal Comentado. $8^{a}$ ed. São Paulo: Saraiva, 2010.

DI PIETRO, Maria Sylvia Zanella. Direito Administrativo. 27ª Edição. São Paulo: Atlas, 2014.

DIAS, José Eduardo Figueiredo, e outro. Noções fundamentais de direito administrativo. $2^{\mathrm{a}}$ ed. Coimbra: Almedina, 2011.

DUARTE, David. Procedimentalização, participação e fundamentação: para uma concretização do princípio da imparcialidade administrativa como parâmetro decisório. Coimbra, Almedina, 1996.

EISENMANN, Ch. O direito administrativo e o princípio da legalidade. Revista de Direito Administrativo, Vol. 56, Abril-Junho de 1959, p. 47/70.

ENTERRÍA, Eduardo Garcia de. As transformações da justiça administrativa: da sindicabilidade restrita à plenitude jurisdicional: uma mudança de paradigma?. Belo Horizonte: Fórum, 2010.

. Problemas del derecho público al comenzo de siglo. Madri: Civitas, 2001.

La lucha contra las inmunidades del poder.3 $3^{\mathrm{a}}$ ed. Madri: Editorial Civitas, 1995.

ENTERRÌA, Eduardo García de. FERNANDEZ, Tomás-Ramón. Curso de Derecho Administrativo I. 12ª ed. Madrid: Civitas, 2004 (reimpresión, 2005).

ESCOLA, Héctor Jorge. El interés público como fundamento del derecho administrativo. Buenos Aires: Depalma, 1989.

ESPÍNDOLA, Ruy Samuel. Conceito de princípios constitucionais: elementos teóricos para uma formulação dogmática constitucionalmente adequada. São Paulo: Editora Revista dos Tribunais, 1998.

. Princípios Constitucionais e Atividade Jurídico-Administrativa: anotações em torno de questões contemporâneas. In: Revista do Tribunal de Contas de Santa Catarina. Julho de 2004. 
FALZONE, Guido. Il dovere di buona ammnistrazione - parte I. Milão: Giuffrè, 1953.

FERREIRA FILHO, Manoel Gonçalves. A Democracia Possível. São Paulo: Saraiva, 1972.

FIGUEIREDO, Marcelo. Probidade Administrativa - Comentários à Lei 8.429/92 e Legislação Complementar. $4^{\mathrm{a}}$ ed. São Paulo: Malheiros, 2000.

FIGUEIREDO, Nelson Lopes de. O Estado infrator. Belo Horizonte: Fórum, 2012.

FURTADO, Lucas Rocha. Curso de Direito Administrativo. $4^{\mathrm{a}}$ ed. Belo Horizonte: Fórum, 2013.

GALVÃO, Jorge Octávio Lavocat. O Neoconstitucionalismo e o Fim do Estado de Direito. São Paulo: Saraiva, 2014.

GARCIA, Emerson; ALVES, Rogério Pacheco. Improbidade Administrativa. $6^{\text {a }}$ Ed. Rio de Janeiro: Lumen Juris, 2011.

GARCIA, Maria Gloria F. D. P. Estudos sobre o princípio da igualdade. Coimbra: Almedina, 2005.

GARCÍA, Manuel Calvo. Transformaciones del Estado y del Derecho. Bogotá: Universidade Externado de Colombia, 2005.

GASPARINI, Diógenes. Crimes na licitação. 4a ed. São Paulo: Editora NDJ, 2011.

GIANNINI, Massimo Severo. Il pubblico potere - stati e amnstrazioni pubbliche.Bologna: Il Mulino, 1986.

GOMES, José Jairo. Direito Eleitoral. 8ª Edição. São Paulo: Atlas, 2012.

GORDILLO, Agustín. Tratado de derecho administrativo. 1. Tomo. $7^{\text {a }}$ ed. Belo Horizonte: Del Rey e Fundación de Derecho Administrativo, 2003.

. Tratado de derecho administrativo. 5. Tomo. $1^{\mathrm{a}}$ ed. Buenos Aires: Fundación de Derecho Administrativo, 2012.

GRECO, Rogério. Curso de Direito Penal: parte especial, volume IV. 9a ed. Niterói, RJ: Impetus, 2013. 
GRIMM, Dieter. Constitucionalismo y derechos fundamentales. Tradución Raúl Sanz Burgos y José Luis Muñoz de Baena Simón. Madri: Trotta, 2006.

GROTTI, Dinorá Adelaide Musetti. Instrumentos de profissionalização da função pública licenças para capacitação e vantagens pecuniárias. In: Almeida, Fernando Dias Menezes de; MARQUES NETO, Floriano de Azevedo; MIGUEL, Luiz Felipe Hadlich; SCHIRATO, Vitor Rhein (Coord.). Direito público em evolução: estudos em homenagem à Professora Odete Medauar. Belo Horizonte: Fórum, 2013.

GUASTINI, Riccardo. Teoría e ideologia de la interpretación constitucional. Madri: Trotta, 2008.

GUEDES, Demian. O Estado democrático de direito e os seus castigos: uma reavaliação do ato sancionador. In: Os caminhos do ato administrativo/ Odete Medauar, Vitor Rhein Schirato (organizadores). São Paulo: RT, 2011.

GUIMARÃES, Bernardo Strobel. Reflexões acerca do princípio da impessoalidade. In: Princípios de direito administrativo: legalidade, segurança jurídica, impessoalidade, publicidade, motivação, eficiência, moralidade, razoabilidade, interesse público. Thiago Marrara (org.). São Paulo: Atlas, 2012.

HÄBERLE, Peter. Libertad, igualdad, fraternidad. 1789 como historia, actualidad y futuro del Estado constitucional. Madrid: Trota, 1998.

HACHEM, Daniel Wunder. Princípio constitucional da supremacia do interesse público. Belo Horizonte: Fórum, 2011.

HOMEM, António Pedro Barbas. O justo e o injusto. Lisboa: Associação Académica da Faculdade de Direito de Lisboa, 2001.

JUSTEN FILHO, Marçal. Curso de direito administrativo. $7^{\mathrm{a}}$ ed. Belo Horizonte: Fórum, 2011.

Comentários à Lei de Licitações e Contratos Administrativos. 16a ed. São Paulo: Editora Revista dos Tribunais, 2014.

. O direito administrativo de espetáculo. In: ARAGÃO, Alexandre Santos de; MAR- 
QUES NETO, Floriano Azevedo (Coord.). Direito administrativo e seus novos paradigmas. Belo Horizonte: Fórum, 2012.

LARENZ, Karl. Derecho Justo: Fundamentos de ética jurídica. Madrid: Civitas, 1985.

LIMA, Ruy Cirne. Princípios de direito administrativo. $7^{\text {a }}$ ed. São Paulo: Malheiros, 2007. . Sistema de direito administrativo brasileiro. Porto Alegre: Gráfica Editora Santa Maria, 1953.

LOPES, Pedro Moniz. Princípio da boa-fé e decisão administrativa. Coimbra: Almedina, 2011.

LUHMANN, Niklas. Legitimação pelo procedimento. Tradução de Maria da Conceição CôrteReal. Brasília: Editora Universidade de Brasília, 1980.

LUÑO, Antonio Enrique Pérez. Perspectivas e tendências atuais do Estado Constitucional. Tradução de José Luis Bolzan de Morais e Valéria Ribas do Nascimento. Porto Alegre: Livraria do Advogado Editora, 2012.

MACHADO, J. Baptista. Participação e descentralização - democratização e neutralidade na constituição de 76. Coimbra: Almedina, 1982.

MARINONI, Luiz Guilherme e ARENHART, Sérgio Cruz. Processo de Conhecimento. $7^{\text {a }}$ Ed. São Paulo: Editora Revista dos Tribunais, 2008, p. 515.

MARTINS-COSTA, Judith. A ressignificação do princípio da segurança jurídica na relação entre o Estado e os cidadãos: a segurança como crédito de confiança. R. CEJ, Brasília n. 27, p. 110-120, out./dez. 2004. http://www2.cjf.jus.br/ojs2/index.php/cej/article/viewArticle/641 MARQUES NETO, Floriano de Azevedo. Regulação estatal e interesses públicos. São Paulo: Malheiros, 2002.

. (Coord.). Direito administrativo e seus novos paradigmas. Belo Horizonte: Fórum, 2012.

Interesses públicos e privados na atividade estatal de regulação. In: Princípios de direito administrativo: legalidade, segurança jurídica, impessoalidade, publicidade, moti- 
vação, eficiência, moralidade, razoabilidade, interesse público. Thiago Marrara (org.). São Paulo: Atlas, 2012.

. A superação do ato administrativo autista. In: Os caminhos do ato administrativo. MEDAUAR, Odete; SCHIRATO, Vitor Rhein (coordenação). São Paulo: Editora Revista dos Tribunais, 2011.

. "Ubiquidade constitucional: os dois lados da moeda. In: SOUZA NETO, Cláudio Pereira de; SARMENTO, Daniel. (Coord.). A constitucionalização do direito: fundamentos teóricos e aplicações específicas. Rio de Janeiro: Editora Lumen Juris, 2007.

MARRARA, Thiago (organizador). Princípios de direito administrativo: legalidade, segurança jurídica, impessoalidade, publicidade, motivação, eficiência, moralidade, razoabilidade, interesse público. São Paulo: Atlas, 2012.

MARTINS, José Renato Silva. O dogma da neutralidade judicial. Rio de Janeiro: Editora Lumen Juris, 2007.

MEDAUAR, Odete. Direito administrativo moderno. 18 a ed. São Paulo: Editora Revista dos Tribunais, 2014.

O direito administrativo em Evolução. $2^{\mathrm{a}}$ ed. São Paulo: Editora Revista dos Tribunais, 2003.

. A processualidade no direito administrativo. São Paulo: Editora Revista dos Tribunais, 1993.

. Controle da administração pública. 2 2a ed. São Paulo: Malheiros, 2012.

Administração pública: do ato ao processo. In: ARAGÃO, Alexandre Santos de; MARQUES NETO, Floriano Azevedo (Coord.). Direito administrativo e seus novos paradigmas. Belo Horizonte: Fórum, 2012, p. 405-419.

. Administração Pública ainda sem democracia, Problemas Brasileiros, v. 23, n. 256, p. 37-41, 44-53, mar./abr. 1986.

. Trecho inicial da apresentação da obra Atuais Rumos do Processo Administrativo. 
MEDAUAR, Odete; SCHIRATO, Vitor Rhein (organização). São Paulo: Editora Revista dos Tribunais, 2010.

Ato administrativo: origem, concepções, abrangência. In: Os caminhos do ato administrativo. MEDAUAR, Odete; SCHIRATO, Vitor Rhein (coordenação). São Paulo: Editora Revista dos Tribunais, 2011.

MEIRELES, Hely Lopes. Direito Administrativo Brasileiro. 37ª Edição. São Paulo: Malheiros, 2011.

MELLO, Celso Antônio Bandeira de. Curso de direito administrativo. 28a ed. São Paulo: Malheiros, 2011.

Pareceres de direito administrativo. São Paulo: Malheiros, 2011.

. Grandes temas de direito administrativo. São Paulo: Malheiros, 2010.

Eficácia das normas constitucionais e direitos sociais. São Paulo: Malheiros, 2009.

MENDES, Gilmar Ferreira. Curso de Direito Constitucional. $6^{\text {a }}$ Edição. São Paulo: Saraiva, 2011.

MERLONI, Francesco. Istituzioni di diritto amministrativo. Torino: G. Giappichelli Editore, 2012.

MERUSI, Fabio. La legalità amministrativa. Bologna: Il Mulino, 2012.

MIRAGEM, Bruno. A nova administração pública e o direito administrativo. São Paulo: Editora Revista dos Tribunais, 2011.

MIRANDA, Jorge. Teoria do Estado e da Constituição. $3^{\mathrm{a}}$ ed. Rio de Janeiro: Forense, 2011. MODESTO, Paulo. O controle jurídico do comportamento ético da administração pública no Brasil. Revista eletrônica sobre a Reforma do Estado - ReRE, Salvador, Instituto Brasileiro de Direito Pùblico, n. 10, junho/julho/agosto 2007. http://www.direitodoestado.com/ revista/RERE-10-JUNHO-2007-PAULO\%20MODESTO.pdf

MONIZ, Ana Raquel Gonçalves. Traços da evolução do direito administrativo português. 
Boletim da Faculdade de Direito da Universidade de Coimbra. Vol. LXXXVII (Separata). Coimbra, 2011.

Direito administrativo - textos e casos práticos resolvidos. Coimbra, Almedina, 2012.

MORAES, Antônio Carlos Flores de. Administração pública transparente e responsabilidade do político. Belo Horizonte, Fórum, 2007.

MORAIS, Jose Luis Bolzan de. As crises do Estado e da Constituição e a transformação espaço-temporal dos direitos humanos. $2^{\mathrm{a}}$ ed. Porto Alegre: Livraria do Advogado Editora, 2011.

MOREIRA, Egon Bockmann. Processo administrativo: princípios constitucionais e a lei 9.784/1999. $4^{\text {a }}$ ed. São Paulo: Malheiros, 2010.

MOREIRA NETO, Diogo de Figueiredo. Curso de Direito Administrativo: parte introdutória, parte geral e parte especial. 14 ${ }^{\mathrm{a}}$ Edição. Rio de Janeiro: Forense, 2006.

Poder, direito e estado: o direito administrativo em tempos de globalização. Belo Horizonte: Fórum, 2011.

. (coord.) Uma avaliação das tendências contemporâneas do Direito Administrativo.

Rio de Janeiro: Renovar, 2003.

Para a compreensão do direito pós-moderno. In: Almeida, Fernando Dias Menezes de; MARQUES NETO, Floriano de Azevedo; MIGUEL, Luiz Felipe Hadlich; SCHIRATO, Vitor Rhein (Coord.). Direito público em evolução: estudos em homenagem à Professora Odete Medauar. Belo Horizonte: Fórum, 2013.

MORRIS, Clarence. Org. Os Grandes Filósofos do Direito. São Paulo: Martins Fontes, 2002. MUÑOZ, Jaime Rodríguez-Arana. Direito Fundamental à boa administração pública. Tradução de Daniel Wunder Hachem. Belo Horizonte: Fórum, 2012.

La vuelta al Derecho Administrativo (a vueltas con lo privado y ló publico). In: Revista de Derecho de la Universidad de Montevideo, nº 7, 2005, p. 89 a 102. 
NABAIS, José Casalta. Procedimento e processo administrativo. $8^{\text {a }}$ ed. Coimbra: Almedina, 2013.

NEIVA, José Antonio Lisbôa. Improbidade administrativa: legislação comentada artigo por artigo: doutrina, legislação e jurisprudência. 3ª ed. Niterói/RJ: Impetus, 2012.

NERY JÚNIOR, Nelson. Princípios Fundamentais - Teoria Geral dos Recursos. São Paulo: Editora Revista dos Tribunais, 1996.

NETTO, Luísa Cristina Pinto e. Participação administrativa procedimental: natureza jurídica, garantias, riscos e disciplina adequada. Belo Horizonte: Fórum, 2009.

NEVES, Marcelo. Entre Hidra e Hércules: princípios e regras constitucionais como diferença paradoxal do sistema jurídico. São Paulo: Martins Fontes, 2013.

NIETO, Alejandro. El desgobierno de lo público. 2ª Edición. Barcelona: Planeta (Ariel), 2012.

NOJIRI, Sérgio. O dever de fundamentar as decisões judiciais. 2ª Ed. São Paulo: Editora Revista dos Tribunais, 2000.

OLIVEIRA, Fábio de. Por uma teoria dos princípios: o princípio constitucional da razoabilidade. $2^{\text {a }}$ ed. Rio de Janeiro, Lumen Juris, 2007.

OLIVEIRA, Gustavo Justino de. Direito administrativo democrático. Belo Horizonte: Fórum, 2010.

OLIVEIRA, Rafael. A constitucionalização do direito administrativo: o princípio da juridicidade, a releitura da legalidade administrativa e a legitimidade das agências reguladoras. Rio de Janeiro: Editora Lumen Juris, 2009.

OSÓRIO, Fábio Medina. Teoria da Improbidade Administrativa. $3^{\mathrm{a}}$ Ed. São Paulo: Revista dos Tribunais. 2013.

OTERO, Paulo. Legalidade e administração pública - O sentido da vinculação administrativa à juridicidade. Coimbra: Almedina, 2011.

Manual de Direito Administrativo. Volume I. Coimbra: Almedina, 2013. 
PALMA, Juliana Bonacorsi de. A Teoria do Ato Administrativo e a Prática da Consensualidade. In: Os Caminhos do Ato Administrativo. Org. Odete Medauar e Vitor Rhein Schirato. São Paulo: Ed. Revista dos Tribunais. 2011.

PEDUZZI, Maria Cristina Irigoyen. O princípio da dignidade da pessoa humana na perspectiva do direito como integridade. São Paulo: LTr, 2009.

PEREZ, Marcos Augusto. A administração pública democrática: institutos de participação popular na administração pública. Belo Horizonte: Fórum, 2009.

RAMOS, Dora Maria de Oliveira. Notas sobre o princípio da impessoalidade e sua aplicação no direito brasileiro. In: Princípios de direito administrativo: legalidade, segurança jurídica, impessoalidade, publicidade, motivação, eficiência, moralidade, razoabilidade, interesse público. Thiago Marrara (org.). São Paulo: Atlas, 2012.

REIS, Márlon. Direito Eleitoral Brasileiro. Brasília: Alumnus, 2012.

RIBEIRO, Carlos Vinícius Alves. Interesse público: um conceito jurídico determinável. In: Supremacia do interesse público e outros temas relevantes do direito administrativo. São Paulo: Atlas, 2010.

RIBEIRO, Maria Teresa de Melo. O princípio da imparcialidade da administração pública. Coimbra: Almedina, 1996.

ROCHA, Cármen Lúcia Antunes. Princípios constitucionais da administração pública. Belo Horizonte: Del Rey, 1994.

ROSSI, Giampaolo. Principi di diritto amministrativo. Torino: G. Giappichelli Editore, 2010. SANTAMARÍA PASTOR, Juan Alfonso. Principios de derecho administrativo general - I. $2^{\text {a }}$ Edición. Madrid: Iustel, 2009.

SANTIAGO, José María Rodríguez de. La ponderación de bienes e intereses en el derecho administrativo. Madrid/Barcelona: Marcial Pons, 2000.

SANTOS NETO, João Antunes dos. O impacto dos direitos fundamentais no direito administrativo. Belo Horizonte: Fórum, 2008. 
. Da anulação ex officio do ato administrativo. $2^{\mathrm{a}}$ ed. Belo Horizonte: Forum, 2006.

SARLET, Ingo Wolfgang. Dignidade da pessoa humana e direitos fundamentais. $3^{\mathrm{a}} \mathrm{ed}$. Porto Alegre: Livraria do Advogado Editora, 2004.

SARMENTO, Daniel. Por um constitucionalismo inclusivo: história constitucional brasileira, teoria da constituição e direitos fundamentais. Rio de Janeiro: Editora Lumen Juris, 2010. - (org) Interesses públicos versus interesses privados: desconstruindo o princípio da supremacia do interesse público. Rio de Janeiro: Editora Lumen Juris, 2005.

SARTORI, Giovanni. Teoría de la democracia. 1. El debate contemporâneo. Madrid: Alianza Editorial, 2009.

SCAFF, Fernando Facury; SCAFF, Luma Cavaleiro de Macedo. Comentários à Constituição do Brasil. J.J. Gomes Canotilho... [et al.]. São Paulo: Saraiva/Almedina, 2013.

SCHIER, Paulo Ricardo. "Novos desafíos da filtragem consitucional no momento do Neoconstitucionalismo”. In: SOUZA NETO, Cláudio Pereira de; SARMENTO, Daniel. (Coord.). A constitucionalização do direito: fundamentos teóricos e aplicações específicas. Rio de Janeiro: Editora Lumen Juris, 2007.

. Ensaio sobre a supremacia do interesse público sobre o privado e o regime jurídico dos direitos fundamentais. In: Interesses públicos versus interesses privados: desconstruindo o princípio da supremacia do interesse público. Rio de Janeiro: Editora Lumen Juris, 2005.

SCHIRATO, Vitor Rhein. Algumas considerações atuais sobre o sentido de legalidade na Administração Pública. In: Interesse Público, Ano X - 2008 - nº 47. Belo Horizonte: Fórum. . O processo administrativo como instrumento do Estado de Direito e da Democracia. In: Atuais novos rumos do processo administrativo / organizadores Odete Medauar, Vitor Rhein Schirato. São Paulo: Editora Revista dos Tribunais, 2010.

SCHMIDT-ASSMANN, Eberhard. La teoría general del derecho administrativo como sistema: objeto y fundamentos de la construcción sistemática. (tradução espanhola do original: Das Allgemeine Verwaltungsrecht als Ordnungs Idee). Madrid/Barcelona: Marcial Pons, 2003. 
SCHWIND, Rafael Wallbach. Processo administrativo em evolução. In: ALMEIDA, Fernando Dias Menezes de; MARQUES NETO, Floriano de Azevedo; MIGUEL, Luiz Felipe Hadlich; SCHIRATO, Vitor Rhein (Coord.). Direito público em evolução: estudos em homenagem à Professora Odete Medauar. Belo Horizonte: Fórum, 2013.

SILVA, Clarissa Sampaio. Limites à invalidação dos atos administrativos. São Paulo: Max Limonad, 2001.

SILVA, José Afonso da. Curso de Direito Constitucional Positivo. São Paulo: Malheiros, 2014.

SILVA, Suzana Tavares da. Um novo direito administrativo? Coimbra: Imprensa da Universidade de Coimbra, 2010.

Direito administrativo europeu. Coimbra: Imprensa da Universidade de Coimbra, 2010.

Direitos fundamentais na arena global. Coimbra: Imprensa da Universidade de Coimbra, 2011.

SILVA, Virgílio Afonso da. A constitucionalização do direito: os direitos fundamentais nas relações entre particulares. São Paulo: Malheiros, 2005.

Direitos fundamentais - conteúdo essencial, restrições e eficácia. 2ª ed. São Paulo: Malheiros, 2011. . (organizador). Interpretação constitucional. São Paulo: Malheiros, 2010. . Na encruzilhada liberdade-autoridade - a tensão entre direitos fundamentais e interesses coletivos. In: Almeida, Fernando Dias Menezes de; MARQUES NETO, Floriano de Azevedo; MIGUEL, Luiz Felipe Hadlich; SCHIRATO, Vitor Rhein (Coord.). Direito público em evolução: estudos em homenagem à Professora Odete Medauar. Belo Horizonte: Fórum, 2013.

SILVEIRA, Ana Teresa Ribeiro da. A reformatio in pejus e o processo administrativo. Belo Horizonte, n. 30, ano 7, Março 2005 Disponível em http://www.editoraforum.com.br/bid/ bidConteudoShow.aspx?idConteudo=50028, Acesso em: 25 fevereiro 2010. 
SILVEIRA, Raquel Dias da. Profissionalização da função pública. Belo Horizonte: Fórum, 2009.

SIMÕES, Mônica Toscano. O processo administrativo e a invalidação de atos viciados. São Paulo: Malheiros Editores, 2004.

SOARES, Luís Miguel Pereira. A ética na administração pública. Lisboa: Universidade Técnica de Lisboa - Instituto Superior de Ciências Sociais e Políticas, 2008.

SORACE, Domenico. Diritto delle amministrazioni pubbliche - una introduzione. $6^{\mathrm{a}}$ ed. Bologna: Il Mulino, 2010.

SOUSA, Marcelo Rebelo de. MATOS, ANDRÉ Salgado de. Direito administrativo geral introdução e princípios fundamentais. Tomo I. $3^{\mathrm{a}}$ ed. Alfragide: Dom Quixote, 2008.

Direito administrativo geral - actividades administrativas. Tomo III. $2^{\mathrm{a}}$ ed. Alfragide: Dom Quixote, 2009.

. Responsabilidade civil administrativa - Direito administrativo geral. Tomo III. Alfragide: Dom Quixote, 2008.

SOUSA, Nuno J. Vasconcelos Albuquerque. Noções de direito administrativo. Coimbra: Coimbra Editora, 2011.

SUNDFELD, Carlos Ari. Direito administrativo para céticos. São Paulo: Malheiros, 2012. Fundamentos de direito público. $4^{\mathrm{a}}$ ed. São Paulo: Malheiros, 2005.

TÁCITO, Caio. O Princípio da legalidade: ponto e contraponto. In: BANDEIRA DE MELLO, Celso Antônio (org.). Estudos em Homenagem a Geraldo Ataliba-2 - Direito Administrativo e Constitucional. São Paulo: Malheiros Editores, 1987.

VALDIVIA, Diego Zegarra. La motivación como elemento esencial del acto administrativo. In: Os caminhos do ato administrativo. MEDAUAR, Odete; SCHIRATTO, Vitor Rhein (organizadores). São Paulo: Editora Revista dos Tribunais, 2011.

VALLE, Vanice Regina Lírio do. Direito fundamental à boa administração e governança. Belo Horizonte: Fórum, 2011. 
VEDEL, Georges e DELVOLVÉ, Pierre. Droit administratif - tome 1. Paris: PUF, 1992.

VIEIRA, Leonardo Carneiro Assumpção. Merecimento na administração pública - concurso público, avaliação de desempenho e política pública de pessoal. Belo Horizonte: Fórum, 2011.

VILLEY, Michel. O direito e os direitos humanos. Tradução de Maria Ermantina de Almeida Prado Galvão. São Paulo: WMF Martins Fontes, 2007.

WALTER, Carlos. Discurso jurídico na democracia: processualidade constitucionalizada. Belo Horizonte, Fórum, 2008.

WAMBIER, Luiz Rodrigues, ALMEIDA, Flávio Renato Correia de e TALAMINI, Eduardo.

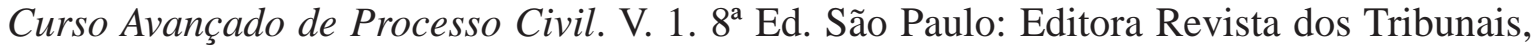
2006.

WOLFF, Hans J. BACHOF, Otto. STOBER, Rolf. Direito administrativo. Vol. 1. $11^{\mathrm{a}}$ ed. Tradução de António F. de Sousa. Fundação Calouste Gulbenkian, 2006.

ZAGO, Lívia Maria Armentano Koenigstein. O princípio da impessoalidade. Rio de Janeiro: Renovar, 2001.

ZAGREBELSKY, Gustavo. El derecho dúctil - ley, derechos, justicia. 6a Edición. Madrid: Editorial Trota, 2005.

ZAGREBELSKY, Gustavo. MARTINI, Carlo Maria. La exigencia de justicia. Madrid: Trotta, 2006. 
O presente trabalho foi realizado com o apoio da Procuradoria-Geral do Distrito Federal - Brasil (Resolução n ${ }^{\circ}$ 10, de 05/03/2010) 